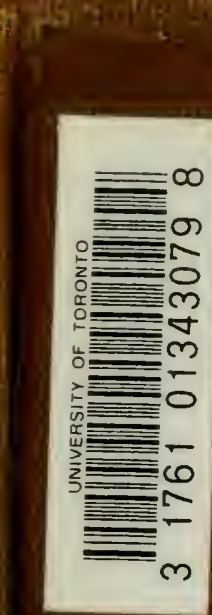



BIWOTNA T.TST UIL I F 1929 



\section{JOHNS HOPKINS UNIVERSITY STUDIES}

IN

\section{Historical and Political Science}

Under the Direction of the

Departments of History, Political Economy, and

Political Science

\section{VOLUME XXXVIII}

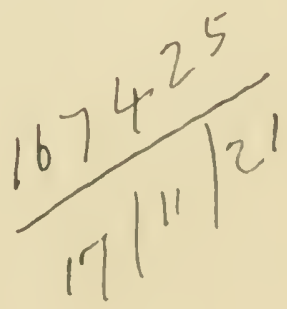

BALTIMORE

THE JOHNS HOPKINS PRESS 
COPYRIGHT $1920 \mathrm{KY}$

THE JOHNS HOPKINS PRESS

PRESS OF
THE NEW EA COATING COMPANY
LANCASTER, PA. 


\section{CONTENTS}

I. The United States Department of Agriculture. By William L. Wanlass ........................ I

II. The Amalgamated Association of Iron, Steel and TiN Workers. By Jesse S. Robinson ................ I33

iII. The Employment of the Plebiscte in the Determination of Sovereignty. By Johannes Mattern ......... 299 

THE UNITED STATES DEPARTMENT OF AGRICULTURE 



\title{
JOHNS HOPKINS UNIVERSITY STUDIES
}

IN

Historical and POLItical SCiEnce Under the Direction of the

Departments of History, Political Economy, and Political Science

\section{THE UNITED STATES DEPARTMENT OF AGRICULTURE}

\section{A STUDY IN ADMINISTRATION}

\author{
$\mathrm{BY}$ \\ WILLIAM L. WANLASS, PH.D. \\ Assistant Professor of Economics and Politics in Un!on College
}

\section{BALTIMORE}

THE JOHNS HOPKINS PRESS 


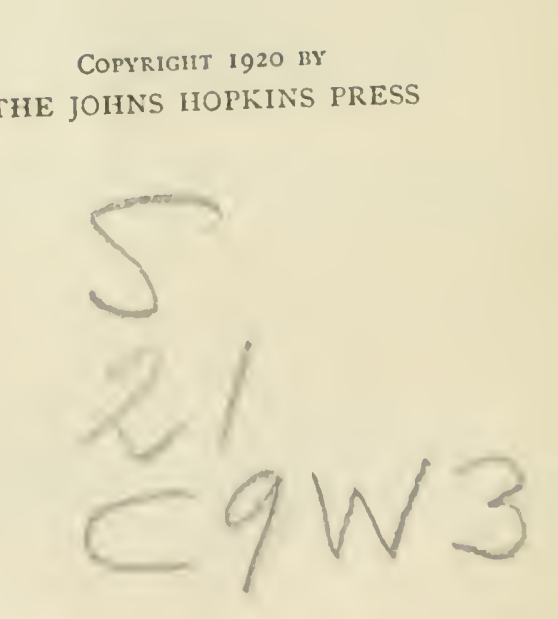




\section{CONTENTS}

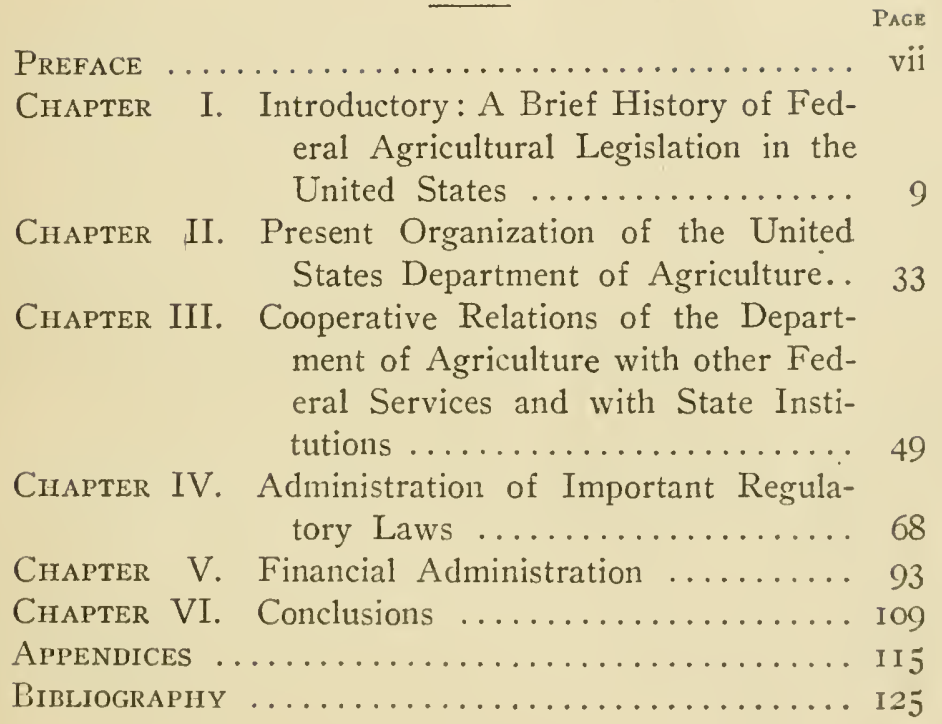





\section{PREFACE}

While employed in the United States Department of Agriculture during the years I9I2-I9I7, the writer first became interested in the growing importance of this relatively new executive unit, and particularly in its purely administrative or regulatory work, as distinct from its research and educational activities. The aim of this study, as the title and table of contents indicate, is to describe, examine, and criticise the conduct of this administrative work. It is believed that such studies will be conducive to a better understanding of the actual operations of our government-a subject to which too little attention has been given.

No attempt has been made to examine the constitutional basis of the various statutes affecting the Department of Agriculture. This is an interesting subject, but its consideration lies outside the scope of the present study.

Likewise no account has been taken of the important "war legislation" committed to the Department of Agriculture for administration during 1917 and I9r8. While some permanent changes in organization and function may result from these extraordinary activities, it is probable that most of the work thus undertaken will prove to be of a temporary character.

Both in the inception of this study and in bringing it to completion valuable assistance has been received from Professor W. W. Willoughby, Dr. A. C. Millspaugh, and President Frank J. Goodnow. I am also greatly indebted to many officials of the Department of Agriculture for information and assistance.

W. L. IV. 



\section{THE UNITED STATES DEPARTMENT OF AGRICULTURE}

\section{CHAPTER I}

\section{Introductory: A Brief History of Federal Agricul- tural Legislation in the United States}

When one contemplates that immense organization known as the United State Department of Agriculture, with its thousands of officers and employees scattered over the entire United States and its insular possessions, and, in peace times, exploring the remotest regions of the earth, it seems almost incredible that it has existed as an executive department of the first rank hardly three decades. It is true that an institution called the Department of Agriculture, under direction of an officer styled "Commissioner of Agriculture," was established by Act of May I5, I862. ${ }^{1}$ However, it was not until February 9, I $889,{ }^{2}$ almost exactly a century after the establishment of the Government under the Constitution, that this greatest of all American industries was given the recognition of a seat in the President's Cabinet Council.

This delay in granting such recognition to so large and important a part of our industrial and social structure was not due to a lack of demand on the part of those directly interested, but rather to certain feelings or traditions in the minds of many of our legislators and other men of influence. First, there was a very prevalent opinion that the activities of the general government should be limited to what might be termed political affairs as distinct from those which had to do with domestic industry and commerce. It is note-

1 I2 Stat. I. 387 ; Rev. Stat., Secs. 520, 521.

225 Stat. I. 659. 
worthy that Hamilton, the greatest champion of the powers of the federal government, should have been almost the first to declare that agriculture could never become one of the "desirable cares of a general jurisdiction." It is also worthy of note that up until the establishment of the Department of Agriculture in I889, all of the then existing executive departments-State, Treasury, War, Nary, Post Office, Interior and Justice-with the possible exception of the Department of the Interior, performed functions generally considered as political in character and essential to the conduct of a central government. Moreover, there existed a very wide-spread opinion that the individual States were fully competent to take care of "their own agricultural interests: and since agricultural conditions were so diverse, each state would be better fitted to cope with its own diffcultics than any central organization could possibly be." It hardly need be said that while this feeling may still exist in the minds of some men, it is no longer a factor which needs to be seriously considered.

While Hamilton does not seem to have rested his objections to the general government's concerning itself with the encouragement of agriculture on constitutional grounds, there were not lacking those who did believe that the assumption of a function so obviously of local concern was clearly outside the authority and powers granted in the Constitution. Even Washington, who was undoubtedly the most consistent and infuential of the earlier advocates of federal encouragement of agriculture, never seemed to be entirely certain as to his constitutional position, particularly as to the expenditure of funds for this purpose.

In a letter to Hamilton in October 1791, he wrote:

How far in addition to the several matters mentioned in that letter would there be propriety, do you think, in suggesting the policy of cncouraging the growth of cotton and hemp in such parts of the United States as are adapted to the culture of them? The advantages, which would result to this country from the encouragement of these articles for home manufacture, I have no doubt of ; but low

she Federalist (ed. Ford), no. 17, p. 93. Later Hamilton seems to have changed his opinions to some extent. 
far would bounties on them come within the powers of the general government, or it might comport with the temper of the times to expend money for such purposes, is necessary to be considered, and without a bounty, I know of no means by which they can be effectually encouraged. ${ }^{4}$

If Vashington had doubts as to the authority of Congress to appropriate money for the promotion of agriculture, there was no such doubt in the mind of Jefferson. In a letter to Livingston in February, I8OI, he wrote:

I have on several occasions been led to think on some means of uniting the state agricultural societies into a central society: and lately it has been pressed from England with a view to cooperation with their board of agriculture. You know some have proposed to Congress to incorporate such a society. I am against that, because I think Congress cannot find in all the enumerated powers any one which authorizes the act, much less the giving of public money to that use. I believe too if they had the power, it would soon be used for no other purpose than to buy with sinecures useful partisans. I believe it will thrive best if left to itself as the Philosophical societies are. ${ }^{5}$

It is not the intention to enter upon a discussion of the general question of the constitutionality of agricultural legislation, except to point out briefly the influence of this factor in determining the progress of such legislation. It is perhaps sufficient to say that from the earliest history of our government up to the present time, ${ }^{\circ}$ legislators and students have questioned the constitutional right of Congress to authorize investigative and experimental work relating to agriculture. Such authority as exists is to be found in article $I$, section 8 , clause $I{ }^{7}$ This particular point does not appear to have been adjudicated by the courts; but it seems safe to assume that, should the matter be seriously questioned, the practice of Congress in making appropriations for this purpose for the past eighty jears would be given great weight by the courts. ${ }^{8}$

4 Writings of George Washington (ed. IV. C. Ford), vol. xii, p. \&4.

-Writings of Thomas Jefferson (ed. P. L. Ford), vol. vii, P. 492.

- For a recent discussion, see Am. Law Rev., vol. $\mathrm{xxx}, \mathrm{pp} .7 \bar{S} 7-700$.

7 "Congress shall have power to lay and collect taxes, duties, imposts and excises, to pay the debts and provide for the common defense and general welfare of the United States."

${ }^{8}$ Stwart v. Laird; Cranch 200; Marshall Field Co. v. Clark; 43 U. S. 649,683 . 
Most of the regulatory laws administered by the Department of Agriculture are based on the power of Congress, under article 8 , section $S$, generally known as the "commurce clause." Several of these acts have been passed upon by the courts, and, for the most part, they have been upheld. The validity of the food and drugs act has been specifically recognizerl by the Supreme Court. ${ }^{\circ}$

Another factor which seems to have been of considerable importance in retarding the granting of full recognition to agriculture was the feeling, or perhaps, the fear, that when this step was once taken, there was no definable limit beyond which this new type of governmental activity might not go. If the farming interests of the comntry were to be permitted to have a representative in the President's Cabinet, would it be possible to deny such recognition to commerce, to mining, to manufacture, or to labor? And if all these were to be given seats at the President's Council table, would not that body become so large and unwicldy as to render it inefficient as an aid to the President? That this fear was not wholly unfounded is shown by the subsequent establishment of the Departments of Commerce and of Labor.

There was, morcover, a rather general feeling, particularly among those not directly interested in agriculture, that the very favorable natural conditions with which that industry was surrounded in this country, made government aid or other artificial stimulus entirely unnecessary, if not undesirable.

\section{Early Agricultural Legislation}

In the eighteenth century, the ideal colony was the one whose products did not in any way compete with those of the mother country. In their economic pursuits, mother country and colony were to be mutually complementary. "The aim was to create a self-sufficient commercial empirc, which, while independent of competing European powers, would be alle to make them dependent on it." ${ }^{\prime \prime 0}$

"Hipolite Esgg Co. $v$. United States, 220 U. S. 45.

$10 \mathrm{G}$. L. Becr, Lritish Colonial Policy, 1754-1765, p. 134. 
While the continental colonies of Britain were a good market for British manufacturers, they also produced agricultural products which duplicated those of England. So long, then, as England remained primarily an agricultural country, and the older idea of empire persisted, it could hardly be expected that Parliament would do very much for the encouragement of that industry in America. Despite this condition, however, both the home government and several of the colonial legislatures granted small sums of money from time to time for the promotion of various agricultural projects. For the most part, these were not likely to compete with home products. As early as I622, the Government of James I tried to encourage the growing of mulberry trees and the breeding of silkworms in Virginia; in I642, the general court of Massachusetts authorized the payment of premiums for the best trpes of sheep produced in the colony. From I633 to I643 Parliament granted six hundred thousand dollars to promote the growing of indigo and other crops in Georgia. By the time of the Revolution, England had become primarily a manufacturing country and the more modern view that the colonies were to furnish a market for home manufacture had become the dominant one. Had not this political change occurred, it is more than probable that agriculture would have received much greater governmental aid, not only to supplement the mother country's declining agricultural production, but to keep the colonists diverted from manufacturing.

During the ten years immediately following the establishment of the Government under the Constitution, Washington was undoubtedly the most ardent and influential advocate of governmental aid for the promotion of agriculture. Even when the affairs of state secmed to be most pressing, he found time to speak and write about it, both in an official and a private capacity. In the course of his first annual message to Congress, he referred to agriculture as a pursuit which should be encouragred along with commerce and manufactures. ${ }^{11}$ At this time, Washington seems to lave

11 Messages and Papers of the Presiclents, vol, i, p. 66. 
had no very clear notion as to what form such encouragement might take.

In 1793, the British government, through the earnest efforts of Sir John Sinclair, at that time a nember of Parliament, rather reluctantly consented to the establishment of a central board of agriculture. Sir John was made president of this board, and under his guidance, it secms to have been successful until ISiz when, through failure of appropriations, it went out of existence.

It was due to the example of this board and the subsequent correspondence between himself and Sinclair that IVashington, in his last annual message to Congress in 1796 , was able to make a much more urgent and definite appeal in behalf of agriculture. In this message he said:

It will not be doubted that with reference either to individual or national welfare agriculture is of primary importance. In proportion as nations advance in population and other circumstances of maturity this truth becomes more apparent, and renders the cultivat:on of the soil more and more an object of public patronage. Institutions for promoting it grow up, supported by the public purse: and to what object can it be dedicated with greater propriety? Among the means which have been enployed to this end none have been attended with greater success than the establishment of boards icomposed of proper characters) charged with collecting and diffusing information, enabled by premiums and small pecuniary aids to encourage and assist a spirit of discovery and improvement by stimulating to enterprise and experiment, and by drawing to a common center the results everywhere of individual skill and observation and spreading them thence over the whole nation. Experience accordingly has shown that they are very cheap instruments of immense 11 ational benefits. ${ }^{12}$

This part of Washington's message was favorably received in both branches of Congress. In the House of Representatives, it was referred to a committee which reported, recommending a plan, the principal parts of which were, that an agricultural socicty consisting of congressmen, fedcral judges, heads of departments, and such other fersons as might be eligible be established at the seat of government. Annual meetings were to be held at which a President and secretary and a hoard of not more than thirty persons-to be called a "Board of Agriculture"-were to

12 Ibicl., vol. i, ก. 202. 
be chosen. Only the secretary's salary and expenses were to be paid out of the public treasury, and if the state of the treasury was such as to make this seem inadvisable, not even these were to be paid by the Government.

The report of the committee was referred to a committee of the whole to be brought up the next Monday, but it became confused with a discussion of direct taxes and was never brought ip..$^{13}$

During the next twenty years, there seems to have been no more definite proposals in Congress for extending the aid of the government to agriculture; but in I $\mathrm{I}_{\mathrm{I}}$, Representative Hulbert presented a petition of the Berkshire Association for the promotion of agriculture and manufacturing in Massachusetts, praying "that the aid of the National Government may be extended to the promotion of the interests of agriculture and manufacturing either by the establishment of a national board or by such other means as in the wisdom of Congress may seem meet and proper." This petition was referred to a select committee and was never again revived. ${ }^{14}$ For the next twenty years, the activity of Congress with respect to agriculture was practically limited to the appointment of a committee on agriculture in the House in $1820,{ }^{15}$ and the appointment of a similar committee in the Senate in $1825 .{ }^{10}$ Both of these still exist and are now very important committees; but at the time they were created they seem to have been little more than convenient repositories for such petitions, memorials or other documents relating to agriculture as might come before Congress.

There was enacted, however, during this period, such legislation as was necessary in the devclopment of our public lands policy. While this legislation affected the development of agriculture, as indeed it did the entirc history of the nation; it cannot be said that the public lands policy of Congress had as its aim the promotion of the interests of

\footnotetext{
13 Annals of Cong., 4th Cong., 2d sess., p. 1835.

14 Ibid., r 4 th Cong., $2 d$ sess., pt. I, p. 760.

13 Ibid., 16 th Cong., ist sess., pt. 2, p. 2179.

10 Register of Debates in Congress, 10th Cong., 1 st sess., cols. $5,7$.
} 
that part of the population which was engaged in farming. The public land laws formed then, as they do now, a body of legislation quite distinct from that which has later been enacted directly in the interest of the agricultural class.

The almost complete apathy of Congress, during the first sixty years of our history, toward lending the aid of the Government to the promotion of agriculture stands out in marked contrast to the attitude of that body today. Such an attitude is explainable only by the absence of any widespread or organized demand for such legislation; for no doubt the congressman then, as now, had 'an ear to the ground.' With a liberal public land policy, with an abundance of virgin soil and with the raw products of agriculture comparatively unimportant in domestic commerce, the life of the man who desired to till the soil was a relatively free and independent one during the first half of the nineteenth century. The period of 'scientific agriculture' had not yet begun.

However, if Congress was content during these early years to let the business of the farmer follow its natural course, or receive such aid as it might from the various states and localities, there was another branch of the federal government whose activities in this ficld were destined to have a marked infuence on the future course of events. Following the example set by Franklin while he was a representative of Pennsylvania in England. American consuls, after the Revolution, adopted the practice of sending home specimens of foreign seeds, plants and domestic animals which might he used to enrich and diversify the agricultural production of the United Siates. At first this practice was largely extra-official, but later it was made a part of the duty of these officers. For several years, there does not appear to have been any regular agency designated to receive and clispense these contributions.

In IS36, Henry L. Ellsworth, then Commissioner of Patents (at this time the Patent Office was in the Department of State), assumed the responsibility, independent of 
his office, of receiving and distributing to farmers throughout the country such seeds, plants and animals as were received from consular officers or other sources. In his report the following year, he strongly urged upon Congress the desirability of creating a suitable depository to care for this increasing business. ${ }^{17}$ Two years later, and largely as a result of Mr. Ellsworth's efforts, Congress appropriated one thousand dollars for "the collection of agricultural statistics, and for other agricultural purposes." 18 This appropriation, small as it was, marks the real beginning of what has since become a great national enterprise.

\section{Fifty Years of Development, I839-I889}

This meager appropriation made in 1839 was repeated in I842, the amount was doubled in I844, and, since the latter year, the item, "Collecting Agricultural Statistics," has formed a part of the annual appropriations of Congress. While the collection and distribution of seeds and plants was not specifically provided for in the appropriation, that function and the collection and publication of agricultural statistics constituted the chief activities carried on in the interest of agriculture by the federal government for the succeeding twenty years. From $\mathrm{I}_{552}$, the purchase and distribution of seeds was specifically provided for.

During the latter part of this period, small additional appropriations were made from time to time for the investigation of special subjects. Such were the appropriations of one thousand dollars in I850 for chemical analyses of vegetable substances, ${ }^{19}$ and three thousand five hundred dollars in 1858 for the collection and publication of information relating to the consumption of cotton in the various countries of the world. ${ }^{20}$ The expenditure of these various funds as well as that of the regular ammual appropriations

17 25th Cong., 2d sess., H. Doc. no. 112.

18 Stat. L.. pp. 353-354.

199 Stat. L., p. 364.

20 II Stat. L., p. 226. 
continued under the direction of the Commissioner of Patents until i $\$ 62$.

Even after Congress had definitely committed itself, in this small way, to a policy of utilizing public funds for the aiel and encouragement of agriculture, there was no immediatc and popular demand for an extension of this activity. However, there were not lacking progressive farmers and business men who looked to the future and saw the need of a better and more scientific system of farming than that generally practiced in this country. Several years prior to the period about which we are now speaking. such men, many of whom were what might be called, 'gentlemen farmers,' whose leisure gave them opportunity for thought and reflection, and whose social positions gave their efforts adcled weight, were instrumental in promoting and organizing local and state agricultural societics and associations. Such were the Philadelphia Society for Promoting Agriculture, organized in $17 S_{5}$ and incorporated in $1 S_{0}$; the Charleston (S. C.) Society for the Promotion of Agriculture; the Pennsylvania Society of Agriculture, organized in ISoS; and the Berkshire Agricultural Society in western Massachusetts, organized in isio, chicfly through the efforts of Elkanah Watson. ${ }^{21}$ It was the last of these, as we have seen, which succeeded in focusing the attention of Congress in ISI7, at least momentarily, upon the need of some kind of national agricultural institution.

These societies grew rapidly both in number and nembership. In 1852 , it was estimated that there were approximately three hundred such organizations scattered over all the settled portions of the country. ${ }^{22}$ By $186 \mathrm{I}$, the number had reached almost a thousand. ${ }^{23}$ The first of these to reach more than state-wide importance was the Columbian Agricultural Society with headquarters at Washington. While its existence was very bricf (ISOO-ISI5), it cnlisted

\footnotetext{
21 Bailey, Cyclopedia of American Agriculture, vol. iv, p. $291 \mathrm{ff}$.

23 Journal of the U. S. Agricultural Socicty, vol. i. p. 3. p. 26 .

3 The Quarterly Journal of Agriculture (Washington), vol. viii,
} 
the patronage of many influential men and was successful in making available a great deal of valuable information. ${ }^{24}$

For forty years after the War of I8I 2 had terminated the brief existence of the Columbian Society, there does not appear to have been any central organization which was really representative of any very considerable part of the interests of the agricultural class of the country. During this period, agriculture, no less than other American industries, had been profoundly affected by the great changes that had taken place. The unprecedented westward expansion called by some the most significant fact in American history; the wonderful development of transportation facilities; the enormous influx of immigration; the invention and use of machinery; the extensive entry of farm products into commerce both domestic and foreign;-these and other factors were destined to bring about a new era for agriculture in the United States and to bring the rural element in our society directly into contact with the political life and thought of the nation.

It is not surprising, then, that when a call was sent out in $\mathrm{I}_{52} 2$ for a national convention of agriculturalists to meet in Washington, for the purpose of forming a national agricultural society, it should have met with a general and ready response. One hundred and fifty delegates representing numerous societies met in June of the same year and formed the proposed national organization. The Hon. Marshall P. Wilder of Boston was elected as the first president.

A somewhat similar attempt had been made in $\mathrm{I} 8_{4} \mathrm{I}$ to form a national society: The principal immediate objective in view was the securing of all, or part, of the Smithson bequest, recently received from England; but when this failed the organization which had been formed quictly went out of existence, after holding only one annual meeting.

From the first, the United States Agricultural Society, organized in 1852 , numbered among its membership many men of national prominence. Many others of equal promi-

24 Ilbid., vol. vii, p. 105 ff. 
nence, including the President and Ex-Presidents of the United States, were interested enough in its work to read and contribute to its publications, and to address its meetings. During the ten years of its existence (1 $\$ 52-1 S 62)$, this society was without doubt by far the most potent factor in directing attention, both official and private, to the agricultural needs of the time. The society recorded itself, time after time, as favoring the establishment of a national department of agriculture to be equal in every respect to the other great executive departments. Presidents, in their messages to Congress, had frequently renewed the request of Washington, that some governmental machinery should be established to care for and promote the interests of agriculture; $;^{25}$ but it is to the work and influence of the United States Agricultural Society, more than anything else, that we are indebted for the passage on May 15,1862 , of an Act establishing an independent organization called the Department of Agriculture.

This measure, like so many others passed by Congress, was a compromise between two contending forces. While the new establishment was called a department and was independent of any of the existing administrative units, it was to be under the direction of a Commissioner, appointed by the President. It did not rank with the so-called executive departments, and its principal officer was not entitled to a place in the Presiclent's Cabinet Council. To this extent it fell considerably short of the expectations of the most enthusiastic proponents of the scheme. Nevertheless, all were agreed that the action taken was a long step toward the proper recognition of the great agricultural interests of the country, and marked the beginning of a new era for this industry.

It is remarkable that such legislation could have been exacted from Congress during what was, perhaps, the most

25 President Taylor in 1849. Messages and Pajers, vol. v, p. 18, President Fillmore in 1851, Ibid., vol. v, p. 127 , and President Lincoln, Ibid., vol. v, p. 398 . 
critical period of the Civil War. That the new Republican party, which had just come into full power, was in close alliance with the farming interests of the North is further attested by the passage, in this same year, of two other far-reaching acts in the interests of agriculture: that of June, I862, called the 'Morrill Act,' after its principal sponsor in the Senate, granting large tracts of public lands for the establishment of an agricultural college in each of the States; and the homestead law, which provided for giving public land to the individual who had occupied and improved it, instead of paying a purchase price.

The act of May I 5, I862, ${ }^{26}$ generally known as the 'organic act,' states, after the usual introduction and provision for the establishment of a Department of Agriculture, as already indicated, that the general designs and duties of such department "shall be to acquire and to diffuse among the people of the United States useful information on subjects connected with agriculture in the most general and comprehensive sense of that word, and to procure, propagate, and distribute among the people new and valuable seeds and plants." The act further provides for the appointment of a Commissioner of Agriculture at a salary of three thousand dollars and a chief clerk at two thousand dollars, and briefly outlines the duties and procedure of these officers.

The new department was established and began its operations at once. The agricultural appropriation act for the fiscal year I863 carried eighty thousand dollars, and the cntire amount was expended.

That the work of the department found favor with the people and Congress from the beginning is shown by the fact that its appropriations were increased from year to year even while the war continued. When peace was established, the department's activities soon began to expand to cover new ficlds and to include new subjects, some of which were probalily never contenplated by those who had sanctioned the organic act, broad and general as were some of

${ }^{26} 12$ Stat. L. 387. 
the terms of that measure. Chief among these new activities were the study of diseases and insects injurious to plants and domestic animals, and the best means of eradicating or suppressing such diseases and insect pests $; 27$ investigating the culture and manufacture of tea, silk, cotton, tobacco, and sugar;2s introducing new forage plants and grasses to improve grazing conditions in arid sections $:^{20}$ studying the effects of the adulteration of various foods; ${ }^{30}$ collecting statistics relating to the manufacture and food value of margarine, butterine, and other butter substitutes $;^{31}$ and experimenting in the field of aryicultural chemistry. ${ }^{32}$

By ISSt, the work of the Department relating to the protection and improvement of the live stock industry of the country had become so extensive that Congress deemed it advisable to create a new bureau. called the Bureau of Animal Industry, to have special charge of this work. This bureau was to be placed under the immediate direction of a veterinary surgeon, appointed by the Commissioner of Agriculture. ${ }^{33}$ It is noteworthy that this law was the first to confer upon the Department power to regulate the conduct of citizens, a power which is very important in the performance of its present functions.

The first appropriation for the investigation of subjects relating to forestry was made in $1876^{34}$ Ten years later, a division was established in the Department to further these investigations.

One writer ${ }^{35}$ has said that the year I 887 marks the beginning of at new stage in the derelopment of American agricul-

27 I 5 Stat. 283, 208; 20 Stat. L. 206, 240; 24 Stat. L. 100.

2821 Stat. L. 292,294 ; 22 Stat. L. 408,410 ; 12 Stat. L. 682, 691 ; 13 Stat. L. 22, 23: 21 Stat. L. 292, 295.

2924 Stat. L. 683 .

3024 Stat. L. Io0.

3122 Stat. L. 8 0 , go.

3212 Stat. L. 683 . For these and other acts see, "Laws applicable to the Department of Agriculture," compiled by Otis H. Gates, under the direction of the Solicitor of the Department.

${ }^{3} 23$ Stat. L. 31.

34 ig Stat. L. 143.

${ }^{85}$ T. N. Carver, Bailcy's Cyclopedia of American Agriculture, vol. iv, p. 68 . 
ture, primarily because it was in this year that the so-called Hatch Act, providing for the establishment of agricultural experiment stations, was passed by Congress. This was the beginning of a much more comprehensive application of experimental science in the field of agriculture than had been heretofore attempted.

Although the work of the Department thus continued to grow and expand, and correspondingly increased amounts of public funds were appropriated from year to year, the more ardent and enthusiastic leaders and representatives of agricultural associations and interests were not satisfied. At least as early as $1881,{ }^{36}$ agitation was renewed in Congress for the placing of the Department of Agriculture on a plane of equality with the other executive departments, with a secretary entitled to a place in the President's Cabinet.

Numerous petitions and memorials poured into Congress. The agitation was greatly accentuated by the granger and populist movements of this period. Much hope seemed to center in having a representative of the farming class in the immediate council of the President.

Attention has already been directed to the apprehension on the part of some members of Congress of the danger of establishing the precedent of giving to any special interest a place in the President's Cabinet. "Class legislation" the proposal was called by some. This argument was repeatedly brought forward during the years ISSi to i $S S 9$. Despite this and other objections, Congress finally yielded, and a bill raising the Department of Agriculture to the grade of an executive department with a Secretary of cabinet rank was passed, and approved by the President, February 9. I889. All existing laws pertaining to the Department remained substantially as before. Two days later President Cleveland nominated Norman J. Colnan, the Commissioner of Agriculture, as the first Secretary of Agriculture. The nomination was confirmed by the Senatc on February 13.

${ }^{36}$ Congressional Record, vol. xix, 4479. 


\section{TIIE UNITED STATES DEPARTMIENT OF AGRICULTURE}

Thus another victory had been won by the persistent and, for the most part, intelligent expression of public opinion.

\section{Period of Expansion, isS9 to I9I7}

Agriculture has been defined as "the art or science of cultivating the ground, especially in fields or in large quantities, including the preservation of the soil, the planting of seeds, the raising and harvesting of crops, and the rearing, feeding, and management of live-stock." ${ }^{37}$ The organic act of IS62, which is still in effect, authorizes the Department "to acquire and diffuse . . useful information on subjects connected with agriculture in the most general and comprehensive sense of the word ...."

Even with this broad scope of activity, it is difficult to see how some of the many laws which are now administered by the Department of Agriculture can logically be classed as agricultural legislation. On the other hand, it is asserted by an eminent authority, ${ }^{38}$ that extensive and far-reaching as the operations of the Department now are, they do not yet in all respects cover the field marked out for it in its charter.

The period which we are now considering, more than any previous one in American history, is characterized by the wide-spread assertion, on the part of the federal government, of what has been called its police power; that is, its power to regulate and supervise the conduct of individuals in the interest of the general welfare of society. Much of this type of legislation fills the modern statute books of the lesser units of government as well. Why there should have been such a great demand for legislation of this character we shall not stop to consider in detail. The great number of health and safety laws in recent years, according to Professor Freund, "represents less a change of legislative policy than a change of conditions that had to be met by

${ }_{37}$ Webster's Unabridged Dictionary, quoted in Dillard v. Webb, Ala. 474 .

${ }_{38} \wedge$. C. True in Ammals of American Academy of Political and Social Sciences, vol. xi, p. 10. 
an extension of state control";39 or, as Professor Turner says, it was the voice of the insurgent West "demanding increase of federal authority to curb the special interests, the powerful industrial organizations, and the monopolies, for the sake of the conservation of our natural resources and the preservation of American democracy." 40

It is not surprising, then, to find that of the very considerable number of recent laws, with whose administration the Department of Agriculture has been charged, a very large proportion of them should be of the regulatory type, or at least concerned with general social welfare. While the work of the Department has been and still is, primarily educational and investigational, there can be no doubt that the more recent expansion of its activities has been on the side of the regulation of the conduct of citizens. May we not say, then, that instead of this Department being an anomaly among the so-called political departments, as was feared by many at the time of its establishment, it is itself rapidly becoming one of them?

As already indicated, the regulatory work of the Department was inaugurated with the establishment of the Bureau of Animal Industry by special act of Congress in $18 S_{4}$. The primary intent of this act was to prevent the foreign exportation or interstate shipments of live stock affected with contagious, infectious, or communicable diseases. For a number of years this law was administered jointly by the Secretary of the Treasury and the Secretary of Agriculture. By act of February 2, $1903,{ }^{41}$ this authority was conferred exclusively on the latter of these officers, and his powers to prevent the spread of contagious discases of animals were considerably extended. Authority was granted the Secretary of Agriculture in $1890^{42}$ to inspect live stock imported into this country and prohibit the landing of any found to

30 Ernst Freund, Standards of American Legislation, p. 20.

$10 \mathrm{~F}$. J. Turner, "Social Forces in American History," in American Historical Review, vol. xvi, no. 2, p. 223.

1132 Stat. L. 79r.

4226 Stat. L. 414 . 
be infected with dangerous discases or of any which had recently been exposed to such discases. The so-called cattle quarantine act, ${ }^{43}$ which authorizes the Secretary of Agriculture to establish a quarantine in any state or district - found to be infected with contagions cliseases of animals, has the same general object, that is, the protection of the live stock industry.

One very potent force in bringing about this legislation was the prohibitions that had been established by foreign countries against American live stock and animal products and the consequent injury to the live stock business.

That the measures taken were effective is attested by President Harrison who said in his message to Congress in December, I89I :

If the establishment of the Department of Agriculture was regarded by any one as a mere concession to the unenlightened demand of a worthy class of pcople, that impression has been most effectually removed by the great results already obtained. . . The inspection by this Department of cattle and pork products intended for shipment abroad has been the basis of the success which has attended our efforts to secure the removal of the restrictions maintained by European governments. ${ }^{4}$

Two other measures which relate directly to the live stock industry are the so-called twenty-eight hour $1 a w^{45}$ and the virus act. ${ }^{48}$ The former of these is not so much intended to foster the live stock industry as to protect the animals thenusclves. Its enactment was brought about largely as a result of the work of humane societics. Briefly, it prohibits the confinement in railroad cars and boats of all animals in course of interstate transit for a period longer than twenty-eight hours without being unloaded for feed, water, and rest for at least five hours, except that, upon written request in advance, the period may be extended to thirty-six hours. Carriers may relieve themselves from the operation of this law by supplying the required facilities for

13 Act of March 3. 1905, 33 Stat. L. 126.4

11 Messages and Papers, vol. ix, p. 206.

13 Act of June 29, 1906, 34 Stat. L. 607.

45 Act of July 1, 1902, 32 Stat. L. 728; Act of Mar. 4, 1913, 37 Stat. L. 828 . 
feeding and watering on board. The virus act regulates the importation and interstate shipment of viruses and similar remedies for the treatment of animal diseases. While most of these laws were enacted primarily to promote the raising of live stock, to the extent that they are effective in increasing the consumable products from this source and improving the quality, they are of general benefit.

By no means all of the recent regulatory measures relate directly to the animal industry. The insecticide act, ${ }^{47}$ the plant quarantine act, ${ }^{48}$ and the seed importation act, ${ }^{49}$ have for their purpose the encouraging and protection of the business of growing plants and crops. The insecticide act is intended to prohibit the misbranding or adulteration of insecticides and fungicides manufactured in territory immediately subject to the United States or which moves in interstate commerce. The plant quarantine act is designed to prevent the spread of plant diseases by authorizing the regulation of importations of plants and the establishment of quarantines in infected districts. The seed importation act is intended, as the title suggests, to prohibit the importation of secds which are adulterated or which are for any other reason unfit for use.

The so-called Lacey Act, ${ }^{50}$ and the migratory bird act ${ }^{51}$ are primarily intended to assist the States in conserving the game supply, to protect insectivorous and other birds which are beneficial to agriculture, and to prevent the introduction of foreign animals or birds that would be injurious to plant life.

Two other regulatory laws, which have been committed to the Department of Agriculture for administrative purposes, are the meat inspection act ${ }^{52}$ and the well known food and drugs act of June 30 , $1906 .^{53}$ It need hardly be said that

${ }^{47}$ Act of $A$ pril 26, 1910, 36 Stat. L. 33I.

18 Act of Aug. 20, 1912, 37 Stat. L. 315.

10 Act of Aug. 24, 1912, 37 Stat. L. 506.

80 Act of May 25, 1900, 31 Stat. L. 187; Act of March 4, 1909, 35

Stat. L. 1088, 1137

${ }_{51}$ Act of March 4, 1913, 37 Stat. L. 828, 847.

82 Act of June 30, 1906, 34 Stat. L. $660,674$.

5334 Stat. L. 768. 
both of these are primarily designed as health measures and as such relate no more to the agricultural class than to any other. These measures form an important part of that body of restrictive legislation which marks the second acl- ministration of President Roosevelt as a period of moral awakening. They are administered by the Department of Agriculture simply because that department, by reason of its facilities, was better prepared for the task than any other. A summary of these laws will be given in another chapter. ${ }^{54}$

The cotton futures act, which was cnacted in 1914 and re-enacted with amendments in 1917 , is a regulatory measure of a somewhat different character from those which have previously been mentioned. Its object is to regulate and supervise trading in cotton, particularly future trading; but instead of fixing penalties, it levies a tax which must be paid under certain conditions. Thus it is incidentally a revenue measure, and, as such, finds its constitutional basis in the taxing power of Congress. More will be said later of its content and enforcement. ${ }^{55}$

Not all of the laws which have been committed for administrative purposes to the Department of Agriculture, during the period now under consideration, have been of the regulatory or police type. Several very important educational and constructive measures have been cnacted by Congress and added to the work of the Department. Some of these, particularly those that have been enacted in very recent years, involve varying degrees of cooperation on the part of the respective States.

The work of the agricultural colleges established under the land grant act of $1 \$ 62$ was so favorably received that a further endowment of public funds amounting to $\$ 25.000$ a year for cach college was made in I 890 . Both of these acts are under the administration of the Department of the Interior, but they represent very important agricultural legislation. ${ }^{56}$

84 Chapter iv.
85 lbid.
86 Stat. L. 419. 
The Hatch Act of 1887 , which did so much to place agriculture on a higher basis by providing for the establishment of experiment stations throughout the States, was supplemented in 1906 by what is known as the Adams Act, after its chief sponsor, Henry C. Adams. Under this act the amount of money to be granted to each State was doubled so that it now aggregates $\$ 30,000$ per annum for each State. ${ }^{57}$

As early as 1876 , the Department had begun the study of problems relating to forestry. Under an act of Congress, approved February I, I $905,^{58}$ the administration of the vast forest reserves in the United States was transferred from the Department of the Interior to the Department of Agriculture. This work has continued to grow, both in scope and importance, as the area of forest reserves has been increased and the need for conserving and enlarging our timber resources has been more clearly discerned.

Perhaps the most significant and far-reaching piece of agricultural legislation in recent years is that of May 8 , I9I4, commonly known as the Smith-Lever Act. ${ }^{59}$ By the year 1923, there will be appropriated under this law an annual sum exceeding five million dollars, to be expended in cooperation with state institutions, for practical instruction and demonstration in agriculture and home economics. Under the terms of the act, this large sum must be supplemented by at least an equal amount appropriated by or on behalf of the States. Wisely expended, such a sum of money should make this measure, "the greatest piece of agricultural legislation ever enacted by any country."

Another cooperative law of first rate inportance is that known as the Federal Aid Road Act, approved July II, I9I $6 .{ }^{80}$ The administration of these and other measures involving cooperation between the Department of Agriculture and other governmental agencies will be treated in another chapter ${ }^{01}$

${ }^{87} 34$ Stat. L. 63.

5833 Stat. L. 628.

5038 Stat. L. 372.

${ }^{60} 39$ Stat. I.. 355.

01 Chapter iii. 
The United States Grain Standards Act, ${ }^{62}$ authorizing and directing the Secretary of Agriculture to determine and establish official standards to be used in interstate and foreign commerce in grains. and the United States WVarchouse Act, ${ }^{63}$ authorizing the Secretary of Agriculture to issue licenses to, and require bonds from, owners or managers of warchouses used for the storage of agricultural products, who desire to conduct their business under federal control, furnish striking evidence of the ever increasing scope of the central government in general, and of the Department of Agriculture in particular.

When Congress, as a part of the legislative policy it has adopted, specifically authorizes and instructs an executive department or officer to perform certain functions, it is, of conrse, incumbent upon that body to appropriate the necessary funds as the need therefor arises. Such is the case with most of the statutes which have been cnumerated above. Very much, in fact, the major part of the work of the Department of Agriculture derives its legal authority, not from the enactment of permanent laws, but from the appropriations that are made by Congress from year to year. This is particularly true of the experimental, investigational, and educational activities. Many divisions, and, indeed. entire burcaus owe their existence to the annual appropriation acts; and would cease to exist by the mere failure of Congress to appropriate the necessary funds, without the repeal of any existing law.

It would be outside the scope of the present study to attempt to give anything like an adequate idea of the present work of the Department of Agriculture when viewed as a whole. Nuch less would it be possible to give any dependalile estimate of the value of this work to the people of the country. From its beginning in 1839 up to $A$ pril, 1917 , the Department of Agriculture cost the people of the United

\footnotetext{
1239 Stat. I. 482 .
}

6.3 Stat. L. 486. 
States approximately two hundred and eighty-five million dollars. Various attempts have been made to show that this sum is a mere bagatelle when compared with the huge increase in agricultural production directly attributable to better and more scientific methods of farming. That farming is now generally conducted on a better basis no one will deny. To what extent this improvement may be credited directly to the work of the Department of Agriculture is more problematical. There seems to be no question, however, but what it has been the chief and most valuable single agency. That this is the belief of those whom we elect to represent us in Congress is abundantly evidenced by the ever increasing number of activities with which it is charged, and the ever mounting sums of public funds placed at its disposal. Small as these sums may be when compared with those necessary for the conduct of some of the other departments of the Government, the rate of increase is most significant. ${ }^{64}$

Beginning with a single clerkship in the patent office in I843, it now numbers its officers and employees by the thousands. In 1917 not less than eighteen thousand seven hundred and fifty men and women, most of them specially trained for their respective tasks, were devoting their time to the multitudinous duties of the Department of Agriculture. As previously indicated, not all of the work of this department is directly in the interest of agriculture and the agricultural class. However, the welfare of the farming industry and of those who carry it on is still, and probably will continue to be, the goal and raison d'ctre of this inportant agency of government.

Having briefly traced some of the forces that have been

${ }^{64}$ In his report for $189 \mathrm{r}$, Secretary Rusk said: "In concluding the review of the work done under the several divisions of this Department since the date of my last annual report, it gives me pleasure to state, and I say this advisedly, that each one of more than a dozen divisions whose work I have reviewed has returned in actual value to the country during the past year far more than the entire annual appropriation accorderl to this Department." 


\section{THE UNITED STATES DEPARTMENT OF AGRICULTURE}

active in shaping what might be termed the policy of the federal government toward the agricultural interests of the conntry, and having seen how at least a part of that policy has been translated by Congress into concrete laws, let us - now examine the kind of institution that has been developed and organized in order that the will of the people thus translated and expressed may actually be carried into effect. 


\section{CHAPTER II}

\section{The Present Organization of the United States Departaient of Agriculture ${ }^{1}$}

Administration has been called the "function of execution." 2 In other words, it is the carrying out or the execution of the expressed will of that organ of government which is authorized to say what the law shall be. For the most part, it consists of applying general rules or laws to individual cases, as need therefor arises. How satisfactorily and effectively this shall be done depends, in large measure, upon the character of the organization of machinery that has been developed for the performance of this function.

The executive branch of the federal government, as is well known, consists of one great hierarchy with the President of the United States at its head. While he does not have the power, as we shall see later, of determining the nature of the machinery that shall be instituted for making effective the expressed will of the legislative body, he is held responsible for its proper and efficient operation. To this end he has been given an important voice in the selection of those persons upon whom he must rely, and a practically unqualified power to remove from office any of these persons whom he may deem unfitted for the place. ${ }^{3}$

The Department of Agriculture, like the other federal

\footnotetext{
1 For an outline of the organization according to subdivisions and functions, see Appendix I.

2 Goodnow, Comparative Administrative Law, vol, i, p. 5.

3 "Within itself the federal administration is a single administration. All of its subdivisions are internal ones as in the case with any centralized administration; while in any decentralized adninistration, like that of the states, the organization is based upon external division." (Wyman, Administrative Law, p. 187. See also Team v's. Davis, 100 U. S. 257; in re Neagle, 135 U. S. 1.)
} 
executive departments, and unlike the corresponding institutions in the various States, is a smaller hierarchy within a larger one, with the Secretary of Agriculture at its head. It is true that there are a few of the subordinates of the Secretary in whose appointment he does rot share, and who are therefore not subject to his power of removal. He is, however, responsible to the President for the work of all of his subordinates and of the department as a whole.

All of the officials of the Department of Agriculture, except the Secretary, the Assistant Secretary, the Chief of the Weather Bureau, and the Solicitor are in the classified civil service. Perhaps no other department of the Government is so nearly free from the evils of political appointments. The expert scientific and technical knowledge which bureau chicfs and other important officials must have for the proper performance of their cluties, and the added value which long and certain tenure of office gives to their services, have operated to remove these positions almost entirely from the domain of politics. Both Congress and the successive Secretarics have very wisely allowed these men to remain undisturbed irrespective of party allegiance. The great majority of the appointments to office are regularly made from the registers of the Civil Service Commission. Even the relatively large number of technical and scientific experts who, in accordance with special legislation, might have been appointed outside the classified civil service, have been almost invariably selected with reference to their qualifications for the work expected of them, after an examination prepared by representatives of the Department and conducted by the Civil Service Commission.

That the elevation of the Department to the first rank of governmental establishments, and its consequently close relationship with the presidential office and with practical politics, have not resulted in a departure from non-partisan and scientific ideals in its work should be encouraging to all who are interested in the improvement of the civil service.

The Presiclent's Cabinet, and the great executive depart- 
ments of the federal government are political and administrative devices which have grown up almost wholly outside of the written Constitution. It is true that in the enumeration of the powers and duties of the executive branch of the government, reference is made to "executive departments" and to the principal officers thereof $;^{4}$ but there is only the slightest indication as to how these departments are to be brought into existence and organized. In speaking of the President's power of appointment the Constitution enumerates certain officers, "and all other officers of the United States whose appointn ents are not herein otherwise provided for, and which shall be established by law." Goodnow thinks we may assume from these clauses that the men who framed the Constitution intended that there should be executive departments and that the power to organize them was to be vested in Congress. ${ }^{5}$

The President's Cabinet, says Dr. Learned, "came into being as one result of the discretionary power with which the makers of the Constitution intended to endow the chief magistrate. It was created by President Washington in the opening years of our Government under the Constitution in response to a demand of the President for a board of qualified assistants and confidential advisers, a demand so fundamental and natural as to be felt, but not anywhere at that time definitely formulated or at all clearly expressed."

If we grant that the formation of a small advisory council grew out of the immediate necds of the President for such assistance when the Government was first established under the Constitution, the same cannot be said of the creation of the executive departments of which these first officers, and others of similar rank, have become the heads. The power to create and organize all of the machinery of government, except that which is specifically provided for in the Constitution itself has from the first been assumed and exercised by Congress. To what extent Congress shall

4 Art. 2, sec. 2.

5 Goodnow, Principles of Administrative Law of the U. S., p. 122.

${ }^{6} \mathrm{H}$. B. Learned, The President's Cabinet, p. $3(x)$. 
go in fixing and regulating the details of organization within the various units of government created, is a matter which lies wholly within the discretion of that body. In practice, however, there seems to have been no uniform policy. In some instances great care has been taken to provide, in advance, the exact type of organization, and to fix not only the dutics and powers of the head of the department, but also those of his subordinates as well. In other cases, the department head has merely been intrusted with certain powers or charged with certain duties and the organization of the machinery necessary for carrying these into effect has been left almost entirely to him. However, when a permancnt organization is formed as a result of administrative action it generally reccives legislative sanction, either expressed or implicd, by the subsequent appropriation of money for its continuance. ${ }^{7}$

In the law of 1862 , providing for the establishment of the Department of Agriculture, very little was said about the kind of organization that was to be effected. Only two officers were mentioned-a Commissioner of Agriculture and a chief clerk. One duty of the latter was to appoint, as Congress from time to time made provision therefor, chemists, botanists, entomologists and other persons skilled in the sciences pertaining to agriculture. As the work of the Department expanded such persons were appointed. Generally, the only congressional approval obtained for such appointments was the appropriation of funds for the payment of additional salaries and expenses upon the recommendation of the department head. In a similar manner, divisions, and later, bureaus, were organized to carry on the principal lines of work. This has not always been the case, however. In some instances burcaus have been added or transferred by specific legislation, as was the case in the establishment of the Burcau of Animal Industry in I884, and the transfer of the Weather Burcau from the War Department to the Department of Agriculture in $1891 .{ }^{8}$

I Gondnow. Principles of Administrative Law of the U. S., p. 75. 826 Stat. L. 653. 
Prior to 1913, by far the greater part of the work of the Department, aside from its regulatory activities, was concerned primarily with the improvement, both in quality and quantity, of crop and animal production. As the result of years of careful experimentation, many notable improvements were made in the agricultural flora and fauna of the country. While a great deal of money and effort had been expended in trying to raise the standard of agricultural science and to better the farm products, and while, admittedly, very much had been accomplished in this direction, it was the belief of the present Secretary of Agriculture, who came into office in March, I9I3, that the greater part of this vast fund of accumulated information was not readily available, and consequently not utilized, largely because of defective methods for its proper dissemination among the farmers. The betterment of methods for the more effective education of those engaged directly in agriculture has been, and still is, an important part of the policy of the present administration.

Until very recent years, very little attention has been given, either by federal or state institutions, to that phase of agriculture which might be summed up under the head of agricultural economics, or more specifically, the marketing of farm products, rural credits and finance, and the organization of farmers and rural communities. There were many persons who agreed with the present Secretary of Agriculture that these problems had been neglected to the great detriment of the agricultural interests of the country, and that special attention should at once be given to their solution."

Very largely as a result of this new attitude, and at his own request, the agricultural appropriation act for the fiscal year I9I5 authorized and directed the Secretary of Agriculture "to prepare a plan for reorganizing, redirecting, and systematizing the work of the department as the inter-

9 Report of the Secretary of Agriculture, 1916, p. 9. See also article on "Agricultural Organizations" in Bailey's Cyclopeclia of American Agriculture. 
ests of cconomical and efficient administration may require." 10

Complying with these instructions, a plan of reorganization was submitted in the Book of Estimates of appropriations for the fiscal ycar I916, the estimates for the Department of Agriculture for that year being based upon the proposed plan. The recommendations were accepted by Congress practically as submitted, and were approved by the act of March 4 , $1915 .{ }^{11}$

As alrcady indicated, the object of this latest reorganization was not to change radically the normal functions of the department. but rather to make possible a change of emphasis among these functions. It is true that as a result of this and other legislation of the last few years, new functions have been added, and many older ones have been greatly stimulated and enlarged; but with a few minor exceptions the previously existing organization, with its bureaus, offices, divisions and sections, was not changed. In a few instances new designations were adopted which were intended to indicate more clearly the principal functions of the various mints. The important changes that were made had to do with the re-grouping and the reapportionment of the activities of the department.

In making these changes, four fairly distinct objects were kept in view : first, the aroidance of all unnecessary duplication of cffort; sccond, the assignment of each activity to that subdivision which was best adapted to the proper handling of it; third, the provision of more and better facilities for performing those functions which it was desired to emplnasize; and fourth, the division of the activities of each bureau into three distinct groups comprising, respectively, its regulatory, its research, and its educational functions.

At first glance, it might appear that a more logical grouping would have been secured by giving to certain bureaus all of the regulatory work, to others all of the research work,

1038 Stat. L. 415.

1138 Stat. L. 1086. 
and to still others all of the educational work; but, as we shall see later, such a division would have been very undesirable, if not impossible.

The primary subdivision in the Department of Agriculture, as in the other federal departments, is the bureau. Not all of the units of this rank are called bureaus, because of the selection in some instances of designations that are intended to indicate more clearly the functions performed. For instance, the bureau which is charged with the administration of most of the acts of Congress involving cooperation with the various States, is called the States Relations Service. The difference, however, is merely in the name, and not in its relation to the head of the department or to the units of the same rank. Each bureau is under the supervision of a bureau chief who is directly responsible to the Secretary. In the larger bureaus, much of the administrative work is under the immediate direction of an assistant chief of bureau, who, in the absence of the chief, becomes the acting head. The principal administrative units within the bureau are generally known as divisions. These vary in number according to the number of distinct activities which have been assigned to the bureau. Where the work of the division is very large or diverse, this unit is in turn subdivided into lesser units called sections. In some instances, where the work of the section is unified, not voluminous, and not related to the work of any division, the head of the section is associated administratively directly with the chief of bureau. For purposes of centering responsibility and giving definiteness to the work, divisions and sections are sometimes still further divided into projects. These projects are immediately supervised by a project leader who reports to the section or division head.

Not all of the activities of the department are grouped into bureaus for administrative purposes. Those functions which relate to the department as a whole have been assigned to units which although not forming a part of any bureau, are ranked as divisions, whose principal ofticers are 
directly responsible to the department head. Examples of this are the Division of Publications and the Division of Accounts and Disbursements. Other activities have, by law, been assigned to boards composed of representatives from - various bureaus. Such units as this constitute anomalies in the general scheme of organization. Still other activities are, for various reasons, carried on by units which form integral parts of the Secretary's office. These subdivisions are designated as offices, with appropriate names to indicate their principal functions.

This general plan of organization, with its rather numerous divisions and subdivisions has been criticised as constituting too wide a gap between those officers who are directly engaged in doing the actual work of the department and those who are responsible for the success or failure of that work. Such a condition, it is asserted, is conducive to what is called government "red-tape" and the consequent loss of energy and proper understanding. It is true that many of the principal administrative officers have a very inadequate appreciation of some of the work which they are directing.

In an organization whose activities are fairly unified, or which are sufficiently simple that they might be grasped in some cletail by one or a few men, such a criticism as the above would be valid. But in an institution such as the Department of $\Lambda$ griculture, with its extensive field of operation and its multiplicity of diverse activities, it is impossible for one man to obtain a comprehensive grasp of the whole. The same is largely true even in some of the larger bureaus. Chiefs of bureaus are not always sufficiently familiar with the details of their respective functions to give them the most effective direction and coordination. Furthermore, these men are for the most part trained scientists and not trained administrators. Frequently, their special scientific interests claim their time and attention to the detriment of other equally important administrative problems.

Perhaps the only effective way to remove this administra- 
tive difficulty would be to create additional bureaus. In the opinion of those responsible for the present plan of organization, the creation of more bureaus, and the consequent increase in overhead expenditures, the splitting up of functions that are naturally similar in character and the resultant duplication of equipment and effort would more than offset any possible advantages to be gained by a more intimate relationship between administrator and worker.

The organization, as effected under the act of March 4, IOI $5,{ }^{1 \times}$ and as at present recognized by Congress, consists of eighteen fairly distinct administrative units, comprising eleven bureaus, two offices, two divisions, two boards, and a library. In order to indicate how the entire work of the department has been distributed for administrative purposes, it is believed advisable to give a very brief summary of the principal functions of each of these units. Changes in the assignment of minor duties, are, of course, made from time to time; but it is very unlikely that any important changes will occur except as a result of a complete reorganization. ${ }^{13}$

\section{Office of the Secretary}

The office of the Secretary exercises general administrative or supervisory authority over the entire personnel and activities of the department. The Assistant Secretary is required to perform such duties as may be assigned to him by the Secretary. ${ }^{14}$ In case of the absence or disability of the Sccretary, the Assistant Secretary may act as Secretary. If both of these be absent or disabled, the Chicf of the Weather Bureat, the only other officer whose appointment is subject to confirmation by the Senate, acts as Secretary.

\footnotetext{
1238 Stat. 1086
}

13 In summarizing the work of the various units, the "Progran of Work of the U. S. Dept. of Agriculture for the fiscal year I917" has been used. No account has been taken here or elsewhere of the numerous and important war activities undertaken by the Department since April, 1917. Wlite these may result in some permanent changes both in the organization and duties of the Departunent, their temporary character makes it seem inadvisable to include them here.

${ }^{11} 34$ Stat. L. 1256. 
Rather peculiarly, the principal subdivisions of the Secretary's office are also called offices. These are: the Office of the Chief Clerk, the Office of Information, the Office of Inspection, the Office of Exhibits, the Office of Forest Appeals, and the Office of the Solicitor.

The Chief Clerk is charged by law with the general supervision of the duties of the clerical workers of the Department ${ }^{15}$ and the superintendence of the buildings occupied by the department. ${ }^{16}$ He also makes provision for the securing of supplies and miscellaneous services. In the performance of his duties the Chief Clerk cooperates very closely with the chief clerks of the principal units of the departments; whose dutics, within their respective spheres, are similar to his own. As an aid in the enforcement of the gencral administrative regulations of the department, the regulations have been conveniently arranged in a small manual, which is supplemented by the issuance of general orders, either by the Secretary or the Chief Clerk, as the need therefor arises.

The primary function of the Chief of Information is to prepare and issue to the press current information regarding the work of the department in general. It also issues a weckly news letter containing seasonal and other information in popular form.

The Office of Inspection assists the Secretary in adjusting financial claims made against the department or units thereof, and in matters pertaining to persomnel inspection.

The Office of Exhibits has direct charge of all matters relating to agricultural exhibits made by the department at fairs and expositions.

The Office of Forest Appeals was created to assist the Secretary in reaching final decisions on appeals made from the decisions of the Forest Service in matters relating to the administration of the national forests.

As the name implies, the Office of the Solicitor is con-

18 Rev. Stat. secs. 173, 174.

${ }^{10} 36$ Stat. L. 417. 
cerned with the supervision and direction of the legal work of the department, ${ }^{17}$ including that connected with the enforcement of the various regulatory laws.

The Office of Farm Management is another unit of the department which is administratively closely associated with the Secretary's office, but is not integrally a part of it. Its primary function is the investigation of various types of farm organization and management, including studies of the cost of production of various agricultural products, and farm accounting.

\section{The Weather Bureau}

The Weather Bureau was transferred to the Department of Agriculture in I89I. ${ }^{18}$ Its principal duties are the forecasting of the weather; the issue and display of weather and storm warnings for the benefit of agriculture, commerce, and navigation; and the study and observation of various climatic conditions in order that dependable records may be kept. Numerous stations and substations have been established throughout the country. This bureau has no regulatory duties.

\section{Bureau of Animal Industry}

As previously indicated, this bureau was established by special act of Congress for the purpose of encouraging and protecting the live stock and meat industries of the United States. Besides conducting scientific investigations relating to the production and care of domestic animals, and the causes and prevention of animal diseases, this bureau is charged with the administration of all the regulatory laws relating to the live stock industry. In this latter function, as we shall see in a later chapter, this bureau cooperates very closely with the Solicitor's office.

\section{Bureau of Plant Industry}

This bureau is charged with the investigation of those problems which have to do with agricultural production. It

${ }^{17} 36$ Stat. I. 417.

1826 Stat. L. 653. 
conducts studies in the causes and prevention of plant discascs: of methods of improving soil fertility, of plant breeding, of the introduction of foreign seeds and plants, and of many other phases of crop production. It las charge of - the administration of the seed-importation act.

\section{Forest Service}

The Forest Service was estahished as a bureau in 1902.." For many years prior to this time, investigations relating to forestry had been carried on by a division in the department. Such investigations are still continued: but since 1905. the chicf work of this bureau has been the administration of the numerous laws and regulations relating to the vast national forests of the country.

\section{BURE.IL OF CIIENISTRY}

The work of the present Bureatn of Chemistry is the outgrowth of a small appropriation made in $S_{4} S$ for the chen:ical analyses of regetable substances. Since then its investigations have been extended to cover a wide range of food products including eggs, poultry, and fish. It also engages in chemical investigations for other departments of the Government. In addition to its investigative work, this bureau, becance of its excellent laboratory facilitics, has been charged with the administration of the food and drugs act of 1906 and the annendments thereto. This involves the analysis of numerous samples of foods and drugs, which are collected and sent in by agents of the burcau who are scattered throughout the country. This law and its administration will be treated in detail in a later chapter. ${ }^{20}$

\section{Bureau of Soils}

As the name implies, this bureau is primarily concerned with the chemical and plysical analyses of soils. It has

1932 Stat. I. 295.

20 Chapter iv. 
made numerous and extensive soil surveys in various parts of the country. Because of the recently increased demand for natural fertilizers, this bureau has begun extensive investigations of the fertilizer resources of the United States. It also assists in the classification of agricultural lands on the reclamation projects and in the national forest reserves.

\section{Bureau of Entomology}

The Bureau of Entomology conducts extensive investigations relating to insects, particularly those which are injurious or beneficial to plant or animal life and the best means of destroying those found to be injurious. It assists in supervising and enforcing such quarantines as are established by the Secretary for the prevention of the spread of insect pests.

\section{Bureau of Biological Survey}

This burcan is charged with the maintenance and supervision of the various game bird reservations that have been established in recent years. It conducts investigations regarding the food habits of birds and wild animals; makes surveys relating to the supply, migrations, and geographic distribution of such birds and animals; carries on experiments and demonstrations in the control or eradication of birds and animals which are injurions to agriculture and animal husbandry; and cooperates with state agencies in the protection of game. This bureau is also in charge of the administration of the two federal laws which have been passed for the protection of wild game.

\section{Bureau of Crop Esthmates}

The principal function of this bureau is the securing, and compiling of data regarding crop and animal production and the making and publishing of periodical estimates based thereon. Most of its information is derived from reports reccived from thousands of voluntary crop reporters. These reports are cliecked and compared with nore general 
reports received from county reporters, and with information received from a salaried agent in each state whose duty it is to inspect and supervise the work of the voluntary reporters. This bureau also collects numerous agricultural - statistics relating to foreign and domestic agriculture. This latter was the principal object contemplated under the original federal appropriation for agriculture in $S_{3}$.

\section{States Relation Service}

Prior to the reorganization of the department in I9I 5, this unit was known as the Office of Experiment Stations, because it had been established primarily for the purpose of supervising and coordinating the work of these State institutions. As a result of the more logical re-grouping of the department's activities, its scope was enlarged to include the supervision of practically all of the work involving direct cooperation with state agricultural institutions, including the very extensive work contemplated under the Smith-Lever Act of May, 19I4. The functions of this burean are thus almost entirely regulatory and educational. It docs, however, carry on important research work in the ficld of home economics and methods of agricultural education. An examination of its coopcration with state institutions will form an important part of the following cliapter.

\section{Office of Public Roads and Rural Engineering}

While this unit is not officially designated as a bureau, it docs have very nearly the same administrative status. It is one of those units which has no independent statutory basis, lut exists solely by virtue of the annual appropriations made by Congress.

Its chief function is the investigation of methods of road construction, maintenance and management; experimenting with various linds of road materials; and giving expert advice relating to these subjects. Since the reorganization in I I 5 , it also investigates and advises upon questions con- 
nected with irrigation, farm drainage, and other rural and agricultural engineering problems. It also supervises the administration of the recently enacted Federal Aid Road Act. $^{21}$

\section{Bureau of Markets}

The Bureau of Markets, although the newest of the principal subdivisions of the department, has grown to be almost the largest from the standpoint of amount of money expended and the number of people employed. This is one noteworthy result of the great emphasis that has been placed upon agricultural economics during the last four or five years.

The investigational work of this new bureau centers around the transportation, marketing and distribution of farm products, and the improvement and encouragement of cooperative efforts, both economical and social, among farmers. It also does important investigational work in the testing of cotton and in the establishment and demonstration of market grades and standards. In addition to its investigative functions, this bureau is charged with the administration of three very important regulatory measures: the United States cotton futures act, the United States warehouse act, and the United States grain-standards act. This important work will receive further consideration. ${ }^{2}$

\section{Miscellaneous}

Other subdivisions of the department are: The Division of Accounts and Disbursements, which exercises general supervision over the fiscal affairs of the department; The Division of Pulblications, which supervises the printing and publication work of the entirc department; The Insecticide and Fungicide Board, already mentioned, which supervises the enforcement of the insecticide act; The Federal Horticultural Board, created by the Secretary by direction of

21 See chapter iii.

22 See chapter iv. 
Congress, to assist in the administration of the plant quarantine act; and the Library, which is considered to be one of the largest and most valuable collections of scientific books and materials bearing upon agriculture in the world.

From this very brief summary of the principal lines of work of the Department of Agriculture, some conception may be gained of the multiplicity of activities of this-one of the most recently created-federal exccutive department. It is only by sucl detailed study that we are enabled adequately to appreciate the tremendous work of the Government, and the administrative machinery required for its proper execution.

The revelations are all the more impressive when it is remembered that we are living under a political system founded on the theory that the great majority of the subjects about which we have been speaking are matters originally considered to be primarily of local concern and hence not within the domain or sphere of the central government.

In what has been written thus far, frequent reference has been made to the cooperation of the Department of Agriculture with other governmental agencies in the performance of its duties. It will be our purpose in the following chapter to consider in some detail the administrative organization and methods involved in this cooperation. 


\section{CHAPTER III}

\section{Cooperative Relations of the Department of Agricul- ture with Other Federal Services aNd with State Institutions}

As indicated in the preceding chapters, one objective in the development of the organization of the Department of Agriculture, and particularly in the reorganization effected in 1915, has been the bringing together into one bureau or other subdivision of those activities which are, by their nature, closely related. In general, this has been accomplished with marked success. However, there are certain to be here, as in other administrative organs whose activities are numerous and varied, many functions which are difficult properly to classify and to assign. Should the investigation of soil fertilizers and fertilization be made a part of the general study of soils, or is it more closely related to the subject of crop production? Should the work of eradication of insect pests which are alike harmful to fruit trees, shade trees, and forest trees be assigned to the Forest Service or to the Bureau of Plant Industry? These and similar questions are constantly being presented for solution. Indeed, the proper distribution of functions so that they will be most effectively performed, with a minimum waste of energy and the least duplication of effort, is here, as elsewhere, a primary concern of the general administrator. Generally, careful attention to all of the factors involved will make a logical and satisfactory assignment possible. In rare instances, an arbitrary decision may be necessary.

Where the grouping of functions has not been predetermined by legislative enactment, ${ }^{1}$ it is the general adninis-

1 Discussion of the fundamental problems here suggested, viz., should administrative functions be assigned by legislative or by administrative agencies? - has beeu purposely avoided as not properly 
trative policy of the Department of Agriculture to assign each activity to that subdivision which, all things considered, seems best fitted to perform it effectively. When the activity in question is related to the work of two or more administrative units, effort is made to avoid friction and duplication by close cooperation between the subdivisions involved.

No attempt will be made to trace the numerous forms which such cooperation may take. It may be very formal, based upon a written agreement which stipulates the duties to be performed and the expenditures to be made by each mit; it may be informal, based upon a verbal agreement or understanding; or it may be merely the common use of certain facilities or materials. In the main, these intermal cooperative efforts have accomplished the desired ends.

When Congress assumes the tasli, as it commonly does in larger matters, and frequently does even in detail, of not only creating the administrative machinery, but also assigning the tasks which each unit shall perform; that body is confronted with essentially the same problems as confront the administrator when these questions are not predetermined for him. That Congress has not always fully appreciated the nature of its task is shown by the incongruities which have existed, and which to some extent still exist, in the work of the executive departments. The existence of these anomalies is largely attributable to the more rapid growth of governmental activities than of governmental machinery or organization. The reluctance of Congress to create additional executive departments has resulted not only in the overtaxing of department heads, but also in the bringing together, in some instances, of many totally unrelated functions. In recent years an outlet has been found in the creation of mumerous independent boards and commissions.

Another constantly recurring problem for the National

forming a part of the present study. For a discussion of this question, see Goodnow, Principles of Administrative Law of the United States, P. 90, and Freund, Standards of American Legislation, p. 143. 
Legislature is the assigning of those activities which are essentially related to the work already being done by two or more departments. Suppose it is decided that all importations of food shall be rigidly examined before they are permitted to enter the channels of domestic trade. Should the administration of a law, designed to accomplish this end, be assigned to the Treasury Department, which already has inspectors situated at the ports of entry, but has no facilities for the analyzing of foods; should it be assigned to the Department of Agriculture, which has splendid facilities for the testing of foods, but has no agents at the ports; or should an entirely new organization be created? Generally, the solntion in such a situation has been to charge one department with the enforcement of the law in question, and to impose upon other departments or officials the duty of giving such information or assistance as their facilities or position especially qualify them to give. The proper administration of this type of laws requires various kinds of cooperative arrangements between the departments or other units concerned. The form which this cooperation shall take is largely determined by the nature of the task to be performed under the law. It will be the purpose of the next few paragraphs to show, by giving some typical examples, how the expert knowledge and facilities of the Department of Agriculture are utilized in the administration of these cooperative measures.

In order to encourage the introduction of improved breeds of domestic animals into this conntry, paragraph three hundred and ninety-seven of the tariff of October I 3 . I9I3, provides for the free entry of certain animals imported for breeding purposes. Under the further provisions of this paragraph, customs officials must obtain for the frec entry of such animals, certificates issued by the Department of Agriculture stating that the animals are pure bred, of a recognized breed, and duly registered in the foreign book of record established for that breed. Upon the arrival of the animals at the port of entry, notice is sent to the Secretary 
of Agriculture. They are then examined by a representative of the Department of Agriculture, who reports to the Washington office the breed, sex, age, color, and markings. In case the data on the foreign certificate does not agree with the animal imported, the certificate of pure breeding will not be issued. Where all papers are found to be satisfactory, the certificate of pure breeding is sent to the collector of customs, and the foreign certificate is authenticated and returned to the importer. ${ }^{2}$

The enforcement of the various laws which have been enacted to prevent the importation and the exportation of diseased animals, animal products, and plants requires the closest cooperation between the officials of the Department of Agriculture and those of the Treasury Department. As the Department of Agriculture has no regular corps of port inspectors, it must rely very largely upon Treasury officials for primary information regarding shipments.

The prevalence of dangerous animal diseases in countries from which the United States obtains hides, and other animal by-products, was the occasion for the recent issue of what is known as Treasury Department and Department of Agriculture Joint Order No. I, entitled, "Regulations gorerning the certification and disinfection of hides, fleshings, hide cuttings, parings, and glue stock, sheep-skins and goatskins and parts thereof, hair, wool, and other animal byproducts, hay, straw, forage or similar material offered for entry into the United States." 3 It provides for the careful handling of the various products mentioned and their disinfection under official supervision, either at the port of entry or at the point of destination.

Such regulations as these are binding upon the officials of both departments issuing them; and have, of course, the same force as the law upon which they are predicated.

The work of collecting and introducing into the United States specimens of forcign plants and animals, which was

2 Act of Aug. 5, 19m, 36 Stat. L. 11.

${ }^{3}$ This Joint Order is dated Oct. 21, 1916, effective Jan. I, 1917. 
assumed by Franklin and other early American representatives in foreign countries, has now been made a part of the regular duties of diplomatic and consular agents. The instructions issued by the Department of State now require that these officials cooperate with the Department of Agriculture, either by actually collecting and transmitting specimens believed to be of value, or by making arrangements, for scientific exploration parties. ${ }^{4}$ Diplomatic and consular officers are also required by law to procure and transmit, for the use of the Department of Agriculture "monthly reports relative to the character, condition, and prospective yields of the agricultural and horticultural industries and other fruiteries of the country in which they are respectively stationed." 5

The work of the Department of the Interior and that of the Department of Agriculture touches and overlaps at so many points that it is sometimes difficult for Congress and the department heads properly to determine their respective spheres. Indeed, it may truthfully be said that the newer department is largely an outgrowth or overflow from the older. Despite the many shiftings of functions from one department to the other, there are still many activities in which there must be close cooperation and definite understanding. The administration of the national forests is under the control of the Department of Agriculture; but the national parks, which for the most part are situated within and form a part of the national forest reserves, are administered by the Department of the Interior. The installation and management of the great irrigation reclamation projects form an important part of the work of the Department of the Interior; but the investigation of methods of irrigation, canal construction, the determination of the amount of water required for the growing of various crops, and the demonstration of the use of irrigation water upon the land

- Program of Work, pp. 199-200.

5 Rev. Stat. sec. 1712, as amended by Act of June 18, 1888,25 Stat. L. 186. 
reclaimed under the projects have all been assigned to the Department of Agriculture.

Here, as elsewhere, the degree and form of cooperation are determined by the nature of the task to be accomplished in cach case.

Numerous additional examples might be given to show at least some of the difficulties in organizing and distributing the multiplicity of functions which are performed by the modern government. No matter how finely the division lines may be drawn, there are certain to be many points of contact and overlapping. As previously indicated, the important task of the organizer, whether it be Congress or department head, is to secure the desired ends with the least duplication and expenditure of effort.

\section{Cooperation with State Institutions}

$Y$ ears before the first appropriation of federal funds for the encouragement of agriculture was made in 1839 , sevcral of the States had made important progress in this direction. As early as I79I New York had begun to issue annual reports on agriculture; and in 1820 had made provision for a state board of agriculture, including appropriations for its farming interests. ${ }^{\circ}$ It was largely because of the work already being done by state institutions that many Congressmen failed to see the need of federal aid, when the matter was first urged upon them. The results of the efforts of the states, thus early begun, had reached considerable proportions when the Department of Agriculture was established in I 862. Much of the work done was, of course, purely of local interest and value, and of a non-scientific character. However, this and the achievenents of private societies and associations constituted the principal sources for the early fedcral agricultural publications prior to 1862.

These state agricultural institutions continued to grow,

B Elkanah Watson, History of . . . the Rise, Progress, and Existing State of Modern Agricultural Societies, on the Bershire System, p. 152, Albany, 1820 . 
both in number and importance; but it was not until the extension of federal aid under what is known as the Hatch Act of 1887 , that their research work was placed upon a sound scientific basis. ${ }^{7}$

This $a t^{8}{ }^{8}$ provided for the establishment of experiment stations in the land-grant colleges created under the Act of 1862. It also provided for a permanent annual appropriation of fifteen thousand dollars for each State or Territory. This sum was doubled by the passage of the so-called Adams Act of 1906. This fund is to be expended exclusively for agricultural research. Since 1887 one important function of the Department of Agriculture has been the supervision and coordination of the work of these experiment stations. This is accomplished in various ways; but primarily through periodical inspections by department representatives, and the publication of what is known as "The Experiment Station Record." This scientific journal, which is perhaps the oldest and best known of all the Department of Agriculture's periodical publications, briefly describes the research work that has been completed or is in process in each of the experiment stations. It also indicates the investigational work that is being done in agriculture by other agencies, both domestic and foreign ${ }^{10}$ By this means it is possible to make known to the widely separated workers what has already been done, and thus avoid much needless duplication.

The general policy of the department respecting state agricultural research institutions, is to urge upon them the need of giving special attention to those problems which are of local importance, or for which their facilities or environment peculiarly fit them; and to leave to federal agencies the solution of those problems which are of more general concern. There is, however, in most of the investigational work of the department, extensive cooperation with state

7 'T. N. Carver, "History of American Agriculture," in Bailey's Cyclopedia of American Agriculture, vol. iv, $\mathrm{\rho}$. 15.5.

${ }_{24}$ Stat. L. 440.

34 Stat. L. 63.

10 See Anmual Reports of the Department of Agriculture, 1916, p. 303 . 
institutions and workers. Thus, in the eradication of plant and animal diseases, ${ }^{11}$ in the investigation of dairying and milk sanitation, ${ }^{12}$ in the development of marketing and marketing facilities, ${ }^{13}$ in the promotion of boy's and girl's clubs, ${ }^{14}$ and in the study of problems of forestry, ${ }^{15}$ extensive use is made of the work that has been done by local agencies and of the facilities afforded by them. Because of the special interest of Wisconsin in the study of forestry, and the exceptional equipment that has been provided there, very much of the work of the department in this field is done in closest cooperation with the agricultural college and experiment station of that State.

In the relationships of the Department of Agriculture with state institutions, as in those with other fecleral services, the particular form of agreement or working program is determined by the nature of each case. Generally, if a specific object is to be accomplished, if a definite sum is to be expended by each party, or if all or a certain portion of the time of workers is to be utilized in a joint undertaking, the project is reduced to the form of a written agreement. A copy of such an agreement is shown in Appendix II. Similar project arrangements are also made for much of the purely research work.

Most of the cooperative relationships between the Department of Agriculture and state institutions to which attention has been directed, except the general supervision of experiment stations, are such as have naturally grown out of the circumstances; and are not enjoined upon either party by specific legislation. In recent years, however, a number of laws have been enacted by Congress which have as their basic principle direct cooperation with state institutions. Besides the laws providing for the establishment and aid of

11 Program of Work, pp. 33-40, 96, 104, 107.

12 Ibid., p. $41 \mathrm{ff}$.

13 Ibicl., p. 459 .

14 Ibid., pp. 65-70.

16 Ibid., 1p. 248-249. 
agricultural colleges ${ }^{18}$ and experiment stations, to which reference has already been made, the Smith-Lever Act of May, I9I $4,{ }^{17}$ and the Federal Aid Road Act of July, IgI $6,{ }^{18}$ both require extensive cooperative relations with state agencies. ${ }^{19}$ It is to the consideration of the administration of these measures that the remainder of this chapter will be devoted.

The Act of 1862 , providing for the establishment of state agricultural colleges, made no provision for the exercise of federal supervision or control over the expenditures made by the states of funds derived from the federal treasury. All that was required was that reports should be made annually of the progress of each college, the sales of land script, and the use made of the proceeds therefrom. The Act of 1887 , creating the agricultural experiment stations, likewise made no adequate provision for effective control, by the federal government, of the funds appropriated by Congress. In addition to the usual annual reports, it required the experiment station to publish bulletins periodically showing the results accomplished, and made it the duty of the Commissioner (now Secretary) of Agriculture to furnish certain forms, to indicate lines of inquiry which might be most profitably followed, and to give advice and assistance. Somewhat more adequate control was reserved to the federal government in the act of 1906, (supplementary to the act of 1887 ) which, in addition to requiring the annual reports of expenditures, made the payment of the

18 The laws appropriating federal funds for the aid of agricultural colleges, the so-called Morrill Act of 1862 and amendments thereto, are administered by the Department of the Interior. Only those relating to the experiment stations are administered by the Department of Agriculture. The law of 1890 , supplementing the Morrill Act, requires that copies of financial reports be sent to the Secretary of Agriculture as well as the Secretary of the Interior.

1738 Stat. L. 372 .

1839 Stat. L. 355 .

10 The so-called Smith-Hughes vocational education act is not administered by the Department of Agriculture, but by a vocational education board, of which the Commissioner of Education is chairman. The Secretary of Agriculture is a member of this Board. This is also a cooperative measure. 
yearly sums appropriated for each State and Territory conditional upon the ascertainment by the Secretary of Agriculture that it had complied with the provisions of the act and was entitled to receive its share of the appropriations for agricultural experiment stations.

The Smith-Lever Act of 1914, however, in addition to requirements and conditions similar to those imposed by the acts of ISS7 and 1906, as a prerequisite to sharing in appropriations of federal funds, provides a detailed and comprehensive scheme of administration and control of expenditures. It not only requires annual reports to be made of receipts from all sources, and expenditures for carrying out the objects of the act; but expressly limits the scope of activitics of the state institutions under the act to cooperative work of such a character as shall be mutually agreed upon by representatives of cach college and the Secretary of Agriculture. It also makes prior approval by the Secretary, of plans for the work to be carried on during eacl year, an indispensable condition precedent to the payment of any of the funds appropriated by Congress.

The purpose and scope of the Smith-Lever Act, as stated in its first two sections, are as follows:

Section I. That in order to aid in diffusing among the people of the United States useful and practical information on subjects relating to agriculturc and home economics, and to encourage the application of the same, there may be inaugurated in connection with the college or colleges in each State now receiving, or which may hereafter receive, the henefits of the Act of Congress approved July sccond, eightecn hundred and sixty-two, entitled 'An Act donating public lands to the several States and Territories which may provide colleges for the benefit of agriculture and the mechanic arts,' ... agricultural extension work which shall be carried on in cooperation with the United States Department of Agriculture. ...

Section 2. That cooperative agricultural extension work shall consist of the giving of instruction and practical demonstrations in agriculture and home economics to persons not attending or resident in said colleges in the several communitics and imparting to such persons information on said subjects through field demonstrations, publications, and otherwise; and this work shall be carried on in such manner as may be mutually agreed upon by the Secretary of Agriculture and the State agricultural college or colleges recciving the benefits of this Act. 
The initial appropriation under this law for the fiscal year I9I5 was four hundred and eighty thousand dollars-ten thousand dollars to each of the forty-eight States. This sum was to be increased by six hundred thousand dollars for the next fiscal year until the total sum should be four million five hundred and eighty thousand dollars. Thereafter a permanent annual appropriation of this latter amount is to be made. No payment is to be made to any State except by the assent of its legislature, or Governor, if the legislature is not in session, to the terms of the act. The amounts appropriated in excess of the original ten thousand dollars to each State is to be prorated among the States in the proportion which the rural population of each bears to the total rural population of all the states, as deternined by the next preceding federal census. ${ }^{20}$ It is further provided that no part of this latter amount shall be paid to any State until an amount of money at least equal to the prorata share of that State shall have been appropriated for the year by the legislature or other agencies within the State, to be expended for the purposes contemplated under this act.

If, for any reason, the Secretary of Agriculture refuses to certify that any State is entitled to its portion of the appropriation, provisions are made for an appeal by sucl state to Congress.

Immediately after the approval of this act, the Secretary of Agriculture appointed four of his subordinates as a committee, pending the reorganization of the department, to make arrangements to carry it into effect. A memorandum agreement between the Secretary of Agriculture and the presidents or deans of the agricultural colleges was drawn up and adopted by practically all of the state representatives. The assent of all the States to the provisions of the act was obtained, and an organization for the administration of funds granted to the colleges under this act, as well as the funds appropriated for extension work by state

\footnotetext{
20 In determining the rural population, the policy of the Bureau of the Census has been to count as rural all persons who live in communitics of less than 2500 inluabitants.
} 
agencies, was formed in each of the state colleges. These organizations resemble and are coordinate with the agricultural experiment stations. They have at their head directors of extension work corresponding to the directors of experiment stations.

Through the extension divisions of the colleges a large number of projects for cooperative extension work in a great variety of lines have been formulated and agreed upon under the general memorandum of agreement. ${ }^{21}$

In the reorganization of the department in 1915 , a new administrative unit was created, in which has been brought together practically all of the administrative and advisory work of the department in its relations with state agricultural institutions. This bureau is called the States Relations Service. Under a regulation issued by the Secretary, all business of the department with these state institutions must be transacted through the States Relations Service.

The supervision of the work of the experiment stations is conducted by a subdivision of this burcan called the Office of Experiment Stations. This has already been described. Administration of the cooperative work is accomplished through two other subdivisions called, respectively, The Office of Extension Work in the South, and The Office of Extension Work in the North and West. As the names indicate, the division of work is territorial. This arrangement is due in part to the existence of very dissimilar problems and conditions in the respective fields, and in part to the previous existence of similar administrative units. There is, of course, the closest relationships between these subdivisions and the extension divisions of the various colleges; but always following the general procedure previously inclicated.

Perhaps the most distinctive feature or development under the Smith-Lever Act is the official generally called the connty agent. The field of these workers, as the designation inplies, is usually limited to one county. Although they work

${ }^{21}$ Reports of the Department of Agriculture, 1915, p. 290. 
under the immediate direction either of the state director of extension or the state county agent leader, they are in reality officials of the federal and state governments. They are paid from the joint cooperative funds. Such agricultural agents or teachers may now be found in more than half of the counties in the United States.22

The county agents are greatly aided in their work by what are known as county farm bureaus. These are organizations of farmers and others interested in agriculture formed largely for the purpose of cooperating with the county agent. They also assist in the providing of funds in those states which depend in part upon voluntary contributions.

In a constantly increasing number of counties, particularly in the South, the work of the county agent is supplemented by the work of a woman home economics demonstrator, whose duty it is to assist in the education of rural women by conducting demonstrations in homes or in rural community gatherings. The ultimate plan is to supply each rural county with at least one county agent and a home economics demonstrator.

This system of county agents, when fully developed, should constitute a most efficient administrative device for the effective and rapid promulgation of any general agricultural policy. While the appointment of these workers is left almost entirely to the States, with the consequent lack, in most cases, of civil service tests, the appointments thus far seem to have been based upon merit, and have been made with little or no regard to political affiliation. The great majority of them are chosen from the graduates of the agricultural colleges. Politicians will probably not fail to see the strategic political advantages which men working in this capacity have. The value of the service, therefore, will depend in large measure on the extent to which it is subverted to the accomplishment of political ends.

In the great majority of instances the cooperative rela-

22 There are approximately 3500 comties in the United States. 
tionships between federal and state agencies under the Smith-Lever act have been harmonions. The only serious disagreement of which the writer is aware, arose in Illinois shortly after the act became effective. In this State very - large appropriations are made for the advancement of agriculture. It was the belief of some of those concerned with the administration of this fund, including the Dean of the Agriculture College, that the fecleral funds were not of sufficient importance, relatively, to justify the State in submitting to the regulations imposed by the federal government. ${ }^{23}$ After considerable discussion, a somewhat tentative agreement was concluded, but not without the pressure incident to the war and the necessity for speeding up all agricultural processes. It is the opinion of the Director of the States Relations Service, however, that the difficulties can be amicably settled when more complete understanding is reached.

Another measure which contemplates less fortuitous and more deliberate cooperative relations with state institutions than the earlier and more general laws committed to the Department of Agriculture is the Federal aid road act, approved July II, 1916. ${ }^{24}$

The enactment of this law marks a very considerable advance in federal policy concerning the improvencut of the public highways. For more than twenty years, prior to this time, the efforts of the federal government had been limited to research and education for the purpose of developing improved methods of roal construction and maintenance and imparting such information to local road builders.

The wide-spread interest in improved lighways, due largely to the rapidly increasing use of motor vehicles, has led to the introduction at each recent session of Congress of many measures calling for federal aid to supplement the cfforts of the States and counties. In 1912 a joint com-

23 A cojy of these regulations is included in appendix ii.

2439 Stat. L. 355. 
mittee of both houses of Congress was created for the purpose of investigating the subject of federal participation in highway construction. This committee made an exhaustive report in the following year, and a standing committee on roads was appointed in the House of Representatives.

The Federal aid road act, which marks the culmination of this agitation, carries an appropriation of seventy-five million dollars to aid the States in the construction of rural post roads, and ten million dollars to be expended for the construction and maintenance of forest roads and trails. The appropriation for rural post roads was made available at the rate of five million dollars for the fiscal year ending June 30, I9I 7 , ten million dollars for the next fiscal year, fifteen million dollars for the third, and so on for five years, ending June 30 , I92I.

The appropriation for forest roads and trails was made available at the rate of one million dollars per fiscal year beginning July I, I9I6. A sum not to exceed three per cent of the post road appropriation may be used by the Secretary of Agriculture for administering the act. The apportionment of this fund among the States, after deducting the amount allowed for administration, is based upon the relative areas, population, and mileage of rural delivery and star routes in each State, each of these factors having a weight of one-third. Any unexpended balance of an allotment to a State remaining unexpended at the close of the fiscal year for which it is made may be carried over to the next fiscal year. If such balance is not expended by the close of the sccond ycar, the amount is re-allotted among the States on the basis of the original apportionment.

The federal appropriation for post roads may be expended only for construction, must not exceed fifty per cent of the total estimated cost of the road, and in no case be more than ten thousand dollars per mile, exclusive of bridges of more than twenty feet clear span.

In order that a State may receive the benefits of the post road provisions of the federal act, it must have a state 


\section{THE UNITED STATES DEPARTMENT OF AGRICULTURE}

highway department, and the construction on which federal funds are expended must be done under the direct supervision of that department. The act requires, as conditions precedent to participation by any State, that the legislature or governor shall formally assent to the terms of the act, that an amount of money at least equal to the federal funds shall be made available by or on behalf of the State, and that the plans, specifications, and estimates for all projects shall be submitted to and approved by the Secretary of Agriculture.

The sum appropriated for the construction and maintenance of forest roads and trails is to be derived from the sale of forcst products. The amount which may be cxpended under this section of the act in any one State, Territory or county shall not exceed ten per cent of the value of the timber and forage resources which are or will be available for income from the national forest lands within the respective county or counties wherein the roads or trails are constructed. The State, Territory or county is required io cnter into a cooperative agrecment with the Secretary of Agriculture for the survey, construction, and maintenance of such roads and trails upon an equitable basis.

The cooperative requirement is the only new feature in this section of the Federal Aid Rond Act. At least three other measures ${ }^{25}$ had been previously passed by Congress providing for the sharing of the reccipts from national forests between the federal government on the one hand and the state and county governments on the other. In so far as the funds sccured under the operation of these acts are expended for construction and maintenance of roads and trails, the Department of Agriculture is represented by both the Forest Service and the Office of Public Roads and Rural Engineering. Otherwise they are administered by the Forest Service alone.

The administration of that part of the Federal Aid Road

25 Act of May 23, 1008, 35 Stat. L. 251; Act of March I, 1911, 36 Stat. L. 963 ; Act of March 4, 1913, 37 Stat. L. 828. 
Act relating to post roads has been assigned by the Secretary of Agriculture to a previously existing administrative unit known as the Office of Public Roads and Rural Engineering. Prior to this time the work of this office had been almost wholly devoted to research and the giving of expert advice to road builders. The administration of this new measure necessitated a complete reorganization. To meet the new demands, the work of the office was grouped in two branches, known, respectively, as the engineering division and the management and economics division. At the head of these divisions were placed a chief engineer and a chief of management, respectively, who are under the immediate supervision of the director of the office. There are also two general inspectors who operate independently of the two branches and report immediately to the director. For administrative purposes the country has been divided into ten districts, with a supervisory engineer in charge of the construction work in each district. These engineers report directly to the chief engineer. ${ }^{26}$

Immediately after the passage of the act, and under the authority contained therein to make rules and regulations for carrying into effect its provisions, ${ }^{27}$ the Secretary of Agriculture called a conference of the heads of the various state highway departments, to whom was submitted a tentative draft of rules and regulations. Most of the suggestions of the state officials were incorporated in the final draft.

The procedure adopted provides for the submission of an application, known as a project agreement, by the state highway department to the district engineer, who examines the road that it is proposed to improve or construct, and

26 Reports of the Department of Agricuiture, 1917. p. 359.

27 This and a number of other recent acts specifically confer upon the officer or department charged with the administration power to make necessary rules and regulations. Under our system of government this power would exist irrespective of any specific grant. Such rules and regulations must, however, conform strictly to the law upon which they are predicated. 
transmits the project statement with his recommendations to the IVashington office.

If the project statement is approved, the plans, specifications and estimates are then submitted by the state highway department to the district engineer, who in turn sends them to the central office with his recommendations. If they are found to be suitable, a formal certificate to that effect is issued by the Secretary of Agriculture to the Secretary of the Treasury and to the state highway department, and a formal project agreement is signed. As the work progresses, or upon its completion, payment of federal funds is made to the depository named in the agrecnent.

Thus it will be seen that the procedure required is somewhat elaborate. However, it does not seem to be more than is neecssary properly to safeguard the expenditure of so large a sum of money and the interests of those officials who are made responsible. The actual procedure has been greatly simplified by the adoption of standardized forms, arrangements of plans, estimates, and specifications.

It is perhaps too early to form any estimate of the success of this measure. The most notable result thus far has been the effect upon the highway laws and institutions of the States. At the time of the passage of the act, fully onefourth of the States could not avail themselves of its provisions because of inadequate organization. At the present time, all of the States have highway departments; and most of them have passed such legislation as to centralize the construction and maintenance of roads in these departments. This should greatly facilitate the cooperative administration contemplated under the act.

Whether the application of the cooperative principle to the vast enterprise of building the highways of the nation will produce the largest measure of benefit to the people remains to be seen. If the arlministrative difficulties can be amicably and properly solved, there would seem to be little doubt as to the practical benefits. The two cooperative measures described in this chapter should furmish ample 
opportunity for testing this comparatively new principle in the relations between the two branches of our federal form of government.

In one of his recent books, Professor Laski in the course of a rather severe criticism of our governmental practices says:

No kind of working compromise has been reached between the States on the one hand, and the Federal Government on the other. Each has gone its way often almost wilfully, duplicating the work of the other. ... The possibility of cooperation is not considered. The lines of demarcation are never made plain.2s

Had Professor Laski been aware of the progress already made in the directions he indicates, it is probably that his criticism might have been turned to commendation.

${ }^{28}$ H. J. Laski, The Problems of Sovereignty, March, I9I7. 


\section{CHAPTER IV}

\section{- Administration of Important Regulatory Laws}

Thus far in our consideration of the administration of law, we have been primarily concerned with that type of legislation which, while controlling the actions of administrative officers, leaves the citizen, in whose interest the laws have been enacted, practically free to avail himself of any benefits which may be derived, or to disregard them altogether. Such is that very considerable body of legislation upon which the purely educational activities of the Department of Agriculture are based.

There are, however, as has been previonsly pointed out, other laws, whose administration has been committed to this department. which have as their primary and immediate object the regulation and control of the conduct of the citizcns themselves. Of course, the ultimate object is the same in both cases, that is, the advancement of the welfare of those for whom the government acts. The difference is mainly in the means and the methods employed. This difference in procedure gives rise to several important administrative consequences in the latter type of legislation which are not present in the former. It is to the consicleration of some of these that the present chapter will be devoted.

Professor Learned says:

The fabric and the administrative machinery rest on the written laws. But the laws, as Burke very well understood, reach but a very little way. Administration, to be effective, must often depend on practices of which the written law takes little or no account. Behind the law there are assumptions which give room for the exercise of individual judgment and discretion essential to their proper exccution. ${ }^{1}$

It is in these federal laws which are intended to govern the conduct of individuals that the truth of this statement

1 Learned, P. 368. 
is most clearly seen. Generally, they are what may be termed conditional statutes. Such statutes, says Goodnow, "lay down the conditions and circumstances in which it will be lawful for the administration to act, and the act of the administration in enforcing them does not consist merely in seeing that the laws as passed by the legislature are executed; but rather in elaborating the details as to points which the legislature is unable to see, or which, if it can foresee, it is unable to regulate. While the absolute unconditional statutes are, as a general thing, addressed to the persons subject to the obedience of the state, these conditional stautes are rather addressed to the administrative authorities and are in the nature of instructions to them how to act in the general classes of cases for which provision has been made. The action of the administration in the case of the unconditional statute is confined simply to the execution of the state will. In the case of the conditional statute, the administration has not merely to execute the state will; but has as well to participate in its expression as to the details which have not been regulated by the legislature."2

The legislative ideal of the United States, contrary to that which prevails in most European countries, has been to furnish minute and detailed instructions and directions to the executive. The laws have been so drawn as to leave the administrative officials little or no discretion. Jealously guarding their powers and prerogatives, legislators have attempted to foresee and to provide in the wording of the bills for all possible contingencies.

So far as the national legislature is concerned, there seens to be a different tendency in recent years. This tendency is particularly noticeable in the exercise of what has heen termed the 'police power.' Either because of the tremendous expansion of the activities of the central government in this field, which lias marle it impossible for the legislative

${ }^{2}$ Gooduow, Principles of the Administrative Law of the United States, p. 325. 
hody to keep pace; or because of the greater complexity of this type of legislation, which has made congressmen recognize their inability to provide for all contingencies which may arise, more latitude is being given to the executive authorities. All of the measures which we shall consider in this chapter specifically authorize the Secretary of Agriculture to promulgate such rules and regulations as may be necessary for making them effective.

It is this provision which gives elasticity to otherwise rigid laws. To what extent it may be necessary or desirable thus to supplement the statutory law, depends in part upon the provisions of the law itself and, in part, upon the nature of the subject or relationships to which the law is applicable. Even administrative officers find that they must rely largely on experience in formulating such regulations as will most effectually carry out the intent of the legislative body. The result is that the regulations are either issued serially as the need arises, or must undergo periodical revision.

The power to issue these regulations, as previously indicated, is purely a delegated one. Under the American system of government, administrative officers have no general ordinance power. Such regulations as are issued, then, derive their legal force from the law upon which they are predicated, and which they are intended to supplement. ${ }^{3}$ To the extent that they represent a reasonable interpretation of the statutory provisions, they have the same legal force as the law itself.

In determining what is the real intent of the law, or of the legislative body, administrative officers are frequently confronted with problems which are not unlike those that are presented to the courts in their interpretation of the law. Generally, and unless otherwise specifically provided, the question as to the conformity of an administrative regulation with the law nust, where appeal is made, be answered by the courts. In determining whether the regulations are consistent with the law, there must be applied the same rule

Ibid., p. 143. 
of decision which controls when an act of Congress is assailed as being unconstitutional; that is, a regulation should not be annulled unless in the judgment of the court it is plainly inconsistent with the law. ${ }^{4}$

Within the scope of its jurisdiction, the adjudications of the administrative authorities is generally final, unless there is legislative provision to the contrary. ${ }^{5}$ This is particularly true in those rules which are of general application.

Acting under the authority which has been delegated to him by Congress, the Secretary of Agriculture has issued rumerous rules and regulations for the guidance of his subordinates and others affected by the operation of the various regulatory laws. Sometimes these are called circulars of the office of the Secretary; sometimes they are issued as general orders of the bureau immediately concerned. In either case they must, of course, be authorized by the Secretary.

In the enforcement of those regulatory laws which provide penalties for their violation, the Department of Agriculture, like the other executive units, must cooperate very extensively with the Department of Justice. Indeed, it may be said that the Solicitor of the Department of Agriculture, in this work, is very much like an assistant to the Attorney General.

Under an agreement with the Department of Justicc, arrangements have been made for the more expeditious and economical prosecution of criminal cases and highly technical cases arising under the food and drugs act and other regulatory measures. By this arrangement the Solicitor of the Department of Agriculture reports criminal cases to the Department of Justice in the form of criminal informations, which, if approved by the United States attorneys, may be immediately filed in court.

In the trial of the cases arising under these acts the points at issue frequently call for a thorongh unclerstanding on the part of the legal representative of the Government of highly:

4 Bruce Wyman, Administrative Law, p. 290.

- Litchfield v. Register and Receiver, 9 Wall 575. 
technical questions of chemistry or other science. In cases where such questions are involved, arrangements have been made whereby the Solicitor and his assistants will assist the United States attorneys in the actual trials. In this way there will be placed at the disposal of the Department of 'Tustice the more intimate knowledge which must necessarily be obtained by the law officers of the Department of Agriculture in the preparation of the cases than can be acquired by the United States attorneys through correspondence or in the brief time at their command.

With this bricf introduction, let us now turn to a consicleration of the actual administration of a few of the most important of those regulatory measures whose enforcement has been committed to the Department of Agriculture.

\section{Meat Inspection Act}

Since the establishment of the Bureau of Animal Industry in May, iSS4. numerous laws relating to the live stock industry and its products have been passed by Congress. At first, the primary, if not the sole object of this legislation, was the giving of encouragement and and protection to the industry itself. Generally, the object was to be attained either through the suppression or eradication of animal discascs; or by cxtending and protecting the forcign market through a rigid inspection of animals and animal products intended for export.

However, as early as 1891 , the Secretary of Agriculture was instructed to inspect, prior to their slaughter, "all cattle, sheep, and hogs which are subjects of interstate commerce and which are about to be slaughtered . . . the carcasses or products of which are to be transported and sold for human consumption in any other state or territory. . . ."

The making of post-mortcm examinations. which now constitutes the most important feature of meat inspection, was left entirely within the discretion of the Secretary of Agriculture. The law of 1891 was supplemented by subse-

B. 26 Stat. L. 1090 . 
quent enactments; but it was not until 1906 that an adequate statute, providing for a thorough inspection of meats and meat products, and having as its primary object the safeguarding of the health of the people, was passed by Congress. This latter measure was slightly amended and reenacted in its present form March 4, 1907.?

Under the present law emphasis is placed upon the postmortem examination. The inspection of animals prior to their slaughter is left within the discretion of the Secretary of Agriculture. In general, the act provides for the maintenance by the Department of Agriculture of a system of inspection in packing houses and other establishments in which cattle, sheep, swine and goats are slaughtered, or the carcasses or meat products of which are prepared for interstate or foreign commerce; and prohibits the shipment or transportation of such articles in interstate or foreign " commerce unless they bear the mark of federal inspection and approval as required by the act.

The provisions of the meat inspection law requiring inspection do not apply to animals slanghtered by farmers on the farm nor to retail butchers and dealers. However, the regulations of the department require that such butchers and dealers, in order to ship meat or meat food products in interstate or foreign commerce, shall first obtain certificates of exemption; but no such requirement is made of farmers. These certificates are issued only after an examination of the premises of the applicant, and after certain sanitation requirements have been met. They may be summarily revoked for any violation of the regulations.

The requirements as to sanitation in the establishments that operate under federal inspection form a very important part of the meat-inspection regulations. ${ }^{8}$ Ample authority on this subject is granted in the act. The requirements are of two kinds: those relating to the cleanliness of rooms and equipment, and conduct of operations in plants already in

${ }^{7} 34$ Stat. L. 1256.

8 Bureau of Animal Industry Order no. 211, Issued July 30, 1914. 
existence; and those fixing rules for the construction of new plants and the installation of new equipment. Prior to the inauguration of inspection, an cxamination of the establishment and premises must be made by an employee of the Dqpartment of Agriculture and the requirements for sanitation and the necessary facilities for inspection specified.

Some idea of the scope of these sanitary regulations may be gained from the following: There must be sufficient light to insure sanitary conditions in all rooms and compartments; there must be adequate drainage and plumbing systems; the water supply must be clean and ample and subjected to laboratory tests to insure its purity; sanitary and adequate dressing rooms, toilets and lavatories must be installed; floors, walls, ceilings and other structural parts must be of such materials as to make them susceptible of being readily and thoroughly cleaned; and all rooms and equipment used for edible products must be kept separated from those used for inedible products. Many other regulations have been prescribed to prevent the introduction or spread of communicable diseases. Inspection is not inaugurated until a satisfactory compliance with the sanitary requirements is shown and proper facilities for the conduct of the inspection are provided.

The proprictor or operator of an establishment which is subject to the provisions of the meat inspection law must file an application and submit triplicate copies of the plans and specifications of the plant. The plans are referred to the architect of the Burcau of Animal Industry to determine whether the structure and arrangements conform to the regulations. Each establishment to which inspection is granted is assigned an official number. This number identifies the plant, and must appear in every instance as a part of the mark of inspection.

When inspection is granted and an official number assigned, a force of inspectors is detailed to the establishment to perform the inspection and enforce the regulations under the direction of an inspector in charge. 
Under the federal system of inspection, at least two examinations are made in all cases. While the ante-mortem examination is not now a requirement of the law, it is made in practically every instance primarily as an aid to a more effective post-mortem examination. Generally, the antemortem inspection is performed in the pens or yards just before the animals enter the plant. If any of a lot of animals show symptoms of disease, the entire lot is subjected to further and individual inspection. When the appearance of any animal is such as to cause the inspector to suspect that it is affected with disease that may warrant its condemnation in whole or in part on the post-mortem inspection, it is marked for identification by means of a numbered metal tag marked "U. S. Suspect." A record of the tag number and any other pertinent information is sent to the inspector in charge of the post-mortem examination. This information is given due weight by him in determining the final disposition of the animal. "Suspects" are slaughtered separately from those which are passed on the ante-mortem examination. Animals which are found in such condition as to be unfit for food are marked "U. S. Condemned," and must be destroyed or disposed of in such manner as to prevent their use for food.

The post-mortem inspection really consists of a series of examinations. These include an examination of the entire carcass immediately after slaughter, and later an examination of each of the parts. Where the output is small one inspector performs all the inspections. In large institutions the work is so arranged that each inspector gives his entire attention to some particular part. In this way each becomes a specialist, with the result that a high degree of individual and collective proficiency is attained.

Animals or parts thereof found to be free from disease or any doubtful condition are marked "Inspected and Passed"; those in which any disease or doubtful condition is found are retained for final examination.

An important requirenent in the conduct of the post- 
mortem inspection is that the identity of the carcass and each of its parts be carefully maintained until the inspection is completed, so that if there is disease in any one organ or part all of the other parts of the carcass may be brought to-gether for final examination. This is accomplished through a system of numbered tags marked "U. S. Retained."

The carcasses retained on the regular inspection are sent to a room equipped with special facilities where they are subjected to a searching examination by men of special skill and thorough training and experience. The findings of these experts are final, except that appeal may be made to the Chief of the Bureau of Animal Industry or to the Secretary of Agriculture. A detailed record of each final examination and the disposition made is prepared and retained. When the several examinations have been completed, each carcass or part thereof is plainly marked to indicate the disposition that is to be made of it.

The meat inspection regrulations governing the disposal of condemned articles emphasizes three important requirements. First, that every article condemned shall be plainly marked to show that it is condemned; second, that all condemned articles shall remain in the custody of the inspector until they are properly disposed of ; and, third, that the required destruction or denaturing of condemned articles shall be done by the establishment in the presence of the inspector, who must render a report of the proceedings.

On account of the fact that meat which was entirely sound and wholesome at the time of slaughter niay becone unsound and contaminated through improper care or handling, and because healthful products may be rendered unwholesome through adultcration or the addition of delcterious substances, and for the purpose of protecting the consumer against false or misleading labels, inspection of the varions processes of preparing and labeling meat products becomes necessary. This is an important part of the general system of federal inspection. Persons are selected for this work because of their practical knowledge and experience in the 
handling of meats and meat food products. District laboratories are maintained at convenient points for the making of chemical analyses or other technical examinations. It is the duty of the lay inspectors to see that the requirements of the regulations as to sanitation are observed.

The meat inspection act provides that when meat or meat products which have been inspected and passed are packed, the establishment shall cause a label to be affixed to the container or covering stating that the contents have been inspected and passed. The act also provides that no meat or meat product shall be sold, offered for sale, or shipped in interstate commerce under any false or deceptive name. The regulations define at length what may or may not appear upon any label. Copies of all labels intended for use in plants under inspection must be approved in advance.

The penalties prescribed for violation of the meat-inspection act are applicable both to persons selling or offering for sale goods which have been prepared in violation of the law, and to persons or companies accepting such goods for transportation in interstate or foreign commerce. Unusually scvere penalties are prescribed for the offer or acceptance of any bribe with the intent to influence any inspector or other officer in the performance of his duty.

Because of the general approval of the law and the cooperation of those engaged in the industry to which it relates, there are very few violations upon which action must be taken-less in fact than under any other of the important regulatory laws administered by the Department of Agriculture. ${ }^{\circ}$

Approximately twenty-six hundred persons are directly engaged in the federal inspection of meats and meat products, distributed in approximately eight hundred and fifty establishments. All are under the general direction of the Chief of the Bureau of Animal Industry. They are divided into two general classes-professional and non-professional.

\footnotetext{
ture.

- Annual Reports of the Solicitor of the Department of Agricul-
} 
The professional class consists primarily of veterinary inpectors and laboratory inspectors. The non-professional class is composed of the so-called lay inspectors and administrative or clerical employees. All are required to pass civil service examinations before appointment.

Certain veterinary inspectors, selected because of their experience and general qualifications, are known as traveling veterinary inspectors. Each is assigned a district in which he makes special inspection of establishments and reports directly to the Chief of the Bureau of Animal Industry as to whether the law is being properly enforced and the regulations are being observed. These visits and reports are helpful in raising the general standards of the administration of the law.

Upward of three and a quarter millions of dollars is spent annually for federal meat inspection.

The regulations which have been issued under the authority of the meat inspection law seem to be very broad and comprehensive. The original set was prepared by representatives of the Department of Agriculture in cooperation with a board of seven eminent outside scientists, of which Dr. William H. Welch of Johns Hopkins University was chairman. These have been supplemented and changed from time to time, but the general principles remain the same.

Perhaps the chief criticism of the federal meat inspection grows out of a misunderstanding as to the limitations under which the officers charged with its administration are required to work. While some form of inspection is maintained over the entire product of all establishments which sell any of their goods in interestate or foreign commerce, this does not include more than sixty or sixty-five per cent of the entire output of the country. Thus it is possible that much of the laxity of the state and local inspection is erroncously ascribed to the federal system.

Effort is being made by federal authorities to secure a higher degree of cooperation with local health officials in 
raising the standards in the preparation of meat and meat products. Until this is accomplished the object of the law cannot be fully realized.

Another criticism which has been urged against the meat inspection law is that it tends to defeat the purpose of the earlier legislation passed to promote the live stock industry. The validity of this criticism rests upon the degree of fairness used in the administration of the law. Necessarily, there must be something of a compromise between the protection of the health of the people and the protection of the live stock industry. The loss which live stock producers suffer in the rejection of animals considered unfit for food is perhaps more than offset by the advantages such a system of inspection affords in detecting, localizing and eradicating animal diseases.

\section{The Food and Drugs Act}

As has already been indicated, it is only within comparatively recent years that the federal government has concerned itself directly with the protection and conservation of health. For many years this was thought to be the province and business of the States. However, in the tremendous increase in the activities of the central government in other matters directly and immediately affecting the lives and welfare of individuals, a very considerable body of federal health legislation has been gradually developed. At the present time, each of the ten executive departments is engaged directly or indirectly in the administration of one or more acts of Congress designed primarily to safeguard the health of the people. ${ }^{10}$

The food and drugs act," commonly called the "pure food law," was approved the same day as the meat inspection act, June 30 , 1906. Both were the outgrowth of previous statutes which had proved inadequate or ineffective.

Briefly stated, the food and drugs act forbids the im-

10 Report of the Solicitor of the Department of Agriculture, 1914.

${ }^{11} 34$ Stat. L. 768. 
portation into the United States, the exportation from the United States, the introduction into interstate commerce, and the manufacture and sale in the District of Columbia and the Territories of mishranded and adulterated foods and drugs. In 1912, the so-called Shirley amendment ${ }^{12}$ to the act was passed prolibiting false and misleading statements as to the curative or therapeutic effects of medicines. On March 3. I9I3, the act was further amended so as to require articles of food in package form to bear a statement or label showing the quantity of the contents in terms of weight, measure or numerical count. ${ }^{13}$

Prior to June, I9I3, domestic meats and meat products which had been prepared uncier federal inspection were specifically exempted from the operation of the food and drugs act by the rules and regulations for the enforcement of that act. Since this date, howerer, these articles have been subjected to the same treatment as other food irrespective of any prior inspection.

Section nine provides that no dealer shall be prosecuted for violations of the act if he can establish a guaranty signed by the wholesaler, jobber, manufacturer, or other party residing in the United States, from whom he purchased the articles in question, to the effect that the same are not adulterated or misbranded within the meaning of the act, designating it. In such cases the party or parties making the guaranty shall be amenable to the prosecutions, fines, and other penalties which would otherwise attach to the dealer. ${ }^{14}$

1237 Stat. I. 416

13.37 Stat. L. 732

11 Regulation 9 of the Rules and Regulations for the enforcement of the fooil and drugs act. June 30, 1906, 34 Stat. 768, is hereby amended, effective May I, 1915, so as to read as follows:

"(a) It having been determined that the legends 'Guaranteed under the Food and Drugs Act, June 30, 1906,' and 'Guaranteed by (name of guarantor), under the Food and Drugs Act, June 30 , 1006, horne on the lahels or packages of food and drugs, accompanied by serial numbers given by the Secretary of Agriculture, are each misleading and deceptive, in that the public is induced by such legends and serial numbers to believe that the articles to which they rclate have been examined and approved by the Government and that the Government guarantecs that they comply with the law, the 
Penalties for the violation of the act may consist of the seizure and condemnation of the goods, or fine and imprisonment. Goods transported in interstate commerce are subject to seizure only if remaining unloaded, unsold, or in original, unbroken packages. ${ }^{15}$

While the food and drugs act is properly called a health measure, it is only in a somewhat indirect manner that the object is to be attained. In other words, it is primarily a measure intended to enforce honest labeling of foods and drugs, and only secondarily does it directly prohibit harmful adulteration. Thus the benefits to be derived are largely dependent upon the degree of education of the consumers.

Each of the terms "food," "drug," "misbranded," and "adulterated" is specifically defined in the act. When used in the enforcement of the law, it must be in the statutory sense. Thus "drug" as used in the act, includes "all-medicines and preparations recognized in the United States Pharmacopœia or National Formulary for internal or external use, and any substance or mixture of substances intended to be used for the cure, mitigation, or prevention of disease of either man or other animals."

All misbranding and much statutory "adulteration" may be corrected by the use of appropriate names and labels. The statute recognizes two classes of adulterated foods. In one class adulteration of an article is dependent upon the

use of either legend, or any similar legend, on labels or packages should be discontinued. Inasmuch as the acceptance by the Secretary of Agriculturc for filing of the guaranties of manufacturers and dealers and the giving by him of serial numbers thereto contribute to the deceptive character of legends on labels and packages. no guaranty in any form shall hereafter be filed with and no scrial number shall hereafter be given to any guaranty by the Secretary of Agriculture. All guaranties now on file with the Secretary of Agriculture shall be stricken from the files, and the scrial numbers assigned to such guaranties shall be canceled."

15 "Regulation 2.-The term 'Original unbroken package' as used in this act is the original package, carton, case, can, box, barrel, bottle, phial, or other receptacle put up by the manufacturer, to which the label is attaclied, or which may be suitable for the attachment of a label, making one complete package of food or drug article. The original packige contenplated includes botlo the wholesale and the retail package." 
name or label under which it is sold. Change of name or label so as correctly to describe the product will relieve it from the clarge of adulteration, which could otherwise be maintained against it, because of false or misleading statements or representations as to its identity, quality or strength.

Adulteration of the second class of articles is inherent in the articles themselves, irrespective of names or labels, and cannot be corrected by renaming or relabeling. The more important provisions of the act affecting products of this class declare those foods adulterated which "consist, in whole or in part, of a filthy, decomposed, or putricl substance, or any portion of an animal unfit for food," or containing any added poisonous or cleleterious ingredient which may render the article injurious to health.

The food and drugs act contains no provision as to the adulteration of drugs in any popular sense of the word. Whether a drug is adulterated or not depends solely upon the labeling of the container. The various kinds of "adulteration" of drugs which are prohibited may all be cured by correct or honest labeling.

The limitations and restrictions within the statute itself coupled with serious omissions, such as the absence of authority to inspect establishments where foods and drugs are manufactured, prepared, or stored, the lack of legal standards for foods, and the failure to take cognizance of fraudulent statements covering foods and drugs which are not in or npon the food or drug package; these and other limitations have made this law exceptionally difficult to administer effectively. It was to call attention to this fact that these shortcomings of the law have been dwelt upon somewhat at length. The so-called Shirley amendment, already mentioned, is one step in the direction of strengthening the original act.

The food and drugs act is administered, nuder the Secretary of Agriculture. by the Burean of Chemistry. This work constitutes the principal, but by no means, the only 
function of this bureau. That part of the organization which is directly engaged in the enforcement of the act includes: (I) Field inspectors who procure samples for analysis and information regarding the manufacture and sale of drugs; (2) chemists and clerks in the laboratories in Washington and branch laboratories in a few other large cities; and (3) the Board of Food and Drug Inspection, whose duties are to consider all questions arising in the enforcement of the act upon which the decision of the Secretary of Agriculture is necessary, and to conduct all hearings based upon alleged violations of the law.

At first there were about twenty branch laboratories. This number has recently been reduced to four, experience having shown that the work can be done more effectively and economically where specialization can be introduced.

Each of these laboratories is the center or central office of a district. All of the workers within a district are under the immediate direction of a district supervisor, who is in turn under the direction of the Chief of the Bureau of Chemistry.

Information secured by inspectors or from analyses is reported to the Chief of the Bureau of Chemistry, who places it before the Board of Food and Drug Inspection. If the information indicates a violation of the law, the Board makes recommendations to the Secretary of Agriculture regarding the exclusion of adulterated or misbranded imported articles, or prosecutions for the shipment or sale of domestic goods in violation of the law. All persons charged with any violation of the statute are afforded a hearing at which testimony may be offered, before prosecution is commenced in the courts or before any other action is taken.

In the case of imported foods and drugs no prosecutions are made. The efforts of government officials are confmed to preventing the importation of illegal goods, and causing their reshipment or destruction. The Secretary of the Treasury is instructed to deliver to the Secretary of Agri- 


\section{SA TIIE UNITED STATES DEPARTMENT OF AGRICULTURE}

culture, upon his request, samples of foods and drugs which are being imported into the United States or offered for import.

If it appears from the examination of such samples that 'the goods are misbranded or adulterated within the meaning of the act, the Secretary of Agriculture shall refuse delivery to the consignee, and shall cause the destruction of any goods which are not exported within three months from the date of such refusal.

Notice of the arrival at ports of entry of slipments of food or drugs is given by the transmission of a copy of the invoice to the representative of the Department of Agriculture. Upon the basis of this invoice it is determined whether samples should be required or not. In all of this work there must be close cooperation between the representatives of the Department of $A$ griculture and those of the Treasury Department.

The methods of procedure in enforcing those provisions of the law which relate to domestic goods differ considerably from those concerning imports. In the case of domestic goods, the efficient and effective enforcement of the law depends in large measure upon the work of the inspectors. In order to protect the public against imposters, the inspectors are provided with an identification card signed by the Secretary of $\Lambda$ griculure and enclosed in a case opposite a photograph of the inspector, on which is imprinted the seal of the Depariment of Agriculture.

Simples sccured ly inspectors are forwarded to the laboratory in the district in which they are working. The samples are there examined and if found to be in violation of the law, the dealer or shipper is smmmoned for a hearing. The purpose of these hearings is to afford an opportunity for the presentation of evidence to show that an error has been made in either the collection or amalysis of the sample, or to show that a guaranty has been received from the person from whom the goods were olstained.

$\Lambda$ fter such a hearing the information secured is con- 
sidered in connection with the data presented by the inspectors and chemists relating to the sample. If the hearings are held at a branch laboratory, the findings are subsequently reviewed by the Board of Food and Drug Inspection in Washington. If it appears that the law has been violated the Board makes the appropriate recommendation to the Secretary of Agriculture, who certifies this fact to the proper United States Attorney, through the Department of Justice, together with the necessary information regarding the case. It is then the duty of the United States Attorney to prosecute the case "promptly" in the United States district courts.

State authorities, charged with the enforcement of health, food, or drug laws, may, when authorized by the Secretary of Agriculture, institute proceedings in federal courts for the violation of the food and drugs act.

Although the enforcement of this law has been committed to the Secretary of Agriculture, the rules and regulations for carrying out its provisions must be made by a board, consisting of the Secretary of the Treasury, the Secretary of Agriculture and the Secretary of Commerce.

In the drafting of the original set of regulations, ample opportunity was given to all persons who would be affected by the operation of the law to present such information as they thought proper. In addition, a board called the "Referee Board of Consulting Scientific Experts." of which President Ira Remsen was chairman, was appointed to pass upon the larger questions of policy. Extensive experiments were conducted and voluminous reports were rendered.

Experience has made numerous changes and additions necessary, but lefore any new regulation or decision is issued, effort is made to secure adequate information. ${ }^{16}$

The law requires that all judicial decisions in cases arising uncler it shall be published not more than thirty days after they are rendered. Since these are printed in con-

16 Rules and Regulations for the Finforcement of the Food and Drugs Act, Office of the Secretary, Circular no. 21, Seventh Revision. 
venient form for distribution and give the complete information upon which the case is decided, they furnish a valualle supplement to the rules and regulations. These decisions and those of the Board of Food and Drug Inspection are published under the caption. "Service and Regulatory Announcements."

No information relative to any case is given out until the judgment of the court has been given. If, therefore, an error is male no injustice is done to the reputation of any mannfacturer or dealer or to any brand of goods. No information regarding any class or brand of goods is published, except such as is found in the judgment of the court.

The authorities charged with the administration of this statute have been criticized for failing to publish lists of articles of food and drugs which comply with the provisions of the law. It is felt that the publication of such a list would be a disadvantage rather than an advantage because it has been found, in the enforcement of similar laws, that some firms having secured the publication of the names of their goods on such a list. and have subsequently altered the character of their products though they still used the list for advertising purposes.

The chief criticisms of the administration of the law have grown out of and are attributable to the weaknesses of the act itself, to which attention has already heen called. These weaknesses have been accentuated by various court decisions. It is hoped that some of these defects may be overcome by a greater degrce of cooperation with state authorities. With this object in view, a division of state cooperation has recently been established in the Bureau of Chemistry, from which notable results have alreatly been achiered. At the same time effort is being made to secure more adequate legislation by Congress. 


\section{The United States Cotton Futures Act}

By act of May 23, 1908, ${ }^{17}$ the Secretary of Agriculture was authorized to establish standards for the various grades of cotton which are handled in the cotton markets. This was the first of a series of such acts establishing grades or standards for the more important agricultural products. ${ }^{18}$ At first their use was permissive or optional; recently the use of most of them has been made obligatory in those transactions which involve interstate commerce.

It was believed by those persons who were instrumental in securing the establishment of cotton standards that even their voluntary use would prove helpful in eradicating some of the evil and harmful practices in the marketing of cotton, particularly those relating to future exchanges which had proved most detrimental to cotton producers. This expectation was not very fully realized. Accordingly, on August I8, 19I4, Congress passed an act, "to tax the privilege of dealing on exchanges, boards of trade, and similar places in contracts of sale of cotton for future delivery, and for other purposes." ${ }^{13}$ This measure, with some amendments, was re-enacted August II, 1916.."

While the compulsory use of the official cotton standards extends only to contracts on future exchanges made under the provisions of the act, they have now been accepted and are used voluntarily in practically all of the important "spot" cotton markets of the country. Through the county agents, demonstrations as to the value of these standards have been made among the farmers themselves.

Ostensibly, the present cotton futures act is a revenue or taxation measure. Its primary purpose, however, is to regulate the business of cotton exchanges with the object of eliminating some of the evil features of future dealing in cotton, and to stabilize cotton marketing generally.

\footnotetext{
${ }^{27} 35$ Stat. L. 251 .

18 The most important of these is the U. S. Grain Standards Act to which reference has already been made.

1038 Stat. L. 603.

2039 Stat. L. 446.
} 
The act imposes on all contracts of sale of cotton for future delivery, made at, or on, any exchange or similar institution or place of business an excise tax of two cents on each pound of cotton involved in such contracts. It then provides for exemption from this tax of such contracts as comply with the provisions of the act.

Most of these conditions which relieve transactions from the tax have to do with the form and terms of the contracts: The principal requirements are: (I) all contracts must conform to rules and regulations made pursuant to the act; (2) they must specify the basis grade for the cotton involved in the transaction. which must be one of the grades for which standards have been established by the Secretary of Agriculture and none other; (3) if cotton other than the basis grade be tendered or clelivered in settlement of a contract, the difference above or below the contract price which the receiver shall pay shall be the actual commercial difference as determined by the Secretary of Agriculture: (4) the total weight involved in a contract must be tendered and the person making the tender shall furnish to the person receiving the same a written notice or certificate stating the grade of each individual bale to be delivered and, by means of marks or numbers, identify each bale with its grade; (5) in case a dispute arises between the parties to the contract, as to the grade of any cotton tendered either party may refer the question for determination by the Secretary of Agriculture, his findings to be accepted in all courts of the United States as prima facie evidence of the true classification of the cotton involved: and, (6) that the delivery of cotton under the contract shall not be effected by means of a "set-off" or "ring" settlement, but only by the actual transfer of the specified cotton mentioned in the contract.

The administration of that part of the cotton futures act which relates to what might be termed the technique of cotton handling, marketing, and grading, and the settlement of disputes between the parties to contracts, has been conmitted, by Congress, to the Secretary of Agriculture. That 
part which has to do with the imposition and collection of the tax is administered by the Secretary of the Treasury. Each of these officers is authorized and instructed to make and promulgate such rules and regulations as may be deemed necessary for the enforcement of the various provisions of the act. In this, as in so many other instances, cooperation between the two departments is essential to the effective administration of the law.

The enforcement of that part of the act which was assigned to the Secretary of Agriculture has been delegated by him to the Chief of the Bureau of Markets. This work constitutes one of the principal functions of this newly created bureau. Rather logically, it falls under four main heads: (I) general administration or supervision; (2) the determination of disputes; (3) the establishment and promulgation of official cotton standards, and the preparation and distribution of practical forms thereof ; and (4), the investigation of future and "spot" cotton markets, primarily to see that the provisions of the law are being observed in the first, and to secure reliable information regarding cotton marketing and prices in the second. This information is supplemented by daily market quotations from all of the principal markets and exchanges.

The general supervision of the enforcement of the cotton futures act is under the immediate direction of the Chief of the Bureau of Markets. In this work, he is assisted by a board of examiners and by a committee on final inspection. Their principal function is to formulate and enforce the rules and regulations which are promulgated by the Secretary. They also pass upon general questions of policy and method. The personnel of these committees is very nearly the same as that of the other administrative units in this division. They are mercly required to act in a somewhat different capacity.

Practically all of the men who are made responsible for the technical work involved in the administration of this law have had extensive experience, either in the production or the handling and marketing of cotton. 
When a dispute arises between the parties to a future contract as to the grade, quality, or length of staple of cotton tendered, either party may appeal to the Secretary of Agriculture for a determination of the question. In such cases, a fair sample of each bale of cotton involved in the dispute is forwarded to Washington or other designated point, by the complainant, together with the suitable marks of identification, a statement of the question at issue in the case of each bale, and other detailed information regarding the transaction. ${ }^{21}$ An answer may be filed by the respondent within three days after the filing of the complaint. This time may be extended by the Secretary where good cause is shown. A copy of cach complaint, answer, certificate or affidavit must be served upon the adverse party. Either party may request an oral hearing or other inquiry. The answer signed by the respondent or agent must admit or deny each allegation of the complaint, and must give full information regarding the disputed points. Both the complaint and the answer must state whether the parties have agreed upon samples to be submitted to the Secretary of Agriculture, and if some have and some have not been agreed upon, the marks identifying each bale in dispute, the sample of which has been agreed upon. Either party may submit samples. If the examiners are not satisfied with samples submitted they may demand others drawn from any or all of the bales involved in the transaction by some disinterested party. When all hearings have been held and the samples finally graded and classified, a copy of the findings upon any dispute is promptly served upon each party, either personally or by mail.

The costs for the determination of any dispute are based on a minimum charge of thirty cents per bale, with a total minimum cost of five dollars for each dispute. The costs so fixed may be assessed against either party, or apportioned against both, as the Secretary of Agriculture may find to be

${ }^{21}$ Rules and Regulations under the U. S. Cotton Futures Act of Aug. 11, 1916, Office of the Secretary; Circular no. 64, pp. 6-16. 
just in each case and set forth in his findings. Generally, they are prorated on the basis of the errors in the claims of each party.

In the establishment of official standards for the various grades of cotton, bales representing the characteristic qualities of the cotton of each state are purchased throughout the cotton belt, and used for the preparation of copies of the official standards. These are placed in boxes especially constructed for the purpose, certified under the seal of the Department of Agriculture, and are accompanied by photographs made of the contents of each box at the time of certification. Sets of the official standards or fractional parts thereof are sold to those desiring them at cost of preparation. Purchasers of official standards, however, hold them subject to examination by representatives of the Department of Agriculture, and if for any reason they are found to have deteriorated since their preparation or to misrepresent the official cotton standards in any way, the certificate of grade may be cancelled or removed. Such inspections are made without charge and official standards are renewed at a nominal cost. Each set contains standards for nine grades. Each box contains twelve samples showing the degree of variation which may be allowed within each grade. These standards are used in most of the leading European cotton exchanges, as well as in all important American cotton markets.

The price quotations of future contracts on cotton exchanges have a commanding influence upon the prices paid for spot cotton. Prior to the enactment of the law, it was believed that these quotations were not true barometers of spot-cotton prices, but usually were unwarrantably low, and at times fluctuated unduly in response to manipulation. This condition was attributed largely to certain evil features which had crept into the practices on future exchanges as embodied in the form of contract used. One primary object of the act, as already indicated, was to correct these practices by inducing exchanges to adopt a form of contract free from these objectionable features. 
To secure a better observance of the requirements of the law, and to enable the Secretary to determine equitable commercial values in those cases where cotton other than the specificd grade is tendered, a system of periodical investigations of, and daily reports from, both future and spot 'markets is maintained. ${ }^{22}$ The act requires that only the quotations from "bona fide" or approved spot markets shall be used in the determination of commercial values. Such markets must be designated by the Secretary of Agriculture after inspection.

No adequate criticism of the operation or administration of the cotton futures act is available. According to those officials who are engaged in the enforcement of the statute, it has accomplished the chief economic objects anticipated by its framers. Future quotations now represent spot values more accurately; sharp and sudden fluctuations have become less common, and prices have been increasingly stabilized. Generally, these changes help the producer to obtain more equitable prices. They also benefit the cotton dealer or manufacturer by giving him a truer index of the advance value of raw material. Furthermore, they secure to all concerned in the financing of the cotton crop a safer hedge. It has also operated to remove some of the suspicion which formerly attached to exchanges that transactions were not always fairly conducted. ${ }^{23}$

That conditions are improving is shown by a marked decrease in the number of disputes submitted in the fiscal year I9I7 as compared with previous years.

The act is interesting as a historic step in the movement for goverumental supervision and cooperation in the transaction of business. ${ }^{24}$

${ }_{22}$ Program of Work, Fiscal Year, 1917, pp. 461-462.

${ }^{23}$ Report of Secretary of Agriculture, 1915, p. 45.

24 For an analysis of the Cotton Futures Law and of the circumstances leading to its enactment, sec Journal of Political Economy, vol. xxiii, p. 465; and American Economic Review, March, 1915, vol. v, p. 1 . 


\section{CHAPTER V}

\section{Financial Administration}

The law of the United States relating to the preparation of estimates, the submission of financial reports, and the expenditure of appropriations is very meager and fragmentary. Indeed, it may be said that there is no general or comprehensive statute designed to regulate the financial affairs of the executive departments or of the other units of government. Such financial legislation as there is, then. consists almost wholly of small excerpts or sections from general laws or appropriation acts. Some of the earlier of these have been incorporated into the Revised Statutes; most of them are to be found only by searching the volumes containing the Statutes at Large. Many of these legislative fragments give evidence of hasty and ill-considered action intended to correct some undesirable practice or abuse on the part of administrative officers : few, if any, of them show that their framers had any grasp of the whole situation. ${ }^{1}$

Speaking generally, the financial affairs of the Department of Agriculture are subject to the same law and the same methods and procedure as those of the other government services. There are, however, some notable differences. These will be noted and emphasized in the proper place in this chapter.

The federal law governing the preparation of estiniates of appropriations and their submission to Congress deals almost exclusively with the form which the estimates shall take, the channels through which they shall be transmitted, and the time when they must be furnished to Congress.

1 For a good discussion of federal laws relating to government finances see the Report of the President's Commission on Economy and Eifficiency, "The Need for a National Budget," part 1, pp. 15-12S. 
By act of July 7, ISS4, Congress imposed upon the Secretary of the Treasury the duty of classifying, compiling, indexing, and printing what is known as the "Book of Estimates." The centering of this function in one place resulted ' in greater uniformity than had been possible previously, but each year there were numerous changes in substance as well as in the sequence of items. In order to secure greater continuity in the form of the estimates. Congress, by act of Iune 22, 1906, ${ }^{3}$ required that thereafter the estimates for the expenses of the Govermment, except those for sundry civil expenses, should be prepared and submitted each year according to the order and arrangement of the appropriations acts for the year preceding. Any changes in such order and arrangement, and any transfer of salaries from one office or burcau, and any consolidation of offices or bureaus, desired by the head of any executive department were required to be submitted by note in the estimates.

Section three thousand six hundred and sixty-nine of the Revised Statutes says: "All annual estimates for the public service shall be submitted to Congress through the Secretary of the Treasury." This section was subsequently modified so as to require that "hereafter all estimates of appropriations and estimates of deficiencies in appropriations intended for the consideration and secking the action of any of the Committees of Congress shall be transmitted to Congress through the Secretary of the Treasury, and in no other manner."

By act of March 3, 1901, ${ }^{5}$ officers authorized to make estimates are required to furnish them to the Secretary of the Treasury on or before the fiftecnth day of October of each year. If they fail to clo this as required, it is the duty of the Secretary of the Treasury to cause to be prepared, on or before the first day of November, estimates for such appropriations as in his judgment shall be requisite.

223 Stat. L. 254.

334 Stat. I. 448.

- 23 Stat. L. 254.

31 Stat. L. goro. 
Aside from these legal requirements, and several others having similar intent or purpose, the actual preparation of the estimates rests very largely with the heads of the executive departments and the principal officers of the various independent administrative units. The only exception is that found in the sundry civil appropriation act of June 23, I9I3, which provides that hereafter the head of each executive department or other Government establishment, shall designate from among the officials employed therein one person whose duty it shall be to supervise the classification and compilation of all estimates of appropriations to be submitted by such department or establishment.

This decentralization in the preparation and submission of estimates is in accord with the expressed attitude of Congress, which has thus far resisted all attempts to secure greater centralization or executive control.

With the exception of the proviso just noted, nothing is contained in the statutes which indicates the method to be pursued by heads of the departments and other officiers either in making up their estimates or in the consideration of estimates before they are submitted. Various methods are employed. Briefly stated, the usual procedure in the Department of Agriculture is as follows: Shortly after the beginning of the fiscal year the Sccretary of Agriculture addresses a letter to each chief of bureau or other primary subdivision, requesting that estimates for the next fiscal year be prepared and submitted to his office on or before a certain date. This letter also calls attention to the form which the estimates must take and to any general policy or policies which may have been adopted with reference to this matter by the administrative head of the department.

Upon receipt of this letter, the bureau chief causes copies of it to be marle and sends one copy, together with his own instructions that estimates be prepared in accordance with it, to each of the division heads or similar officers. These latter officials, in the case of the larger livisions, pass the task on, in somewhat less formal manner, to their own subordinates. 
Ordinarily, then, it is the section head or project leader who actually begins the preparation of the estimates, particularly with respect to the amounts of money to be requested. In this task, he must of course be governed by a number of considerations: (I) due regard must be had for any special instructions contained in the letters from the Secretary and the Chief of Bureau; (2) there are many rules, based either upon statutes or administrative orders, governing changes in salaries both on lump sum and statutory rolls; and, (3) if any increased amount is requested either for additional workers or for the prosecution of new work, a comprehensive statement justifying the request must be submitted.

If no change, either in anount or content, is requested, the work of preparing estimates is a comparatively easy task, and the ascent of the administrative ladder will probably be made without much friction. It is only where there is departure from the estimates of the previous year that any serious difficulties are likely to be encountered. This fact constitutes the chief defect of the entire procedure. A line of work, once established, may be continued long after the original objects have been attained, while new projects of equal or greater importance may receive recognition only with the greatest cffort, or not at all.

It is true, as we shall see. that Congress has attempted to correct this defect by imposing 11pon the Secretary of Agriculture the cluty of reporting. from time to time, the status of the work under each project. So far as the writer is aware, however, there is no systematic attempt to correlate this report with the estimates themselves. This tendency to perpetuate work once begun is accentuated by the desire of each executive officer to magnify his own position. He is always willing to cssay a new task, but never willing to forego the old.

Since the passage of the law, in 1913 , requiring each department head to designate some official to supervise the preparation of estimates, each bureau in the Department of Agriculture designates one of its officers to cooperate with 
him during the period when estimates are being prepared. It is the duty of this bureau official to assemble the estimates and arrange them for inspection by the chief of bureau. This done, they are then revised and put in form for transmission to the supervisor of estimates. After examination by the Secretary and his assistants, they are put in final form and transmitted to the Treasury Department to be incorporated in the book of estimates. It is in this form that they are transmitted to Congress.

Section seven of an act of March 4, I909, provides that:

If the estimates for appropriations, ... shall exceed the estimated revenues the Secretary of the Treasury shall transmit the estimates to Congress as heretofore required by law, and at once transmit a detailed statement of all of said estimates to the President, to the end that he may, in giving Congress information of the state of the Union and in recommending to their consideration such measures as he may judge necessary, advise the Congress how, in his judgment, the estimated appropriations could with least injury to the public service be reduced so as to bring the appropriations within the estimated revenues; or, if such reduction be not in his judgment practicable without undue injury to the public service, that he may recommend to Congress such loans or new taxes as may be necessary to cover the deficiency. ${ }^{6}$

This is the only statutory provision requiring or authorizing the executive branch to exercise any supervision over the estimates as a whole. Even this is merely an advisory power and is exercised, if at all, after the original estimates have been transmitted to Congress. It was, however. used with notable effect during the period of declining revenues following the outbreak of war in Europe in 1914.

As head of the administrative department of the gorernment, the President may, of course, exercise a very salutary influence over his subordinates in the general policies to be followed in the preparation of estimates. No doubt this has often been done.

Of the fifteen regular or usual appropriation bills which are annually submitted to the House of Representatives, only six are prepared by the Committee on Appropriations. The remainder are prepared and submitted by various other

\footnotetext{
"35 Stat. L. 1027.
} 
committees in accordance with well established rules and customs of the House. Thus, when the book of estimates is received by the Speaker of the House, to whom it is sent by the Secretary of the Treasury, he merely refers the various estimates to the appropriate committees, without any formal action on the part of the House itself.

The Committee on Agriculture in the House of Representatives, to which are referred the estimates for the Department of Agriculture, was established as a standing committec, May 3. IS20. At first it was hardly more than a convenient repository for the petitions and memorials relating to agriculture which from this time began to reach the House in increasing volume. Unimportant at first, it has gradually grown to a place of importance among the many committees of the House of Representatives.

Section ten of Rule eleven of that body gives to the Committee on Agriculture jurisdiction of all subjects relating to agriculture and forestry and the appropriations for the Department of Agriculture. In practice the scope of this jurisdiction has been construed very liberally.

From the personnel of the committee it would appear that effort has been made to make its eighteen members fairly representative of the principal agricultural sections of the country. Its present chairman, Mr. Asbury Lever of South Carolina, is a strong advocate of public aid and encouragement to agriculture. He has done very much to secure congressional support of the relatively large number of measures passed in the interest of agriculture during the past few years.

Unlike the estimates for most of the departments and services, those for the usual appropriations of the Department of Agriculture are considered by only one committee, and when presented constitute only one bill. This obviates the necessity for cooperation with any other committee.

In keeping with the general practice of congressional com-

iHind's Precedents of the House of Representatives, vol. iv, sec. 4149 . 
mittees, a bill is first prepared on the basis of the estimates as submitted. This serves as a working paper for the members of the committee and others who are interested. The next step is the calling of department officials to make statements or to answer questions with respect to the needs of the various bureaus or divisions. This examination may be limited to include only the principal officers, or it may be extended to include even project leaders. Both procedures are followed. These "hearings," with some interruptions, generally spread over a period of several weeks. Much is said, both relevant and irrelevant, to the various matters under discussion. One feature of the procedure which impresses the onlooker is the narrow sectionalism manifested by the members of the committee, and the failure to view the various problems presented from the larger national viewpoint. Collateral discussions arising out of this narrowness often result in a failure to give adequate consideration to the actual matter in hand. From a somewhat limited observation, it has seemed to the writer that the actual contents of the ordinary estimates receive only the most meager consideration.

Besides the information contained in the hook of estimates and such as may be adduced from the "hearings," the committec has at its disposal the detailed statement of expenditures for the entire department for the last and previous fiscal years. This is supplemented by several special statements or reports relating to certain phases of the work of the department. To what extent these are used by the committee in the preparation of its final report, it is difficult to say.

Apart from the riclers and extraordinary proposals which it frequently carries, the report of the Committee on Agriculture, or the agricultural appropriation bill, does not elicit very much discussion on the floor of the House. Such as there is, like that within the committee, is often characterized by sectionalism. In the bill for the fiscal year ig16, an item of one hundred thousand dollars was doubled by the 
'committce of the whole,' without reference to the needs of the service. but simply to "equalize" expenditures in the North and the South.

In the Senate, the agricultural bill is referred to the Com- mittee on Agriculture and Forestry. This committec could, of course, conduct hearings also. In practice, however, it relics largely upon the published reports of the hearings of the House committec, supplemented by such additionai information as may lie furnished at its request by the department. Generally; its report to the Senate is not very different from that made to the Honse. The conference committee of the two Houses is thus scldom confronted with many conflicts relating to the agricultural bill proper.

Beginning in $1 \& 39$, one thousand dollars was set aside by Congress from the receipts of the Patent Office for the purpose of collecting and distributing secls and procuring agricultural statistics. By $18_{79}$, the appropriation had been increased to three thousand five hundred dollars, and by I 859 , to sixty thousand dollars. In I 869 , seven years after the department had become an independent establishment, the appropriation amounted to one hundred and seventy-two thousand five hundred and ninety-three dollars, and in IS 7 ). to two hundred and six thousand four hundred dollars. When the department was raised to the first rank in $I S S 9$. the appropriation was one million and thirty-four thousand four hunclred and eighty clollars. By this time the administration of the financial affairs of the department had developed to such importance that a separate division of accounts and disbursements was created to insurc proper disbursement of the funds. In IS99. the amount appropriated had been further increased to two million eight hundred and twenty-nine thousand seven hundred and two dollars; and by inom, had been very consideral,ly increased to fifteen million three hundred and eighty-five thousand, eight hundred and six dollars. At the present time (I9IS) the amount annually appropriated is approximately double this last sum, or thirty million dollars. The recent rapid in- 
crease in the agricultural appropriation is merely another indication of the growing importance of the work of the Department of Agriculture in our governmental system. ${ }^{8}$

The Division of Accounts and Disbursements, created in ISS9, is still the central accounting office. Its chief is the principal fiscal officer and is also the disbursing clerk of the department. He is charged by the Secretary of Agriculture with the duty of preparing all requisitions for the advance of public funds from the Treasury Department to the Department of Agriculture or its disbursing clerks, the keeping of general appropriations ledgers, and the payment of all vouchers and accounts properly submitted by the various offices, bureaus and services of the department. $\mathrm{He}$ must furnish bond in an amount acceptable to the Secretary ; and is, of course, subject to the various laws and comptroller's decisions governing public disbursing officers and the application of public funds.

Section three thousand six hundred and seventy-nine of the Revised Statutes, as amended, requires that "all appropriations made for contingent expenses or other general purposes,... shall, on or before the beginning of each fiscal year, be so apportioned by monthly or other allotments as to prevent expenditures in one portion of the year which may necessitate deficiency or additional appropriations to complete the service of the fiscal year for which said

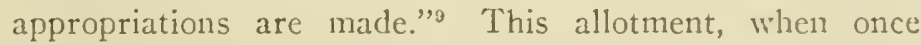
macle, nay not be changed, except by specific authority of the department head.

The agricultural appropriations are allotted each year on the quarterly basis. For many years the intent of the law just quoted was evaded by allotting to the first quarter the major portion of the appropriation, with progresively decreasing amounts for each of the other quarters. In very recent years this practice has been corrected by allotting the

* For a more nearly complete statement of appropriations for the Department of Agriculture, see appendix iv.

${ }^{3} 33$ Stat. 1. $1257 ; 34$ Stat. L. 48. 
same amount or proportion to ench quarter. While this latter practice undoubtedly conforms more nearly to the law, it greatly increases the funancial administrative work by requiring such close scrutiny of unencumbered balances. It also tends to enhance the evil, which is found throughout the government services, of postponing the expenditure of a large part of the appropriation until late in the fiscal year, with consequent hasty and ill-considered expenditures at the end of the fiscal year to aroid having any considerable part of the funds revert to the Treasury:

At the beginning of each fiscal year, after the allotments have been completed, a 'letter of authorization' is issued by the Secretary of Agriculture to the head of each bureau or other primary unit giving him authority to incur expenses, in accordance with law, to the amount of the funds appropriated for the use of the particular administrative unit. This letter then constitutes the basis of authority for the chief of bureau when conferring authority to incur expenses upon his own subordinates. Only in a few pre. scribed instances is further anthorization required from the Secretary:

All of the detailed financial records of appropriations and expenditures are kept in the various bureaus or other primary administrative units to which they relate. By act of July 31 , IS94, ${ }^{10}$ all accounting forms must be cither prescribed or approved by the Comptroller of the Treasury. This requirement together with the constant general supervision exercised by the Office of the Secretary has resulted in a fair degree of miformity both as to forms and procedure, in the various bureau accounting offices. The work of these offices is further systematized and coordinated by the publication and periodical revision of an authoritative manual of fiscal regrulations of the department. This manual also serves as a convenient guide in fiscal matters to all officers of the department. ${ }^{11}$

in 28 Stat. I. 162.

11 Such regulations are required by law. 28 Stat. L. 207. 
For several years prior to the fiscal year I9I3, the administrative examination or audit of all vouchers submitted for payment was made in the Division of Accounts and Disbursements. By act of August 23, 1912,12 the task of making the administrative examination of all public accounts, preliminary to their audit by the accounting officers of the Treasury, was specifically committed to the administrative heads of the bureaus or divisions in the executive departments. Aside from a very cursory examination made under the direction of the disbursing clerk for his own protection and to see that they represent legal claims, the only audit to which vouchers are subjected, prior to their payment, is that made in the various bureaus. In the case of doubt as to any claim, the disbursing clerk is authorized to secure a decision from the Comptroller of the Treasury. In common with all public vouchers, those of the Department of Agriculture are examined, subsequent to their payment, by the auditors of the Treasury Department. At the end of each quarter a statement of exceptions is submitted to the disbursing clerk. As the bonded financial officer, he is primarily responsible for any unauthorized or improper payments made by him. Usually, however, he can recoup by appealing through the bureau accounting officers to the persons to whom the erroneous payments were made.

As an aid to the administrative head of the department in securing general supervision over the fiscal affairs, and as a means of checking and verifying all financial records, the disbursing clerk is required to list or schedule the payments charged against each bureau.

At the end of each quarter, and before the vouchers are sent to the Treasury Department, these lists are transmitted to the various bureaus for comparison with the bureau financial records. When the differences, if any, have been adjusted the lists are approved by the clice of bureau, and the accounts are assumed to be correct. The vouchers are

1237 Stat. L. 3Go. 
then transmitted to the Treasury Department for final settlement, as required by law. ${ }^{13}$

Not all of the funds appropriated for and expended by the Department of Agriculture are disbursed by the Chief of the Division of Accounts and Disbursements. In those outlying places where the delay or expense incident to sending accounts to Washington for payment would hamper the conduct of government business, special disbursing agents, having very limited jurisdiction, are appointed by the Secretary of Agriculture to make disburscments. Funds for the purpose are warranted to these officers, on requisition signed by the Secretary, just as in the case of dishursing clerks. These special agents are thus not only authorized to incur expenses, as are other officers to whom the usual letter of authorization is issued, but may also clisburse public funds to meet these expenses. While this special authority is conferred clirectly by the Secretary, the agents are subordinate officers of the bureau or bureaus to which their work is administratively related. Paid accounts are transmitted to the burean for reexamination and record, and are then forwarded to the Treasury through the usual channels. An acceptable surety bond is required from each special disbursing agent.

Federal funds appropriated for expenditure in cooperation with state agencies are paid by the Treasury Department, upon requisition or warrant of the Secretary of Agriculture, to the state treasurer, or to such other officer as may be designated by state law under each cooperative act, to receive such funds. This officer is required to render to the Secretary of Agriculture a detailed statement of the funds received and of their clishursement on forms prescribed by the Secretary of Agriculture. ${ }^{14}$ These statements constitute the basis for special reports to Congress as required by the various acts to which they may relate.

There is a gencral provision of law ${ }^{15}$ requiring that each

${ }_{13} 25$ Stat. I. 371.

14.34 Stat. I. $63 ; 37$ Stat. L. 207.

13 Rev. Stat. sec. 193: 19 Stat. L. 306. 
department head submit a very detailed report of all expenditures from contingent funds. Each secretary or other administrative head also submits, as a part of his regular annual report to Congress, a detailed statement of expenditures for all appropriations applicable to his department or service. Besides these, the reports referred to in the preceding paragraph, and a number of special reports required from all department heads, the Secretary of Agriculture is required to render special and detailed reports regarding the suppression of animal diseases, ${ }^{16}$ and the purchase and distribution of seeds. ${ }^{17}$

So far as these reports relate to expenditures, they are referred to the House Committee on Expenditures in the Department of Agriculture and to a similar committee in the Senate. As previously stated, there appears to be no systematic attempt to utilize any of these reports when.the estimates for the department are under consideration. Even if the attempt were made, the information contained in most of these reports, except those where detailed information is specifically required, is too meager to be of very great value.

Rule Eleven, paragraph forty-two, of the House of Representatives provicles as follows:

The examination of the accounts and expenditures of the several departments of the Government and the manner of keeping the same; the economy, justness and correctness of such expenditures; their conformity with appropriation laws; the proper application of public moneys; the security of the Government against unjust and extravagant demands; retrenchment; the enforcement of the payment of the money due to the United States; the economy and accountability of public officers; the abolishment of useless offices; the reduction or increase of the pay of officers, shall all be subjects within the jurisdiction of the nine (now ten) standing committees on the public expenditure in the several departments, as follows: ..

50. In the Department of Agriculture-to the Committee on Tixpenditures in the Department of $\Lambda$ griculture.

Despite the claborate and comprehensive anthority thus conferred, it is well known that these committees on expenditures, in both the Hotse and the Senate, are very

1023 Siat. I., 33.

1737 Stat. 1. 278. 
largely only nominal bodies and seldom meet for the consideration of business. When they have acted, they have usually been looked upon as agents of the Congress for ferreting out some suspected maladministration rather than for systematic consideration of expenditures, or for rendering assistance to the various appropriation committees. ${ }^{13}$

Section five of an act of June 30, 1906, provides as follows :

Hereafter the Secretary of the Treasury shall require and it shall be the duty of the head of each exccutive department or other government establishment to furnish him, within thirty days after the close of each fiscal year, a statement of all money arising from proceeds of public property of any kind or from any source, other than the postal service, rcceived by said head of department or other government establislument during the previous fiscal year for or on account of the public service, or in any other manner in the discharge of his official duties, other than as salary or compensation, which was not paid into the General Treasury of the United States, together with a detailed account of all payments, if any; made from such funds during each year. All such statements, . . . shall be transmitted by the Secretary of the Treasury to Congress at the beginning of eacli regular session. ${ }^{10}$

The principal sources of revenue of the Department of Agriculture, other than the sale of discarded furniture, equipment or other miscellaneous property, are: (I) the sale of cotton standards, the sale of loose cotton, and the costs of cotton futures disputes; (2) the sale of photo prints, lantern slides, and card indexes: (3) the sale of agricultural products from the four insular experiment stations of Alaska, Hawaii, Porto Rico, and Guam; and (4) the sale of forest products from grazing privileges on the national forests.

Of the revenues thus received the only portion which has been, until very recently, available for expenditure by the Department of Agriculture was that received from the sale of products at the insular experiment stations, seldom anounting to more than three or four thousand dollars annually. Even this must now be covered into the Treasury

19 President's Commission on Economy and Efficiency, "The Need for a National Buclget," part 2.

1034 Stat. L. -63. 
as miscellaneous receipts. The act of February $\mathrm{I}, 1905,{ }^{20}$ transferring the administration of the forest reserves from the Department of the Interior to the Department of Agriculture, provided that all money received from these reserves for a period of five years should be covered into the Treasury as a special fund, available, until expended, as the Secretary of Agriculture might direct, for the administration and improvement of the forest reserves. At first, proposed expenditures from this source were not even included in the book of estimates. This apparent oversight was soon rectified, but before the five year period had expired a law ${ }^{21}$ was passed requiring that all funds received from forest reserves be covered into the Treasury as miscellaneous receipts. Thereafter only so much of these funds was made available as was necessary to make refunds for payments erroneously received.

As previously noted, ${ }^{22}$ a very considerable part of the receipts from the forest reserves are available, by various acts of Congress, for the construction and maintenance of schools and roads in the States and counties in which the forests are located. All of these receipts, however, are covered into the Treasury in the usual manner and the amount is merely used as a basis in determining the sums which the various States and counties are entitled to receive. The seven district fiscal agents, whose duty it is to supervise the financial affairs of the forest reserves, transmit their collections directly to the Treasury and merely send copies of their reports to the Department of Agriculture.

The privilege of expending the receipts from the sale of products at the insular experiment stations was retained for several years only by a most urgent annual appeal to the House Committee on Agriculture.

If the experiences of the Department of Agriculture may be taken as typical, and there is reason to believe that they

2033 Stat. L. 628.

213.4 Stat. I. 1256.

22 Chapter iii. 
IO8 TIIE UNITED STATES DEPARTMENT OF AGRICULTURE

are, it would seem that it is the present policy of Congress to depart entirely from the practice of granting " appropriations in aid," 23 which is still an important factor in the British financial scheme, and which has heretofore characterized the American system as well.

${ }^{23}$ For a discussion and criticism of the subject of "Appropriations in Aid," see Willoughby, Willoughby, and Lindsay, Financial Administration of Great Britain, chap. v. 


\section{CHAPTER VI}

\section{Conclusions}

From the time of its establishment as an administrative unit of the first rank in 1889 to the fiscal year 1917 , the Department of Agriculture enjoyed a more rapid comparative growth, both in the amount of its appropriations and in the number of its personnel, than any other of the executive departments. Some effort has been made in the foregoing chapters to give an idea of the scope and multiplicity of its present activities. During the past few years, the writer has been frequently surprised to find how little is popularly known concerning the work of this great institution, which by the very nature of its duties and functions, should be the most popular of all the governmental departments. Contrary to the prevalent opinion, the activities of the Department of Agriculture are by no means limited to the protection or promotion of the interests of any one class or of any one industry.

The primary purpose of this study, however, has been to describe in some detail and to examine the nrganization. and administrative methods of this institution of government as an instrument or machine for making effective the expressed will of the representatives of the people. The value of the various measures, with whose enforcement it is charged, is a question not here considered.

Numerous and diverse as are the functions of the Department of Agriculture, they are still more nearly homogeneous in character than are those of most of the executive departments. As previously indicated, this has made possible a relatively simple organization. The reorganization effected in 1915, while disturbing only slightly the previous structure, secured a mucli more logical and effective grouping of the 
various functions to be performed. In perfecting the present organization, the department head was given a degree of freedom by Congress not usually enjoyed by administrative officers. If it is not effective, the responsibility can be definitely placed. After making reasonable allowance for that administrative indirectness, which seems to be almost inherent in governmental institutions, the present plan, with its functional basis and its deliherate attenipt to minimize duplication of effort, gives promise of meeting the expectations of those responsible for it. What might be called the "cross-sectional" grouping of functions according as they are primarily investigative, educative, or regulative, has greatly clarified the work of the various subdivisions.

In committing measures for administration or enforcement to the various executive departments, Congress is frequently confronted with many difficulties. Many factors must be, or at least should be, considered. The wisdom of that body in committing certain measures to the Department of Agriculture has frequently been questioned. This is particularly true of those laws whose primary purpose is the safeguarding of the public health. Since we already have a fedcral public health service, it is argued, why should it not be charged with the administration of all public health laws? Serious attempts have been made in Congress and elsewhere to secure this change. ${ }^{1}$

Undoubtedly, the chief consicleration which determined Congress to cliarge the Department of Agriculture with the administration of such measures as the food and drugs act was the very superior laboratory facilitics which this department had, and the fact that it already had a consiclcrable staff of chemists and bacteriologists. These facilitics and the scientific personnel have, of coursc, been greatly enlarged since the assumption of the added duties, and as a result of the general expansion of the work of the department. Since it must have extensive laboratory facilities and

I Report of the Secretary of Agriculture, Igro. 
a large staff of chemists, bacteriologists and veterinarians for the conduct of its normal or ordinary duties; and since these can be used to a large extent in the enforcement of these health laws without proportionate increase in expense; the Department of Agriculture would seem to be better fitted to perform this work than is any of the other departments. Aside from the matter of equipment and facilities, the effective administration of these or any other laws is dependent upon the character of the responsible administrative officers. Such requisites are quite as likely to be found in the Department of Agriculture as in any other department or service.

The administration of public health law seems to be the most striking anomaly in the functions of the Department of Agriculture. There are other functions, however, where the difficulty is not in harmonizing them with the primary, work of this department, but in delimiting them from the functions of the other departments. This is particularly true, as we have seen, with respect to the work of the Department of the Interior. Where Congress, either because of ignorance of the situation or through sheer inability logically to divide so many governmental functions among so few departments and independent services, has not clearly defined their respective fields, friction may be eliminated and duplication of effort minimized by proper cooperative relationships between the departments concerned. It has already been shown, too, how extensively this same plan has been followed in the legal and voluntary relationships of the Department of Agriculture with State agencies. This cooperative system of action scems to offer a possible solution for many of the difficulties growing out of our federal form of government.

The policy of the Department of Agriculture in the dissemination of the results of its researches has frequently been the object of criticism. Both the character of the various publications and the manner of their distribution have been assailed as ineffective in securing the desired re- 
sults. Many expensive bulletins have been prepared which, either because of their content or the method of presenting the subject, proved to be of little value in the promotion of agriculture. Long mailing lists of names have been built - up to which many thousands of bulletins have been sent largely irrespective of the needs or desires of the recipients. To these were added a large number of indiscriminate lists and requests from nembers of Congress. It is difficult, if not impossible, to form any estimate of the value of these publications on the one hand, and the needless waste on the other.

There seems to be no question, however, but that there has been, and to a less extent, still is, opportunity for improvement in this matter. To the extent that Congress interferes directly in the distribution of publications, the department is, of course, powerless.

It may be recalled, from what has previously been said, that one of the first steps of the present administration was to improve the methods of the department in making available the results of its work. The Smith-Lever extension and demonstration act was largely a result of this general policy. The various publications, though not lessened in number, ${ }^{2}$ have been simplified and made more practical. A much wider and more systematic use is now made of the public press to popularize the work that is being clone. To this end an office of information has been created. This office also issues a widely circulated weekly news-letter. Provision is made for a continuing revision of mailing lists. Fewer publications are distributed freely; more are offered for sale at cost by the document section of the Government Printing Office. ${ }^{3}$

Py these means and others, notable improvements have been made in the methods of making the work of this institution available and effective. Here again, however, one can do no more than form an estimate on general principles.

2 Sec appentix iv.

${ }^{3}$ Reports of the Department of Agriculture, 1917, p. 271. 
The value of this type of governmental activity is, by its nature, largely immeasurable.

With the present facilities for immediate personal contact with farmers through the County Agent system, the department has an ever ready means of direct communication; but it has in it, also, certain inherent dangers. Already there are evidences that the farmers do not welcome too much direct interference in the conduct of their business.

The organic relationship of the Department of Agriculture to Congress is peculiarly fortunate. Through the Committee on Agriculture in the House of Representatives, to which are referred practically all proposed measures in which the Department of Agriculture is interested, it is possible to have a very close articulation between these two agencies of government. This, of course, presupposes favorable political and personal relationships. This unusually fortunate situation, though the result of fortuitous circumstances rather than deliberation, has proved very beneficial to the department. A very similar arrangement has been proposed by one eminent authority as the basis of a plan to secure a more workable correlation between the legislative and administrative branches of our government as a whole.* This would, of course, involve almost a complete reorganization of the committee system of Congress.

Despite this favorable and unique relationship of the Department of Agriculture to Congress, which has frequently facilitated the passage of legislation, there is no evidence that Congress exercises any more adequate control or supervision over the work of this department than over that of any other. This, as we have seen, is not due to the absence of reports and other information, but rather to the failure of Congress to secure a proper coordination of reports, estimates, and other data in such a way that they might be used as a basis for control and supervision of the administration. Or, as Professor Willoughby says, it is due to the failure of

4W. F. Willoughby, The Problem of a National Budget, 1918, p. $104 \mathrm{ff}$. 


\section{II4 THE UNITED STATES DEPARTMENT OF AGRICULTURE}

Congress to conceive of itself as a board of directors supervising and controlling a great enterprise. ${ }^{5}$

In concluding an administrative study of one of the great departments of government, perhaps the strongest impression one receives is that, while a given department may make, or fail to make, many minor improvements which, if made, would go far toward more effective administration, there can be nothing like an adequate solution of our administrative problems short of a complete reorganization and revivifying of the system as a whole. There are ever increasing evidences that important changes will be made in the not distant future.

¿ Ibid., p. $96 \mathrm{ff}$. 


\section{APPENDIX I}

Outline of the Organization of the Department of Agriculture as it was during the Fiscal Year

I917. (Prior to April 6, I9I7)

United States Department of Agriculture.

A. Institutional Units.

I. Office of the Secretary.

a. Secretary's Office proper.

b. Assistant Secretary's Office.

c. Solicitor's Office.

d. Disbursing Office.

e. Library.

f. Office of Information.

g. Office of Inspection.

h. Office of Exhibits.

i. Office of Forest Appeals.

j. Chief Clerk's Office.

k. Mechanical Superintendent's Office.

B. Functional Units and Functions.

I. Office of Farm Management.

a. General Administration.

b. Investigations in Farm Economics.

c. Application of Farm Economics to Farm Practice,

d. Clearing and Utilization of Logged-Off Lands.

2. Weather Bureau.

a. General Administration.

b. Collection of Meteorological Data.

c. Forecasts and Warnings.

d. General Investigation and Research.

e. General Educational Work.

3. Bureau of Animal Industry.

a. General Administration.

b. Eradication and Control of Animal Diseases.

c. Inspection and Quarantine of Imported Animals, and Inspection of Animal Exports.

d. Eradication of Cattle Ticks.

e. Live Stock Demonstrations.

f. Dairy Investigations.

g. Animal Husbandry Investigations.

h. Investigation of Animal Diseases.

i. Control of Manufacture and Shipinent of Viruses, Serums, etc.

j. Control of Meat and Meat Food Products.

4. Bureau of Plant Industry.

a. General Administration.

b. Plant Pathology. 
c. Fruit Disease Investigations and Control.

d. Investigation of Forest Pathology.

e. Cotton, Truck, and Foragc Crop Disease Investigations.

f. Crop Physiology and Breeding Investigations.

g. Soil Bacteriology Investigations.

h. Plant Nutrition Investigations.

i. Soil Fertility Investigations.

j. Crop-Acclimatization Investigations.

k. Poisonous and Drug Plant Investigations.

1. Agricultural Technology Investigations.

m. Fiber Plant Investigations.

n. Biophysical Investigations.

o. Seed Testing.

p. Cereal Investigations.

q. Tobacco Investigations.

r. Paper Plant Investigations.

s. Sugar Plants.

t. Economic and Systematic Botany Investigations.

u. Dry Land Plant Investigations.

v. Pomological Investigations.

w. Horticultural Investigations.

$x$. Foreign Seed and Plant Introduction.

y. Seed Distribution.

z. Demonstrations on Reclamation Projects.

5. Forest Service.

a. General Administration.

b. National Forest Administration.

c. Agricultural Settlement.

d. Forest Fire Suppression.

c. Forest Products Investigations.

f. Range Investigations.

g. Planting National Forests.

h. Sylvicultural Investigations.

i. Surveys of Forest Resources.

j. Construction of Roads and Trails.

k. Exchange of Forest Lands.

6. Bureau of Chemistry.

a. General Administration.

b. Investigations in Agricultural Clemistry.

c. Chemical Investigations for other Departments.

d. Testing Export Food Products.

e. Poultry and Egg Investigations.

f. Fish Investigations.

g. Investigation of Colorings.

1. Enforcemcit of the Food and Drugs Act.

i. Food and Pharmacological Investigations.

j. Investigation of Naval Stores and Methods of Production.

7. Bureau of Soils.

a. General Adıninistration.

b. Soil, Chemical Investigations.

c. Soil, Plyysical Investigations.

d. Investigations of Fertilizer Resources.

e. Soil Surveys. 
f. Classification of Agricultural Lands in Forest Reserves.

8. Bureau of Entomology.

a. General Administration.

b. Deciduous-Fruit Insect Investigations.

c. Cereal and Forage Insect Investigations.

d. Southern Field Crop Insect Investigations.

e. Forest and Shade-Tree Insect Investigations.

f. Truck-Crop and Stored Product Insect Investigations.

g. Bee Culture Investigations.

h. Tropical Fruit Insect Investigations.

i. Moth Investigations.

j. Miscellaneous Insect Investigations.

9. Bureau of Biological Survey.

a. General Administration.

b. Game Preservation.

c. Economic Investigations.

d. Biological Investigations.

e. Enforcement of Migratory Bird Law.

I0. Division of Publications.

a. Publication Work of the Department of Agriculture.

b. Distribution of Documents.

II. Bureau of Crop Estimates.

a. General Administration.

b. Crop Reporting and Estimating.

c. Crop Recording and Abstracting.

I2. States Relations Service.

a. General Administration.

b. Relations with Experiment Stations.

c. Relations with Extension Divisions of State Agricultural Colleges.

d. Farmers' Cooperative Demonstrations in the Southern States.

e. Farmers' Cooperative Demonstrations in the Northern and Western States.

f. Farmers' Institutes and Agricultural Schools Demonstrations.

g. Home Economics Investigations.

13. Office of Public Roads and Rural Engineering.

a. General Administration.

b. Road Management Investigations.

c. Road Building and Maintenance Investigations.

d. Roarl Material Investigations.

e. Field Experiments.

f. Adninistration of Federal Aid Road Act.

g. Farm Irrigation Investigations.

h. Farm Drainage Investigations.

i. Rural Engineering.

14. Burcalı of Markets.

a. General Administration.

b. Marketing and Distribution Investigations.

c. Collecting and Distributing Market Information.

d. Preparation of Market Reports on Live Stock and Meats. 


\section{THE UNITED STATES DEPARTMENT OF AGRICULTURE}

e. Investigations and Demonstrations of Cotton Standards.

f. Rural Organization Investigations.

g. State Cooperation in Marketing Work.

h. Extension and Demonstration Work in Marketing and Distribution and in Rural Organization.

i. Enforcement of the U. S. Cotton Futures Act.

j. Administration of the U. S. Warehouse Act.

k. Administration of the U. S. Grain Standards Act.

15. Insecticide and Fungicide Board.

a. Enforcement of the Insecticide and Fungicide Act.

16. Federal Horticultural Board.

a. Enforcement of the Plant Quarantine Act. 


\title{
APPENDIX II
}

\section{United States Department of Agriculture Office of Markets and Rural Organization}

\author{
Extension Work in Agriculture and Home Economics in the State of \\ Wisconsin by Cooperation between the United States Depart- \\ ment of Agriculture and the Wisconsin Agriculture College \\ under the Terms of the General Memorandum of \\ Understanding, Dated...............
}

This project agreement has been entered into between the Office of Markets and Rural Organization, United States Department of Agriculture, and the Wisconsin Agricultural College, Madison, Wis., for extension work in supplying local communities in the State of Wisconsin with suggested programs on social and economic topics for community interests.

Name of Project:
Location:
Headquarters:
Date EFFective:
Legal AUthority:

Овјест :

Method of Procedure:

Organization:
Community Program, Wisconsin.

Wisconsin.

Wisconsin Agricultural College, Madison, Wis.

"General Expenses, Office of Markets and Rural Organization, 1917 ," the SmithLever Act of May 8, I9I4............ To provide plans and programs for community meetings and to render assistance in the promotion of community discussion along lines of rural organization work for general social and economic improvement.

By cooperation between the Extension Service of the IVisconsin Agricultural College and the Office of Markets and Rural Organization, U. S. Department of Agriculture, programs of meeting will he made out and sent to committees in selected communities, who will be further assisted by correspondence and occasionally by personal visits. In this work County Agents will be requested to suggest neighborhoods and local leaders and to take such part in this work as their other duties as Agent will permit. The Specialist in Rural Organization of the Office of Markets and Rural Organization in cooperation with the representative of the Director of the 119 


\section{COOPERATION :}

AsSigNant :

Source of Maistexance: Appropriation, 1917. "General Expenses,

Publications:

Estimaten Uitimate Cost :

Results EXPECTED:

Date................. Office of Markets and Rural Organization," and the Smith-Lever Act of May 8. 1914.

Extension Service of the Wisconsin Agricultural College, shall arrange for the preparation, compilation, and distribution of the community programs, and receive reports thereon.

It is understood that the program material shall be jointly prepared by the IVisconsin Agricultural College and the Office of Markets and Rural Organization. while the field work shall be carried on under the direction of the Director of Extension of the Wisconsin Agricultural College.

The subject matter taught shall be acceptable to both cooperating parties; no cliange of policy shall be made without the consent of the parties to this agrcement, which may be abrogated by either party upon giving thirty days' notice in writing to the other party.

The Office of Markets and Rural Organization agrees to furnish the desired number of multigraph copies of such program material as may be jointly approved by the Wisconsin Agricultural College and the Office of Markets and Rural Organization. The Wisconsin Agricultural College agrees to supply such program material to rural community clubs in the State of IVisconsin, to make ficld trips in the interest of community club development, and to furnish the Office of Markets and Rural Organization with copies of reports received from community clubs.

Mr. C. WV. Thompson, of the Office of Markets and Rural Organization, U. S. Department of Agriculture, and Professor C. J. Galpin, of the IVisconsin Agricultural College, University of Wiscultural

Publication of the results of this work shall not be made unless mutually acceptable to all the parties to this agreement and shall show on the title page thereof the cooperative arrangement under which it was donc.

Chicf, Office of Markets and Rural Organization. 
Date

Dean of Agricultural College and $\ddot{\mathrm{Di}}$ rector of Extension Service.

Date.

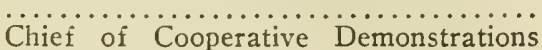
Work, North and West.

Date Director States Relations Service.

Date Secretary of Agriculture. 


\section{APPENDIX III}

\section{Memorandum of Understanding}

IV HEREAS, has or may have, under its control Federal and State funds for extension work in agriculture and home economics, which are and may be supplemented by funds contributed for similar purposes by counties and other organizations and by individuals within said State, and the United States Department of Agriculture has or may hereafter have, funds appropriated directly to it by Congress which can be spent for demonstration and other forms of extension work in the State of

THEREFORE, with a view to securing economy and efficiency in the conduct of extension work in the State of - , the President of - , acting subject to the approval of the Board of said — and the Secretary of Agriculture of the United States, hereby make the following memorandum of understanding with reference to cooperative relations between said and the United States Department of Agriculture for the organization and conduct of extension work in agriculture and home economics in the State of

I. (a) To organize and maintain - a definite and distinct administrative division for the management and conduct of extension work in agriculture and home economics, with a responsible leader selected by the —— and satisfactory to the Department of Agriculture:

(b) To administer through such Extension Division thus organized any and all funds it has or may hereafter receive for such work from appropriations made by Congress or the State Legislature, by allotment from its Board of - or from any other source:

(c) To cooperate with the United States Department of Agriculture in all extension work in agriculture and home economics which said Department is or shall be authorized by Congress to conduct in the state of

II. The United States Department of Agriculture agrees:

(a) To establish and maintain in the Department of Agriculture a States Relations Committee, pending the authorization by Congress of a States Relations Service, which shall represent the Department in the general supervision of all cooperative extension work in agriculture and home cconomics in which the Department shall participate in the State of and shall have charge of the Department's business connected with the administration of all funds provided to the States under the Smith-Lever Act.

(b) To conduct in coopcration with all demonstration and other forms of extension work in agriculture and home economics which the Department is authorized by Congress to conduct in the State of 
III. And the United States Department of Agriculture mutually agrees:

(a) That, subject to the approval of the President of and the Secretary of Agriculture, or their duty appointed representatives, the cooperative extension work in agriculture and home economics in the State of - involving the use of direct Congressional appropriations to the Department of Agriculture shall be planned under the joint supervision of the Director of Extension work of - and the agriculturist in charge of Demonstration work of the United States Department of Agriculture in the North and West; and that the approved plans for such cooperative extension work in the State of shall be executed through the Extension Division of in accordance with the terms of the individual project agreements :

(b) That all agents appointed for cooperative extension work in agriculture and home economics in the State of

under this memorandum and subsequent project agreements, involving the use of direct Congressional appropriations to the Department of Agriculture, shall be joint representatives of - and the United States Department of Agriculture, unless otherwise expressly provided in the project agreements; and the cooperation shall be plainly set forth in all publications or other printed matter issued and used in connection with said cooperative extension work by either - or the United States Department of Agriculture:

(c) That the plans for the use of the Smith-Lever fund, except so far as this fund is employed in cooperative projects involving the use of Department funds, shall be made by the Extension Division of the - but shall be subject to the approval of the Secretary of Agriculture in accordance with the terms of the Smith-Lever Act, and when so approved shall be executed by the Extension Division of said

(d) That the headquarters of the state organization contemplated in this memorandum shall be at

IV. This memorandum shall cake effect when it is approved by the President of — and the Secretary of Agriculture of the United States and shall remain in force until it is expressly abrogated in writing by either one of the signers or his successor in office.

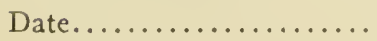

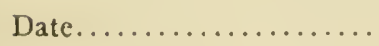

Secretary of Agriculture. 


\section{APPENDIX IV}

\section{Statistical Data Regarding tile United States Department of Agriculture}

\begin{tabular}{|c|c|c|c|c|c|}
\hline $\begin{array}{l}\text { Fiscal } \\
\text { Year }\end{array}$ & $\begin{array}{c}\text { Amount } \\
\text { Appropriated }\end{array}$ & $\begin{array}{l}\text { Amount } \\
\text { Expended! }\end{array}$ & $\begin{array}{l}\text { Fiscal } \\
\text { Year }\end{array}$ & $\begin{array}{l}\text { No. of } \\
\text { Officers and } \\
\text { Employees? }\end{array}$ & $\begin{array}{l}\text { Copies of Public - } \\
\text { tions of all Kinds } \\
\text { (New and Reprints) }\end{array}$ \\
\hline I 839 & $\$ I, 000.00$ & $\$ 1,000.00$ & I 839 & - & \\
\hline 1849 & $3,500.00$ & $3,500.00$ & I $8+9$ & I & \\
\hline I 859 & $60,000.00$ & $60,000.00$ & 1859 & 20 & \\
\hline 1869 & $172,593.00$ & $172,593.00$ & I 869 & 90 & \\
\hline 1879 & $206,400.00$ & $206,360.00$ & I 879 & 93 & \\
\hline 1889 & $1,13+, 480.80$ & $1,033,590.22$ & 1889 & +79 & $1,200,000^{\circ}$ \\
\hline I 899 & $2,829,702.00$ & $2,827,795.65$ & 1899 & 2,949 & $7,075,975$ \\
\hline 1909 & I $6,153,534.7 t$ & I $5,595,502.25$ & 1909 & II, 1 \&O & $17,190,3+5$ \\
\hline 1910 & $17,115,410.35$ & $16,704,470.48$ & 1910 & 12,200 & $25,190,465$ \\
\hline 1911 & $20,888,449.28$ & $20,424,767.92$ & I9́ I I & 12,704 & $27,594,857$ \\
\hline 1912 & $22,402,301$. I I & $20,985,299 \cdot 39$ & 1912 & 13,800 & $3+, 6-8,557$ \\
\hline 1913 & $25,177,164.68$ & $24,486,776.90$ & 1913 & 14,468 & $33,356,366$ \\
\hline 1914 & $24,449,824.37$ & $23,690,994.40$ & 1914 & 16,060 & 38, I 86,392 \\
\hline 1915 & $26,8+0,43+\cdot 55$ & $26,046,032.17$ & 1915 & 16,223 & $36,0-75,561$ \\
\hline 1916 & $29,019,703.98$ & $22,320,158.85$ & 1916 & 17,227 & $39,09 \$, 239$ \\
\hline 1917 & $37,188,852.00$ & $28,056,272.03$ & 1917 & 18,751 & $47,023,635$ \\
\hline
\end{tabular}

1 Annual Reports of the Department of Agricultu-e, 1917, p. 268-269.

2 Letter from Appointment Clerk, Dated 3/1/19.

${ }^{3}$ Reports of the Department of Agriculture, 1917, p. 278.

- Estimated. 


\section{BIBLIOGRAPHY}

Allen, Edwin W. Some ways in which the Department of Agriculture and the experiment stations supplement each other. (In U. S. Department of Agriculture Yearbook, 1905, pp. 167-82. Washington, 1906).

Annual Reports of the Department of Agriculture. (Reports of the Secretary of Agriculture and Bureau Chiefs, 1913-17).

Bear, William E. Departments of Agriculture. Fortnightly Review, April I, I883, n. s. v. 36: 500-13.

(An account of the departments of Agriculture in various countries including the United States.)

Brief Statutory History of the U. S. Department of Agriculture. Beer, G. L., British Colonial Policy, 754-65.

Caffey, Francis G. A brief statutory history of the United States Department of Agriculture. Case and comment. Feb. and March, I9I6, v. 723-33, 850-6.

Carver, T. N. Historical Sketch of American Agriculture, in L. H. Bailey's Cyclopedia of American Agriculture, vol. iv, p. 155:

Cooperative Agricultural Extension Work, Organization and Finances, States Relation Service, Doc. 40.

Crosby, Dick J. Cooperation between the United States Department of Agriculture and state school authorities in promoting agricultural education. (In National Education Association of the United States. Journal of proceedings and addresses, I90\$, pp. 303-7.)

Dean, W. H. What's the matter with the Department of Agriculture? Country Gentlemen, March 3-31, 1917, צ. 82: 415-6, 482$3,532-3,589,641$.

Federal Legislation, Regulations, and Rulings Affecting Agricultural Colleges and Experiment Stations. Issued Aug. 25, 1917.

Freund, Ernest. Standards of American Legislation.

-. American Administrative Law. Pol. Science Quart., vol. ix, p. 415 .

Flower, B. O. Work of the agricultural department and the experiment stations. Arena, Dec., I901, v. $26: 650-6$.

Galloway, Beverly T. Relation of the United States Department of Agriculture to the agricultural colleges and experiment stations, by B. T. Galloway, assistant secretary of the United States Department of Agriculture. WVashington (Govt. print. off.), 1913.

An address delivered at the meeting of the Association of Amcrican Agricultural Colleges and Experiment Stations, Nov: I4, 1913.

Work of the U. S. Department of Agriculture in its relation to the development of the Middle West.... (n. p., 1903), pp. 49-61.

From Report of the Kansas state hoard of agriculture for the quarter ending March, 1003.

Goodnow, F. J. Comparative Administrative Law.

Politics and Administration. 
- Principles of the Administrative Law of the United States.

Greathouse, Charles H. Historical sketch of the U. S. Department of Agriculture; its objects and present organization. 2d revision. WVashington, Govt. print. off., I907, 97 p., III pl.

Index to the Yearbooks of the United States Department of Agriculture, 1901-1905. Prepared by Charles H. Greathouse. . . . Washington, Govt. print. off., I908, 166 p. (U. S. Dept. of Agriculture, Division of publications. Bulletin No. 9.)

- Index to the Yearbooks of the United States Department of Agriculture, 1906-1910. Prepared by Charles H. Greathouse. ... Washington, Govt. print. off., I9I3, I.46 p. (U. S. Dept. of Agriculture. Division of publications. Bulletin No. 10.)

Regulations Governing the Meat Inspection of the United States Department of Agriculturc. B. A. I. Order 2II. Issued July 30, I9I4.

Reports of the Secretary of Agriculture, . . 1862-93. Washington, Govt. print. off., I $863-9.4$.

1840-61 pub. in the Report of the commissioner of patents, ... Part II. Agriculture. I862-88 have title: Report of the commissioner of agriculture.

The annual report on agriculture began in 1837 with a twopage statement in the Report of the commissioner of patents, and formed part of his report (making a separate volume after 1849) until I 862, when the Department of Agriculture was established. The head of the department became a cabinet officer in I889. No report on agriculture was issued for I 466 .

The reports appear in the set of Congressional documents, with the exception of those for $1872-73,1875-79$.

Beginning with 1894 , the report has been issued in two parts : the Yearbook, and the Annual reports of the Department of Agriculture.

Rules and Regulations of the Secretary of Agriculture under the U. S. Cotton Futures Act. Issued Aug. 12, 1916.

Rules and Regulations of the Secretary of Agriculture under the U. S. Grain Standards Act. Office of the Secretary. Cir. No. 70. Issued Nov. 6, 1916.

Rules and Regulations for the Enforcement of the Food and Drugs Act. Office of the Secretary. Cir. No. 21. Issued April ro, I9r3. Service and Regulatory Announcements of various Bureaus.

Swank, James M. The Department of Agriculture: its history and objects. Washington, Govt. print. off., 1872, 64 p. (U. S. Dept. of Agriculturc. Report No. 7.)

Thompson, Carl W. How the Department of Agriculture promotes organization in rural life. (In U. S. Dept. of Agriculture Yearbook, 1915, pp. 272A-272P. Washington, 1916.)

Contribution from the Office of Markets and Rural Organization.

True, A. C. United States Department of Agriculture. American academy of political and social science. Annals, March, Igr2, v. $40: 100-9$.

Haskin, Frederic J. Department of Agriculture. (In his American Government. New York, 1911, pp. 117-29.) 
Hays, W. M. United States Department of Agriculture. Outlook, Aug. 5, 1905, v. 80: $863-7$.

Hinds. Precedents in the House of Representatives. Secs. 4149-6I. Historical sketch of the United States Department of Agriculture. Compiled in part from Bulletin No. 3 of the Division of Publications. Quarterly bulletin of Alpha Zeta, April, I915, v. I3, No. 5,89 p., illus.

Houston, David F. (Address on U. S. Department of Agriculture.) (In New York Farmers. Proceedings, Season I9I6-I9I7.) New York, 1917, pp. 7-17.

Jefferson, Thomas J. Writings (P. L. Ford, editor). See index.

Laws Applicable to the United States Department of Agriculture. Compiled by Otis H. Gates, under the direction of the Solicitor, including Ist, $2 \mathrm{~d}$, $3 \mathrm{rd}$, and 4 th supplements.

Learned, Henry B. The President's Cabinet. Chapter on the Secretaryship of Agriculture.

Messages and papers of the Presidents.

Newton, Eben. Agricultural Bureau. Speech of Hon. Eben Newton, of Ohio, in the House of Representatives, April 20, 1852, in favor of establishment of an agricultural bureau. (Washington, printed at the Congressional Globe office, 1852), 8 p.

Program of work of the United States Department of Agriculture for the fiscal year I917. . . . Washington, Govt. print. off., igr6, $502 \mathrm{p}$.

(The program of work is an outline of the projects of each bureau and office, with an indication of the object, and cooperative relationship of such projects. Its purpose is to inform the workers as to what is expected of them, reduce useless duplication, and assist in correlating the work.)

Turner, F. J. "Social Forces in American History," in Am. Hist. Review, vol. xvi, p. 223.

- Significance of the Frontier in American History. Annual Report, Am. Hist. Ass'n., I893.

United States Dept. of Agriculture. Index to Service and Regulatory Announcements. Issued Oct. 17, I918.

- Congress. House. Committee on Agriculture. Agriculture appropriation bill. ... Report. Washington, Govt. print. off., I9I 6 -date.

_ Hearings .... on the estimates of appropriations for the Department of Agriculture for the fiscal year ending June 30, 1905-date. Washington, Govt. print. off., 1904-date. . Committee on appropriations. Agriculture appropriation bill. Hearings .... (and Report) for the fiscal year ending June 30, 1915-. Washington, Govt. print. off., I914-date. Contmittee on expenditures in Dept. of Agriculture. Hearings ... (and Reports). WVashington, Govt. print. off., 1907-date. - Congress, Senate. Committee on Agriculture and Forestry. Agricultural appropriation bill. Hearings (and Reports) ... the fiscal year ending June 30, 1905-date. Washington, Govt. print. off., 1904-date.

Vrooman, Carl S. Mecting the Farmer Halfway. ( $m$ U. S. Dept. of Agriculture Yearbook, 1916, p1. 63-75. Washingto1, 1917.) 


\section{28 TIIE UNITED STATES DEPARTMENT OF AGRICULTURE}

- Work of the U. S. Department of Agriculture. (In Am. association of farmers institute workers. Proceedings, I9I6. (n. p., 1917), pг. 27-30.

Agricultural Revolution. Century, Nov., 1916, v. 93 : III-23. Washington, George. Writings (ed. W. C. Ford). See index.

Wilson, Woodrow. The Study of Administration. Pol. Science Quart., vol. ii, p. 207.

Wyman, Bruce. Principles of Administrative Law.

Yearbooks of the Dept. of Agriculture, 1913-17. (Various articles.) 


\section{INDEX}

Accounts, in Division of Accounts, IOI ; in bureaus, I02; audit of, in department, I03: in Treasury, 103.

Accounts and Disbursements, Division of, 47 ; functions, IOI.

Adams Act, passage of, 29 ; administration of, 55 .

Administration, definition of, 33 .

Administrative regulations, use of, 70; interpretation of, 7I.

Agricultural Economics, 37.

Agriculture, Board of, British, I4; American, I4.

Agriculture, Department of, raised to first rank, 23; cost of, 31 ; growth of, 31 ; relation to other departments, 34 ; organization, 36; reorganization, 37 ; growth of, I00, I09; administration of bealth laws. I10; criticism of, III ; outline of organization, II5.

Agriculture, definition of, 24 .

Animal Industry, Bureau of, established, 22; powers of, 25 ; functions of, 43; administration of Meat Inspection Act, 76 ; outline of organization, II 5 .

Appropriations, estimates of, 93 ; preparation of, 93 ; criticism of method of, 96 ; submission to Congress, 97; amount of, 100, 124; allotment of, IOI.

Authorization, Letters of, 102.

Berkshire Association for Promotion of Agriculture, petition to Congress, I5; organized, 18.

Biological Survey, Bureau of, functions, 45 ; outline of organization, 117.

Bureatus, organization of, 39,40 ; cooperation between, 49 ; assigning functions to, 50 .
Cattle Quarantine Act, passage of, 26.

Charleston Society for Promotion of Agriculture, organized, 18.

Chemistry, Bureau of, functions, 44; administration of food and drugs act, 82; outline of organization, II6.

Civil Service, in the Department of Agriculture, 34.

Colonial Policy of Great Britain, I2, 13.

Columbian Agricultural Society, I8.

Commissioner of Agriculture, office created, 9.

Committee on A griculture, House, creation of, I4; handling of estimates, 98 ; criticism of, 99 ; relation to department, II3.

Committee on Agriculture and Forestry, Senate, creation of, 14; handling of estimates of appropriations, 100.

Constitutionality of agricultural legislation, II.

Cooperation, between bureaus, 49; between executive departments, 51; with State institutions, 54 ; receipt and expenditure of funds under cooperative acts, 104; form of agreement, 119.

Cotton Futures Act, passage of, 28 ; provisions of, 87 ; administration of, 88; settlement of disputes, 90 ; crticism of, 92.

Cotton Standards, establishinent of, 91 .

County Agent, Go, 113.

Crop Estimates, Burcall of, functions, 45; outline of organization, 117. 
Department of Agriculture, date established, 9; raised to first rank, 23; cost of, 3I; growth of, 31, 100, 109; relation to other departments, 34 ; organization 36 ; reorganization, 37 ; administration of health laws, I10; critcism of, III; outline of organization, II 5 .

Disbursing Agents, Special, work of, 104 .

Division of Puhlications, work of, 47 , I12: outline of organization, $11 \%$.

Early Agricultural Legislation, 12.

Ellsworth. Henry L., distributing forcign sceds and plants, 16.

Entomolosy; Burenu of, functions. 45 ; outline of organization. 117.

Estimates of Appropriations, legal hasis, 93: preparation of, 94; in Department of Agriculture, $95 ;$ criticism of method, 96; submission to Congress, 97.

Executive Departments, constitutional basis, 35: establishment of, 35 : organization, 36 ; cooperation between, 51 .

Expenditures, accounting for, IOI; cooperative funds, IO4; reports of, 105; total amount of, 124.

Experiment Stations, Office of, co.

Federal Airl Road Act, 20; administration of, 62,65 ; provisions of, 63.

Federal Horticultural Board, 47.

Food and Drugs Act, constitutionality upheld, 12: passage of, 27 ; provisions of. So ; limitations of, 82 : administration of, 82 ; administrative regulations, 85 ; criticisms, 86.

Forest Service, functions of. 44; outline of organization, II6.

Franklin, Benjamin, first to add forcign plants and animals, 16 .

Frcund, Ernst, on the extension of police power, 24.
Goodnow, Frank J., 33, 69.

Hamilton, Alexander, on goversment aid to agriculture, 10. Harrison, President, on work of Department of Agriculture, 26 .

Hatch Act, passed by Congress, 23; administration of, 54 .

Insecticide Act, passage of, 27.

Insecticide and Fungicide Board, functions, 47.

Interior, Department of, transfers forestry work to Department of Agriculture, 29; cooperation with Department of Agriculture, 53 .

Jefferson, Thomas, on government aid to agriculture, $\mathrm{II}$.

Lacey Act, passage of, 27.

Legislation, early agricultural, I2.

Library, of Department of Agriculture, 48 .

Markets, Bureau of, functions, 47; administration of Cotton Futures Act, 89; outline of organization. II7.

Marshall Field Co. v. Clark, II (note)

Meat Inspection Act, passage of, 27 ; provisions of, 73 ; administration of 75 ; cost of, 78 ; limitations, 78 .

Morrill Act, passage of, 21.

Organic Act, provisions of, 2r.

Pennsylvania Society of Agriculture. organized. 18.

Plant Industry, Burcau of, functions, 43 ; outline of organization, II5.

Plant Quarantine Act, 27.

Pliladelphia Society for Promoting Agriculture, organized, 18.

Publications, Division of, functions, 47.

Regulatory Laws, administration of, 68 .

Reports, of Secretary, 105. 
Revenues, sources of, 106; disposition of, 106.

Roads and Rural Engineering, Office of Public, functions, 46; administration of Federal Aid Road Act, 65; outline of organization, II7.

Secretary of Agriculture, becomes member of Cabinet, 23 ; office of, $4 \mathrm{I}$; outline of organization of office, 115 .

Sinclair, Sir John, 14.

Smith-Lever Act, 29; administration of, 57 ; provisions of, 58.

Soils, Bureau of, functions, 44 ; outline of organization, I16.

Solicitor, Office of, functions, 71.

State Institutions, cooperation with, 54, 56; meat inspection,
85 ; expenditure of cooperative funds, 104.

States Relation Service, functions, 46,60 ; outline of organization, II7.

Stuart' v. Laird, II (note).

Turner, F. J., 25.

Twenty-eight Hour Law, 26.

United States Agricultural Society, organized, 19; influence of, 20 .

United States Grain Standards Act, 30 .

Virus Act, 26.

Washington, on government aid to agriculture, IO, II, I3, 14 .

Weather Bureau, functions of, 43 ; outline of organization, 115. 
192 
THE AMALGAMATED ASSOCIATION OF IRON, STEEL AND TIN WORKERS 



\title{
JOHNS HOPKINS UNIVERSITY STUDIES
}

IN

Historical and POLITICAL SCIENCE Under the Direction of the

Departments of History, Political Economy, and Political Science

\section{THE AMALGAMATED ASSOCIATION OF IRON, STEEL AND TIN WORKERS}

\author{
BY \\ JESSE S. ROBINSON, PH.D. \\ Professor of Economics in Carleton College
}

BALTIMORE

THE JOHNS HOPKINS PRESS

1920 
COPYRIGHT 1920 BY

THE JOHNS HOPKINS PRESS

PRESS OF
THE NEW ERA PRINTING COMPANY LANCASTER, PA. 


\section{CONTENTS}

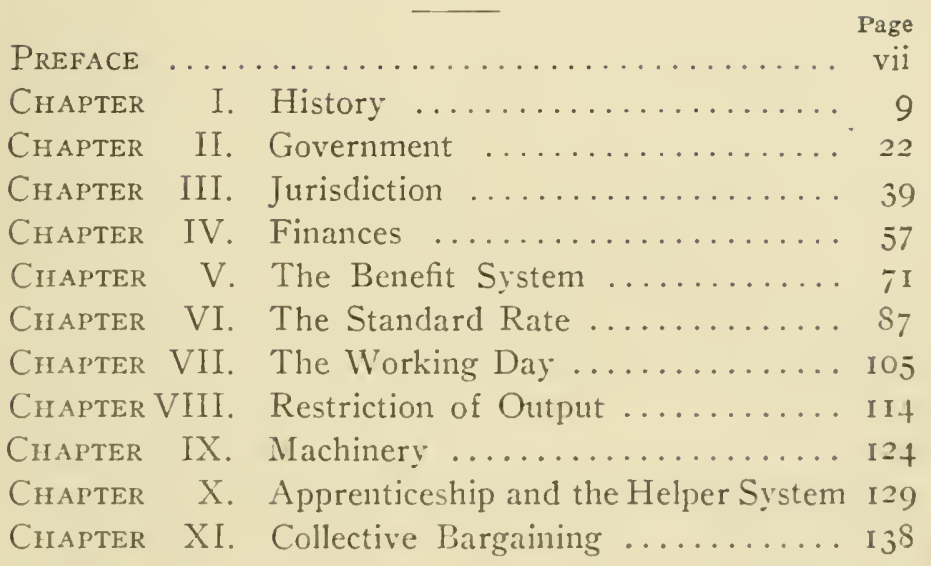





\section{PREFACE}

This monograph is the outgrowth of an investigation carried on by the author while a member of the Economic Seminary of the Johns Hopkins University. The chief sources of documentary information have been the tradeunion publications contained in the Johns Hopkins library and the files of the Amalgamated Association. This study of the printed material has, however, been supplemented by intimate association and personal interview with officials of the union and with employers in the iron and steel industry. To these-and to Mr. John Williams, president of the union, and to Mr. M. F. Tighe, secretary-treasurer, in particular-the writer feels his deep indebtedness.

The number of references inserted as footnotes is, it is feared, abnormally great; but an endeavor has been made to supply them in each instance in order to show that the statements in the monograph are based upon concrete evidence and, it is believed, actual fact.

The writer desires to express his sincere appreciation to Professor Frank C. Lockwood, Department of English Literature, University of Arizona, for helpful suggestions in the preparation of the manuscript; and especially to Professor Jaco') H. Hollander and Professor George E. Barnett, to whom he owes his first practical guidance in economic study. 



\title{
THE AMALGAMATED ASSOCIATION OF IRON, STEEL AND TIN WORKERS
}

\author{
CHAPTER I
}

\section{History}

The Amalgamated Association of Iron, Steel and $\mathrm{Tin}^{1}$ Workers is a trade union which had its genesis in a combination of various organized labor forces of the iron and steel mills of this country about forty years ago. The tin workers were incorporated into the organization in the.year I88I, when their importance as a distinct class of workmen justified membership. For fifteen years after its formation, the Association increased in strength, membership and influence. It consisted, in June, IS92, of two hundred and ninety-two lodges in good standing, and about twenty-four thousand taxable members, exclusive of those holding traveling cards. The great labor contest of $\mathrm{I} 892$, unparalleled in the history of the organization and of great importance in the development of the American labor movement, ended disastrously for the union. This struggle, part strike and part lockout, took place at Homestead, Pennsylvania, between the Amalgamated Association and the Carnegie Steel Company, Limited, of Pittsburgh, owners of the Homestead Steel Works. The contest was hard fought, but the union was crushed. Gradually it was driven from one mill after another, until its complete overthrow in the East was constummated in the year 1901. 'Todiny its elief stronghold lies in the iron mills in the western section of the country.

1 The word "Tin" was inserted in the name of the union in the late nineties. The president, in his 1807 report, addressed the convention as, "The Amalgamated Association of Iron, Tin assl Steel Workers." 
Its strength numerically is only about one-third of what it was in I892, and its relative importance has waned.

As its name implies, the Amalgamated Association of Iron and Steel Workers of the United States is the result primarily of the consolidation of three orders or societies. The present society was organized at Pitts)urgh in August, 1876. The unions which were consolidated were known as the United Sons of Vulcan, consisting of boilers and puddlers, the Associated Brotherhood of Iron and Steel Heaters, Rollers and Roughers of the United States, composed of men employed at the furnaces and rolls, and the Iron and Steel Roll Hands' Union, which included in its membership catchers, hookers, helpers, and others engaged about the trains of works. A fourth organization, less important, included in the amalgamation, was the United Nailers, composed of a few local unions in the nail industry.

The Pittsburgh puddlers were the pioneers in the labor movement in the iron industry. Miles S. Humphreys has given an admirable account of the conditions which prevailed in the iron industry before there is any record of union activity. ${ }^{2}$ The first great strike occurred in $1849^{3}$ and lasted from the twentieth of December of that year until the twelfth of the following May:* The manufacturers succeeding in reducing the price of puddling, ${ }^{5}$ and the work-

2 Pennsylvania Annual Report of the Secretary of Internal Affairs, part 3. Industrial Statistics, 1878-1879. pp. 150-151.

${ }_{3}$ The price paid for boiling in 1837 was $\$ 7.00$ per ton; for puddling, $\$ 4.25$. By 18.42 , boiling was reduced to $\$ 5.00$ and puddling to $\$ 3.50$. The first strike of the boilers on record was caused by a reduction in the price from $\$ 5.50$ to $\$ 5.00$ per ton in February, $18+2$. The strike was ended on the 9th of July by the surrender of the strikers, and $\$ 5.00$ was paid until 1845 . In May of that year, an advance of one dollar per ton was demanded and refused. A strike followed, which ended successfully in the latter part of August, and $\$ 6.00$ was paid until the close of 1849 . Early in 1848 , the puddlers at the Phoenixville Rolling Mills, Chester County, Pa., struck against a reduction from $\$ 5.00$ to $\$ 3.50 \mathrm{per}$ ton, but were beaten. In conducting these strikes some form of organization must have been created; but it was probably crude and not permanent.

1 Pittsburgh Commercial Gazette, May 30, 1882.

- The proposed reduction in the wages of the ironworkers in Pittsburgh was as follows: Puddlers, from $\$ 4.00$ to $\$ 3.50$ per ton; boilers, 
men in this strike learned the necessity of organization. The puddlers resumed work at $\$ 4.50$ per ton, greatly depressed and discontented, many scattering to new fields of employment throughout the West.

The next decade was a period of frequent bickerings between the men and the employers, due to mutual distrust and lack of cooperation. When prices fell, manufacturers sought to secure a reduction in wages, and also "to alter the rules forced upon them in the times of high prices when they were powerless to resist." Such was the condition of the iron trade when the crisis of 1857 occurred. The iron industry of Pennsylvania was notably slow in reviving, and the production in 1858 was estimated at only one half of the previous year, the majority of mills being idle from October, I857, until the following spring.

The panic and the reductions in wages resulting therefrom brought the union into existence. ${ }^{6}$ Pittsburgh was the center of the heavy iron trade of the country, and the tremendous growth of the industry in this section had brought together a large body of skilled workmen, chiefly from the iron working centers of England, Scotland and Wales. The desire for unity of action crystallized into secret meetings of the workmen in the iron mills. The outcome was the formation on April 12, 1858, of a local union, known as Iron City Forge of the Sons of Vulcan. Only a select few were admitted to the secret circle. Mathew Haddock, James Davis, Patrick Graham, Hugh Hagan, and Joseph Mellard were among the number who attended the first meetings. Little was done for two years for fear of the inevitable "black list." The Civil War and a favorable tariff in r86r caused a revival in the iron trade, and a renewal of interest in the Sons of Vulcan. Miles Humplireys

$\$ 6.00$ to $\$ 4.50$; refiners, $\$ 1.00$ to 80 cents; scrappers, $\$ 3.75$ to $\$ 2.50$; heaters, $\$ 1.37$ to $\$ 1.00$ (The Labor Movement, ed. by George E. McNeill, chap. xi).

- In 1858 Easteru mills were paying $\$ 3.00$ per ton for hoiling: and for puddling, as low as $\$ 2.20$. There is one instance in which $\$ 1.90$ was paid for puddling at Danville, Pa. The pay was generally in store orders (McNeill, chap. xi). 
was elected "Crand Master." The next year vigorous efforts were made to extend the influence of the organization, and a national union was formed in Pittsburgh, September S, I862. The convention declared that the association should be known as "The Grand Forge of the United States, United Sons of Vulcan." At the sccond anmual session, held at Whecling, W. Va., a constitution and bylaws were adopted. ${ }^{7}$

Local "forges" were instituted in New York, New Jersey, Maryland, Penusylvania, Ohio, West Virginia, Kentucky, Illinois and other States. The convention of August 5,7 and 8 , I 865 , reported the formation of more local forges in the four months preceding than cluring the entire seven years of its previous existence. ${ }^{8}$ Delegates from five different States were present, and the membership of the union had trebled. The next year traveling organizers were appointed, with Miles Humphreys as leader of the squad. The efforts of the organizers met with exceptional success, largely due to the rise in market prices and consequent success in demands for higher wages. They traveled throughout the iron manufacturing districts of the country and reported the establishment of forges in all the mills "with but few exceptions." Of the thirty-six active forges, all but one sent delegates to the session held in Pittsburgh in I $867 .{ }^{10}$ The reports of twenty-three forges showed a total membership of I5I 4 , by no means all paid-up members.

The inability of the national body to provide financial support for members involved in labor clifficulties caused a falling off in membership. ${ }^{11}$ Until 1870 , strikes and lockouts were inaugurated solely by the men employed in the

7 McNcill, p. 271.

s Fincher's Trade Review, November 16, 1865 . quoted by John Fitch in "The Steel Workers."

"Vulcan Record, vol. i, no. 1, p. 8.

10 No official record of the proccedings of the ammul meetings of the National Forge was published until 1867, when the issue of the "Vulcan Record" and a "Scmi-Amual Record" was begun.

${ }_{11}$ The funds in the treasury were not even sufficient to inect the expenses of the traveling organizers. Mr. Immphreys says he paid a balance of not less than $\$ 100$ out of his own pocket. 
mill where the grievance arose, and financed entirely by voluntary subscription. Frequently strikes were lost through the lack of proper financial aid. The loss of a strike invariably caused the dissolution of the local union. Eleven forges lapsed in 1867 , and sixteen the following year. The active membership was not more than six hundred. When in 1870 the control over strikes became centralized in the national body, and the machinery for the levying and collecting of strike assessments was perfected, the organization experienced a steady and rapid growth. The membership increased to 2000 in 1871 , and to nearly 3500 in 1873 . This was a high water mark. The effects of the panic depleted the ranks of the local unions during the next two years, although new forges were constantly being added. The growth of the union until I875 may conveniently be observed in the following table:

Table Showing the Growth of the United Sons of Vulcan

\begin{tabular}{|c|c|c|c|c|c|c|c|}
\hline Reported to Convention at: & Year & $\begin{array}{l}\text { Active } \\
\text { Forges }\end{array}$ & $\begin{array}{l}\text { Tax- } \\
\text { able } \\
\text { Mem- } \\
\text { bersb }\end{array}$ & $\begin{array}{c}\text { Forges } \\
\text { Re- } \\
\text { porting }\end{array}$ & $\begin{array}{l}\text { Dele- } \\
\text { gates }\end{array}$ & $\begin{array}{l}\text { Forges } \\
\text { Repre- } \\
\text { sented }\end{array}$ & $\begin{array}{l}\text { Average } \\
\text { Mem- } \\
\text { bership } \\
\text { per } \\
\text { Forge }\end{array}$ \\
\hline Pittsburgh......... & $1867^{a}$ & 36 & I 514 & 23 & 5 I & 35 & 65.8 \\
\hline $\begin{array}{l}\text { Buffalo.............. } \\
\text { Semi-annual Report }\end{array}$ & 1868 & $\begin{array}{l}30 \\
22\end{array}$ & $\begin{array}{l}665^{c} \\
65^{c}\end{array}$ & $\begin{array}{l}20 \\
19\end{array}$ & 20 & 14 & $\begin{array}{l}33.2 \\
28.7\end{array}$ \\
\hline Wheeling.... & 1869 & $\begin{array}{l}24 \\
26\end{array}$ & $\begin{array}{r}816 \\
1083\end{array}$ & $\begin{array}{l}24 \\
26\end{array}$ & 29 & 18 & $\begin{array}{l}34.0 \\
41.6\end{array}$ \\
\hline Harrisburg . . . . .... & 1870 & $\begin{array}{l}33 \\
38\end{array}$ & $\begin{array}{l}1265 \\
1454\end{array}$ & $\begin{array}{l}33 \\
38\end{array}$ & 42 & 27 & $\begin{array}{l}38.3 \\
38.2\end{array}$ \\
\hline $\begin{array}{l}\text { Chicago............ } \\
\text { Semi-annual Report }\end{array}$ & 1871 & $\begin{array}{l}50 \\
54\end{array}$ & $\begin{array}{l}1959 \\
2191\end{array}$ & $\begin{array}{l}50 \\
54\end{array}$ & 60 & 42 & $\begin{array}{l}39.2 \\
40.5\end{array}$ \\
\hline $\begin{array}{l}\text { Covington .... } \\
\text { Semi-annual Report }\end{array}$ & I 872 & $\begin{array}{l}70 \\
76\end{array}$ & $\begin{array}{l}2614 \\
3095\end{array}$ & $\begin{array}{l}69 \\
73\end{array}$ & 64 & 56 & $\begin{array}{l}37.8 \\
42.4\end{array}$ \\
\hline Troy (N. Y.) Semi-annual Report & I 873 & $\begin{array}{l}81 \\
92\end{array}$ & $\begin{array}{l}3331 \\
3048\end{array}$ & 83 & 88 & $7 \mathrm{I}$ & $\begin{array}{l}45.6 \\
37.6\end{array}$ \\
\hline $\begin{array}{l}\text { Youngstown } \\
\text { Semi-annual Report }\end{array}$ & 1874 & $\begin{array}{l}99 \\
99\end{array}$ & $\begin{array}{l}3038 \\
2485\end{array}$ & $\begin{array}{l}86 \\
76\end{array}$ & 81 & 74 & $\begin{array}{l}35.3 \\
32.7\end{array}$ \\
\hline Philadelphia ........ & I 875 & 98 & 2732 & 93 & 73 & 67 & 29.3 \\
\hline
\end{tabular}

a No statistics are available for the years previous to 1867 .

b These figures represent the membership enrolled in the books, but not all members were active.

o President J. O. Edwards later reported the membership for this year at 583 in June and 677 in December. By States there were thirty forges in Penusylvania, 17 in Ohio and 29 in all other States together. 
The Grand Forge ${ }^{12}$ received no recognition from employers until i 865 . Wages had steadily increased since the beginning of the war and there was little cause for disagreement. The attempt to reduce wages at the close of the - war brought the manufacturers into conflict with the union. The strike lasted eight months; as a result, a scale of wages was devised and agreed upon, based on the selling price of bar iron. This scale, made on the $13^{\text {th }}$ of February, 1865 , was the first of its kind in the iron industry and doubtless in the United States. The plan embodied in the scale of I 865 by which wages fluctuate in accordance with the price of the product (the adjustments being made bi-monthly and wages fixed two months in advance), is still in force without substantial modification in the iron shops where the union is recognized.

The first national officers received no salaries. They did the work at night, after the day's work in the mill. In I866 the organizers were paid the trade wages and traveling expenses. Later, the custom of presenting the president with a purse of a few hundred dollars at the close of a convention developed. As the union grew in importance, the duties of the national president demanded his entire attention and a salary was provided. The secretary likewise received pay for his work. In 1874 the duties of secretary were added to those of the president, and the salary was fixed at $\$ 1500$. The organization was financed by means of a tax, paid semi-annually. The levy for the support of members engaged in a legalized strike was made separately. Until 1870 this assessment was voluntary. The question of establishing sick and death benefits was discussed in several conventions, but each time the proposition was defeated.

The first known organization in the finishing trades was a local union instituted in Troy, N. Y., August 6. 1864,

12 This title was changed to National Forge at the convention in 1870 in Harrislourg. The titles of the officers were also changed. the Grand Master being designated as "President," and the Grand Vulcan as "Vice-President." The officer of "Grand Knight "was eliminated. 
known as the "Troy Iron Rollers Association." It was composed of "all rollers, roughers and catchers" having "a practical understanding of the business." In 1865 the "Iron Mill Rollers Union and Benevolent Association of Elmira" was organized. ${ }^{13}$ Trade union activity among the heaters has been recorded as early as 1865 . On the 6th of July, I 865 , delegates of heaters' unions met in convention at Cleveland, Ohio, to organize a national union, or more properly, to effect a more complete national organization. ${ }^{14}$ Although the movement would appear from these facts to have been rather widespread, the finishers' unions appear to have completely disappeared in a short time.

The first permanent local unions of men employed at the furnaces and rolls in the finishing departments originated in Chicago. ${ }^{15}$ In I86I, a local lodge of heaters was organized under the name of "The Associated Brotherhood of Iron and Steel Rail Heaters." Other local organizations sprang up within the next few years, and in August, I872, ${ }^{16}$ nine lodges sent delegates to a convention in Springfield, Illinois. Membership was extended to include heaters in bar, plate and guide mills. ${ }^{17}$ In 1873 , the brotherhood had twenty-two lodges and a membership of 480 , with lodges in seven States-Illinois, Missouri, Michigan, Kentucky, Ohio, Pennsylvania, and New Jersey. Rollers and roughers were made eligible, and the name of the organization became "The Associated Brotherhood of Iron and Steel Heaters, Rollers and Roughers of the United States."18

The organization as an independent body lasted only four years. It had few members east of the Alleghany moun-

${ }^{13}$ Fitch, Steel Workers, p. 8I.

14 Fincher's Trade Review, July 22, 1865, p. 64, quoted by Fitch.

15 National Labor Tribune, April 28, I888, p. 2, col. 1. See also Fitch, pl). 81, 82.

1" According to Jarrett (McNeill, p. 277) Friendship Union Lodge of Chicago is the earliest; and it was this lodge that took the initial steps to "form" a national mion by calling a convention August 30 and 31,1872 .

17 Pennsylvania Burcat of Industrial Statistics, 1887, p. G 2, quoted by Fitch.

18 Fitch, p. 82. 
tains. The officers were unsalaried, the president and secretary receiving merely an occasional donation for their services. The income of the union never exceeded $\$ 500$, raised by per capita assessment. In case of strikes, volunfary contributions were made for those engaged therein. No sick or death benefits were established, and the control of strikes was left entirely to the local bodics, as was also the adjustment of wages. Internal dissension dissipated much of the energy which should have been devoted to building up a strong organization, and the brotherhood was not as effective as it might have been. When it was merged with the other two bodies in 1876 , the Committee on the State of the Order reported fourteen lodges in good standing, having in all 412 members. Sixteen lodges sent no report to the convention, and three needed financial assistance.

An organization of roll hands was formed in a North Chicago mill in 1870 . The Heaters' Union, as has been noted, admitted rollers and roughers in 1873 , but the Roll Hands' Union admitted all men engaged about the train of rolls-catchers, hookers, straighteners, and buggymen, as well as highly paid rollers and roughers. To some extent, therefore, the jurisdictions of the unions conflicted.

The Roll Hands organized a national union at Springfield, Illinois, June 2, I 873 , with fifteen lodges and 473 members. It was named "The National Union of Rollers, Roughers, Catchers and Hookers of the United States." At the second convention, held at Columbus, Ohio, in April, IS74, in view of the admission of two other classes of workmen, buggymen and cold straighteners, the name of the association was changed to "The Iron and Stcel Roll Hands Union." The Roll Hands' Union was never very large. Strikes were ordered by the local mions, and strike benefits paid by voluntary subscription. No sick or death benefits were paicl. The limit of a day's work was fixed at six rounds. 
It is difficult to trace the beginnings of unionism in other branches of the iron industry. Mr. Fitch refers to an announcement in the Boston "Weekly Voice" of August 2. I867, of the "seventh annual" convention of "Nail Makers of the United States and Canada" in New York City. The correspondent referred to it as "one of the strongest and most permanent organizations of mechanics in this country." In 1876 there were a few local lodges of nailers, but no national organization.

The main reason for consolidation of the unions in the iron trade may be briefly stated. In time of strike, it was a source of weakness that the various trades were in no position to act in concert. If, for example, the puddlers had a grievance, bar already puddled was purchased and the heaters and rollers would continue at work. The formation of the Amalgamated Association was one of the earliest attempts in American trade-unionism to substitute industrial unionism for separate organization by trades.

Impressed with the necessity of organizing the separate factors into one large union, the members of Columbus Lodge no. I I of Iron and Steel Roll Hands at Columbus, Ohio, began to agitate the amalgamation of all men working in iron and steel rolling-mills into one body. The three local organizations in Columbus formed an amalgamated association and put their theory into practice in the settlement of disputes in the works. The matter was discussed in the columns of the National Labor Tribune ${ }^{19}$ and cditorial comment served to crystallize sentiment in favor of the movement. The mill men of Louisville. Kentucky, and New Albany, Indiana, met in Louisville December Io, 1874 , and framed an appeal to the mill men all over the country, which was published in the Tribunc. ${ }^{20}$

At first the Roll Hands were jealous of their independence, due to the fact that most of the trades represented in their organization were not admitted to the Heaters' and

19 The National Labor Tribune is a labor paper, established in Pittsburgh in 1873 , devoted chiefly to the interest of the iron, steel and mining industries.

${ }_{20}$ National Labor Tribune, December 26,1874 , vol. ii, no. 5I, p. 1 . 
Puddlers' Unions. This feeling soon disappeared, and the Roll Hands in $I_{574}$ sent a representative to the Heaters' convention at Covington, Kentucky, in July of that year, for the purpose of effecting a consolidation of those bodies. Committees representing the Heaters and Roll Hands met ht Indianapolis, Indiana, August 3, I875, and after four days adopted a constitution and by-laws. The Sons of Vulcan at the time were assembled in convention at Philadelphia. Although the question of amalgamation had received favorable consideration in the Youngstown convention of the previous year, no definite action had been taken. The Heaters and the Roll Hands, uncertain what action the Puddlers would take, decided not to wait. On August 23, I875, however, a communication was received from the Sons of Vulcan stating that favorable action had been taken. A meeting of the three committees was held in Pittsburgh, December 7,1875 , and a constitution and a code of by-laws for the government of the proposed Amalgamated Association were adopted. Copies of the new constitution were printed and submitted to every lodge and forge throughout the country. Delegates were instructed by the local organizations and sent to the conventions of the three unions which by arrangement met simultaneously in Pittsburgh on the first Tuesday of August, is 76.

Each organization met in separate session, voted to amalgamate, and, after disposing of such business as pertained to the individual society, announced its readiness to enter into a joint session to consider the subject of amalgamation. On August 3. 1876, the delegates of the three associations and one from the United Nailers met in Emerald Hall, Pittsburgh. Only two amendments were made to the proposed constitution which was then adopted as a whole. On August 4, 1876, the delegates "declared themselves an amalgamated body," and the Amalgamated Association of Iron and Steel Workers of the United States was formed.

The Association was generally successful until 1892. In 1878 , however, the price of iron fell and there were many 
strikes both against the reduction of wages and the "contract system," by which the first four weeks' wages and a percentage, usually twenty-five per cent, of all subsequent wages were retained until the end of the year, then to be paid to the men if profits should "justify such payment." In I879 trade revived, and there was a cessation of strikes. In 188I Canada was included within the jurisdiction of the association, and colored men were made eligible to membership. In I 883 the steel rail manufacturers reduced wages one third and strikes were frequent. The union, however, won the majority of its demands. Membership grew rapidly for several years, from 10,000 in 1880 to $I 1,800$ in I883. Reverses in strikes caused a decline of membership to 6000 in 1885 , but after that the association grew rapidly-to 15,000 in 1888 , and nearly 25,000 in 1892 , when it undertook the great strike at Homestead, and was defeated.

In I 892 the union began to decline. The membership fell to 10,000 in 1898 , then increased until 1902, when the union was rooted out of all steel mills in the East. The convention of 1909 reported a membership of 8,000 , when a strike against the American Sheet and Tin Plate Company, the last subsidiary company of the Steel Corporation to deal with the union, depleted its ranks one-half.

The industry has at no time been thoroughly organized. In 1878 it was roughly estimated that there were 30,000 workers eligible to membership in the union. ${ }^{21}$ Of these, a little over 4000 were organized, or scarcely fifteen per cent. Half of the mills were reported "unorganized"; these were principally in the Eastern and New England States.

The union was at its highest point of membership, 24,068, in 1891 . The number who were eligible was probably roo,000. There were eight districts, with centers at Pittsburgh, Wheeling, Cincinnati, Chicago, Indianapolis, Youngstown, Birmingham and Philadelphia, respectively. The first, or Pittsburgh, district had always been the stronghold

21 Proceedings, 1878, pp. 139-140. 
and the "model" in organization. The sixth, or Youngstown, district ranked second. The eighth, or Eastern district, although it had at this time a large number of local unions, was never permanently organized.

The accompanying table shows the decline of the organization from 1892 to 1912 , and its very partial recovery in recent years. The three big strikes-in the years ISg2, Igor and Igro-tell their own silent story in the figures. The Pittsburgh and Youngstown districts, it will be noticed, lost their position of prestige for organization; effective

Number of Local Unions, by Districts

\begin{tabular}{|c|c|c|c|c|c|}
\hline District & 1891 & 1902 & 1912 & 1016 & Central City \\
\hline 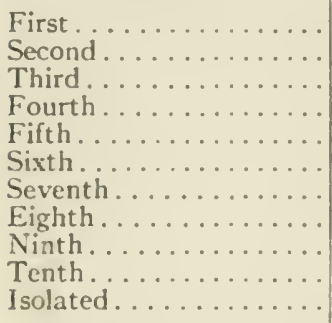 & $\begin{array}{l}94 \\
18 \\
17 \\
18 \\
17 \\
53 \\
7 \\
54 \\
12\end{array}$ & $\begin{array}{r}30 \\
19 \\
10 \\
17 \\
18 \\
41 \\
11 \\
9 \\
10 \\
9\end{array}$ & $\begin{array}{r}7 \\
8 \\
7 \\
9 \\
7 \\
16 \\
\\
12 \\
3 \\
8\end{array}$ & $\begin{array}{r}4 \\
7 \\
8 \\
12 \\
7 \\
18\end{array}$ & $\begin{array}{l}\text { Pittsburgh. } \\
\text { Wheeling. } \\
\text { Cincinnati. } \\
\text { Chicago. } \\
\text { Indianapolis. } \\
\text { Youngstown. } \\
\text { Birmingham. } \\
\text { Philadelphia. } \\
\text { St. Louis. } \\
\text { Reading. }\end{array}$ \\
\hline 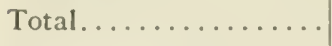 & 290 & 174 & 77 & 90 & \\
\hline Total membership ..... & 24,068 & 14,467 & 4,318 & 7,860 & \\
\hline $\begin{array}{l}\text { Average membership per } \\
\text { union ............. }\end{array}$ & 83 & 83 & 56 & 87 & \\
\hline
\end{tabular}

Growth of the Sons of VulcaN

\begin{tabular}{c|c|c|c|c}
\hline Year & $\begin{array}{c}\text { Number Dele } \\
\text { gates }\end{array}$ & Number Lodges & Members & $\begin{array}{c}\text { Average Lodge } \\
\text { Membership }\end{array}$ \\
\cline { 1 - 2 } $1867 \ldots \ldots \ldots$ & 51 & 36 & $1514^{\circ}$ & 66 \\
$1868 \ldots \ldots \ldots$ & 20 & 30 & 665 & 33 \\
$1869 \ldots \ldots$ & 29 & 24 & 816 & 34 \\
$1870 \ldots \ldots$ & 42 & 33 & 1265 & 38 \\
$1871 \ldots \ldots$ & 60 & 50 & 1959 & 39 \\
$1872 \ldots \ldots$ & 64 & 70 & 2614 & 38 \\
$1873 \ldots \ldots$ & 88 & 81 & 3331 & 46 \\
$1874 \ldots \ldots$ & 81 & 99 & 3038 & 35 \\
$1875 \ldots \ldots$ & 73 & 98 & 2732 & 29 \\
\hline
\end{tabular}

a Overestimated. 
organization shifted to the West, where unionism in these trades is still alive. Repeated efforts have been made to regain the East, and various expedients have been adopted from time to time, but without success.

Growth and Decline of the Amalgamated Association

\begin{tabular}{|c|c|c|c|c|}
\hline Year & $\begin{array}{c}\text { Number } \\
\text { Delegates }\end{array}$ & $\begin{array}{l}\text { Number } \\
\text { Lodges }\end{array}$ & Members & $\begin{array}{c}\text { Average Lodge } \\
\text { Membership }\end{array}$ \\
\hline 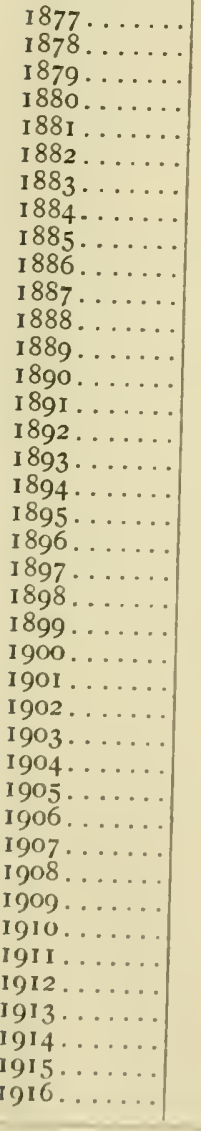 & $\begin{array}{r}75 \\
89 \\
105 \\
193 \\
173 \\
213 \\
153 \\
149 \\
88 \\
121 \\
172 \\
194 \\
194 \\
253 \\
294 \\
254 \\
168 \\
96 \\
85 \\
111 \\
123 \\
117 \\
140 \\
202 \\
200 \\
212 \\
201 \\
207 \\
166 \\
170 \\
150 \\
115 \\
97 \\
116 \\
69 \\
69 \\
87 \\
88 \\
81 \\
99 \\
15\end{array}$ & $\begin{array}{l}111 \\
113 \\
104 \\
155 \\
166 \\
197 \\
183 \\
160 \\
107 \\
106 \\
154 \\
172 \\
189 \\
234 \\
290 \\
291 \\
234 \\
150 \\
125 \\
132 \\
145 \\
153 \\
145 \\
181 \\
160 \\
174 \\
185 \\
183 \\
157 \\
144 \\
139 \\
124 \\
114 \\
103 \\
85 \\
77 \\
79 \\
87 \\
85 \\
90 \\
13 \\
130\end{array}$ & $\begin{array}{r}3,755 \\
4,044 \\
5,400 \\
9,550 \\
10,359 \\
16,003 \\
11,800 \\
9,242 \\
5,702 \\
7,219 \\
11,426 \\
14,946 \\
16,117 \\
20,781 \\
24,068 \\
20,975 \\
13,613 \\
10,000 \\
10,000 \\
11,000 \\
10,500 \\
10,050 \\
11,050 \\
14,035 \\
13,893 \\
14,467 \\
15,198 \\
14,306 \\
10,904 \\
11,410 \\
10,216 \\
7,472 \\
6,295 \\
8,257 \\
4,355 \\
4,318 \\
6,304 \\
6,880 \\
7,283 \\
7,860 \\
\end{array}$ & $\begin{array}{l}34 \\
36 \\
52 \\
62 \\
62 \\
81 \\
64 \\
58 \\
53 \\
68 \\
74 \\
87 \\
85 \\
89 \\
83 \\
72 \\
58 \\
67 \\
80 \\
83 \\
72 \\
66 \\
76 \\
73 \\
87 \\
83 \\
82 \\
78 \\
69 \\
79 \\
73 \\
60 \\
55 \\
80 \\
51 \\
56 \\
80 \\
79 \\
86 \\
87\end{array}$ \\
\hline
\end{tabular}




\section{CHAPTER II}

\section{GOVERNMENT}

The Sons of Vulcan, the oldest and most important of the constituent societies of the Anlalgamated Association, adopted a constitution and by-laws in 1863 . The committees which formulated the constitutions both of the Roll Hands' and of the Heaters' Unions borrowed, with slight changes and unimportant omissions, the constitution of the Puddlers' Union. ${ }^{1}$

The joint committee of the three unions which drew up in 1875 the tentative draft of the constitution of the Amalgamated Association likewise used the Vulcan constitution as a basis upon which to build. The system of government employed by the puddlers was continued by the consolidated body.

From what societies the Sons of Vulcan have borrowed in piecing together their instrument of government cannot be determined. It is reasonably certain that they obtained it from no one source. The fraternal societies, no doubt, exercised an important influence on the government of this as well as of nearly all the older unions.

Fraternal orders have influenced the government of the union in minor ways. The mystery of a secret pass word, the ceremony of initiation, the regalia, and other forms

1 The first available constitution of the Sons of Vulcan is to be found in the Proceedings of 1869 . It contains the Grand Forge constitution in full "along with all amendments adopted since 1866 " (Vulcan Record, no. 4, pp. 23-3I). The first sub-forge constitution is printed in the Proceedings of 1870 (ibid., no. 6, pp. 56-67).

2 G. E. Barnett, "The Printers: A Study in American Trade Unionism," in Amcrican Economic Association Quarterly, third series, vol. $x$, no. 3, p. 58. Professor Barnett las pointed out that the constitution adopted by the first permanent national trade union in the United States, the National Typographical Union, was borrowed by the committce "almost without change... from the Constitution of Odd Fellows of the United States of America." 
associated with the secret society, have been introduced into the labor organization. The influence of the fraternal order is shown also in the use of names, such as "grand forge," or "grand lodge," "subordinate lodge," "grand vulcan," "grand knight," "conductor" or "guide," "doorkeeper," or "inside and outside guards." But the constitution of the Sons of Vulcan provides for a more highly centralized form of government than any fraternal order was likely to possess.

The nature of the government of the early local unions in the iron trades of the United States cannot be set forth definitively. No constitution of any of these early unions is extant. No doubt, government is too high-sounding a phrase to apply. The workmen gathered in simple and informal shop meetings, and elected a presiding officer viva voce. These meetings were held sometimes within the industrial establishment, more often perhaps in some dingy room over a store or a saloon, usually on Saturday night. They were clandestine in character, because of the workmen's fear of discharge. When the need arose, special committees were created to lay the demands of the journeymen before the employer.

The form of government of the local union, so far as we know, has never undergone any radical change. It is still essentially government by mass-meeting. Originally five "practical workers" was the minimum number necessary to organize a local union. In 1880 the minimum was increased to ten. The whole body of members assembling "at least once in every two weeks" is the final authority for the transaction of all business, legislative, executive and judicial. The general meeting may adopt amendments to the by-laws, may bring to trial accused members and by a two-thirds vote suspend or expel them, and may order the payment of bills for local expenses; but it has no power to declare a strike. The sole authority to legalize a strike is vested in a special committee created for this purpose by 
the national assembly. In any important business, the local socicty appoints a committee to investigate the matter and report at the next meeting; but no decision is binding except by a vote of the members. The meetings are held in some convenient hall, or sometimes several local unions join to rent a building where each may have its office and meeting room. During the meetings the officers are stationed in various parts of the room, upon slightly raised platforms or behind small tables, the procedure resembling that of a fraternal order.

The Amalgamated Association endeavors to divide the local unions when they reach considerable size. In early times, a single local society frequently had members working in several mills. When the membership became too large for proper administration of local affairs, members of the same mill were organized in separate unions. By about I 880 the number of members in a single union from the larger mills became so great as to inmair the efficiency of the general meeting. The local unions were again divided so that the different branches of the trade were organized into separate lodges. Thus, the finishers belonged to one local union, the boilers to another, the steel workers to a third, and so on. In I 890 the average membership of a subordinate lodge was less than ninety, the largest having over four hundred members, and the smallest less than a dozen. Only in a few of the larger local unions was there any danger of the monthly mecting degenerating into an unwieldy body.

A second less important method employed by the association to limit the size of the subordinate lodges is by restricting the choice of lodges in which an itinerant member may deposit his card. According to the constitution, any member removing from one locality to another, and obtaining a situation, is required to deposit his card in the lodge which controls the mill wherein he works, and all cards not deposited within four wecks thereafter are annulled. Where there are two or more lodges in one mill, 
the members are obliged to join the lodge relating to the department in which they are employed. This regulation keeps the separate local unions intact, with a more or less homogeneous membership.

The limitation on the size of the local unions has two advantages. In the first place, the reduction of the size of the general meeting lessens the chance of ill-advised legislation. Secondly, since the local unions in each mill must act in concert, the decision of important matters must be referred to a joint committee-the district or executive conmittee. It is obvious that a general meeting composed of over a thousand members, such as there were in the Jones and Laughlin Mills in I890, could not carefully and wisely pass upon affairs of importance.

The general meeting is a crude mechanism for rendering judicial decisions and for transacting executive business. In the period between regular meetings matters are constantly arising which demand inmediate consideration. This defect is somewhat lessened by the creation of certain committees, although the local union is reluctant to delegate its functions. Many committees are appointed for particular purposes. Certain standing committees have also emerged, the most important of which is the mill committee. The national unicn has adopted rules requiring the subordinate lodges to create such committees, "consisting of three nembers, on each turn, from each department represented in the lodge." It is the duty of the committee "to superintend and guard the interests of the Association in their several departments" and to adjust, if possible, all difficulties which arise between the manager of the works and any member or members of the union. ${ }^{3}$ Two other standing committes of the local union are the grievance committee and the auditing committee. The former considers

${ }^{3}$ In 1912, in order to facilitate the work of the mill committee, local lodges were authorized to draw up shop rules, which were to be submitted to the management for approval. These rules were to regulate conditions not covered by the scale or the constitution (Proccedings, 1912, P. 2825). 
charges against a member who is brought to trial; the latter audits the accounts of the officers who have charge of the funds.

The important officials of the local union are a president, a recording secretary, a financial secretary, and a treasurer. The financial secretary keeps accounts of receipts and expenditures. The local dues of the secretaries and treasurer are sometimes remitted as pay for their services. The minor officers are a vice-president, three trustees, an inside guard, an outside guard and a guide. In recent years there has been added a journal agent, who solicits patronage for the trade journal, and for his effort receives a small compensation. All the officers work at their trades and perform their official duties during spare time. A business agent is rarely employed by any local union.

The distinctive feature of the constitution of the Amalgamated Association of Iron and Steel Workers, adopted in $18 ; 6$, was the supreme authority given to the annual convention of delegates ${ }^{4}$ from the local societies. The national union has power to elect its officers, to decide "all matters of general importance relating to the welfare of the several Lodges," and to determine "the customs and usages in regard to all matters pertaining to the interests of the Association." Executive and judicial as well as legislative functions are exercised by a single body. In the exercise of its legislative power it has equal authority to pass every kind of law. No distinction between constitutional and statutory law is recognized. At one moment, therefore, the assembly may be remodeling the constitution or transferring important functions from the subordinate societies to the national union; at another, it may" be passing

- The convention meets at present annually on the first Tuesday of May. Delegates to be eligible must be clear on the secretary's books. must be working at some trade under the jurisdiction of the union, and must have served six months in some office of the local union. The national lodge pays railway fare only; the local union pays other necessary expenses. Any sub-lodge failing to send a delegate without suffient excuse is fired fity dollars. 
a rule that no member be allowed to smoke in the assembly hall while the convention is in session. ${ }^{5}$

In its judicial capacity, the convention considers grievances brought by national officers, local unions, or individual members. The charges may be some violation of the rules of a local union, equally as well as dereliction in duty to the national union. The assembly, in one instance, may suspend or even expel a local union for serious violation of the rules; while, in another case, it may be sustaining a subordinate lodge in imposing a fine of a dollar or two on a member for some petty misdemeanor. Much valuable time of the convention is wasted in the consideration of trivial appeals.

The principal executive functions of the assembly are the levy of taxes, the appropriation of revenue, and the ratification of agreements. The convention fixes the amount of dues and assessments; it controls disbursements; it has the final power in making agreements. The Amalgamated Association, continuing the practice established by the Sons of Vulcan, for a time held two conventions annually, one to regulate the internal government of the organization, the other to draw up the scale of wages to be demanded from the employers. The district conventions, as also the scale convention, composed of delegates elected by the various district conventions, always met immediately before the joint conference between employers and employes, and outlined the terms which its representatives were to demand. Since $I 8 S_{5}$, these conventions have been merged. ${ }^{\circ}$ The national assembly elects its own officers and audits their accounts.

As the union grew in numbers the convention became too large to transact business efficiently. While the number of

5 Any amendment to the laws must previously have been sent :0 the national lodge to be printed in the "programme of business." This provision was made in 1877 .

- By the merging of these conventions, the union effected a saving estimated at $\$ 3000$ a year. The session was changed to meet in June instead of in August, and the date of scale termination irom June Ist to July ist (National Labor Tribune, August 15.8955 .9 .4 , col. 1 ). 
delegates in attendance at the first few conventions of the Association was only about a hundred, there were nearly three hundred present in IS9I, and over two hundred in 1902. Careful formulation of policies or proper sifting of evidence in judicial cases by such a body is impracticable. In consequence the assembly has followed the practice of creating committees to perform certain duties. The duties of these several committees are not always carefully coordinated. For example, the work of the committee on grievances and that of the committee on appeals is very similar. Amendments to the rules are drafted and submitted to the assembly not only by the committee on constitution but also by committees formed for wholly different purposes. Amendments are frequently recommended, for example, by the president, one of the several vice-presidents, or the secretary-treasurer in their reports to the convention. The committce on officers' reports considers these proposals independently of the committee on constitution. It is not surprising, therefore, that conflicting resolutions are occasionally passed by the convention.

The efficiency of the convention as a governmental instrument is limited by the infrequency of its sessionsonce each year-and by the shortness of the sessions. The length of the session, however, has been cxtended as the importance of its activities has increased. In IS-6 the convention lasted three days, whereas it lasted seventeen days in 1902. Two weeks, the average duration of the convention, or even three weeks, the maximum period, seems a very short period in which to adopt needed legislation, settle judicial cases, elect officers, levy dues, appropriate funds, audit accounts, and transact numerous other matters of business which accumulate from one year to the next. There must also be taken into account time lost in waiting for committees to report. Little can be accomplished the first day, since the credentials of the delegates must be examined. After listening to an address of welcome by a municipal executive or a local trade union leader, a recess 
is taken until the committee on credentials is ready to report. Then follows the appointment of committees and assignment of work to each group. Since nothing can be done until the committees have formulated their reports, the delegates are usually entertained in the meantime by a picnic or a visit to some point of interest in the city. Consequently, much of the business is crowded into the latter part of the session. During the last few days the election of officers must take place, and the selection of a city for the next convention. If the contest is close, still more time is consumed in electioneering and wire-pulling, and in taking a number of ballots. Only a very few days are spent in considering new rules and in formulating trade policies.

In fixing the basis of representation in the convention the same opposition has existed between the large and small local unions as existed at the time of the founding of the American Commonwealth between the large and the small States. The members of the large unions demanded that representation should be proportional to membership, pointing out the unfairness of equal representation and minority rule. The small local societies clung to the principle of equal representation, fearing that under the other plan two or three large societies might dictate policies. "A subordinate lodge with less than one hundred members shall be entitled to one representative. A sub-lodge with one hundred and twenty-five members shall be entitled to two representatives, and one representative for each additional hundred."

The smaller unions, however, are by no means as fully represented at the annual sessions as are the large unions. The system of representation by proxy has never been tried. The Association has always paid the railway fare of their delegates in order to place the branches at a distance from the place of meeting at an equal advantage with those near at hand, as well as to aid the small local societies which could not otherwise afford to send representatives. The subordinate unions have had to bear the other expenses of 
their delegates. The cost of sending a delegate is obviously a heavier burden to a small union than to a large one. At the Pittsburgh session in 1891 , only 220 subordinate unions out of 300 , or 70 per cent, were represented. The 220 unions represented had, however, 23.300 members, or 96.8 per cent of the total membership.

There are two objections to the national union's paying all the expenses of the delegates. First, the large local unions would be taxed in order that the small ones might be represented. Secondly, if the expenses of representatives were borne by the national organization, the size of the convention would become too large for governmental efficiency. The increase in the number of subordinate lodges has been partly due to the tendency to split up the original local unions into small units according to branch of trade or nationality. The result has been that the convention has grown in numbers. In 1877 seventy-seven delegates were present, in 1883 there were a hundred and fifty-three, and at the convention of I89I, two hundred and ninety-four. Proposals to reduce the size of the convention by grouping the societics into districts which would elect delegates to represent all the unions in the several districts have been steadily defeated. The local unions, jealous of their political prerogatives, have refused to be merged in any form of district organization.

As the activities of the national union increase, the convention decreases in effectiveness as a means of transacting business. The history of the convention may be marked off roughly into three periods characterized respectively by (a) the predominance of the representative assembly; (b) the enlargement of the power of the officers; (c) the struggle for the referendum.

During the first of these stages, the convention was practically the sole organ of government. Its functions were primarily legislative and judicial. The officers were elected from the delegates at the convention or those who had been clelegates at a previous convention, and their dutics were 
chiefly in connection with the sessions. They consisted, originally, of a president (known as grand master), a vicepresident (with the title of grand vulcan), a secretary, a treasurer, a conductor or guide, and a doorkeeper. There was also an officer, with the title of grand knight, whose duty it was to display to the delegates his knowledge of the ritual. The office of grand knight was abolished in 1870 , and in 1874 the offices of president and secretary were amalgamated. The officers were elected for one year, and assumed their duties at the close of the session at which they were elected.

The amount of executive work in the interval between sessions was very limited. The issuing of charters and cards, the preparation of the convention proceedings for publication, the collection and disbursement of the small revenue needed for general expenses, and the collection and distribution of voluntary strike contributions, constituted the important administrative duties during the first period of the union's history. In 1867 the national officers seldom heard from local officers. At first the officers were unpaid. Later, the secretary was voted annually by the convention a certain sum of money. The president was customarily presented with a purse by the local unions. ${ }^{7}$ In $I S 72$ the donation amounted to seven hundred and sixty-six dollars. The free will offering was always sufficiently large to prevent the positions going begging, and the convention usually continued the same men in office for several years.

The second stage appears with the growth of the activities of the central organization. It is marked by the creation of paid and unpaid officials and boards of management which levy assessments, sanction the declaration of strikes, and perform many detailed executive duties, make judicial decisions, and sometimes exercise a very limited legislative power during the period between conventions. A district

"The Heaters "agreed to pay" their president, known as Grand Worthy Sire, $\$ 200$ for the year ending July 7,1874 (MS., Proceedings Heaters, 1874). 
executive committee has the power to declare strikes. ${ }^{8}$ A board of investigation makes judicial decisions, and has been known to make new rules on the ground of expediency. The final authority, however, still resides in the representa- tive assembly. It contimues to elect officers, to audit their accounts, and to remove then for misdemeanors or neglect of duty. At the same time, the influence of the paid officers grows rapidly. They devote their entire time to the work of the union, and thus gain an intimate knowledge of the conditions of the trade and the internal affairs of the association. The delegates must rely greatly on their judgment. Accordingly; by far the larger part of the time of the convention is devoted to the ratification or rejection of the legislative and executive program outlined by the officers in their reports to the assembly of delegates.

This stage was quickly attained in the union of the iron boilers and puddlers, whose activitics increased so rapidly that it was necessary to have one man devote his entire time to the affairs of the union. In 1873 , all powerexecutive, judicial and even legislative-was vested during the interval between sessions in a single paid official, known as the president. He was voted a salary of \$ 500 "clear of all traveling expenses." The president acted as financial and corresponding secretary, supervised the publication of the convention proceedings, and chartered new local societies. When time permitted, he attempted to organize the workers in non-union mills. He visited localities where a strike threatened, and endeavored to adjust the difficulty. In the interpretation and enforcement of the national constitution, he was at once policeman and judge. As a legislator, he advanced new rules not covered by the existing constitution, and broke the rules whenever he thought the emergency called for such action. He could not declare a strike, nor was he entrusted with the care of funds; otherwise his power was absolute during the period between conventions.

${ }^{8}$ The national officers may be brought to trial, reprimanded, suspended, or expelled by a similar board. 
Early in the history of the union, the president appointed deputies, one for each state, whose duty it was to organize local unions, to visit localities where strikes were imminent or in progress, and whenever possible adjust the difficulty. No provision was at first made for paying these officials. In I867 the system of state deputies was abandoned, the country was divided into districts, and a deputy appointed for each district. These officials worked at their trade, and received compensation for lost time and traveling expenses incurred in the discharge of their duties. This feature of government was carried over without change into the Amalgamated Association in 1876 .

As the Association increased in size, however, and new functions were constantly being assumed, it was found diffcult for the president and the deputies to perform all the duties of administration. New offices were created to meet this condition. The president was given the assistance of a secretary, to be appointed by him and paid fifty dollars per month. In I 880 the convention created the office of secretary, the official to be elected from among its delegates at a salary of \$1000 per year. Again, in I 890 an assistant secretary became necessary. In order to concentrate the funds in the hands of one responsible person and thereby facilitate administration, the offices of secretary and treasurer were combined in I9OI.

Instead of deputies, the Association created the office of vice-president, whose duty was that of strike deputy and organizer. One vice-president was elected for each of the eight districts. These officials appointed three deputies to assist them in their duties. They were paid for lost time and expenses. In I905 the system of district vice-presidents was altered. Five paid vice-presidents, one for each division-boiling, finishing, sheet and tin-and one for the East, were elected. In 1909 this number was reduced to two who were continuously employed at a fixed salary of \$ 440 a year. ${ }^{\circ}$ One vice-president represented the boiling and

\footnotetext{
- The convention of 1916 increased the salary to $\$ 1800$.
} 
finishing divisions, the other the sheet and tin divisions. Each vice-president appointed one deputy to each of the districts of his division, to assist him in administration.

The enlargement of the functions of the national union das had a tendency to increase the importance of the president and the secretary-treasurer. The president acts as chairman of the annual assembly and of the general executive board. ${ }^{10}$ Since 1890 he has been a member of each district executive committee, which has power to declare strikes for that district. In conjunction with the vicepresidents and their respective deputies, he enforces the rules of the national union, and with them as a board of investigation brings to trial delinquent subordinate unions in the several districts. The decision of the board is final, unless non-concurred in by a two-thirds vote of the convention. The president travels frequently to various parts of the country to organize new local unions, to encourage the weak ones, and to adjust disputes between the workmen and their employers. The secretary-treasurer acts as secretary of the meetings of the convention and of the general cxecutive board. He keeps the financial accounts, and has charge of the funds. The president and the secretarytreasurer together administer the funds.

Perhaps the greatest power of the president is his influence over legislation. The constitution from the beginning has given to the executive the power to appoint the various

10 The national executive board superseded the advisory board in 1907 , and, like it, this board had no definite functions except the vague one of advising the national officers in matters "not clearly defined by law" (Constitution 1911, p. 14). It was composed of the national president, secretary-treasurer, and divisional vice-presidents. In 1909 there were added to the board the assistant secretary, man. aging editor of the Journal, and residing trustee; and in 1915, the insurance secretary. In I913 its functions were defined to include, in addition to subjects not covered by the rules, "all rulings on, or interpretations of, the scale of prices, footnotes, memorandum of agrcement, addenda, convention actions and resolutions"; and any constitutional laws made by the national president, vice-presidents or national executive board are printed in the financial statements and read in the lodge meetings of the local unions (Constitution Ig13, p. 15$)$. 
committees of the national asscmbly. All proposals are considered and sifted by the various committees, who make their reports to the delegates. Even if proposed measures are presented to the convention, the unfavorable action of a committee constitutes a serious check to its adoption. $\mathrm{By}$ the judicious selection of members for service on the several committees, the president is able to influence appreciably the action of the session.

The other elective officers of the national union are three trustees, who hold the bonds of the president, the secretarytreasurer, and assistant secretary, audit the accounts of the national lodge quarterly, and deposit with the president their bond for the faithful performance of their duty. A managing editor is elected to edit the "Amalgamated Journal." In the nineties, the national president was empowered to appoint an assistant to act as organizer. At present, this power of appointment is vested in the executive board.

The third stage, namely, the substitution if government by popular vote for the representative form of government, is of recent origin, and is even now in process of development. First mention of this new and more democratic form of government was made in I894, when a local union of Akron, Ohio, presented a resolution to have scales of prices and constitutional amendments made "by the adoption of the Initiative and Referendum." 11 Again, in I9OI, it was proposed to elect all national officers by the membership at large. ${ }^{12}$ These proposals were rejected by the delegates in convention. By Igr I sentiment in favor of the referendum had increased to such extent that it received the endorsement of the committee, and was adopted in the matter of constitutional amendments. Any proposition to change the laws required the endorsement of five lodges in three States within sixty days' time before it conld legally be sulmitted to popular vote. The columns of the "Amalgamated Journal" were open for discussion. The propo-

11 Procecdings, 1804, p. 4687.

12 Proceedings, 1001, p. 6182. 
sition was submitted to the membership by the national secretary "without preamble or comment." Amendments proposed by the national convention also required the sanction of a referendum vote before they became a part of the constitution. All amendments went into effect sixty days after their approval. The national president, secretary, and the editor of the Journal constituted a board to canvass the votes and publish the results. This provision did not apply to the wage scale or the appointment of conference committecs. ${ }^{13}$ The law soon proved defective in that certain details important to the working of the law were not included. To add to the problem, an insurgent movement developed. ${ }^{14}$

Immediately the Newport, Kentucky, lodge-a leader in the insurrection-set about to have submitted to a referdum vote what it had advocated unsuccessfully in the convention, namely, the election of the national officers by a direct vote of the membership. The executive board thought it was "contrary to the expressed will and judgment of a majority of the delegates" of the last session. The proposed amendment received the legal endorsement of five lodges. Since the law provided no date for closing the debate in the Journal columns, the board decided that five lodges, by vote, could close the discussion. The proposition was submitted to the membership, but the result was disappointing. Some lodges having a membership of a hundred cast less than a dozen votes; others did not vote at all. So the matter remained unsettled until the next annual session.

${ }_{13}$ Proceedings, 1911, pp. 9189-9192, 9372-9374; Constitution, 1911, p. 72.

14 During the year 1912-1913 two movements, insurgent in character, took place. The one originated among the workmen in Niles, Ohio, and was in the nature of a secession, the new organization styling itself "The Industrial Iron and Steel Workers of America." The other was a radical movement within the organization, and the leaders of it called themselves "The Progressive Movement of the A. A. of I. S. and T. W." The Progressives advocated, among other things, industrial unionism and the cxtension of the referendum. How far these outbreaks infuenced the more liberal use of the initiative and referendum is uncertain. The present officials would deny that they had any influence. 
In I9I 2 it was enacted that the national officers should be elected by means of the initiative and referendum, and also be subject to recall. The term of office was lengthened to two years. A call for nominations was sent out on the first of February; two candidates were named by each local union for each position; nominations by five lodges entitled a candidate to a place on the ballot; majority vote elected, except in the case of trustees, in the case of whom the three receiving the most votes were chosen. The results of the election were sealed and forwarded by registered mail to the national office, and remained unopened until a canvassing board of five members counted the vote and announced the results of the election at the next convention.

Similar machinery was provicled for the recall of a national official. Upon the request of ten subordinate lodges, a reelection was held. No newly-elected officer could be recalled until he had served three months in office. Nor was the president or either vice-president subject to removal from May I to August 3I, that is, during the conference season when scales were being signed, or while a strike was in progress in which ten per cent of the membership was involved. When a petition was initiated by a local union for the recall of an official, the reasons for such action were set forth in two hundred words upon the printed ballot. The official in an equivalent space gave his "justification of his course in office."

The defects in the provision for the adoption of constitutional amendments were also remedied. The essential changes were: the proposed amendment was to be printed in the Journal, and the matter was to be open for free discussion for sixty days, the time-limit for the receipt of proper endorsement. Members in good standing only were entitled to vote, and all votes were to be cast at a single meeting of the local mion. Any proposition purporting, in the opinion of the officials, "to question the integrity and veracity of any officer or member" or tending " to weiken the position of the organization in a strike ... or scale settle- 
ment" was first submitted to the lodges in a special circular. A majority vote decided whether or not it should be submitted to a referendum. It was further provided that the constitution as amended June I should go into effect on August $I$, and be in force for a year. ${ }^{15}$

Thus far the results of the referendum rote have by no means vindicated its advocates. Only a small percentage of the membership rotes on the propositions. The total vote on the constitutional amendments proposed by the convention of 1912 was 534 , or 12 per cent ; in 1916 , i 176 votes, or 16 per cent. The maximum vote on any single proposal during the year was less than 2000, and the minimum, 944 ; the average, 1394 , or barely 25 per cent. During the year I914-I9I 5, a proposal was submitted to popular vote, giving the American Federation of Labor power to levy and collect a tax or assessment on the members of affiliated unions to support strikes of a general character. It was adopted by a vote of 560 to $38_{4}$; the total vote cast being 944 , or If per cent of the membership. This vote is ridiculously small, in view of the importance of the issue, which affected the income of every member.

The appended table shows the votes cast upon matters submitted to the referendum:

Tarle Showing the Percentage of Membership Voting on RefERENDUM PROPOSITIONS

\begin{tabular}{|c|c|c|c|c|c|}
\hline lear & $\begin{array}{c}\text { Total Mem. } \\
\text { bership }\end{array}$ & $\begin{array}{c}\text { Votes Cast } \\
\text { for Conven- } \\
\text { tion Amend- } \\
\text { ments }\end{array}$ & $\begin{array}{c}\text { Per Cent. } \\
\text { Membership } \\
\text { Voting }\end{array}$ & $\begin{array}{l}\text { Average of } \\
\text { Votes Cast for } \\
\text { Amendments } \\
\text { During Year }\end{array}$ & $\begin{array}{l}\text { Per Cent. } \\
\text { Membership } \\
\text { Voting }\end{array}$ \\
\hline $\begin{array}{l}1912-13 \ldots \\
1913-14 \ldots \\
1914^{-1} 15 \ldots \\
1915-16 \ldots\end{array}$ & $\begin{array}{l}4,318 \\
6,304 \\
6,880 \\
7,283\end{array}$ & $\begin{array}{r}534 \\
758 \\
1,091 \\
1,176\end{array}$ & $\begin{array}{l}12 \\
12 \\
16 \\
16\end{array}$ & $\begin{array}{r}1,416 \\
1,763 \\
944\end{array}$ & $\begin{array}{l}33 \\
28 \\
14\end{array}$ \\
\hline Average. & 6,196 & 890 & 14 & 1,374 & 25 \\
\hline
\end{tabular}

13 In 1916 three changes were effected: (a) the national exccutive board was empowered to offer amendments for referendum vote; (b) the amended constitution went into effect on the Ist of September, one month later, except in case of (c) a referendum initiated by a local lodge or the executive board during the year. If approved by a majority vote, the proposition became effective thirty dlays after its adoption, and was printed in the Journal until the constitution was reprinted. 


\section{CHAPTER III}

\section{JURISDICTION}

"The primary aim in the formation of a trade union," according to Professor Barnett," "is to obtain unity of action among the workmen in that trade. For the attainment of effective unity it is indispensable that within a given territory there shall be but one union." Accordingly, it is the custom of each national union to define the territory over which it claims jurisdiction and the class or classes of workmen from which it expects to recruit its membership. These claims are called respectively territorial jurisdiction and membership jurisdiction.

The Iron and Steel Workers found no great difficulty in defining the classes of workmen over which each subordinate union should have jurisdiction. By reserving to itself the right to determine what classes of employees should be eligible to membership in the local societies, the national union eliminated the question of membership jurisdiction so far as the suburdinate lodges were concerned. Among the early organizations-the Vulcans, the Heaters and the Roll Hands-only "practical workmen," that is, journeymen, were within the jurisdiction of the union for the purpose of organization and admission to membership. Each local union controlled the regular admission of persons at work within its own jurisdiction, and only the more highly skilled workmen gained admittance. Even after the Association had opened its doors to helpers and other classes of semi-skilled workers, local unions not inf requently discriminated against them.

The union has uniformly refused to allow local unions to be divided on the basis of nationality. Agitation for sepa-

\footnotetext{
1 Barnett, p. 41.
} 
rate unions of German members arose in the early societies. In IS72 the national president of the Vulcans suggested the establishment of a German branch and the creation of a national official to issue charters to German forges. The delegates, particularly those of German origin, opposed the movement, and Julius Arnd refused to accept the presidency of such a branch, if established, on the ground that it was not "necessary.". In IS74 there was a similar agitation among the Roll Hands to grant separate charters to German local lodges, but no action was taken. It was decided, however, to have two hundred copies of the constitution and by-laws printed in the German language. The Roll Hands at no time had more than five hundred members, so it is apparent that a considerable percentage of their membership was German-speaking.s

The policy of the union has been to divide the larger local organizations on the basis of trade. In the early history of the union, when the local societies were small, no such regulation was necessary. But, as the local societies grew in size, it was found expedient for the boilers to be in one local union, the finishers in another, and the steel workers in a third. In 1883 , for example, the finishers complained that they were not adequately represented in the annual meeting, and threatened to secede. The establishment of separate unions of finishers and of boilers put an end to this growing dissatisfaction. Applicants for admission to membership in the union were required to join the lodge governing the trade in which they were employed. The same rule applied to members who took out traveling cards and moved from one locality to another. Such a member must deposit his card in the local union in whose jurisdiction he was to work. In ISgr a further subdivision was made, providing for separate subordinate lodges for tonnage men and men working by the day or by the hour."

2 Vulcan Record, vol. i, no. 10, p. 22.

3 Procecdings, Iron and Steel Roll Hands, 1874, p. 25.

1 Constitution, $180 \mathrm{I}$, art. 23 , sec. 1 . 
The problem of defining the territorial jurisdiction of subordinate unions was even more simple. At the outset, the Puddlers organized a forge wherever a nucleus of a half-dozen workmen could be found willing to assume the responsibility of a charter. These forges were located at convenient centers. There was usually one forge to a city in which one or more mills were located. When conditions seemed to warrant it, a new society was chartered in the same city. Accordingly, in any one city, a local forge might have members working in several mills. In 1873 , in order to put an end to this state of confusion, the territory assigned to a forge was made coextensive with a particular "mill." Members obtaining permanent employment in a mill under the jurisdiction of another forge were required to transfer their membership to that forge. In I880, when some of the larger societies were subdivided according to trade or allied trades, a further limitation of the jurisdiction of a subordinate union became necessary. In case there were two or more lodges in the same mill, a local union had jurisdiction, not over the entire mill, but only over a particular department in the mill.

In the matter of national jurisdiction the situation has been less favorable. Not only has the union had its membership claims disputed, but it has time and again been forced to struggle in order to preserve its territorial jurisdiction intact. The controversies have resulted in dualunion disputes. "In a dual-union dispute," according to Dr. Whitney, "the jurisdiction claimed by one of the disputants is either exactly coextensive with that claimed by the other or is entirely inclucled within it." In other words, it is a dispute not as to which trade the particular work lelongs, but mercly as to what union shall have control over the workers in a particular trade. A dual union, then, is "an organization which claims the right to maintain itself as a body independent of, and usually rivil to, another asso-

s N. R. Whitney, Jurisdiction in American Building-Trades Unions, p. 62. 
ciation controlling the same classes of workmen and operating within the same territory." The Association has never experienced any serious disputes over demarcation.

The tendency of the national union has been to widen the scope of its territorial jurisdiction. When the Puddlers formed a permanent organization and adopted a constitution in IS62, they gave it the title, "Grand Forge of the United States, United Sons of Vulcan." Thus, at the very outset, the union claimed the right to organize in all the territory embraced in the United States. An identical claim was made by the Heaters in 1872 , and the Roll Hands in 1873 . The three unions, when they combined in $I S ; 6$. called themselves the "Amalgamated Association of Iron, and Steel Workers of the United States." In ISS2 Canada was included within the jurisdiction of the Amalgamated Association. ${ }^{6}$ Again, in 1908 , the national union extended its jurisdiction to include all of North America. This action was taken to preclude the possibility of another organization in Canada. Local unions have been organized in Canada and in Mexico from time to time, but most of these have been short-lived. Jurisdiction beyond the confines of the United States has been potential rather than actual. ${ }^{7}$

Similarly, the membership jurisdiction of the union has been constantly widened. The Vulcans admitted none but "puddlers and boilers." The Heaters included in their number rollers and roughers, as well as heaters, but refused admission to all other classes of workmen. Partly as a reaction against the undemocratic Heaters' Union, which granted membership only to the highly paid men, the Roll Hands' Union was organized, and its memberslip consisted of practically all men working around the trains of rollscatchers, hookers, buggymen and straighteners, as well as rollers and roughers. Both the Heaters and the Roll Hands

\footnotetext{
- Proceedings, 1882 , p. 956.

In 1885 the Association lost the only lodge it then had in Canada, Ontario Lodge, located at Hamilton: Canada was considered " morc expense than gain" (Proceedings, 1885, pp. 1574, 1660). Its readmission was left to the discretion of the president (Proceedings, 1887, p. 2118).
} 
claimed the right to organize rollers and roughers, and to this extent there was an overlapping of jurisdiction. These two organizations were of short duration, and their consolidation with the Vulcans put an end to all craft disputes.

For many years after its formation, the Amalgamated Association consisted exclusively of skilled workmen. At the outset, only "puddlers, boilers, heaters, roll hands, nailers, hammermen and helpers" were admitted. ${ }^{8}$ Helpers had been consistently debarred by the constituent organizations, and their admission to membership at first encountered strong opposition. Though eligible, they were frequently discriminated against. Prior to 1877 large classes of workmen, skilled as well as unskilled, were ineligible to membership. In this year, four new classes of semi-skilled workmen, namely, knobblers, turners, boiler-plate men. and sheet-iron shearmen, were admitted. ${ }^{9}$ In 1887 the president proposed that "all branches of labor directly interested in the manufacture of iron and steel should be made eligible to membership." The measure was adopted in I889, and "all men working in and around rolling mills, tin mills, steel works, nail, tack, spike, bolt, and nut factories, and all works run in connection with the same, except laborers, were admitted." Laborers might be admitted at the discretion of the subordinate lodge. ${ }^{10}$ Foremen have been consistently excluded from membership. ${ }^{11}$ Chain works were later included in the list of mills and factories, but otherwise the membership jurisdiction of the Association remained unchanged. ${ }^{12}$ Since $19 \mathrm{I} \mathrm{I}$, as a result of the agi-

${ }^{8}$ Constitution, 1876, p. 6.

9 Procecdings, 1877 , pp. 50, 74-77.

10 Proceedings, 1887 , pp. 1953, 2118; 1888, p. 2352; 1889, p1. 2686, 2687, 2791; Constitution, 1910, art. I, sec. 1 .

11 Constitution, 1912, art. 17, sec. 16.

12 The Association has always rigidly adhered to the principle of trade-union autonomy. This was the crux of the dispute with the Knights of Labor. In 1888 furnace builders were refused menulership, because the Bricklayers claimed jurisdiction over them (Proceedings, 1888, p. 2273). For similar reasons, water tenders, stationary engineers and firemen were not admitted in 1900 (Proceedings, Iyoo, p. 5845). Yet, the Association in 1907 refused to grant to the 
tation for industrial unionism, the Association has opened its doors to laborers, thus extending its jurisdiction to embrace all men in the iron, steel and tin industry. ${ }^{13}$

Immigrant skilled workmen have ordinarily been affiliated in separate local unions. Now and then, particularly in the eighties, a cry of protest against the large numbers of incoming aliens has been heard. In I 879 the secretary communicated with the Amalgamated Ironworkers' Society of Great Britain concerning immigration to this country, declaring that "bad results would accrue from an influx of people to our shores, for whom there was no possible chance of employment." ${ }^{14}$ In consequence of the large immigration and importation of laborers under contract, the Amalgamated Association in I $88_{4}$, as did many other trade unions about this time, urged upon Congress the enactment of restrictive legislation, ${ }^{15}$ and began to discriminate against immigrant workmen in admission regulations. A rule requir-

Elcctrical Workers jurisdiction over men in charge of the crane and charging machine in the open-hearth plant at Granite City. Ill.; "simply hecause the machine had elcctricity for its motive power" (Proceedings, 1907, pp. 7922-7924); and the Electrical Workers did not force their claim before the American Federation of Labor. Also, in 1916, the Blacksmiths claimed jurisdiction over the bolt and nut workers at Kansas City, Mo., but the Amalgamated has held that they are not blacksmiths and will not relinquish its jurisdiction over them (Proceedings, 1916. pp. II521-11523).

${ }_{13}$ A "Central Secret Lodge" was established in 190.4, for the purpose of enlisting as members workmen employed in uon-union plants. The following rules, with reference to membership in the Secret Lodge, were adopted: (I) Applications must be cndorsed hy the vice-president of the district or division. (2) Applicants must be working in a mill where no Amalgamated lodge exists. (3) Withclrawal or honorary cards must be applied for by members leaving the locality or the trade through the secretary of the Central Lodge. (4) The initiation fee was two dollars, and the quarterly dues \$1.po, payable in advance. (5) No strike benefits werc paid, hut members in good standing were entitled to death benefits. (6) $\Lambda$ member who was suspended and not reinstated was "stigmatized a non-union man." The Central Lodge dates from September 24. Ixo.4, and is yet extant. It has not, however, justified the large hopes held by those who advocated its establishment. I" 1 yod it was decided to enforce the spirit of the law that laborers be admitted "for the gond of the Association."

14 Proccedings, 1880, pp. 363.366.

15 Proccedings, 1884 , p. 1390. 
ing citizenship of members was frequently proposed as a national provision. ${ }^{16}$

To what extent the unskilled workmen will be organized in subordinate lodges is uncertain. They are not unlikely to suffer discrimination, as did the helpers in the earlier days. The advantage of such an alliance appears greatly in favor of the unskilled. A vast organization of unskilled workers in all industries does not seem possible, since the constant tide of immigration during normal times makes any effective regulation of the supply of general laborers impracticable. ${ }^{17}$ It entails a sacrifice upon the skilled, who will have to fight the battles of the anskilled. On the other hand, the introduction of machinery has forced many of the highly-skilled trades from their position of aloofness. As division of labor becomes more minute, as the old method of apprenticeship fails, and as the groups of skilled and semi-skilled are being recruited by the promotion of the common laborers to an ever increasing extent, there is a growing tendency to admit such potentially dangerous competitors to the union. The growing spirit of class consciousness may effect a satisfactory alliance of skilled and unskilled.

The Iron and Stecl Workers, in 1913 , widened the scope of its membership jurisdiction by the merger of the Tin Plate Workors International Protective Association with the Amalgamated Association. The Tin Plate Workers' Union was instituted in 1898 , and it was composed of what were commonly known as "wash house" men. ${ }^{18}$ At the time of its organization, only seven out of twenty-one tinplate plants had local unions. The Amalganated Associntion had organized principally the hot-1nill men, but it felt

\footnotetext{
${ }_{16}$ Proceedings, 1888, pp. 2482, 2497.

17 T. W. Glocker, "Amalgamation of Related Trades in American Unions," in the American Economic Review, September, 1915, vol. v, no. 3, Pp. 572-575.

18 The Tin Plate Workers also admitted female employees. At the time of consolidation, the local muion at Stenlsenville, Ohio, had a few female members. These becane members of the Amalgamated. There are none now belonging to the Association.
} 
that the tin house workmen could best serve their own interests by having a separate organization, and arranging their own scale. ${ }^{10}$ The organization was never large numerically, having at the time of its affiliation with the Amalgamated about five hundred members.

The difficulties encountered with the American Sheet and 'Tin Plate Company, and the gradual loss of control of the sheet and tin industry, lent impetus to the movement to consolidate. An invitation was extended the Tin Plate Workers to join with the Amalganated as early as $1906 .^{20}$ When the Iron and Steel Workers became involved in the 1910 strike, the American Federation of Labor advised consolidation, and the following convention of the union gave the executive board full power to act. ${ }^{21}$

Nothing definite was done until June, 1913, when the exccutive board met and outlined the terms of consolidation. These were presented at a joint meeting of both organizations on July 30 of that year, and the arrangement was agreed to. The Amalgamated Association was given "full and complete jurisdiction," and the president of the Tin Plate Workers was employed in the capacity of organizer. Local tin-plate unions, it was agreed, should receive charters and supplies free of charge, and should be required to pay no initiation fee, except the regular two dollars for insurance. ${ }^{22}$

The Association from the beginning did not discriminate against negroes by constitutional provision. ${ }^{23}$ They were

10 Proceedings, 1000, pp. 5718, 5762.

20 Proccedings, $1906, \mathrm{p} .776 \mathrm{r}$.

21 Procecdings, 1910, p. 8843.

22 Proceedings, 1914 , p. 10428.

23 The early unions ont of which the Amalgamated was formed did not arlmit colored workmen. Even after the Association was formerl, the white workmen refused to work with them or afford them any protection. Accordingly, colored men "scabbed" on the strikers in the mills at Pittsburgh and Homestead. Membership in the union was offered the negro only after he had made himself indispensable to the organization. Recent attempts have been made to organize the colored workmen, but without much success (Proceedings, I905, p. $7255 ;$ 1908, pp. 8259-8260, 8333, 8340). In general, unionism has been more of a hindrance than a help to the negro. (R. R. Wright, Jr., "One Hundred Negro Steel Workers," in Wage-Earning Pittsburgh, pp. 106-109.) 
not engaged in the industry to any considerable extent, and as to the few that were, all available evidence supports the conclusion that none were admitted. ${ }^{24}$ In 1877 the union refused to declare them eligible, but in $188 \mathrm{I}$ provided for their inclusion within the class of eligible persons, "past experience having taught the craft that they were indis-

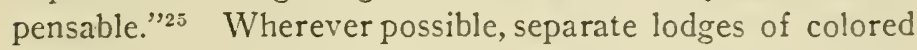
members were organized, as, for example, Garfield Lodge in Pittsburgh in I887. The number of negroes in the organization, however, has never been large.

Although occasional protests are heard against the admission of incompetents, ${ }^{26}$ the aim of the Association has been to make the conditions of membership as simple as possible. There is no provision in the rules for a specified term of apprenticeship as a requisite for membership. The "helper" system has made such a regulation unnecessary, since the helper has an opportunity of watching the work of a journeyman and of thus acquiring a trade. Despite much opposition, it was found necessary to admit helpers into the union at an early date. A two-thirds vote is required to admit and to expel. The Association has considered a few cases of appeals by non-members who were rejected for insufficient cause, and has made certain persons membersat-large, though the union has not specifically recognized this right.

During the history of the Amalgamated Association, no distinct trade organization, that is, a trade union whose members did not previously belong to the Association, has ever disputed its jurisdiction. A possible exception to this statement is the Knights of Labor. The Knights of Labor was a completely rival organization to all trade unions, in that it sought to unite all workmen in one large union "with-

${ }^{24}$ The men in the Birmingham, Ala., rolling mill, and in other plants in the South refused to work with negroes, even though they were legally eligible to union membership (Proceedings, 1900, p. 5874; 1905, p. 7255).

25 Proceedings, 1876, p. $82 ; 1881$, p. 708.

20 Procecdings, 1884, p. 1363. 
out regard to nationality, sex, crced or color." ${ }_{27}$ In I 880 the Knights of Labor admitted negroes, and in I $S_{5} 5$ the negroes flocked into the ranks of the order in the South. ${ }^{28}$ The Knights of Labor was organized by industries, rather than by trades, so that an iron and steel local assembly would include in its range all men working in a single mill, both skilled and unskilled. Indeed, the Knights sometimes embraced all sorts of workmen, including common laborers and gas producer men.

Friction between the local unions of the Knights of Labor and the Amalgamated Association in those places where both organizations lad members working in the same mill was constant. In $I 88_{3}$ a Pittsburgh labor paper ${ }^{29}$ stated that the steel workers of Braddock, Pennsylvania, had had their wages reduced steadily for five years, and declared that this was due to weakness, resulting from a division of the union forces into two separate organizations. In December of the same year, the men of the Edgar Thomson Steel Works at Braddock were notified of a reduction of thirteen per cent, to take effect at the beginning of the next year. A joint committee of the local unions of the Association and the Knights of Labor held a conference with the company, and were informed that the reduction was to affect only the tonnage men. This affected every member of the Amalgamated Association, but only a small part of the Knights of Labor. The assemblies of the Knights refused to act in any way. This meant, of course, that they would continue work; and the tonnage men, as they had done the year previous, accepted the reduction.

The most serious dispute between the Association and the Knights of Labor occurred in I 887 at the Mingo Stecl Works. $^{30}$ After the United Nailers were readmitted to the Amalgamated Association many of the men at this plant

\footnotetext{
27 Proceedings, General Assembly, Knights of Labor, 1884, p. 780 .

${ }^{28}$ F. E. Wolfe, Admission to American Trade Unions, p. 116.

20 National Labor Tribune, December 22, 1883.

30 Proceedings, 1887, pp. I935-1945; National Labor Tribune, February 26 and March $5,1887$.
} 
joined the Knights of Labor. The skilled men of the nail factory, however, organized an Amalgamated lodge so as to get the higher scale. The local union was composed of heaters, rollers, and roll hands of the nail mill. One day a crane broke, and since the Knights of Labor agreement, under which the men were working, provided that "only actual tonnage" be paid for, the men, realizing it would require several hours to repair the crane and that they would not get a full day's work, went home. The manager next morning discharged them.

Both unions, each claiming jurisdiction, took up negotiations in an attempt to effect a settlement. The executive committee of the Amalgamated legalized a strike February ro. A joint committee of both organizations was suggested but refused. The Knights declared the mill open, and endeavored to start it up. The manager, after ten days, since the Knights were unable to operate the plant, arranged a conference with the Amalgamated Association, and signed a scale.

In 1886 the Knights of Labor invited the Amalgamated to join them. ${ }^{31}$ The offer was submitted to a vote of the local unions, and almost unanimously refused. The next convention forbade members of the Association to belong to the Knights "after April 1, r888." 32 This action served to accentuate the breach between the two organizations. The Knights organized "National District Assembly 2I7, Iron, Steel and Blast Furnacemen, Knights of Labor," and applied to the American Federation of Labor for a charter which was not granted. ${ }^{33}$ To this assenzbly the Knights admitted, in the words of Secretary Martin, "anybody and evcrybody working in and around rolling mills and steel mills." The first annual convention was held in Pittsburgh, June 4, I888, and eighty delegates were reported from eight

\footnotetext{
31 Proceedings, 1886, pp. I806-1808.

32 National Labor Tribune, June 25, 1887, p. 4, col. 3 ; Proceedings, 1887, D. 2129.

${ }^{3}$ Financial Statement for quarter ending October 3r, ISS9, p. 4 . 
different States. ${ }^{34}$ Secretary Martin, in order effectively to counteract the inroads of the Knights of Labor, advised all Amalgamated unions to "take in every man in the mills outside of common labor, and him too, if necessary." Thus the influence of the Knights upon the Amalgamated Association served, in a measure, to democratize the union. ${ }^{35}$ Similar disagreements with the Knights took place in 1888 and 1889 , as the result of conflicting wage scales: also, at the Chicago Steel Works, as late as 1892 . The Knights of Labor, however, did not succeed in getting control of any great number of mills. After the formation of the American Federation of Labor, the power of the Knights waned, and it has since played no important part in the organization of the iron and steel trade.

Similarly, in recent years, the Industrial Workers of the World have shown activity in organizing unions in iron and steel mills. ${ }^{36}$ Like the Knights of Labor, the I. W. W. is a dual union with respect to all craft unions. This has been recognized by the Association, which forbade its members to mite with the I. W. W. on the ground that it was a dual organization.

${ }^{34}$ National Labor Tribune, June 9, 1888, p. I, col. 5.

35 Secretary Martin, in urging the local unions to admit the unskilled, said: "Be liberal and admit to membership the men whom the Knights of Labor are playing to reduce wages. ... We mean the unskilled workmen. ... Yes, even the daily laborer. IVe have nothing to lose and all to gain by the admittance of these men. All they ask is recognition. Failing to get that, they naturally seek and get in the Knights of Labor." He chided the local unions for being "aristocratic" and "narrow" (Financial statement for quarter ending January 31,1888, p. 5 ).

${ }_{36}$ In 1000 the I. W. W. were trying to secure a foothold at Reading, $\mathrm{Pa}$., by scattering literature, talking with the men, and making arrangements for meetings (Proccedings, 1906, pp. 749.4. 7500, 7678). In 1910 the Clark Rolling Mill, of Massillon, Ohio, was placed on the prolibitive list, because the men refused to organize; whereupon, the men formed a local union of the I. WV. W. "with the consent of the manager" (Proceedings, 1010, P. 8859). In 1915 a disruptionist movement was originated in the Wheeling district by certain malcontents, advocating industrial unionism, but President Williams declared that the Association would "never become the tail of a kite to any seceding organization, particularly one of the character of the I. IV. IV." 
In 1882 the finishers were dissatisfied because they were outnumbered by the puddlers and not adequately represented in the annual meetings, and there was agitation for a reorganization and some discussion of a new union. ${ }^{3 i}$ Similarly, in $188_{3}$, a local union of Terre Haute, Indiana, issued a circular which urged the withdrawal of the boilers and a reorganization of the old "Sons of Vulcan." The president of the national union threatened to revoke its charter unless the local union retracted the action, and the Terre Haute organization renounced the circular by a small majority. President Jarrett had urged the organization of separate lodges for the crafts as a means of lessening the friction between the finishers and the boilers. This plan was put into effect a little later and the dissension was temporarily stopped.

The nailers seceded from the union in 1885 . The nailer had been accustomed to good wages. Due to the introduction of machinery, there was so considerable an increase in productive capacity that nail manufacturers restricted the output. Nail mills were not infrequently idle six months in a year, yet new machines were constantly being added to old plants, and occasionally a new factory was built. Machines were multiplied to such an extent that even the demand of a very prosperous year could not have kept the nailers in work much over half time. The nailers had two other grievances. First, the law provided that the number of apprentices to be taken on should "not exceed two per cent (outside of nailers' sons) of the machines per annum.", Some years the nailers would not admit the legal quota, and in that case the Association granted the employer the privilege of hiring "green hands" up to the two per cent mark. To this the nailers objected. Again, there was clispute as to the price for cutting steel nails. The scale convention held in Pittsburgh, April 5, I884, made the price for cutting nails ont of steel "when harder than iron" twenty per cent

\footnotetext{
${ }^{37}$ Proccedings, 1882, p. 967; 1883 , pp. 1113-1114.

эн Constitution, I884, p. 36.
} 
extra. Not a few nailing lodges in the vicinity of Wheeling refused to abide by the scale, some even claiming to prefer cutting steel to iron. This caused an altercation with the boilers. who, when the nailers continued to cut steel for the same price as iron, were thrown out of work. Hershey Lodge, of Bellaire, in January, I885, issued a circular " to the nailing fraternity," charging the Association with partiality to the puddlers and discrimination against the nailers, and calling for a meeting of the nailers in Wheeling on February 5. Hershey Lodge, upon its refusal to rescind its action, had its charter revoked two weeks later. This local union then began to work for the withdrawal of the nailers from the Amalgamated Association, and issued a call for a convention of nailers to be held in Wheeling on April 2, I885. At this convention a resolution was passed to withdraw, and the new organization was called "The United Nailers of America." 39

Practically all lodges of nailers voluntarily withdrew and allied themselves with the new organization. The few that remained the Amalgamated advised to join the United Nailers, so that the new union would be free to arrange their scale for the next year without interference. According to Secretary Martin, the loss occasioned by the secession of nailers was 835 ; of these, I 53 were nail feeders. The first annual convention was held in Wheeling July I4, I885, and lasted four days. Delegates were present from the neighboring states of Pennsylvania, Ohio, and Kentucky only. Nail-plate heaters and rollers were admitted, and the name changed to "The Nailers' and Nail Plate Rollers' and Heaters' Association." The wage scale occupied most of the delegates' attention.

The Nailers, because of hostility to the nail feeders who took their jobs, refused to admit the feeders. The nail feeders, accordingly, organized a union, known as the "Nail Feeders' Union of the Ohio Valley." 10 So, too, those feeders who wereopposed to taking the nailers' places organized

ao Proccedings, 1885, pp. 1558-1559.

10 National Labor Tribune, April 25, 1885, p. 4, col. 2. 
a similar short-lived organization, "The United Nailers, Rollers and Heaters of the United States." 41

The Nailers, during their existence as a separate organization, had anything but smooth sailing. Failing in an attempt at a conference with the Western Nail Association, unsuccessful in the maintenance of a wage scale, in frequent bickerings with the recalcitrant nail feeders, they turned for protection back to the Amalgamated. When the twenty-three delegates met in Pittsburgh, June r, I886, not a voice opposed the proposition to apply for readmission. The Amalgamated met in June, and nine of the nailers presented the petition, "most respectfully" begging "your honorable body to allow us to return to the protecting wing of the Amalgamation," and to it was appended a long list of names. The request was granted, not quite unanimously, and the Amalgamated undertook to settle the nailers' strike then in progress. A compromise scale was effected and signed, and after the bitter feeling between the nailers and feeders subsided, the nail feeders were likewise gradually reorganized.

Factional feeling and internal strife were rampant throughout the nineties. At different times the puddlers manifested a rebellious spirit, though no definite action was taken. Roll turners, ${ }^{42}$ tin-plate workers, ${ }^{43}$ wire drawers, ${ }^{44}$ rod-mill men, ${ }^{45}$ each in turn, threatened the union with secession and the formation of separate organizations. These "Judases," says Vice-President Larkin, "appear in times of trouble," when the union is facing a reduction. In 1892 , when the conflict with the Carnegie Steel Company was at its hottest. some finishers, principally in the mills of Pittsburgh and Youngstown, in an effort to dodge the strike tax for the enforcement of the closed shop, formed a short-lived finishers' union called "The National Union of Iron and Steel

41 Ibid., September 5, 1885.

12 Proceedings, 1804, p. 4564.

43 Proceedings, $1805, \mathrm{pp.} 4808-4812$.

14 Ibid., pp. 4812-4813.

15 Proceedings, 1899 , pp. 5626-5627. 
Workers of the United States." They enlisted a following under the promise of no assessment, and sought to get a scaile signed so that their members might "black-sheep" under the guise of unionism. The inducement of no assessments had a distressing effect on the collection of the tax from nembers of the Association and, according to President Garland, "disheartened the men at Homestead to such a degree that they lost hope of winning the strike." ${ }^{46}$ The Amalgamated refused to recognize the finishers as a rival organization, on the ground that it would form a "precedent" for any small group of seceders to demand recognition in the future. The Finishers' Union established temporary headquarters at Youngstown, but within a few years it disbanded and its members drifted back into the fold of the Amalgamated.

Perhaps the gravest disruption in the history of the Association was the secession of the puddlers in 1907. The movement originated in Brown's Tenth St. Mill, Pittsburgh. ${ }^{47}$ A meeting of puddlers, scrappers, and muck mill hands was called in the Old City Hall, on the 24th of February, and a temporary organization was effected. At the next meeting on Sunday, March 10, the puddlers decided to withdraw in a body from the Amalgamated Association, and for sentimental reasons the new union assumed the title of the early puddlers' union, "Sons of Vulcan." The first convention was held in Pittsburgh in June of that year, and delegates from sixteen lodges were present. ${ }^{48}$ Headquarters were established in Pittsburgh. They sought a reciprocal agreement with the Amalgamated, but of course the Association would not consider such an arrangement. The Sons of Vulcan drew up a scale, which was a prototype of the A malgamated scale, and, in the attempt to have it signed,

10 Proceedings, 1893 , pp. 4325, 4350-4351.

17 The reasons for the formation of a separate union of the puddlers were "the failure of the Amalgamated Association to secure satisfactory conditions for the Boiling Department, and the belief that their interests can best he subserved hy being independent of all other departments" (Procedings, 1907, pp. 7914-7915, 7918).

14 National Jabor Tribune, June 6, 1007. 
came into conflict with the Association in a number of places.

The Sons of Vulcan met with considerable success for several years although they had few lodges outside of the Pittsburgh and Youngstown districts. It is doubtful if, at any time, they had an active membership of over a thousand, although they claimed a much larger number. Internal bickerings and dissension crept into the organization, and the last convention was held in Pittsburgh in I9I3. Since that time, the Amalgamated has been gradually recovering its lost members. ${ }^{49}$

Two attempts to form dual unions were initiated during the interval between the conventions of I9I 2 and I9I3. The one was a secessionist movement, originating in the sheet and tin mills of Niles, Ohio. The aim in view was to include in one organization "practically all workmen working in and about said industries, with one single exceptionthat is, the rollers." ${ }^{50}$ The new organization, "The Industrial Iron and Steel Workers of America," in a manifesto, declared for direct action as a means of securing justice, and began the campaign by walking out of the Empire plant at Niles. The cooperation of the union and the employers prevented this insurgent movement from gaining any appreciable vogue.

The other disturbance was avowedly a movement within the parent organization, and not a secession from it. It was styled "The Progressive Movement of the Amalgamated Association of Iron, Steel and Tin Workers." It was an attempt to place the control of the Association in the hands of a democratic minority, who sought to reorganize the union on an industrial basis. The Progressives also advocated the extended use of the initiative and referendum, and the right of recall. These innovations have since been introduced, and after their adoption, the movement lost its purpose.

\footnotetext{
49 Proceedings, 1915, p. rog93.

so The roller, being the highest-priced workman, was naturally the object of envy of other workmen.
} 
The employers have always been on the side of the conservatives. They consider a trade agreement with the union, covering those men most indispensable to the trade. as a safeguard against a more extensive organization of their employes which might force terms for all in the mill. The unskilled laborers, from whom the future skilled men must be selected, are largely: Southern Europeans whose allegiance to union principles is slight. These men, at present, are largely ignored by those who compose the union membership. If the democratic minority should gain control, it is probable that a reorganization would take place along inclustrial lines. The movement thus far has been unsuccessful. 


\section{CHAPTER IV}

\section{Finances}

The early national unions, because of their loose organization, did not require large financial resources. The chief functions of a national union, in the earlier days, were the supervision of a "traveling card" (by means of which a member moving from the jurisdiction of one local union to that of another became entitled to all the privileges of membership), and the collection of voluntary contributions for the aid of local unions in conducting strikes. ${ }^{1}$ Thus, the funds of the Heaters' Union were never over a few hundred dollars.

Revenue.-As a consequence of these limitations, both in activity and in authority, the early organizations in the iron and steel trade were granted revenues of meager character. A per capital tax was paid, at regular intervals, by each local union for the privilege of representation in the annual convention. In the case of the Roll Hands, it was a monthly assessment of twenty-five cents per member. ${ }^{2}$ The Sons of Vulcan levied a "semi-annual tax," the amount per capita being fixed by the president and varying according to the funds required. ${ }^{3}$

As the Sons of Vulcan extended its functions, larger revenue was granted. The annual tax increased irregularly from fifty cents in 1867 to $\$ 1.75$ in 1873 . Delegates to the convention in 1872 were paid wages for lost time, in addition to railway fare, by the national union. In 1873 a salary was paid the president. These expenditures were reflected in the increased capitation tax, as seen in the semi-annual assessments from 1867 to 1873 :

1 A. M. Sakolski, The Finances of American Trade Unions, p. 11.

2 Constitution, Iron and Steel Roll Mands, 187t, p. 11.

${ }^{3}$ Vulcan Record, no. 14, 1P. 18, 34; Constitution, 1874, p. 9. 


\begin{tabular}{|c|c|c|c|}
\hline Year & First Assessment & Second Assessment & Total \\
\hline I $867 \ldots \ldots$ & 25 cents & 25 cents & 50 cents \\
\hline $1868 \ldots \ldots \ldots$ & 50 “ & $30 " 1$ & 80 \\
\hline I $869 \ldots \ldots$ & $30 "$ & $30 \quad 11$ & 60 \\
\hline $1870 \ldots \ldots$ & 50 " & 50 " & \$1.00 \\
\hline $1871 \ldots \ldots$ & 50 “ & $25 \quad$ " & 75 \\
\hline $1872 \ldots \ldots$ & 75 " & 50 & $\$ 1.25$ \\
\hline $1873 \ldots \ldots$ & 50 & $\$ 1.25$ & $\$ 1.75$ \\
\hline
\end{tabular}

The "per capita tax" method of supporting the national union was continued by the Amalgamated Association. It was a convenient fiscal device. The principle of local autonomy was preserved; and local unions apportioned their funds to suit their own peculiar needs. ${ }^{*}$ The local unions were financed by means of monthly dues. Some revenue accrued from initiations, reinstatements and fines, but these sources of income were of minor importance.

The amount of the ordinary per capita tax has increased proportionately with the growth of the activities of the national organization. Also, the extension of the field of collective bargaining has meant increased cost of administration. The quarterly assessment, which in $\mathrm{I} S S_{5}$ was twenty-five cents, was increased to fifty cents in I900, and since 1905 has been one dollar. Journal dues of $\$ 1.20$ annually were added in Igor, and raised to \$1.50 in 1907. The convention has frequently exempted lodges from the per capita assessment, if it has been clearly shown that they were unable to pay. The capitation tax was designed to cover ordinary administrative expenses, although frequtently the revenuse from this source was insufficient and the deficit was borrowed from the defense fund. In I9I th this method of financing was remedied by the consoliclation of all funds.

An increase in the national revenue by means of an assessment of a higher per capita tax upon local unions carried with it, as a corollary, the requirement of higher dues from the individual members of the subordinate unions. The

The so-called "community of funds" system (which provides for the merging of the local funds with the national resources) has never met with the favor of Association leaders. 
value of high dues and large treasury funds as a means of promoting the strength and stability of the organization had been generally recognized by the Association leaders, but the members were reluctant to grant more revenue until their immediate interests were involved. The big steel strike of IgOI was the most effective factor in breaking the persistent opposition to increased local dues.

The substitution of a tax on earnings for the capitation tax has been discussed in the convention at various times. In 1905 the session considered the introduction of the "percentage system" for the collection of national dues. Two advantages of the new system were presented: the automatic exemption of unemployed members, and a more equal distribution of the burden of taxation. The chief argument in opposition was the difficulty in determining the amount of dues under this system. Two years later, the percentage system of dues was reconsidered, and the conference committee endeavored to arrange for collection by employers. The employers expressed a willingness to enter into an agreement to collect the dues of union members, but the proposal was defeated at the referendum.

Although the Association was unwilling to adopt the percentage system, it was clearly felt that uniform national dues were undesirable, since the membership differed widely in earnings. In lieu of the rejected percentage system, a plan for graded dues was adopted in 1905 . The monthly dues were graded as follows: members earning $\$ 2.50$ per day or less, 65 cents; over $\$ 2.50$ and less than $\$ 5.00$, So cents; and $\$ 5.00$ or more, $\$ 1.00 .^{5}$ This system of dues, although the grades have been changed twice, has since continued in force. ${ }^{\circ}$

5 Proceedings, 1905, p. 7217.

- The scales of dues in 1912 and in 1916 were as follows:

\begin{tabular}{ccc} 
Daily Earnings & \multicolumn{2}{c}{ Montbly Dues $^{\circ}$} \\
Less than $\$ 2.50^{8}$ & .60 & 19.6 \\
$\$ 2.50$ to 5.00 & .80 & .85 \\
$5 .(x)$ to 7.50 & 1.25 & 1.05 \\
7.50 to 10.00 & 1.25 & 1.25 \\
10.00 to $15 .(6)$ & 1.50 & 1.50 \\
15.00 and more & 1.75 & 1.75 \\
& & $2 .(x)$
\end{tabular}


The national revenue has been partly made up of such incidental receipts as charter fees, initiation fees, fines, interest, and the income derived from the sale of stationery and supplies. The Journal also has been a source of annual gain. ${ }^{7}$ These sources of revenue require but brief consideration. Charters were originally granted a newlyorganized local union for the sum of five dollars. Supplies were purchased separately. Because of the fact that new organizations would deprive themsclves of necessary supplies in order to save expense, the national union in IS87 decided to make the cliarge for organizing a local lodge twenty-five dollars. This inclucled equipment requisite to carry on its business properly.

Initiation fees mean a considerable item where the membership is growing and the personnel constantly changing. Until 1909 the charge for initiation was left to the discretion of the local unions. In 1906 the national union fixed the minimum ${ }^{8}$ at five dollars, and provided that two dollars of this amount should be placed in the benefit fund. Fines are employed chiefly by local unions.

The importance of a reserve fund for "defensive" purposes while realized by the leaders of the union, has not been appreciated by the membership at large. The Iron and Steel Workers have never been willing, or able, to build up a big reserve fund which would enable the members to cngage successfully in protracted strikes. In the early unions, no effective measures were taken to accumulate central reserve funds for the purpose of defense. The Heaters' and Roll Hands' organizations left the settlement

a In 1916, the dues covered all purposes (Constitution, 1916, p. 70); in 1912, all excepting the assessment for the benefit fund, for which twenty-five cents per month was collected.

6 The montily dues of laborers earning $\$ 1.75$ per day or less were fixed at sixty-five cents.

7 The annual gain from the publication of the Journal has ranged in the years 1910-1916 from \$500 to \$5000.

${ }^{8}$ Since 1913, members earning less than $\$ 2.50$ per day may be initiated for $\$ 3.00$ (Procecdings, 1914, p. 10665 ). 
of wage disputes to the local unions and their strikes were financed largely by voluntary contributions. ${ }^{9}$

Until I 870 the puddlers financed strikes by "voluntary donations."10 The Sons of Vulcan, in the convention held at Harrisburg that year, passed a resolution empowering the president "to levy a per capita tax upon all taxable members . . . sufficient to pay to each member" engaged in a legal strike "the sum of not less than three dollars a week."11 Strike levies were made, but only about onethird of the assessments were paid. ${ }^{12}$ In 1874 a new system was adopted, whereby each district supported its own strikes. ${ }^{13}$ Only when one-third of the membership was on strike was national aid granted. In 1876 provision for a "protective fund" was incorporated in the constitution of the newly-formed Amalgamated Association. Local unions were to "deposit in bank the sum of twenty-five cents per member per month, subject to the call of the president in case of strike." ${ }^{14}$ Members in good standing engaged in a legal strike were entitled to five dollars weekly benefit. ${ }^{15}$

The system of protective funds, maintained by the local unions and held in local treasuries, was subject to abuse and neglect. In 1878 President Bishop said that legitimate claims were not met "for the simple reason that at least half our lodges and members neglect our revenue laws and consequently sub-lodge treasuries are empty." The members were neglectful or refused to pay, officers were indifferent, and the protective fund was "a mere name and nothing more."10 In some cases the money was used to defray local expenses. The reserve fund was supplemented

9 The Roll Hands in 1874 levied a strike assessment of ten cents per month (Proceedings, 1874, p. 14); but the defense fund was never large enough to be effective.

10 Vulcan Record, no. 6, 1870, p. 31.

11 Ibid., p. 26.

12 Jbill, no. 14, 1874, p. 10.

13 Ibid., pp. 29, 41, 43 .

14 Constitution, $1876,1 \% .13$.

15 Weekly strike benefits were reduced to four dollars in 1879 (Proceedings, 1879, p. 282). They have remained at four dollars per week since.

${ }^{10}$ Proceedings, 1878, pр. 122, 125. 
by special assessments, but only slight relief was aftorded. The difficulty of collection and the delay in receiving returns madc the assessment method of raising funds peculiarly unsuited for strike financing. Such levies frequently did 'not bring returns until the occasion for them was past. ${ }^{17}$

The need of a strong national reserve fund, because of the existence of manufacturers' associations in the trade and the possibility of general strikes, was apparent to the leaders, but the members had to learn the lesson by experience. The big strike in $18 S 2$, which included three districts, was lost because of lack of funds and the inability of the assessment method to supply them. The union then decided to build up a permanent reserve fund. The revenues applied to it consisted of a quarterly per capita tax of seventy-five cents. ${ }^{18}$ When the protective fund was "depleted by a long and continuous drain," it was the duty of the president to levy a special assessment to replenish the fund.

The amount of this assessment varied. In I $\$ 93$ the president was empowered to levy an assessment of from one to five per cent of earnings for a period of one month, whenever the amount in the fund fell below $\$ 25,000$. Even this was insufficient in the tin-plate strike in $1894-1895$. In 1902, after the big steel strike, an assessment was provided for every three months until the reserve fund reached the sum of $\$ 200,000$. This provision was annulled the following year, and the matter of assessments was put in the hands of the advisory board. In 1905 a percentage system of assessment was established, graded in accordance with

17 Proceedings, I880, p. $355 ; 1882$, p. 922 . Secretary Martin, in his report to the convention of 1880 , said: "It is high time the Association got down to plain practical working in this regard, and devised ways and means for the accumulation of a contingent or strike fund, so that when necessity required we would be prepared to financially sustain a strike of a thousand members for a year at lcast."

18 In 1903 the capitation tax was decreased to sixty cents, but in 1906 it was increased again to seventy-five cents. Men working in the East and in unorganized milis are exempt from the assessment for the protective fund. In case of strike they are entitled only to such support as the National Lodge is disposed to afford (Constitution, 1916, p. 24). 
the number of men who were on strike. In I 909 a new plan of assessment was accepted, graded both as to the number of men on strike and the daily earnings of the members.

The strike of I9Io proved the inadequacy of this measure to meet the requirements of a great strike. A ten per cent assessment was levied, and the following convention provided that no special assessment of over two per cent of the earnings of members could be levied without submitting it to a vote of the membership.

The results of the new system were immediate. Whereas prior to 1880 benefits were not paid with any degree of regularity even in local troubles, and the legal provision to pay strike benefits was not effective after that date, the obligations of the national union were met promptly. The sympathetic appeal has not been used extensively as a supplementary method of supporting strikes. The union has realized that it is a confession of financial weakness. Only in cases of emergency, as in the great strikes of 1892,1901 , and 19ro, has it been employed. In these struggles, however, the income from these appeals was large, and enabled the Association to continue the contest much longer than it otherwise could have done.

A minor source of revenue to the protection fund was the interest which accrued from the so-called "rebate fund." By the provisions of the rebate plan, entered into with the tin-plate manufacturers in October, 1902, a certain percentage of the wages of the men was held in trust, and on rebate trade (tin plate sent abroad intended for re-export, thus entitling the buyer to the (lrawlack clause of the Dingley tariff) twenty-five per cent reduction from scale rates was paid the manufacturers upon presentation of documentary evidence. This arrangement was discontinued after the 1910 strike. The amount placed in the defense fund from interest on these trust funds was $\$ 14,2.10 .38$.

In addition to the revenue for general and for defensive purposes, now for some years merged in a single funcl, the 
union devotes a part of its revenue to the support of a benefit fund. This subject will best be discussed, however, in connection with a description of the benefit features of the union.

- Expenditure.-The development of the union is naturally characterized by an increase in expenditure. A rough dividing line in its fiscal history is the formation of the Association in 1876 . Since that time, the expenditure has continuously, although irregularly, increased. The average annual expenditure of the Puddlers from 1867 to I 876 was $\$ 8,036.70$. The maximum amount spent in any one year was $\$ 23,316.95$ in 1875 . The increase in disbursements from 1870 to 1875 was due to three innovations: (a) the adoption in 1870 of a rational assessment plan for defensive purposes, (b) in $1 S 72$ the payment of wages and fare to convention delegates; and (c) provision in 1874 for a salaried official.

The following table shows the growth in expenditure of the Sons of Vulcan from I867 to 1875 :

\begin{tabular}{|c|c|c|c|c|c|c|c|}
\hline \multirow{2}{*}{ Year } & \multirow{2}{*}{$\begin{array}{c}\text { Member- } \\
\text { ship }\end{array}$} & \multicolumn{3}{|c|}{ Expenditures } & \multicolumn{3}{|c|}{ Per Capita Cost } \\
\hline & & General & Strikes & Total & Genera! & Strikes & Total \\
\hline $\begin{array}{l}1867 . \\
1868 .\end{array}$ & 665 & $\$ 960$ & $\$ 2,108$ & $\begin{array}{r}\$ 1,650 \\
3,068\end{array}$ & $\$ 1.44$ & $\{3.17$ & $\$ 4.61$ \\
\hline 1869. & 816 & 720 & 390 & I, I I & .88 & .48 & I. 36 \\
\hline 1870. & 1,265 & 1,429 & $1,7 \mathrm{II}$ & 3,140 & 1.13 & 1.35 & 2.48 \\
\hline $187 \mathrm{I}$ & I,959 & 2,337 & 675 & 3,012 & 1.19 & .34 & 1.53 \\
\hline 1872 . & 2,614 & 2,387 & 6,330 & 8,717 & .91 & 2.42 & 3.33 \\
\hline 1873. & 3.331 & 6,483 & 11,995 & 18,478 & 1.95 & 3.60 & 5.55 \\
\hline & 3,038 & $5,62 \mathrm{I}$ & 4,215 & 9,836 & 1.85 & 1.39 & 3.24 \\
\hline & 2,732 & 5,233 & 18,084 & 23,316 & 1.92 & 6.62 & 8.54 \\
\hline
\end{tabular}

The establishment of a "protective fund" in I 876 marked a change in fiscal policy. The total expenditure is markedly greater during the years of the big strikes, namely, I8S2I 883, I 892-I 893, I901-1902, 1905 and I910-191 I. Barring these periods of unusual disturbances, the annual per capita expenditure increased from $\$ 1.26$ in 1877 to approximately $\$ 3.00$ in $1885, \$ 8.00$ in 1906 , and $\$ 10.00$ in 1915 . The aver- 
age for the forty years of the union's history is $\$ 6.71$. In I904 a death benefit fund was established; and in Ig09 a sick and accident benefit. In I9I4, a normal year, the annual per capita expenditure was \$12.62. The increase in expenditure far outstripped the growth in membership. Since 1900 , roughly speaking, the expenditure has constantly increased while the membership has actually declined.

The growth of expenditure of the Association is conveniently shown in the following table giving the per capita expenditure for various purposes at five year intervals since 1877 :

Comparative Table Showing the Growth of Expenditure of the Association for Various Purposes, from its BeginNing

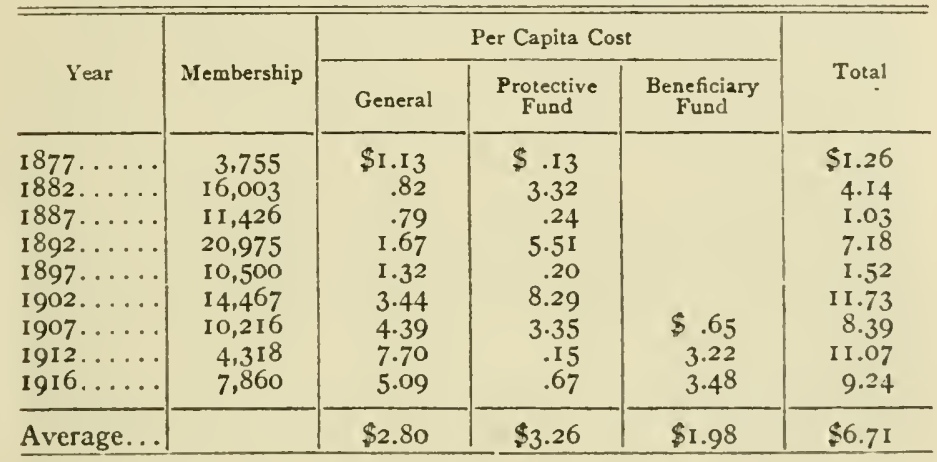

The disbursements of the union are classified under three heads, and correspond to the divisions made, until $1915,{ }^{19}$ in the funds $(a)$ for general purposes, $(b)$ for "protective" purposes, and $(c)$ for benefits.

(a) The disbursements of the union for administrative and miscellaneous purposes are classed as general expenditures. They include, besides the ordinary charges of administration and office management, the expenses of "organizing," printing, Journal publication, and the cost of

${ }^{10}$ In 1915 the three funds were merged into one general fund; this obviated the necessity of transferring funds from one account to another. 
conventions and conferences. These disbursements, as a rule, varied but slightly from year to year until 1900. In IS 77 the annual per capita expenditure for general purposes was $\$ 1.13$; in I $899, \$ 1.47$. Since then there has been a. rapid increase in general expenditures from $\$ 27.364 .40$ in 1900 to $\$ 43,756.92$ in 1914 . The anmual per capita expenditure has increased much more rapidly from $\$ 1.95$ in I 900 to $\$ 8.0 \$$ in I9II. In I9I4, a normal year, the per capita cost for general expenses was $\$ 6.36$. The increased outlay has been the result, chiefly, of the cost of publishing the Amalgamated Journal, undertaken in $1899,{ }^{20}$ and an increase in office expenses. The greater increase in per capita outlay is the result of a decrease in membership.

(b) The expenditure of the Association for "protective" purposes includes the benefits paid for the relief of members on strike, the expenses of administration and special donations made to assist local unions not legally entitled to benefits.

The introduction of labor-saving machinery, together with changes in the conditions surrounding the industry, have affected the amount of strike expenditure. The expenditure is highly variable from year to year. Strikes have frequently been of considerable magnitude, often covering a whole competitive district, but occurring only at long intervals. Such, for example, were the strikes of I882, I 895 , I900, and I910. Onitting from account the several great strikes, it will be noted that the per capita expenditure seldom exceeded $\$ 3$. In 1893 the per capita outlay for strikes was $\$ 11.03$; in I902, $\$ 8.29$; in 1905 , $\$ 8.47$; in 1910, \$19.59; and in 191 I, \$25.89. These were years of unusually bitter contests.

(c) Since 1904, the Association has paid a death benefit. The amount, originally $\$ 100$, has since been increased; the

20 Until 1903 subscription to the Amalgamated Journal was optional with the members. Since then a quarterly per capita tax has been levied for its support; 30 cents originally, but $37^{1 / 2}$ cents from $1907 \mathrm{on}$. The expenditures have been included in the disbursements for general purposes, but a separate account has been kept by the manager for convenience in comparison. 
benefit is now graded according to the term of continuous good standing. In I 909 sick and accident benefits were included. The union pays a weekly benefit of five dollars in case of sickness or disability, for a period of thirteen weeks. From the table given above, it will be seen that in recent years the expenditure has greatly increased on account of the change made in the character of the benefits.

Administration.-Improvement in fiscal administration has progressed with the development of the Association. This progress may be described under three heads: (I) better provision for an administrative staff, (2) safeguarding of the union funds, and (3) improvement in the fiscal administration and discipline of the local unions. ${ }^{21}$

In the early years of the union, slight provision was made for an administrative staff. National officers, being unsalaried, attended to the business matters of the union after the day's work in the mill. Permanent headquarters were not established until the early seventies. The employment of paid officials and the establishment of permanent central headquarters mark the beginning of progress in financial adninistration. The offices of secretary and treasurer were combined in I90I, thus tending to promote fiscal efficiency.

The officer in charge of the financial administration of the union is the national secretary-treasurer. As secretary, he has full charge of the books; he must keep the accounts between the local branches and the central office. As treasurer, he receives and pays out all money belonging to the union, is custodian of the funds, and prepares reports, quarterly and annually, of all financial transactions.

The safeguarding of union funds against misappropriation has been, with every trade union, a serious problem. Being unincorporated, the union is without legal redress. The Iron and Steel Workers has been no exception to the rule, and certain defalcations have occurred, particularly in the local branches.

21 Sakolski, p. 123. 
In order to safeguard the national funds, a board of trustees is elected to exercise supervision. The board holds the bonds of the officers; the amount of the security has been increased as the funds of the organization became larger. The trustees audit the accounts of the national union every three months, and a copy of their report is sent to each local union. They deposit with the president a bond, $\$ 5000$ in the case of the resident trustee and $\$ 1000$ for each non-resident trustee. The officials are authorized to secure these bonds from a reputable security company. The funds of the Association are deposited at interest in banking institutions from which withdrawals can be made on short notice, and are distributed in several banks so as to reduce risk. ${ }^{22}$

The national association exercises very little control over the local unions in matters of financial administration. ${ }^{23}$ Local officers are selected by the local membership. If they are remiss, the only expedient which the national union can employ is the suspension of the local union from the rights and privileges of the national organization-a step entailing numerical and financial loss, and generally causing discord.

The gravest problem in the fiscal adninistration of the Association has been the inefficient collection of national revenue. Through the gradual development of a card system, the national union was able to enforce the regular payment of dues, since the cards of a local union that was in arrears to the national organization were not to be accepted by other local unions. A local union, in debt to the national association $^{24}$ (unless exempted because its members were unemployed), received no support from the national union in case of trouble, and was not entitled to representation in the national convention. ${ }^{23}$ If a local union in arrears sent

${ }^{22}$ Proceedings, 1801. p. $350 \mathrm{I}$.

${ }^{23}$ The only rules of the national union concerning local finances are provisions relative to the safeguarding of local funds: the treasurer is required to give bond; the local funds may not be divided, etc.

21 The charter of a local union failing to send a delegate or to report for two successive sessions was rescinded (Constitution, 1874, P. 9).

23 Vulcan Record, 1874 , no. 14, p. 38. 
a delegate to the convention, the amount of the indebtedness was deducted from the mileage of the delegate. ${ }^{26}$ When the death benefit was introduced, in 1904, an additional incentive was afforded a subordinate union to keep in good standing. No claim for benefits was allowed if the union of which the deceased was a member was in arrears for its per capita tax or assessment. The number of unions actually suspended in recent years has been negligible.

Great difficulty was experienced in the prevention of " $\operatorname{tax}$ dodging." Local unions failed to report the full quota of members in good standing, and in this manner evaded a part of the burden of the per capita tax. ${ }^{27}$ In early years members were provided with "due" cards, showing the debit and credit account of members with the local union. But the national union had no effective check on the number of members for whom the local union was required to pay a per capita tax.

Finally, a new system was devised to prevent the evasion of dues by subordinate unions. Every member ${ }^{28}$ was given an "annual working card" and a card number. Under this system, it is the duty of the mill committee to see that every man is provided with a working card before going to work. The card number appears on the member's working card on the local ledger account of the member, and in the card catalogue of the national union. Every member, on payment of his per capita tax, has his working card reccipted monthly by the financial secretary, and a member not in possession of a paid-up working card is not entitled

26 Ibid., 1875, pp. 6-7; Proceedings, 1916, p. 23.

27 Proceedings, 1905, pp. 7253-7254.

28 In 1900 members were provided with " a working card . . issued at the end of each quarter upon payment of all fines, dues and assessments," and subject to the inspection of the mill committee (Proceedings, 1900, p. 5917). The next year, the "duc card" was abolished, and the quarterly working card was made to serve as both due and working card (Proceclings, 1901, p. 60\%0). Since 1906 this card has been issued at the end of each year, called an "annual working card," and the memler is not entitled to the henefits and privileges of the association, unless the card shows that the member is in good standing. 
to any benefits. All claims for benefits call for card numbers, and unless the accounts of the local union and the national unions correspond, the claim is not allowed. It has thus been made practically impossible for a subordinate union to escape the payment of dues on every member. The advantage of the system in securing the payment of dues cannot be estimated, but its adoption appreciably increased the paying membership.

In order to facilitate the work of the local financial officers, as well as to avoid losses to the national union arising from errors in accounts, a uniform system of bookkeeping and accounting has been introduced in local unions. Printed ledgers, cash books and necessary blank reports are prepared and supplied by the central office, in which detailed instructions as to the method of accounting are set forth. The auditing of local accounts is likewise simplified. 


\section{CHAPTER V}

\section{The Benefit System}

Any extension of the traditional functions of a trade union meets with determined opposition on the part of the members. Many influential trade unionists advocate confining the activities of the union to the maintenance of a minimum rate and to securing shorter hours of labor and better working conditions. They argue that the inclusion of mutual benefit features means diffusion of energy and loss of effectiveness. ${ }^{1}$ Also, they maintain that a system of benefits militates against the prime requisite of trade unionism-extensive organization-in that the expense of maintaining benefits means higher membership dues, with the result that persons who might otherwise join the union are prevented from doing so. ${ }^{2}$ The concrete proposition upon which issue was joined in the Amalgamated was the establishment of insurance against sickness, accident, and death. Unemployment insurance and old age pensions have never been seriously considered. ${ }^{3}$

At the second annual session of the Sons of Vulcan, held at Wheeling in 1863 , a general constitution was adopted in which one of the specified objects of the organization was declared to be "to aid sick and distressed members." Shortly" after the close of the Civil War the rapid growth of mutual insurance companies attracted the attention of trade unionists everywhere. The local union at Wheeling, through its

1 A. J. Portenar, Problems of Organized Labor, p. 55.

2 J. B. Kennedy, Beneficiary Features of American Trade Unions, p. I0.

s Instead of paying unemployment benefits, the union has provided that in case members were thrown out of work "through overproduction or other causes," such as a double-turn inill going on single turn, the work should be equally divided (Proceedings, 1836, p. 1850; Constitution, 1916, art. 17, sec. 6). 
delegate to the annual convention, proposed the introduction of benefit features by the national union. This subordinate lodge already had a beneficial society that was operating successfully.

-In I870 President Edwards recommended the establishment of a mutual benefit society. He proposed that admin-' istrative duties be performed by the local union, but that the dues and payments be regulated by the national lodge. The society was to be styled "The Boilers and Puddlers Cooperative Association." The plan was as follows: The national secretary was to be the executive of the association, keeping account of all money transactions. Any member of the union in good standing was to be eligible for membership. Upon the death of a member, the secretary was empowered to draw upon all local forges at the rate of one dollar for each member of the society. The sum of one thousand dollars was to be paid to the widow or heirs, and the balance-in case there was a surplus-was to be laid aside as a contingent fund. The age limit for admission was set at fifty, and membership was not to cease when a nember for any reason severed his connection with the union."

The scheme did not meet with favor in the eyes of the majority of local forges, and was reported back to the next session as "impracticable." However, the formation of local beneficial societies was strongly recommended by the committee. The opinion of the leaders was divided. President-elect McLaughlin was an ardent advocate of a national system, and in support of his argument cited examples of other national organizations in which the plan had worked successfully. "Aside from the benefits . . . individually," he said, "it will have a tendency to place our organization on a firmer basis and there will not be so many suspensions reported in each report. Then men will have something more at stake and will he nore anxious to retain membership." Ex-President Edwards replied, in rejoinder, that

4 Vulcan Record, December r87o, no. 7, pp. 20-23. 
a national fund would "act as a drag on the progress" of the organization, and that any plan for the collection and disbursement of the funds by the national lodge would be "so extensive and complicated in character that considerable annoyance and dissatisfaction would . . . resuit."'s As an alternative plan, he suggested the payment of one hundred dollars either by the local forge of which the deceased was a member or, in the case of forges having few members, by the combined resources of several small forges, grouped in a district, so that the assessment would be uniform and not exceed one dollar per member. Surplus funds were to be used for the benefit of widows and orphans. The proposal for a national system of benefits failed but there is evidence that the more prosperous lodges were paying benefits during these earlier years.

In 1878 the Mahoning Valley Mutual Relief Association offered to admit members of the Amalgamated to membership on the following terms: forty per cent discount from the regular membership fee; a member of the union was to be trustee ex officio of the Relief Association and another member general agent; collection of dues to be deferred in case the union became involved in a strike or lockout. The proposition was accepted, and Edward McGinniss was elected general agent. But it is doubtful if many arailed themselves of the offer.

For twenty-five years, the question of benefits was discussed in the annual conventions. But the Association steadily voted down all proposals for a national system. A local union frequently paid $\$ 50$ in case of death of one of its members. Sick and disabled members were aided by voluntary contributions. For example, in ISSo, a member was permanently incapacitated for work by the loss of sight, and he received donations to the amount of about $\$ 2000 .^{\circ}$ Another got $\$ 1000$, another $\$ 500$ and so on. In $18 S 2$ there was raised $\$ 8,466.96$ " for disabled members and persons

"Ibid., December 1872, no. 11, pp. 20-21.

- Proceedings, 1880 , pp. $388-389$. 
on strike not entitled to benefits." "These charities were considered the first step "towards establishing a superannuation fund for our disabled members." It was not, however, soon realized.

- An attempt to establish out-of-work benefits was made by a local union of nailers. The nailers, as has been noted above, suffered more from unemployment than any other craft in the industry. Not even in a good year could they hope for much more than half-time. To meet this exigency, the nailers of the Ohio Valley, at a meeting in Wheeling in ISS9, decided to form a pool by assessing every working machine so much for the support of those who were idle. This action was commended as a "boon" to the trade and a "barrier against reductions in wages."

Finally, in 1903, a measure for a national system was enacted. Ten per cent of all the money in the treasury of the national union was set aside for the purpose of creating a death benefit fund. This amounted to $\$ 13,000$. The law went into effect October I, I903. Provision was made for a death benefit of $\$ 100 .{ }^{8}$ The per capita assessment was compulsory on all members. A preliminary membership of three months was necessary to entitle the heirs to benefits. An arrearage of three months in dues debarred from benefits.

Several reasons were urged for the adoption of a benefit system by the national union. Some maintained that it would attract new members, others that it was effective in retaining old members. Many saw in the system substantial aid in carrying out trade policies, namely, fewer suspensions either for misconduct or for non-payment of dues, and a stronger defense fund. More important reasons were the real need for bencfits of this kind, the fact that nearly all other national organizations were thus aiding their membership, and the desire of the members to have benefits. In not a few cases the beneficiaries were reported by the secretary as "penniless."

7 Ibid., I882, p. 992.

${ }^{8}$ Proceedings, 1003, p. 6768. 
Provision was made in 1904 for members in good standing who had retired from mill work to continue their membership in order to participate in the death benefit. At first the law required that retirement must be caused by old age or disability; in 1907 , it was provided that members withdrawing by honorary card might by becoming "silent members" retain their rights to benefits. "Silent members" were assessed at the rate of one quarter's dues annually (not to exceed $\$ 1.80$ ) in addition to the regular death benefit assessment. Members who went to work without permission in a non-union mill could not continue as silent members. ${ }^{9}$

Experience soon demonstrated that the original assessment of ten cents per quarter was not sufficient to cover the amount of the claims and the cost of management. By I 906 the original fund had dwindled from $\$ 13,000$ to less than $\$ 9000$. The secretary stated that one reason was that the union was obliged to take bad risks which no insurance company would take. In order to place the fund on a paying basis the quarterly rate was increased to twenty cents per member.

The system of death benefits increased the desire for other benefits. The convention of 1906 appointed a committee "to formulate by-laws relative to the creation of a sickness, accident and out-of-work benefit fund to be conducted in conjunction with the death benefit fund." The committee investigated the matter ${ }^{10}$ and reported at the next annual session, and copies of the report were submitted to sub-lodges for final action. In Igos the report of this special committee was adopted, with the exception of the provision for out-of-work benefits. The new benefit scheme, compulsory on all members, becane operative Oc-

9 Proccedings, 1910, p. 9087; Constitution, 1905, p. 30.

${ }^{10} \mathrm{Mr}$. Bowers studied the constitutions of all trades unions in the United States and one in New Zealand and presented in his official report the best features of other unions' plans. Sentiment in favor of extending benefits was crystallized through the columns of the Journal. 
tober I, Igos. The system which was initiated and which replaced the old death benefit will be discussed under three general heads: $(a)$ the character of the several benefits; (b) the cost of benefits and the amount of claims paid; and (c) the administration of the funds.

The new law provided for death benefits graded as follows: (a) a death benefit of $\$ 100$, after three months' continuous good standing; \$I 50 , after two years; $\$ 200$, after three years; $\$ 300$, after five years; and $\$ 500$, after ten years. The grading of the benefits serves a two-fold purpose: first, as a protection to the funds, since the minimum is hardly large enough to be attractive to "bad risks"; and second, as an effective agency in holding members. The requirement of a preliminary term of membership for eligibility to the benefit serves as a protection against the entrance of persons in ill health. Since no deliberate selection of risks is made, the mortality is higher than it would be if the applicants were examined. But the death benefit is considered not so much a matter of strict business as of charity; and the slightly increased cost is regarded as more than compensated for by the increased solidarity of organization. Members of the union quitting the trade, by becoming silent members, may continue the death benefit at a rate not exceeding $\$ 2.60$ a year, payable quarterly or yearly in advance. Any silent member failing to pay his fee allows his claim to lapse, and is not again permitted to become a silent member. No silent nember is entitled to more benefits than the amount he would have received at the time of his withdrawal by honorary card. Applications for honorary cards and silent membership must be made at the same time.

The rate of mortality, according to the records of the union during the period of twelve and one-half years, during which death benefits have been paid, is fairly even. With the exception of onc year, in which it was abnormally low (due perhaps to the abnormal condition of the union 
occasioned by the I9Io strike), the rate has ranged from five to seven per thousand members. The average rate for the whole period is 6.2. The record of mortality for members not in good standing and so in eligible for benefits is not kept. Five hundred death claims to the amount of $\$ 5 \mathrm{r}, 300$ have been paid by the union, or an average of $\$ 4,904$ per year, and \$123 per claim. Until I9I I no claims were paid for more than $\$ 100$. In 1918 a part of the membership will be entitled to the maximum benefit of $\$ 500$. The average age of deceased members is forty-two years. The essential facts are set forth in the accompanying table.

Table Showing Mortality Rate from Oct. I, I903, to Mar. 3I, Igi6 (Fiscal years ending March $3 \mathrm{I}$ )

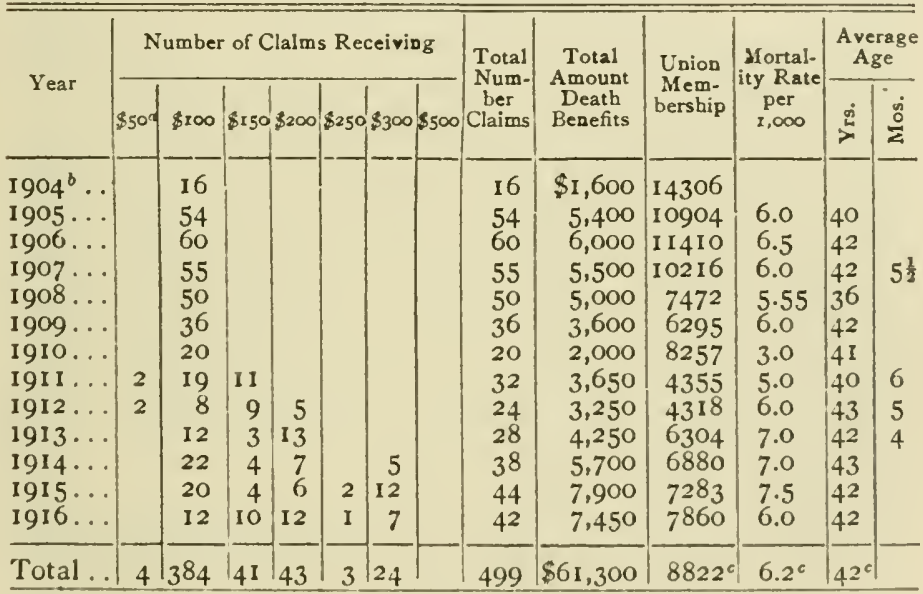

It will be noted that despite the decline in membership the mortality rate has not risen, nor has there been a perceptible increase in the average age at death. On the other hand the average benefit paid is increasing rapidly. The net result will be a higher cost.

The union pays a total disability benefit upon the basis of the death benefit. The amount of the benefit is one-half

a Wife's death benefit of $\$ 50$ was deducted from the nember's death benefit.

$\checkmark$ Six months, Octolser 1, 1903, to March 31, 190.4.

- Average. 
of the amount which the member would be entitled to in case of death, and is deducted from the death benefit due the member at death. To be eligible to total disability benefits, the member must have been in continuous good standing for six months, and the disability must not be caused by "intemperance, debauchery or other immoral conduct." $U_{P}$ to I9I7 the union has had but one case of total disability.

Upon the death of the wife of a member who has been in good standing continuously for six months immediately preceding his wife's death, the sum of fifty dollars $(\$ 50)$ is paid to the member. This amount is deducted from the amount of the member's death benefit. The object of the payment of a wife's death benefit is, of course, the defrayal of the cost of burial. It is stipulated that the money shall be paid only in case, "at the time of her death, they are living together as man and wife," and also that "if the member dies first, the insurance on the wife ceases forthwith." ${ }^{11}$ The preliminary good standing is computed from October I, I90S, so the law did not actually become operative until April I, 1909. There is no way to ascertain the mortality rate of members' wives, but the average age at death for the period of seven years is thirty-eight.

The following table shows the operation of the wife's benefit from 1909 to 1916, inclusive:

\begin{tabular}{|c|c|c|c|c|}
\hline \multirow{2}{*}{ Year } & \multirow{2}{*}{ Number Claims } & \multirow{2}{*}{$\begin{array}{l}\text { Total Benefits } \\
\text { Paid }\end{array}$} & \multicolumn{2}{|c|}{ Average Age of Deceased } \\
\hline & & & Yrs. & Mos. \\
\hline $\begin{array}{l}1909 \ldots \ldots \ldots \\
1910 \ldots \ldots \ldots \\
1911 \ldots \ldots \ldots \\
1912 \ldots \ldots \\
1913 \ldots \ldots \ldots \\
1914 \ldots \ldots \ldots \\
1915 \ldots \ldots \ldots \\
1916 \ldots \ldots \ldots\end{array}$ & $\begin{array}{l}27 \\
20 \\
11 \\
16 \\
28 \\
31 \\
24\end{array}$ & $\begin{array}{r}\$ 1,350 \\
1,000 \\
550 \\
800 \\
1,400 \\
1,550 \\
1,200\end{array}$ & $\begin{array}{l}41 \\
39 \\
45 \\
36 \\
38 \\
38 \\
38\end{array}$ & $\begin{array}{l}6 \\
1 \\
8 \\
6\end{array}$ \\
\hline Total.......... & 157 & $\$ 7,850$ & & \\
\hline Arerage........ I & 24 & $\$ 1,121$ & 38 & \\
\hline
\end{tabular}

11 Constitution, 1908, p. 36. 
The greatest innovation was the provision made for sick and accident benefits. The Association pays five dollars a week, for a period of not more than thirteen weeks in all in any one twelve-month, to members sick or disabled so as to be incapacitated for work. The total amount that may be drawn in any one year is sixty-five dollars. It is provided that no benefit be paid if the sickness or disability is caused by "intemperance, debauchery or other immoral conduct." 12 In I9Io the law required that a member found under the influence of liquor should be put off the sick list. To be eligible to participate in the benefits, a member is required to have been in good standing continuously for six months, ${ }^{13}$ and he must not be indebted to the local lodge to the extent of three months' dues. Members thus in arrears or who have been suspended are not entitled to benefits for three months after dues have been paid or suspension raised. ${ }^{14}$ Payments do not begin for seren days after the sickness is reported, and no benefit is paid for a fractional part of a week. In I9I4 it was found that certain members were drawing the maximum number of weeks' benefit yearly who were totally incapacitated for work. In order to prevent this drain on the funds, the union adopted the ruling that no member should receive benefits for more than two successive years for the same disease, unless he is able to work for at least three months during the year after the first claim. Likewise, members suffering from "incurable or constitutional diseases" were obliged to apply for a total disability payment, after which sick benefits were to be discontinued; and in I9I6 the proviso was added, "unless members shall recover and work for at least six months."

\footnotetext{
12 Ibid., p. 30.

13 The preliminary period of six months was required of members depositing honorary cards before they became eligible to sick and accident benefits.

${ }^{14}$ In 1909 this penalty was increased to six months; and arrearages were defined as "any debt either to the sub-lodge or to the National Lodge, or both, for dues, fines, assessments, etc., either separately or collectively."
} 
The occasions for the disallowance of clains were alike for death and for sick and accident benefits, and may be illustrated by example. In 1907, i 3 death claims were disallowed; 9 because the members were not in good standing, one each because of non-payment of dues, failure to deposit card within the allotted time, neglect of local lodge to send reports on time, and going to work in a non-union plant. Not infrequently in such cases the convention voted to "appropriate" or "donate" \$100 to the family. In I9II there were 32 disallowed sick and accident claims; of these, 12 members were reported not in good standing, 16 were in arrears, 3 were ineligible because their lodges had failed to send to the national office quarterly reports, and one because of intemperance.

The union statistics of morbidity, as given below in tabular form, show that, during the period of eight years in which sick and accident benefits have been paid, the number of claims increased from about 450 to slightly over 800 ; the average was approximately 500 per year. The increase from 1912 is attributable to increase in membership; since the union does not pay out-of-work benefits, there is a tendency for those who are unemployed to feign illness. The exact number of such cases it is impossible to deter-

Sickness Benefit

(Fiscal years ending March 31)

\begin{tabular}{|c|c|c|c|c|c|}
\hline Year & $\begin{array}{c}\text { Number } \\
\text { Claims Paid }\end{array}$ & $\begin{array}{c}\text { Average } \\
\text { Amouat Per } \\
\text { Claim }\end{array}$ & $\begin{array}{l}\text { Total Num. } \\
\text { ber Weeks } \\
\text { Disability }\end{array}$ & $\begin{array}{l}\text { Total Mem. } \\
\text { bership Union }\end{array}$ & $\begin{array}{l}\text { Per Cent on } \\
\text { Basis of } x 3 \\
\text { Weeks }\end{array}$ \\
\hline $1909^{\circ} \ldots \ldots$ & 148 & $\$ 21.66$ & 649 & 6,295 & 一 \\
\hline $1910 \ldots \ldots$ & 443 & 22.14 & $1,95^{2}$ & 8,257 & 2.0 \\
\hline $1911 \ldots \ldots$ & 463 & 22.46 & 2,080 & 4,355 & 3.0 \\
\hline $1912 \ldots \ldots$ & 371 & 23.39 & $1,73^{8}$ & 4,318 & 3.3 \\
\hline $1913 \ldots \ldots$ & $42 \mathrm{I}$ & 19.42. & 1,675 & 6,304 & 2.6 \\
\hline $1914 \ldots$ & 668 & 26.12 & 2,907 & 6,880 & 3.3 \\
\hline $1915 \ldots$ & 69.4 & 23.70 & 3,288 & 7,283 & 3.5 \\
\hline $1916 \ldots \ldots$ & 812 & 21.28 & 3,457 & 7,860 & 3.4 \\
\hline $\begin{array}{l}\text { Total... } \\
\text { Average }\end{array}$ & $\begin{array}{r}4,020 \\
536\end{array}$ & $\$ 22.52$ & $\begin{array}{r}17,746 \\
2,366\end{array}$ & 6,444 & 3.0 \\
\hline
\end{tabular}

a Six months, October 31, 1908, to March 31, 1909. 
mine. The total amount paid for sick and accident benefits was $\$ 88,755$, averaging $\$$ I I, 834 per year. However, there was little variation in the average amount paid per claim, or in the percentage of the membership receiving benefits on the basis of the maximum period of thirteen weeks. The average claim was about $\$ 22$; the rate of morbidity, on a thirteen-week basis, was scarcely three per cent.

The annual per capita cost of the death benefit, when established in 1903 , was ten cents, and in 1906 twenty cents. The assessment was raised in order to put it on a sound basis. This kept the fund nearly on a parity for two years when the organization widened its field of activities to include death, disability, sick and accident beneficiary features. The per capita assessment for all benefits was placed at a fixed lump sum of 75 cents per quarter or $\$ 3$ per year. Members in good standing leaving the trade and desiring to continue the death benefit, as stated previously, were assessed $\$ 2.60$ per year and known as "silent mentbers." In I9I4 such members were also allowed to participate in the sick and accident benefit by paying $\$ 2.25$ per quarter, apportioned as follows: 75 cents for insurance, \$1.00 for national lodge dues, and 50 cents for local dues. As distinguished from the "silent members," they were designated as "part paying members." 15

In addition to the per capita assessment, the national lodge received for the benefit fund $\$ 2$ for every initiation and reinstatement. The minimum initiation and reinstatement fee was fixed at $\$ 5$. Previously the fee for reinstatement varied; usually $\$ 2$ was collected. In 1913 the law provided for an initiation fee graded according to the earning power of the members; $\$ 5$ for members earning more than $\$ 2.50$ a day, and $\$ 3$ for those who were making $\$ 2.50$ or less per day. Also when a new lodge wats chartered, two dollars was charged each menber for the fund. Any surplus was utilized in building up a defense fund.

15 In 1917 it was provided that "part-paying" members must pay" to the national lodge $\$ 2.50$ per quarter, the allocation of dues being as follows: 75 cents for henefits, and \$I.75 for all other purposes. 
The figures seem to show that the fund is on a sound basis. In twelve and one-half years, the union has paid out for all beneficiary features over one hundred and fifty thousand dollars, an average of $\$ 12,644$ per year. Until I907 there was an annual deficit. With the new system inaugurated in 1908 , and the increased per capita cost, the balance in the benefit fund grew steadily from nine to thirty-three thousand in 1913 , when the original loan of $\$ 13.000$ was replaced in the general fund. In I9I4 the benefit fund was merged with the general fund. The reserve fund has since decreased, due chiefly to the payment of higher death benefits graded according to length of membership, and the fact that very little "new blood" has been added to the organization in recent years. ${ }^{16}$ The average cost of management has been thirteen cents.

The administration of the beneficiary system is carried on largely by the officers who manage the general affairs of the Association. The secretary-treasurer is the chief official concerned in administering the benefits. At first, he handled the entire business himself, but in 1904, by action of the convention, he was authorized to hire an assistant to be known as insurance secretary at a salary of one hundred dollars per month. Since that time the office has been made elective, and the incumbent is a nember of the national executive board.

The national union handles all the funds and makes payment of benefits through the local unions. Naturally, the adjudication of claims is the most important administrative task. The national officials rely on the local unions for cooperation in preventing fraud. In case of death, a certificate properly signed is usually indisputable evidence of the fact of death. In the matter of sick and accident benefits, the local union is a more essential part of the administrative machincry of the national union. The system is guarded against fraud by the requirement of a physician's certificate, a sworn statement of the financial secretary or

10 Secretary Tighe's Report, Proceedings, 1912, pp. 9706-9707. 
other officer, and an investigation by a committee of three members of the local lodge.

The administration of the death benefit is relatively simple. The local union reports the death and certifies to the good standing of the deceased member in the local lodge. If the records of the national union and the local union correspond, and the deceased member is clear on the records of both, the claim is approved by the national offcers, and payment is made through "the president, vicepresident and recording secretary, in conjunction with the corresponding representative," ${ }^{17}$ to the designated beneficiary, or legal heirs of the deceased. The receipt of any ore of the heirs is "a full acquittance and discharge of all claims" against either the local union or the national union on account of the death of a member. The report of the subordinate union to the national union, covering the case in point, contains a certificate validating the claim, sworn to before a notary public by the financial secretary, together with an abstract of the ledger account upon which the local officers based their decision for the payment of the claim. Upon receipt of a "claim for death benefit," the national insurance secretary, secretary-treasurer and president examine it, and if satisfied as to its validity, order immediate payment; if the claim is questionable, it is referred to the national executive board for final adjustment. A claim to be valid must be filed within six months after the death of a member. The decision of the board is "conclusive and final without appeal," except by the board's permission.

The adjudication of a disability claim is perhaps more difficult than that of a death claim. No definition of "total disability" is given. The fact and the cause of the total disability must be secured from a "reputable" physician in the locality of the member, the certificate sworn to before a notary public, and attested by the president, financial secretary and corresponding representative of the local union. This certificate must also contain the correct lodge record

${ }^{17}$ Constitution, 1916, pp. 40-41. 
of the member. The local officers forward the claim to the national union, and, if approved, payment is made through the local union to the legal claimant.

The greatest amount of care is required in administering sick and accident benefits. The chief defenses against fradu are the certificate of the attending physician and the statement of the visiting committee, together with the sworn record of the financial secretary. A member who becomes sick or disabled must notify within a week the financial secretary, vice-president, or a member of the sick committee, and fill out a blank giving date and cause of sickness or disability. No benefits are paid for a week. At the expiration of two weeks, the physician certifies to the date, nature, and cause of illness. and the sick or benefit committee certifies that the member is "unable to work" and that the disability is not caused by immorality. This report is forwarded to the national union. Each week thereafter a supplementary report, similar to the original claim, is sent to the national office. If the records of the member are clear, the local union is instructed to pay sick bentefits to the member, and upon the termination of the sickness, the subordinate lodge is reimbursed by check from the national lodge.

The law provides that the local union shall arrange for a "benefit committee" to visit sick members, consisting of at least three members. The vice-president is chairman ex officio. This committee is required to have a reputable physician sign the reports, to visit every sick member, and to fill out blank forms provided for the purpose. If a committee is refused admittance, except by order of the boart of health, it is not "obligatory" to pay weekly benefits until such refusal is discontinued. Visiting committees are not required to visit members having "malignant or contagious discases," but to make a report of such cases on the benefit chaims. Officers found guilty of obtaining benefits for a member fraudulently are fined twenty-five clollars. National officials, of course, cannot be sure of the honesty of the physicians and the good faith of the visiting committee. 
Every member is catalogued on a card. The union has a mailing list for its Journal, and the address of every member is here recorded. Benefit payments are entered on a member's card. Members moving from one local union to another and attempting to draw more benefits than the legal provision are thus detected. In case an excessive morbidity is noted in any locality the matter is investigated. The same system is employed by the Molders. ${ }^{18}$

It may be well in closing this account to point out some of the advantages of beneficiary features to the union. As stated before, the real reason for their inauguration was the need of the members and the desire to meet this need. In addition to the individual benefits derived, however, there are certain general advantages to the system.

The effect of the benefit system upon the Association may be summarized as follows: (I) It tends to attract new members, and to make the membership more stable. While this cannot be proved, it is the settled opinion of the union leaders. In Igog Secretary Williams said: "Our beneficiary features have now passed the experimental stage, and are fixtures that are destined to add strength and stability to our membership. It is my firm opinion that, had these features been added a number of years past, our numerical standing would be much stronger than it is at the present time." (2) If the fact that benefits serve to increase the membership is doubtful, certainly they are a factor in retaining members, once they join. Naturally a member is slow to drop his membership when at the same time he gives up his right to valuable and increasing benefits. (3) The presence of a large reserve fund, although it increases the probability of aggressive action, nevertheless is an incentive to conservative action. A union without funds, like a man without property, is inclined to be radical. Lastly, (4) the disciplinary power of the union over its members is strengthened by the use of benefit features. It is a club to

${ }^{18}$ Kennedy, p. 115. 
keep members paid up in their dues since by suspension a member loses the rights of continuous good standing. Besicles, a member of a local union will not withdraw upon slight provocation, and thus lose the privilege of benefits. ${ }^{19}$

.20 F. T. Carlton, History and Problems of Organized Labor, pp. I53-154. 


\section{CHAPTER VI}

\section{The Standard Rate}

The chief concern of the Amalgamated Association throughout its history has been the maintenance of "a fair remuneration to members for their labor." 1 Not only has the rate of wages been a matter of prime concern, but the union has also interested itself in such ancillary matters as the securing of regular periodic payments.

"In order to make any effective regulation concerning the price at which the workman in the trade shall sell their labor to the employers," Professor Barnett says, "it is mecessary for a union to formulate or adopt a measure for the labor which is to be sold and to fix a price upon it. This price is ordinarily called a 'standard' or 'minimum' rate." Below this rate no workman is permitted to work; the rate rests uniformly upon all the members of the union whom it is designed to affect. Remuneration in the iron and steel trade since 1865 has been by the piece. The scale in use is known as a "sliding scale," since it is so adjusted that rates advance and decline in accordance with the price of the finished product. By means of this mechanism, the union has sought to obtain its primary purpose of substituting collectively established rates of wages for those which its members could obtain by competition in individual wage bargains or by isolated strikes.

1 Wages in the iron and steel inclustry have been the subject of several reports published by the Bureau of Labor Statistics, the Sixtl Annual Report (1891), the Nineteenth Annual Report (1904), and Bulletins nos. 59, 65, 7I, 77, 15I, I68. Two Senate documents contain reports of investigations made by the Bureau of Labor Statistics and give valuable information as to wages in the iron and steel industry: (I) Report on Strike at Bethlehen Steel Works (S. Doc. no. 52I, 6rst Cong., 2d sess.): and (2) Report on Conditions of Employment in the Iron and Steel Industry in the United States (S. Doc. no. ro, 6ad Cong., ist sess., 4 vols.).

2 Barnett, p. 108. 
The present chapter deals with (I) the area over which the scale has been applied and (2) the three elements directly affecting the rate of remuneration, namely, $(a)$ the differentiation in rate corresponding to differences in produict, $(b)$ the definition of the work, and $(c)$ provisions for payment when material is made under abnormally difficult conditions. $^{3}$

The Area of the Standard Rate.-In the development of the union there has been a gradual extension from a local scale to a national scale. The scale of the Sons of Vulcan originally covered all the puddle mills in Pittsburgh and the immediate vicinity. The originators of the scale, according to Miles S. Humplnreys, the sole survivor of the group, "had no idea of its spreading" to other localities.

Workmen in neighboring mills were soon quick to observe the advantages of the scale, and to seek a similar arrangement. The scale spread rapidly to all mills in the Pittsburgh district. In I 867 the Puddlers' Union divided its jurisdiction into districts, the object being to include in each district forges which should be governed by similar prices. ${ }^{4}$ By the time of the formation of the Amalgamated in 1876 , all districts west of the Alleghany Mountains had scales for puddling, and continued effort had been made to secure a scale for the Eastern section. These attempts were attended with but temporary success in the East. ${ }^{5}$ The puddlers' example was followed by the workmen in the rolling branches of the iron trade. The Guide Mill Rollers made a scale for the Pittsburgh district by agreement with the iron manufacturers in April, IS72. ${ }^{\circ}$ In 1877 , the first year after the amalgamation of the rolling branches with the puddlers. President Bishop pointed out the injurious effect of

3 D. A. McCabe, The Standard Rate, p. I9.

- These district boundary lines were changed from time to time. In 1868 there were five districts, with centers at Pittsburgh, Whecling, Youngstown, Chicago and Philadelphia, consecutivcly. In 1869 the third district shifted its center to Cincinnati (Vulcan Record, nos. 2-4).

S Vulcan Record, 1870, no. 6, p. 19: Proceedings, 1877, p. 65.

B $A$ copy of this agrecment is contained in Proceedings, 1880 , Appendix. 
mills working at low rates, and urged the necessity of establishing uniform prices for each branch of labor to prevent employers from forcing wages to the level of lower priced mills in the district, and recommended the adoption of uniform district scales by district conventions. The convention authorized the vice-president of each district to call a district convention for the purpose of formulating a district scale for all mills in the district, and an article was inserted in the constitution to this effect. ${ }^{\top}$ For nearly ten years the Amalgamated Association adhered to the policy of district scales. ${ }^{8}$

These early district scales, however, did not cover all branches of work. It was difficult to make them uniform, and the rates originally applied only to the leading men of the crew. In I879 scales were arranged in conference with the manufacturers for scrapping, knobbling, shingling and muck rolling. Such workmen as bar mill heaters and catchers, roll turners, and mill hands were still without uniform scales of prices. ${ }^{9}$ Two districts in particular were unable to enforce uniform district scales; the fourth district, centering about Chicago, in which practically all of the plants were steel mills, ${ }^{10}$ and the district east of the Alleghanies, where a condition of demoralization in the ranks of the organization persisted. ${ }^{11}$ Special scales were drawn

7 Proceedings, 1877, pp. 57, 76; Constitution, 1878, p. 22; Proceedings, 1880 , p. 469.

8 The eight districts which the Sons of Vulcans had in 1875 were continued by the Association. The five districts of 1869 had been retained, with boundaries somewhat changed, and three more added.

9 Proccedings, I 880, p. 343.

10 The rail mill lodges held a meeting in Chicago in December 1880 , but it was impossible to agree on a uniform scale, because of "the different construction of mills and various other causes"; but a satisfactory base price for the different mills was estahlished (Proceedings, 1881, pp. 561-562). Later a scale for steej-mill lodges of the fourth district was adopted in convention, but it was not strictly enforced (Proceedings, 1883, pp. 1183-1194; 1884, p. 1340). The Association was never able to establish with any degree of permanence a scale, district or national, for the large steel-rail mills.

${ }^{11}$ In 1880 a scale was granted for Philadelphia, with a differential of $\$ 1$ below Pittshurgh, but it did not affect neighboring mills to any great extent (Proceedings, 18So, P. $3.49 \mathrm{ff}$.; for copy of the agreement see Proceedings, 1881, Appendix). 
up for mills doing special work or having equipment peculiar to themselves. For example, a steel rail mill of Chicago, because of exceptional automatic machinery, had a special agreement for the workmen. ${ }^{12}$ Carnegie Brothers plant at Pittsburgh was given a special scale for rolling; this was designed to cover mills of similar character, but separate contracts for specialty mills were made between the manufacturers and the workmen. ${ }^{13}$ The employers in the same competitive district were placed on an equal basis, the same prices being granted those having similar equipment.

In addition to the lodges governed by a district scale, there were a few lodges, outside any district, which were supervised directly by the national officials. These lodges followed as closely as possible the prices of the nearest competitive district, or agreed to a differential on the basis of the Pittsburgh scale, as for instance, the Birmingham, Alabama, agreement in 1882 .

By I 885 the Iron, Steel and Tin Workers had obtained a uniform national scale for nearly all of the branches of their membership. This scale applied west of the mountains only, and was arranged in conference with the Western Iron Association. The union was never recognized by the Eastern manufacturers as a group, and a scale for the East could not be maintained. The Western scale, then, may be regarded as a uniform scale for the effective jurisdiction of the Association.

From the outset, there had been tendencies toward a uniform price in the several district scales of the union. The Pittsburgh district had long set the pace in the price for boiling throughout the trade. The prices for boiling in other districts were gencrally expressed in terms of a differential from Pittsburgh prices. ${ }^{14}$ The third district-

\footnotetext{
12 Proceedings, 1884, p. 1320. This plant was the South Chicago Bessemer Works. The men had been working on a per diem rate; the output increased from 150 to 300 tons, and the men struck for a tonnage scalc.

13 Proceedings, 1881, Appendix; Pittsburgh Scales of Prices, 18841885 , p. 18.

14 Proceedings, 1880, pp. 409, 459, Appendices; 1882, p. 799.
} 
Cincinnati-agreement adopted in July, ISSI, was the Pittsburgh scale plus ten per cent, and the Wheeling or second district scale for the rolling branches in I88I-I882 was precisely the Pittsburgh scale. Nail-plate rolling west of the mountains was at the Pittsburgh price. The same was true of puddling and most of the finishing branches in the fourth district.

In I880 the Association began the movement toward uniformity by requiring that all district scales be approved by national committees of the respective branches before being presented to employers. As a further step in the direction of uniformity, the convention of $188 \mathrm{I}$ provided that the Pittsburgh price should be taken as the basis of all district scales. ${ }^{15}$ Accordingly, when the Pittsburgh district went on strike for an advance in prices in 1882 most mills in other districts became involved. ${ }^{16}$ The third district agreed to work with the understanding that it was to receive Pittsburgh prices when that scale was settled. ${ }^{17}$ When the settlement was reached that fixed the rates for the first, fourth, and sixth districts, the second district retained its differential for boiling of twenty-five cents above the Pittsburgh scale. ${ }^{18}$ With this exception, the settlement of 1882 left the scales for the various branches practically uniform for the region west of the mountains. ${ }^{39}$

The adoption of uniform scales in all branches as a definite policy was delayed by the refusal of certain districts to give up their differentials above Pittsburgh rates. In I 882 the Cincinnati and St. Louis divisions of the third district were compelled temporarily to accept Pittsburgh prices, but they were unwilling that such rates should be permanent.

The plan of taking the Pittsburgh scale as the basis of all

15 Proceedings, 1881, p. 693 ; Constitution, 1880, art. 14, p. 23; Constitution, 1882, art. 10, pp. 22-24.

16 Proceedings, 1882, 0. $814 \mathrm{fr}$.

17 Ibid., pp. 804-806, 814-817; 1883, p. 1197.

18 Proceedings, 1883 , pp. 1084-1088.

${ }^{10}$ Certain classes of workmen in steel mills, such as steel-converting and furnace men, were as yet unprovided with a uniform scale. The union conld not effectively organize them in all mills, and they were empowered where organized to arrange their own scales. 
district scales proved unsatisfactory. Two objections were offered to it: first, the Pittsburgh district could not always effect a settlement, and other districts were left in an uncertain state; and again, the Pittsburgh district had the entire burden of the struggle, while all the others received equal benefits. ${ }^{20}$ The convention of $\mathrm{I} S \mathrm{~S} 2$ cnacted that all district scales for iron mills should be referred to a national "scale convention," which should convene immediately before the stated convention. The scale convention was composed of the president, secretary, vicc-presidents and delegates elected by the elistrict conventions. ${ }^{21}$ The scales were still to be presented to the manufacturers in separate district conferences, by conference committees, appointed by the national president. ${ }^{22}$

As ratificd by the first scale convention which met in April, ISS 3 , the price for puddling in the fifth district scale was $\$ 6.00$ per ton-fifty cents above the Pittsburgh priceand the prices for finishing mills were likewise higher than the Pittsburgh scale. ${ }^{23}$ The same puddling rate of $\$ 6.00$ was adopted for the third district, and for finishing mills prices were fixed at ten per cent above Pittsburgh, the differential desired in $\mathbf{I} 88 \mathrm{I}$. The attempt to maintain prices higher than Pittsburgh, in both districts, met with failure. The third district was disorganized, and failed to enforce the scale generally. In the fifth district only four mills signed the district scale, and the agreement finally reached practically called for the Pittsburgh scale of prices. ${ }^{24}$

The scale adopted by the 1884 convention was again uniform, except for the boiling differential of twenty-five cents in the Wheeling district. ${ }^{25}$ This scale became generally

${ }^{20}$ Procecdings, 1882, p. 799.

21 Ibid., pp. $96 \mathrm{I}-962$.

22 Constitution, 1882 , art. I0, pp. 22-24.

23 Proccedings, 1883 , pp. 1082, 1 197-1199.

24 Proceedings, 1884 . pp. $1346-1348,1420-1423$. An attempt was made to secure the Wheeling rate of $\$ 5.75$, but it could not be obtained.

25 Proceedings, 1884, pp. 1333-1335; Scales, 1884-1885. The manufacturers, the year previous, did not meet with district committees for the first, second, fourth, and sixth districts, but with a gencral committec of the scale convention (Procecdings, 1883, p. 1078). 
operative, except in the Cincinnati and St. Louis districts, which were badly disorganized. In 1885 the scale convention decided to ask for the existing prices, and also to make the price of boiling uniform for all mills west of the mountains. $^{26}$ This made the scale practically uniform. The failure of the conference committee that year to reach an agreement with the manufacturers as a body caused a split in the Western Iron Association. The Pittsburgh manufacturers finally broke ranks and signed the scale for their district, and this scale became the union scale for other districts. Any mill in the Association was privileged to start up under this scale. A uniform scale was thus enforced in finishing mills in $1885 .{ }^{27}$ This scale was as nearly uniform as any single scale ever had been. Uniformity was brought about, however, by the refusal of employers in one district to pay a higher price than those in another, and not by the enforcement in lower-priced districts of prices paid in the districts enjoying a differential advantage.

A uniform scale was never maintained for the Eastern district, although many attempts were made to establish one based on the Western scale and a fixed differential. In certain years, such a scale was adopted for many branches included in the Pittsburgh scale. ${ }^{28}$ In other years a scale was signed for Philadelphia and its immediate vicinity $;^{29}$ but in 1889 , when there was a Philadelphia scale, only three mills outside of Philadelphia paid the same prices. An attempt was made as late as 1907-1908 to establish an Eastern

${ }^{26}$ The second district was persuaded to give up its twenty-five-cent differential.

27 After 1885 the Association, in order to economize in the matter of expenses, eliminated the scale convention, and thereafter a wage committee recommended to the general convention for definitive action any desired changes in the scale. The convention met in June instead of, as before, in August; and the scale expired June 30. Conferees of the several divisions were appointed by the president to carry on negotiations with the manufactusers (Proceedings, 1885. pp. 1581, 1657, 1690; 1886, p. 1825; 1887, p. 1960).

28 Vulcan Record, 1874, p). 13, 19; Eastcrn Scale of Prices, I890$189 \mathrm{I}$.

20 Proceclings, 1880 and $188 \mathrm{r}$, Appendices. 
scale, but it failed because of the variations in prices paid. The East has always been an expense to the Association without any permanent results.

The union was never successful in establishing a uni- form wage scale for the workmen in the steel trade, particularly in the converting and rail-rolling departments. Allusion was made previously to the failure to establish district scales for them. The workmen arranged local scales for the various steel plants in which they were employed, differing according to equipment and working conditions. ${ }^{30}$ In I887 a special convention of steel workers formulated a scale, but, following the recommendation of the steel workcrs' wage committee, the convention of ISSS decided it would be unwise to attempt to enforce a uniform scale at that time. ${ }^{31}$ This practice of adopting local steel scales, after they had been approved by a wage committee, was continued by subsequent sessions. The Association lost control of the steel mills a fter the Homestead strike of I S92, and by 1900 the steel plants were weakly organized., ${ }^{32}$ After the struggle of I90I, the steel mills of the United States Steel Corporation were lost to the union.

Since 1885 the policy of the Amalgamated has been to maintain, west of the mountains, uniform prices for similar work and conditions. Since 1893 the scale has provided that. "whenever deviations from the Western Iron Scale . . . are made," either they shall be corrected or "all other mills shall receive the same." 33 This policy was carried out in practice. For example, in 1894 , the manufacturers as a body failed, after many conferences, to reach an agreement. A few manufacturers agreed to the Association terms, and the scale thus signed became the union scale. In September the scale was modified in some particulars in conference with other manufacturers, and these changes, including cer-

${ }^{30}$ Proccedings, 1886, p. $1756,1825 \mathrm{ff}$; 1887, pp. 1922-1924. 19461947.

${ }_{31}$ Proceclings, 1887, pp. 2145-2147 : Programme of Business, I888, p. 50 ; Proccedings, 1888 , pp. 2221, 2275, 2337.

32 Proceedings, 18099 . Pp. $5664-5666 ; 1000$, p. 5309.

35 Procecdings, 189, P. 42.46 ; 1904. D. 7113. 
tain reductions, were granted to all employers, including those who had previously signed. The union, though its membership has declined since I90I, still maintains the policy of uniform scales west of the mountains. It is the practice to hold three annual conferences, two on the puddling and finishing scales, and one for the sheet and tin division. ${ }^{34}$

The national scale does not, however, contain scales for all union mills in its jurisdiction. A number of mills and departments of mills have from time to time been given separate special scales because of variations from the regular types. Also, the few scattered mills of the East controlled by the Association have individual scales. Finally, there are some members of mill crews, particularly on muck and finishing mills, working under the uniform scale who do not have their rates specifically provided in the scale. Hookers, for instance, did not obtain a scale rate until the 1916 convention; finishers and straighteners are not yet included in the scales of prices. The officials of the national union have repeatedly tried to extend the uniform scales so as to include these workmen but have failed because of non-uniformity in the work that these men are required to perform in different plants. The rollers in some instances employ these men. The roller may, if he chooses, do part of the work of his crew himself; frequently he plays the rôle of finisher. ${ }^{35}$ The wages of such workmen may be adjusted by the local union either with the roller or with the employer. ${ }^{36}$

Differentiation of the Rate.-The function of the piece scale is to provide a distinct rate for each varicty of product

34 These conferences are held with the Republic Iron and Steel Company, the largest producer of muck iron; the Western Bar Iron Association, composed of bar-iron manufacturers; and the Independent Shect and Tin Plate Manufacturers, an association of independent manufacturers of sheet and tin plate (Proceedings, 1916, pp. $11,502-11,510)$.

${ }^{26}$ The finisher, on a har mill, passes the long strip of molten iron throuph the rolls the last time.

${ }^{36}$ These workmen not provided for in the scale are not admitted to membership by many local unions. 
and for each different type of conditions under which the product is normally made. These lines of differentiation are, chiefly, the form of the product, which includes variations in size, shape, and finish, and differences in materials entering into production.

The first of these-differentiation in the form of the product-is by far the most common of those variations that require rate differentiation. The particular variety of product for which a given rate applies is determined, in some cases, by a gradation in physical measurements; in others, by the measure of comparative time required. In the boiling department, a "heat" of, say, five hundred and fifty pounds normally requires less than two hours. The grade of skill necessary to produce a heat within this timelimit is that assumed to be the average among the workmen in the trade. If iron or any mixture of material required longer time for boiling, extra pay was demanded. ${ }^{37}$ In the sheet and tin division, the price list for rolling iron and steel bars or plates into shects was based on the physical dimensions of the product. The sheets were rolled into the desired thinness and size. The index of thinness is the gauge number ${ }^{38}$ and the gauge number indicates the weight per square foot. The smaller the gauge number, the thicker is the sheet and the greater its weight per unit of measurement. ${ }^{30}$ The price is given per ton for each of the various gauge numbers in the list. ${ }^{40}$ The thinner the sheets, the

${ }^{37}$ Scales of Prices, $1890-1891$, p. 5, foot-note 2 ; and all subsequent scales.

${ }^{38}$ In 1803 the United States Standard Gauge was inserted in the scale (Proceedings, 1894, p. 4534). Previously the Partridge Standard Gauge hat been used (Proceedings, 1887, p. 2161).

30 Western Scales of Prices, 1916, pp. 36-38. The number of pounds considered a ton varied. In 1880 the union passed a rule prohibiting any department making more than 2240 pounds of iron (but not of steel) for a ton (Proceedings, I880, p. 458). In knobbling, however, 246.4 pounds is the standard weight of a ton, ten per cent being added to take care of loss (Western Scales of Prices, 1916, p. 17).

40 The Association occasionally harl troulle with mills in which the members were required by the management to work "light gauges" without extra pay. In such cases, the union rule was that the "mean price" should govern (Proceedings, 1905, pp. 7247-7253; 1906, pp. 7535, 7559-7560). 
greater is the number of passes through the rolls required and, consequently, a longer time is required to reduce a ton of bar-plate to the specified gauge number, the price per ton for sheets of the same dimensions consequently increasing with the gauge number. ${ }^{41}$ Of course, it does not rise proportionately, since the difficulty does not increase in absolute ratio. The rates for rolling in "finishing" mills vary not only with the width of the rolls and the sizes of the iron, but also with the shapes. The great variety of shapes makes it necessary that the price list shall be descriptive of patterns as well as a schedule of rates according to differences in measurements. ${ }^{42}$

Questions of rate differentiation are particularly difficult when the matter of the materials employed in production is involved. Such variations are more complex than variations in size and shape, and the greater effect upon earnings of price differentials according to materials has made the latter of greater relative importance. This is particularly true in the price for boiling. In this division of the trade, a tonnage rate for boilers is paid for working metal through a process. This rate originally presupposed that the pig iron worked was of standard grade, and the first scales contained no foot-note provisions for variations. ${ }^{43}$

Gradually the manufacturers began to substitute iron of lower grade, or other materials to be worked with pig iron, and frequently these several materials were mixed and worked together. This practice gave rise to disputes as to the rates of pay, and consequently it became necessary to provide rates for these various materials or mixtures. As

1 Gauges eight and heavier, called "plates," are rolled in the plate mill; up to nineteen gauge- "firebed"-is rolled in a jobbing mill; gauges nineteen and lighter,- "sheets,"-are made in sheet mills (Western Scales of Prices, 1916, pp. 36-39).

42 Ibil., 1916, pp. 25-34.

43 The first scale (February 13, 1865) may be found in the national Labor Tribune, February 7, $187 \%$, also in the Report of the Pennsylvania Bureau of Statistics, 1887, p. G. 15. The second scale (July 23,1867 ) is given in the Vulcan Record, no. I3. December, 1873, p. 36, and also in the Regnert of the Massachusetts Bureau of Labor, I881, p. 12. The third scale (Aprit 14, 1875) is contained in the Vulcan Record, no. 16, 1875, pp. 34-35. 
early as 187 I the national union upheld a local forge in a dispute involving a differential price for a particular kind of iron. ${ }^{44}$ In I874 workmen in the Pittsburgh and Youngstown districts demanded fifty cents extra for working "hoop iron." By IS75 differential prices were paid for working "castings," "hoop iron," and "scrap," and the convention considered the question of making such rates uniform. Uniform prices were not enforced until several years later. In 1877 the price for working "physic iron" was rated at one-fourth more than common iron. ${ }^{45}$ From ISSI to I9I6 five prices were added to the scale for materials rated higher than common pig iron, and, in a few cases, prices were added for materials rated at less than the regular boiling scale of prices.

The convention of 1894 enacted that the price for mixed material not provided for in the scale should be the "mean price" between those for the materials used. ${ }^{46}$ Nevertheless disagreements as to the price for particular mixtures have been frequent.

In the finishing department, the question of rate differentiation to meet a difference in materials was raised when the practice of rolling steel in iron mills was introduced. Attention was first given the matter in I880, when the convention adopted a resolution that in mills not working steel as a specialty" "price and one-half " 4 should be paid. In I 884 the scale provided that "iron mills [except sheet mills] working steel" should pay "price and one-half for steel, except mild steel," the output of which equalled that of iron when working the same sizes. It was further provided that the rule of price-and-one-half should apply "when the output of steel is but three-fourths the output of iron." 48

44 Vulcan Record, 1872, no. 10, p. Jo.

4 Proceedings, 1877, p. 83 . The rule made was that boilers who made four heats of physic iron should be paid the same amount as for five heats of common iron.

4 A Proceedings, I894, p. 4653.

47 Proceedings, I880, pp. $4 \mathrm{II}, 444$.

49 Pittsburgh Scales of Prices, 1884-1885, p. 2, "Memorandum of Agreement." 
The adoption of a price differential for steel could not be maintained. The justification for the higher price for steel was the diminished output, since the steel was rolled on rolls particularly adapted to iron. But the men proved the fallacy of this argument. Spurred on to increased output by the higher price, the workmen produced as much steel as iron, and in some cases even more steel than iron. What the result would be was evident-the employer insisted on an elimination of the differential rate. In I8S6 the scale was altered so as to make the price for rolling iron and steel, for one class of finishing mills at least, identical. ${ }^{49}$ The output continued to increase, so that by Igor the rates for finishing steel had dropped slightly below the price for iron. ${ }^{50}$ In 1906 steel rates were reduced again as compared with those for iron. ${ }^{51}$ In the sheet-mill division, likewise, a higher price for steel than for iron was maintained in the scale, up to 1904 , for rolling the lighter gauges. ${ }^{52}$

Definition of the Work.-Complementary to the necessity of standardizing the rate of payment for each variety of product is the need for defining in the scale the work which the piece worker must do for the specified rate. Without clear definition of the work, the practice is apt to vary considerably in different plants or localities. Such variations among the Iron, Steel and Tin Workers have been generally with respect to (I) the auxiliary work which may or may not be done by the man who receives the rate and (2) the payment by the worker, instead of by the employer, of helpers who work under the direction of the man receiving the piece price.

Generally the work required for a specified rate has been so well established by custom that it is not necessary to

41 Proceedings, 1886, pp. 1756, 1825 .

bit Western Scales of Prices, 1902-1903, pp. 14, 22.

51 Amalgamated Journal, Junc 21, 1006. The scale, however, still provided that "where the ontput of steel is but three-fourths the output of iron," the rule of price-and-one-half should obtain.

52 Western Scales of Prices, 1903-1904, p. 25; 1904-1905, p. 25. A differential price was maintaned for gauges 22 and lighter. 
define it in the scale. Such practice has been fixed largely by protests on the part of workmen against innovations. In $I 875$ the puddlers successfully fought on attempt to make them wheel their own cinder, ore, and "fix," and to remove ashes, so as to dispense with certain laborers; and the advantage thus gained accrued to the workmen of other mills in the district. ${ }^{53}$

Attempts to require the men to see that furnaces were in proper conditions for "heats" and to look after them when the heats had been drawn was a source of much friction. In 1878 twenty-five cents extra was demanded for "putting up a hot fix." 54 The constitution of 1888 states that any" boiler found putting "jams" or "checks" in the furnace with brick or fire clay should be fined five dollars. ${ }^{53}$ Similar regulations were adopted governing the prohibition of certain extra tasks in the case of other work. For example, the practice of sheet-mill heaters assisting in changing rolls was discontinued in I880. In I 899 it was provided that rollers should be paid two dollars, and roll hands a day's wages of common labor for changing rolls. The same year a rule was adopted that "any tin roller or other member of his crew who should clean, grease or change rolls or other castings," should be fined for the first offense, and expelled from the union for the second offense, unless such work was paid for. There were many similar instances.

The most important rules defining the worker's tasks have from time to time been inserted in the printed copy of

\footnotetext{
53 Vulcan Record, 1875, no. 16, p. 31.

54 Proceedings, 1878 , p. 169 . Puddlers were generally expected to sce that the furnaces were provicled with "fix" before each heat. By "fix" is meant the mixture that was used to line the inside surface of the furnace so that the molten iron would not eat through the walls. "Hot fix" was molten metal used as "fix" and had to be heated first. By using "hot fix" a better grade of product was marle.

s3 The "jam" is the wall-like partition which allowed only so much heat to come in contact with the iron. This rule was not intended to prevent a puddler from putting a ball of fire-clay in the "jam" during the weck in order to keep his furnace working; but to kecp puddlers from doing the work of furnace builders, especially on Sundays (Proceedings, 1888, p. 22633; National Labor Tribunc, June 23,1888, p. 4. June 28,1890, p. 4).
} 
the scale as foot-notes. They cover a variety of subjects. Several examples will iliustrate. In the boiling and busheling department, the employer agrees to do "all necessary fixing, including the cutting of grates, hanging of doors, and all new brick work on bridges," except "the usual fixing between turns and heats." All heavy scrap for busheling must be cut into eight-inch pieces or smaller, and all materials placed within ten feet of the charging door. ${ }^{56}$

The payment of helpers and assistants by the recipients of the piece rate has been for years an important feature of the working system in the Amalgamated. In the early days of the union the puddler and the roller were recognized as being in complete charge of the work of their respective departments. They hired the necessary helpers, and also paid them from their own wages. ${ }^{57}$ The puddler paid his helper; the roller, the members of his crew. Scales have since been adopted for these workmen, first for the heater, then gradually for those employed about the set of rolls; and they are now paid by the employer.5s Since the scale explicitly stipulated by whom the regular members of the crew should be paid, there has seldom been occasion for disagreement. Disputes have occurred chiefly over the payment of "extra" men who are needed on orders for heavy material.

Unless the employer furnished additional help when thus needed, or increased the rate, a reduction in the roller's wages was made. An extra man was usually required to handle the heavier sizes, and the difficulty of handling was greater than the increase in tonnage. Not infrequently, upon the request for extra help, the employer insisted that the roller should pay for it. Every branch of the trade ex-

56. Western Scales of Prices, 1916, p. 9.

87 J. H. Ashworth, The Helper and American Trade Unions, p. 72.

s. Not until recently were scales made for the catcher, the rougher. and the hook-ups in the bar mill; and for the roughers, catchers, and the stranders in the guide mill. The only workmen now paid by the roller are the straightener and the finisher. Sometimes, particularly in the mills of only one furnace, the roller does the work of the finisher himself, since the output is small. 
perienced disputes of this nature, resulting in a scale provision covering the points at issue. The Pittsburgh scale of 1887 provided that extra help be furnished for the heater by the employer on all iron and steel weighing over 160 pounds, and extra men (not to exceed two) for sheet-mill rolling "on all sheets thirty-six inches wide and over." The same scale contains a clause that muck-mill rollers shall be given additional help in rolling billets "one inch and a half or less." ${ }^{59}$ The convention of 1899 adopted a resolution that, on bar mills, "one man's help shall be furnished by the company on piles of 150 pounds, and an additional man on piles of 250 pounds, to shove under at the rolls on all passes, and for every additional roo pounds and over an additional man shall be furnished." Similar foot-notes have been inserted gradually in the scale until today there is a considerable number of such provisions. They have not, however, been gained without serious opposition from the manufacturers.

The Association has established the rates to be paid by members to helpers, who also belong to the union. Puddlers' helpers receive not less than "one-third and five per cent" of the puddlers' rates; heaters' helpers in sheet mills "not less than 40 per cent of heaters' wages." The helper frequently receives more than this; and, in some cases, the two men work the furnace "level handed," that is, on equal shares. In ISSO the rates to be paid by rollers to roughers and catchers were, by agreement, inserted in the scale. Since that time the wage rates of other workmen have been added to the scales. Men who are not "regular" members of the crew, enployed about the rolls, but who belong to the union, make their own terms with those who employ them, subject to the scrutiny of the local union. Their wages may not be reduced during the scale year, and are subject to the fluctuations of the sliding scale. ${ }^{60}$

59 Pittsburgh Scales of Prices, 1887-1888, Memorandum of Agrcement. pp. 3, 6, 18 .

60 Proccedings, 1899 , pp. 5565, 5620; 1905, p. 7366 ; Constitution, 1901, art. 17 , sec. 22 ; 1916, art. 17, sec. 21 . 
Within recent years, the Association has endeavored to include in the scale specified rates for all members of crews, and to have them paid directly by employers. In 1905 the sheet and tin agreement provided that "all regular tonnage and day hands" should receive their pay envelope from the office. This rule has since remained in force. ${ }^{61}$

Abnormally Difficult Conditions of Production.-Finally, deficient materials which make the production of iron or steel abnormally difficult have demanded attention on the part of the workmen because of the effect on earnings. In the puddling division, coal and iron of poor quality caused considerable trouble. In 1877 the puddlers in a Pittsburgh forge refused to fire their furnaces with slack coal, which did not produce sufficient heat and consequently increased their labor. In the same year there was a strike against poor ore. ${ }^{62}$ Such grievances became so numerous that, in I 883 , the convention adopted a resolution that iron requiring more than an hour and three-quarters to make a heat should be considered a grievance. In 1885 it was provided in the scale that cracked or flawed iron made out of old rails be paid for, otherwise the price for working old rails should be ten per cent above that for working common pig iron. ${ }^{63}$

In the sheet and tin divisions for a long time the "turn" system of working and payment was in vogue. This system is a combination of piece work and a guaranteed wage. The regular members of the crew were paid a fixed wage per turn, except the roller who received a tonnage rate. Their wages per turn and the stipulated number of "pairs" to be rolled per turn were fixed in 1880 and specified in the scales. ${ }^{64}$ The turn limits agreed upon for those who were

01 Amalgamated Journal, July 6. 1905, p. I.

62 Proceedings, $1877, \mathrm{pp} .46-47,83$.

${ }^{63}$ In 1878-1879 old rails were substituted for muck bar, and the pudillers complained that the iron was "of bad quality " and would not "stand the test of heating" (Proceedings, 1878, p. 13I). A differential of thirty cents alove the price of heating and rolling was demanded (ibid., p. 178), but could not be obtained (ibid, 1879, p. 224).

${ }^{64}$ Pittsburgh Scales of Prices, 188r, p. 15. 
paid by the roller and those paid by the employer were identical. If the number of pairs was increased, the turn wage increased proportionally. By the provisions of this system, if the members of the crew failed to reach the stipulated number of pieces, ${ }^{05}$ through no fault of their own, they received the turn's wage. In 1905 the turn limits were given up entirely. ${ }^{66}$ Thereafter, the turn workers were practically on an unlimited system until Igos, when they were put on a straight piece basis. ${ }^{67}$

65 The number of pieces per turn was generally the limit of output. These were usually averaged for a period of, say, two weeks. So the failure to reach the number on any one day meant no loss to the members of the crew in average earnings.

60 Amalgamated Journal, July 6, 1905, p. I.

67 Western Scales of Prices, 1908-1909, pp. 32-40. 


\section{CHAPTER VII}

\section{The Working Day}

The demand for a shorter work day in the iron trade began with the close of the Civil War, and the struggle has been kept up unabated until the present. The success of the union in diminishing the hours of labor has been gradual and continuous, though not uniform in the various departments of the industry. Reductions in hours of work once gained have been well defended and seldom relinquished. In times of depression, the incentive for employers to reduce wages is stronger than to increase hours, since there is less demand for labor. Efforts to maintain Sunday and the usual holidays as days of rest also have met with success. The shorter workday, although sometimes obtained by means of strikes, has been procured in most cases by trade agreement. The present discussion will concern itself with the development of the policy of the Association with reference to the standard hours of labor in the several departments- $(a)$ boiling, $(b)$ finishing, and $(c)$ sheet and tin divisions. The problems of each were essentially different.

Boiling Division.-Complaints against slavish hours of labor were commonplaces among the early puddlers. In I 870 certain mills were reputed to be working fourteen and fifteen hours a day. The length of the day was fixed by custom; the puddlers fired their furnaces between three and four o'clock in the morning, and consiclered six "heats" a day's work. The time required varied with conditions, as for instance, the quality of the metal, but the puddler seldom quit before sunset.

The earliest reductions in the working hours were closely associated with measures designed to limit output. The 
restriction on the number of heats, ${ }^{1}$ and the limitation of the weight of the charge had considerably reduced the long hours of the puddler by isgo. The next year, in order to prevent the employment of hard iron from increasing the hours of the boiler, the convention enacted that the limit of time for a heat in a single furnace should be an hour and three-quarters. ${ }^{2}$ This rule met with determined opposition for a few years on the part of the enployers, but was ultimately acquiesced in.

These regulations, directly intended to restrict the output, at the same time prescribed a definite limit to the length of the working day. Five heats averaging an hour and threequarters per heat would require approximately nine hours. In addition, the puddler must heat up his furnace before starting, do the ordinary "fixing" between heats and leave the furnace in shape for the next turn coning on. The time required for this supplementary work varies from one to two hours. Consequently, on double turn, the puddler generally averages over ten hours a day; and, on single turn mills, in which six heats are allowed, practically twelve hours. Such is the status of the hours of labor in the boiling division at present writing. ${ }^{3}$

Attempts to introduce the system of three eight-hour shifts in boiling have been, in general, unsuccessful. The objections have chiefly been on the part of the workmen, and are twofold: In the first place, earnings are less, since it is not easy to make five heats in eight hours, and it is imperative that the puddler have his heat out by the time the next turn comes on. Secondly, the workman enjoys less freedom under an eight-hour system. The puddler

\footnotetext{
1 See below.

2 Proceedings, 1891 , p. 3330 . The time limit for larger furnaces was graded as follows: double furnace, one hour, fifty minutes: double double furnace, two hours; Siemen's furnace, one hour, fiftyfive minutes. The time was reckoned from the moment the door was dropped until the heat was ready to draw, barring accidents and unpreventable drawbacks.

${ }_{3}$ The Louisville convention of 1916 adopted the cight-hour day for all departments, but it was not pressed in the conference with $\mathrm{em}$ ployers on account of the temporary scarcity of labor.
} 
has always been accustomed to arrange for himself the time for starting and quitting. He objects to being hurried in order to produce a reasonable output. For these reasons, ${ }^{4}$ the three-turn system is considered impracticable. The Amalgamated has succeeded in resisting the demands of the manufacturers for three turns in union plants $;^{5}$ there are, however, a few non-union mills employing three shifts. ${ }^{6}$

In the busheling department, the workmen generally work three shifts. This is explained by the fact that busheling requires only a few minutes for a heat. Scrap and swarth are used very largely, and the iron is not fomented. Consequently, bushelers need not come to work until about fifteen minutes before the muck mill begins to roll. ${ }^{\top}$ The eight-hour system for bushelers has become so well established in practice that no specific rule is necessary. Practically the only exception among union plants is the Empire mill, Cleveland, where the nine-and-a-quarter-hours' rule obtains. $^{8}$

Finishing Mills.-Long hours have been a characteristic feature of the work day in practically all finishing mills. In 1877 instances of heaters and roll hands working a fifteen-hour day were not uncommon. The Columbus session of that year provided, as a restrictive measure, that the first heating furnace should quit charging at three o'clock

4 A minor obstacle to the three shifts was the fear of introducing more men into the trade than could be absorbed (Proceedings, I 894 , p. 4562 ).

"For instances of disputes over the three-turn system, see Proceedings, I885, pp. I559-I 560; I893, pp. 4267, 4335-4336; I894, pp. $4561-4562$.

B Several mills of the United States Steel Corporation, as for example, the Frankstown mill and the Wharton plant, both of Pittsburgh, and the A. M. Byers Co. of Girard, Ohio, work three shifts of eight hours.

7 The scale does not prescribe three turns for muck-mill hands, but it is provided in a foot-note that "on muck or puddle mills on which three crews are employed three rollers shall also be employed" (Proceedings, 1904, p. 6850; Western Seales oi Prices, I916, p. I4).

${ }_{8}$ The nine-and-a-quarter-hours' clause was adopted in 1802 for scrapping and busheling departments to apply to mills not working shorter charging hours (Proceedings, I\&)2, p. 3856). 
when the rolls started at five in the morning. After allow. ance for the time required to heat the furnace before the rolls began to operate, and the necessary time for drawing the last heat, this regulation did not limit working hours beyond a twelve-hour day. Resort was next had to limiting the daily output in the several mills-bar, nail, plate, and guide-to a fixed tonnage. ${ }^{9}$ This measure likewise proved ineffectual, since the workmen either employed the same time by working less vigorously or-even more commonly-violated the fixed limit. Finally, after repeated efforts, spurred on by the widespread agitation of the American Federation of Labor for the eight-hour day, the union, in IS92, adopted the so-called " nine-and-a-quarterhour" system for all finishing departments. ${ }^{10}$ This clause fixed the length of the work day at "nine hours and fifteen minutes from the regular time the mill begins to roll until the first furnace commences to charge the last heat." This rule has remained valid up to the present. ${ }^{11}$

The Amalgamated Association, in its attempts to introduce the eight-hour day in finishing mills, encountered diffculty analogous to that experienced in the boiling division. The movement met with opposition both from the employers and the workmen. At the St. Louis convention of the American Federation of Labor, the representatives of the Iron and Steel Workers registered their votes in favor of the eight-hour day "in order to have the matter go out as being unanimous, but with the distinct understanding that it was utterly impossible [for the union] to enforce the movement in the mills at present, owing to the diversity of work and the irregular hours" of employment of the members "who work on the tonnage system." ${ }_{12}$ All members were urged to attend the mass meetings and show by their presence that the union "at heart" favored the propaganda,

Proceedings, 1878 , pp. 176-177.

10 Proccedings, 1892, p. 3856.

11 Western Scales of Prices, 1916-1917, pp. 21, 22, 32; the clause is inserted in scales for bar and 12 -inch mills, specialty mills working pipe or skelp, guide, ten-inch, hoop, and cotton tic mills.

${ }_{22}$ Financial Statement, January 31, 1889, pn. $G-7$. 
but to take no active part in them, lest such action be "construed as committing [the organization] to the enforcement of the eight-hour system on May I, I890, the date set for its inauguration." Consistently with this position, the succeeding convention enacted that "wherever practicable, any" mill, department or factory under the jurisdiction of this Association, desiring to do so, may upon agreement with the management arrange to work on the eight-hour system." ${ }^{13}$ The union did not, however, think it advisable "to go into conflict in order to obtain it." Several mills adopted it without any contest, such as the Homestead Steel Works, Oliver and Roberts' wire rod mill, and the Braddock Wire Company. ${ }^{14}$ This was practically as far as the Association got in the direction of the eight-hour day. ${ }^{15}$

The union more recently-in the conventions of 1915 and 1916-has adopted resolutions in favor of the eight-hour day in all union plants, that is, in the finishing and puddling departments as well. The reason for the delay by the convention was the opposition of the workmen. It meant a temporary wage reduction, and they were unwilling to accept it. Consequently, finishers generally work two turns -in the vernacular of the men- " the night turn can always shake hands with the day turn." The union leaders maintain that the three-turn system has been successful in plants in which it is now operating; that "it decreases the waste,

13 Proceedings, I 890 , pp. 3029, $3137 \mathrm{ff}$.

14 National Labor Tribune, July 19, I890, p. 4, and July 26, I890, p. 4. For a time, the eight-hour day seemed to gain in popularity. The union was never successful in reducing the hours of labor in nail factories, although laws were passed to this effect (Proceedings, 1879, p. 262). Nor could the eight-hour turn be enforced in rail mills and steel plants, except temporarily. The Homestead Steel Works employed the twelve-hour shifts after the struggle of $1 \mathrm{~S} g$ ? and the large steel plants of the United States Steel Corporation began to operate certain departments twelve hours a day, including Sunday, after the big steel strike in 1901 .

15 Proceedings, 1902, p. $6261 ; 1907$, pp. 7831, 7861. The cight-hour system was insisted upon in case of 10 -inch, guide and hoop mills averaging $\$ 35$ per turn (based on a one-cent card rate) on a single furnace, and $\$ 65$ per turn on two furnaces; also in bar and 12-inch mills averaging 60,000 pounds on single, and 80,000 pounds on double furnaces. 
increases the output, and in consequence of that fact decreases the cost of production"; that "to the men it gives assurance of sufficient tine to rest and think, while under the present conditions all they can do is eat, sleep, and work" "it and finally, that it is the only means to maintain the wage rate, since manufacturers, in requesting a reduction, invariably point to the large output of certain mills and the large carnings of the workmen. The manufacturers, moreover, although they have in conference expressed a willingness to give the three-turn system a trial, as a body are not favorably disposed toward its introduction, because of alleged increased cost of production. The union feels disinclined to force it on employers for fear of "squeezing out" the high cost mills.

Shect and Tin Plate Mills.-The sheet and tin-plate departments alone have the universal three-turn system, or the eight-hour day. As early as I885, sheet mills were allowed to work three shifts of eight hours, providing the crews did not exceed the specified limit of output. This, however, was not conceded by the union without some opposition. ${ }^{17}$ The objections which the union offered to the introduction of the triple-turn were, principally, $(a)$ overproduction, and $(b)$ the admission of too many workmen into the trade, causing ultimate slackness of employment ${ }^{18}$ and reduction in wages. The manufacturers, on the other hand, jointed out the waste of keeping the furnaces hot between turns, and the necessity of continuous and uniform output in order to keep the rolls in proper working condition. The logic of their arguments was compelling; and within a few years the system of three turns for sheet mills was generally conceded. The eight-hour turn was pecu-

\footnotetext{
16 Proceedings, 1907, p. 7998.

17 For examples, see Proceedings, 1880 , pp. 458-459; 1883, p. 1171 ; 1895, p. 1547.

${ }^{18}$ In 1808 cx-President Garland, in his report to the convention, stated that three-fourths of the members of the union were working on the eight-hour system; and that the workmen who were employed eight hours per day averaged more days' work per year than those working the longer shifts (Proccedings, 1808, p. 5418).
} 
liarly well adapted to working conditions in the sheet mill department.

When the tin business began to prosper about 1890 , the union allowed the use of the three-turn system of operation for tin mills. ${ }^{19}$ In addition, the scale provided what should constitute the limit of output for a day's work. It was frequently the case that the crew produced the fixed tonnage in less time than eight hours, particularly when rolling the wider sizes of sheets. The manufacturer objected to any interval between successive turns, during which the rolls were allowed to cool off. They argued also that it was prodigal to be obliged to keep the furnaces hot when the mill was not running. Accordingly, they insisted that the crews "follow out," that is, one crew should succeed another without any loss of time. It was also pointed out by employers that this method of working, since the last crew would finish earlier on Saturday, would give the management an opportunity to make any necessary repairs in the plant.

The union did not view the practice of "following out" with favor. In the first place, the privilege-it was so alleged-was abused. Certain mills were reported to have finished the week's work by Saturday morning, and even earlier. ${ }^{20}$ Such abuse, they reasoned, would, if continued, lead to a request by the manufacturers for a removal of the limit. As a remedial measure, the Association adopted a provision that "eight hours shall be a day's work on tin or black plate mills, said mills not to follow out except on Friday and Saturday, when a full day's turn shall not be made in less than seven hours and forty-five minutes." ${ }^{21}$ A penalty was attached-suspension or forfeiture of char-

19 Proceedings, 1800, p. 3142.

20 In 1003 the sheet department of Zug's mill, Pittsburgh, finished the week's work "as early as midnight on Friday." The lodge of which the workmen were members was found guilty of violating the union rule in this respect, and ordered to give up the practice under threat of having its charter revoked (Proceedings, 1903, Pp. 6596$6(04)$.

21 Proccedings, 1900, P. 5736. 
ter-but the law was not rigidly enforced. All restrictive measures as to output were abolished in 1905. The eighthour shift has been continued in practically all tin-plate plants. ${ }^{22}$

- Until the early eighties, the national union made no attempt to preserve, as days of rest, Sunday and the usual holidays. The matter was left to local agreement between the workmen and the employer. ${ }^{23}$ In ISS3 the convention passed a resolution that "all Bessemer mills governed by this Association cease all Sunday work, except that which is necessary, after the first of January, ISS4." 24 This action did not, of course, put an end to the practice, and protests were frequently made. The belief was held, as in the case of excessive production, that Sunday labor tended to reduce wages, as well as to cause physical harm of the workmen. Accordingly, steel and rod mills-which commonly operated on Sunday-were required to stop rolling not later than five o'clock on Saturday and not to commence again until Monday morning. ${ }^{25}$

The Amalgamated provides not only that no skilled workmen be required to work on Sunday, but also for a shorter work day on Saturday. Puddle mills, on single turn, make five instead of six heats. Bushelers quit charging after seven hours. Finishing mills stop rolling seven hours from the time the mill started to roll; sheet and tin mills work the first eight-hour shift only. Such advantages have not been maintained, however, without vigilant effort.

Until Igo3, the union provided no uniform rule as to working on holidays, with one exception. No mentber was

22 In a three-turn mill, no member of a crew was permitted to work longer than eight hours (Proceedings, 1901, p. G051).

23 Vulcan Record, 1872 , no. 10, p. 43. Occasionally mills were constrained to cease operations on Sunday, by pressure of public opinion and local civic and philanthropic societies (National Labor Tribune, May 13, I882, p. 4, col. I).

24 Proceedings, 1883, p. 1238.

25 Proceedings, 1894 . p. 4677 ; 1806, p. $4988 ; 1897$, p. 5188. Many of the plants of the United States Steel Corporation, particularly the large steel mills, now non-union, operate on Sunday. In some instances, the statc law requires one day's rest in seven. 
allowed to work on Labor Day, under penalty of a fine of from five dollars to twenty-five dollars. In 1903 mills were forbidden to operate on six holidays-New Year's, Decoration Day, Fourth of July, Labor Day, Thanksgiving, and Christmas. Four years later, Thanksgiving, New Year's and Decoration Day were eliminated. The remaining holidays-Fourth of July, Labor Day, and Christmasare still observed. Other holidays are left for local arrangement. A shorter workday is provided for days preceding holidays, such as is required for Saturday. 


\section{CHAPTER VIII \\ RESTRICTION OF OUtPut}

Restriction of output has been practiced both by employers and employees in the iron and steel industry. In 1904 there were at least seven associations or pools of manufacturers in which separate companies had entered into agreements to fix prices by restricting output. ${ }^{1}$

The Amalgamated Association, until 1905, prescribed in the annual scale, negotiated with the manufacturers, numerous limitations upon the output of workmen in the various kinds of mills. These limitations took three forms: (a) restrictions on the size of the charge and the number of heats per turn in puddling mills; $(b)$ restrictions on the number of bars to be rolled per turn in sheet mills; and (c) restrictions on the number of pounds of tin plate to be rolled in tin-plate mills. The prevalence of the team system combined with payment on a piece rate or tonnage basis was largely responsible for the union's action in limiting the amount of work of the majority of its members. The purpose of such regulations has been to prevent wage reductions, ${ }^{2}$ exhaustion of the workers, and reduction of the

${ }_{1}$ Eleventh Special Report of the Commissioner of Labor, '1904. pp. $235-236$.

2 The union argument that excessive output tends to wage reductions was somewhat as follows: Let us assume that a puddler is working at a piece-ratc of $\$ 5$ per ton; and that his average output per day was, in five heats, a ton and a quarter. His daily earnings, then, would be $\$ 6.25$. (Out of this amount he must pay his helper). By greater excrtion and longer hours, the puddler makes six heats, and, if the output is a ton and a half, he averages $\$ 7.50$ per day. Immediately thereafter the scale is reduced to $\$ 4.25$ per ton, and his daily carnings for increased output are reduced to the former level of practically $\$ 6.25$. Again the puddlers seck to increase their output and, by still greater cxertion, a few of them manage to make seven heats; whercupon, after a few months, the tomnage scale is cut to $\$ 3.75$, and only the more efficient workmen can now earn $\$ 6.25$ per day. Only a few men can earn a fair wage, while the majority 
number employed; and it was the firm belief of union leaders that these effects were directly traceable to excessive output. $^{3}$ The "health-of-the-worker" argument was given greatest emphasis by the union leaders. Since the entire team must work together, by "speeding up," any member who was physically inferior was subject to strain and overexertion. ${ }^{4}$ The idea of making jobs for other workmen figured very slightly.

The puddlers were the pioneers in the adoption of measures for the curtailment of the finished product. ${ }^{5}$ The method employed was to limit the number of "heats "which a puddler might work. In 1867 the convention limited a day's work to five heats in double-turn mills, and six for a single turn. This applied to mills west of the Alleghany Mountains only, in consequence of the different mode of working in the East. This rule, however, did not immediately put an end to the practice of working extra heats and long hours. In 1870 , for example, President John Edwards pointed out that "some mills were known to be working seven heats, from four in the morning to seven and eight o'clock at night," and that the men were "not only killing themselves, but depriving others from making a living by stopping the double turn."

The desire of the men to swell their earnings by increased output led to overcharging the furnace. Though the union

are thrown below it. The result is apparent. The higher rate is undermined, the quality of the product suffers deterioration, the health of the workmen is endangered, and the majority of them are underpaid (see, for example, Proceedings, 1889, pp. 2690-269I).

${ }^{3}$ Proccedings, 1877 , pp. 53-54; 1883, p. II15; 1905, p. 7227.

1 Proceedings, 1886, p. 1834; 1887, pp. 1917, 1950; I888, pp. 2307. 2326-2328; 1899, p. 5586; 1900, pp. 5741, 5909; 1902, p. 6411; 1903, p. 6701 .

${ }^{5}$ Puddling is the reduction of pig iron to muck bar. This is done by boiling the iron. In early times the metal was "baked," so to speak, instead of "hoiled," until the alloyed metals became viscous or "pasty"; this was, in the strict sense, the process correctly described as "puddling." There is practically no puddling done in the United States today. The words "puddling " and "boiling" are used interchangeably, the former being more common in the East, the latter in the West.

- Vulcan Record, i867, no. 1, p. 10. 
law did not cover this point, it was patent to the leaders that such action served to increase the evils which the union sought to ameliorate. Heats were charged so heavily that they could not be made in any less time, and in addition it required more laborious effort to handle the iron properly and the product was consequently of inferior quality. ${ }^{7}$ To remedy this defect, the convention of 1878 fixed the weight of a charge for a boiling furnace at 500 pounds. ${ }^{8}$ This made the day's output 2500 pounds for a double turn, and 3000 pounds on a single turn. Six years later the union increased the limit of weight for a charge to $55^{\circ}$ pounds for single furnaces. ${ }^{\circ}$ This rule has since continued in force, modified only by provision for averaging the two weeks' work.

A minor question of dispute between the union and employers was the discharge of puddlers for breakage of machinery due to the large size of puddle balls. In 1887 the Association adopted a resolution that puddlers should work each heat into balls weighing not more than 250 pounds, ${ }^{10}$ in order to claim the protection of the union. If any part of the machinery was broken by putting in large balls, the puddler was subject to dismissal without recourse to the organization for redress. The matter of determining whether or not a particular breakage was due to the over-

7 Ibid., 1873 , no. 12, p. 5 I.

8 Proceedings, 1878 , p. 179.

- Proceedings, 1884, D. 1457. Turn limits were likewise fixed for other workmen in the puddling department, such as knobblers (Procecdings, 1881, p. 709), and bushelets (Proceedings, 1884, p. 1457). The weight of the cliarge was adjusted proportionately for larger furnaces whicls were introduced from time to time (Western Scales of Prices, 1903-1904. p. 6; Constitution, 1903, art. 18; 1916, art. 18).

10 Proceedings, 1887 , p. 1924; National Labor Tribune, June 25. 1887 . p. 4, col. 2 . When the iron reaches the boiling stage, it is said to "have come to nature," somewhat analogous to the coming of butter in a churn. At this stage, the puddler works the molten metal into balls, and by means of tongs these balls are conveyed on a buggy, or more usually by a trolley, to a squeezer. The squeczer consists of a stationary rim and a revolving immer rim, containing teeth-like grooves, which operate somewhat on the principle of a coffee mill. It squeczes out much of the slag in the balls and clongates them into blooms, which in turn are passed through the rolls and drawn out into muck bars. 
size of balls was left to the mill committees and the district deputies.

The most important problem was how to enforce the rule restricting average output. The Sons of Vulcan were never able to do this successfully. The Amalgamated Association, in I889, required that, although the weight should be averaged for two weeks, the weight of each turn should be displayed on a board. ${ }^{11}$ The next year it was provided that the penalty for wilful violation of the legal limit would be suspension, and the publication of the names of offenders in the quarterly report. ${ }^{12}$ In I9OI the penalty was made either a heavy fine or expulsion. Lodges allowing this practice were fined for the first offense, and if they persisted in the practice the charter was withdrawn. The charter of a local union was rarely revoked for violation of the law-though there were such cases-and the abuse continued. The leaders of the union began to feel that the remedy lay, not in restricting the output, but in limiting the hours of the workday. So flagrant were the violations of the limit on swarth in the busheling department that, in I905, in accordance with the agreement with the employers, other manufacturers were given the privilege of working without limits. The limit has been nominally retained in the puddling department, but it is no longer effective.

The manufacturers, as a rule, have not found the restriction on the output of puddle furnaces irksome. ${ }^{13}$ The scale in I904 provided that five heats should constitute a day's work in double-turn or three-turn mills, but allowed six heats in a single-turn mill. Large mills usually employ three shifts so as to get the greatest possible production in twenty-four hours, and on three turns it is a physical impossibility to make over five heats per turn; usually only four can be made. Most employers agree that 550 pounds of pig iron is an cconomical charge; that it is as much as two

11 National Labor Tribune, July 6, 1880, p. 4.

12 Proceedings, 1800, p. 3167.

13 There were instances in which the union regulation was repugnant to the employer (Proceedings, 1883, p. 1168). 
men (a puddler and his helper) can handle to advantage. It has also been found to be an economical charge as regards waste. In case the charge is excessive the iron must remain in the furnace longer, and the longer it is in the furnace the greater is the percentage of waste.

In puddling mills where the restriction of the union has applied, the production of each furnace on double-turn mills was 30,250 pounds a week. ${ }^{14}$ In such mills the puddlers regularly puddled that amount per week, barring accidents or other causes. There were no complaints that the limit of output was not reached; but in three-turn mills five heats were impossible in puddling certain kinds of iron. In summer the puddlers sometimes made only three or four heats in a turn-occasionally only two-on account of the extreme heat. The production of non-union mills was often not more than the union scale, and in some cases even less. ${ }^{15}$

The Amalgamated scale placed the limit of time for each heat in a single furnace at an hour and three-quarters. ${ }^{10}$ The time was reckoned from the moment the door of the furnace was dropped after charging until the heat was ready to draw, barring accidents and unavoidable detentions. If a majority of the furnaces required longer time, the management was notified.

In the finishing department limits were adopted from time to time, but without success. ${ }^{17}$ These limits on the weight of a day's output were replaced by a restriction as to the time. The nine-hour-and-fifteen-minute rule applies, that is, nine hours and a quarter is allowed for rolling "from the regular time the mill begins to roll" (say, five o"clock in the morning) "until the first furnace commenced to

\footnotetext{
14 This was calculated as follows : 550 pounds per charge $\times 5$ heats $X 11$ turns per week. The union allowed but one turn on Saturday, and no Sunday work.

15 For instances, see Eleventh Special Report of the Commissioner of Labor, 1904, pp. 243-244.

is The time for larger furnaces was proportionately longer. Sec Western Scales of Prices, 1904-1905, p. 6; 1916-1917, p. 5.

17 Proceedings, Iron and Steel Roll Hands, 1873, p. 9; Proceedings, Amalgamated Association, 1880, p. 41.4; 1888, p. 2290; 1802, p. 4108 .
} 
charge the last heat." 18 Rolling all that is in the last charge, however, may require another hour. The scale also provided that "on all finishing mills the last furnace shall not be charged later than one hour after the first furnace." The object of this rule is to have each shift out of the way of the shift next in turn.

The sheet mill hands' scale fixed the limit of output per turn. The limit was expressed in number of bars, usually by "pairs." 19 At first the union viewed with disfavor the operation of the third turn. In I885, however, sheet mills were allowed to run three turns, of eight hours each, providing " no turn shall exceed 180 pairs single, or 105 double iron, and that no single or double turn mill shall exceed 216 pairs single, or 120 pairs double iron, for a turn." 20 Subsequent scales for many years were based on the limit of 105 pairs, or 2ro bars, per turn for rolling in doubling mills, with but slight modification. This is on the basis of seven heats of 15 pairs per heat. The limits for iron and steel were identical; and a heavy penalty was provided for wilful violation of the scale. ${ }^{21}$

About 1900 manufacturers began to chafe under the union restrictions upon the output of its members. They

18 Western Scales of Prices, 1908-1909, and subsequent scales.

19 Sheet steel is made from steel bars varying in size and thickness according to the desired dimensions of the finished sheet. To prepare the bars for rolling they are heated in what are called "pair" furnaces, because the bars are heated in pairs. Fifteen pairs, or thirty bars constitute a heat, but often in practice a smaller number are heated at once. The bars are first rolled in a roughing-down mill, and then taken to a finishing mill. Sheets that will finish 24 to 28 gauge are matched in threes; sheets lighter than 28 gauge are matched in fours-that is, three or four sheets are rolled together. The sheet is ordinarily reduced one-half in length by doubling under a press, after which process it is reheated and rolled to the proper dimensions. The edges are then sheared to the required size. The team whicl operates a pair furnace and a set of rolls consists of seven men-a pair heater, a rougher, a catcher, a matcher, a heater, a roller, and a doubler. One sliearman, one opener (who seprarates the sheets-and they do not adhere if properly rolled), and one scrap boy can generally handle the sheets that three teams produce.

20 National Labor Tribune, Angust 15,1885, p. 4, col. 2; Pittsburgh Scales of Prices, $1887-1888,11,18$.

21 Proccedings, 1800, p. $3167 ; 1903$, p. 6773. 
claimed the restriction was unjust, especially as it applied to sheets of all sizes, gauges, or weights. By Ig02 the union had raised the limit to nine heats, or 135 pairs, on threeturn, and ten heats, or 150 pairs, on two-turn mills. ${ }^{22}$ This met the requirements of mills working sheets 30 or more inches wide and 104 inches long, as no greater number of sheets of such large size could be produced in one turn of eight hours. But when smaller sheets were worked, such as 24 by 72 inches and up to 28 by 96 inches, it was often the case that the men turned out the limit of 135 pairs in about seven hours, so that a mill would be idle an hour or more between each turn, or three or four hours in a day. Manufacturers asked that the limit be increased that they might be put on a parity with non-union mills, particularly those of the American Sheet Steel Company, in which the workmen operated the rolls practically for the full eight hours for each turn and in which no limit was placed on output. ${ }^{23}$ It was pointed out also that even in union mills the men voluntarily violated the scale limit. ${ }^{24}$

The chief objection made by the manufacturers, however, has been that the limitation endangered the chilled rolls.

22 Western Scales of Prices, 1902-1903, p. 29, foot-note 4. By this time, the three-turn system was practically universal in sheet mills.

23 It has been shown by employers that average earnings per day were greater in non-union mills than in union plants. Piece rates were identical in both classes of mills, and working conditions were said to be similar. The greater earnings by non-union workmen was due to the fact that they made more heats and therefore their output was larger. The average daily earnings as given by one employer for four months in 1902 was $\$ 2.56$ in union mills, and $\$ 2.67$ in non-union mills; for the same period in 1903 , earnings were $\$ 2.68$ in union plants and $\$ 2.76$ in non-union plants. Average daily earnings were 4.3 per cent higher in non-union than in union mills in the first instance, and 2.9 per cent in the second. A non-union employer showed that in a period of seven weeks in 1903 the average number of pairs rolled per turn was 152.55 , or 13 per cent over the limit set by the union. In case of narrow iron and very light gauges, the number of pairs rolled per turn frequently cxceeded 200. The price for rolling the lighter gauges is greater than that for rolling the heavy gauges. but the weight is relatively less, and consequently earnings are less. For the detailed statistics, sec Elcventh Special Reporl of Commissioner of Labor, 1904, pp. 249-255; Proceedings, 1904. pp. 6o09-6914.

24 Proceedings, 1903, pp. 6720-6721; 1904, p. 6009 ff. 
The rolls are costly and the smooth chilled surface requires careful treatment to prevent breakage and also to produce a good quality of iron. Rolls are likely to be cracked by too much pressure being put upon them, or by too sudden changes of temperature. The rolls are heated from the hot metal which passes between them, and unless the heat is regulated by the output - that is, by the number of bars passed between them-the expansion and contraction to which they are subject may cause them to break. For this reason, employers contend that there should be no arbitrary limitation, and that the conditions under which the rolls should be operated ought to be left to the judgment of the foreman and the skilled workmen. If the rolls are not in proper condition, the sheets will be unevenly rolled, causing them to "buckle."

At the solicitation of the sheet manufacturers the Amalgamated Association called an "expanded sheet conference" in December, 1903, and modified the restriction of output, making it more liberal. The limit was increased from nine heats, or 135 pairs of bars, to Io heats, or 150 pairs, to take effect January I, I904. The rule was modified in another respect. It was provided that the new limit was to be the average daily output during the "pay period," which is usually a fortnight. Previous to this time, no shortage for a particular day could be made up on another day. ${ }^{25}$

The new limit did not long meet the requirements. The members wilfully persisted in making overweight, and the company tacitly encouraged it. A rule was adopted that all overweight or surplus earnings should be collected by the lodge, in addition to a fine for violating the scale. ${ }^{20}$ These measures were ineffective, since the sentiment of the work-

25 Proceedings, 1904, p. 6914. The next year, the number of extra pairs per turn to make up shortage was limited to 15 (Proccedings, 1905, D. 7184).

26 Proceedings, 1905, p. 7428. The "overweight secretary," it was provided, should receive twenty-five per cent of all overweight collected. 
men was not heartily in favor of their enforcement. Finally, in 1905, in conference with the American Sheet and Tin Plate Company, the limit of output was abolished. ${ }^{27}$

The tin industry did not begin to flourish in this country until early in the nineties. The Cleveland convention of IS94, following the precedent established by the puddlers and sleet-mill hands, placed a linit on a turn's output in tin-plate mills. ${ }^{28}$ The limit was 5000 pounds of Standard tin plates-that is, no. 30 gauge plates, 20 by 56 inches. $^{29}$ The alleged reason for the restriction was the fear of excessive output by the more able-bodied workmen and a consequent reduction of wages by manufacturers. The workmen also thought that by limiting the output the number of men who would be able to obtain employment would be increased.

The workmen soon proved that they were capable of a greater output. Accordingly, the limit was gradually increased until in 1903 it was 6250 pounds on no. 30 gauge. ${ }^{30}$ In addition, there was a provision in the scales that the limit of output might be increased on the wider sizes of sheets. ${ }^{31}$

27 Proceedings, 1906 , p. 7562.

28 Proceedings, I894, pp. 4508, 467 I. All turns are eight lioursthree turns a day.

20 In making tin plates, bars of steel are heated in pair furnaces and then passed through chilled rolls until the plates are of the required gauges. The steel plates are immersed in sulphuric acid, which removes all foreign substances, and are then placed in annealing furnaces. This process toughens the plates and makes them pliable. They are then passed through chilled rolls which give a smooth surface to the plates, are annealed once more, and after a final bath in sulphuric acid they are stored in water boshes to prevent rusting until they are required in the finishing department. In the finishing department the plates are passed through a flux which floats on top of the molten tin, then through the tin, then through palm oil, then through rolls which remove all surplus metal from the sheets, then through a branner which removes all oil and grease. then through what are known as "skin rolls," which remove all dust and polish the sheets, after which they are assorted. Most tin plates manufactured are nos. 30 and 31 gauges.

30 Proceedings, 1895, p. 4777; 1904. p. 6002; Western Scales of Prices, 1902-1903. pp. 33-34; 1903-1904. pp. 34-35.

31 An excess of ten per cent above the limit on sizes $201 / 2$ by 56 , and fifteen per cent above the limit on 26 inclies wide and over (Western Seales of Prices, 1904-1905, pp. 34-35). 
This was allowed because, as the employers pointed out, the wider sizes required faster work to keep the rolls to their proper temperature and shape.

The tin-plate scale in 1902 provided for an average of the week's work; but in making up lost weight, no more than 500 pounds could be made up in any one turn on $3^{I}$ gauge and heavier, and 250 pounds on all lighter gauges. In case of a "drawback" the percentage excess could not be made on the same turn. The provision for averaging a week's output was omitted from the scales for subsequent years.

The manufacturers of tin plate found practically the same objections to the restrictive measures of the union as did the sheet-mill manufacturers. They claimed that it was arbitrary, unreasonable and unjust ; that it endangered the rolls, exposed union employers to an unfair competition with non-union employers, and finally that the workmen, in saying that "the limit of human endurance" had been reached, had belied their statements by demonstrating the contrary regularly. Attempts to penalize members for violations of the limit proved futile $; 2$ so the limit of output was removed by the union in 1905 , simultaneously with the abolition of sheet-mill restrictions.

32 Proceedings, 1897 , p. 5199 ; 1899 , p. $5594 ; 1900$, pp. 5792-5794; 1906, p. 7564 ff. 


\section{CHAPTER IX}

\section{Machineri}

Probably no industry has been subject to such continual change and constant development directly and indirectly resulting from new inventions and the introduction of improved processes and labor-saving machinery as has the iron and steel industry. Improved methods of iron manufacture have lagged behind those of steel, but even these have been considerable. It would require too much space to trace the effects of all such innovations upon members of the union; but the most important of these will be discussed, and the attitude of the union toward them analyzed.

The most notable inventions affecting the industry have been the "Bessemer" and "Open Hearth" processes for manufacturing steel. Not until the late fifties-about the time the Puddlers' Union was organized-did Sir Henry Bessemer finally succeed in producing malleable steel from cast iron. In 1865 the new process was introduced in this country. ${ }^{1}$ Production rapidly increased to an enormous extent. Many improvements followed, particularly in the manufacture of steel rails, and many workmen were thrown out of work by these new inventions and appliances. ${ }^{2}$ The displacement of manual labor completely changed the relative strength of employers and employees; and to this is due, in large measure, the failure of strikes in the large Bessemer works, and in certain localities-particularly in the East-the complete subjugation of labor to the $\mathrm{cm}$ ployers.

1 The first Bessemer steel rails made in the United States were rolled at the North Chicago rolling-mill on May 24, 1865; but not until 1867 was any considerable quantity marle. From 2550 net tons in 1867 , the production increased to $1,438,155$ net tons- the highest print-in 1882 .

2 Proceedings, 1885 , p. $15 G_{3}$. 
The actual amount of displacement occasioned by the new appliances varied with the size of the plant and the extent of the improvements made. In some cases, the number of workmen thrown out of employment was large. For example, in 1885 , improved machinery was installed in the Edgar Thomson Steel Works, Braddock, Pennsylvania. The company immediately decided to run double turn, of twelve hours each, instead of the three eight-hour shifts. On the heating furnaces, at which 23 men per turn, or 69 men on the three turns, were formerly employed, 6 men per turn or 12 men on double turn were required-a displacement of 57 men on the furnaces. On the rail-mill train, 21 men were required for each turn, or 63 men for the three turns; to operate the improved train, only 6 men per turn, or 12 men in all, were necessary-thus displacing 5 I men on the rail train. By putting the blooming and nail mills on double turn, there was a labor-saving of 62 chargers, helpers and others workmen. Consequently, in the blooming and nail mills alone, there was a displacement of 170 men. By introducing the two-turn system in the converting and blast-furnace departments, it was estimated 300 men were obliged to find employment elsewhere. ${ }^{3}$

The effect of the improved methods of operation was not only a reduction of the number employed but also a change in the piece rates of those workmen who were retained. Since uniform scales for steel mills were impracticable, special agreements were drawn up for individual plants. The problem of machinery was likewise a disturbing feature at the annual conference between the union and the

${ }^{3}$ National Labor Tribune, February 7, 1885, p. 4. col. I. For the reduction of wages occasioned, see ibid., February 14, i885, p. 4. col. 2. For a description of this mammoth automatic rail train, see ibid., October 13, 1888, p. 4, col. 3. The immediate effect of the new machinery was the dissolution of two local unions at Braddock (itjid., March 14, 1885). For other instances of great displacement of skilled men due to the introduction of machinery, e.g., in the manufacture of iron and steel bolts, nuts, rivets, washers, chains, forgings, and wrought iron pipe, see Thirteenth Report of the United States Commissioner of Labor, 1808 , vol. i, p1). 291-206. 
employers'association." Steel operators generally employed the twelve-hour turn. Wages were reduced in practically every instance, sometimes as much as one-third. ${ }^{5}$ The national union consented to local scales being signed for specialty plants even at reduced rates, provided it was clearly shown "that the work of the men was decreased" by the new piece of mechanism. ${ }^{6}$ Frequently, this provision was inserted in the local agreement. For example, in the signed contract between the workmen and the Illinois Steel Company, there was a clause pledging the men, in case the plant was improved in any way, "to assist in developing such improvement and abide by whatever modification such improvement may permit in the rates and number of men." "7

One of the bitterest struggles for the control of a single machine in the trade was occasioned in the eighties by the introduction of an automatic nail-making macline. This new device for cutting nails displaced many nailers and nail-feeders. ${ }^{8}$ The capacity of the machine was prodigiously large. At fifty revolutions per minute, the machine turned out 900 eight-penny casing nails. This meant 48,000 nails, or 330 pounds, per hour. The simplicity of the new machines made it possible for one man to run at least six

4 National Labor Tribune, April 14 1888, p. 2, col. 2. The Iron Age, the official organ of the manufacturers, alleged that the union laid claim to every new device projected "either by reason of improved processes, machinery or materials" (quoted in the National Labor Tribune, May 2, 1885, p. 4, col. 2); the Association through the editor of its paper, thus complained: "There should be an end somewhere to labor standing the brunt of cheapened production" (ibirl., April 14, 1888, p. I, col. I).

- Proceedlings, 1880 , p. 2736.

e Proccedings, 1899 , p. 5629.

- Proceedings, 1891, p. 3412. For an instance of such adjustment with the Illinois Steel Co., see Proceedings, 1901, pp. 7027-7020.

${ }^{8}$ The first invention was a self-feecling device, known as the Haddock self-feeding machine (Proccedings, 1850, pp. 347, 407). The new appliance displacerl the nail-feeders, as one man could tend more than one machine. Nailers were not permitted to put on a selffecter nail machine, as it was decmed "injurious to the trade of the nail fecters" (Proceerlings, 1882, p. 973). Emplnyers demanded that nailers look after the machine for one-half the price of nailing, the firm to retain the other half and pay the fcelcr (Proceedings, 1880, p. $407 ; 1883$. p. 1093). 
machines. ${ }^{9}$ The nailer's skill was no longer an important factor in production; and to this is largely due the bitter feeling of the nailers against the nail feeders, who frequently got the nailing jobs by wage-cutting.

The policy of the union was to attempt to limit the number of machines which one man might operate. At first, it was enacted that four machines should constitute "one job," and members of the union were not permitted to hold more than one job. ${ }^{10}$ The provision, however, could not be enforced. In the first place, nail mills could not be effectively organized. Because of excessive production, mills were idle half-time. The men had no interest in an organization that could be of little benefit to them. Again, there were too many men competing for the decreased number of jobs. Nail feeders were equally as capable of running the machine as the skilled nailers. Consequently, the employers were able to drive a bargain with the union; if not, they began to run non-union. By 1889 Secretary Martin pointed out that nailers got little, if any, more for operating eight machines than they did previously for four. ${ }^{11}$ There were instances of employers demanding that the men work ten machines. ${ }^{12}$

Varied and numerous were the mechanical improvements which invention and discovery made available in the puddling and finishing divisions. Improved furnaces made the work of the puddler somewhat less laborious and also increased the output. ${ }^{13}$ Continuous rolls, with new feeding devices; new machinery for blooming mills, having "all the levers that operate the screw, the rollers and the manipulators in one place"-thus making it possible for the roller

- National Labor Tribune, January 28, 1888, p. 4. col. 1. The machine, it was said, cost $\$ 600$. It was introduced extensively.

10 Constitution, 1884 , art. 18 , sec. 5 .

11 Proceedings, 1880 . pp. 2600-26n1.

12 National Labor Tribune, February 9, 1889. For a similar instance of one man's onerating an excessive number of bolt machines, sec ihill, March 29, I8,0, p. 4. col. 2.

${ }^{13}$ For instances, see Villean Record, 1872, no. 10, p. 42: Proceedings, 1878 , 1.172 ; National Lalon Tribume, March 4. $1882,0.4$ col. 3: Western Scales of Prices, 1916-1917, P. 5. 
to operate all these levers with ease: automatic shears and patent feeders; three-high rolls on sheet-bar mills ; improved hoop mills; automatic straightening beds; and patents in tinning processes are a few of the many innovations that 'may be cited.

The union policy of dealing with these various devices was essentially the same in all cases. Two methods were employed. First, there was a revision in the scale at the next conference of employer and employed, and a new piece rate agreed upon. Where it was clearly shown that the labor of the workmen was actually lessened, the union accepted a reduction in the rate. If men were temporarily displaced they were obliged to seek employment elsewhere. In the second place, the union defined what should constitute a "job" for the workman; and no member was permitted to hold more than one job. For example, in $188_{4}$, the constitution provided:

One furnace, single turn, one train of rolls, double turn, four nail machines, one steel gas smelting furnace both turns, or two steel gas smelting furnaces, single turn, shall constitute one job. Also, one steel smelting gas furnace with a capacity of 24 crucibles shall constitute one job for one Teemer, two Puller-outs, and two Molders. and no Puller-out or Molder shall be required to fill more than six pots to each heat, and three heats shall be a day's work at all times.

Any workman holding "two or more jobs" was pronounced to be a "blacksheep," and union men might refuse to work with him. ${ }^{14}$ In 1890 it was provided that no member might work two or more consecutive turns at a job in a mill when other competent members in the immediate vicinity were suffering an enforced idleness. This one-job provision has been modified from time to time; but, in its amended form, it is in force today.

14 Constitution, 1885 , art. 18 , sec. 5 ; National Labor Tribune, Junc 25. 1887, p. 4, col. 3; Constitution, 1887, art. 18, sec. 14; 1916, art. 17 , sec. 8 . 


\section{CHAPTER X}

\section{Apprenticeship ANd the Helper System}

The Iron and Steel Workers, unlike many trade unions, have never attempted to establish a general system of apprenticeship. Certain apprentice regulations have from time to time been suggested for various branches of the industry, ${ }^{1}$ but they have not met with favor in the annual conventions, except in the case of the nailers. In I88I it was provided that "no nailer shall be allowed to take on an apprentice without the consent of three-fourths of the nailers in the factory in which they are employed," and the number of apprentices that might be taken on was fixed at "two per cent of the machines per annum." The following year, the convention passed a provision to the effect that a nailer having a son eighteen years old might teach him the nailing trade, but he was not allowed to instruct more than one son in three years. Furthermore, a nailer having a son who had reached the age of fifteen was not permitted to teach any other person. ${ }^{2}$ In case the workmen did not take on the required number of apprentices, the employer had the right to do so, if he desired, up to the two per cent limit. This ruling, however, caused considerable friction, and was responsible, in part, for the secession of the nailers several years later. Thereafter, the Association judiciously avoided any national apprenticeship regulations for any branch of the trade.

Where rules for apprenticeship were needed, the matter was dealt with locally. There have been several instances in which local unions have thus legislated. For example,

1 Vulcan Record, 1870, no. 6, p. 20; Proceedings, Iron and Steel Roll Hands, 1873, p. 8; Proceedings, Amalgamated Association, $1800,11.3134$, for wire drawers; 1900, p. 5930, for till plate mills: 1902, p. 6471; 1909, р. 8715; 1916, pp. I1, 825 .

2 Procecdings, 1881, p. $700 ; 1882$, p. 972. 
Forward Lodge (no. 121), of New Castle, Pennsylvania, composed of wire drawers who were employed in the nail factory, in I $\&$ o had local regulations governing apprentices, and introduced a resolution in the convention of that year providing an elaborate system of national control over apprentice wire drawers. ${ }^{3}$ Henry Cort Lodge (no. 8I), composed of roll turners of the scveral shops in Pittsburgh. required three years' apprenticeship to become a journeyman roll turner.* To what extent such provisions were made by local unions can not be determined from the scant references which have been recorded.

An apprentice system is impracticable in the iron and steel industry, in which workmen advance almost entirely by promotion. The Association, however, has always favored the employment and promotion of "helpers." A "helper" has been defined by Dr. Ashworth as "any person employed to help the skilled journeyman under whose supervision he works," as distinguished from an apprentice "who, by promise, indenture or covenant, for a specified time, is being tauglt the trade by a master of the trade or someone in his employ."s For example, in the puddling department, a pucdler usually has a helper and sometimes two helpers. ${ }^{\circ}$ They are employed to assist the puddler in his work, and are directly under his supervision. The helper proper gives the journeyman a spell. He takes hold of the paddle when cincler is put in to "thicken it up," that is, to make the flux. The second helper-commonly known as a "third hand," or "green hand"-generally breaks down the pig when it begins to melt, chocolate-like. He gives a "push" or a "shove" in drawing the heat, and does similar work that requires little knowledge or skill. The work of each " $1 n$ derhand" is so clearly understood by custom, that it is usually unnecessary to have specific rules defining it. Where

${ }^{3}$ Proceedings, 1800, p. 3134.

- Procecdings, 1891 , pp. 3510-3511.

- Ashworth, pp. 22-23.

"A puddler, if he can do the work alone, need not take on a helper, unless the company can show that he is retarding the output unduly. 
the work of a helper is made definite, it is done to prevent misunderstandings. The union encourages the promotion of helpers in regular order according to seniority, provided the workman next in line of promotion is able to handle the work. ${ }^{7}$ The advancement of helpers, however, is for the most part left to the employers. There is little or no complaint heard, since helpers are advanced automatically as vacancies occur. No helper can be employed who is under sixteen years of age.

The development of the helper system among the Iron and Steel Workers has been marked, in general, by two problems: $(a)$ the organization of the helper, and $(b)$ the hiring and paying of the helper.

(a) The early unions in the iron industry excluded unskilled and semi-skilled workmen from their organizations on the ground that the welfare of the trade demanded it. ${ }^{8}$ The Amalgamated Association changed this policy, and made helpers eligible to membership in the union." The term "helper" was defined as "the underhand or the as-

${ }^{7}$ In earlier times, however, the union placed certain restrictions upon the promotion of helpers. In 1872 it was provided that any puddler allowing his helper "to ball heats," without the consent of the mill committee, should be fined or expelled (Vulcan Record, 1872 , no. 10, p. 43). As late as 1891 , a resolution was discussed requiring each puddler's helper to "help one year and be six months a member of the association before he be allowed the privilege of boiling a heat." But the motion was lost (Proceedings, I881, p. 682).

The policy of the union with reference to the promotion of its members, as stated by the secretary-treasurer, is as follows: "The ranks of skilled workmen are filled by men who fill the minor positions; hence, we endeavor to prevent men from learning the skilled positions before they have served in the minor ones. If they are permitted to learn the skilled jobs, it would necessarily mean that those holding the minor positions would have no opportunity for improvement" (Report of Industrial Commission, 1901, D. 2I4). The line of promotion in the bar and guide mills is as follows: roller, catcher, rougher-down, rougher-up, hooker-down, hooker-11p, straightener, and finisher. In the guide mill, the workman analogous to the looker is called a "stranner": otherwise, the seniority ruling is identical. Frequently a roller does not employ a finisher, but does that part of the work himself.

8 Minutes of Heaters' Convention, 1874; Proceedings, Iron and Steel Roll IIands, 1874, p. 20; Vulcan Record, 1872, no. 10, p. 23 ; 1875, 110. 16, pp. 42,44 .

${ }^{0}$ Constitution, 1876 , art. 1 , sec. 1. 
sistant of all the trades named" in the constitution. ${ }^{20}$ The change of policy was due, principally, to two causes. In the first place, the journeymen were unable to control the helpers as long as they were unorganized or organized in separate unions. Moreover, the common interests of the two classes became more clearly recognized. The first of these reasons for organizing the helper was the most potent factor in persuading artisans to admit helpers into the organization. Experience had taught the journeymen that it was difficult, if not impossible, to control the mills if their helpers were unorganized or organized independently.

The Sons of Vulcan, in I 867 . suggested "the propriety of organizing a helper's union, subordinate to the local forge," and that the helpers should "meet separately" and "be superintended by at least three members of the sub-forge, who shall be called superintendent, president and vicepresident." ${ }^{11}$ It was proposed that the helpers be assessed for strike purposes one-half as much as puddlers, and receive relief in like ratio. Whether any such local unions of helpers were instituted, cannot be said. ${ }^{12}$ But in 187 I the puddlers' helpers of New Albany, Indiana, were on strike, and voluntary strike relief was collected for their support amounting to \$149. The men, in a letter of appreciation to President Hugh McLaughlin, expressed a desire "to be in some shape connected with the [puddlers'] organization." ${ }_{13}$ The fact that puddlers' helpers held meetings, declared strikes, and solicited strike benefits indicates the existence of at least a desultory local organization. Again, in I873, the puddlers' helpers in Chicago called a strike contrary to the wishes of the puddlers. The president of the Puddlers' Union, in his report to the convention, intimated that these helpers had an independent local organization. ${ }^{14}$

${ }^{10}$ Procecdings, 1877 , p. 50.

11 Vulcan Record, 1867, no. 1, pp. 10, 11, 18.

12 It is doubtful, for, in 1872 , the president called the attention of the delegates in convention to "the necessity of having the helpers organized," so as to assist each other in case of strikes (Vulcan Record, 1872, 110. 10, p. 23).

${ }^{13}$ Vulcan Record, December, 1871, no. 9, pp. is-19.

14 Ibid., 1873, no. 12, pp. 11-12. 
Not only were helpers likely to go on strike contrary to the will and interest of journeymen or "fore hand" puddlers, but sometimes they acted as strike-breakers. When the puddlers had trouble with employers, the helpers did not always go out on strike with them. The reason usually given for failing to cooperate was that the helpers had no organization and were not assured of strike benefits. The president of the Sons of Vulcan urged that helpers, in order that their support might be secured, be admitted to the union. As a substitute measure, the plan of half-assessment and proportional strike benefits for the support of helpers on strike was adopted. ${ }^{15}$ In Chicago the helpers refused to accept this plan and formed an association of their own. Later, when a new workman was employed contrary to the wishes of the helpers, they went on strike. The puddlers continued to work, and striking helpers went to Knightsville, Indiana, and, by taking the places of boilers who were then on strike, helped to defeat the boilers in their contest against the employer. ${ }^{18}$ Such action made it difficult for the journeyman puddlers to control the shops in that trade.

It is a significant fact that not until other expedients to control the helpers had failed did the Amalgamated Association adopt the policy of admitting them as members. In 1876 the more advanced helpers were admitted into the union, ${ }^{17}$ but not until 1889 did the union open its doors to all men working in and about iron and steel mills. At that time, the Knights of Labor were making inroads upon the jurisdiction of the Amalgamated, initiating in droves all classes who sought admittance, including common laborers. ${ }^{18}$ The Association, in order to meet this competition and to avoid trouble in the future, legislated so as to have complete control of all men working in and around mills. The present policy is to prevent as far as possible any discrimination

\footnotetext{
15 Ibid., 1872, no. 10, p. 48 .

16 Ibid., 1873, no. 12, pp. 10, 11, 12.

17 For a time these helpers suffered discrimination (Proccedings, 1877, p. 50).

18 Sce chap. iii.
} 
of the more highly skilled workmen against the unskilled, or common laborers.

A less important motive for organizing helpers was a growing consciousness of the common interest of all classes of workmen. If a journeyman lacked any of his assistants, his work was hampered. He must either do all the work himself or combine with other crews. In either event, earnings were greatly reduced. On the other hand, if journeymen were kept from work, their helpers were left unemployed. This intimate relationship and mutual dependence has, doubtless, served to turn sentiment in favor of a more democratic organization.

(b) The problems involved in the hiring and compensation of helpers have been, in the main, two: (I) who shall hire and pay them, and (2) how much shall they be paid.

As pointed out in a previous chapter, it was customary in the early history of the iron industry in this country for the puddler and the roller to be responsible for the work in their respective departments. They hired and paid their assistants. With the introduction of the manufacture of steel, shect-iron, and tin plate, the same plan of cmploying helpers was adopted, ${ }^{19}$ and the system was established throughout the industry. ${ }^{20}$

Within recent years, it has been the policy of the union to have all helpers paid from the offices of the firm. This method has two advantages. Obviously it is more convenient, and it is immaterial to the firm whether the whole amount be paid to the heads of the various crews or to the individual workmen. In the sccond place, this system of payment by the employer is conducive to a uniform wage rate for helpers doing the same grade of work. Otherwise the helpers may not abide by the union scale. Since a roller

19 The hiring of "green hands" was, in 1900, subject to the approval of the mill committce (Proceedings, I900, p. 5873).

20 The nature of the iron and steel industry is such as to require a certain number of helpers, and at the same time to make it difficult for helpers to encroach upon the work of the journeymen. For this reason, the helper system is not distasteful to the workers and helpers are naturally considered the rightful learners of the trade. 
or a puddler is obliged to have help, ${ }^{21}$ the terms which a helper is likely to make with his contractor will then be determined by supply and demand. With so many employers, competition is sure to produce non-uniformity in the wages of helpers. This breach of union regulation can not easily be detected, since the wage agreement is known only to the journeyman and the helper. When the helper is paid by the firm, it is difficult to evade the law. The rate of pay for helpers is printed in the wage scale, and it can be violated only by rebate to the head of the crew or by extra wages paid to the helper.

While the policy of the union has been to favor the payment of helpers by the firm, it has never favored the hiring of the helpers by the firm. In 1899 the convention adopted the following provision, which has since been inserted in the constitution: "All men are to have the privilege of hiring their own helpers without dictation from the management." 22 The union justifies its position on the ground that each journeyman is closely associated with his helpers, and is held responsible for the work turned out by his crew; consequently, it is advisable that the head of the crew have the privilege of selecting his own assistants. Again, since the output of the journeyman, and accordingly his earnings, depend upon the efficiency of the help employed, the hiring of the help by the journeyman shifts the responsibility from the employer to the "captain" of the crew.

The chief concern of the Amalgamated Association in connection with the employment and payment of helpers, however, has been not who shall hire and pay them, but how much shall be paid them. The Puddlers, as early as 1870 , considered the subject of uniform wage rates for helpers, and a petition was submitted to limit the amount

21 In 1904 it was provided that "all rollers, doublers, and heaters," in tin and black plate mills, were "required to employ helpers at all times," under penalty of fine, suspension or expulsion (Proceedings, 1004, P. 7104 ).

22 Procecdings, 1809 , p. 5684 ; 1907, p. 8060 ; Constitution, 1916, art. 17, sec. 21 . 
which should he paid a helper to "one-third," and in case of two helpers, "one-half of what the furnace makes." The committee to which the resolution was referred expressed itself in favor of the proposition, "but," the report continued, "to make it uniform through the action of this 'national forge would be impracticable," since all localities - were not "a unit upon the subject." 23 The matter was referred to the subordinate unions for local treatment. The following year the deputies were authorized to call general meetings of "fore hand" boilers, or puddlers, with a view to establishing the "one-third rule" of paying help. ${ }^{24}$ No definite action was taken, however, and the subject was brought up at subsequent conventions of the national forge. ${ }^{25}$

Gradually the "one-third and five per cent" rule for the payment of puddlers' helpers was adopted in the various districts, and in 1891 it was made a national provision. ${ }^{26}$ A number of local unions, particularly in the sixth, or western, district, protested on the ground that it reduced the wages of boilers "seven and one-half per cent," but the convention refused to reconsider the matter. ${ }^{27}$ Uniform wage rates for helpers in all departments have from time to time been established. In sheet and tin mills, they were paid a specified rate per turn, and until 1905 the limit of a turn's work was fixed. Since then, they have been paid a piece rate. In nail factories, helpers were sometimes paid a fixed rate per heat. At present, heaters' helpers in jobbing mills receive thirty-five per cent of heaters' wages, in

23 Vulcan Record, 1870, no. 6, p. 20.

24 1bid., 1871 , no. 8 , p. 23 .

25 Ibid., 1872 , no. 10 , p. 43 ; 1875, no. 16, pp. $44,58,62$.

26 Proceedings, 1891, pp. 3274-3275, 3279.

27 Ibid., pp. 3325-3326. This enactment caused ill feeling among puddlers in the West and there was talk of sccession. The Advisory Board, in order to maintain harmony, construed the law to mean "onc-third and five per cent on the net earnings of the boilers" rather than "on the whole output of the boiling furnace" (Proceedings, 1802 , pp. $3849,3857,3952,3984)$. For example, if the output of the furnace amounted to $\$ 120$, the helper would get onc-third of $\$ 120$ or $\$ 40$, plus five per cent of $\$ 80$ (not $\$ 120$ ), or $\$ 4$, making a total of $\$ 44$-his share of the two wecks' picce-wage. 
sheet mills, forty per cent. These rates are understood to be a minimum price. The helper may receive more than this if he can secure it from his employer. Very often, particularly in the boiling department, the journeyman and his helper work "level-handed," and divide the earnings equally. The constitution provides that "no member shall be permitted to discharge a helper, except for just cause," nor "reduce the wages of a helper during the scale year."

A minor question in the recruiting of the trade that has caused considerable discussion in the conventions of the union has been-in the vernacular of the workmen-" "the practice of learning green hands." The objections to this practice were: (I) more men were drawn into the trade than the trade could absorb, and (2) an incentive was thus given to employers to reduce wages. The convention of I 878 passed a law forbidding members to give instructions to "green hands" $;^{28}$ but a mechanic was permitted "to learn his sons and brothers." By a "green hand" was meant any person who had not worked at any of the trades under the jurisdiction of the union, and consequently was not eligible to membership. This rule, however, did not put an end to all disputes in this regard.

28 Proceedings, 1878 , p. $133 ; 1879$, p. 230. 


\section{CHAPTER XI}

\section{Collective Bargaining}

Every trade union finds it necessary to devise methods to enforce its rules. The most usual of such methods is that of collective bargaining. ${ }^{2}$ This method of enforcement is supplemented in some unions by the boycott, ${ }^{2}$ and the union label. ${ }^{3}$ The two latter devices have been unimportant in the iron and steel industry.

Developments in the method of collective bargaining in the iron and steel industry have moved pari passu with changes in the area governed by uniform prices. As pointed out in a previous chapter, ${ }^{4}$ the extent of territory over which the standard rate of wages is binding has been gradually enlarged.

The Iron and Steel Workers were the first union in the country to introduce a system of regular annual conferences at which joint agreements are made between employers and employed. These agreements cover both wages and the conditions of cmployment. The system of joint agreements in the iron trade had its beginning in a joint conference resulting in an agreement covering the wages for puddling in 1865 . The puddlers had frequently made demands upon

${ }^{1}$ Legal enactment has played an inconspicuous rôle in the enforcement of the demands of the Iron and Stecl Vorkers.

2 The hoycott has been tricd by the Amalgamated on several occasions (National Labor Tribunc, April I7, I886, p. I, col. 5; November 17, 1888, p. 4, col. I ; Proceedings, 1888, p. 2357; 1906, p. 7554), but this weapon has never been important in the successful outcome of any conflict.

3 The association adopted a union label in 1905 (Proceclings, 1905, p. 7442). It was used by two companies-the Champion Horse Shoc Company, of Pawtucket, R. I., and the Kansas City Nut and Bolt Company, of Kansas City, Mo. The adoption of the label did not bring as gratifying results as its advocates anticipated. The product of iron and steel mills is sold to individuals belonging to the employing class, who are not attracted by the label.

4 Chapter vi. 
their employers for increases in wages. There had been many strikes, chiefly in the mills around Pittsburgh in the years previous to 1865 . In 1849 and again in 1857 there were extended and prolonged strikes, and after I 857 smaller strikes were numerous. ${ }^{5}$

The conference of 1865 was desired both by the union and the employers. The initiative seems to have been taken by the employers. ${ }^{6}$ The puddlers, in concert with representative employers, finally established a scale of prices to be paid for boiling pig iron. The amount to be paid for boiling iron ranged from $\$ 4$ a ton, if iron was sold for $2^{\mathrm{t} / 2}$ cents a pound, to $\$ 9$ per ton, if the price was $8 \mathrm{r} / 2$ cents per pound. This is the first recorded sliding scale in the United States. ${ }^{7}$ The depression following the Civil War reduced prices to such an extent that the scale was repudiated. Two years later another joint conference drafted a new sliding scale. This agreement, with slight

5 For a review of labor conditions in the iron trade previous to the activity of the union, see the account of Miles S. Humphreys, first president of the Puddlers' union, in the Report of the Pennsylvania Bureau of Industrial Statistics, 1878-1879, pp. I50-15I.

${ }^{8}$ The plan of the sliding scale was suggested by B. F. Jones, of Jones and Laughlin's American Iron Works, Pittsburgh, and a tentative draft was made by Mr. Humphreys for submission to the employers (National Labor Tribune, April I4, I888, p. 2; Pennsylvania Bureau of Statistics, I887, p. G 2). A copy of the scale of r 865 may be found in the National Labor Tribune, February 7,1874 , and in the report of the Pennsylvania Bureau of Statistics, I887, p. G I5.

7 There were no doubt sliding scales in England before this time. S. J. Chapman says: "The first sliding scale was Thornicroft's, which was introduced in 1840" (Econ. Journal, I903. "Some Theoretical Objections to Sliding Scales," p. I 86, note). Carlyle, writing in 1843, mentions "sliding-scales" (Thomas Carlyle, Past and Present, pp. $36,180,242$ ), but he may have had in mind the sliding scales of tariff duties. However, the Webbs, relying upon a statement furnished by Mr. Daniel Jones, of the Midland Iron and Steel Wages Board, to Professor Munro, and cited in the latter's "Sliding Scales in the Coal and Iron Industrics," P. I4I, point out that the sliding-scalc arrangement appears to have been familiar to the iron trade as early as the time when Carlyle wrote. "At the time of the great strike of Staffordshire puddlers in 1865 ," the Webbs further state, " a local understanding of a similar nature appears to have been in existence." Its introduction into the coal tracle of Great Britain dates from 1874, though it was not until 1879 that its adoption becanne widespread (Sidney and Beatrice W ebb, History of Trade Unionism, Appendix ii, pp. 484-485). 
modification, ${ }^{8}$ was not terminated until 1874 , when the manufacturers forced a strike against a reduction of wages. The strike lasted during the winter of $1874-1875$, and ended with the manufacturers individually signing the scale.

In the course of time, the iron trade became specialized and split up into several branches. New methods of manufacturing soft steel enormously enlarged and changed the industry. Tin mills began to be built more extensively in the early nineties, and the manufacture of tin increased by leaps and bounds. Through all the changes, the Amalgamated Association clung to the old tradition, and endeavored to include all the new branches in the scale and to cover the whole of the country: ${ }^{9}$ Its passion for extension and completeness prevented the growth of geographically sectional societies such as exist in England and Scotland, or the separation of the steel workers from the iron workers. And throughout, the Amalgamated Association has held to its policy of annual conferences and joint agreement to sliding scales.

The original scale was signed by a committee of the puddlers and a like committee which represented the entire group of manufacturers. The strike of 1874 put an end to this practice. Since that date, the union has formulated its scale, and has presented it for signature to individual

8 A slight technical change was made in 1871 , cutting up the divisions of advance or decline into tenths, instead of quarters, of a cent per pound in the price of pig iron. In Ig08 a further change in the system of computation was made. The rate was subdivided into twentieths (Proceedings, 1908, pp. 8246-8247). This modification has continued to datc. A copy of the scale of July 23, I867, may be found in the report of the Massachusctts Bureau of Labor, 188I, p. 12; also in the Vulcan Record, December, 1873 , no. 13, p. 36 . The scale of April 14, 1875, is printed in the Vulcan Record, 1875, no. 16, pp. 34-35. The first scale in the finishing departments was a scale for guide mill rolling. April, 1872. A copy of the agreement is recorded by Jos. D. Weeks in the report of the Massachusetts Burcau of Labor, 1881 , p. I4.

- The scale of 1881-1882 was a pamphlet of fifteen pages and covcred fourtecn items. In 1890 there were separate pamphlets for iron and stecl, the iron scale having thirty-one pages and the stcel thirtyfour. The Western Scales of Prices for 1916-1917 contained fiftyfour pages. 
employers. In I 882 an association of manufacturers was instituted in Pittsburgh. The avowed object of this organization was "to attend to wages and labor."10 When the conferences between the union and the manufacturers failed to result in an agreement, the scale was presented by the union to individual firms. Frequently, as for example in 1885, after one employer had signed the union scale, the rest, although reluctant, would follow suit. ${ }^{11}$ In 1888 a committee of manufacturers appeared personally before the delegates of the union assembled in convention. The arguments of the employers, however, had little weight, and no general conciliatory agreement was reached. The association of manufacturers was again dissolved, each member being authorized to act in his individual capacity relative to signing the scale. In I 890 the union held a conference with the Pittsburgh Iron Manufacturers, and the scale thus arranged was presented to mills in the West and South for signature. ${ }^{12}$

In 1893 the plan of holding divisional conferences was adopted. There were three divisions: one for the boiling department, including also scrapping and busheling, muck mill rolling, and knobbling; another, for the manufacturers of bar, guide, plate, structural and jobbing; and a third, for sheet, tin, and black-plate manufacturers. ${ }^{13}$ Later, separate conferences were held with the sheet and the tin-plate

10 The immediate purpose of the formation of an employers' association was to resist the union demand for a $\$ 6$ per ton boiling rate in 1882 ; and it was effective in doing this, as the outcome of the "Pittsburgh strike of 1882 " bears testimony. It was distinct from the Western Iron Association, whose primary function was to fix prices. The organization was known as the Amalgamated Association of Manufacturers of Iron, Steel and Nails; its elected officers were A. F. Keats, president, and Joseph D. Weeks, secretary ( National Labor Tribune, June 17, 1882, p. 4, col. 2; January 24, I885, p. 4, col. 2). The need of such an organization of employers was urged by such organs as the Iron Age (quoted in the Iron Molders' Journal, September 10, 1876) and the Journal of Industry (Pittsburgh), June $22,1880$.

${ }_{11}$ National Labor Tribune, 1885, issues of May 9, 30, June 6, г3. 20 and 27.

12 Proceedings, 1891, pp. 3357-3359.

13 Proccedings, $1893, \mathrm{pp} .+202-4203$. 
manufacturers. ${ }^{14}$ In I 899 because of alleged dissatisfaction with the Conference Committee, President Shaffer was authorized to request the manufacturers to meet all the delegates of each craft and settle the scale during the convention. The manufacturers replied that they considered it "impracticable" because of the various combinations of employers then pending. ${ }^{15}$

In 1900 the situation was as follows: four scales were drawn up annually by as many divisions of a general conference committee appointed by the annual convention of the Association, ${ }^{16}$ in consultation with the several interests involved. The employers were no longer represented, as they had been, by associations of manufacturers, but by single great companies which had supplanted the individual employers. Thus, one division negotiated a scale for puddling (that is, boiling) and allied processes with the Republic Iron and Steel Company, instead of with the Association of Bar Iron Manufacturers, because the company now included most of the muck and bar-iron mills. ${ }^{17}$ A second division made an agreement with the same company covering the prices of iron bars and plates and similar products. A third conferred with representatives of the American Sheet Steel Company, which included nearly all the sheet-stecl mills in the country, and no longer with an Association of Iron and Steel Manufacturers. Finally, a fourth negotiated with the American Tin Plate Company, which had brought together nearly all the tin-plate mills.

14 In 1808 the conference on puddling and bar mill prices failed. The matter was referred to a vote of the membership. The local unions decided to have a joint meeting of all lodges, and have the conference reconvened. Accordingly, 9I delegates from the local unions met the employers in conference on July $3 \mathrm{I}$-an unusual event.

15 Proceedings, 1899 , p. 5598.

10 The conferees have heen appointed by the president, as a rule; in 1896 , however, one division elected its own committec, while the others were appointed by the president, subject to the approval of the delegates (Proceedings, 1806, p. 4995).

17 The American Steel Hoop Co. (formerly known as the Carnegie Hoop and Steel Co.) refused to meet in conference with the Republic (Proceedings, 1003. p. 6572). Consequently separate conferences were granted until the Carnegic mill severed relations with the union several years later. 
The scales in no case applied to unskilled laborers, not members of the union. Uniform annual agreements covering a majority of plants obtained in most branches of the trade in 1900; for example, prices were set for bar iron, various special forms of iron, sheet steel, and tin plate. On the other hand, conditions in steel-rail mills and in other classes of mills differed so greatly that uniform scales proved impracticable. In such establishments separate agreements were adopted from time to time. These were in the nature of local agreements and were not settled by the general conferences.

For some years after the formation of the United States Steel Corporation in I90I, two general conferences were annually held, the one known as the bar, and the other the sheet and tin conference. At the former the Republic Iron and Steel Company, the largest manufacturer of bar iron, dealt with the union. At the latter the American Sheet and Tin Plate Company, which was organized in 1903 by the merger of the American Sheet Steel Company and the American Tin Plate Company, represented the employers. In 1906 the independent manufacturers of bar iron, who had previously signed the scale agreed upon in conference with the Republic, organized the Western Bar Iron Association. This association is composed of twelve independent companies, organized because of the mutual interests involved in the competition with steel. One of the essential functions of the new employers" association is "to act as an organization with the Amalgamated Association and endeavor as far as practical to get a uniform rate and practice."18 Since that time, the scales arranged with the Western Bar Iron Association and the Republic Iron and Steel Company have been identical.

In 1909 the American Sheet and Tin Plate Company severed conference relations with the union; and the sheet and tin conference has since been held with the Western, sometimes known as the Independent, Sheet and Tin Plate

18 Proceedings, 1906, D. 7550. 
Manufacturers, who had previously signed the American Sheet and Tin Plate agreement.

At present, then, two associations of manufacturers-the Western Bar Iron Association ${ }^{19}$ and the Western Sheet and Tin Plate Manufacturers' Association-are organized for the purpose of dealing collectively with labor. Mr. James $H$. Nutt, sometime trustee of the Amalgamated Association, acts in the capacity of secretary for both employers' organizations. In addition to the function of collective bargaining, these associations at their meetings, held whenever there is important business to transact, act on the tariff and discuss trade conditions, prices and other topics of common interest. Only those manufacturers who make agreements with the union are members of either employers' association. Assessments are made by the secretary to meet the expenses of the preceding month on the basis of the number of trains of rolls in each mill. There are only slight differences in the capacities of the mills represented, and each member has one vote. ${ }^{20}$ In 1916 , the Western Bar Iron Association had fifteen members; the Western Sheet and Tin Plate Association, ten.

The joint agreements consist chiefly of scales of wages for different classes of work. The agrcement fixes first the base rate in each branch of the industry, such as boiling, busheling, etc. The sliding scale with a fixed minimum is based upon the market price of bar iron, and adjustments are bi-monthly.

${ }^{19}$ The Republic Iron and Steel Company abides by the Western Bar Iron agreement.

20 The employers' associations appoint conference committees to represent all the manufacturers who are members. Each employer usually sends a representative. Each committee has as its chairman Mr. Nutt, who is satisfactory to all interests. In 1905 the Republic sent but one official. The representatives of the union are appointed by the president. In recent years there were five from each of the four main divisions. The tin house, however, is generally represented by but one or two members. The president, vice-president and secretary are ex-officio members of each conference. In 1916 there were 15 conferees in the sheet and tin, and 13 in the bar-iron conference. 
The principle of the sliding scale is not very clear. Mr. Miles S. Humphreys, one of the originators of the scale, said:

Iron had never sold below two cents and a half, and the puddlers at the time had no idea the selling price would go below three cents. The cost of living and the cost of production did not enter into the consideration at all; only a fair proportion of the profits or of the selling price. ${ }^{21}$

However, we do find one writer for the official organ of the puddlers trying to determine, in 1874 , what the base of the scale should be in terms of the prices of commoditiespotatoes, flour, meat, ${ }^{22}$ etc. The testimony of Mr. Humphreys is essentiaily corroborated by Mr. John Jarrett, the second president of the Amalgamated Association. He said, in substance: The puddlers realized that the profits of iron manufacturers were enormous and that wages were out of proportion to profits; but they had no actual figures to determine what these profits were. The scale was an experiment; and, though not based on absolute knowledge, the rate was constantly increased. The union was trying to hit upon a reasonable and equitable proportion. The puddlers in Great Britain got a shilling to the pound of the selling price, that is, one-twentieth, and a bonus increased it to one-sixteenth. American puddlers decided they ought to get one-twelfth, because of superior resources and better management. Such were the considerations. ${ }^{23}$

21 Interview, November 30, 1914.

22 "The great question to be settled when an advance or decline of wages is proposed is: Does the present rate of wages leave the proper margin between the cost of living and what should be the reserve fund? If the usual margin is reduced, then wages should advance. If the margin is too large, then wages could come down without damage. ... That all parties may be informed in the premises occupied by the boilers and puddlers, we give in pounds and measures the quantity of the nine principal commodities (flour, liam, sugar, tea, molasses, potatocs, rice, coffee and beef) used for living that the price per ton of hoiling would procure at our wholesale houses in each quarter [of the years $1871-1874$ inclusive], having been careful to make a weekly average, then monthly, and quarterly, D. P. H." (National Labor Tribune, December 19, 1874, p. 1).

23 Interview, November 28, 1914. 
It is significant that the views of the present officials of the union do not greatly differ from these given. Both the president and the secretary hold that the scale is fixed "on a common sense basis." It is a matter of "give-and-take." The association through its conference committee endeavors to calculate the cost of production, although the committee has no exact data. The main consideration is this: If the price of iron advances, they fecl the men ought to have a "fair" share. Just what is meant by" "fair" is uncertain; "they take what they" can get." it is apparent that the scale has not developed in accordance with scientific principles. The scale was not made; it grew.

The base of the scale has been subject to relatively little change. It has ranged from $\$ 4.00$ (the lowest) to $\$ 5.50$ (the highest). The progress due to science and invention is largely reflected in the corresponding minimum selling price. For example, the scale for boiling in $\mathrm{I} 6_{5}$ was based on a $2^{1 / 2}$ cent minimum ; for $1887-1888$, on a two-cent card ; since I90I, on a one-cent card. In the present scale, the differentials below the $\frac{3}{10} \mathrm{ct}$. rate are small, because the manufacturers claim they are either running the mill at a loss or else they are barely covering expenses and keep the mill running for the sake of the machinery. The union accepts the truth of this statement. "We know," said one union official, "that at one cent the manufacturer can't make a profit; it isn't in the business." At $\mathrm{I}_{1}^{3} 0$ ct., it is alleged, the employer begins to run the plant at a profit, and the differential is greater. Instead of ten per cent, the advance in wages is nearly twenty per cent of the increased selling price.

Until I 895 the market price was based on the card rate of the Western Iron Association (an organization whose sole function, it appears, was to fix prices). This scheme caused considerable friction, because iron was frequently

\footnotetext{
24 Interviews with President John Williams, and Secretary-Treasurer M. F. Tighe, September 30 and October 19, 1916. For an example of an estimate of cost of production, see Procecdings, 1895, pp. $4781-4782$.
} 
reported to be selling above the official card rate. ${ }^{25}$ In June, I895, an agreement was made with the bar-iron manufacturers that prices should be based on "the average selling price of base sizes of bar iron." This estimate of the average price received for the total product sold during a sixty-day period by all mills represented in the Association fixed the wage rate for the succeeding two months. The manufacturers furnished the secretary of their association with a sworn statement of prices; and, in case of doubt, a committee of the union might examine the employers' books and bills of sales. ${ }^{26}$

The number of mills entering into these settlements has varied. In 1907 only the mills of the Republic Iron and Steel Company and the independent plant of the Union Rolling Mill, Cleveland, were represented in the bar-iron settlements. The sheet and tin prices were submitted by the American Sheet and Tin Plate Company. This was sometimes a cause for complaint, since the independent firms alleged that the "trust" at stated periods paid their selling agents one dollar per ton "rebate," whereas their original quoted prices did not include this differential. The union, in rejoinder, said that the American Sheet and Tin Plate Company had granted the advance to union and nonunion mills alike, and thus maintained "the same relative competitive position" as previously. The average prices for 1915 were based on returns from four selected mills in the case of boiling and finishing, and on three plants each for sheet-mill and tin-plate workers. ${ }^{27}$

The foot-notes determine the working conditions. Until I905, they set certain limits upon output. At present, they fix prices for "extras," or special classes of articles, and make provision for shields on furnaces, supply of top buggies, payment for lost time, and payment for spoiled mate-

25 Financial Statement of the Amalgamated Association for quarter ending January 3I, 1887; National Labor Tribune, Jamuary 24). 1887, 1. 4, col. 1; March 3I, 1888, p. 4, col. 2.

26 Proceedings, 1806 , pp. 5014-5010.

27 Procecdings, 1916, p. II, 514. 
rials. The footnotes also prescribe the number of helpers in some branches of the trade, and the sources of their wages; the number of rollers to be employed in each mill; the proportion of helpers' wages to that of skilled men in some instances, etc.

In the case of steel-rail mills, and various other classes of mills not covered by the uniform scale, the local agreements establish sliding scales based either upon the general scales, with allowances for local conditions and peculiarities, or based upon the prices of steel rails and other articles as published in standard trade journals.

Since the consolidation of the several unions in the iron and steel trade in 1876 , the agreement has never been allowed to lapse. It has alway's been renewed and has steadily increased in scope. The agreement each year has usually represented a compromise between what the union asked and what the employers were at first willing to grant. In addition to the reasons which make this true in every trade agreement there are two reasons peculiar to the Amalgamated Association. The scale is in two parts-the base rate and the footnotes. Since there has been relatively little change in the base rates during the life of the agreement system, changes come principally through the footnotes. The officials of the union have found it to their advantage to demand a new agreement, even though few changes are expected. Many footnotes are requested, which the union leaders do not expect to be accepted. Others are presented in the hope that they may be accepted by the manufacturers on their face value or pass through as "jokers." A footnote once included is not easily eliminated.

The first scale was not signed for any particular period; it was simply made effective from a given clate. but it was tacitly understood to last for a year at least. Ninety day's' notice was required to terminate the agreement. The termination period was reduced to thirty days in the I 867 agreement. In May, IS 76 , the union submitted to the con- 
ference a time-limit of one year to the life of the agreement, and effectively enforced this demand. The puddlers for the first time in the history of the organization enjoyed the assurance of work continuing for one year at least. This was hailed with delight, and the triumph thus scored has endured to the present.

Since 1876 , then, the agreement has operated for one year, originally from June I to May $3 \mathrm{I}$; and later, from July I to June 30 . The union has, from the very beginning, been insistent that the scale shall terminate in the summer, and not during the winter months when the men are least able to offer effectual resistance to employers' demands. Employers would prefer a long-time agreement-three to five years-since in the history of the agreements there have been few periods of decreasing wages and since they feel that a more settled condition of the trade would obtain under a long term wage contract. The union prefers a one year agreement.

The constitution of the union stipulates the methods to be used by the workmen in securing the adoption of the general scales. Any local union desiring a change in the scale must, after a formal vote in its favor, submit it to the national union. The national union, at least six weeks prior to the meeting of the annual convention in May, distributes to the local unions a printed copy of all proposed amendments to the scale. These proposals are discussed in local meetings and delegates come to the convention under instruction as to the wishes of their respective constituencies. A wage committee, appointed by the president. considers these proposals, and makes recommendations to the convention. It is decided by ballot what demands are to be made in conference with the manufacturers. A twothirds vote of the delegates is required to recommend a change in the "base" of any existing scale. Nominally the convention adopts a scale, but in practice the terms are sulject to modification by conference with the employer. 
At the annual convention the president appoints a conference conmittee to meet the manufacturers. The number of conferces selected to represent the workmen has varied. The prime requisite is that each department shall be adequately represented. This was peculiarly necessary in the early years when all branches met the manufacturers in one general conference. Linder the system of divisional conferences, naturally, members of the interested group are chosen. For example, in 1901, nine members represented the boiling department and in conference with the representatives of the Republic Iron and Steel company established a scale for boiling iron and the allied processes of scrapping, busheling, muck-mill rolling, and knobbling. A second division of the conference committec consisted of eleven members from the bar, guide. plate, and structural departments, and from jobbing mills working pipe iron. This division, in connection also with the representatives of the Republic Iron and Steel Company, adopted scales for a considerable number of different products falling under the heads indicated. A third division consisted of nine members of the steel and jobbing mills, who conferred with the members of the American Sheet Steel Company. Finally, there was a division composed of nine representatives of the tin and black-plate mills and timning houses, who conferred with the representatives of the American Tin Plate Company. The president and secretary of the union were members of all the divisions.

The members of the employers' associations or of the industrial combinations usually send to the national conference one or more representatives from each plant. The number of conferees representing the manufacturers has varied greatly, the large corporations sometimes negotiating through one or two officials. In 1905 the Republic sent but one official; in IgoI the American Shect and Tin Plate Company sent two. At present, the two employ'ers' associations usually have a fair representation of members. As a matter of fact, however, it is not essential that there shall 
be an equal number of employers and employees at the conferences. Votes are not taken jointly, but the members of each side stand together and continue negotiations with the other side until an agreement is reached. In connection with each proposal that requires formal action, the representatives of the two sides adjourn for separate caucuses, and, by vote among themselves, decide as to the position which shall be taken. If these two votes iail to result in an agreement, further negotiation in joint conference tales place. ${ }^{2 s}$

The extent to which conference committees of the union were bound by the instructions of their constituents has been an important feature in the development of collective bargaining among the Iron and Steel Workers. In the early years of the scale convention, the conference committee had no power to act whatever. It was simply "messengers of the Association to carry its dictates to the manufacturers." 29 Later, the committee was given certain limited powers. For example, in I885, it was instructed by the scale convention to demand the old scale, but, "if necessary, to accept a reduction of ten per cent upon all scales, except the sheet and jobbing mill scales." 30 In other years, the committee was given discretionary power on "extras" and "iootnotes," but not on the "base" of the scale.

The Homestead disaster served to accentuate the need of a more liberal policy. President Weihe, upon racating his office, voiced this sentiment in these words: "The aim of trade unions should be to remedy the strike system, by either adopting a method of arbitrating between them and employer, or granting conference committees more discretionary powers to overcome these bitter struggles that have so frequently taken place during the past few years." 31 In

${ }^{28}$ In 1901, if one or more of the divisions of the conference committce failed to reach an amicable agreement, the general conference met and endeavored to adjust the matter.

22 President John Jarrett's report to the convention, Proceedings, 1883, p. 1102.

${ }^{30}$ Proceedings, 1885 , p. 1551 .

${ }^{31}$ Financial Statement of the Association for the quarter ending October $31,1822$. 
1894 , after a spirited discussion, the conference committee was given plenary power. ${ }^{32}$ President Garland maintained this authority during his term of office.

President Shaffer was not so successful as his predecessor in preserving the prerogatives of the conference committee. Consequently, in 1900 , when full authority was withheld, the failure to reach an agreement in conference with employers meant the submission of the point at issue to a plebiscite of the local membership. ${ }^{93}$ President Shaffer, in his report to the following convention, deprecated this restriction of the power of the committee, ${ }^{34}$ but his eloquence was of no avail. The convention sent to the conferences of Igor committees bound by instructions to demand that the scale be signed for all mills or none. The steel strike of Igo I was the outcome of this policy. Since rgor the instructions of the convention have been advisory, not mandatory, and the conference committec has been granted plenary power to bargain.

In the case of rail mills and other classes of steel mills not covered by the general agreements above described. scales were adopted by conferences between the local union or unions affected and the individual employers. According to the constitution, the local lodges must formally vote upon proposed changes in scales. The holding of meetings by members of the organization outside the lodge room, for the purpose of "agitating" class legislation, was prohibited. A two-thirds majority was required to propose changes in the scales. In each plant there was a mill committee, or two or more committees, representing different classes of work. These committees presented the proposed changes

\footnotetext{
32 Proccedings, 1894 , pp. 4697-4698.

33 It required two-thirds of the voting membership to insist upon the demands which gave rise to the disagrement. If the local lodges insisted upon disagreement, all the members working in plants affected by the scale must cease work. As a matter of fact, there have been few gencral stoppages caused by failure to reach a settlement, although negotiations have been, in some instances, greatly prolonged.

34 Procecdings, 1901, pp. 6033, 6049-6050.
} 
in the scale to the officers of the company for adoption, and informal conferences for discussion of the terms were held. If an agreement was not reached, the case was referred to the district executive committee of the union, which conferred with the manufacturers. In case of failure to sign a scale before June 20, all departments of the establishment ceased work at that time.

The Association has consistently adhered to the principle of conciliation, and opposed the method of settling disputes arising under the agreement by arbitration. The makers of the original constitution provided for arbitration, but the convention in 1876 provided for settlement by "conciliation." 35 The officials of the union have repeatedly maintained that conciliation was the only equitable method of reaching a settlement, because no outsider understood conditions as well as the two parties involved.

All disputed questions are settled, if possible, in the mills in which they arise. These matters are taken up with the management by the mill committees, usually composed of three members, who represent the workmen in the different branches of the trade. If the dispute cannot be adjusted by the local committee, it is referred to the district executive board. Such questions usually relate to the wage scale or to trade usage. There must be no suspension of work while the committee has the matter under consideration. All decisions of the executive committee are binding until reversed; neither can an employer refuse to continue any one in his employ under the conditions laid down, nor can any workmen refuse to continue at work on those terms.

35 Article 1, section 2, of the original draft read: "The objects of this Association shall be to obtain by arbitration, or by other means that are fair and legal, a fair remuneration to the members for their labor. ..." The idea of arbitration being obnoxious to the delegates, the word "conciliation" was used in licu of "arbitration." The early Puddlers' union, it would appear, did not oppose certain methods of arbitration (Vulcan Record, 1872, no. 10, p. 33; 1873. no. [2, 1. 20); but the Amalgamated has been decided in its opposition (National Labor Tribute, September 23, 18S3, 1. 4, col. 1 ; May 31, 1884, p. 4, col. 1 ; December 25, 1856, p. 4. col. 1; July 16, 1887, p. 4, col. 4). 
In 1901 the Republic Iron and Steel Company proposed a plan which would insure their plants continuous operation. ${ }^{30}$ Previous to this time, at the expiration of the annual scale on June 30 , there was a general stoppage of mills pending scale negotiations. The plan agreed upon was as follows: A yearly scale was presented to the Republic Iron and Steel Company by the first of May to take effect July 1. In case of failure to reach an agreement by July I, one conciliator was selected by each side, and the two so selected chase a third. These three conciliators met the representatives of both sides in conference, and tried to effect an agreement. It was understood that mills were to run pending negotiations, and the wages finally agreed upon were to be paid during the period in which a settlement was being made.

Because of the delay in obtaining a conciliation board to adjust certain differences in 1904, a new method for choosing the third conciliator was adopted. ${ }^{3 i}$ Each side selected one man, and the third conciliator was chosen in the following manner: Each side presented a list of ten names, from which the other side selected five. From these ten names, which were submitted to the two conciliators, they were to choose a third before the adjournment of the annual convention.

Upon the formation of the Western Bar Iron Association, a similar but more specific arrangement was entered into. A yearly scale was presented by June $r$, and a conference held as soon as possible. If no agreement was reached by July Io, the points in dispute were referred to a board of conciliation selected in the same manner as had been provided for in the Republic agreement. If the conciliation board could not agree within thirty days, the scale

36 James H. Nutt, who has for many years acted as adjuster in bar-iron mills and has been active in the conferences of employers and employees, a sort of buffer between opposing interests, is reported to have persuaded the Republic to arbitrate in case of the failure of the conference to agree: but the union rejected the proposal (Report of the Industrial Commission, 1901, vol. 17, p. 341).

37 Proceedings, 1905, p. 7232. 
was referred back to the conference committee. The books of the company were open for inspection to an examining committee, composed of the three conciliators and two union officials agreeable to the employers. It was understood that the mills were to operate, pending negotiations, at the old rate of wages; and that any proposed changes in the scale were to be considered in conference between January I and March I5, at which time either side was at liberty to terminate the scale if it so desired..$^{38}$

This scheme was tried in 1907 , and the result proved disappointing to the manufacturers. A revised conciliation agreement was formulated the following March. Its essential differences from the former plan were these: (I) One conference only was held, and disputed points, instead of being decided by a board of outsiders, were referred to a subcommittee, composed of three representatives of each side. In the event the subcommittee was unable to agree, it might call in a disinterested person to act as conciliator. It was held that the sub-committee could be no more biased than the outsider whom it would select, and would be better able to understand the matters submitted to it and thus dispose of them with greater dispatch. (2) Either side might request another conference before calling in a conciliator, provided it had a modified proposition to submit with reasonable hope of settlement. (3) The time set for a decision was August I-a ten days' shorter period-made possible by the provision for holding only one conference. (4) The failure to reach a settlement by August I did not end the negotiations, unless the conference committce so determined. This plan was not put to a real test, and in 1909 it was abandoned. ${ }^{39}$

Since that time, the agrecment has not provided for a conciliation board. A conference is held by July I. In case of disagreement, old conditions continue for one month without strike or lockout while negotiations are being car-

8s Proceedings, 1907, pp. 7903-7005.

80 Proceclings, 1009 , [1). 8517-8529, 8540. 
ried on. These deliberations may continue longer than one month by mutual consent of the parties concerned. It is understood that there shall be no interruption of work during the life of an agreement. This plan is in effect with both the Western Bar Iron Association and the Republic.

Professor Marshall, in discussing the question as to how far it is possible for frank dealing in a friendly spirit between employers and employed to remove those unfair dealings, and suspicions of unfair dealings, which are the chief causes of industrial war, agrees that "the best method is that of conciliation"; and that, "for the settlement ... of a price list for a wide area, a well thought out sliding scale seems to be the best means attainable under our present social conditions." ${ }^{40}$ Conciliation, when thoroughly established and recognized, may pave the way for what may be called the automatic regulation of wages by sliding scales. Sliding scales, while by no means perfect, ${ }^{41}$ are theoretically a step in advance of the methods now generally in use. The principle on which they are based is that wages are to vary according to the selling price of the product. $^{42}$ This general plan admits of considerable variety in application. But it usually provides that wages shall not decline below a certain point. ${ }^{43}$ The employer is free to sell his material lower than this minimum, but he can not reduce wages below it. By this method, then, the laborer shares in the advance and the decline of the price of the product.

The chief advantages of these sliding scales may be said to lie on the one hand in their elasticity, and on the other

40 L. L. Price, Industrial Peace, Preface, p. xvi ff.

42 See A. C. Pigou's estimate of Sliding Scales, Principles and Methods of Industrial Peace, pp. I37-146.

12 For an exhaustive definition of the sliding scale, see J. E. C. Munro, Sliding Scales in the Coal and Iron Industries, p. 6.

${ }^{43}$ The chief objections to the scale of the South WVales Miners was-in the words of the inen-that "the confounded thing had no bottom" (W. J. Ashley. The Adjustment of Wages, p. 54). 
in their automatic action. They admit of adaptation, ${ }^{44}$ as we have seen, to diversified situations; and as Professor Munro has stated, they "give a steadiness" to trade and to wages. ${ }^{45}$ Employers will avail themselves of fresh openings with more rigorous enterprise, if freed from the apprehension of a sudden and forcible cessation of industry. W. S. Jevons maintains, somewhat extravagantly, that the sliding scale, along with the system of arbitration, is to be regarded as a "stepping stone to some still sounder method of partnership and participation in profits which a future generation will certainly enjoy." ${ }_{46}$

The chief difficulty in arranging a sliding scale is in fixing upon a basis. In both Great Britain and the United States, selling prices have been adopted by common consent as the suitable basis, and the variations in wages are to follow the fluctuations in prices. In the manufactured iron trade of the north of England, sliding scales were adopted on four occasions, based on the selling prices of iron, and each time they were abandoned. This was the result of the contention, by the one party or the other, that other circumstances besides mere selling prices should be taken into consideration. The arguments advanced on different occasions were the relative wages of ironworkers in other districts, the condition of the labor market, alteration in the cost of materials, transportation, etc., the character of the management of business undertakings, the contraction in the demand for iron, and the cost of living. ${ }^{47}$ Pro-

1 Because the principle of the sliding scale holds out such great promise of adaptability to different contingencies, Professor Munro has most enthusiastically described it as "the greatest discovery in the distribution of wealth since Ricardo's enunciation of the law of rent" (Munro, p. 26).

15 Munro, pp. 17-18. In so far as scales, instead of settling disputes, avoid them, they certainly promote trade stability. Francis A. Walker points out that a strike following a period of overproduction may result in clearing the market more thoroughly than would otherwise be done (The Wages Question, p. 39I, foot note): but the fact remains that employers are likely to enter upon contracts with greater confidence, if they have reasonable assurance that there will be no industrial disputes for a twelve-month.

${ }^{10}$ W. S. Jevons, State in Relation to Labor, p. 162.

17 Price, 111. 66, 93. 
fessor Munro urged, as to perhaps the most important of these contentions, that the scale may, and ought to take into account those elements in the cost of production which are subject to considerable variations.

In one important respect, a sliding scale is superior to other forms of wage adjustment. It automatically obviates disputes growing out of changes in the general level of prices. An employer who has bought his materials and entered into wage contracts when prices are high, and is compelled to sell his product when prices are low is at a disadvantage. Professor Marshall considers ${ }^{48}$ that the best simple scale for the iron tracle would probably be "based on the excess of the price of a ton of iron of a certain quality over the sums of the prices of the coal and ironstone used in making it"; but, inasmuch as these latter prices are subject to much the same influences as that of iron, he says. "the plan of basing the scale on the price of iron simply seems not to work badly." Money, he thinks, is a had measure in which to express such an arrangement; the government could, and ought to publish from time to time "the money value of a unit of purchasing power," and scales should be based on that unit.

When the character of the basis has been settled, there are of course numerous matters of technique to be adjusted. How great a variation in price is to be held necessary to warrant a corresponding variation in wages? How much shall this variation in wages be, and shall it proceed according to a uniform succession or according to a principle of graduation? How often shall prices be ascertained, and wages revised? In general, it may be said that these questions can hardly be answered on any definite set of principles, but they nust be answered by an appeal to the principles of stability of wages, and equality in bargaining power.

It has been pointed out by Professor Ashley ${ }^{49}$ and others

48 Ibid., Preface, pp. $x x, x x i$.

${ }^{43}$ Ashley, pp. 56-57; Chapman, pp. 186-106. 
that one great defect in sliding scales has been in the provision for fixing future wages by past prices. His argument is that future prices are not reasonably certain. Professor Pigou's argument seems more valid. He shows that, since the oscillations of the labor demand lag behind those of the public demand for the commodity in time, wage changes ought to take place after, and not contemporaneously with, the price changes in which they correspond. Only after prices have remained up for some time do employers generally expand their business, and, on the other hand, they hesitate about reducing production when a depression sets in.

These general considerations may be illustrated by the history of sliding scales as employed by the Iron and Steel Workers. It is the only trade in which the system has continuously existed. Here it has worked fairly well, although it has not been successfully applied to all kinds of work. The success or failure of the system must be considered in the light of such supplementary influences as the character of the union and its leadership, the nature of the industry, and the policies of leading employers in the industry.

The first question is whether the failure of the union to increase in influence proportionately with the growth of the industry is in any degree attributable to the system of sliding scales. The Association grew steadily during the first fifteen years of its existence, and the success of the union in the iron industry was continuous and progressive. Mr. Weeks pointed out in $188 \mathrm{I}$ that not since the origin of the scale in 1865 had there been a single instance of disloyalty to it. In 1890 nearly all mills signed the scalc.

In the steel industry the union never gained the foothold it enjoyed in the iron industry. In its strongest years it probably did not control more than half of the steel workers, and hence a majority of the steel mills were never unionized. The production of steel was growing rapidly. Frequent changes were made in the technique of the industry and with each improvement the union demanded the 
full advantage of the new machinery ${ }^{50}$ and tried to keep the per tonnage rate of wages at about the same level as hefore. Each improvement made possible the substitution of a greater proportion of unskilled labor for skilled workmen. The union did not organize these unskilled men and hence did not have their active support in labor disputes. Finally, the union limit of output restricted production to such an extent that continuous operation of the mills on either a two turn or a three turn basis was impossible. The refusal of the union properly to adjust the linit to meet this condition antagonized the manufacturers. In the steel industry, then, it was not the sliding scale but the adherence of the union to policies of limitation and restriction which was responsible for its failure. Increased production, introduction of technical machinery on a large scale, substitution of unskilled for skilled men,-all demanded new union policies. The rules of the Association were inelastic.

The iron industry, on the other hand, has experienced only slight changes in technique in forty years, and the skilled men still dominate the industry. Capital in the iron industry is far less concentrated. English-speaking workmen still hold the skilled positions. The union membership includes but a small proportion of the workmen, even in union plants, and the agreements cover probably less than half the mor employed.

Up to I 890 there seemed to be fairly general satisfaction with the agreement system and the sliding scale. Employers in most cases appreciated the advantages of a standard wage scale, the adjustment of disputes and the intimate conference relationship. The growing dissatisfaction of the steel manufacturess with the union policies led in 1892 to the tragic strike at Homestead. ${ }^{51}$ The result of this ill-

so Iron Age, as quoted by the National Labor Tribune, May 2, 1885. p. 4 , col. 2.

"The writer, like Professor Ashley, "gladly" relieves himself "of the responsibility of pronouncing upon the merits of the dispute " by referring the reacler to what he considers an impartial account of the strike in the Economic Journal, i 80,3 , by Professor F. IV. Taussig. For other accounts of the struggle, sce article cn- 
fated strike was to disrupt the local branches of the union, and to create a state of affairs in which no workman dared join the Association.

The Carnegie mills were not the only non-union mills in 1892. A considerable number of plants in the American Sheet Steel Company and the American Tin Plate Company (though a minority in each branch) were unorganized. The scales signed annually in joint conferences, though doubtless affecting the wages paid in non-union mills, covered only such mills as the company regarded as union. Such was the situation when the United States Steel Corporation was formed early in IgOr.

To narrate the history of the formation of that gigantic capitalistic combination would lead us too far afield. Suffice it to say that in the steel business there had come to be two groups of great consolidated companies: one, in which the Carnegie Company was the greatest, produced steel billets, ingots, bars, plates, and slabs; a second group of companies turned these materials into tubes, wire, tin plate, sheets, and other finished materials. Each group was beginning to feel the need of entering into the business of the other. ${ }^{52}$ To prevent conflict, the financial interests intervened and welded the opposing interests into one great organizationthe United States Steel Corporation.

Three of the great companies with which the Amalgamated had been accustomed to arrange annual scales entered into this combination. The leaders of the union knew the policy of the Carnegie management and they naturally had misgivings as to the future of their organization. They decided to attempt the complete unionization of the trust. Accordingly, they demanded that the scale be signed

titled "Tragic Episode at Homestead in 1892 " by Carroll D. Wright in American Federationist. September, 1901, p. 333; another, by J. W. Sullivall, "Drama of Homestead," ibid., November, 1901, p. 467. Also cliapter 1 of Miss Margaret F. Byington's book, "Homestead; The Houscholds of a Mill Town."

62 E. S. Mead gives a history of the matter in the Quarterly Journal of Economics, August, Ixom. See also A. Berglund, The United States Steel Corporation, pp. 62-63. 
for all the mills belonging to the several companies, union and non-union alike. ${ }^{53}$ The United States Steel Corporation accepted the challenge of "all or none," and, in the strike that followed, the Amalgamated was badly beaten. The union miscalculated its strength, and exaggerated the probable effect of the strike upon the stock exchange. There was little public interest, no panic in the money market, and the strike failed. It was not a strike for wages in the present, but avowedly one to compel complete recognition of the union, so as to influences wages in the future. With the failure of the steel strike, unionism was completely driven from the steel trade, the only steel mills which remained union being the few scattered shops of the Republic Iron and Steel Company and several small individual establishments. In 1909 the policy of the "open shop" in all mills was put into effect by the United States Steel Corporation. The union made a desperate fight, but was unable to secure any concessions.

53 When consolidation became the order of the day in 1900 , the union added this provision to its constitution: "Should one mill in a combine or trust have a difficulty, all mills in said combine or trust shall cease work until such grievance is settled." 


\section{INDEX}

Administration, fiscal, improvement in, 67; of beneficiary system, 82 ; visiting committee for, 84 .

Amalgamated Association of Iron, Steel and Tin Workers, 9, 10, $17,18,20,22,65$; territorial jurisdiction of, 42 ; revenue of, 58 ; beneficiary features, 74; helpers, 102, I3I, 133-134; policy of, 105, 107, I10, II2-II3, I28, I40 ; eighthour day adopted by, I09; restriction of output enforced by, II7, 160; strength of organization of, I59, 160 .

Amalgamated Ironworkers' Society of Great Britain, 44.

Amalgamated Journal, election of editor of, 35 ; annual dues, 58 ; as source of gain, 60 ; expense of, 65,66 ; mailing list, 85.

American Fedcration of Labor, advisory function of, 46 : application of Knights of Labor to, for iron and steel charter, 49; agitation of, for eighthour day, 108.

American Sheet and Tin Plate Company, strike in I9Io, I9, $46,63,66$; conference relations severed by, 143; scale negotiations of, I43; prices submitted by, I 47 .

Annual clues. See Assessment.

Apprentice rcgulations, 129 .

Arbitration, 153, 154 (note).

Arnd, Julius, 40.

Ashley, W. J., on sliding scales, I56 (note), I50.

Asliworth, J. H., I01, 130.

Assessment. Sce Revenue.

Associated Brotherhood of Iron and Steel Heaters, Rollers and Roughers of the United States, 10, 14, 16, 22, 23, 39, $42,57,107$.
Associated Brotherhood of Iron and Steel Rail Heaters, 15.

Auditing, committee on, 25-26.

Barnett, G. E., 22, 39, 87.

Benefit committee, 84 .

Benefit features, $64,66,78,8 I$; death, $72,75,76,83,84$; outof-work, 74 ; total disability, 77; disallowance of claims for, 80 ; advantages of, 85 .

Berglund, A., 78, I6I (note).

Bessemer, Sir Henry, I24.

Boilers and Puddlers Cooperative Association, 72.

Boiling. See Puddling.

Bowers, John A., 75 (note).

Boycott, 138.

Byington, Margaret F., $160-161$ (note).

Carlton, F. T., 86.

Carlyle, Thomas, reference to "sliding scale" by, I39 (note).

Carnegie Steel Company, strike in I892, 53; constituent company of U. S. Steel Corporation, 161

Chapman, S. J., I39 (note) ; 158 .

Collective bargaining, as method of enforcement, I38; procedure in, I42, I +3 .

Conciliation, $153 \mathrm{ff}$.

Conference committee, I $40-142$, I 50-152.

Conferences, annual, system of, 95, 138; divisional, I 4 I.

Constitution, amendments to, 22, 28.

Convention, annual, $26-29,92,93$ (note), I.42.

Deatli benefit. Sec Benefit features.

Displacement of labor, due to invention of machinery, 125.

"Due" card, Go. 
Edgar Thomson Steel Works, Iron industry, labor conditions 125. in, IO-II.

Edwards, J. O., 13 (note), 72, 115 .

Eight-hour day, introduction of, I06-108, I10, 118; adoption of, 106 (note), I09. IIO.

Employers' Association, I4I, 150.

Executive board, national, 34, 153.

Expenditure, annual, of the Sons of Vulcan. 64; of the Association, 65, 66 .

Fitch, John, 15.

"Following out," II I.

Foot-notes, IOI; purpose of, 147.

Fraternal orders, 22.

Gauge number, of sheets, 96,97 .

Glocker, T. IW., 45.

"Green hands," I30, I34, I 37.

Grievance, committee on, 25-26.

Heaters' Union. See Associated Brotherhood of Heaters, Rollers and Roughers of the United States.

Heats. restriction on number of, in boiling department, 106.

Helpers, 47, 101, 102, 130-135.

Homestead Strike, 9, 54, 63, 94, 109 (note), I5I, I60.

Hours of labor, I05, I07, I09, IIO, II 2 , II 5 .

Humphreys, Miles S., II, I2, 145.

Immigration, attitude of union toward. 44.

Industrial Iron and Steel Workers of America, origin of, 36 (note) ; aim of, 55 ; defeat of, 55.

Industrial Workers of the World (I. W. W.), activity of, in iron and steel mills, 50.

Initiative and referendum. See Referendum.

Insurance. Sce Benefit features. Iron and Stcel Roll Hands' Union. 10, 16, 22, 23, 39, 42, 57, 60,107 , II 8 .

Iron and Steel Workers. See Amalgamaterl Association.

Iron Mill Rollers Union and Benevolent Association of Elmira, I5.

Iron, Steel and Tin Workers. See Amalgamated Association.

Jarrett, John, I5 (note), I45, I 5 I.

Jevons, W. S., 157.

Job, one, defined, 128 .

Joint agreements, I38, I 44, I 48 , 159.

Jones, B. F., 139 (note).

Jones and Laughlin Mills, number of union workmen in, 25 .

Jurisdiction, membership, 39, 4243 ; territorial, 42.

Jurisdictional disputes, 43 (note), 47 .

Kerinedy, J. B., 7I, 85.

Knights of Labor, 43 (note), 48-50, I33.

Labor conditions, early, in iron trade, 139.

Legal enactment, as means of enforcement, I38 (note).

Machinery, labor-saving, $66, \mathrm{I} 16$, 124-128, 159-160.

Mahoning Valley Mutual Relief Association, 73.

Marshall. Alfred, 156, 158.

Martin, William, 50 (note), 62 (note), 127.

Mead, E. S., I6r (note).

Mean price, for working mixed material, 96 (note), 98 .

Mill committee, 25, 153 .

Morbidity, statistics of, 80 . Sec also Benefit features.

Mortality, rate of, 76,77 .

Munro, J. E. C., I39 (note), I56, $157,158$.

McCabe, D. A. 88.

McLaughlin, Hugh, 72.

McNeill, Gcorge E., Io (note), 11 (note).

Nail Feeders' Union of the Ohio Valley, 52 .

Nailers. Sce United Nailers. 
Nailers' and Nail Plate Rollers' and Heaters' Association, 52. National Labor Tribune, 17 (note).

National Lodge, 26, 39, 42, 58; affairs of, $3 \mathrm{I}, 34,37$; territorial jurisdiction of, 4I-42.

National Lnion of Iron and Steel Workers of the United States, 53-54.

Negro workmen, 46 (note), 47.

Nutt, James H., I44, I54 (note).

\section{Old age pensions, $7 \mathrm{I}$.}

Out-of-work benefits, proposed. 74.

Pigou, A. C., I56 (note), I59.

Pittsburgir scale of prices, 90 , 102.

Portenar, A. J., 7I.

Price, L. L., I 57.

Progressive Movement, 36 (note) $, 55,56$.

Puddlers' Union. See United Sons of Vulcan.

Puddling, process of, II 5 (note), II6 (note).

Rebate fund, 63.

Referendum, 35-38.

Republic Iron and Steel Company, 142, I 43, I 54, I 50.

Reserve fund, defense, $60-62,64$, 66,82 .

Restriction of output, Io6-108, III, II 4, II, II, I19, I2I123, 160; by employers, I14; abolition of, I22, 123.

Revenue, 58-64, 68, 81.

Roll Hands' Union. See Iron and Steel Roll Hands' Union.

Sakolski, A. M., 57, 67.

Scales, 89, 94, 95, 103, 126, 135; uniform national, go-93; definition of work in, 99; clianges in, 149. Sec Sliding scale.

Secret lolge', central, 44 (note).

Silcet stcel, how to make, IJ (note).

Sliding scale, 14, 89, 101, I39, 145, 158; fumction of, 95 ; aclvantages of, 156; base of, 145. $1.16,157$.
Sons of Vulcan. See United Sons of Vulcan.

“Speeding up," II5.

Standard rate, area of, 88; differentiation of, corresponding to variations in form of product, 96, 97; definition of work to be done for, 99 ; provisions of, when material is made under abnormally difficult conditions, 103.

Steel strike, I9, 59, 94, I09; sympathetic appeal used in, 63 ; magnitude of, 66 ; cause of, 152 .

Strike benefits. See Revenue and Expenditure.

Sullivan, J. IV., 160-I6I (note).

Sympathetic appeal, 63.

Subordinate lodge, 39,4 I, 58 .

Taussig, F. W., I6o (note).

Tighe, M. F., I46.

Tin Plate Workers International Protective Association, 9, 4546.

Tin plates, how to make, 122 (note).

Troy Iron Rollers Association, I5.

Union label, 138 .

United Nailers, I0, I7, 5 I.

United Nailers, Rollers and Heaters of the United States. $52-53$.

United Sons of Vulcan, IO, II, $13,39,42,61,64,105$.

United States Steel Corporation. 107 (note), I61 ; "open shop" policy of, 162.

Unskilled workmen, 39, 43, 45. 160.

Vulcan Record, I2 (note).

Wages, 87 (note), 126, 120 (note), 135,138 .

Walker, Francis A., 157 (note).

W(ls), Sidney and Bestrice, I30) (note)

IV eeks, Joseph D., r50.

Weile, William, 151 .

Western liar lron Associatiun. formition of, 143; plan of conciliation with, $154,155$. 
Western Iron Association, 146

Western scale of prices, as uniform scale, 90 ; for steel rolled in iron mills, 99.

Western Sheet and Tin Plate Manufacturers' Association, 143.

Whitney, N. R., 4I.
Williams, John, 5o (note), 85 ,

Wolfe, F. E., 48.

Working card, annual, 69

Wright, Carroll D., 160-16r (note).

Wright, R. R., Jr., 46 (note). 
THE EMPLOYMENT OF THE PLEBISCITE IN THE DETERMINATION OF SOVEREIGNTY 

JOHNS HOPKINS UNIVERSITY STUDIES

IN

HISTORICAL AND POLITICAL SCIENCE Under the Direction of the Departments of History, Political Economy, and Political Science

\title{
THE EMPLOYMENT OF THE PLEBISCITE IN THE DETERMINATION OF SOVEREIGNTY
}

\author{
BY \\ JOHANNES MATTERN \\ Assistant Librarian in The Johns Hopkins University
}

BALTIMORE

THE JOHNS HOPKINS PRESS

1920 
COPYRIGHT 1920 BY

THE JOHNS HOPKINS PRESS

THE NEW ERA PRINTING COMPANY 


\section{CONTENTS}

Preface $\ldots \ldots \ldots \ldots \ldots \ldots \ldots \ldots \ldots \ldots \ldots \ldots$ vii

CHAPTER I. Introduction $\ldots \ldots \ldots \ldots \ldots \ldots$ I I

Chapter II. The Plebiscite in Ancient and Feudal Times ................. 28

Chapter III. The Plebiscite in the French Revo-

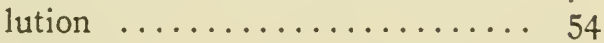

Chapter IV. The Revival of the Plebiscite in Italy 80

Chapter V. The Plebiscite from the Middle of the rgth Century to the Beginning of the World War........... 97

Chapter VI. The Plebiscites in the Peace Treaties Ending the World War....... I28

Cirapter VII. The Practical and Theoretical Aspects of the Plebiscite........ I5I

Cirapter VIII. The Plebiscite in International and Constitutional Law .......... I7I

Cinapter IX. Conclusion ............... 196 Bibliography 204 



\section{PREFACE}

The employment of the plebiscite in the determination of sovereignty was proclaimed as a government policy by revolutionary France. Since that time the advocates of the doctrine of popular consent as the sine qua non of territorial settlements involving changes of sovereignty have endeavored to secure its universal recognition in theory as well as in practice. In the course of the nineteenth century plebiscites have been held in a number of territorial transfers, resulting in changes of sovereignty without, however, establishing the resort to such popular votes as a general practice in international law.

In the attempt to form an opinion as to the justification of the employment of a plebiscite in the determination of sovereignty, either as a general principle or as a proper mode of settlement in individual cases, we turn instinctively to the past in search of its precedents illustrating the practice of the nations, and for records of opinions of leading statesmen and international jurists.

The present study aims to estimate the evolutionary momentum of the doctrine actually applied, in so far as it is traceable through the mass of alleged or genuine precedents of ancient, feudal, and modern times, and to consider the theoretical and practical aspect of the subject from the point of view of international and constitutional law in the light of more recent developments.

The most complete collection of precedents which a review of the bibliography of the subject secms to ofter is found in F. Frendenthal's Die Volksabstimmung bei Gebietsabiretungen und Eroberungen . . Erlingen, 1Sgr, and E. Solière's Le Plébiscite dans l'annerion, étude historique et critique de droit des gens, Paris, Igor.

The international legal aspect of the question is treated 
by most statesmen and international jurists in the briefest fashion, amounting to practically nothing more than an expression of a favorable or unfavorable view.

Freudenthal, and before him Stoerk in his Option und Plebiscit bei Eroberungen und Gebietscessionen . . . , Leipzig, 1879, discusses in some detail the historical development and the constitutional and international legal phases of the doctrine of popular consent up to the time of their writing.

Rouard de Card in Les Annexions et les plébiscites dans l'histoire contemporaine (Etudes de droit international . . ., Paris, 1890), and Solière in the work cited, are less comprehensive in this respect than either Stoerk or Freudenthal, while Borgeaud's study, Histoire du plébiscite... , le plébiscite dans l'antiquité-Grèce ct Rome-Genève, I887, confines itself to considerations of the plebiscite as an expression of the popular will in the inner affairs of ancient Rome and Greece.

André David's recent doctoral thesis, Les Plébiscites et les cessions de territoires, Paris, 1918, contributes to the existing literature chiefly in his last chapter, in which he argues in favor of the return to France of Alsace and Lorraine without the consultation of the population by way of a plebiscite.

E. Wittmann's Past and Present of the Right of $\mathrm{Na}$ tional Self-Determination, translated from the Hungarian by C. Biddle, Amsterdam, I919, could not be secured in time to be considered for the present study. A perusal of Wittmann's work does, however, show that the author devotes himself primarily to the treatment of the principle of national self-determination as an end in itself, and that the plebiscite as the means towards this end finds only a passing mention.

The following consideration of The Employment of the Plebiscite in the Determination of Sovereignty had its origin in a Seminar paper undertaken in the fall of 1917 at the instance of Dr. $\Lambda$. C. Millspaugh, who, during Prof. W. W. Willoughby's absence from The Johns Hopkins 
University, was then conducting the courses in Political Science. After Dr. Willoughby's return to academic work, the former study was, at his suggestion and under his encouraging guidance, elaborated and given its present form.

After the manuscript had gone to press, Miss Sarah Wambaugh's Monograph on Plebiscites appeared. This work was "prepared under the supervision of James Brown Scott, Director of the Division of International Law of the Carnegie Endowment for International Peace," and was published by the Oxford University Press, New York, 1920. Its more than a thousand pages contain an historical summary, a detailed account of the plebiscites recorded, and a collection of documents comprising more than two-thirds of the volume.

Miss Wambaugh's book covers in part chapters III-V of the present study. In the matter of historical detail her presentation is more exhaustive than that of the chapters named. The historical side of the question has been treated in the latter, not with the intent of giving a minute description of the precedents cited, but rather with the object of furnishing an analytical basis for the deduction of conclusions and for the technical discussions of the later chapters. The instances of self-determination by assembly vote or by popular suffrage in connection with the American secession movement and the vote in the section of the District of Columbia, retroceded to the State of Virginia, have been omitted from Miss Wambaugh's Monograph. They are, however, included in the following investigations for reasons which will appear from the text.

A number of references to Miss Wambaugh's study have been added to the manuscript where they seemed helpful and convenient. 



\section{THE EMPLOYMENT OF THE PLEBISCITE IN THE DETERMINATION OF SOVEREIGNTY}

\section{CHAPTER I}

\section{INTRODUCTION}

In its common application the term plebiscite is generally used as the equivalent of the principle of popular consent. For practical purposes this is not incorrect. To the popular mind the two terms are indeed identical. However, technically speaking, the principle of popular consent represents an end in itself, the right of the people to decide by simple or larger majority vote matters of government or state, while the term plebiscite denotes merely the node of expressing or withholding such popular approval of each measure submitted.

Modern authorities define the plebiscite as "a direct vote of the whole of the electors of a state to decide a question of public importance, e. g., a proposed change in the constitution, or the ratification or rejection of a measure approved by the legislature . . . also by extension, a public expression, with or without binding force, of the wishes or opinion of a community." Within the scope of this definition the term is identical with the nodern referendum which the same authority describes as " the practice or principle (chiefly associated with the Swiss constitution) of sulbmitting a question at issue to the whole body of voters."

${ }^{1}$ J. A. H. Murray, A New English Dictionary, Oxford, 1888-, Plebiscite 2, Referendun 1.

${ }^{2}$ fumile de Laveleye in "La démocratie et le régime parlementaire" distinguishes between what' Murray defines as the plebiscite and the referendum, referring to the former as "direct legislation by the people, as practiced in the democracies of ancient Greece and 
It is the plebiscite in this narrower sense of the "referendum" that concerns us here-the plebiscite as a popular decision of matters affecting the existence of the state, such as a change of government, peace and war, the acceptance of a constitution and amendments thereto, the transfer of territory, and the like-and not the recurring elections of representatives to legislatures and referenda on similar matters subject to, or growing out of, an accepted policy or practice. Drawing the lines still closer, plebiscites on changes of government, on the question of peace or war, etc., will be considered only in so far as they have been instrumental in popularizing the use of the plebiscite in interstate or international relations and in so far as they have been cited in justification of, and as precedents for, the application of the plebiscite in the transfer of territory.

The plebiscite is thus identified with universal suffrage, or, at least, universal suffrage is considered as its indispensable attribute. The history of the plebiscite, however, reveals the fact that this view is not supported by actualities, though a growing practice seems to tend in that direction. Only where "the whole of the electors," or "the whole body of voters," terms used in the definitions quoted, imply a direct and unrestricted casting of the ballot, can we speak of a plebiscite by universal suffrage.

The Roman plebiscitum, for instance, originated not as an expression of the will of the entire Roman people but of the plebeian members only.

The reign of oppression and extortion, practiced at the end of the 6 th and the beginning of the 5 th century B. C.

in the Alpine cantons of Switzerland," and to the referendum as "the acceptance or the rejection, by universal suffrage, of the laws voted by the deputies" (Revue des deux mondes, Dec. 15, 1882, vol. liv, p. 47). Borgeaud speaks of a legislative and an executive plebiscite (C. Borgeaud, Histoire du plébiscite, le plébiscite dans l'antiquité-Grèce et Rome-Genève, Paris, 1887, p. xiii). Laveleye's is a distinction of form, Borgeaud's one of content. Francis Lieber distinguishes between the national plebiscite in matters of internal affairs and the international or annexationist plebiscite in internation relations (Licber, De la valeur des plébiscites dans le droit international, in Revue de droit international et de législation comparée, 1871, vol. iii, pp. 140-141). 
by the patricians after the expulsion of the kings, forced the plebeian population to seek ways and means of bettering their political and economic conditions. Assemblies of the plebs and resolutions and decrees, plebiscites passed in these assemblies, were the outcome.

With the creation of the office of the tribuni plebis in the year $494^{3}$ these assemblies seem to have gained official recognition and stability in so far as their convocation was one of the duties and rights of these newly created tribum plebis. Their historical status, however, seems to be somewhat obscure. Borgeaud, after reviewing the prevalent opposing opinions, concludes that the definition of the plebiscitum as a decree enacted in the comitia tributa, the assembly of the Roman tribus, is incorrect. The comitia tributa included, at least after the law of the Twelve Tables was passed, also the patricians, distributed, like the plebeians, among the three local tribus, a view entertained by Niebuhr, Becker-Marquardt, Walter, Blasel, and others. ${ }^{4}$

The Roman jurists, however, are very emphatic and explicit on the one point that the plebiscitum is a decree by the plebeian members of the populace only. Gaius, for instance, defines the plebiscite in a manner which allows of no doubt: "Lex est quod populus iubet atque constituit. Plebiscitum est quod plebs iubet atque constituit. Plebs autem a populo eo distat, quod populi appellatione universi cives significantur, connumeratis etiam patriciis; plebis autem appellatione sine patriciis ceteri cives significantur."' In Poste's translation": "A statute is a command and ordinance of the people: a plebiscite is a command and ordinance of the commonalty. The commonalty and the people are thus distinguished: the people are all the citizens, including the patricians; the commonalty are all the citizens, except the

8 E. Meyer, Der Ursprung des Tribunats, in Hermes, vol. xxx, p. Iff.

Borgeaud, pp. 58-59.

s Gaius, Institutiones, I, 3.

"Gai lustitutiones, or Institutes of Roman Law, with a translation by Edward Poste, 4t's ed., E. A. Whittuck, Oxford, 1904, p. 1. 
patricians," or, as Muirhead7 renders it: "A $l e x$ is a law enacted and established by the whole body of the people; a plebiscite, one enacted and established by its plebeian members. ..."s

On the other hand, Mommsen and his school hold that Rome had, since the time of the deccmviri, two kinds of popular assemblies, the comitia tributa, convened by the order of the patrician magistrates and comprising all Roman citizens, and the concilia plebis, called to meet by the tribuni plcbis or the acdiles. ${ }^{\circ}$ Borgeaud, who adheres to this view, explains the difference, or rather the confusion, on this subject by the fact that the concilia plebis are often referred to as the comitia tributa, but only by the historians ${ }^{20}$ and in the popular language, by virtue and in consequence of their political importance, but not in accordance with their juridical nature. ${ }^{11}$ However, uncertain as this matter may be, accepting the definition of the Roman jurists, we can safely state that the plebiscitum was a decree passed in public meeting by the Roman plebcians only.

The Roman plebiscitum then was the result of the attempt made by the Roman plebs to secure for itself a voice in public matters in opposition to the ruling patricians represented by the Senate with its exercise of the auctoritas patrum. It served at the same time as the means for making this voice heard more often and more audibly until finally the Senate, weary of bcing compelled-by force of popular threats $^{12}$ - to yield to these revolutionary plebiscites, de-

'Gaius, The Institutes of Gaius and Rules of Ulpian, with a translation by James Muirhead, Edinburgh, 1880, p. 2.

${ }^{8}$ The same distinction is made by Capito and Laclius Felix, cited in Gellius, Noctium Atticarum libri XX, bk. X, 20, 6; bk. XV, 27, 15-25; in the Institutiones Justiniani, I, 2, 4; and elsewhere. Festus defines the Scita plebci as "ca quac pleps suo suffragio sine patribus iussit, plebeio magistratu rogante" (Sexti Pompei Festi De verborum significatu quae supersunt, ed. W. M. Lindsay, Lipsiae, 1913. Scita plcbci).

${ }^{8}$ Borgeaud, pp. 59-61; Laclius Felix in Gellius, hk. XV, 27, 15-25.

${ }_{10}$ Livius, $\mathrm{Ab}$ urbe condita, bk. II, 58, I ; Ciccro, Epist. ad Atticum, IV, 3 .

13 Borgeaud, p. 62.

12 Ibid., pp. $125-128$. 
cided by the acceptance of the lex Valeria-Horatia of 449 , to give the plebiscitum the validity of law binding upon all Roman citizens, provided, of course, that the plebiscitum, with the consent of the Senate, was laid before, and adopted by, the comitia centuriata and then given the auctoritas patrum in the Senate. ${ }^{13}$ Thus, after all, it was the post festum ratification by the Senate which made the plebiscite law for all Romans. However, as Borgeaud states, "during this new period in general all the plebiscites obtain the formal, even though more or less bought, adhesion of the Senate." ${ }^{14}$ Thus the plebs, for all practical purposes, succeeded in making its will supreme for all Rome through the enforced sanction of its decisions by the Senate.

Attempts were of course made to check this legislative supremacy of the plebs. A little more than a hundred years after the passage of the lex Valeria-Horatia the reforms of Quintus Publius Philo effected a considerable modification of the power of the plebs in favor of the practically disfranchised patricians. The lex Valcria-Horatia had won for the plebiscitum legal validity for all Romans. The will of the plebs generally secured the auctoritas patrum. The lex Publilia Philonis of 339, still held the plebiscitum to be law for all the Romans, but this law stipulated, so it seems, that the tribuni plebis henceforth must solicit the consent of the Scnate (patrum auctoritatem) before they could submit any proposed law to the vote of the plebs. Such at least is the theory entertained by M. Willems ${ }^{15}$ and accepted by Borgeaud. However, in the course of time the plebs refused to abide by this limitation of its acquired prerogatives. If and when the Senate refused its auctoritas in advance to those matters which the plebs wished to do or to have done, the latter did not hesitate to enforce its will

18 "Ut quod tributim plebes iussisset, populum teneret" (Livius, bk. III, 55). See also Madvig, quoted hy Borgeaud, p. 130, wote 1; Willoughisy, The I'olitical Theories of the Ancient World, New York, Loudon, 1003, 0p. 235-230.

1+ Borgeatud, 1). 132.

15 Ibid., pp. 133-137. 
by means of extra-legal plebiscites. ${ }^{16}$ When, finally, on the eve of the second Samnite war the Senate refused to approve the popular demand, expressed by a plebiscite, for distribution of land and cancellation of debts, the plebs left the city for Mount Janiculus, and the result was that in the same year the lex Hortensia, 287 B. C., was passed, stipulating that "what the plebs ordered should be binding for all Romans." 17

That the Roman plebiscite, even shortly after this method of registering and enforcing the public will had asserted itself, was anything but a mere form was demonstrated by the plebiscitum held on the occasion of the trial of Coriolanus, the patrician, who by this decree of the plebs was banished from Rome for his contempt of, and opposition to, the commons. ${ }^{18}$

With the fall of the Republic the Roman plebs surrendered its hard-fought-for rights to the Emperor and the Senate.

In the fourteenth book of the Odyssey we are told by the hero of the epic that "When Zeus . . . devised at the last that hateful path which loosened the knees of many a man in death, then the people called on me and on renowned Idomeneus to lead the ships to Ilios, nor was there any way whereby to refuse, for the people's voice bore hard upon us." 18

Proceeding to more historic times we find that in both the Dorian and the Ionian city states, at one time or another, the gradual process or progress from oligarchy and monarchy towards government by the dèmos.

In Sparta two centuries of civil strife between the kings and the aristocracy were ended by the laws of Lycurgus, which carried into effect the answer given by the Delphian

\footnotetext{
${ }^{16}$ Ibid., pp. 140-141.

17 "Ut quod ea iussisset, omnes Quirites teneret" (Plinius, Naturalis historia, bk. XVI, 10, 15; Gaius, I, 3).

18 Plutarch, Lives, Coriolanus.

10 Homer, The Odyssey.... done into English prose hy S. H. Butcher and A. Lang, 3 d ed., New York, Macmillan and Co., XIV, 235-239.
} 
oracle, commanding Lycurgus to divide the people into phylai and óbai, to establish a senate of thirty members, to call the Apella from time to time and there to introduce and rescind measures, but to give to the people the deciding voice and power. ${ }^{20}$ Thus "the aristocracy and the kings steeped the city in blood through their quarrels and the constitution of Lycurgus brought them into accord, giving to the Assembly of the people the very power about which they were in dispute."'21

However, the people in this Spartan Apella did not record their will and wishes by individual vote but, like the Greeks of Homeric and pre-Homeric times, by acclamation or murmurs. Still, K. O. Müller is of the opinion that "this manner of voting ... has the merit of indicating in a fashion, sufficiently exact ... not only the number of those who accept and reject, but also the intensity of their will.",22 .

In Athens the hereditary kingdom, passing through the stages of government of the aristocracy and tyrants, developed into a pure democracy. "The people, assembled in the agora ... or in the theatre, decided on peace or war, received ambassadors, fixed taxes, disposed of public revenues, appointed and recalled magistrates, ... lodged indictments, granted pardons, in short, it exercised directly all the rights of the sovereign, except one-the making and applying of the laws." ${ }^{23}$ Here the process of expressing popular favor or disfavor was that of individual marking of the voting stone, the ostrakon, as described by Plutarch, in his touching story of the plebiscite taken at the occasion of the ostracism of Aristides. ${ }^{24}$

In Sparta the office of the ephoroi, created $757-756$, soon

20 Plutarch, Lives, Lycurgus, VI.

21 Borgeaud, pp. 5-8.

${ }^{22}$ K. O. Müller, Geschichten Hellenischer Stämme, Breslau, 1844 . vol. iii, p. 85 .

23 Borgeaud, pp. 13-14.

24 Plutarch, Lives, Themistocles and Aristides. For details on the pleliscites in Rome and Greece, see Borgeaud. Miiller, in the book cited, has traced the democratic movement of more than twenty Doric city states. 
became the rival of the Apella as far as popular rights were concerned. It did not restrain, but it absorbed the rights of the former and "the ephorate takes thus in Sparta the place which the Assembly of the people preserves to the end in the Athenian democracy." ${ }^{25}$

While the decree of the Assembly of the people, together with the formulated code is the source of the written law of Athens, "neither a decree of the Senate nor of the people can supersede the law." in 403 after the expulsion of the thirty tyrants by Trasybulus. But, remarks Borgeaud, "wise as it was, such a fundamental distinction between the law and the decree of the sovereign assembly was incompatible with the development of a democracy as absolute as the one which reigned in the country of Cleon. By and by the 'psēphisma' (the decree of the Assembly) came, at least in fact, to take the place of the 'nomos' (the written law) and the will of the sovereign people was to dictate the law of the state; ... this had become the rule in the last century of the independence and under Macedonian hegemony." ${ }^{27}$ At that time the law can be defined in the words of Theon: "A law is a decree enacted by the multitude or by an illustrious man in matters of government not for a definite period of time.",28

In Sparta and in Athens the right of the people to vote on matters of government and law had not, as was the case in Rome, been secured by threats and application of force, but rather by the established process of constitutional method and procedure. It was, however, in the Greek city states as well as in Rome the result of a political struggle between the ruled and the ruling.

In Rome the plebiscite was the expression of the will of the plebeian population. It had, after 449 , the force of

\footnotetext{
25 Borgeaud, pp. 9-11.

${ }^{26}$ Andocides, De mysteriis, 87, 89, cited by Borgeaud, p. 26.

27 Borgeaud, pp. 26-27.

28 Theon, Progymnasmata, XIII, $\pi \epsilon \rho l v b \mu o v$, I (Rhetores Gracci ex recog. Leon Spengel, Leipzig, 1854, vol. ii, p. 128).
} 
law for all Roman citizens including the patricians, and, of course, for all non-freemen. Also in the Greek city states the popular vote was limited to one stratum of the population, but here the privilege favored the ruling class as represented by all freemen, for only the latter were entitled to the vote, not the conquered and the natives and their descendants, the perioikoi and the helotes in Sparta and the metoikoi in Athens. To appreciate the significance of this restriction of the unfree, one need only consider that in the year $309 \mathrm{~B}$. C. the population of Attica numbered 2I,000 citizens, 10,000 metoikoi and domiciled strangers, and 400,000 heads of slaves. The figures for the citizens and the metoikoi include only the major males. ${ }^{29}$

In the first century of the Christian era Tacitus, describing the land and customs of the Germani, told his fellow Romans that among the German tribes "on affairs of smaller moment, the chiefs consult; on those of greater importance, the whole community, yet with this circumstance, that what is referred to the decision of the people, is first maturely discussed by the chiefs. They assemble, unless upon some sudden emergency, on stated days. ... An inconvenience produced by their liberty is, that they do not all assemble at a stated time, as if it were in obedience to a command; but two or three days are lost in the delays of convening. When they all think fit, they sit down armed. ... Then the king, or chief, and such others as are conspicuous for age, birth, military renown, or eloquence are heard, and gain attention rather from their ability to persuade than their authority to command. If a proposal displease, the assenbly reject it by an inarticulate nurmur; if it prove agreeable, they clash their javelins. . ." 30 It is to this division of, and balance between, authority that Montesquieu traces the origin of the English free institu-

20 Borgeatrd, p1). 7, 174.

80 Tacitus, Germany (The Works...), Oxford translation, vol. ii. 
tions. ${ }^{31}$ The turbulent times of German migrations and the development of feudalism in the remaining German tribes practically eliminated from their political life those popular gatherings and the assertion of popular approval or censure which had elicited the admiration and marvel of the Roman. ${ }^{32}$ Even the "free institutions of England" do not show anything to compare with the plebiscite of the old Romans or Athenians or with the popular deliberation of their German forefathers. "The nearest approach ever made in England to the recognition of an authority capable of self-expression higher than the ordinary legislature," was the "Agreement of the people" of Cromwell's times, which was, however, not put into opcration. ${ }^{33}$

The only spot in Europe where the old gatherings and expressions of popular wishes have not entirely gone out of practice is Switzerland. When, in the fifth century, the Alemanni and Burgundi invaded Celtic-Roman Helvetia,

31 "In perusing the admirable treatise of Tacitus "On the Manners of the Germans' we find it is from that nation the English have borrowed the idea of their political government. This beautiful system was invented first in the woods" (Montesquieu, Spirit of Laws, translated by Thomas Nugent, London, 1909-1914, bk. XI, chap. vi). See also J. M. Vincent, State and Federal Government in Switzerland, Baltimore, 1891, p. 4.

${ }^{32} \mathrm{E}$. Mühlbacher, referring to the old practice of the freemen to gather annually in the Maifeld, describes the changed conditions under Charlemagne at the end of the seventh century in the following words: "The great political decisions had long been removed from the influence of the people. The old right of the freemen, to appear at the Reichsversammlungen, had not quite become obsolete, but it has become impaired on account of the impossibility for the frecmen to come annually from such large distances. Furthermore, the decisions at these Reichsversammlungen had already for an earlier time rested with the clerical and wordly magnates who, through their position in the administration of the state and at court, or though their large possession ... had to a certain degrec become the representatives of the people. . . Even when the consent of the people was solicited, it was done more as a formality, as a reminiscence of the old time, and it was done only at the occasion of big warlike undertakings which had already been decided upon or had already been commenced..." (Deutsche Geschichte unter den Karolingern, Stuttgart, 1896, p. 261).

${ }^{33}$ W. A. Dunning, A History of Political Theories from Luther to Montesquicu, New York, London, 1916, pp. 238-239. 
they introduced and continued their system of communal self-government with its popular deliberations and decisions of public affairs of importance until the growth of feudalism centered the right and power of making and administering the law in the hands of the feudal lords, the lesser nobles and the clergy. ${ }^{34}$ But with the first signs of reaction against this feudal overlordship, "the communal organism and the municipal spirit were revived and gradually developed in those same localities where they had flourished previous to the feudal period." 35 The progress of this development was, to quote Cherbuliez, "for certain reasons retarded in the western parts and accelerated in the eastern sections of Switzerland, but finally, it led everywhere to the same result.... The entire community assembles in order to decide questions of weight, in particular in order to sanction all transactions enacted in its name, with individuals or with foreign states. ..."

In some of the rural communities of Uri, Schwyz, Unterwalden, Appenzell, Zug and Glarus, "the people have never ceased to legislate for themselves and vote their own taxes from the thirteenth century downwards. They met together, at least once a year, for the purpose in solemn conclave, called the Landsgemeinde." ${ }^{36}$ The first Landsgemeinde of which we have a record is that held in the canton of Schwyz in the year $1294^{37}$

While in practice the ancient principle of popular selfdetermination in matters of internal politics disappeared from the life of the nations except in isolated counties of Switzerland, in theory the shibboleth of the sovereignty of the people remained alive throngh the Middle Ages and was transmitted to modern times in the teachings and writ-

${ }^{94}$ Vincent, yp. 4-6; A. E. Cherbuliez, De la démocratie en Suisse, Paris, 1843 , vol, $i$, pp. 13-17.

${ }^{35}$ Cherbuliez, vol. i, p. 30.

so S. Deploige, The Referendum in Switzerland, translated into English by C. P. Trevelyan, London, New York, 1898, pp. 3-4.

$87 \mathrm{~J}$. J. Blumer, Staats und Rechtsgeschichte ier schweizerischen Denokratien, St. Gallen, 1850-1859, vol. i, 11. 135. 
ings of the poets, the philosophers, and jurists of England, Germany, France, Spain and Italy. ${ }^{38}$

The final evolution of English and American Democracy in theory and practice owes much to writers like Milton and Harrington. Milton differs from the sixteenth century anti-monarchists in so far as he bases his argument on rational instead of on scriptural support. "All men naturally were born free" and were endowed with right and power of self-defense. ${ }^{30}$ "Kings and magistrates, thus, are but the agents of the people; they possess no power save what is originally in every man and is delegated to them, and they exercise no power save under the restriction of the laws." 40 Harrington believes that government must be either "the empire of laws and not of men" or "the empire of men and not of laws." 41 To quote Dunning:

These two conceptions he regards as characteristic respectively of ancient and of modern philosophy, represented typically by Aristotle and Hobbes.... Adopting the idea of the ancients as the sound one, Harrington proceeds to investigate the principles which must underlie a government aiming at the conmon welfare. ... Harringtion expatiates upon the peculiar importance of the secret ballot, which he conceives to be of the very essence of just popular government. The devices through which he secks to insure absolute freedom of the voter from all constraint upon his choice are not the least striking of the ideas which bring Harrington in very close touch with the politics of the nineteenth century. ${ }^{42}$

It would seem then that Harrington thus leads us back not only to the principle of popular sovereignty of the ancients but also to their method of giving voice and life to this principle by the employment of the plebiscite or referendum with individual expression of the will of the voter. However, this ancient method could no longer be

${ }^{38}$ A detailed account of the development of the theory of popular sovereignty is given in Dunning's two books, $\Lambda$ History of Political Theorics, Ancient and Mediacval, Ncw York, London, 1916; and A History of Political Theorics from Luther to Montesquicu; see also O. Gierke, Political Theories of the Middle Age, translated by F. W. Maitland, Cambridge, 1913.

30 Dumning, A History of Political Theorics from Luther to Montesquicu, p. 242.

40 Ibid.

11 Thick., p. 249.

12 Ibid., pp. 249, 252. 
applied with the same simplicity with which it had been worked two thousand or more years ago. The affairs of a modern state were no longer a matter of interest of a single locality or a number of cities. Nor was it still possible to call the "freemen" of a country together at a certain date and place as did the German tribes at the time of which Tacitus wrote. The vote now had to be taken wherever people lived and the results had to be communicated to a central place, the seat of Government, or, according to the system advocated by More in the Utopia, the people had to send their chosen representatives to voice their opinion and will through them and, if necessary, pass final judgment of approval or rejection by popular vote on the decisions reached by their representatives. ${ }^{43}$

It was in France that the modern plebiscite found its first application. Here Bodin, Bossuet, Fénélon, and their adherents, the monarchists, opposed to popular sovereignty, were followed by men like Rousseau, Voltaire, and others who through their writings prepared the way for the reassertion of popular rights-and the culmination of that reassertion in the revolution.

A reference to what may prove to be the earliest record of an application of the principle of the modern referendum or plebiscite in the affairs of state, we have in a letter written to the Comte D'Argental by Voltaire, dated March 30, 1776. Speaking of the "Remonstrance of the province of

13 In his Utopia, in the chapter "Of the Magistrates," Sir Thomas More tells us that "matters of great weight and importance are brought to the election house of the Syphograuntes, who open the matter to their families. And afterwards, when they have consulted among themselves, they show their devise to the counsel" and that "sometimes the matter is brought before the counsel of the whole island." The Agreement framed by the Council of Cromwell's army in 1647 as the basis for an adjustment with the King and Parliament declared itself to be an expression of the will of the people, and made the meaning of the declaration entirely clear by providing that every individual who was included in the people should sign that document (Dunning, A History of Political Theories from Iuther to Montesquieu, pp. 238-239). 
Gex,"'44 a missive addressed to Louis XIV in 1776 , signed by "all the citizens of the province of Gex, without exception," in appreciation of the granting of a franchise in amelioration of the conditions complained of, Voltaire says:

I do not believe that the remonstrances of a province "aussi chevite que celle de Gex" could create a great sensation in Paris. I presume that they will worry mighty little about delivering us from leases, servitudes and privileges. But I admit that $I$ would be greatly pleased if the plain and blunt gratitude of a little and almost barbarian country could reach the ear of Sesostris and Sesostra. ... Perhaps some of the adherents of the old feudal government will find our remonstrances too popular. We can answer them that in ancient Rome and even now at Geneva and Basel45 and in the cantons of Switzerland "ce sont les citoyens qui font les plébiscites, c'est à dire les lois." 46

The French Revolution proclaimed as the fundamental basis of all government the principle of popular sovereignty. ${ }^{47}$ It gave the French people representative government through its own elected deputies, but the voting system providing for the election of national representatives, de-

44 An agrarian province in the extreme south of France, which in the past had suffered from the oppression and extortion of government officials.

45 No record of the use of the plebiscite in Basel has been found in the course of this investigation.

${ }^{46}$ Voltaire, Oeuvres complètes, Paris, 1877-1885, vol. $\mathrm{xxx}$, pp. 34I-344; vol. xlix, pp. 570-57I. Remonstrances to the king by the Parlement de Bretagne, i.e., by the royal court of Brittany, are on record for a considerably earlier time. The text of seventeen has been collected and discussed by A. Le Moy; the first, of January I0, 1718, the last, of May 12, 1789. Le Moy estimates that more than a hundred of such remonstrances, chiefly on the subject of court appeals, finances or economics, and religious matters, had been sent to the court at Paris during the I8th century. While these remonstrances were not popular in the sense that they were voted on or signed by the people of Brittany, they are, according to one of them (October 26, 1718), intended "to make the voice of the people pass to the throne" (Remonstrances du Parlement de Bretagne au XVIII ${ }^{\circ}$ siècle. Textes inédits précédés d'une introduction . . par A. Le Moy, Angers, 1909).

47 Art. 3 of the Declaration of the rights of man and citizen of 1789 reads: "Le principe de toute souveraineté réside essentiellement dans la nation. Nul corps, nul individu ne peut exercer d'autorité qui n'ell émane expressivément" (Arch. parl., ser. I, vol. ix, p. 236). Art. 25 of the revised version of 1793 states: "La souveraineté réside dans le peuple. Elle est une et indivisible, imprescriptible et inaliénable" (Arch. parl., ser. I, vol. lxvii, p. 107). 
partmental and municipal officers, was restricted. ${ }^{48}$ While the Constitution of the year 1793 and that of the third year of the Republic were submitted to a vote in primary assemblies, ${ }^{49}$ the decree abolishing the monarchy and establishing the republic was not subjected to popular referendum. ${ }^{50}$

It was in 1799 that Napoleon Bonaparte engineered the coup d'ctat of the I8th brumaire, which replaced the Directoire by the Consulat provisoire. As the Premier Consul he offered to the French nation a new constitution (known as the Constitution of the 22 frimaire of the year VIII, December 13, 1799). This new instrument omitted the Declaration of the rights of man and citizen, and did not guarantee the liberty of the press and conscience. It gave the people the right to elect its deputies, to make through them its laws and to regulate its finances. By this new constitution the right to vote was to be given to all citizens, and

48 The election law of Dec. 22, 1789, divides the French into passive and active citizens. The former are entitled to all civi! rights and protection; only the latter are to take part in the formation of government. "The qualifications required to be active citizens are: (I) to be a Frenchman; (2) to have completed the 25th year of age ; (3) to be actually domiciled in the canton, or at least for a year; (4) to pay a direct contribution equivalent to the local value of three days of labor; (5) not to be in the condition of a domestic, that is, not to be a paid servant." For a detailed description of the history of the law and its actual application sce F. V. A. Aulard, Histoire politique de la révolution française, Paris, I90I, pp. 60-80.

40 The adoption by the National Convention of the Constitution of June 24, 1793, was followed by a decree regulating the system of the voting in the primary assemblies to which the Constitution was to be submitted for popular acceptance or rejection (Archives parlamentaires de 1787 à 1860 , Recueil complet des débats législatifs et politiques des chambres françaises, ser. I, vol. lxvii, pp. 367-368). The Constitution of the year III (Aug. 22, I795) was adopted by a primary assembly vote of 914,853 against 41,892 (Larousse, Grand dictionaire universel du XIX sieccle, Constitution). The first French revolutionary constitution of Sept. 3, I79I, was adopted in the $\mathrm{Na}$ tional Assembly and offered by order of the Assembly to the king for acceptance. On Sept. 14, Louis XVI rendered the oath on the constitution in the Assembly (Arch. parl., ser. I, vol. xxx, pp. ISo$190,6,35)$

Bo This decree was passed in the National Convention on Sept. 21 , 1792. On the same day the Convention ordered the verlatim report of the meeting to be sent to the departments aud to the armies. It was ortered further that "the decree pronomincing the abolition of the kingdom he solemnly proclaimed in Paris tomorrow and in all municipalities the day after its receipt" (Arch. parl., ser. I, vol. lii, 1). 74). 
citizens were to be "all Frenchmen, twenty years of age and doniciled for one ycar, except paid domestics." ${ }_{11}$

The system under which the vote was taken on this new constitution admitted all citizens, but they were forced to record their vote in public. By the Law of the 23 frimaire it was decreed that in each commune public registers were to be opened, one for acceptance and another for non-acceptance. Each citizen had to enter in person his "yes" in the register d'acception, or his "no" in the register de non-acception. When the date set for the roting arrived Napoleon found a way to extend the time over nearly two months, and by another coup d'ctat, in the midst of the voting (by the Law of the 3 nivose) placed in operation the very same constitution whose acceptance or rejection was subject to the vote which was not concluded until the end of the same month." The "yeas" counted 3,011,007, the "nays" $1,562 .{ }^{54}$

Aulard refers to this plebiscite as the one which brought the term "le suffrage universel" into usage. He cites Mallet du Pan, writing in London on the Constitution of the year VIII, as the first to use the term when he applied it in the Mercure britannique of January, 1800 , and he judges that it was Mallet who introduced the term "universal suffrage" into English political phraseology. ${ }^{55}$

With this successful vote on the constitution there began in France the era of the plebiscites, or, as Aulard expresses it. "thus was founded in France the République plébiscitaire."

In the year X of the Republic ( $\mathrm{ISO}$ ) another plebiscite by oui and non was held. Out of a total of 3,577,259 not less than $3,568,885$ citizens voted in favor of making Napoleon Bonaparte consul for life. ${ }^{57}$

\footnotetext{
61 Aulard, pp. 701-711.

62 Ibid., p.709.

63 lbid.

84 Ibid., pp. 7 10-7II.

55 Ibid., pp. 706 (note), 710-711.

50 Ibid., p. 711.

57 Ibid., pp. 750-75I.
} 
The sénatus-consulte of the 28 floréal of the year XII (May I8, I804) provided that "le gouvernement de la république est confié à un empéreur, qui prend le titre d'empéreur des Français" and that "Napoléon Bonaparte, premier consul de la république, est empéreur des Français." ${ }_{58}$ The same decree provided for the heredity of the new dynasty. By popular vote the decision of the Senate was confirmed. "Out of 3,524,254 electors who registered their votes in the books prepared for this purpose, 3.521,675 voted in favour of the proposal which called Napoleon to the imperial throne. There were only 2,579 opponents." ${ }_{59}$

From 1848 to 1852 France was the scene of three plebiscites, which, in their consequences, made Napoleon Emperor of the French and which, on account of their results rather than their conduct, have served more than any other to create for the plebiscite a place in European state and interstate affairs.

By popular vote Louis Napoleon was elected President of the French Republic in $18488^{60}$ The plebiscite of December $20,185 \mathrm{I}$, declared that "they [the people] want the maintenance of the authority of Louis Napoleon, . . ." ${ }_{61}$ and by referendum of November, 21, 1852, the French people confirmed the sénatus-consulte conferring the hereditary title of emperor upon Napoleon. ${ }^{62}$

58 Quoted by Aulard, p. 776.

${ }^{80} \mathrm{C}$. F. de Méneval, Memoirs Illustrating the History of Napolean I from 1802 to 1815 , New York, 1894, vol. i, p. 285 .

${ }_{00} \mathrm{P}$. La Gorce, Histoire dn second empire, Ioth ed., Paris, I908, vol. i, p. 3; Histoire de la seconde République française, 5th ed., Paris, 1909, vol. ii, p. 2.

is Ia Gorce, Histoire du second empire, vol. i, p. 12.

02 Ibid., Pp. 100-102. 


\section{CHAPTER II}

\section{The Plebiscite in Ancient and Feudal Times}

When a territory is transferred from the sovereignty of one state to that of another, the consent of the inhabitants of the territory thus affected is required to make the transfer valid. Such is in essence and extent the doctrine of popular consent, commonly called the right of self-determination or self-definition. ${ }^{1}$

Under the existing rules of international law, the inhabitants of the territory ceded cease to be subjects or citizens of the ceding state and become, or are forced to become, sooner or later, subjects or citizens of the acquiring state. ${ }^{2}$ It is this enforced change of the personal relation to the states involved, rather than the change of the state's sovereignty over the territory itself which provides the incentive to, and the justification for, the demand that the voice of the people be heard when such territorial changes are effected. ${ }^{3}$

1 See note 3 .

2 "As the object of cession is sovereignty over the ceded territory, all such individuals domiciled thereon as are subjects of the ceding State become ipso facto by the cession subjects of the acquiring State" (L. Oppenheim, International Law, 2nd ed., New York, 1912, vol. i, p. 289). See also A. Rivier, Principes du droit des gens, Paris, 1896 , vol. $i$, p. 204 . The privilege of option, a more recent development, permitting inhabitants to choose between the acceptance of the new and the retention of the old citizenship, will be discussed later.

8 "The hardship involved in the fact that in all cases of cession the inhabitants of the territory lose their old citizenship and are handed over to a new Sovereign whether they like it or not, lias created a movement in favour of the claim that no cession shall be valid until the inhabitants have by a plebiscite given their consent to the cession. ..." (Oppenheim, vol. i, pp. 289-290.) The same view prevails among American writers on international law. In American Insurance Co. v. Canter, the United States Supreme Court states that "the same act which transferred their territory transferred the allegiance of those who remain in it," and in Boyd v. Thayer the 
Modern international law sanctions the transfer of territory from one state to another under the following forms: by succession, by conventional exchange or sale, by voluntary cession or cession enforced by treaty of peace (after conquest), by lease ${ }^{4}$ and, recently, also, by pledge. ${ }^{5}$

Territorial changes by succession were chiefly responsible for the formation of the great European nations, partly also for the dismemberment of others. They were as a rule conditioned by dynastic family pacts but they are "no longer possible for those peoples who concede the principle that sovereignty resides in the nation." 6

Exchanges of territory between states, usually known as frontier rectifications or determinations, as a rule cover small areas, but the territories exchanged are sometimes of considerable size, as was, for instance, the part of Bessarabia which Rumania, by the Treaty of Berlin in 1878 , was forced to exchange with Russia for the islands at the conflux of the Danube, the Sandjak of Toultcha and a strip of the Dobrudja. ${ }^{?}$

Territorial changes by sale are too numerous to be cited here; suffice it to mention the purchase by the United States of Louisiana, and of the Danish West Indies. ${ }^{8}$

Voluntary cessions have been equally frequent in the past." However, the old maxim that "the sovereign held eminent domain over the soil, that the inhabitant was the subject of the sovereign and that the sovereign had legally the power to dispose freely of the soil and the inhabitant "10

court declared that "the nationality of the inhabitants of territory acquired by conquest or cession becomes that of the government' under whose dominion they pass, subject to the right of election on their part to retain their former nationality by removal or otherwise as may be provided" (WVilloughby, The Constitutional Law of the United States, New York, 1910, vol. i, pp. 443-444).

H. Bonfils, Manuel de droit international public, 3rd ed., Paris, 1901, nos. 564-560, 571 1 .

Oppenheim, vol. i, p. 271.

- Bonfils, no. 564 .

7 E. Hertslet, The Map of Europe by Treaty ... since the General Peace of 1814. London, 1875-91, vol. iv, p. 2791.

8 Extended list given by Bonfils, no. 566.

Bonfils, no. 567 .

${ }_{10} \mathrm{~T}$. Funck-Brentano, and A. Sorel, Précis du droit des gens, 3rd ed., Paris, 1900, p. 156. 
has, under the influence of the principles proclained in the French Revolution, been modified to the effect that today the nation is recognized as an essential part of the state and that the nation is the carrier of sovereignty. ${ }^{11}$

Voluntary cessions are those transiers of territory which are effected without the use of force by one of the contracting states. More frequently, however, territorial transfers are the price of a peace forced by one state upon the other and are preceded by war and the ensuing conquest and military occupation of the territory ceded, as was the case of the cession of Lombardy by Austria to France in I859, of Alsace-Lorraine by France to Germany in 1871 , of Cuba, Porto Rico, the Philippines, the Island of Guam by Spain to the United States in $1898 .{ }^{12}$

Territorial changes by leases are usually stipulated to be for a certain number (99) of years, but for all practical purposes they are considered as final. China leased Kiaochau to Germany, Port Arthur to Russia and Wei-Hai-Wei to Great Britain. ${ }^{13}$

Transfers by pledge are those which are to take effect at a later, a fixed date or after certain conditions have been or have not been fulfillled. The Republic of Genoa pledged Corsica to France in 1768, Sweden pledged Wismar to Mecklenburg in $1803 .{ }^{14}$

Technically speaking, all these forms are territorial changes known in international law as cessions. With the exception of the transfer by lease all involve the immediate or eventual change of allegiance of the inhabitants of the territories thus ceded or transferred and to all therefore

${ }^{11}$ Bonfils, no. 567. It is on the strength of this view that most of the French publicists favor the plebiscite in the transfer of territory. But among the opponents of the principle of popular selfdetermination as the means of territorial settlements, chiefly German, English and American writers, we find also French dissenting opinion. Rivier, for instances, states that: "The theory of the plebiscite is attached to the ill-comprehended dogma of popular sovereignty and to the principle of nationalism; it is for this reason it could play a role in France and Italy" (p. 21 ; ; Bonfils, no. 570).

12 Ronfils, nos. 564-569, $571^{1}$; Oppenheim, vol. i, pp. $270-271$.

23 Bonfils, no. $57^{1}$; Oppenheim, vol. i, p. 271.

14 Oppenheim, vol. $i$, p. 271. 
the modern demand for popular consent or self-determination may be extended.

The diplomatic study of the historical cessions of the past reveals the fact that the principle of popular consent has in some form or other been applied chiefly in cases of territorial transfers by what we have called voluntary cession, enforced cession, and, in some cases, in transfers by sale.

While ancient Rome and Greece practiced the plebiscite or referendum in their internal affairs and thus recognized the principle of self-determination as applied to themselves in their doings at home, in matters of foreign relations, in their relations to their neighbors, they recognized no other rights than those of their own will and power. All other nations were deemed barbarians who were to be left alone when strong but were to be conquered and enslaved when weak. The German publicist Rotteck writes:

From the oldest times up to the present and almost everywhere and always peoples have been forced to let themselves be treated like cattle, to be sold like common merchandise, to be exchanged, pawned, given away, to be offered in payment, to be stolen, distributed, to be inherited according to civil law ... and to be thrown in as dowry of marrying women... . That such should have happened in ancient times should not prove strange, since in those early times there existed hardly any conceptions, or at least only dark ideas, of law, especially of international law.... The powerful rulers of the far-reaching territories of the East and the little tyrants of the West considered themselves the unrestricted proprietors of their lands and of all that they included, peoples no less than real property.... When they warred among each other, the loser was deprived of all or part of his territory. ... The peoples which were thus transferred from one rule to another were not consulted. ... They did not really become members of the new state . . but they remained booty of war, property subject to the 'Sachenrecht.'

Even when Republics made conquests...this was done solely on the basis of Sachenrecht. Political right, citizenship proper renained exclusively with the conquering tribe. . . . Thus it was with the Greek republics, ... thus it was with the world ruler-Romewhich of the subjugated lands and peoples accepted only those of Italian soil into the relation of allies and very much later into citizenship, while she treated all the rest under the name of provinces as subject to Sachenreclit.

During llic storms of the migrations... brute force reigned supreme. Iater, after the growth of feudalism even the small national ties were torn. Of former peoples nothing but greater or 
smaller groups were left, ... absolute property of their masters, ... inheritable chattle of the manor. ${ }^{15}$

Thus we seek in vain for anything that might be construed as a precedent for the application of the principle of popular consent in the practical international relations of those early states and peoples who, in the inner affairs of their political life, were the most jealous of popular rights and prerogatives, at least as far as they, as freemen or citizens, were concerned.

The earliest recorded manifestations of popular consent or refusal in the case of the transfer of sovereignty or allegiance we find in France.

Solière enumerates as plebiscites a number of cases where peoples, by public expression, give or withhold their consent to changes of allegiance proposed by their feudal lords, or choose or reject a new lord by the assertion of their own will. The cases cited belong to a time when feudalism in France had long ceased to be in its prime, but they are supposedly based on what Solière calls the droit fíodal, or the ancien droit. "We do not fear to affirm," he writes, "that in the I $4^{\text {th }}$ century and at the beginning of the I $5^{\text {th }}$ century, it is a rule generally enough admitted, that no annexation can be pronounced without the assent of the people or the notables." And in the last chapter he says: "it is a rule generally admitted and founded on the principles of the droit ancicn, that in the 12 th and 13 th centuries no annexation can be pronounced without the assent of the people and the notables."16

Solière does not, in substantiation of his affirmation, adduce documentary evidence for any case prior to the middle of the I 3 th century.

In the chapter on the duties of the scigneur, Achille Luchaire quotes Fulbert de Chartres and the Etablissements

${ }^{16} \mathrm{~K}$. W. R. von Rotteck, Das Staats-Lexikon. Encyklopädie der sämmtlichen Staatswissenschaften für alle Stände, hrsg. von Carl von Rotteck und Carl Welcker, Altona, 1845-1848, Kotteck, Abtretung.

${ }_{10} \mathrm{E}$. Solière, Le plébiscite dans l'annexion, Paris, 1901, pp. 7, 156. 
de St. Louis to the effect that the rights and duties of seigneur and vassal are reciprocal and are based on contractual relations, whether the contract "exist in the form of an authentic charter or merely is supposed to exist as the result of a situation dating from time immemorial." Luchaire continues:

The feudal situation, resulting from a tie which unites the suzerain and the vassal, cannot be modified except by the consent of both parties, [and] just as the vassal has not the right to alienate the fief without the consent of the suzerain ... thus the suzerain would be lacking in his duties if he would alienate the fief or the seigneurie without the agreement of his vassals. ... The vassals are thus considered as having a real right over the seigneurie of which they form a part. The seigneur cannot dispose of their allegiance [hommage] in favor of his creature. ${ }^{17}$

It must then be admitted that during the prime of feudalism no transfer of feudal territory could be made without the consent of the vassals. A number of cases where the vassals made actual use of their right of consent or refusal in such changes during the eleventh century are given by Molinier in his Administration féodale dans le Languedoc. $^{18}$ The admission, however, does not concede Solière's clain, that "in the 12th and I 3 th centuries no annexation can be pronounced without the assent of the people and the notables." Feudal society consisted of more categories than seigneur and vassal.

To make matters clear we have to consider the fettdal politico-social system a little more closely. Let us move down from the top: the king is the suzerain of both the grands seigneurs and the smaller vassals. The grands seigneurs, or grands vassaux, are the holders of the seigncuries, the great fiefs. These grands z'assau $x^{\circ}$ in turn have around or under them a host of smaller vassals who have received from them their smaller fiefs for personal services rendered in the past or to be rendered in the future and hold them as personal gifts. Above their feudal attaclment to their seigneur these smaller vassals owe at the same time

${ }^{17}$ A. Luchaire, Mannel des institutions françaises. Période des Capreticus directs, Paris, 18 2 , pp. $214-218$.

in Cited by Luchaire, p. 217, wote 2. 
allegiance to the king, as the suzerain of both seigneur and vassal. ${ }^{19}$ The territorial arrangement was as follows:

Each seigneur possessed a certain number of rights which he exercised, within the limits of a territory more or less extended, over diverse classes of people. The territory of a seigneurie... was ordinarily composed of three categories of lands: the one the seigneur inhabited with his family and his men [gens], comprising his château and his diverse residences, with dependencies and houses, gardens ... forming the propriétés scigncuriales; the second which were occupied by his urban and rural tenants, whose direct administration he had reserved to himself. These formed his domain proper. And the last whose enjoyment and droits wtiles he had conceded to his vassals, under obligation of hommage and noble service; these formed his fiefs, feoda. In each of these categories of lands there were nobles, men of the church, bourgeois and villains, serfs and other mainmortables. ${ }^{20}$

J. Flach describes the state of society in the formative stages of feudalism as one of violent instability and he speaks of the mightiest man as "the one who has a numerous fighting force [hommes d'armes], retreats [castella] secure in case of alarm": who will "attract soldiers to his clientele [vassalité], peasants into his dependence [poteslas], villages into his tutelage [commandise]." ${ }^{21}$ We have here a clear characterization of the vassal as the soldier, the fighting man, as distinguished from the peasant, the dependent and the villager. Considering now Solière's statement that "peoples and notables" had to be considered in every case of a transfer we find his term people decidedly too wide and too indefinite. It may be objected that Solière limits his statement to the 12 th and $13^{\text {th }}$ centuries and that during this time "the people" actually were consulted.

E. Glasson, describing the system of alienation of the fief, distinguishes two periods with differing modes of alienation. He writes:

10 In a letter to one of his vassals Fulbert de Chartres, in the beginning of the eleventh century, admonishes the addressee thus: "I exact from you the security of my life, of my limbs and of the land I possess. ... I count at the same time on your aid against any person in the world, except against King Robert" (cited by Luchaire, p. 192).

${ }^{20} \mathrm{La}$ Grande encyclopédie illustrée, Féodalité, régime politique.

${ }^{21} \mathrm{~J}$. Flach, Les origines de l'ancienne France, X' et XI' siécles, Paris, 1886-19a4, vol. i, pp. 128-129. 
During a first period the vassal, wishing to remit his fief to another, had to remit it into the hands of his seigneur with the request that the seigneur invest with it the person to whom the vassal wished to present it. In fact the fief was inalienable and this was a natural consequence of its original character: the seigneur had conceded the property by reason of certain personal services which the vassal should render him and any mutation would have modified the situation. . . Such was the ordinary mode of the transmission of fiefs during the gth and loth centuries. This process has fallen into desuetude, but it was never abrogated and one need not be astonished to meet it sometimes in the texts of a later epoch. During a second period the formalism was suppressed and the vassal himself directly transmitted his fief, but with the consent of his seigneur. This second period seemed to open with the IIth century. The scigneur limits himself to give his consent to the alienation, but he is careful to secure payment for his consent. Thence dates the right of sale which already appears in the patents of the iIth century. A great number of texts speak of the necessity of the consent of the seigneur in almost all parts of France. ${ }^{22}$

Glasson does not mention the question of the consent by the people of the fief thus transferred by the vassal, the villagers, bourgeois, and the serfs and others. Luchaire refers to one case in the 12 th century where, in 1127 , in the election of a successor to Count Charles le Bon of Flanders, "one sees participate not only the 'hauts barons flammands,' but even the bourgeois of the large cities, Gand and Bruges. ...." ${ }^{23}$ However, the bourgeois were not the people. "The totality of those enjoying the benefit of the franchise constitute the body of the bourgeois. . . The conditions required to be a bourgeois of a free city are nearly the same from one end of the territory to the other. .. The population of a free city does not always coincide exactly with the body of the bourgeoisie. There remain ordinarily outside $(a)$ the agents of the seigneur ..., (b) the noblesse and the local clergy ...., (c) the strangers, properly called... and certain inferior categories, (d) the subjects of the seigneurs who have not been conceded the franchise...."

Solière's repeated statement we would therefore modify to the extent of holding that during the 12 th and $13^{\text {th }}$ cen-

22 f:. Glasson, Ilistoire du droit et des institutions de la lirance, Paris, 1003, vol. iv, PI). 326-327.

2s Luchaire, \%. 218, note 1.

241 hid., pp. 3\%-39i. 
turies no peaceful alienation of fiefs by the seigneur could be pronounced without the consent of the vassals and that in some cases the bourgeois asserted the right of choosing their own liege lord.

However, such consent cannot be construed as a concession or assumption of popular rights in the modern conception. The relations between seigneur and vassal were of a personal character, based on the need of mutual protection. As Flach expresses it, "to attach hearts was in this period of unbridled violence the essential point. It was the surest, in truth, the only way, to be assisted, supported and protected. . .." ${ }^{25}$ Fulbert de Chartres has formulated the relations of vassal and lord in the year $1020 .{ }^{28}$ The duties of the vassal he divides into negative and positive obligations. He must do nothing to harm the life and estate of his licge lord, and he must protect his life and estate. "However the lord in all his relations must give to his vassal the same in return." "Doninus quoque fideli suo in his omnibus vicem reddere debet." Hence the lord conceded to his vassal the right of consent or refusal to a change of feudal allegiance, but he did concede it as a measure of prudence and self-protection. For a vassal forced to an unwilling allegiance was a poor protection and a doubtful security for the new lord and the changes of allegiance were indeed many. As Luchaire remarks, "feudal France, from the point of view of territorial conditions, has been something essentially moving and floating [flottant]. . ." "In almost all regions of France the order of tenures or dependence [des mourances] has varied not only from period to period ... but also considerable changes have taken place during each period, sometimes from one year to another."27

The same argument holds good for the valuation of the concession to the bourgeoisie of consent or refusal in matters of choice of feudal homage or allegiance to the king.

25 Flach, vol. ii, P. 518.

$2 n$ lhid., quoted, vol. ii, pp. 518-510.

27 L.uchaire, p. 221. 
This concession on the part of the seigneur was no more a recognition of popular or democratic rights than was the contractual right of consent or refusal of the vassal. With the growth of the extent of the cities and the increase of the enfranchised men and women of these growing centers of habitation the question of contentment or discord, of attachment or hostility to the seigneur came to be a most vital one. Expressed voluntary allegiance afforded a greater sense of security to the seigneur than an enforced and resented submission, especially in the turbulent times of the formative and declining period of feudal times.

In the relations of bourgeoisie and king this concession of consent or refusal was a welcome means of enlarging royal suzerainty and sovereignty, in fact it was the chief means by which the king finally emerged triumphant out of the struggle with his more or less independent feudal lords. ${ }^{28}$

This class, intermediary between the villains and the seigneurs of the fiefs, did not achieve all its importance until the end of the reign of Louis le Gros and the erection of the communes. ... Aided in the I2th century by the kings, who protected it against the feudal lords and granted it charters, in turn it obligated them by the sacrifice of blood and money at Bouvines, Taillebourg, Mons-en-Puelle. ${ }^{29}$

Finally-and above all - of the people in feudal society of the I2th and $13^{\text {th }}$ centuries, the bourgeoisie represented a decidedly privileged class.

Upon examination the cases cited by Solière fail to support his theory even for the time after the I 3 th century.

The earliest case is that of the secession of the Lyonnais from the Holy Roman Empire and its accession to France in 1307.

At the end of the twelfth century the Lyonnais had secured its independence from the Empire. ${ }^{30}$ To escape the domination of the Church "the citizens of Lyons pro-

28 Il)icl., pp. 221, 391-392.

$29 \mathrm{Ch}$. Dezolıry and Th. Baclıclet, Dictionuaire général de biographie et d'histoire, Bourgeoisic.

so "Lyomais, grand gouvernement of ancient France, consisted of three provinces: the I,yomais proper, Forez and Beanjolais. . . Under lie Romans this comntry formed part of the first Lyomuase. It came afterwards under the domination of the Burgundians (413), 
claimed themselves subjects of the King of France and asked him to take them under his special care."s1 The Treaty of Pointoise of 1307 between the king and the Church of Lyons finally established French sovereignty over Lyons. By royal act the text of the treaty was read and explained by the notary Chérubin de Prinn to the people of Lyons. From November 30 to the end of December he proceded from village to village, calling together "by the ringing of church bells and the sounding of the rustic horn" ${ }^{32}$ the majority of "the inhabitants and nobles," submitting to them the pact in their own vulgar language and, so Solière states, "no document relates any refusal of approbation." 3 s

According to Solière the treaty itself did not recognize the right of the citizens of Lyons to be heard in the transfer of their city to French allegiance. It was only "at the last moment that the king betook himself to reflect that the matters touched in the treaty concerned the Lyonnais rather closely." ${ }^{34}$ Then by a new act it was ordered that the Lyonnais be consulted, and only then was the decision reached to "heed their objections [riclamations], if such will be justified, or well-founded [ $s^{\prime} i l$ y' a lieu]." Solière

then under that of the Franks (534), was assigned by the Treaty of Verdun $(846)$ to Lothaire... and later came to be one of the possessions of Charles le Chauve (869). In 955 the King of Burgundy had the Lyomnais ceded to him by King Lothaire. Having become independent... the country was posscssed by the Counts of Forez. The German Emperor Frederic I ceded his rights over Lyon and the Lyonnais to the archbishop of Lyon and his Chapter. King Philippe Auguste [of France] ratified this cession in I183" (Larousse, Grand Dictionnaire universel du XIX' siècle, Lyonnais).

31 Solière, pp. 10-11. "In the middle ages Lyon was successively a part of the kingdom of the Burgundians, of the empire of Charlemagne, the kingdom of Lothaire; finally, in 879 , of the kingdom of the Provence. ... Owing to the troubles which marked the end of feudalism, the temporal power slipped from the house of Bourgogne... (1032), and came to rest, despite the protests of the counts of the Lyonnais and of Forez, in the hands of the archbishops (1173). But owing to the appeal of the citizens of Lyon [bourgoisic lyonnaise] to Philippe IV, they [the archbishops] had to share their sovereignty with the King of France (1274)" (Nouveau Larousse illustré, Lyon). This section seems to suggest that in 1274 a popular demonstration occurred, similar to, or identical with, the onc here cited by Solière.

32 Solière, pp. 10-13.

33 Ibid.

s' Ibid. 
attributes this belated and sudden consideration for the Lyonnais on the part of the king to the influence of the church dignitaries of Lyons. The Chapter "knew how to persuade the king that it would be better first to conclude the treaty and then to make it valid by [the consent of] the Lyonnais." 35 Solière does not search after the motives for this attempt at persuasion.

Considering the facts in the case, as presented by Solière, we may venture to offer the following in explanation: The citizens of Lyons had acclaimed the King of France as their sovereign. In case they had been consulted in the making of the treaty they would, most likely, have agreed to its stipulations. Hence it was unnecessary to consult them. The citizens of the Lyonnais outside of the city, in the villages, had apparently not yet expressed any desire for annexation to France. If consulted during the making of the treaty they, however, might have done so. On the other hand, if afterward confronted with the established fact of transfer without their pre-solicited consent they might, in a mood of resentment, raise those objections which the king, in the treaty, actually promised to respect, or ordered to be respected, in case they would be justified. It was this possibility which might have given the Chapter a new lease on its escaping prey. As things turned out, "no document relates any refusal of the approbation" of the treaty. Another reason for the action of the Chapter of Lyons might have been that it wished first to secure the kind of bargain it desired with the king himself, and then afterward would solicit, as a matter of form, the assent of the people concerned so as to allay the unrest and strife which had forced the intervention on the part of the king in favor of the Lyominas against the political assumptions of the Church.

Soliere refers in this case to the citizens of Lyons, and to the inhabitants and the nobles of the Lyonnais. In the light of the facts given in the exposition of fendal society the citizens of Lyons, or even of the Lyomais, including the villages and the surrounding country, were the bourgeois.

ab lbid. 
The same can and must be said of the "inhabitants" who, with the nobles, were called together by the ringing of the church bells and the sounding of the rustic horn. Solière himself adnits they were called together to have explained to them that "an agreement had been effected between the Church and the king, but that the approbation of the agreement by the Lyonnais was awaited in order to have it executed." Serfs and other non-enfranchised inhabitants of the Lyonnais could not give nor would they be asked to give their approbation to an agreement between the Church and the king, ${ }^{36}$ unless by special privilege granted by the Church or the king. The case as presented by Solière, however, does not justify the assumption of such privileges. We accept then the term inhabitants, used by Solière, as equivalent to bourgeois.

From a Latin letter written to Alphonse de Poitiers et Toulouse, the son of Louis IX, then King of France, by Thibaut d'Etampes. Alphonse's chaplain, we learn that the people of Marseilles, in public gathering (in parlamento z'ocato), offered their city to the House of Toulouse by acclamation of those present. The letter as cited by Solière reads :

And so about the affair concerning Marseilles in regard to which you have requested me to talk anew with Rostano de Alto Podio and Guilelmo de Castro, I was told by magister P. de Vincenobrio what he had discussed with them in secret: and they told magister P. under oath that they themselves had been present in Marseilles, when in the presence of R., of good memory, the former comes, your predecessor, and the greater part of the magnates and the plebeians of the city [plebcium ciritatis], ${ }^{37}$ there arose one from the city and said, in the convention called [in parlamento vocato]: "we have given our city of Marseilles for life to the comes and the written instruments have thus been made out." And after that there arose another and said, in the presence of the comes and his own and the people [populo]: "the comes has done us the greatest good and honor, let us give to him and to his heirs our city in perpetuity," and then hegan the people to cry "Sye, Sye. Syc," which, in the vulgar language, means "it be, we wish it, it pleases us." And in such manner was this expression [zerbum] divulged and exclaimed that there was no other word heard in public. ${ }^{38}$

8B Ibicl.

${ }^{37}$ Civitas, urbs episcopalis (Du Cange, Glossarium mediae et infimae latinitatis, Civitas).

${ }^{38}$ Soliere, pp. 13-14. 
We have here again the contradistinction of people and nobles in the terms plebes and magnates. The plural plebes is used in mediaeval Latin in the meaning of fideles, qui Episcopo vel Sacerdoti proprio subsunt ${ }^{39}$-the faithful under their Bishop, or their own priest. ${ }^{40}$

In the year I2I4 la ville basse of Marseilles recovered its independence from the counts of the Provence and constituted itself a republic. La ville haute remained in submission to the bishops and was erected into an episcopal fief by them. ${ }^{41}$ Furthermore, the author of the letter, using the term plebium, was chaplain to the son of the King of France, and as an ecclesiastic ${ }^{42}$ was likely to refer to the inhabitants of Marseilles, an Episcopal city (civitas), ${ }^{43}$ as fideles, or faithful. Using, as he does, the two terms magnates and plebes in juxtaposition, his use of the word plebes must, however, imply more than ecclesiastical noțation. It seems safe to state that the plebes, as here referred to, are the bourgeoisie.

The assertion on the part of the plebes and magnates of Marseilles in favor of the House of Toulouse lacks the aspect of spontaneity which a genuine case of self-determination should exhibit. Aside from the indication of intrigue suggested by the secrecy spoken of by the writer of the letter, the text of the document clearly proves the motive for the assertion. "The comes has done us the greatest good and honor, let us give to him and to his heirs our city in perpetuity. ..." But even the House of Toulouse could not continue to do the greatest good, for in the following year Charles d'Anjou, after a war of eight months, made himself master of the city ${ }^{44}$ and apparently without the consent of the plebs and magnates.

so Du Cinge, Plebes.

10 Paroclus proprius, le curé propre (Luchaire, p. 4).

11 Larousse, Grand dictionnaire universel, Marseille.

12 "I.es chapelains, les officiers ecclésiastiques de la maison du roi et des princes, qui servent ì leurs chapelles" (Littré, Dictiounaire de la langue française, Clıapelain).

${ }^{33}$ See note 34.

14 Larousse, Marseille. 
The case of the people of Pamiers, agreeing by acclanation to the change of overlordship in 1285 , assumes a very different aspect from that shown in Solière's presentation if we consider in their entirety the sources quoted and referred to. Solière states:

In 1285 Philippe le Hardi, having invaded Roussillon, traversed the Pyrenees and besieged Gerone, saw his army decimated by fever and warfare. It could not retire save by the aid of Roger Bernard, Count of Foix. To show his gratitude to the latter, Philippe ceded to him by diverse charters his rights over Pamiers. In order that the seigneurie of Pamiers be well-assured him, Roger Bernard hastened to present his credentials to the consuls. ${ }^{45}$ The people convened in the public place, consented by acclamation to agree with him.

Solière then quotes part of the approbatio concessionis ... per consules et unizersitatem ville Appamic, which, in its essentials, may be given as follows: "And there the said lord, the count, asked and inquired of the said people [hominibus] of the said city, whether they consented to the agreement and pact.... And the people answering together, or the greater part of then, said at the same tine [pluries] with a loud voice 'thus, thus we will it, we will it." But the same source continues: "and the said lord, the comcs, in turn replied to the said people and the aforesaid city [universitati] and said that he himself wished always to have harmony and agreement with them and that at the present [in presenti] consented to this understanding and agreement." "Would it be saying too much to assert that the mutual assurances between the people and the new lord resembled more the contractual relations and agreements of the feudal lord and his vassals than the free choice of allegiance in the sense in which we are wont to speak of it today? A further examination of the same source referred to by Solière shows that owing to the opposition of Bernard Saisset, the Abbe de Saint Antonin, the mutual agreement of people and lord was of no avail.

A royal patent, approving the transfer of Pamiers from

45 Consul, administrateur d'une ville libre dans le midi et le centre de la France, officier féodal dans certaines villes du Midi... (Luchaire, PD. 365-366, 40I, 429-443). 
Philippe le Hardi to Roger Bernard, had stipulated a time of seven years to elapse before the transfer should become effective. ${ }^{46}$ The King of France died less than a month after the agreement of Villanueva was effected. The heir to the throne confirmed the pact. ${ }^{47}$ Roger Bernard, who would not wait his allotted seven years, then moved to gain possession of Pamiers by the consultation and the consent of the people in the manner described. The Abbot resisted his attempt. Roger Bernard, in spite of his pact and agreement, was compelled to wait. In February, I 295, ten years after the first agreement and the popular expression of consent, "Parliament ordered that "the hand of the king be lifted from the city and the castle of Pamiers." "48 It seems, then, that the consent of the people of Pamiers was appreciated and heeded by no one except Roger Bernard himself, whose interest would be directly furthered by it. The conditions of the royal patent, approving the transfer of Paniers without the consent of the free inhabitants, and the opposition of the Abbot to the transfer were both held superior to and more effective than the expressed desires or consent of the people. It should be mentioned, however, that the royal letter of approval of 1285 admonished the Abbot, the Conventus, and the people of the city to prove themselves tractable and favorably and benevolently inclined towards an agreement with Roger Bernard. ${ }^{* 9}$ While this request tends to show a certain amount of consideration for the people of Pamiers on the part of the king, it does, on the other hand, rob the supposedly free choice in favor of the new master of that vestige of spontaneity which Solière wishes to attribute to it.

In 1420 Amédée VII, the first duke of Savoy, having bought the Comte de Genevois, planned to annex also the city itself. However, the Conseil géníral of Geneva suc-

46 Lettres inédites de Philippe le Bel. . . Avec une introduction par Ad. Baudoun, Paris, 1887, pp. xxii, 126.

17 Hbid., pl), xxiii, 129.

4 Abid., p. xxiii.

45) Ibid., p. 127. 
cessfully opposed his plans. "EEclesiastics and laymen, merchants, the military, proprietors and commoners, all inhabitants of Geneva, without exception and distinction, took seat, equal before the law, in that sovereign assembly' and with unanimous voice resisted the abdication which was to be imposed on them." 50 Here we seem to have the first case on record where the whole population of a city, without exception and without distinction and all equal before the law, assert their own will in matters of allegiance; to all appearances a case of plebiscite answering the strictest tests of the present day champion of popular rights.

Still, the principle underlying the refusal of the people of Geneva to be annexed must be sought less in the insistence on the popular right of self-determination than in the consciousness of an established privilege. "It was a matter of franchises which Geneva had received in the fourteenth century from Fabri, one of its prince-bishops, privileges which were not subject to revocation by Fabri's successors." ${ }^{1}$ Even in this case, then, the question of policy was the stronger motive governing the choice of the means to the end.

In his Etude sur la réunion de Montpcllier au domaine royal (1349), ${ }^{52}$ A. Molinier discusses the complicated feudal relationships of Montpellier. Describing the passing of this barony in the year 1236 as an arrierc-fief under the suzerainty of the Bishop of Maguelonne to Jayme I, King of Aragon, Molinier does not refer to a plebiscite or to any other mode of expression by the populace. Nor does it seem that the inhabitants had any voice in the assumption of suzerainty in 1293 by the King of France over the feudal lordship of the bishop.

In the year I 34 I Don Jayme, King of Majorca, who had come into the arrière-ficf rights of Montpellier, solicited the support of the inhabitants of the fief against the King of

on Solicre, p. 15.

51 Ibid.

82 A. Molinier, Etude sur la réunion de Montpellier au domaine royal (1349) in Revue historique, 1884, vol. xxiv, mm. 249-302. 
France whose suzerainty he refused to recognize. As to the result of his solicitations the authorities conflict. One source states that Jayme succeeded in gaining the assistance sought. Another, a contemporary report, claims, according to Molinier, that, "to the contrary, the consuls and notables remained neutral in the quarrel and only affirmed their respect for their two suzerains." ${ }^{53}$ We have here a request for support, military or moral, or both, implying of course a practical expression or manifestation of preference for one side-the side seeking it. The possibility of a choice is not implied in the request, though it is manifested in the action of the consuls and notables showing a determination in the negative direction.

The annexation of the Kingdom of Majorca to the Kingdom of Aragon in the year I344 was the result of the war between the two countries. To quote Molinier:

The act uniting Roussillon and Cerdagne to the Kingdom of Aragon was read in the Church of Saint Jean in the presence of the people. The rest of the country seems to have submitted without resistance, and within the following months the officers of Pierre over-ran Conflent, Vallespir and Cerdagne, receiving the homage of the nobles and the oaths of the communities. Later, Don Jayme [King of Majorca] accuses his subjects of treason toward himself; this term was perhaps too strong, but one must recognize that they resigned themselves easily to this change of masters, either fearing the power of Aragon or being weary of a struggle the issue of which was certain in advance. ${ }^{64}$

We have here a case of resignation without even the pretense of an attempted self-determination in the form of a plebiscite or otherwise.

When the former King of Majorca was finally forced by his indebtedness incurred in consequence of his three wars with Aragon to sell his title to Montpellier to the King of France, the latter legalized the sale by treaty. Molinier mentions that "the sale was then confirmed by the children to the King of Majorca." Whether the inhabitants of Montpellier or the consuls and notables were consulted he does not say. ${ }^{.5}$

\footnotetext{
5s Molinier, 11. 263.

5. Ilvirl., pp. $205-306$.

BS llidi., P. 300.
} 
The deductions to be drawn from the case of the feudal relations of Montpellier as presented by Molinier would indicate that at least in the I 4 th century transfers of feudal allegiance from one seigneur to another actually took place without the previous solicitation of the consent of the consuls and notables of the fiefs concerned. They seem to imply further that many more settlements, especially of armed conflicts involving transfer of territories, were made during those medieval feudal struggles without the consent of the smaller vassals and that of the notables of the cities and villages thus transferred.

Solière's affirmation "that in the I4th century and at the beginning of the $5^{\text {th }}$ century it is a rule, generally enough admitted, that no annexation can be pronounced without the assent of the people or of the notables" seems to be untenable in its given form if we assume, as we should, assent to mean voluntary choice and not inevitable submission. It becomes tenable only if we limit the cases of annexations to transfers by peaceful means excluding those forced by conquest in consequence of the defeat of the former holder. Nor need we hesitate to insist that his identical affirmation for the 12 th and 13 th centuries are subject to the same qualification.

The proposed cession of Guyenne to England in I344 involved the complete surrender of French soil to a foreign potentate. Discussing the case, the cardinals meeting in Avignon expressed themselves in effect as follows:

It did not seem possible to them that the Duchy of Aquitania could thus be separated from the crown of France and be assigned to the King of England so that the latter would hold it free. [libere] because even if the King of France were willing to give his consent, the country [rcgnum] neverthelcss would object nor would it permit that the property of the crown be thus divided, which from antiquity was together [integra]; nor would the people [gcutes] nor the community of the said duchy permit that such be donc, who did not wish to be subjected to one so much different from themselves [qui nollent precisc subjice (sic) altcri corum tantum].56

wo Solière, pp. 15-16. 
This is a case wherein we have to deal not only with the consent or refusal of assent of the people to be transferred but also of the will of the entire nation in the matter of transfer of any of its parts.

With the decline of feudalism at the end of the I 3 th century the former feudal lordships concentrated around the king as the strong national figure representing the multitude of former feudal lords as the national sovereign. "Gradually even the larger seigneuries fell into the hands of the representatives of the monarchy." ${ }^{57}$ A national consciousness arose out of the Hundred Years War. The kingdom was reestablished on a stable basis. Assemblies of the three social states came into being for the established provinces and for the entire kingdom. The principle that the seigneur could not cede his vassal to another lord without the former's consent was extended to the realm in the sense that the king as sovereign could not cede French territory to a foreign potentate without the consent of the Etats Généraux as the representative body of the realm. The principle of the inviolability of French soil was born $;^{58}$ the same principle by which Thiers tried to prevent the cession of AlsaceLorraine after the Franco-Prussian War.

"In general the chief feudal states have all taken proper measures to assure the perpetuity of their dynasties by proclaiming the indivisibility of their power and of their domain. They have suppressed the custom of partition, and they have let the integral transmission of the seigneurie to the oldest male pass into law." difficult to sec in this practice the motive for the principie of the inalienability of the realm as applied to the entire kingdom, especially if we consider that the holders of these chief feudal states sat as representatives of their state in the fitats Généraux with which, as has been stated, lay at least nominally the right of consent or refusal in the case of any proposed surrender of French soil to a non-French ruler.

87 Luchaire, 1). 244.

on Solierre, p. 3 ; see also below, p. - note -

ou Luchaire, [. 239. 
Solière cites and clescribes in some detail a number of cases where treaties stipulating the cession of French territory to England were submitted to the Etats Généraux for their approval and he calls these cases plebiscites. He says:

IVe shall now examine the plebiscite by the Etats Généraux. Here... we are in the presence of regularily constituted bodies which are to be consulted by royalty I It seems at the first glance. that these declarations of the Etats Généraux should be compared to the ratifications of treaties which under a constitutional régime the sovereign must ask nowadays of the representatives of the nation, rather than to plebiscites. However, it must not be forgotten that the deputies to the Etats Généraux were, in matters of their powers, subject to a régime which is called the mandat imperatif. They were obliged to present the complaints and objections with which they were charged by their constituents. . . . The king's letters of convocation specified the affairs for which they were convened and they recommended to the Three Orders that they give to their representatives sufficient powers for the expedition of the affairs specified. Consequently, when the Etats Généraux ratified or rcjected this or that treaty, it did so in accordance with the will of the electors; it was a plebiscite in two degrees. ${ }^{60}$

Luchaire's description of the rights and powers of the Etats Généraux does not seem to justify Solière's interpretation. The two privileged orders were convoked by a royal lettre de semonce.

The third estate, convoked by bailiffs and seneschals, comprised under the name bonnes villes and villes insignes, the entire urban population not only of the domain, but of the kingdom. ... In the cities which possessed a municipal organization, the procurcurs, charged with the representation of the people in the Etats, were elected either by universal suffrage (even the women having the right to vote on certain points) or by restricted ballot through the same electoral colleges which elected the magistrates. In the localities depcndent upon seigneurial or royal power, or being without municipal organs, the deputies were designated by general assembly of the inhabitants, or even by the scigneur in accord with the latter. ${ }^{61}$

Concerning the mandate of the deputies, Luchaire writes that "it must have been conceived in the most general terms, in such a fashion as to give them the most extended powers." Differing most radically with Solière's conception of the function of the Etats Généraux, he further states :

on Soliere, p. 18

${ }^{61}$ Luchaire, p. 503. 
The authority of the first General States, in spite of their universality of convocation, was circumscribed within the limits of the solemn assemblies of the period prior to 1302. They had neither the right of initiative, nor the right of deliberation and free discussion. Royalty demanded of them simply, as in the past, adhesion, support, ratification of measures already effected or to be taken. The importance of their role under Philippe le Bel and his sons lay singularly in the solemnity and the gravity of the circumstances which had caused its convocation and not in their effective power. And so was the deputation to the Etats during that period considered as an onerous obligation rather than as a political right. ${ }^{62}$

About ten years prior to the appearance of Solière's study De la Guéronnière in his Le droit public et l'Europe moderne ${ }^{63}$ cites two cases of treaties providing for the cession of French territory, the one being submitted for ratification to the Etats Généraux in 1359; the other in 1527 to the representatives of the Bourgogne, the territory to be ceded. In both cases the decision was adverse to the acceptance of the treaty. De la Guéronnière sees in these two cases the germ of the principle of the plebiscite. Rouard de Card concludes his review of these same cases with the following observations: "Without doubt, these two historical facts present a certain interest from the political point of view, but they can not be considered as the origin of the theory which we are studying. We must not remain on the surface nor must we let ourselves be deceived by appearances. Be it noted first that in these two cases we find no trace of a popular vote. We stand in the presence of regularly constituted assemblics composed of privileged members." ${ }^{4}$ He mentions the fact that in the Treaty of 1359 not only the representatives of the territories to be ceded to England, but those of the entire kingdom, were called together and that the decision by them does not resemble our modern plebiscite but "the ratification of treaties which the sovereign under a constitutional réginc numst nowadiys ask of the representatives of the nation." "6s

\footnotetext{
ค. 11,icl., pp. 50.3-50.4.

as See F. Ronard de Card, les annexions et les pléliscites dans l'histoire contemporaine, in his fitudes de droit international, Paris, $18 \times 1$, p. 42 .

at |lide, p1). 4.4-45.

as lloid.
} 
But even this method of ratification of treaties stipulating cession of French territory to foreigners was destined to fall by the wayside. Besides, the principle of ratification of treaties by the Etats Généraux met in practice with a severe handicap in the power of the king to dissolve by lettre de jussion the recalcitrant Assembly. ${ }^{66}$ Nor did the kings of a later period seem to consider themselves bound to submit treaties to the Assembly. "In I712 Queen Anne demanded that the preliminaries of the treaty signed the preceding year at Utrecht be ratified by the Etats Généraux. Lou:s XIV was not willing to concede this. From that time or the formality of registration fell into desuetude. The treaties carrying with them the cession of Canada to England and of Louisiana to Spain were not registered ( 1763 ). These two alienations were effected contrary to the wishes of the inhabitants. New Orleans was "freed by force" (1769)."

Before we pass on to the revolutionary plebiscites there remains to be considered one more feature of the plebiscites of the time between the feudal and the revolutionary periods. While France developed and applied the principle of inalienability or inviolabilty of French territory, she failed at the same time to concede the right to, and the application of, this doctrine to other nations. This inconsistency found its manifestation in the contemporary wars of conquest waged against the Germanic Empire, culminating in the acquisition by France of many territories situated on the left side of the Rhine, chiefly in the regions known as Alsace-Lorraine.

Solière cites the annexation of Metz, Toul and Verdun ( $155^{2}$ ) among the cases of cession by plebiscite. However, his version, if analyzed, would exclude the annexation at least of Metz and Toul from this class. The following is Solière's presentation: "When in the year 1552 King Henry III [that is, II] annexed the bishoprics of Metz, Toul and

\footnotetext{
${ }^{06}$ Solière, p. 3.

e I Ibid., pp. 3-4.
} 
Verdun, Bishop Robert de Lénoncourt said to the inhabitants of Verdun 'that the King of France had come as liberator, that he wished to treat the bourgeois as good Frenchmen, and that, far from using rigorous measures, he appealed to the free vote of the people." "'ss Solière concludes with the assertion that "it was by universal suffrage that the new French citizens were untied from the old yoke." ${ }^{69}$ Assuming Solière's statement to be correct, we find that the solicitation of the free expression of consent by the inhabitants of Verdun took place after the king had come to Verdun to stay. The reference to rigorous measures, even if it is a negative one, sounds more like an expression of warning than of sympathy.

Ollivier calls this case of popular expression of consent in Verdun absolutely exceptional. ${ }^{70} \mathrm{He}$ discountenances the theory of intervention practiced in the past by all nations and justified by Languet in his Vindiciae contra tyrannos ${ }^{71}$ if it is disinterested and free from all thought of aggrandizement, but he holds that the right of the people to pronounce itself concerning its own destinies in case of conquest was not conceded. ${ }^{72}$ In connection with the annexation of the three bishoprics, Ollivier quotes Sully, who, "a little later, in the way of advice to the conqueror laid down the norm 'not to undertake lightly to join in one borly of state those whom an aversion of mind or contrariety of language, laws and customs might render incompatible, in view of the fact that the most happy and secure dominations were those whose subjects obeyed voluntarily, freely and joyfully." "7s The position taken by Ollivier and the

\footnotetext{
Bu Solière, p. 26. Solière's phraseology is found in E. Ollivier, L'Empire liberal, and ed., Paris, 1895-1915, vol, i, p. 165, with the one difference that Soliere's "Henry III" appears correctly as "Henry 11." Ollivier gives as his source, Janssen, Frankreich's Kheingeliiste, p. 28, which could not be secured for the present study: ${ }^{60}$ Solierre, 1). 26. The idlentical statement is found in Ollivier, vol. i, p. 165 .

70 Ollivier, vol. i, pp. 164-165.

${ }^{71}$ Cited by Ollivier, vol. $i$, p. 165.

72 Ibicl.

78 Ibid.
} 
warning expressed by Sully can give little substance to the claim of those who wish to present the case of Metz, Toul, and Verdum, or at least of Verdun, as instances of cession by consent. In fact it is quite possible to adduce reputable evidence to the effect that, whatever consent was given was nothing short of an acceptance of the inevitable. Le Bas, for instance, describes the capture of Metz as a ruse. The people of Metz were told by their bishop, Cardinal Lénoncourt, that the King of France was marching into Germany to establish freedom and that he desired nothing but quarters in Metz; and so Le Bas writes, "the city having thus fallen into the power of the King of France, the bourgeois were forced to render to him the oath of fidelity." "74 $\mathrm{He}$ then relates how the French army passed through Luneville and Sarrebourg (Saarburg), entering Alsace through Saverne (Zabern). The King's connétable " presented hinself en effet before Strasbourg, accompanied by two hundred of his bravest soldiers who passed as ambassadors curious to see the city. But the inhabitants having learned in advance of the coup planned against them . . . received then by an artillery volley which killed ten or a dozen and forced the others to flee. . . ." As related by Le Bas, "the cities of Toul and Verdun were taken by ruse like Metz, and these three cities have remained since then with France."is For Henry II had at first announced that he was guarding them for the Empire, but after he had mastered them he declared haughtily that he wished to unite them to his monarchy and he recalled that the entire left side of the Rhine had formed part of the Kingdom of France under the Merovingians and Carlovingians." ${ }_{78}$ The emperor's attempt to reconquer the lost cities miscarried through the failure of his siege of Metz, on January I, $1583 .{ }^{77}$ The Treaty of Muenster of

${ }^{74}$ P. Le Bas, France, Annzles historiques, Paris, I840-1843, vol. i. pp. $316-320$.

75 The same version of the conquest of these cities is found in $E$. Lavisse, IXistoire de France, Paris, Ig00-1911, vol. v, part 2, pp. $140-150$.

70 See note 74 .

77 Ibid. 
I648 confirmed not only the acquisition by France of these three bishoprics, but of all its conquest on the left bank of the Rhine comprising practically all of Lorraine and Alsace formerly belonging to the Germanic Empire. Having once come under French sovereignty, these countries were of course now subject to the doctrine of the inviolability of French soil and could never be ceded without the consent of the entire nation. ${ }^{8}{ }^{8}$

We thus find practiced in France in the sixteenth century a policy of opportunism which recognized, or even insisted upon, the principle of popular self-determination in the transfer of cities and territories if such self-assertion was favorable or could be forced into an expression favorabie to France, but which refused to acknowledge any voice or opinion to those it wanted to conquer against their will, or to any section of the kingdom which for some reason or other might wish to sever its former voluntary or forced connection with France. One cannot ascribe to this period and the cases discussed the practice and character of popular consent in the establishment of sovereignty.

\footnotetext{
78 It was on the principle of the inviolability of French soil that, at the end of the Franco-Prussian war, Thiers solicited neutral Europe's aid against the cession of Alsace-Lorraine to the new German Empire. See below, pp. 174-175.
} 


\section{CHAPTER III}

\section{The Plebiscite in the French Revolution}

The French Revolution, itself the product of a growing resentment by the tiers état against the oppression to which they had been subjected by and in favor of the two other estates, proclaimed and defined liberty as the power to "do all that does not interfere with the doings of one's neighbor." 1 According to article 4 of the Declaration of the rights of man and citizen, proclaimed by the Constitutional Assembly in August, I789, "the exercise of the natural rights of everyone [chaque homme] has no limitations save those which assure to the other members of society the enjoyment of those same rights. These limitations cannot be determined except by law." Less than a year later the same Assembly passed a decree which stipulated that "the French nation renounces the undertaking of any war for the purpose of conquest, and that it will never employ its forces against the liberty of any people."3

To place the plebiscites, or rather the annexations by plebiscites, of revolutionary France in their proper perspective and to give them their due historical appraisal we must consider them in the light of these expressions and pledges.

First in line is the acquisition of Avignon and Venaissin

1 Article 4 of the Déclaration des droits de l'homme et du citoyen, adopted Aug. 21, 1789. (Arch. parl., ser. I, vol. viii, p. 464.) Revised edition of the Declaration of June 23, 1793, Article 6: "La liberté est le pouvoir qui appartient à l'homme de faire tout ce qui ne nuit pas aux droits d'autrui: elle a pour principe la nature; pour règle la justice; pour sauvegarde la loi: sa limite morale est dans cette maxime: Ne fais pas à un autre ce que tu ne veux pas qu'il te soit fait" (Arch. parl., ser. I., vol. Ixvii, pp. 106-107).

2 See note $I$.

\& Decree of May 22, 1790: “. . l'Assemblée nationale déclarant, à cet effet, que la nation française renonce à entreprendre aucune guerre dans la vue de faire des conquêtes, et qu'elle n'emploiera jamais ses forces contre la liberté d'aucun peuple" (Arch. parl., ser. I., vol. $x v$, p. 662) 
in 1791 . These two provinces, situated in the Provence, formed part of the Papal States, but by ties of nature belonged to France. The subject of their incorporation in the French State was first brought before the National Assembly on November 12, I789, by the Jacobin Bouche of the Provence. ${ }^{4}$ In June, I790, a petition and a deputation were sent from Avignon to Paris requesting union with France. Introducing the petition in the French National Assembly on June I7, M. Camus stated that "the anniversary of the Constitution should be celebrated in the National Assembly by a great event. Penetrated by admiration and respect for the decrees of the National Assembly the Avignonais have unanimously decided to unite with France.

. The petition for reunion was sent by special courier to MM. Camus and Bouché, deputies to the French Assembly, and was signed, "Raphel, Couls, Peytier, Blanc, Richard, officiers municipaux." The letter read in part as follows:

Gentlemen, you have been informed at the time by M. Raphel, one of us, of the events which have succeeded each other rapidly in our city: he has communicated to us your responses and the obliging offers of service which have been made to him for the city of Avignon. Gentlemen, the moment to accept these offers has arrived. Thursday, the Ioth of this month, our city has been the scene of the greatest disorder. The aristocrats, mustering all their forces, fired from all parts. Masters of the City Hall and of seven pieces of cannon, they cried: Vive l'aristocratie! More than thirty persons, honorable citizens, good patriots, have been the victims of their zeal and patriotism; the people marched against the aristocrats with intrepidation and the cruel assassins, dispersed, have sought salvation in flight. Four of these wretches [scélérats] have been arrested and sacrificed by a people, justly indignant, and horribly massacred [assassiné]. . . The municipality has vainly made all efforts to prevent this. Twenty-two, also arrested, would certainly have been sacrificed except for the help of the national guards of Orange, Courtheson, Jonquic̀res, Bagnols, le Pont-Saint-Esprit, ChâteauRenard and other places. Their generous efforts and the confidence of the people of Avignon in their allies, the French, have stayed their vengeance. . . Quiet las almost been re-established; but, in order to insure it entirely, the national guards of France liave kindly consented to lend us for a few days part of their detachment. Day before yesterday at eleven, the districts assembled in order to consider their position. The union [with France] has been decided upon unanimously. ...

- Arch. parl., ser. I, vol. x, p. 4. Motion for incorporation, with historical and political justification is found, ihid., Pp. $208-215$.

- Ibid., vol. xvi, pp. $256,3(x), 451$. 
On June 26 a deputation from Avignon was admitted to the French Assembly where one of its members delivered in person a request for annexation to France. His address was greeted with applause and was favorably commented upon by the President of the Assembly, but no debate ensued. $^{\circ}$ M. Tronchet's interrupted speech of August 24 brought no decision. ${ }^{7}$ On the 16 th and 18 th of November Pétion de Villeneuve, supported by Robespierre and others, spoke in favor of the demand made by the revolutionists of Avignon; still the opposition prevented any definite action. $^{8}$ On the 20 th the case was once more deferred but a motion was passed advising the king to send troops to Avignon, where violent fighting with Carpentras, the capital city of Venaissin, had broken out. ${ }^{2}$ In the following year, I79I, the petition for incorporation with France was again argued and especially advocated before the Assembly by M. de Menou on April $30^{10}$ and by Pétion and others on May $5 .{ }^{11}$ M. de Menou laid special stress on the "legality" of the plebiscite and on the result of the voting which had taken place in Avignon and Venaissin. In the latter, of 98 communities, 59 had declared for union with France. After spirited debates, the Assembly, on May 24 , defeated the motion for incorporation, 374 voting for, 394 against, annexation. ${ }^{12}$ The motive for this negative decision is found in a speech by M. Clermont-Tonnerre of May 24 , of which a few sentences suffice to illustrate the point in question. He said in part:

The vote of June has been abandoned. It was in point of fact too near the menace which had produced it. But there have been laid

${ }^{6}$ Ibid., vol. xvi, pp. $476-477$.

7 Ibid., vol. xviii, pp. $248-249$

8 Ibid., vol. xx, pp. 474, 521, 523-534.

9 Ibid., vol. $x x$, pp. 559-580. The decree recommends "the sending of troops to Avignon, in order to protect there .. . French establishments, and in order to maintain there, in concert with the municipal officers. peace and public tranquility."

10 Ibid., vol. $\mathrm{xxv}, \mathrm{pp} .452-472$.

11 Ibid., vol. $x x v$, pp. 585-586, 593-594.

12 Ibid., vol. xxvi, pp. 362,382. Freudenthal, Dic Volksabstimmung bei Gebietsabtretungen und Eroberumgen, Frlangen, 18gI, p. 2. For details of the voting see $\mathrm{S}$. Wambaugh, $\Lambda$ Monograph on Plebiscites, New York, 1920, pp. 36-40. 
before you later votes. These are the successive votes cast within the space of a very few months, cast before the French national guards; cast almost always by the dominant factions, arms in hand; cast in the absence of a multitude of the inhabitants driven out by the violence of the dominant party. . . . It is in the absence of this considerable part of the people that they have cast this vote [émis ce voeu]. This absence has not been voluntary; it is the consequence of an act of rigour, an act of injustice; it is the consequence of continued persecution. ...

Having scrutinized the motives of the pro-annexationists he referred to the fact that the advocates of annexation had adduced in support of their policy the expression from other French cities in favor of the reunion of Avignon with France and he claims that "this is rather a weapon in the system of those opposed to reunion." For, so he continued, "it is the desire of the French to unite with themselves the people of Avignon; it is this French influence, which we cannot mistake, this influence which has existed since the beginning of the revolution, which will render suspicious to the veritable friends of truth, all that has been laid before you as the free will [or vote] of the people of Avignon. . . ."13

Furthermore, de Menou himself, the most ardent champion of the annexationists' cause, referring to the first vote of June, 1790, admitted that "one could object . . . that it was taken in the midst of tumult, disorder and the massacre of several citizens." ${ }^{14}$ The series of later petitions and attested votes referring to the voters speaks of " un voeu formé par les citoyens actifs d'Avignon, pour se réunir à la France." One of these petitions attests the rendering of the oath on the French Constitution by "toutes les gardes nat: nales d'Avignon." 15 A letter aldressed to the King of France, asking him for speedy annexation and begging him not to permit "that a good people perish because it wishes to become once more French" is signed: "Sire, de

${ }^{13}$ Arch. parl., ser. I, vol. xxvi, P. 365. See also his speech of Nov, 20, 1790, ibicl., vol. $x x$, pp. 550-563.

14 Ibid., vol. xxvi, pp. 362-36. In this connection see also the petition for annexation of Junc, 1790 , for which see note 5 .

15 Ibicl., vol. xxvi, p1). $362-36.4$. For a clefinition of the term citoyens actifs see above, p. 25, note 48 ; also Wambangh, p. 37. 
Votre Majesté, les fidèles sujets, les maire [sic!] et officiers municipaux de la ville d'Avignon, Richard, maire, Coulet, officier municipal, L. Sauvan, l'aincé, officier municipal, Miel, officier municipal, J. Gérard, officier municipal, Namug, notablc commissaire, Descatte, notable commissaire. Avignon, I6 mai I79I." "16

The discussion was reopened the following day. The attempt to reverse the negative decision failed, but a resolution was passed to send a commission of three mediators to use all possible means to prevent the forces fighting in the Comtat de Venaissin to enter French territory; to recall all French soldiers from the forces of both parties to the civil war; to punish recruiting in France for either party; to settle the dispute between Avignon and the Comtadin and to induce them to "cease all hostilities as a necessary provisory to any ulterior step in relation to the rights of France over those lands." ${ }_{17}$

Finally, on September I4, I79I, the Assembly passed a favorable vote on the question of annexation in the form of the following decree:

The National Assembly having heard the report of its diplomatic commission and the report of the Commission from Avignon. ...

Considering that the majority of the communes and citizens have expressed freely and solemnly their wish [voek] for union of Avignon and of the Comtat of Venaissin with the French Empire:

Considering that, by its decree of May 25 last, the rights of France to Avignon and the Comtat Venaissin have been formally reserved:

The National Assembly declares that in virtue of the rights of France to the united states of Avignon and the Comtat of Venaissin and that in conformity with the freely and solemnly expressed wish of the majority of the communes and citizens of these two countries to be incorporated with France, the said two united states of Avignon and the Comtat Venaissin are, from this moment, an integral part of the French Empire. . . 18

${ }_{16}$ Arch. parl., ser. I, vol. xxvi, pp. 362-364.

17 Ibid., p. 461 : “... d'envoyer des médiateurs qui interposent les bons offices de la France entre les Avignonais et les Comtadins et fassent tous leurs efforts pour les amener à la cessation de toute hostilité, comme un provisoire nécessaire avant de prendre aucun parti ultérieur relativement aux droits de la France sur ces pays."

is Ibid., vol. xxx, pp. 63I-632. G. F. von Martens, Recueil des principaux traités d'alliance, de paix, de tréve ... Gottingue, 17911801, vol. vi, pp. 400-401. 
In consequence of this decree Pope Pius VI, through Cardinal Rezzonico, sent a protest to the Catholic Powers of Europe, opposing the incorporation as "a manifest violation of the law of nations," condemning the revolutionary character of the theories involved in such plebiscites and expressing criticism of the result of the votes. This protest ran in part as follows:

As far as the supposedly free wish of the rebels is concerned it is clear that it could absolutely not be accorded without disturbing general peace [repos]. Will it then be permitted henceforth to everybody to choose a new master in accordance with one's pleasure? [d'après le gré de son caprice?]. For such would be the consequence of the principle adopted by the National Assembly. ..

What the Assembly calls the free and solemn vote of the city of Avignon, which before the revolt had 30,000 inhabitants, is nothing but the signature of about 1000 citizens, extorted under the menace of death, for that only is the actual number of those who, together with a horde of brigands which established itself in the city after the emigration of the nobility and the majority of the respectable people, form all the commune. The rest was forced to leave the country through fear of the satellites in the pay of the National Assembly.... The inhabitants of the Comtat [Venaissin] were forced the same way into this supposedly free vote, by the most fearful pillages. ... This free and solemn vote, on which the decree of Sept. I4 is based, is the result of all these cruelties. .. .

Was it not necessary that also the astonishing number of emigrants from Avignon and from the other communes of the Comtat [Venaisin]... cast their vote if it was a free and general consensus of the entire province that was desired? Why then were they not consulted?. . .19

19 Freudenthal, pp. 3-4; Martens, vol. vi, pp. 402-410; Arch. parl., ser. I, vol. $x \times x, p p .64 I-644$. Another papal protest, addressed to all the European powers, is found in the same volume, pp. 439-400. Condorcet, defending France's annexation of these Papal territories, stated in the National Legislative Assembly on April 20, 1792, that "what the Pope possessed in this land was the emolument [salaire] of the government functions," that "the people, in depriving him of these functions, have made use of a power which a long servitude had suspended, but which it had not bcen able to destroy," and that "the inclemnity proposed by France was not even required in justice" (Arch. parl., ser. I, vol. xlii, p. 2t2). On the same occasion Condorcet refers to the inclemnities offerel by France to certain German princes for the relinquishment to revolutionary France of their feudal rights in the territories of Alsace, over which France had gained sovereignty in the Treaty of Minster, in 1648 . This relinquishment was enforced in consequence of one of the first acts of the French revolution decrecing, on Aug. 6, 1789, the abolition of feudalism: "L'Assemblée nationale détruit entiérenent le régime f́odal; elle decrete que, dans les droits et devoirs, tant fiodaux que censuels, ceux qui tiennent a la main morte réclle ou personnelle, 
The note, so concludes Freudenthal, was laid ad acta; "it could not change a fait accompli."

The papal protest laid great weight on the manner of application of the plebiscite. For this it found sufficient cause in the fact that deputy de Menou on May 5, I791, had pressed the case on the strength of the "legality" of the plebiscite and in the further fact that the decree of annexation takes specific cognizance of the freely expressed will or vote of the majority of the communities for annexation. The same papal note asserted that in the past the inhabitants of Avignon and the Comtat had more than once appealed to their former sovereigns, the Popes Gregory XI, Nicholas V, Calixte III, and Paul III, to be permitted to remain under the rule and law of the Apostolic See, and that "at the first news of the designs of the National Assembly on the provinces in November, 1789 , the city of Avignon ... renewed unanimously on December 10, of this year, and all the inhabitants of the Comtat on November 25 , the solemn declaration of their desire to remain true and obedient to the reigning Popes." 20

One must not lose sight of the circumstance that the repeated adverse decisions of the petition of the people of Avignon by the French Assembly and the latter's insistence on sending a committee of mediators, as well as the conspicuous stress laid upon the action of the mediating body in the final decree of annexation, clearly point to the principle of intervention rather than that of popular self-deter-

et à la servitude personelle, et ceux qui les représentent, sont abolis sans indemnité. Tous les autres sont déclarés rachetables, et le prix et le mode du rachet seront fixés par l'Assemblée nationale ..." (Ibid., vol. viii, p. 356). See also Solière, pp. 32-37.

${ }^{20}$ On Nov. 20, 1790, the Abbé Maury introduced in the National Assembly the texts of a resolution of the States of the province of the Comtat and of a letter from the City of Avignon to the Pope. The resolution states that, upon the news of the motion for union of Avignon with France made in the French Assembly by a member from the Provence, the States of the province of the Comtat have gathered to vote by ballot on the question of loyalty to their present sovereign, the Pope. Each person present having cast his vote, it was found to be unanimously in favor of dispatching to the Pope a letter asserting their unfaltering allegiance (Arch. parl, ser. I, vol. $x x, p .573)$. 
mination on the part of the annexed as the basis of incorporation in the French Republic. ${ }^{21}$

After the case of Avignon and Venaissain had set the example, the growing spirit of the Revolution, with its fascinating theory of liberty and sovereignty of the people, induced the discontented population of a number of neighboring territories to assert their independence from former claimants of their allegiance and to vote for incorporation in the French Republic. This movement found special impetus and support in a French decree of November I9, I792, in which republican France promised aid and succor to all the peoples who desired to regain their liberty. ${ }^{22}$

Typical of the manner in which these secessionists proceeded is a declaration of deputies of the bishopric of Basel, " united in the Constituent Assembly in the Château Porentruy, on November 27, I792, the first year of the Republic of Rauracie."

21 See also note 85 . In his justification of the French declaration of war on the King of Bohemia and Hungary, read in the National Legislative Assembly on the 20th of April, 1792, Condorcet declared it to be the principle of the French revolution that "every nation alone has the power to make its own laws, and the inalienable right to change them, that the will to deprive any foreign people by force of this right is equivalent to the admission that one does not respect this right even in the country of which one is citizen or chief, that it is equivalent to betraying one's fatherland, to becoming an enemy of the human race" (Arch. parl., ser. I, vol. xlii, p. 21I). Nevertheless, when the French Assembly, on Nov. 19, voted fraternal help to all peoples desirous of regaining their liberty, the English Cabinet saw in this decree a covert attempt at interference in the affairs of the neighbors of France, especially as far as Belgium and Holland were concerned; and shortly after the inauguration of the French Republic (Aug. 10, 1792) England interrupted all diplomatic relations with France and soon began to prepare for armed conftict. In his address of Dec. 10, 1792, delivered to the Assembly on the suhject of France's relations with Britain, Le Brun, the French Minister of Foreign Affairs, gives as one of the reasons for the British attitude the decree of Nov, 19, 1792 (Ibid., vol. Iv, pp. $164-1(15)$.

22 "La Convention nationale déclare, au nom de la nation française, qu'elle accordera fraternité et secours à tous les peuples qui voudront recouvrer leur liberté, et charge le pouvoir exécutif de donner aux généraux les ordres nécessaires pour porter secours à ces peuples, et defendre les citoyens qui auraient été vexés, ou qui pourraient l'etre pour la cause de la liberté" (Arch, parl., ser. 1, vol, liii, p. 474). 
We, the deputies and representatives of the free states of the former bishopric of Basel, fief of the German Empire, united in the National Assembly, under the protection of the French Republic....

Considering that the Constitution and the laws of the Germanic Empire are not the result of the general will of the peoples who compose the empire, but of the princes ... who by usurpation have appropriated various authorities over the pcoples forming said nation, contrary to the incontestable ... right of sovereignty which radicalement resides in the people. . .

Considering that the govermment of the bishops of Basel, who by an abuse absolutely contrary to the maxims of the Gospel, combined temporal power with their spiritual office in accepting the lands and seigneuries of their bishoprics with the excrcise of sovereignty over the inhabitants in fief from the Emperor and the empire, was an arbitrary and despotic régime. . .

Considering further that the public treaties and even the decrees of the highest courts of the empire, notably the imperial judgment of Vienna of 1736 , regulating the fundamental constitution of the land, that the whole body of reciprocal rights and duties between princes and people, far from having been respected by the princes, have always been violated when they stood in favor of the people and that the people's reclamations have always been rejected with scorn and contempt.

Considering that the griefs of the people and the objects of its grievances have multiplied in proportion to the barbaric and tyrannical treatment which the bishop princes accorded the inhabitants of the bishoprics, especially in the case of hunting, the administration of communal forests, the repair and maintenance of public roads, the traffic in salt, etc. ...

Having considered all this we . . declare, in the face of Heaven and Earth, that all the ties which attach us to the Emperor and the German Empire, as well as to the bishops of Basel and to their Chapter, are broken, we swear never to renew them. . . .23

The Assembly of the Republic of Rauracie-this was the name assumed by the former bishopric of Basel-formulated and passed this resolution while under occupation by French troops. ${ }^{24}$ After the adoption of the resolution the Assembly sent a deputation to citizen François Demars, commandant of the French military in the Republic of Rauracie, to acquaint him with the constitution of the new republic and to request of him the execution of the decree of Nov. 19, 1792; that is, to ask of him the fraternal aid promised by revolutionary France. ${ }^{25}$

The French Provisional Executive Council took cognizance of the revolution of the Republic of Rauracie and of

${ }^{23}$ For complete text see Martens, vol. vi, pp. 426-430.

24 Ibid., p. 430.

25 Ibid. 
the fact that the new free republic had requested the French military command to support the new state of affairs in accordance with the decree of Nov. 19, 1792. In consequence of these considerations it ordered the French troops, stationed near the Rauracian frontier, to hold themselves in readiness to "assure to the Republic of Rauracie the efficacious and fraternal protection of the French Republic." At the same time it advised its Minister of Foreign Affairs to give to the commissary, previously appointed by the Executive Council, and stationed near the frontier, all instruction necessary to guard over the execution of the decree. . .." By vote of the Assembly of March 8, 1793, the Republic of Rauracie decided in favor of union with France. By decree of March 23 of the same year, the French Republic annexed the Republic of Rauracie under the name of Départment du Mont-Terrible. ${ }^{28}$

The presence of French troops in the new republic may of course be explained by the desire of republican France to render, and of the revolting faction in Basel to obtain, assistance against an expected military suppression of the separatist movement by the Germanic Empire, from whose suzerainty the bishopric was seceding. An additional reason, and perhaps the more convincing one, is found in the fact that the government of the new Republic of Rauracic found it necessary to seek the aid of the French military in the enforcement of the new constitution. It is this latter reason, pointing to the internal dissension and disaffection, which finds its substantiation in a letter from the French commissaries to Jiasel reporting, under date of March I, I793, to the French Convention on the conditions in the bishopric. Among other things they wrote:

On our arrival here, we have found the country divided into two parties, very much incensed against each other. We render justice to whom it belongs; we continue to gather information, lut we cannot yet announce anything lest we risk to detach from us the party which we would declare culpable. That is why we shall defer until after the casting of the vote by the inhabitants of the country ... what we have discovered up to the present concerming the facts

2n Ibid., pI. $430-43$. 
imputed to Rengguer, Demars and Gobel. We can tell you ... that it is not patriotism which has guided the leaders of each of these parties in anything that has been done here. Rengguer and his adherents wanted a republic for themselves and have employed the most vexatious measures to succeed; the other party makes use of the faults of the pretended revolutionists in order to denounce and to render odious a revolution which it attempts to identify with its originators. Today these two parties, on account of their mutual hatred, throw themselves into our arms in order to destroy each other; they are right, for union with France will cause the disappearance of the hopes of the aristocracy .... as well as the attempts to form a patriciate by a family coalition. It will be true to say that the party chiefs will have given themselves to the French, not because they loved us, but because they detest us less than their own adversaries. It is a case of the application of the proverb: Inter duos litigantes, etc. This little notice must convince you that we cannot make public our information about Rengguer, Demars, and Gobel until the strife of the two parties shall have ceased by reunion. . . .27

We may accept Solière's statement that the desire of the people of Savoy for union with France was based on the identity of language, customs, and ideas, and that their antipathy was not to the King of Piedmont personally but rather to the absolutism of the Sardinian governors and military commandants. ${ }^{28}$

While the French Revolution found its echo in the discontented minds of the Savoyans, friction developed between the French Republic and the Court of Turin on account of the latter's favorable attitude to the French princes and emigrés. ${ }^{20}$ In a letter to the Convention nationale, the French Minister of War, on September 24, 1792, announced the invasion of Savoy in accordance with his orders. The invasion was carried out, so he stated, by General Montesquieu, "un homme qui avait profondément médité pendant trois mois tous les moyens d'entrer utilement en Savoie." On September 28 Montesquieu's own report was read under repeated applause and ordered printed. ${ }^{31}$ In this report he advised the Convention, that "today the tree of liberty shall be planted with great ceremony in the principal place of the city." And he added, "it scems to me that the

27 Arch. parl., scr. I, vol. 1x, pp. 235-236.

28 Solièrc, p. 44 .

29 Ibid.

80 Arch. parl., scr. I, vol. lii, p. 116.

${ }^{81}$ Sept. 29, 1792 (Arch. parl., ser. I, vol. lii, pp. 188-189). 
people are disposed to a revolution similar to ours. I have already heard them speak of a proposal to France of an 84th department, or at least, of a republic under French protection. ... It is desirable to know the wish of the Government, for I believe that I shall be in a position to influence the course which may be taken. . .."32 The same day discussion concerning the fate of the liberated Savoyans began in the Convention nationale. ${ }^{33} \mathrm{~A}$ motion to invite them to assemble under French protection and to decide on their own destiny was referred to the Committee. ${ }^{34}$ In a proposed address to the people of Savoy, Cloots informed them that the Convention would send them four of its members to guide their first steps and invited them to unite with France. The project was tabled. ${ }^{35}$

In a proclamation of September 2I, Montesquieu himself had advised the people of Savoy of his intention of military action against the King of Sardinia. He gave assurance that the French army would enter their country not to devastate their fields but that "a free people comes to offer sentiments of union and amity." "Se "Sarate yourselves from your tyrants" was his advice. Finally on October 6 the Commissaries assigned to the Army of the Alps issued a proclamation from which the following quotations require attention:

Brethren and friends: Rise from your lethargy; you owe to the French only esteem and recognition; you have nothing to fear from the Piedmontese; and while our armies guard your liberty, busy yourselves to make it secure. ...

Proud of the success of our arms, we could give you orders, but the French Republic has effaced from its annals the words king, master and subjects, ... we only give you advice.

Primary assemblies are the only kind in which the people can exercise their sovercignty.

Hence, we exhort the free people of Savoy to gather to-day, peaceably, without weapons, under the guidance of the French arms, in each commune, in order to nominate a deputy charged to express in a general assembly their wish for a new government. ${ }^{37}$

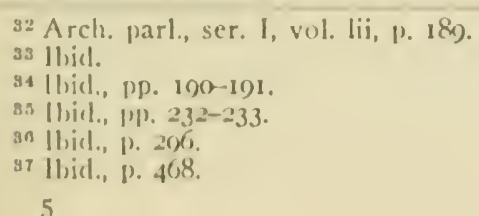


Thus, on October I4, 1792, the citizens of all the communes except three still occupied by the Piedmontese, ${ }^{38}$ gathered in the churches and elected by universal suffrage the deputies who were to decide the future of their land. A large number of the communes left the form of government to the discretion of their representatives. Of the total of $6555^{39}$ not less than 6 ro instructed them to vote for union with France. ${ }^{40}$.

The deputies assembled on October 24 and expressed "the general wish [vocu] of the free and independent nation of the Allobroges to be united to France as an integral part." 41 A Savoyan deputation transmitted a demand for annexation to the French National Convention on November I I. ${ }^{42}$ Another deputation, charged by the Savoyan National Assembly with the transmission of their request for incorporation, appeared before the Convention nationale on November 21. ${ }^{43}$ After a prolonged debate ${ }^{44}$ the French Republic annexed Savoy as the 84th department on Novenber $27,1792 .^{45}$

In a communication dated October 28, I792, the Corps administratif of the united city and former county of Nice informed the French National Convention of the unanimous wish [v'oeu] of their fellow-citizens to be united with France. Here, too, occupation by French troops had preceded the formulation of the request, as is shown by a communication of October 21 which states that "since the arrival of the French ... the flag of liberty adorns all public places." ${ }^{\prime 6}$ A letter of the Provisional Judges of the

88 Ibid., pp. 506-507.

39 Ibid., p. 506 . The total obtained by addition of the numbers given for the various provinces as found in the extract of proceedings of the second meeting of the representatives is 685 (Arch. parl., ser. I, vol. liii, pp. 506-507).

$40 \mathrm{M}$. Grégoire gives this number as 580 (Arch. parl., ser. I, vol. liii, p. 6ir).

41 Solière, pp. 44-49; Arch. parl., ser. I, vol. liii, pp. 506-507.

12 Arch. parl., ser. I, vol. liii, p. 357.

13 Ibid., pp. $506-507$.

14 Ibicl., pp. 507-510; 610-617.

15 Ihid., P. 617.

16 Ibid., pp. 25, 146. 
Tribunal of Nice of October 8 speaks of their courageous labors to make the French laws liked (à faire aimer) by applying them with the severest impartiality. ${ }^{47}$ The French Convention of November 4 refused to entertain the request, repeated by a deputation, until presented in the form of a popular free vote. ${ }^{48}$ Ten days later the substance of a letter presented by a deputation from Nice, was presented in the French Convention to the effect that the country (Nice) was being treated as a conquered and rebellious land. The soldiers of the French army had committed great disorders and had given themselves over to obnoxious excesses. "To-day," so they wrote, "the inhabitants, instead of going to meet the French, as they had planned, take refuge in the mountains. ..." The Convention took immediate steps to remedy the conditions complained of. ${ }^{49}$

Nevertheless, in a Primary Convention, called for the purpose of electing magistrates and of discussing the mode of the impending expression of the national vote in the matter of its future political status, dissension broke out. A letter from the commissaries of the Armée du Var speaks of it as sedition which had to be quelled by French troops. The letter charges Piedmontese agitators with the attempt to disunite the people of Nice in order to dissolve the Primary Convention and to bring about disorder and bloodshed to be laid at the cloor of the French army. ${ }^{50}$

The popular free vote for annexation to France having finally been secured, the National Convention decreed the union on January $31,1793 .{ }^{\circ 1}$

The enthusiasm of the first months of the French Revolution had found an echo also in the Belgian Netherlands and resulted in the revolution of 1789 and 1790 against

17 Ilbid., p. 600 .

48 Ilidid., p. 147

40 Ilicl., vol. liii, p. 405; vol. Iv, pp. 156-157. See also Saliceti's report which largely discounts these disorders (ibid., vol. liii, p. 567), and the report of the Commissaries of the National Convention to the Armée du Midi (ibicl., vol. liii, p). 633-634).

so Arcli. parl., ser. I, vol. Iv, p. 157.

6r Martens, vol. vi, pl?. 416-419. 
Emperor Joseph II. Relations between Belgium and the Emperor had already been strained; the French revolution fanned the flame. "Brussels applauded the fall of the bastille and in the Park, in the churches, in the streets one found placards bearing the words: "Here as in Paris.,"\$52 Open warfare between Belgian volunteers and Austrian troops began in the summer of 1789 . "The Etats of each province assumed for themselves sovereign power, and their mandatories, convened at Brussels in the Etats Généraux to the number of fifty-four, signed on January II, I790, the act of union of the United Belgian States." ${ }^{3}$

Thus Belgium had constituted itself an independent republic. However, civil strife broke out between the moderate revolutionaries under Vander Noot and the extremists under Vonck. The latter appealed for support to the nation; Vander Noot had, without practical results, appealed to the stranger-England, Prussia and Holland. ${ }^{54}$ While Vander Noot was Minister of the new republic, Vonck refused the presidency of the Conscil des finances and of the Cour des comptes.5 The Vander Nootists, or statists, controlling the Etats Généraux, branded Vonck as "inventor of odious novelties" and "the Abbé de Feller exclaimed that he would rather recall the Austrians than live under the rule of the cohue nationale française." Vonck and his adherents fled Brussels and gathered their forces at Namur. The Etats Généraux engaged the Prussian Schoenfeld, recommended by Holland and Prussia, and the Englishman Koehler ${ }^{57}$ to command their troops. While thus civil war was being waged in Belgium, Emperor Joseph II died. He was succeeded by his brother, Leopold II, who offered complete amnesty to the Belgians with as-

${ }^{52}$ A. Chuquet, Jemappes et la conquete de la Belgique (Les gucres de la révolution, iv), Paris, no date, p. 17.

53 Ibid., p. 26.

54 Ibid., pp. 18, 25.

35 Ihid., p. 27.

sB Ibid., p. 28.

87 Ibid., pp. 30-3I, 37. Colonel Bath was in command of the Légion britannique, consisting of some Englishmen and Belgians. 
surance of all privileges formerly held by them under Maria Theresa. His offer and request of submission were refused, as was the suggestion of mediation by the Triple Alliance. The invasion which followed terminated in the subjection of the Belgian Republic to its pre-revolutionary status and the Treaty of peace of December 2, I790, concluded at the Hague. ${ }^{58}$

Revolutionary France, not yet a republic, had watched matters in Belgium with keenest interest. "There is," said Lafayette, "not a Frenchman who does not yield to the Belgian people his applause and good wishes." $59 \mathrm{He}$ had, in the beginning of 1790 , sent two of his intimates to Belgium to incite the Vonckists against the ruling conservatist revolutionists. The Austrian successes aroused the French to the fear that the Austrians, once more masters of the Netherlands, could and would from there easily move to intervene in France in favor of the endangered Louis XVI. War between Austria and France prepared the way for French intervention in Belgium. Belgian refugees in France were working for revenge, thus giving the French further incentive and justification for intervention. In April, 1792, the French Legislative Assembly ordered the attack upon the Austrians in Belgium. The Minister of War favored a Belgian insurrection and expected such to take place with the appearance of the French. Since the Austrian Government had asked the Etats de Brabant to vote the subsidies required for its war, the French considered it their cluty "to invade Belginm without delay, to snatch from the Austrians the gold of the people of Brabant, to give to France "the resources of a great value which it lacked [manquait]." "⿻o The battle of Jemappes or Mons of November 6, 1792, decided the fate of the contestants in favor of the French. Within a month all Belginn11 was in their hands. At the occasion of his entry into Mons, Dumouriez, who had charge of the French cam-

sis thicl., Pp. 35-44.

60 Ibid., p. 46 .

ac Ibid., p. 55 . 
paing, assured the people that "we come, as brothers and friends, to help you close your doors to your old oppressors and defend the liberty which we have conquered for you." "In the evening ... the people of Mons smashed the imperial crown into pieces and cried: 'Vive la République française! Vive le brave Dumouriez! Vivent les sauveurs des Belges!'" Similar declarations by other French officials were numerous. ${ }^{62}$ The Conscil cxecutif in its meeting of November I, I792, had solemnly declared that Belgium need not fear for its independence. ${ }^{63}$ Robespierre announced that the French would leave the Belgian people the liberty of choosing for themselves the constitution they wished to have. The president of the Club of Valenciennes said to Dumouriez: "Make the Belgians free and teach the universe that France finds its glory in the contempt of vain conquests." 64

Nevertheless the French sent thirty commissaries into Belgium, the rear-guard of their army, not "to influence the opinions," but to "supervise the intrigants." commissaries, Pierre Gadolle, "published in November I794 some reflections on the annexation of Belgium."

The professions of the Assembly notwithstanding there existed in France a strong party favoring the extension of France towards her "natural boundaries." "It is necessary to seize the Rhine as barrier," exclaimed Chaussard. ${ }^{67}$ Harou-Romain and Mandrillon considered the Belgians already "as members of the illustrious family comprising the Gauls." ${ }^{8}$ Anacharsis Cloots " demonstrated to the Belgians that they would do well to unite with France instead of forming a Belgian republic." "os Danton declared "that the

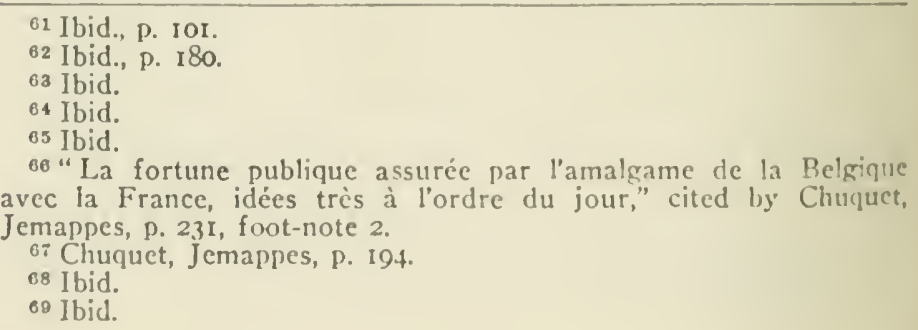


limits of France were marked by nature and that they must be attained by their four points; the ocean, the Rhine, the Alps and the Pyrenees." "io "An opinion is growing here," writes Bissot to Dumouriez, "that the French Republic must have no boundary short of the Rhine. Are the minds with you disposed to such union? They must be prepared." "71 "We have sworn no conquest,' wrote Grégoire, 'but if people, included within the borders of the French Republic, desire political affiliation, must we not receive them?" As Chuquet adds, "Belgium was rich and the fortune of its clergy immense. Why not take hold of those 'gigantic revenues of Flemish superstition' and 'enlarge with it the republican Pactole" "?72 Le Brun, enumerating the advantages of the annexation of Belgium, stated that "France would augment her population by 3 million inhabitants, her army by 40,000 soldiers, her annual revenues by $40,000,000$ pounds, and the mortgage of its assignats more than a billion." "'s

The Belgians, scenting the danger to their freedom, sent a representation to the Assembly in Paris to demand a solemn declaration "that it did not aim at the union of Belgium with France and that it would not impose on Belgium the assignats." But Le Brun induced the Belgian Commission to omit from their request these two vital points, and Barère let them know the real sentiment of the Assembly when he asked then whether they had not immense treasures which religion for centuries had taken as a deposit for liberty? Arms and assignats, he said, is what an enslaved people needs to break its fetters. ${ }^{7 t}$

On December 15, I792, the Assembly adopted the decree which meant the practical annexation of Belgium and

70 Ibid., p. 195.

71 Ibid.

72 llid. See also note 102.

78 Cited by Chuquet, Jemappes, p. 195. More expressions for annexation of Belgium are ciled, ibid., p. $195 \mathrm{ff}$.

${ }^{74}$ Cited, ibid., \$. 197, from Muniteur, Dec. 6, 1792; see also A. Borguet, Histoire des Belges, à la fin du XVIII sicele, a éd, Bruxelles, Paris, $1861-1862$, vul. ii, pp. yo-92. 
the reorganization of the Belgian government after the French pattern. ${ }^{75}$ The act caused a stir of resentment and opposition in Belgium where the elections of December 29 practically restored the statists or conservative revolutionists under Vander Noot. ${ }^{i 6}$ Chuquet cites a number of protests from Hainaut, Namur, Anvers, Louvain, Malines, Tournésis, Herve, Bruxelles, Liège. Pamphlets against France were circulated in great numbers. "Placards attached to the walls of Malines declared the fatherland in danger and invited the Belgians to unite in order to eject the barbarians who had come to annihilate religion, to destroy the corporations and to impose their assignats." the victor of Jemappes, at first refused to proclaim and execute the objectionable decree. "I shall not be," he wrote, "the Attila, the scourge of Belgium, and I shall not play two conflicting roles in this unhappy country: that of the liberator according to my proclamations and that of the oppressor by the execution of the decree. . .". thirty commissioners received their orders in consequence

75 This decree stipulates that in the countries occupied by French troops, in the name of the French nation the sovereignty of the people be proclaimed; all constituted authorities, all existing duties and contributions, feudalism, etc., to be abolished; the people be assured that France brings them peace, help, etc.; that primary assemblies be convened to create a new government; that all former privileged individuals and officers of state be in this instance excluded from voting; that all property of the former princes, their adherents, of the state treasure, of lay and ecclesiastical bodies and communes be placed under the protection of the French nation. These and various other things being done, the French nation shall, so the decree orders, choose commissaries to be sent to these liberated peoples in order to fraternize with them. Article if reads: "La nation française déclare qu'elle traitera comme ennemi le peuple qui, refusant la liberté et l'égalité, ou y renonçant, voudrait conserver, rappeler ou traiter avec le prince et les castes privilégiées; elle promet et s'engage de ne souscrire aucun traité, et de ne poser les armes qu'après l'affermissement' de la souvereigneté et de l'indépendence du peuple sur le territoire duquel les troupes de la République seront entrées, qui aura adopté les principes de l'égalité, et établi un gouvernement libre et populaire." This decree was adopter by the Convention on Dec. 15, 1792 (Arch. parl., ser. I, vol. Iv, pp. $70-76,100-101)$.

${ }^{70}$ Chuqquet, Jemappes, pp. $210,213$.

77 Only the Province of Liege, not Liege city, and the citics of Mons and Charleroi secmed to approve of it (ibid., pp. 200-203).

${ }^{78}$ Ibid., P. 206. 
of the act of December 15 and so, despite all former professions, they set to work to force the Belgian population into formal annexation with France. ${ }^{7 \theta}$

Dumouriez was forced to consent to do what he had at first refused. ${ }^{80}$ The chief tools were the numerous political clubs created and supported by them in the Belgian cities. These clubs did not represent the public opinion of Belgium. ${ }^{81}$ "The democrats who at first frequented them, finally left. In February I793 the Société populaire of Bruxelles counted hardly a dozen Belgians. 'Few citizens,' so the commissioners of the Convention wrote, 'dare to belong to the clubs of Louvain, Malines and Anvers:' the Club of Louvain admitted that it consisted of soldiers from the garrison; that of Malines included 92 Frenchmen and Io members from Malines; that of Tournai, 70 persons at the most. An agent of the Ministère saw in the Club of Gand only few native born. Frenchmen, civilians and military formed the majority of these clubs; 'there are only few popular societies in Westflanders ... and those of the cities are not numerous; almost everywhere officers and French commissaries are at their head. . . '" The patron and protector of the Club of Brusscls was General Moreton who ardently approved of the decree of December I5. "Alexandre Courtois was one of the first to demand the conquest of Belgium because France, as he said, must, to maintain herself, aggrandize herself incessantly. Le Brun charged him to establish new clubs, to speak in the popular societies, to publish bulletins for the instruction of the people... ${ }^{82}$ On December 18 the Club of Brussels ordered the formation of a legion of sansculottes of Belgium and Liege. The first article of its rules proclaimed all troops of the line or national guards, French as well as Belgian and those of Liège, in law and in fact units of the

\footnotetext{
70 Ihid., p. 207.

nul Ibid., pp. $204-207$.

Balbid., p. 214. The following quotations are from the same source, p. 215 If. where the original documents are cited. 8: Ibicl, pi). $216-218$.
} 
legion. This legion ruled Brussels by terror. By means of its support the Club resolved to intimidate those protesting against the decree of December $15 .{ }^{\mathrm{s}}$

It was by such means and through these political clubs and popular societies that the Belgian municipal votes for annexation to France were secured. ${ }^{84}$

In the German territories situated to the left of the Rhine, between Landau and Bingen, including Mainz, Worms, and Speier, the spirit of the revolution, fostered by the propaganda of revolutionary clubs like those at work in Belgium ${ }^{* 5}$ and forcibly encouraged by French occupation, gained sufficient impetus to bring about a separatist movement in favor of annexation to France. ${ }^{80}$ A German imperial order of December 19, 1792, "threatened with severe penalties all those who would render the oath of equality and liberty, or who would consent to further the republic. The French countered with a declaration promising fearful reprisals. The oath was to be the prerequisite to the elections and, in order to escape it, the electors took refuge in the German lines." 87 On January 31 the French Assembly decreed the execution of the law of December 15, wherever French troops entered foreign territory. ${ }^{88}$ The vote in Mayence

\footnotetext{
${ }^{83}$ Ibid., pp. 218-219.

84 For details of the voting, ibid., pp. 221-223. Complete list in Freudenthal, pp. 6-7; Solière, pp. 66-67; for the text of the French decrees of incorporation see Martens, vol. vi, pp. 432-442. For a detailed account of the annexation of Belgium sce also Borgnet.

85 A. Chuquet, Mayence (Les guerres de la révolution, VII), Paris, n. d., pp. I-45, I08. "Le club des amis de la liberté et de l'égalité établi à Mayence m'a écrit pour m'engager à vous demander si vous voulez accorder votre protection aux Mayençais ou les abandonner à la merci des députés qui les menacent. On leur fait craindre (cc sont les termes de la lettre que j'ai reçue) que les Français ne les abandonnent"; statement made by deputy Rühl to the Convention nationale on Nov. 19, 1792 (Arch. parl., ser. I, vol. liii, p. 472). Similar appeals had been made before, one through the good offices of the Amis de la liberté et de l'égalité de Strasbourg. Oct. 29, I792 (ibid., p. 127). This appeal speaks of the delivery of the Mayençais from their tyrants by the citizen general Custine, and asks for the necessary aid to ensure this delivery for the future.

${ }_{80}$ Chuquet, Mayence, p. I ff.

${ }^{87}$ Solière, p. 59.

88 Chuquet, Mayence, p. 83. See also p. 72 , note 75 .
} 
began on February 24, "in the midst of a profound silence, broken only by the sound of the church bells and the patroling cavalry." 80 According to Solière only 260 electors appeared. ${ }^{90}$ Another attempt to increase the number of voters succeeded in producing 345 on March $5 \cdot^{91}$ At Worms 250 and at Speier 342 electors came forth to choose, like those of Mayence, their representatives for the Rhenish Convention. ${ }^{02}$ In these three cities, as in practically all the 125 communities, the population was obdurate and rebellious. Submission was finally achieved only by way of expulsions, arrests and military force. $^{93}$

The Rhenish-Germanic Convention, thus "nominated in a revolutionary manner under the pressure of the sabre and by the minority of the electors," 94 convened in March $1793,{ }^{95}$ and voted by acclamation the acceptance of the following decree on the 2 Ist of March:

The National Rheno-Germanic Convention, considering that the state formed of the territories situated on the left side of the Rhine, between Landau and Bingen, owes its independence, decreed on the 18th of March 1793, to the French Republic and to its victorious arms, that the ties of friendship, of recognition and of reciprocal advantages invite the two nations to a fraternal and indissoluble union, unanimously decrees: that the free Rheno-Germanic people desire the incorporation with the French Republic and that they ask such incorporation; that a deputation be nominated from the body of the National Rheno-Germanic Convention, to make manifest this will to the National Convention of France. . . . ${ }^{20}$

The following quotation from Chuquet suggests the difficulties that were to be encountered in the enforcement of this decree at home:

While Foster ${ }^{97}$ and his two colleagues hurried on their way to Paris to offer the Rhenish lands to France, the Convention at Mayence, directed by Hofmann, took the most rigorous steps against its

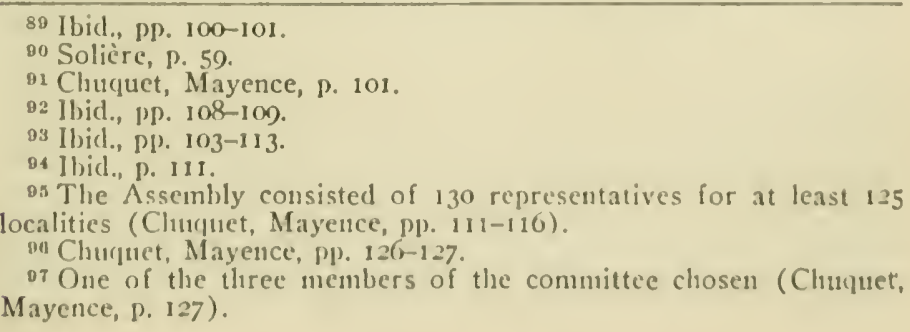


adversaries. Merlin and Reubell had already deported all the monks beyond the Rhine. "The obdurateness is such," said Foster on March 14, "that it is necessary to use the most implacable severity; every day there are deported to the other side of the river thirty or forty persons refusing homage; if necessary we shall end by depopulating the city," and he compared the revolution of Mayence to an energetic and violent cure which demands the use of emetics and the resort to amputations..$^{88}$

A series of decrees were passed against the non-conformists. All who within three days would not render the oath of homage were to be transported with their families. All property of those refusing to render the oath was to be confiscated. All those who had fled since the arrival of the French were declared emigrants. They were ordered to present themselves within three weeks for the oath. Anyone entertaining relations with these emigrants was subject to deportation and confiscation of property. On March 29 another decree ordered all functionaries of the old régime who had not yet rendered the oath, nor intended to render it, to present themselves the next morning at eight o'clock with their families in the place du Chateau for deportation. Failure to comply was to be punished as espionage and treason. From four to five hundred persons were marched across the bridge to the other side of the Rhine on March $30 .{ }^{90}$

The deductions to be drawn from the preceding survey of the plebiscites of the French revolution are these: The French revolution formulated the doctrine of "no conquests" as a guiding principle for France and for mankind. But "no conquests" was not to imply "no annexations," for soon revolutionary France was to be confronted with the possibility of annexations ${ }^{100}$ which, from a na-

88 Ibid., p. I3I.

90 Ibid., Pp. 131-133. For the history of the annexations of Miilhausen and Geneva in I 798 see Wambaugh, pp. 55-57, 359-369.

100 Concerning the annexation of Savoy, M. Grégoire cxpressed the majority opinion of the Frencl national convention in the following words: "Si des peuples occupant un territoire enclavé dans le nôtrc, ou renfermé dans les bornes posécs à la République par les mains de la nature, désirent l'affiliation politique, devons-nous les recevoir? Oui, sans doute; en renonşant au brigandage des con- 
tionalistic point of view, seemed to be fully justifiable. But, in order to annex a territory, formerly in bonds of allegiance to another sovereignty, the former connection had to be broken, if necessary by force of arms. However, to employ arms for a such a purpose would be nothing short of conquest. Hence, in order to divest these annexations of the character of conquest, the principle of popular sovereignty, the alpha and omega of the French Revolution in matters of internal state affairs, was applied to external state relations.

The mental and logical process was simple. The people are the state and the nation; the people are sovereign. As such they have the right to decide, as the ultima ratio, by popular vote and simple majority, all the matters affecting the state and the nation. A people held by force and against their will within the boundaries and under the sovereignty of any state are not in reality a part of that state as a nation. They have, consequently, the right to declare their separation from the dominant state and to proclaim their independence. Having declared their freedom they are themselves a nation and state and as such they are conceded the right to assume a new and different allegiance, where and whenever they wish.

Thus the French Revolution proclaimed the dogma of what we now term national self-determination. It prescribed as the mode of expression of this self-determination the plebiscite ${ }^{101}$ employed in French political life of the past in the form of a more or less restricted expression of opinion or will (vocu), direct or indirect; in feudal times in cases of change of allegiance to liege lord or suzerain, in the election of deputies to the fitats Genéraux, and more

quêtes, nous u'avons pas déclaré que nous repousserions de notre sein des lommes rapprochés de nous par l'affuité des principes et des intérets et qui, par un choix libre, désireraient soidentifier avec nous" (Arch, parl., ser. l, vol. liii, p. 612).

101 See case of Nice, where the request for annexation was refused with the advice that it would be accepted only on condition of a popular vote to that effect (above, p). 67). 
recently, for instance, in the remonstrance of the province of Gex in 1776 .

Applying the plebiscite thus as a means towards the end sought, that is, the consent of the population of the territory to be annexed, success was possible only if and when the plebiscite produced a good majority in favor, first of separation from the old sovereignty, and secondly in favor of annexation to France. Such a result could of course not alwars be taken without running the risk of jeopardizing the chances of annexation and incurring the odium of conquest; in other cases it was sure to be unlikely or impossible. Hence one had to resort to friendly advice and gentle persuasion by means of propaganda and promise of military assistance against the former sovereign, or even military pressure against the penple to be first freed and then annexed. ${ }^{102}$ Thus the plebiscite, originally purely the means towards the end, became more and more the goal itself. The plebiscite had to be resorted to, for only through it could popular sovereignty, the very basis and cornerstone of the revolution, assert itself and make annexation justifiable within the sphere of revolutionary France. ${ }^{103}$ The plebiscite has become the end itself and plebiscite and self-determination were henceforth considered as synonyms. By plebiscite, then, was understood, always and never otherwise, a vote favorable to revolutionary France. This being known also to the neighboring states, freed by French troops from their old allegiance, plebiscites were made to order

\footnotetext{
102 Commissary Chaussard expressed himself to the effect that "le vocu d'un peuple enfant ou imbécile serait nul, parce qu'il stipulerait contre lui-même." M. Chépy wanted the annexations of Belgium achieved "par la puissance de la raison, par les touchantes insinuations de la philantropie, de la fraternité, et par tous les moyens de la tactique révolutionnaire," and, so he added, "au cas que nos efforts soient infructueux, et que l'on continue à nous opposer le systeme désespérant de la force d'inertic, j'estime que le droit de conquete, devenu pour la première fois utile au monde et juste, doit faire l'éducation politique du peuple belge" (quoted from Borgnet, vol. ii, p. 194).

103 Sec note ror.
} 
by decree of the French Assembly and the National Convention. ${ }^{104}$

The dogma of "no conquests" as applied by France was thus robbed by the French Revolution itself of its bona fide character, and the institution of the plebiscite as a method of expression of the popular will in its determination of sovereignty was killed between its conception and birth. The adoption of both, the dogma of "no conquest" and the principle of the determination of sovereignty by popular vote, by the nations at large, was, at least for the time being, made impossible by the fact that the revolution reëstablished the principle of the inviolability of the French territory, imposing the death sentence against anyone considering the cession of French soil, ${ }^{105}$ including, as it did, in French territory all annexations by way of plebiscite. France could annex whatever might be brought to vote for such annexation, but no French territory, once part of France, could ever be disannexed.

France's neighbors and sister states could not recognize the principle of self-determination as conceived and carried into practice by the French Republic without at the same time sanctioning and, in fact, inviting their own dissolution.

\footnotetext{
104 On January 31, 1793, the decree of Dec. 15, 1792 (see note 75), was ordered to be enforced in all countries where French troops had entered or would enter in the future (Arch. parl., ser. I, vol. lviii, p. 104).

105 Decreed by unanimous vote Dec, 16, 1792 (Arch. parl., ser. I. vol. Iv, p. 79). "La Convention nationale décrète que quiconque proposera ou tentera de rompre l'unité de la République française, ou d'en détacher des parties intégrantes, pour les unir à un territoire étranger, sera puni de mort." A similar decree was passed on April 13, 1793 (Arch. parl., ser. l, vol. lxii, p. 3).
} 


\section{CHAPTER IV}

\section{Tixe Revival of tine Plebiscite in Italy}

The annexations of the French Republic on the basis of the plebiscite as the expression of the sovereign will of the people to be thus annexed were, with the exception of a few of the earlier acquisitions of old French enclaves, not of a lasting nature. Most of them were undone by the Peace of Vienna of 18I5. In the first place, Europe outside of France was still very far from accepting the principle of popular sovereignty, established by revolutionary France, as the fundamental basis of government. In the second place, the states of Europe could not be expected to sanction the doctrine of national self-determination as a means of aggrandizement of another state at their own expense. Hence the plebiscite as the instrument of the doctrine of national self-determination could not be and was not considered as a means of settlement of the territorial reapportionment of Europe by the Congress of Vienna. ${ }^{1}$ There was all the less reason why either the doctrine of national self-determination, or the plebiscite, as its proposed method of procedure, should find favor outside of France, because Imperial France herself had discontinued the practice of

${ }^{1}$ The secret gathering of signatures in a part of Savoy in $1 \mathrm{SI}^{5}$ can hardly be considered as a qualification to this statement. After Napoleon's abdication Savoy was occupied by the allies, and by the Treaty of May 30, 18ז4, was divided between France and Sardinia (Piedmont), having belonged to the latter before annexation to France. In the territory allotted to France, comprising 244 communes with a population of from 168,000 to 100,000 , signatures were secretly gathered among the heads of houseliolds known to be favorable to a return to Sardinia. Of 31,676 heads of families considered entitled to a signature, 26,439 signed for reunion with Sardinia. The result was transmitted by the Sardinian diplomats to Louis XVIII, the new king of France, who at once renounced his allotted share of Saroy in favor of Sardinia in a new treaty of Nov. 20, 1815. For a detailed account sec, A. David, Les plébiscites et les cession de territoires, Paris, 1918, pp. 36-40. 
asking the consent of the many peoples conquered and forced under the French domination of the new empire. The French Revolution had not, as some of the advocates of the plebiscite as the expression of national self-determination are wont to assert, ${ }^{2}$ implanted the plebiscite as an institution in European international life and relations. To M. Talleyrand, the French representative at the Congress of Vienna, Emperor Alexander I of Russia said: "You speak to me all the time of principles, your public law is nothing to me; I know not what it is. What importance do you think I attach to your parchments and treaties?"3 It was more than half a century later that the plebiscite again made its appearance in the international life of Europe.

While the doctrine of national self-determination had ceased to operate with the advent of the French Empire the principle of popular sovereignty, though resented and opposed by governments and rulers, made steady headway in western European national life.

It was in the Italian states that the struggle for recognition of the principle of popular sovereignty found its first successful conclusion. Here, analogous to the French Revolution, was a movement which originated in a revolt against oppressive government and a demand for constitutional reform, into which, in the course of the struggle, were injected questions of the relations to each other of the states involved. This extension and broadening of the revolutionary movement in the ltalian states was aimed at nothing less than the abolition of Austrian rule in the two northern provinces of Lombardy and Venetia and the overthrow of the reactionary princes settled upon them by the Congress of Vienna and the Holy Alliance. First as the means to this end and fmally as the goal itself, union with Piedmont (or Sardinia) under Charles Albert, the first of all the

2 "C'est de la Révolution francaise que date la concention subjective de la mationalité, foudéc sur le consentement" (David, p. 17). See also Wambaugh, p. I.

souard de Card, p. 39. 
Italian secular princes to grant liberal reforms of the government and the only one promising national leadership, became the central idea of all revolutionary Italians.

Analogous, also, to the procedure of revolutionary France were the method of expression of the popular will asserting itself in matters of government and the application, as a matter without need of justification, of this method in the termination of their old and the assumption of their new national allegiance.

The efforts of the Holy Alliance to suppress the constitutional and republican tendency of the Italian principalities were marked by decades of autocratic government and persecution of all liberal movements, which stirred the Italian patriots to deeds of desperation. Revolution followed revolution, but these outbreaks were local and sporadic and, as a rule, easily suppressed, and the leaders banished or executed.

Soon the revolutinary element realized that only more concerted action could bring success. The banished political writers and poets wrote from France, Switzerland, and England to inspire and educate their fellow patriots at home. In an open letter Mazzini appealed to Charles Albert, King of Sardinia (Piedmont) to take the lead in the liberalization and unification of Italy or to acknowledge openly his vassalage to Austria. The young priest Gioberti saw in the Pope the natural leader and hope of a new Italy. With the election of Pious IX in 1846 , Gioberti's dream seemed to materialize. Constitutional reforms were promised and given to the people of the Papal States. Charles Albert, not to be outdone by the Pope, followed suit. In May, 1846 , he showed the courage to antagonize Austria in a quarrel over customs duties. In Tuscany Lcopold II was forced to yield to the popular demand for judicial and administrative reforms in 1847. But Ferdinand II of Naples, who had put down an uprising in Sicily in the ycar $18_{3 \%}$, still held out. In Modena, Parma, and Piacenza, Austrian influence and troops were invited to stifle the liberal move- 
ment. In the Austrian subject provinces, the LombardoVenetian states, the iron rule of Metternich tried to stem the popular tide and the growing feeling of national consciousness. ${ }^{4}$

A second revolution in Sicily in January, I848, started the fire which soon swept all Italy. When, with the exception of the resistance of a few strongholds, the revolutionary movement in Sicily had succeeded, Ferdinand, to save his crown, granted a constitution for Naples and Sicily. In February, Charles Albert did the same in Piedmont. The example of Sicily, Naples, and Piedmont, forced the Duke of Tuscany's hand, and soon also the Papal States saw the creation of a lay ministry and the granting of a constitution. Thus, to quote Pietro Orsi, "all Italy, except the territory ruled by Austria, now found itself on the way to freedom."

But even in the territories ruled by Austria things were stirring. In order to "damage the interests of the Austrian government which possessed a tobacco monopoly," ${ }^{\circ}$ the Lombardo-Venetians banished smoking. To break this selfimposed sacrifice the Austrian military employed force, and a massacre followed in Milan, which set the provinces ablaze. The news of revolutions in France and in Vienna hastened matters. On the 17 th of March the civil and military governors of Venice were forced to grant the request for a civil guard. In Milan, the capital of Lombardy, the Viceroy was compelled to flce and the Austrian soldiery under Radetzky was expelled by force. On March 22 the Italian "tricolore" was hoisted over Milan. The revolt spread througl Lombardy and the Austrian troops had to fall back on the fortresses on the Mincio. Soon Venice ejected the foreigner and instituted a provisional government under Daniel Manin. Other Venetian cities, except

1P. Orsi, Modern Italy, 17.48-1848, Londun, New York, 1900, chapters, vii-ix.

ollicl.

- Ibid., p. 16). 
Verona, freed themselves and joined the government of Venice.

The people of Piedmont were highly enthused over the Lombardo-Venetian successes, and began to see in Charles Albert the man destined to free Italy forever from Austrian influence and to unite all Italian provinces under the flag and House of Savoy. He was implored by the populace to send Piedmontese troops to Lombardy and, in fact, Milan asked for his succor. His proclamation "to the people of Lombardy and Venetia" was the reply.i "A few days later the Piedmont army crossed the Ticino and triumphantly traversed Lombardy in the direction of the Minicio."s

In the general enthusiasm the sentiment for fusion grew rapidly. Plebiscites in Piacenza, Parma and Modena "set the example of immediate annexation with Piedmont."

Venice, under Manin, favored a republican form of government and for this reason wavered long, but reverses on the battlefield finally forced the issue. For the sake of protection the Venetian cities of Padua, Vicenza, and Treviso, with the reluctant consent of Venice, decided for annexation to Lombardy. ${ }^{10}$ But at that time annexation to Lombardy meant fusion with Piedmont, since Milan, through a plebiscite, held in the closing days of May, had declared itself for annexation with Piedmont. ${ }^{11}$ A vote taken at the request of Milan in Padua, Vicenza, Treviso, and Rovigo, on June 4, "gave an overwhelming majority for immediate annexation." 12

Still the city of Venice itself held out, until Manin finally sacrificed republican principles for the sake of unity. At first " the government . . . refused to hold a plebiscite, but

7 Ibid., pp. 168-169.

8 Ibid., p. 160 .

9 Ibid., p. I79; B. King, A History of Italian Unity, being a Political History of Italy from 1814-1871, Ncw York, 1899, vol. i, pp. $244,247$.

10 King, vol. i, p. 246

11 Ibid., pp. 243-244.

12 Ibid., p. 246. 
it was forced to order the election of an Assembly to decide on the political future of the city [June 3]. The small polls showed the indifference of the masses, and the fusionists carried all before them. . .."13 The Assembly convened on July 3 , and "by an almost unanimous vote . . . decided for immediate annexation to Piedmont."14 Bolton King's criticism of some of these plebiscites is rather unfavorable. Referring to the vote in Lombardy, he writes:

Later experience has shown how untrustworthy a plebiscite may be, how with a people untrained in political life a vote on a single issue, taken hurriedly without free and full discussion may be far form representing the real feelings of a people. ... The republicans, divided and irresolute... for the most part abstained. Villagers voted under the eyes of the priest, soldiers at their officers' bidding; forgery, pressure, coercion were freely used.

He admits that "the result must have surprised all parties. Five hundred and sixty thousand, or 84 per cent of the electorate, gave their votes, and barely seven hundred were recorded for postponing the question. Making every allowance for the unworthy acts of one party and the disorganization of the other"-so he concludes-"it showed an overwhelming preponderance in favor of fusion." According to King, the plebiscites taken at Parma, Piacenza and Modena showed "majorities proportionately as great." 15

But, "while Charles Albert was collecting votes, Radetzky was collecting men." The campaign went from bad to worse. Milan had to be surrendered, Charles Albert with his beaten army receded to Piedmont, and Venice capitulated in $A$ ugust, I849. What the year 1848 had achieved in the way of unity had to be done again more than a decade later in order to attain permanency. ${ }^{16}$

After the termination of the armistice and the defeat of the Piedmontese at Novara in 18.49 , Charles Albert ablicated in favor of his son, Emmanuel II, who concluded

13 Ilidl., p. 247.

14 Iluid.

15 Ibicl., p. 244 .

1s Hertslet does not include the official decrees of annexation because "tliey led to no jermanent cliange in the map of liurope" (vol. ii, p. 1089 ). 
peace with Radetsky, leaving Lombardy and Venetia to the Austrians-for the time being! Under a liberal government Emanucl set about to reorganize the finances, the economic condition, and the army of the country, never losing sight of the aims and ideals of his father. At the end of the year I852, Cavour became the guiding statesman of Piedmont, and soon succceeded in bringing the subject of Italian unity before the cabinets and councils of Europe. For this the Piedmontese participation in the Crimean war furnished the opportunity.

At the Congress of Paris of 1856 , Cavour "induced the plenipotentiarics of England and France to moot the Italian question at one of their sessions." ${ }^{17}$ Before leaving Paris "Cavour put into the hands of Lord Clarendon and Count Walewski [the French plenipotentiary] a memorial in which, after noting the fact that Austrian opposition had hindered any practical redress of the grievances of Italy, he drew the attention of England and France to the dangers which beset the Kingdom of Sardinia-that kingdom which, alone among the Italian states, had raised an insurmountable barrier to the revolutionary spirit, had kept independent of Austria, and had been as well a counterpoise to the latter's invading influence." ${ }^{18}$ Once more the Italian states began to cast hopeful eyes towards Piedmont. Austria soon saw cause to take notice. Emperor Francis Joseph in the beginning of the year 1857 inaugurated a more liberal policy in the subject provinces which he visited in person. While he was entering Milan, "the municipality of Turin [Piedmont] awarded a commanding site on the Piazza Castello for a monument which the Milanese were dedicating to the Sardinian army." At this Austria took offense and severed diplomatic relations with Piedmont. ${ }^{10}$ Cavour succeeded in bringing about an alliance with Louis Napoleon at their meeting in Plombières in 1858 . The following year Austria, alarmed at the military preparations of the Turin

17 Orsi, p. 236.

19 Ibid., pp. 236-238.

${ }^{10}$ Orsi, p. 241. 
government, strengthened her troops on the Piedmontese frontier and sent an ultimatum demanding immediate disarmament. The Piedmontese reply was followed by a declaration of war from Austria. The Italians under Emmanuel and their French allies under Napoleon had won decisive victories at Magenta, Melegnano, Solferino, and San Martino, when, on the 8th of July, Napoleon met Francis Jọseph and, three days later, signed, unknown to Cavour, the preliminaries of peace at Villafranca. ${ }^{20}$ "Austria was to cede Lombardy to Napoleon who was to relegate it to Piedmont; the Italian states were to be amalgamated into a confederation under the presidency of the Pope, but Venice, though forming part of this same confederation, was to remain under Austrian rule."'21 Cavour opposed these terms and resigned when Emmanuel affixed his name to the treaty.

Napoleon's sudden desertion of the Piedmontese cause was due to his realization that the Italian states not only desired to free themselves from Austrian interference and sovereignty, but that they wanted unity under the House of Savoy. This he desired to forestall-but in reality could no longer do. "They had already decided to summon a representative Assembly in each state [convened in August and September], and the elections on a restricted franchise in Tuscany and Romagna, on manhood suffrage in Modena and Parma, had everywhere resulted in the triumph of the nationalists. By unanimous votes (only three deputies were absent in Tuscany and one in Romagna) the Assemblies pronounced the downfall of the old governments and the annexation of their states to the kingdom of Victor Emmanuel." ${ }_{22}$ Even the final signing of the Treaty of Zürich on November to of the same year (1859) between Piedmont and Austria, confirming Napoleon's scheme, did not

${ }^{20}$ Orsi, p. 263; Ilertslet, vol. ii, p). 1374-1375. See also final Peace Treaty of Zuirich, Nov. 1o, Hertslet, vol. ii, pp. 1380-1413.

21 Orsi, 1). 263.

$22 \mathrm{King}$, vol. ii, Pp. (6-97; F. A. P. Dupanloup, La souveranete pontificale, Paris, 1860, pp. 370, 377-384; Fretudenthal, pp. 9-11; Stocrk, pp. 125-126. 
deter these states in their clamors for union with Piedmont. But owing to Napoleon's opposition, these plebiscites did not lead to the desired fusion with Piedmont.

In glaring contrast to Orsi's optimistic view and King's more critical but still rather apologetic account of the elections and the Assembly votes of 1859 , stands the scathing arraignment which Dupanloup ${ }^{23}$ gives of the official pressure and coercion under which they were, as he claims, conducted.

Speaking of the vote in Tuscany he cites official figures, supplicd by M. Galeotti, Secretary of the Constituent Assembly, showing that "of a population of $1,806,740$ souls, only 35.240 electors took part in the vote." 24 Dupanloup quotes Lord Normanby to the effect that even this vote of 35,240 " has been obtained by intimidation, by corruption in all forms," that "these electors up to the last moment knew not the purpose for which they were electing deputies...," that "these deputies did not know wherefore they were convoked and finally were compelled to vote in the name of the nation in a silent meeting, without debate, without explanation, the forfeiture of the country. . .." ${ }^{25}$

Dupanloup speaks of the "atrocities committed at Parma, under the eyes of the Sardinian authorities," and offers the testimony of an eye-witness, Mr. Bowyer, an Englishman, to prove that conditions in Romagna were equally as bad as those in Tuscany. In a letter published in the London Times, Bowyer, describing his own experiences, states that "nobody is permitted to read, write, and speak a single word in opposition to the reigning faction and the secret societies. The so-called Parliament of the Romagna does not represent one-sixtieth of the population. The admitted total number of electors is but 18,000 , and of this number, force, intimidation and corruption have not been able to drag even one-third to the polling station." ${ }^{28}$

Referring to the charge made at the time by the Vienna

23 Dupanloup, pp. 377-384.

24 Ibid., pp. $379-380$.

2: Ibid., p. 380 .

26 Ibid., pp. $381-382$. 
Gazette that in Modena the dictator Louis Farini willfully excluded the rural vote, a charge which "Mr. Farini has not denied," Dupanloup asserts that "in spite of these exclusions ... there remained in the duchy of Modena still 72,000 electors" of whom hardly 4,000 cast their vote. "But," so he asks, "had these 4,000 the right to enslave the will of all the inhabitants of the duchy of Modena?"27

When, on January I6, 1860, Cavour once more accepted the premiership, he "imagined that since Napoleon III had obtained the imperial throne by a plébiscite, he would not deny the validity of such a claim in Italy, and forthwith submitted this idea to the Emperor who was bound to approve of it." ${ }_{28}$ However, Napoleon did not give his consent until, in accordance with the agreement of Plombières, the cession of Savoy, and in addition that of Nice, was guaranteed to France. ${ }^{29}$ French approval having been won, the final plebiscites in Emilia (including Parma, Modena, Romagna, Bologna, etc.),,$^{30}$ and Tuscany were held on March II-I2, I860. "The decree for the plebiscites had given the vote to all males of age; the ballot papers gave the choice of voting for annexation or ' a separate kingdom.' Twenty per cent of the population voted, or about three out of four of those on the register." 32 Public figures gave in Parma: 53,782 for, 165 against; in Modena: 52,499 for, 56 against ; in Romagna: 200,659 for, 244 against, annexation with Piedmont. ${ }^{32}$ In Tuscany "the autonomists mustered 15,000 votes out of $386,000 .{ }^{\prime \prime 3}$

Victor Emmanuel II, having considered " the result of the Universal Suffrage of the Emilian Provinces, proving their unanimous desire to be united to our State" and "having consulted our Ministers," on March i8 declared these

27 Ibid., p. 382.

28 Orsi, p. 266.

20 Iliid., p. 267 ; King, vol. ii, pp. 115-116.

${ }^{80} \mathrm{King}$, vol. ii, p. 121.

81 Ibid.

32 Stoerk, p. 126; R. von Mohl, Staatsrecht, Volkerrecht und Politik, Tubingen, 1860-1869, vol, ii, p. 294.

sa King, vol, ii, p. 121. 
provinces (Bologna, Ferrara, Forli, Massa and Carrara, Modena, Parma, Placentia, Ravenna and Reggio) "an integral part of the State. . .."34

In the same manner Tuscany was incorporated in the Kingdom of Sardinia by royal decree of March $22 .^{35}$

The Duke of Modena, the Duchess of Parma, the Duke of Tuscany, and the Pope, issued official protests against the annexations of Modena, Parma, Tuscany, and of the Papal Legations of the Romagna. The Duke of Modena protested against "the recent decree of annexation, which it is carefully made to appear as the consequence of a supposed universal voting, and which ... completes the series of unjust and illegal acts by which the sovereignty which we have inherited from our ancestors has been taken from us, after having exercised it for several centuries; sovereignty which . . was by the Treaty of Vienna of 18 I 5 recognized and reinstated in favor of our family by the whole of Europe, happily then coalesced and triumphant over the revolution," and he is convinced that in so protesting "we are thus performing the duties confided to us by Divine Providence. . . ."ss

The Duke of Tuscany raised his voice "to protest on the nullity of the acts consummated by an illegal government; to protest against the consequences which are or may be inferred from those acts by him who has recognized and reserved our rights by solemn treaties [the Preliminaries of Villafranca, the Treaty of Zürich]": he appealed for "our right to all sovereigns, who must recognize in our cause the interests of their own. . . ."

The Duchess of Parma, in behalf of her son, protested "against the pretended right of transfer [dedisionc] proclaimed in favor of the people; a fresh encouragement brought forward for withdrawing them from obedience to constitutional governments; against the proceedings taken

34 Hertslet, vol. ii, p. 1416.

35 Ibid., p. 1417.

30 Ibid., pp. 1418-1421.

37 Ibid., pp. 1424-1 428. 
by the Government of the King of Sardinia in order to obtain at any cost manifestations in its favour by the inhabitants of the Duchy;... against the annexation of the states of our most beloved son to the dominions of the House of Savoy ...., a flagrant violation of European treaties, of all the principles of the Law of Nations, and of the inviolability of States and Crowns." 38

The Pope protested against "the aggrandizement of Piedmont by the spoils of their [the rebellious central states] legitimate sovereigns" and "in consequence, His Holiness, through the obligations incumbent upon him to preserve and defend the rights of his temporal power, has given orders to the undersigned Cardinal Secretary of State to protest against the accomplished spoliation and violation of the incontestable rights of the Holy See, rights which His Holiness intends to maintain in their integrity; and not recognizing, but, on the contrary, declaring as null, because usurped and illegal, everything that has been done, and may hereafter be done, by Piedmont in the said provinces." ${ }^{38}$

These protests, however, did not change the course which events had taken nor did they prevent the continuance of the process of annexation of the remaining Italian states and Papal legations.

In the same year the Neapolitans and Sicilians, having, with the aid of Garibaldi, deposed the House of Bourbon, held a plebiscite and, according to Orsi, "thereby unanimously declared their wish to support the monarchy as represented by Victor Emmanuel." "40 The plebiscite had taken place on October 2I. While "the ballot scems to have been not really secret, and there was no opportunity given to vote for a separate kingdom without the Bourbons," there was at the same time "no open attempt at pressure; in Naples, at all events there was perfect order, and the voting was heavy. ..." "On the mainland I,310,000 voted for

88 Ibid., Pp. 1432-1434.

s9 Ibicl., pp. 1422-1423.

40 Orsi, p. 282; Hert'slet, vol. ii, pp. 1458-1459. 
annexation, and 10,000 against it ; $;^{41}$ in Sicily 432,000 voted for it, and the opposition shrank to a poor 600 ." 42 "A few days later," so King relates, "the plebiscites were held in the Marches and Umbria. In the former the vote for annexation was $I 33,000$ to $I, 200$, in the latter 97,000 to 380 ," and "even the province of Viterbo [in Latium], though reoccupied by French troops, recorded its rote in their despite." 43

By the royal decrees of December I7, I860, the Neapolitan-Sicilian provinces, the Marches, and Umbria were declared integral parts of the Italian state on the strength of "the 'Plebiscito' submitted to universal suffrage in the Neapolitan Provinces convoked in the Comitia on the 2Ist of October last,.... in the Sicilian Provinces convoked in the Comitia on the 21 st of October last, ... submitted to universal and direct suffrage in the Provinces of Umbria in the Comitia the $5^{\text {th }}$ of November, . . . in the Provinces of the Marches... the $4^{\text {th }}$ and $5^{\text {th }}$ of November last. . . ." 44

However, the Peace Treaty of Zürich had left the Venetian provinces under Austrian rule. Cavour now began to lay his plans for their incorporation in the new Kingdom of Italy. ${ }^{45}$ His idea of an alliance with Prussia ${ }^{46}$ was realized after his death and led to Italy's participation in the war of I866. Although Italian arms did not achicve any victories through which Italy could lay clains to the coveted provinces, Austria's defeat at the hands of Prussia was sufficiently effective to secure for Italy the price for which she had given her military aid.

Napolcon, who was asked by Austria to mediate, gladly

41 King, vol. ii, p. 175; Mohl, vol. ii, p. 294, gives 1,102,499 affirmative and $938 \mathrm{I}$ negative votes for Naples.

42 King, vol. ii, p. 175 .

13 Ibid.

14 Hertslet, vol. ii, pp. 1458-146r. Hertslet does not include any protests on the part of the former Bourbon rulers of Naples and Sicily, nor a new protest by the Pope.

45 Victor Emmanuel II adopted the title of King of Italy by decree March 17, 1861 (Hertslet, vol. ii, p. 1468).

${ }_{16}$ Secret treaty signed April 8, 1866 ; see Orsi, p. 303. 
accepted the opportunity in order to secure the cession of Venetia which he had promised Cavour at Plombières in I858.47 On August II, I866, Napoleon assured the King of Italy that: "My aim is to make Venetia her own arbiter [rendre Vénétie à elle même] so that Italy be free from the Alps to the Adriatic. Mistress of her own destinies, Venetia shall soon be able to express by universal suffrage her own will. ..." 48

Austria, however, while willing to accede to the cession, was reluctant to deal with Italy directly, especially on the basis of a plebiscite. After protracted discussions between Vienna, Berlin, and Turin, a modus vivendi was suggested by Napoleon. In the treaty of cession Venetia was ceded to France, Austria agreeing to the introduction of the following passage in the Peace Treaty:

His Majesty the Emperor of Austria having ceded to His Majesty the Emperor of the French the Lombardo-Venetian Kingdom, His Majesty the Emperor of the French on his part having declared hinself ready to recognize the Union of the said Lombardo-Venetian Kingdom to the States of His Majesty, the King of Italy, with the reservation of the consent of the Populations being duly consulted. . . . 49

After the formal transfer of the territories to France, the French General Leboeuf delivered their government into the hands of the city of Venice. The vote in favor of annexation was cast in local assemblies on October $21-22 . .^{50}$

By a royal decree of November 4 , it was declared that "in consideration of the result of the popular vote through which the citizens of the freed Italian provinces, called together in the assemblies on October $2 \mathrm{I}$ and 22, have declared their will to be united to the Kingdom of Italy, . . . the Venetian provinces form an integral part of the Kingdom of Italy." ${ }_{11}$

Now, after all the Italian principalities had come into

\footnotetext{
47 King, vol. ii, pp. 48-49.

4t Moniteur, Sept. 1, 1866, quoted by fireudentlaal, p. 20.

4) Hertslet, vol, iii, p. 1750 .

a) firetulenthal, p). 21-22.

01 llbicl, p. 22.
} 
the fold, united Italy cast her eyes on Rome as the capital of the country.

In opposition to the entire Catholic world, with the nonCatholic states an unknown quantity, and after persuasion had failed to bring the Pope to the point of yielding to the clamor of all Italy, Victor Emmanuel made the most of the favorable conditions offered by France's predicament of IS 7 O. "When, after the disaster of Sedan, the Parisian population rose and proclaimed the Republic, the Italian government felt itself absolved from the observance of the agreement made with the French Emperor in I864.... Victor Emmanuel wrote a letter to Pius IX, in which he implored him, with filial affection, to consider the state of Italy and to renounce the temporal power," but the Pontiff replied that only violence would compel him to yield. ${ }^{52}$ On September 19, I870, the Italian troops, under Genernl Cadorna, appeared before Rome, and a few days later occupied the Holy City, which now became the Capital of Italy and, in the following summer, the seat of the central government.

However, Italy desired to get another title to Rome than that of conquest. A plebiscite was insisted upon, and when the vote was taken on October 2, it showed 133,68I votes for annexation and 1.507 against, on a register of 167.548 , and, so King clains, "though probably many of the Papalists were afraid to go to the poll or thought it useless to vote, the figures proved how overwhelmingly Roman feeling was for annextion."

While King cites Cadorna to the effect that the Italian government showed great moderation, ${ }^{54}$ Dupanloup's remarks must once more be noted. "Who does not know," so he asks, referring to this plebiscite in Rome, "that ... during the elections for the Constituent Assembly, a great number of voters, instead of depositing one ballot in the voting box, threw in as many as thirty, marked with the

E2 Orsi, p. 314

s3 King, vol. ii, p. 378 ; Freudenthal, p. 37.

64 King, vol. ii. p. 377 . 
names of prostitutes and market girls?... Thus one arrived at the number of votes required to make the election valid." And, so he concludes, "this is the truth about these votes of the Italians, about these popular suffrages which are set as the decisive objection against the right of old sovereigns and as the 'raison dernière et péremptoire' for the annexation to Piedmont."

The description of the voting furnished by the correspondent of the Allgemeine Zeitung, Beilage, no. 282, seems to bear out some of the charges made by Dupanloup. "On twelve places of the city," he wrote, "booths were erected. ... Behind the tables draped in the green, white, and red colours were found several gentlemen acting as the priests of the plebiscite. The sacred ceremony was performed in this manner: One after the other of the voters stepped up from the left, offering to the gentlemen their registration certificate, for which in turn they were given two cards, one with the inscription ' $y$ ea,' the other with a 'nay.' The voter then threw the 'yea' card into the voting box on the table, and, leaving by the right, tore the 'nay' card to pieces, accompanying his action with either a cynical grin, dignified disdain, or with a dark mien of rage." ${ }^{8}$

The result of the plebiscite was ratified in the Assembly by a vote of 239 against 20 on December 2I of the same year. ${ }^{57}$

Stock denies to these Italian plebiscites a place in the list of international or annexationist plebiscites. "In their true light," he states, "they represent only measures destined to accord to all 'rechtsfähigen' members of the state of a revolutionary population, participation in the essential change of the previously existing government and in the creation of a new constitution of the state."ss In an earlier chapter Stocrk had referred to Francis Lieber's identical use of the term international and annexationis:

\footnotetext{
85 Dupanloup, p. 384.

so Freudenthal, pp. 37-38.

87 Ibitl.

os Stoerk, p. 126.
} 
plebiscites. ${ }^{59}$ In this connection it must be taken into consideration that Stoerk deals primarily only with the plebiscite in the case of annexations, that is annexations by conquest. Inasmuch as these Italian annexations to Sardinia were not conditioned by conquest on the part of Sardinia, but were rather a spontaneous expression of the free will to be thus united, they may, of course, properly be ruled out of Stoerk's consideration. But they fall within the scope of the present wider study as they bear largely upon the future employment of the plebiscite in European poijtics, especially in so far as Napoleon's apparent and expressed preference for its use is concerned. ${ }^{80}$ One must agree, however, with Stoerk that the plebiscites in these "Italian City States" were indeed superfluous. They were not needed to demonstrate the genuine popular opposition to their foreign princes and of the overwhelming desire of union with Piedmont. "They formed merely the decorative part in the construction of a United Italy and they patently possessed a value only as political manifestations in the face of the desire for intervention by foreign Powers." "61

59 Ibid., p. 40 ; F. Lieber, De la valeur des plébiscites dans le droit international, in Revue de droit international, vol. iii, pp. I39-145.

${ }_{00}$ "I find nothing more honorable than to be the representative of a cause based upon the independence and nationality of a people. Having fought for the independence of Italy, having raised my voice for Polish national existence, I can have no other sentiments, nor follow other principles where Germany is concerned" (quoted by" Freudenthal, p. 44).

${ }^{01}$ Stoerk, pp. $127-128$. 


\section{CHAPTER V.}

The Plebiscite from the Middle of the igth Century to the Beginning of the World War

The plebiscites held in the Italian principalities were clearly of a revolutionary nature in so far as they served as the means of carrying into effect the revolutionary movements against the established governments in those provinces in favor of the new allegiances to the Kingdom of Sardinia. That Cavour realized the probability of European opposition to his contemplated annexations on the basis of a revolutionary principle, seems to follow from his attempt to gain the consent of the Emperor of the French by the reminder that it was through the plebiscite that Napoleon had won the imperial crown. ${ }^{1}$ However, in this process of reasoning, Cavour failed to distinguish between the plebiscite in matters internal and in affairs of an international character. It was of this failure that he in turn was reminded by an officially inspired article of the Constitutionnel, of March 30 , 1860, in which it was made clear that the principle of popular sovereignty could, by false extension, become for Europe the cause of troubles and incessant dangers, that "universal suffrage can be applied only in the interior of a country," and that "it can not serve to modify the exercise of sovereignty in the relations with the outside, nor for an extension of territory." 2 But Napolcon's opposition was not entirely, nor probably even primarily, prompted by an aversion to the principle involved. With him it was a question of practical politics.

Savoy and probably Nice had been the price promised Napoleon by Cavour at Plombieres in 1858 for French

\footnotetext{
1 Orsi, p. 266.

2 Quoted by Solière, p. 5.
} 
assistance, if out of the impending Austrian settlement, the war of 1859 , a united Italy of eleven million inhabitants, a kingdom from the Alps to the Adriatic, would energe. The Piedmontese conception of this kingdom was, of course, one under the House of Savoy. The Treaty of Zürich, enforcing Napoleon's idea to the disappointment of Cavour, provided for an Italian Federation under the "honorary presidency of the Holy Father." the treaty had left Venetia in the hands of Austria. Thus Sardinia did not consider herself bound to cede Savoy and Nice, nor did Napoleon consider himself justified in demanding their cession.

It was not until the unification of the central provinces with Sardinia had assumed a promising aspect that Cavour finally decided on the great sacrifice of holding out to Napoleon the cession of Savoy and Nice as the bribe for his consent to the violation of the fundamentals of the Peace of Zürich. ${ }^{5}$ When the Italian reluctance to abide by the agreement of Plombières had thus given way, Napoleon experienced no further scruples to consent to still more extended annexations by Sardinia, even though they were based on revolutionary plebiscites.

On the first of March, I860, Napoleon announced to the French Assembly that "in the face of the changes which had taken place in Northern Italy and had given into the hands of a mighty neighbor the passes of the Alps, it had been his duty, in order to make secure the French frontiers, to request the French slopes of the mountains."

The Treaty of cession of March 24, 1860, stipulated that "it is understood between their Majesties that the annexation shall be effected without any constraint of the wishes

${ }^{3}$ Orsi, p. 267 ; King, vol. ii, pp. 48-49, 115-116.

4 See above, pp. 87-88.

'By secret treaty of March 12 he pledged hoth Savoy and Nice to France to gain Napoleon's consent to the annexation by way of plebiscites of the Central provinces. On March 24 Cavour was forced to sign a public agreement to that effect (King, vol. ii, pp. (20-121).

${ }^{6}$ Quoted by Freudenthal, p. 7. 
of the populations, and that the governments of the Emperor of the French and of the King of Sardinia will concert as soon as possible upon the best means of appreciating and verifying the manifestations of those wishes."

In his proclamation "to the inhabitants of Savoy and Nice," Victor Emmanuel assured them that while by treaty, concluded on March 24, it had been decided that the union of Savoy and Nice with France should take place with the adherence of the people,-nevertheless "so great a change in the fate [sort] of these provinces should not be imposed on you. It must be the result of your free consent. That is my firm will, that is also the intention of the Emperor of the French. And so that nothing could hinder the free manifestation of your wishes, I recall those of your principal administrative functionaries who do not belong to your lands and I replace them momentarily by several of your own citizens who enjoy general esteem and consideration." 8

French troops sent by Napoleon and two Senators, Laity and Pietri, began their propaganda among a populace which, at least in Chablais and Faucigny [Savoy], favored annexation to Switzerland." But "the zeal for secession sank in proportion to the efforts of the French propaganda." cording to King, "the majority of the Savoyards indeed were probably more than half disposed to separation, or cared little which way their fate went, though the northern portion of the province would have preferred to be joined to Switzerland," while "at Nice the feeling was strong against separation, and the people made pathetic efforts to escape the destiny imposed upon them."11

The election returns of the plebiscites held in April showed in Nice 24,637 votes cast of a list of 29,142 clectors. Of these, 24,448 voted for and 160 against annexa-

\footnotetext{
7 Hertslet, vol. ii, p. 1430.

${ }^{*}$ Quoted by Freucienthal, p. 8.

9 Freudential, p. 8.

10 Ibid.

11 King, vol. ii, p. 122.
} 
tion. In Savoy, with I35.449 electors, I30,533 voted for and 235 against the impending change. ${ }^{22}$

On June 12 a decree of the French Senate proclaimed Sayoy and Nice "an integral part of France."13

The publication of the treaty in the Moniteur was protested by Switzerland on the ground that the "Treaty for the cession of Savoy to France" having "been concluded without the concurrence of Switzerland, which had, however, applied to be allowed to participate in it as one of the principal parties concerned in the negotiations relative to this Cession, this official publication cannot be considered by the Federal Council but as a preliminary act of menace against the rights of which the Confederation is possessed in virtue of former treaties, . . ." and that "a preliminary occupation by foreign agents would be an unfair coercion of the free expression of the wishes of the population of these provinces." 14

The second ground was clearly a protest against the manner in which the expression of free consent was being secured, while the first was tantamount to a charge of violation of past treaties to which, besides France and Sardinia, other signatories were parties. The Powers who had signed the Final Act of the Congress of Vienna and the Declaration of Paris of the 2oth of November, ISI5, had recognized and guaranteed the neutrality of Switzerland and had extended "the neutrality of Switzerland" to part of Savoy (Faucigny, Chablais, and Genevois) forming part of the Kingdom of Sardinia. ${ }^{15}$

The Franco-Sardinian cession treaty of March 24 had taken cognizance of the obligations regarding the neutralized part of Savoy and in Article II had recognized that "the King of Sardinia cannot transfer the neutralized parts of Savoy except on the conditions upon which he himself

12 Ibid.; Freudenthal, p. 9; Stoerk, pp. 129-135.

13 Freudenthal, p. 9.

${ }^{14}$ Hertslet, vol, ii, pp. 1435-36.

15 Ibid, vol. i, p. 67. Art. 5; p. 262, Art. 92 ; p. 328, Art. 4; pp. $370-371$. 
possesses them, and that it will appertain to His Majesty, the Emperor of the French, to come to an understanding on the subject, both with the Powers represented at the Congress of Vienna, and with the Swiss Confederation, and to give the guarantees required by the stipulations referred to in this Article."'16 Prompted by the Swiss protest, Napoleon suggested three proposals for the settlement of the issue of which England officially accepted the first, that of a conference of the interested Powers ${ }^{17}$ to be held in Paris. The proposed conference, however, has never taken place. ${ }^{18}$

It is this first ground of the Swiss protest which explains the wish of part of the Savoyan populace to be annexed not to France, but to Switzerland.

While the French revolutionary plebiscites had led to practically no permanent acquisitions, the unification of Italy was and remained a fact. Furthermore, the accession of Savoy and Nice on the basis of a plebiscite, that is, of national self-determination, was, though challenged, finally acquiesced in by the Powers of Europe. Napoleon III, who had gained the imperial crown through a plebiscite at home, had, by his support of the same institution in the relations of the Italian states, learned to appreciate the value of this instrument for his political ambitions in the affairs of Europe. It was chiefly by his support and insistence that the plebiscite, as the mode of expression of national consciousness and will, was employed in the settlement of matters of international character involving the change of allegiance or determination of sovereignty:

The next important occasion of this kind offered itself in the attempted settlement of the Roumanian question. At the Conference of Vienna, convened on March 15. 1855, to consider the preliminaries to peace between Russia and Turkey and her allies, the Moldo-Valachian question was given a place of prominence for the reason that these

10 llbicl., vol. ii, p. 1430.

${ }^{17}$ Ilicl., vol. ii, Pp. 1448-1450.

18 Ibid, vol. ii, p. 1450, foot-note. 
regions were at the time occupied by some of the Powers concerned and that the settlement of their future adherence to one or the other of the Powers was considered an important item in their peace program. ${ }^{10}$ The task of finding a solution acceptable to the Great Powers and to the principalities themselves was aggravated by the fact that even the leading men in the Moldavia and the Valachia were not in unison in matters affecting the future of their countries. "Some-the greatest number-desire to maintain the suzerainty of Turkey as a safeguard aginst Russia, other, the more resolute, demand complete independence. Some wish to place themselves under the government of a foreign prince, hoping thus to eliminate internal rivalry and to give greater prestige to the dynasty, an idea which on the other hand, was repugnant to others or at least seemed to them to be unessential." 20 This lack of unanimity at home was, of course, known at Vienna and was used to good advantage by the opposing parties until finally the only solution promising a way out of the dilemma was the attempt made by one of the French plenipotentiaries, M. de Bourquenay, to force the issue of the unification of the territories to the fore, the only point on which the Roumanian patriots were known to agree. De Bourquenay submitted a protocol of his government on this point on which, however, no action was taken at the time. ${ }^{21}$ The solution of the question was deferred to the final peace conference to be held in the following year at Paris.

At a preliminary conference of Commissioners in Constantinople, Austria submitted a program of government of the principalities. With the support of Turkey the Austrian plan found acceptance in a protocol signed by the partics to the preliminary Conference on February il. ${ }^{23}$ The provisions of this plan caused a storm of objections in

$10 \mathrm{~J}$. G. Mano, L'Union des principautés roumaines, Paris, 1900, pp. 52-58; N. Jorga, Geschichte des rumänischen Volkes, Gotha, 1905. vol. ii, pp. 303-304.

${ }^{20}$ Mano, p. 55.

21 Ibid., pp. 58-61.

22 Jorga, p. 304; Mano, pp. 79-8r. 
Moldavia and they failed to bring about a solution of the question at the final Conference of Paris. ${ }^{23}$ It was at the suggestion and through the influence of the French Government, which owed its existing form to the notorious plebiscite of $185 \mathrm{I}$, that the Paris Conference decided to leave the solution of this vexing question to the wishes of the people concerned. ${ }^{24}$ In Article 24 of the Peace Treaty of March 30, 1856, "His Majesty, the Sultan promises to convoke immediately in each of the two Provinces a Divan ad hoc [a Parliament], composed in such a manner as to represent most closely the interests of all classes of society. These Divans shall be called upon to express the wishes of the people in regard to the definite organization of the Principalities." 25 Strangely enough, the suggestion to submit the issue to a plebiscite was supported by Austria and Turkey, who desired nothing less than to have a vote of the people show their wishes for union. In fact, they hoped to influence, and for a time succeeded in controlling, the vote to such an extent as to present to the Powers a decision favorable to their, the Austro-Turkish, view, which was then also supported by England. ${ }^{26}$ Austrian influence in the coming elections was enhanced by the fact that the Viennese Government had refused to withdraw its troops until the Bessarabian boundary question found a settlement. ${ }^{27}$

A Commission of the Powers was charged to inquire into the actual conditions of the Principalities and to propose a basis for their organization..$^{28}$ The elections were to be held under provisional governments appointed by the Sultan, ${ }^{20}$ and while the outcome of the elections was to be considered by the Commission and the result of its own labor was to be reported without delay for ratification to a new con-

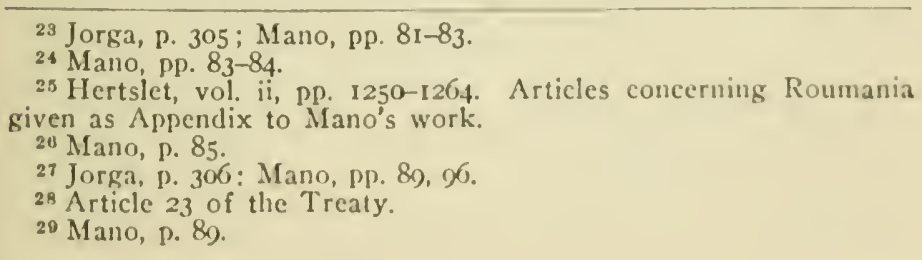


ference to meet once more at Paris, the Commission itself had apparently no authority to concern itself with the actual process of the voting. ${ }^{30}$ Turkey and Austria, with the support of England, centered their obstructive eftorts on Moldavia, the smaller of the two countries, where the desired result seemed easier of accomplishment. The description of the election in Moldavia, as given by Jorga and Mano, shows that the Austro-Turkish-English plan succeeded only too well. The freedom of the press was curtailed. Communication by water and by telegraph was interrupted. Intimidations and arrests were not infrequent. Voters favorable to unification were excluded from the election lists. ${ }^{31}$ According to Thouvenel, "nine-tenths of the population were deprived of their right to vote." ${ }^{32}$ Those of an independent mind, who were left on the lists, disdained to register their vote under such humiliating conditions, and thus the election of July, 1857 , brought forth an anti-nationalist and anti-fusion Divan. ${ }^{33}$

Napoleon at once demanded the annument of these elections. Turkey, however, yielded to this request only when the Emperor of the French had secured the support of Russia and, at a meeting with the Queen of England at Osborne, had overcome the English opposition. ${ }^{34}$ New elections were finally granted by the Sultan, since at Osborne, France and England had consented to limit the extent of the future unity of the Principalities to the "Union des rapports militaires, financiers at judiciaires." 35 This time the provisional government in Moldavia changed its attitude. The electoral lists were revised, and with these new lists the elections were held without illegal interference on the part of the antagonistic alien forces. "The Moldavian Divan convened the $4^{\text {th }}$ of October [Sept. 22],

${ }^{80}$ Article 25 of the Treaty; Mano, pp. 88, 102-103.

31 Mano, pp. 97-98, 103-106.

$82 \mathrm{~V}$. Thouvenel, Trois années de la question d'Orient, Paris, $1 \& 7$, p. IIo, quoted by Mano, p. 106.

83 Jorga, P. 307 ; Mano, p. 107.

84 Jorga, p. 307; Mano, pp. 108-111.

85 Ibid. 
I857, amidst the ovations of the population, proud to be called for the first time to make known its wishes." ${ }^{36}$

The Divan accepted by a unanimous vote the following five resolutions:

1. The acknowledgment of the rights of the Principalities and particularly the right to their autonomy in accordance with the tenor of their ancient Capitulations concluded with the Sublime Porte in I393, I5II, and 1634 .

2. The union of the Principalities in one single state with the name Rumania.

3. A foreign hereditary prince, elected from the reigning dynasties of Europe. ...

4. The neutrality of the territory of the Principalities.

5. The legislative power to rest with a General Assembly in which all the interests of the nation are represented. ${ }^{37}$

These same resolutions were adopted by unanimous vote by the Divan of Valachia. ${ }^{38}$

Nevertheless, the Turkish Government declared publicly that "whatever the wishes expressed by the Divans concerning the union of the two principalities might be, the Sublime Porte, resting its case on the text of the Treaty of Paris, felt absolutely obliged to maintain its former decisions, ..." but it manifested its willingness to consent to a unity in administrative legislation compatible with the Sultan's rights. Austria supported the Turkish contention. ${ }^{39}$

The following Conference at Paris found a temporary solution in the creation of the "Principatele-Unite," giving each of the principalities a prince to be elected for life, and both a common central legislative commission of eighteen members to be located at Foscani, situated on the mutual fronticr, and a united army and judiciary. ${ }^{.0}$

The principle of unity, willed and voiced by the pcople of Valachia and Moldavia, was thus, at least in part, established. The newly created governments found a way' to secure perfect union under the first common prince, Cuza,

se Mano, pp. 111-113.

87 Ibid., p. 113.

88 Ibid., p. 114.

s9 Jbid., 1). 122.

10 Mano, pp. 127-14f; Jorga, pp. 310-311. 
and independence under their first king, Carol of Hohenzollern Sigmaringen. ${ }^{41}$

The application of the plebiscite in the transfer of territory and its legal status were seriously considered by the leading diplomats of Europe during the discussion of the cession of Northern Schleswig in I864. After the first battles during the war between Denmark, Austria, and Prussia, England suggested a conference which met at London on April 20, I864, with the view to arranging peace between the belligerents. ${ }^{42}$ On May 17 , Denmark refused her consent to a personal union between Schleswig-Holstein and Denmark. ${ }^{43}$ After that the questions before the Conference were:

I. Demarcation of the territory to be ceded.

2. Constitutional organization of the territory to be ceded.

3. Extent to which inhabitants should be granted a voice in the decision of questions one and two.4t

Point three was suggested by the French representatives and was supported by Bismarck. ${ }^{45}$ Austria was violently opposed to such a revolutionary practice, and so was Russia. ${ }^{46}$ Berlin was not eager to introduce the plebiscite into international affairs, but it saw no reason for opposing

41 Mano, pp. 144-176; Jorga, pp. 314-379.

42 Freudenthal, p. I3.

43 Ibid. While in personal union with the Crown of Denmark the duchies were to form part of the German Confederation (Freudenthal, p. 15).

44 Stoerk, pp. 136-137; Freudenthal, p. 13.

${ }^{45}$ Freudenthal, p. 13. As early as March 20, Napoleon had sent a despatch to London, Berlin and Vienna in which he asked: "What then is more natural in default of a unanimously accepted rule than to take the wishes of the population as a basis?" He concludes: "This measure which conforms to the veritable interests of both parties, it scems to us, is the best suited to lead to an equitable arrangement and to offer guarantees of stability" (quoted by Freudenthal, p. 14, from Staatsarchiv, vol. vi, p. 726). Bismarck replied through the Prussian Ambassador in Paris, on April 14, that Prussia would support the French plan. But he advised that the plebiscite be deferred until the inhabitants were placed in a position to see that the choice of the House of Augustenburg would be impossible and that the question for them to decide would be, Danish or Prussian. This suggestion prevailed (Freudenthal, p. 15).

${ }^{40}$ Freudenthal, p. 14. 
France and was, therefore, willing to discuss the matter. ${ }^{47}$ As to point one, Prussia and Austria considered the more northern line of Apenrade-Tondern, Denmark the more southern line of Eckernförde and the river Schlei as the line of demarkation between the German and the Danish sections of Schleswig. ${ }^{48}$ France and England, with the approval of Prussia, were willing to let the population decide this question. Austria and Russia were opposed to popular decisions on principle. Denmark opposed a plebiscite in the assuredly Danish sections. France modified its request for a plebiscite, to the effect that it be used, not to settle the boundary, but to decide the choice of sovereign by the section of the territory to be ceded by Denmark. ${ }^{49}$ Finally, in order to prevent the failure of the Conference, France revived its original plan of holding a plebiscite in the sections between the Eckernförde and Apenrade lines in the following form:

It has not been found useful to make an appeal to the wishes of the population where these wishes seemed manifest, but one could consult the populations where the wishes are doubtful. . . . In order to secure desirable guarantees it would be useful that all military force be first eliminated and that the voting take place free from all pressure. ${ }^{50}$

The Conference disbanded on June 25, I864, without agreement, and the decision was left to arms. By the Austro-Prussian-Danish Treaty of October 30 of the same year, Schleswig-Holstein and Lauenburg ceased to be under Danish sovereignty and came into joint ownership of Austria and Prussia. The right of option was extended over

\footnotetext{
47 Ibid., pp. I4-I5.

48 Ibid., pp. 15-17.

48 Ibid., pp. IG-17.

60 Ibid., p. 19. Bismarck agreed that the plebiscite in the sections to be ceded was to decide neither the bomdary nor the choice of ruler, but should merely show whether the people living between the northern line claimed by Austria and Prussia and the southern line demanded by Denmark elserished German or Danish national sentiment. The final decision would be made hy the Conference, not by the people voting (Freudenthal, ค. 17). Austria protested against any plebiscite whatsoever; Denmark objected that the plebiscite should be held only in the future German section, not in the Danish territory (Freudenthal, p. 18).
} 
six years. In the Convention of Gastein of August 14, 1865, Lauenburg was definitely given to Prussia. While the joint ownership rights over Schleswig-Holstein remained in force, the government of Holstein was assigned to Austria, and that of Schleswig to Prussia. ${ }^{51}$

The question of a plebiscite in Northern Schleswig was revived in the settlement of 1866 at the end of the AustroPrussian war. After military victory of the Prussian army was established. Napoleon was asked by Austria to mediate. He suggested that "the duchies of the Elbe be united with Prussia, except the districts of the north of Schleswig where the populations freely consulted, might wish [desiréraient] to be retroceded to Denmark." ${ }_{52}$ This suggestion was agreed to by Bismarck and was in principle incorporated as Article III in the Preliminary Peace of Nikolsburg, and on August 23 as Article V in the Peace Treaty of Prague. ${ }^{53}$

Denmark, hoping to regain part of her lost territory, was now in favor of the plebiscite in those sections. Prussia, however, did not wish to retrocede any part of Schleswig. The Peace Treaty of Prague was referred for ratification to the Prussian Landtag, and a commission of thirteeen was appointed to consider whether and how far the question of the plebiscite in northern Schleswig was compatible with Prussia's interests. The Commission received fifty petitions with 5,I39 signatures from forty-seven communities of Schleswig-Holstein opposing annexation without the consent of a representative Assembly. A petition from the Citizens Union of Apenrade with twelve signatures and a petition of twelve citizens of northern Schleswig domiciled in Hamburg demanded annexation of all of SchleswigHolstein. ${ }^{54}$ Several members of the Commission favored, with the petitioners of the forty-seven communities, a picbi-

\footnotetext{
51 Stoerk, pp. 140-142.

62 Freudenthal, p. 22.

53 Ibid., pp. 22-23; Hertslet, vol. iii, pp. 1608-1701, 1720-1728.

s4 Freudenthal, pp. 25-26.
} 
scite of the entire provinces. But the final report recommended that the vote be restricted to the most northern parts of the section whose retrocession was in question, or the elimination of Article $\mathrm{V}$ from the Peace Treaty altogether. ${ }^{55}$ During the discussions of December 20, Bismarck announced that Article $\mathrm{V}$ was incorporated in the Peace Treaty under pressure from France. Since it was there, it could and should not be ignored, but "the obligations imposed will be carried out by us in a manner that will leave no doubt about the voting, ... its spontaneity and independence, and about the definite will expressed." ${ }^{56}$

Nevertheless, on December 24, 1866, the annexation of all of Schleswig-Holstein was ratified. The exchanges of notes between Denmark and Prussia continued without result. $^{57}$

Austria, in disregard of her former opposition to the plebiscite, at first stood out for the fulfilment of Article V, and on March 28, 1867, expressed her wish in this respect. ${ }^{58}$ But on April I, 1868, the Austrian Government instructed its representative in Berlin to the effect that "regardless of the incorporation of the Prussian promise of retrocession, in the Peace Treaty of Prague we harbor no desire to intervene in this matter. . .."59 Bismarck in the North German Reichstag had insisted that Prussia's obligation for the fulfilment of Article $\mathrm{V}$ was one towards Austria and that no one but Austria was entitled to demand the fulfilment of that obligation, since the two were the parties who had con-

ss Ibid., p. 27.

${ }^{50}$ Quoted by Freudenthal, p. 28. On Sept. 24, 1867, Bismarck had declared in the Reichstag: "If all Danes lived in a district on the Danish frontier and all Germans on this side of it I would consider it as wrong policy not to solve this matter with one stroke by the return of this district to Denmark. I would consider this returu as a plain requisite of the same national policy which we follow in Germany. But with the mixed population the difficulty of the question is that we cannot give Danes to Denmark without giving Germans at the same time" (quoted by Stoerk, pp. 143-144).

or Freudenthal, pp. 28-30.

or Ibid., pp. 30-31.

ov Ibid., p. 33 . 
tracted the Peace of Prague ${ }^{60}$ Finally, these two parties by the Treaty of October II, 1878, abrogated Article V. ${ }^{01}$

The unification of Italy had given Napoleon the occasion to acquire Savoy and Nice in order to obtain for France security of its boundaries. The same motive in 1867 , on the occasion of the formation of the North German Federation, prompted the French desire to secure the annexation of Luxemburg ${ }^{62}$ again, of course, on the basis of self-determination.

The principle of popular consent was stressed in a statement to the French Parliament after the North German Reichstag had opposed the acquisition of Luxemburg by France. Moustier told the Assembly that France would consider the acquisition only if, aside from other considerations, the population of Luxemburg should express their wishes to that effect by universal suffrage. ${ }^{63}$ An appeal from Luxemburg read by Benningsen in the North German Reichstag in April seemed to indicate that the people of Luxemburg, despite their French sympathies, preferred Prussia to France. "If it were not too openly whispered," so the passage in question read, "that by secret agreement we have long been given up by Prussia, you could be assured that there would be no lack of popular expression of our sentiments. In case of a plebiscite, a somewhat certain expectation of a treaty, in any way acceptable, with Prussia would suffice to insure everywhere a vote favorable to the German cause." 64

However, no agreement between Prussia, France, and Holland could be secured, and the Luxemburg question was solved at the Conference of London without a plebiscite. ${ }^{05}$.

Notwithstanding the consistent opposition of both England and Germany to the principle of national self-determi-

60 Ibid., p. 32.

61 Text quoted by Freudenthal, pp. 34-35.

${ }^{62}$ Freudenthal, pp. 35-36.

63 Ibid., p. 36.

${ }^{84}$ Quoted by Freudenthal, p. 36, from Staatsarchiv, vol. xiii, p. 29.

65 Freudenthal, p. 36. 
nation in international relations, the plebiscite was proposed in the case of the cession of Heligoland by England in I89o, the Daily Neres and the Pall Mall Gazette coming out as the most ardent advocates of its application in the island to be transferred. ${ }^{66}$

Prior to the introduction of the bill of cession, various inquiries were made in Parliament as to whether the proposed agreement of cession had taken into account the willingness, or unwillingness, of the people of Heligoland to be transferred from English to German sovereignty. In answer to a question to that effect, put in the House of Lords by the Earl of Rosebery on June I9, 1890, the Prime Minister and Secretary of State for Foreign Affairs, the Marquis of Salisbury, replied:

My answer must be in the negative. The plébiscite is not among the traditions of this country. We have not taken a plébiscite; and I see no necessity for doing so. At the same time, we have good ground for believing that if there has been expressed in past times any objection on the part of any of the inhabitants of Heligoland to this transfer, it has been mainly connected with the fear of a conscription; and if the noble Earl will read the Despatch which has been laid upon the Table he will observe that we have taken the precaution to stipulate that no person alive at the time of the cession shall be subject to obligatory military or naval service. . . ${ }^{67}$

During the second reading the Prime Minister opposed the plebiscite as out of the question. To give people the right to decide whether they wish to be ceded would entail the right to express the reason why they might not wish to be ceded. ${ }^{88}$ Lord Rosebery opposed the transfer of two thousand souls without their consent, reminding Lord Salisbury, who was the sponsor of the cession plan, that he (Salisbury) himself certainly would not cherish the idea of being arbitrarily transferred to another Power. ${ }^{60}$

\footnotetext{
06 Ihid., p. 39.

${ }^{67}$ Hansard's Parliamentary Debates, vol. 345, cols. I311-1312. In this connection sce also ibicl., cols, $1368-1360,1482,1656-1657,1796$; vol. 346, cols. 303-307, 456-457. The Marquis of Salisbury suggested that "it may, perhaps, have occurred to the nolle Earl of Rosebery] that a plébiscite miglit he an awkward precedent as applied to other parts of the Empire" (ibid., vol. 346, col. 305).

$B R$ Ithid., vol. 346 , col. 1263 .

o8 Ibid., col. 1275 .
} 
In the Lower House Gladstone was not in favor of the plebiscite: A handful of British opinions of private individuals should not be set against the conclusions of the government. ${ }^{70}$

Before the passing of the bill MacNeil, Dr. Tamner, Channing, M'Arthur, and Picton favored the plebiscite. They were opposed by Labouchère, who pointed out that the cession of Heligoland was only part of a great treaty whose acceptance or rejection, as Sir James Ferguson, Under-Secretary of State, added, should not be made dependent upon the consent of the people of Heligoland. By a vote of 172 against 76 the demand for a plebiscite was defeated. ${ }^{71}$

The plebiscite which ended the Swedish-Norwegian controversy and led to the separation of the dual monarchy through the establishment of the Norwegian kingdom, is still too fresh in the memory of the present generation to require a detailed introduction. ${ }^{72}$

On June 7, I904, the Norwegian Storthing declared that "the Union with Sweden . . . is dissolved." The declaraticn was embodied in an address to be delivered to King Oscar, who refused to receive any deputation from the revolutionary Storthing. ${ }^{73}$

The Swedish attitude to the fait accompli is laid down in an address delivered to the King by the Swedish Riksdag called in special session. The address states that "by the

${ }^{70}$ Ibid., vol. 347, col. 756. During the Franco-Prussian War of 1870-187I, Gladstone had advocated the consultation of the population of Alsace-Lorraine in the matter of the latter's cession by France to Germany. See below, pp. I74-175.

71 Freudenthal, pp. 40-41. See also Hansard's Debates, vol. 347. An outline of the treaty of ccssion is found in the Annual Register for 1890 , pp. $322-323$.

72 For a detailed account see K. Nordlund, The Swedish-Norwegian Union Crisis, A History with Documents, Upsala \& Stockholm, 1905; N. Edén, Sweden for Peace, The Programme of Sweden in the Union Crisis, Upsala \& Stockholm, 1905; L. Jordan, La séparation de la Suède et de la Norvège, Paris, 1906: K. Gjerset, History of the Norwegian People, New York, 1915; The Annual Register, 1905, pD. 359-367.

${ }_{73}$ Nordlund, pp. 60, 99-101; Annual Register for 1905, pp. 365-366. 
declaration of the Storthing the Union is not dissolved," and that "it can not be dissolved without the consent of the King and Swedish Riksdag. ..." "7t The Riksdag's statement is thus commented on by $\mathrm{K}$. Nordlund:

This does not mean that Sweden will refuse her consent; but it does mean that Sweden can and will demand that her just claims shall be fulfilled before the dissolution will obtain international recognition. Sweden demands a real settlement with Norway. The first condition for such a settlement is that Norway makes a formal request to Sweden for the desired solution. If, however, this request shall be accepted as the uncontested expression of the will of the Norwegian people, it must not be made until that people explicitly has made jts will known either through new elections to the Storthing or by means of a referendum. ${ }^{75}$

A special committee was appointed by the Swedish Government to consider the question of dissolution. This Committee reported on July 25 that "Norway should present a formal request after a new Storthing had been elected, and after the Norwegian people through a plebiscite should signify their desire for the dissolution of the Union. If these conditions were complied with, negotiations might be entered into for the arrangement of terms, on which the final agreement might be based." The report was adopted by the Swedish Riksdag. ${ }^{76}$

On August 13, the Norwegian people were given an opportunity to express by a plebiscite or referendum their opinion on the question of separation as voted by the Storthing on June 7. "The notice given was very brief, and many" sailors and fishermen could not reach home in so short a time. But of the 435,576 voters in the Kingdom, 371.911, or 85 per cent, were able to cast their ballots. Of these, 368,208 voted in favor of the dissolution of the union, and 184 against it. 3,519 ballots were discarded."

Gjerset's comment that "never has a nation expressed a more unanimous opinion on a public question," and that "never has a people made a more determined effort to be

74 Edén, p. 23.

76 llid.

70 Gjerset, pp. 58I-582.

77 lbid., p. 582; Annual Register for 1905, p. 306 . 
present at the polls,"is is apparently fully justified. Even the Swedish Government at the time recognized and appreciated the almost entire absence of an opposing minority. In the Riksdag's address to the King it was admitted that this condition, a Norwegian referendum, was a reality, and a tremendous majority of votes, in fact almost all, had been given for dissolution. In answer to those European papers which hinted at Swedish disappointments as the result of the Norwegian plebiscite, the Riksdag stated in effect, as summarized by Edén, that "in itself this Norwegian unanimity is a relief to us," and that "if the Union is to be dissolved, nothing would have made a settlement more difficult than a strong Norwegian minority against such a solution."78

A few minor cases of territorial cession on the principle of national self-determination expressed by direct or indirect vote, require mention for the sake of record rather than on account of their importance.

The national spirit which was active in the unification of Italy found its echo in Greece. The year 1854 saw the Greeks rise once more in the attempt to secure for Greece, if possible, the lands and islets which once had belonged to her. This new spirit reacted upon the peoples of the Ionian Islands, then under the protectorate of England. ${ }^{80}$ "When the Greek Kingdom became a recognized state of Europe, the wish to be politically united with men of their own race took root among the people of the Ionian Islands." ${ }^{\text {s1 }}$ In addresses and public meetings the peoples gave expression to their wishes. Finally Sir John Young, the English High Commissioner, suggested to the Home Government that the Islands be ceded to Greece. Gladstone went in person to investigate the sentiment of the population and was overwhelmed with petitions. ${ }^{82}$ On June 27,1859 , the Ionian

\footnotetext{
78 Gjerset, p. 582.

${ }^{70}$ Edén, pp. 23-24.

80 Freudenthal, pp. II-I2.

${ }^{81}$ Quoted by Freudenthal, p. 12, from Russel's Circular Note of June 10,1863 .

82 Freudenthal, p. 12.
} 
Assembly had declared unanimously for union with Greece, and it repeated its declaration when, on June I4, I86r, Miaulis in the Greek Chamber assured the Islands that hardly anybody in Greece was opposed to the union. On the occasion of the second vote it was decided to send a copy of its declaration of June 27, 1859, to the British Government and to the other Great Powers. On October 5, 186r, the Ionian Parliament once more voted for annexation to Greece. When Austria, France, Prussia, and Russia, through the Treaty of London of November, I863, had agreed to the union, England relinquished her protectorate in favor of annexation to Greece. ${ }^{83}$

St. Bartholomew, together with a group of ten smaller islets of the Lesser Antilles, were added to the colonial possessions of France in the year 1658 by order of M. Poincy, Governor of the Island of St. Christophe, under the ministry of Mazarin. ${ }^{84}$ The Island was ceded to Sweden in 1784 in consideration of trade concessions in favor of France $^{85}$ and was retroceded to France by sale for the amount of 400,000 francs in the Treaty of August 10, 1877 . But in this treaty both Sweden and France agreed to secure the sanction of the populace to the act of transfer.

83 Ibid. Freudenthal, p. 11, note 3, and Stoerk, p. I35, maintain that the case of the Ionian Islands has only an "äusserlichen Zusammenhang" with the scope of the subject because (I) the cession was not a real change of territorial scvereignty, but merely the termination of a protectorate; (2) the people did not hold a plebiscite, but the issue was decided in Parliament. In this connection see also the case of the Island of Crete, where several assembly votes in favor of union with Greece took place between 1906 and 1912. At that time Crete was still under Turkish sovereignty, though under the protection of four of the Great Powers. A popular uprising in March, 1912, overthrew the government forced upon the Cretons by the protecting Powers and set up a provisional government of their own choosing, "the reception of whose delegates at Athens in October, 1912, was one of the excuses for the outbreak of the Balkan War." The union of Crete with Greece was recognized by the Treaty of Bucharest of August 10, 1913 (Wambaugl, p. 20; The New International Encyclopedia, Crete).

84 E. Plauchut, L'Annexion de l'ile Saint-Barthélemy, in Revue des deux mondes, 1879, vol, xxxii, p. 422.

83 lbid., p. 428. 
Article I of the agreement stipulated that:

"Sa Majesté le Roi de Suède et de Norvège rétrocède à la France l'ile de Saint-Barthélemy. . . . Cette rétrocession est faite sous la reserve expresse du consentement de la population de Saint-Barthélemy et, en outre, aux conditions enumérées dans un protocol special." ${ }^{66}$

By a vote of 350 against a few absentees the population declared for retrocession to France. ${ }^{87}$ Whereupon the people of the island were declared to be subjects of France in a Protocol of October 30, "ayant été consulté conformément à l'article Ier de la convention en faveur d'une réunion de cette ile aux possessions françaises." 88

In his article on the annexation of the Island of St. Bartholomew to France, E. Plauchut rejoices that the retrocession to its former owners was not achieved by war and bloody reprisals, but he regrets that the transaction had been accomplished in a manner similar to the inclusion in the budget of the purchase of a "tableau" or "some war material" without having been accorded even a short but dignified discussion in the Senate or the House of Deputies. ${ }^{89}$ Of the principle of popular consent to be applied as it was he makes light, when he writes:

To vote for their municipal councilors, their deputies or senators, certainly means a great deal in France, but under the equator at Guadeloupe, Martinique, Derisade and soon in St. Bartholomew, is less important. In those regions only so-called colored people are occupied witl politics; the pure white and the negroes abstain, the former because they are to-day in the minority, the latter because they know no other politics than to live without work. ${ }^{90}$

There have been various instances of a resort to the plebiscite in the case of territorial changes in the history of the United States, and one in the international settlement of some of the South American countries.

\footnotetext{
${ }^{86}$ Freudenthal, pp. 38-39.

${ }^{87}$ Plaucliut, p. 430. The absentees were mainly Lutherans of Swedish nationality. "Four hundred English Methodists chose for France" (ibid.). See also Wambaugh, pp. 155-156.

${ }^{88}$ Freudenthal, p. 39.

${ }^{80}$ Plauchut, p. 417.

90 Ibid., p. 432. The chiefs of Tahiti (Society Islands) were consulted regarding the treaty of cession of the island to France in I880 (Wambaugh, p. 2.3).
} 
With the successful conclusion of the Revolutionary War the selection of a federal capital became imminent. The central points of the thirteen states were in Maryland and Viriginia. In March, 1783, New York tendered Kingston; in May, Maryland urged the choice of Annapolis; in June, New Jersey offered a district below the falls of the Delaware. Virginia, having Georgetown for its object, invited Maryland to join in a cession of equal portions of territory lying together on the Potomac; leaving Congress to fix its residence on either side." ${ }_{21}$ The following year a Congressional Committee reported in favor of the location on which Washington now stands and the offers made by Maryland and Virginia were accepted. ${ }^{92}$ But on September 7 , 1846, that part of the District derived from Virginia was retroceded to the Old Dominion upon a petition of its occupants, by a vote of 763 to $222 .{ }^{93}$

In the United States the next occasion for the change of territorial inter-state relations by popular decision came with the issues involved in the slave question and their aftermath, the Civil War.

On the Ioth of December of the year 1860 , the Legislature of the State of Louisiana met and passed a bill authorizing a convention, to be held on January 23 of the following year with the object of considering the question of secession. On January 25, that body passed an ordinance of secession by II 3 yeas and I7 nays. A motion to submit the ordinance to a popular decision, a plebiscite, was defeated by a vote of 84 against $45^{94}$ The secession ordinance

$01 \mathrm{G}$. Bancroft, History of the United States of America, the author's last revision, New York, 1885 , vol. vi, pp. 97-98.

ध2 Ibid., p. 98.

${ }^{3}$ W. F. Dodd, The Government of the District of Columbia, Washington, 1909, p. 32. See also The Encyclopedia Americana, District of Columbia.

v4 E. McPherson, The Political History of the United States of America during the Rebellion, Washington, D. C., 1864, pp. 3-4. A widely held doctrine of American constitutional theory is to the effect that a constitutional convention is to be construed as representing the entire people in their original sovereign capacity and that. therefore, a vote of such a body is to be deemed e(puivalent to a 
was passed in Alabama in secret session, yeas 6I, nays 39 , but the proposition to submit the ordinance to the people was lost by a vote of 53 to $47 .^{.5}$

In Texas the ordinance of secession passed by a vote of I66 to 7 and, when actually submitted to the people, was, on the 23 rd of February, I861, approved by 34,794 votes for and II,235 against the measure. ${ }^{96}$

In Arkansas an act calling for a state convention was passed the Legislature on January 16, I861. The popular vote on the question of calling the convention was, 27,412 for, and 15,826 against it. The convention met on March 4. On the 18 th of March the ordinance of secession was rejected by a vote of yeas 35 , nays 39 . It was then agreed to submit the question of secession to the vote of the people on the first Monday in August. But before that day arrived the convention reconsidered its former action and on May 6 passed the ordinance by yeas 69 , nays $I{ }^{77}$

The North Carolina Legislature passed a bill for a state convention on January 30, I86r. This bill provided that no secession movement would be valid unless adopted by referendum. On February 28, the election of the delegates to the convention took place. The vote was against the calling of a convention by a majority of 662. However, the Governor, favoring the secession of the State, called the Legislature in extra session. On May I, the latter voted for another election of delegates to a second state convention. The election took place on the $3^{\text {th }}$ and the delegates convened at Raleigh on the 2oth. On the following day the secession ordinance was adopted and the Confederate Con-

direct vote of the electorate, that is to say, a plebiscite. In this connection see Roger S. Hoar, Constitutional Conventions, Their Nature, Powers, and Limitations, Boston, 1917, especially chapters iv, $x$, and $x i$.

${ }_{95}$ Ibid., p. 4. The secession ordinances in South Carolina, Georgia, Mississippi, and Florida were passed in state conventions convened by special elections to consider the question of secession. There was no popular ratification of the ordinances by referendum in these states (ibid., pp. 2-4).

as Ibid., P. 4.

97 ibid. 
stitution was ratified. No further referendum on the secession ordinances was held, notwithstanding the fact that the bill of January 30 had provided that no secession movement would be valid unless approved by popular majority vote. $^{98}$

The first popular vote in Tennessee decided against the holding of a state convention by a poll of 67,360 to 54,156 . But on May I the Legislature "passed a joint resolution authorizing the Governor to appoint Commissioners to enter into a military league with the authorities of the "Confederate' States." The declaration of independence, passed on May 6, was submitted to the vote of the people on June 8. Governor Harris declared Tennessee out of the Union, the popular vote resulting in 104,019 for, and 47,238 against the measure. ${ }^{99}$

While the secession ordinances had been voted upon and had been accepted without great opposition in the legislatures of most of the seceding States, and had been approved by popular referendum in Texas and Tennessee, matters moved more slowly in Virginia, where, when they were finally brought to a head, they ended in the division of the State. ${ }^{100}$

"Unequal representation of the counties" as "established in the year I66r, by the House of Burgesses," and "limitation of suffrage to frecholders . . . imposed on the Colony in 1677, by Royal instruction from Charles II, to the Governor of the Colony of Virginia "to take care that the members of the Assembly be elected only by frecholders, as being more agreeable to the customs of England," "had long ago set the countics east and west of the Blue Ridge Mountains in opposition to each other. "With the increase of the population and the organization of counties west of the

98 Ibid., pp. 4-5.

93 Ibid., p. 5 .

100 'The following outline is based on V. A. Lewis' History of West Virginia, Philadelphia, I8\&), chapters x.x-xxv; Appleton's American Anmual Cyclonadia and Register of Important Events of the year 1861, Virginia, and Virginia, Western: McPherson, pp. 5-8. Quotations, unless otherwise stated, are from Lewis. 
Blue Ridge... many of the western counties paid into the public treasury many times the amount paid by some of the Eastern counties, yet the representation of both was the same. . . It was . . . taxation without representation." In the Assembly of 1820 , the East inad one hundred and twenty-four members, while the East had but eighty. The result was "that the East secured to itself nearly everything in the character of internal improvement," while the representatives of the western counties were glad to return home with a "few hundred dollars to be used in the construction of a mud turnpike." What caused the greatest dissatisfaction, however, was the fact that the right of suffrage was restricted, by means of property qualifications, to freeholders, so that in the war with England "thousands marched to the field, who were treated as aliens in the land of their nativity, and that, too, by the very government they were giving their lives to defend." After much opposition a bill was finally passed in the Assembly at the session of 18271828 , providing for a public vote on the question of calling a constitutional convention to revise the old instrument of 1776 . In 1828 the poll registered 21,896 for and 16,646 against the proposition. During the session of this Convention held in October, 1829, in Richmond, the breach between the East and the West widened. When the final vote on the new constitution was taken, every delegate from the counties west of the Alleghenies, except one who was absent owing to illness, voted against it, while all others voted aye -and that for the simple reason that the new constitution secured none of the reforms sought, that it still restricted the right of suffrage and still denied to the West equal representation. When the new constitution was submitted to popular vote, "every county east of the Blue Ridge with one exception (Warwick), gave a majority for ratification: while every county in what is now West Virginia, with two exceptions (Jefferson and Hampshire), voted largely in favor of rejection," and "of the total vote $\left(9.75^{8}\right)$ cast in these [western] counties, 8,375 were for rejection." Thus 
the "new constitution went into effect, and under it was added to the evils of the old political ostracism in the West." During a quarter of a century, Lewis writes, "but one man-General Andrew Moore, of Rockbridge-had ever been chosen from a county west of the Blue Ridge to represent Virginia in the United States Senate, and in the same period but one man-Joseph Johnson, of Harrison -had ever been selected from the counties west of the Alleghenies to fill the Gubernatorial chair." And thus he continues, "men in the West having political aspirations, saw in the supremacy of the East the impossibility of their realization, and smarting under what they deemed to be the greatest injustice, they began to dream of a time when conditions should exist under which a separation from the mother state would be made possible, and in the territory thus separated they, themselves, should assist in establishing a new common-wealth." The majority, however, still hoped that such a separation need not be resorted to in order to change conditions. They finally, in $\mathrm{I} S 50$, succeeded in wresting from the Assembly another act "providing for the submission to the people the question of calling a convention to revise the Constitution." A favorable vote brought the new convention and, through it, a new constitution, with the redress of many evils, but it came too late to bring happiness to the West and peace to both, West and East.

It was the slave question which now became the real bone of contention. The predominance of the freeholders in the East, spelled, of course, opposition to the policies of the North of the Union and led to the victory of the movement favoring the secession of the whole State of Virginia from the Union, while the predominance of the non-freeholders in the counties west of the Alleghenies signified opposition to such an act, resulting in the separation of the western counties from the Old Dominion.

In both the eastern and western counties, spirited neetings were held in which the people gave expression to their respective, that is, opposing, views. In Preston county, a 
resolution was adopted at a mass meeting on November I2, I 860 , declaring that "any attempt upon the part of the State to secede will meet with the unqualified disapprobation of the people of the county." On November 24, the people of Harrison county proclaimed that they would "first exhaust all constitutional remedies for redress before they will resort to any violent measures"; that "the ballot box is the only medium known to the Constitution for redress of grievances." Similar resolutions were adopted at Morgantown, Monongalia county, Taylor county, and by the citizens of Whecling. Nevertheless, the secession ordinance passed in a convention which had been called by the Assembly in an extra session held in obedience to a request irom the Governor. Conventions had heretofore been called by referendum and, naturally, the opposition refused to acknowledge the constitutionality of the Governor's and the Assembly's procedure. The act of the Assembly had provided, however, that the decision of the Convention on the question of secession should be submitted to popular vote.

The ordinance of secession had passed in secret session on April I7, I86I ; with yeas: 88 , nays: 55 . Of the delegates from western Virginia "twenty-nine had voted against it, nine for it, seven were absent and one excused."101 After many meetings of protest in the Western cities and counties, a gathering at Clarksburg of nearly twelve hundred citizens of Harrison county on April 22, called for a general convention to be held at Wheeling on the I $3^{\text {th }}$ of May. This, the first Wheeling Convention, met, "determined to save Western Virginia to the Federal Union." A report of the Committce on resolutions advised that, if the sccession ordinance should be adopted by a popular majority, the dissenting counties elect delegates to a new Wheeling convention for June II, "the business of which should be to devise such measures as the safety and welfare of the people would demand."

101 McPherson, p. 7. 
The popular vote on the ordinance of separation was almost unanimous against it in Western Virginia, while with equal unanimity Eastern Virginia voted in favor of it. It was carried by a large majority of the votes cast."102

The second Wheeling Convention, called in pursuance of a resolution of the first Wheeling Convention of May I3, assembled in Washington Hall on June II. Two days later it issued "a declaration of the people of Virginia represented in Convention at the City of Wheling." The next day it began the reorganization of the state government. The new General Assembly, whose members were duly chosen at the occasion of the vote of the secession ordinance, convened on July $I$ and sent new representatives to the Congress in Washington. On August 6 the Convention assembled once more and three days.later declared "all ordinances, acts, orders ... of the Convention which assembled at Richmond on the I 3 th of February last, being without authority of the people of Virginia constitutionally given .... illegal, inoperative, null, void and without force and effect." It then passed an ordinance providing for the "formation of a new state out of a portion of the territory of this state," the new state to be called the State of Kanawha. This ordinance was to be and was submitted to a plebiscite in the disaffected sections on the fourth Tuesday of the ensuing October. The vote, when taken, "stood eighteen thousand four hundred and eight for the new State, and seven hundred and eighty-one against it." At the Constitutional Convention called by the new Governor for November the name of the new State was changed to West Virginia.

In connection with the principle of self-determination as applied in the secession movement, reference should here

102 Appleton's American Annual Cyclopedia, 1861, p. 738. McPherson gives the total votes cast' as 128,884 for and 32,134 against secession (McPherson, p. 8), while Lewis claims for Western Virginia alone 40,000 against secession out of 44,000 votes cast in that part of the Old Dominion (Lewis, p. 356). 
be made to the doctrine of popular or squatter sovereignty. The essence of the doctrine is found in a letter of Lewis Cass, of December 24, I847, in which the writer "asserts that the principle of the Wilmot proviso "should be kept out of the national legislature, and left to the people of the confederacy in their respective local governments'; and that, as to the territories themselves, the people inhabiting them should be left "to regulate their internal concerns in their own way." "The adrocates of this theory, among them Stephen A. Douglas, "generally accepted the territorial section of the Constitution ... as applicable, not only to the territory possessed by the United States in 1788 , but prospectively to any which might be acquired thereafter." Thus they held "that Congress might make any 'rules and regulations' it might deem proper for the territories, including the Mexican acquisition; but that, in making these rules and regulations, it was wiser and better for Congress to allow the 'inchoate state' to shape its own destiny at its own will. Properly ... there was nothing in the dogma which could constitutionally prohibit Congress from making rules for or against slavery in the territories, if it should so determine, though gradually Douglas and some of its more enthusiastic advocates grew into the belief that popular sovereignty was the constitutional right of the pcople of the territories, which Congress could not abridge." After the new Republican Party had gained control of the House of Representatives in $1855-1857$, the South came to the realization that "if a democratic Congress might make a 'regulation' empowering the people of the territories to control slavery therein, a Congress of opposite views might with equal justice make a 'regulation' of its own, abolishing slavery therein." As a result "the whole South came to repudiate popular sovereignty and the territorial section of the Constitution, and rested on the Calloun doctrine that Congress and the immigrant both entered the territory with all the limitations of the Constitution upon them, including 
its provisions for the protection of slave property as well as property of other kinds." In I857 the United States Supreme Court, in the Dred Scott case, "decided against Douglas and popular sovereignty, and for the full vigor of the Calhoun theory." It was through its hold upon the South that the Calhoun doctrine furnished "the connecting link between the theory of state sovereignty and its practical enforcement by secession.'103

The recent purchase of the Danish West Indies by the United States was preceded by several earlier attempts to consummate such a transaction. After Secretary of State Seward had broached the subject to the Danish minister at Washington in 1865 , Denmark offered, two years later, to sell to the United States the two islands of St. Thomas and St. John for the sum of $\$ 5,000,000$ each and indicated her willingness to cede St. Croix for a like price. An agreement was reached for the sale of the former two for $\$ 7,500,000$. Both Houses of the Danish Diet gave their approval. ${ }^{104}$ "Seward gave his unofficial consent to the holding of an election on the islands to ascertain the will of the inhabitants. ${ }^{105}$ The plebiscite on the islands "carried in favor of annexation by the nearly unanimous vote of I,244 to 22." The project, however, was frustrated by the opposition of the United States Senate, or rather, that of the Foreign Relations Committee under Senator Charles Sumner, the "implacable enemy of President Johnson."

${ }^{103}$ The foregoing quotations are from Alex. Johnston's article on Popular Sovereignty, in Lalor's Cyclopædia of Political Science, Political Economy and of the Political History of the United States.

${ }_{10 t}$ W. F. Johnson, The Story of the Danish Islands, in The North American Review, Sept., 1916, vol. cciv, Pp. 379-384.

105 Seward liad at first positively refused to consider any plebiscite but finally gave his unofficial consent in deference to Denmark's insistence on a popular sanction of the transfer (ibid.e p. 384). The Danish insistence on the plebiscite was due to Denmark's interest in the employment of the plebiscite in international affairs in view of her hope of regaining the Northern part of Selhleswig on the basis of Art. V of the Treaty of Prague of 1866 , which had prescribed a plebiscite in that section. On this point see also Wambaugh, pp. 149-150.

10s Johnson, pp. 385-386. 
The plebiscite taken in Denmark on December 14, 1916, on the question of sale, resulting in a vote of 283.694 for and 157,596 against the cession of the islands, ${ }^{107}$ does not concern us here since it does not include the voice and votes of the inhabitants of the territories to be transferred.

In 1879 the South American States, Peru and Bolivia, became involved in war with Chile. The conflict lasted several years. After a series of defeats on land and sea Peru and her ally were forced to sign a treaty of peace, ratified on March 8, I884. Articles two and three of this Treaty stipulated that:

II. Tarapaca to be ceded to Chile unconditionally forever.

III. The territories of Tacna and Arica, as far as the river Sama, are to be held by Chile for ten years, and it is then to be determined by popular vote, whether those territories are to belong to Chile or Peru. ${ }^{168}$

This plebiscite has however never been held because "at the close of the ten years Chile apparently distrusted the result of the plebiscite, and the matter was allowed to drag on."108

The significance of the plebiscites in American politics is to be found in the fact that though the effect of the Assembly votes and referenda in the seceding States was an-

${ }_{107}$ W. Westergaard, The Danish West Indies, New York, 1917, p. 261 .

108 C. R. Markham, A History of Peru, Chicago, 1892, pp. 423-424.

100 The New International Encyclopedia, Peru. On August 13, 1900, Abraham Konig, Chilean Minister to Bolivia, made the following statement in a note to the Bolivian Foreign Office: "Chile has occupied the coast and taken possession of it by the same right which Germany exercised when she annexed Alsace and Lorraine. ... Our rights are the result of victory, which is the supreme law of nations. That the coast is rich and worth many millions, we already know. We keep it because it is valuable. Were it worthless, we would have no interest in retaining it " (The Question of the Pacific. America's Alsace and Lorraine. The Conquest by Chile in 1879. Illuminating Documents from the Department of State of the United States of America). For a detailed account of the negotiations between Peru and Chile since the signing of the Peace treaty of 1884 sce Wambaugh, pp. 156-165. 
nulled by the outcome of the Civil War, the separation of West Virginia on the basis of popular vote has continued. ${ }^{110}$ An important consideration in the case of the acquisition of the Danish West Indies is the refusal of the American State Department to give official sanction to the plebiscite held in the territories transferred from Danish to United States sovereignty. ${ }^{111}$

110 See below, pp. 167-168.

111 The international legal aspect of this refusal is discussea in chapter viii, pp. 172-173. 


\section{CHAPTER VI}

The Plebiscite in the Peace Treaties Ending the WORLD WAR

Because of the growing disaffection of the foreign elements in some of the countries involved in the late World War, the Allied and Associated Powers found it expedient to offer a settlement of the aspirations of the freedom-seeking peoples on the basis of the principle of national selfdetermination. Thus the historical development of the plebiscite as the mode of expression of this principle of self-definition would seem to have assumed a new phase. Heretofore the principle of national self-deternination had been recognized, and the plebiscite had been employed in international affairs only in individual cases and with the consent of or upon pressure from the power or powers directly or indirectly interested in each instance as it presented itself. With the embodiment of the principle of national self-determination in the officially defined war aims of the Allied and Associated Powers and the submission, even though enforced, of the Central Powers on the basis of these expressed ains, we have in the Peace Treaties the provision for plebiscites apparently sanctioned by all the large and a great number of the smaller nations of the world.

By the Brest-Litovsk Treaty concluded and signed on March 3, I9I8, between Russia and the Central Powers, the former consents in Article III that "the territories lying to the west of the line agreed upon by the contracting parties which formerly belonged to Russia will no longer be subject to Russian sovereignty, ..." that "Russia refrains from all interference in the internal relations of these territories" and that "Germany and Austria-Hungary . . . determine the future status of these territories in agree- 
ment with their population." In Article VI Russia recognizes the independence of Ukrania and "obligates herself to conclude peace at once with the Ukranian People's Republic and to recognize the treaty of peace between that State and the Powers of the Quadruple Alliance. ..." Article 7 of the Supplementary Treaty signed at Berlin, August 27, 1918, reads in part:

Russia, taking account of the condition at present existing in Esthonia and Livonia, renounces sovereignty over these regions, as well as all interference in their internal affairs.

The same article provides that "their future fate shall be decided in agreement with their inhabitants."

Article Io of the same supplement stipulates as follows:

With regard to Esthonia, Livonia, Courland, and Lithuania, agreements, among others, are to be concluded with Russia, as to the following points :

I. With regard to the nationality of the former Russian inhabitants of these territories, as to which they must in any case be allowed the right of option and departure...;

5. With regard to the regulation of the new frontiers;

6. With regard to the effect of the territorial alterations on the State treaties.

By Article VI of the Treaty of March 3, Germany has secured the right to occupy Esthonia and Livonia by a German police force until security is insured by proper national institutions and public order has been established."

There is in the Brest-Litovsk treaties no provision for the application of a plebiscite in any of the territories separated from Russia. The nei -est reference to a consent of the people is found in the statement that the future fate of Esthonia and Livonia "shall be decided in agreement with their inhabitants." From a Protest to the German Government by representatives of the Provisional Esthonian Government against the Treaty of Brest-Litovsk ${ }^{2}$ it appears that "by a vote of the General Esthonian Assembly [Land$t a g]$, which as the legal representative of United Esthonia,

1 The text used is that publislied for the United States Department of State. "Texts of the Russian "Peace" (With Maps)," IVashington, Govt. Printing Office, 1918.

${ }^{2}$ Ibicl., pp. 223-226. 
proclaimed the political independence of Esthonia on November 28, 1917, a Provisional Esthonian Government was formed. Before the invasion of German troops on February 24, I9I8, this Provisional Government, supported by national Esthonian troops, and in fulfiment of the vote of November 28, proclaimed the republican form of government in Esthonia, and at once reestablished political order in most of the districts of the country." The Protest charges the German military police force with the usual method of forcing a favorable public expression for annexation: the press is censored, forced to print pro-German editorials supplied by the forces of occupation, or to be suppressed; all free expression is made impossible by the threat of heavy fines and death; the national troops are disarmed; administrative and local self-governing institutions in town and country, created by the Esthonian Assembly, are set aside. In their place committees have been appointed from the German minority population which, according to the latest Esthonian statistics, is less than two and one-half per cent. The German language is made compulsory for private correspondence and given first place in schools. In place of the Esthonian elected Assembly, a new Assembly has been called by summons of " a few delegates of the communal elders of the peasant communes, as if there was not also an overwhelming Esthonian majority in all the towns of Esthonia." The Protest continues:

Subsequently, in order to give the lacking authoritativeness to the acts of the United Diet, called together in this way, in regard to the annexation of Esthonia to the German Empire, representatives of the German nobility, of the German pastors, and of other Baltic German groups, with the active support' of the military power, started a secret collecting of signatures among the Esthonian population in favor of a closer political connection between Esthonia and the German Empire; in doing this every means was used to terrorize the people in order to sccure the desired result.

The cessions of territory demanded by the Central Powers in the Treaty of Bucharest of May 7, 1918, between Roumania and the Quadruple Alliance, provide for no 
plebiscites, but they grant option with the right, not demand, of emigration. ${ }^{3}$

By the force of the Peace Treaty between the Allied and Associated Powers and Germany, the Treaties of BrestLitovsk and Bucharest have both been annulled. It is chiefly the Treaty of Versailles which requires consideration of territorial changes on the basis of the plebiscite. ${ }^{4}$

According to Articles 32,33 and 34 of the Treaty of Versailles, Germany "recognizes the full sovereignty of Belgium over the whole of the contested territory of Moresnet [called Moresnet neutre]," and she renounces in favor of Belgium German sovereignty over Prussian Moresnet and the whole of the Kreise of Eupen and of Malmédy. "During six months after the coming into force of this Treaty, registers will be opened by the Belgian authority at Eupen and Malmédy in which the inhabitants of the above territory will be entitled to record in writing a desire to see the whole or part of it remain under German sovereignty."

No expression of opinion is provided for in Neutral and Prussian Moresnet.

The result of the public expressions of opinion in Eupen and Malmédy "will be communicated by the Belgian Government to the League of Nations, and Belgium undertakes to accept the decision of the League."

The expression of opinion here provided for is not a free public vote in the sense of a plebiscite for the reason that what is requested is the expression of opinion in writing in public registers. Though the Treaty does not specify the mode of registry, it is clear that in order to give to these expressions in writing any value and significance the individual thus expressing his opinion must either attach his signature or divulge his name to the supervisor of the

${ }^{3}$ Text used is that published for the United States Department of State. "Text of the Roumanian 'Peace' (With Maps)," Washington, Govt. Printing Office, 1918.

T Text used is that of the "Treaty of Peace with Germany" published as number 1.42 by the American Association for Interuational Conciliation, New York, Sept., 1919. 
records. This, of course, would deprive the "expression of opinion" of the secrecy essential to a free and unrestrained voicing of a popular will.

Article 37 provides that "within the two years following the definite transfer of the sovereignty over the territories assigned to Belgium... German nationals over is years of age habitually resident in those territories will be entitled to opt for German nationality." It stipulates further that "persons who have exercised the above right to opt must within the ensuing twelve months transfer their place of residence to Germany."

Concerning the cessions of German territory to Belgium, the German Peace Delegation submitted to the Allied and Associated Powers the following comment ${ }^{5}$ in regard to Neutral and Prussian Moresnet, where no expression of opinion is provided for: "Neutral Moresnet owes its origin to the Prussian-Dutch frontier treaty of June 26 , I8I6. It is a district with 3,500 inhabitants, the majority of which are German by origin and language. . . Prussian Moresnet, too, which belongs to the district of Eupen, has a predominantly German population. Nevertheless, not even a plebiscite has been provided in these territories."

As to the other territories to be ceded it is stated that "historically the districts of Eupen and Malmédy have never belonged to Belgium, or to any of the political formations which may be considered as predecessors of the present Belgium." In the district of Eupen which is clained as purely German, "out of 25,000 inhabitants during the last census only ninety-eight named Walloonian as their mother tongue."

In Malmédy the Walloonians "are considerably in the minority" as the district "has among its 37,000 inhabitants a population of about 9,500 souls speaking Walloonian as their mother tongue."

The comment then raises two objections to the cessions

s "Comments by the German Delegation on the Conditions of Peace," published as number 143 by the American Association for International Conciliation, New York, Oct., 1919. 
stipulated. In the first place, "the German Government cannot, on principle, consent to the cession of indisputably German territories; and a vote cannot be applied to such territories": the second objection is that "apart from this the demand of a cession of the districts of Eupen and Malmédy to Belgium contravenes the principle according to which the settlement of all questions regarding sovereignty is to be brought about, on the basis of free acceptance on the part of the population immediately concerned."

The course of reasoning here applied seems to be this: in territories of indisputably German populations no plebiscites can be consented to and their cession by Germany cannot be conceded. But if their cession is enforced, Germany must insist on the application of the principle of national self-determination by way of a free and secret vote.

The German comment assures the Allies that, in order to secure for Belgium the benefits of the German forests in these districts in reparation for the Belgian forests destroyed, "the German Government declares itself ready, by contracting for the supply of wood, to comply with these aspirations." It adds that "the German Government must point out the inadmissibility of bartering human beings from one sovereignty to another, merely for the sake of wood and zink ore."

The Allied reply to these observations bases the transfer of Eupen and Malmédy on the grounds that these territories were "separated from the neighboring Belgian lands of Limburg, Liège, and Luxemburg in $18 I_{4}-1815$, that at the time "no account was taken of the desires of the peoples, nor of geographical or linguistic fronticrs," that "this region has continued in close economic and social relations with the adjacent portions of Belgium," that " in spite of a century of Prussification the Walloon speech has maintained itself among several thousand of its inhabitants," and that "at the same time the territory has been made a basis for German militarism by the construction of the great camp at Elsenborn and varions strategic railways di- 
rected against Belgium." To the Allied Powers these "reasons seem sufficient to justify the union of the territory to Belgium, provided the petitions to this effect are sufficiently supported by the population of the district." ${ }^{\circ}$

The petitions here referred to must be those of the Walloon population asking for incorporation.

The German criticism of the insufficient provision for a free and unconstrained vote, is answered by the Allies' reply in the affirmation that "the Treaty makes provision for consulting the population under the auspices of the League of Nations."

The stiplations concerning the cession of Neutral Moresnet remain as provided. Prussian Moresnet goes to Belgium, so the reply states, "in partial compensation for the destruction of Belgian forests."

Article 45 of the Treaty stipulates that:

As compensation for the destruction of the coal-mines in the north of France and as part payment towards the total reparation due from Germany for the damage resulting from the war, Germany cedes to France in full and absolute possession, with exclusive rights of exploitation, unencumbered and free from all debts and charges of any kind, the coal-mines situated in the Saar Basin as defined in Article 48.

This transfer of the mines does not ipso facto imply the change of sovereignty over the inhabitants. But Article 47 provides that:

In order to make in due time pcrmanent provision for the government of the Saar Basin in accordance with the wishes of the populations, France and Germany agree to the provision of Chapter III of the Annex hereto.

Chapter II of the Annex here referred to provides for the transfer for fifteen years of the government of the Saar Basin "to a Commission representing the League of Nations." Chapter III contains the conditions under which the plebiscite is to be held at the end of this period. Upon

\footnotetext{
o "Reply of the Altied and Associated Powers to the Observations of the German Delegation on the Conditions of Peace," published as number 144 by the American Association for International Conciliation, New York, November, 1919.
} 
the result of this plebiscite depends the ultimate sovereignty of the Basin. The only measure suggesting an accord of the government with the wishes of the population during the fifteen years seems to be the inclusion in the membership of the Governing Commission to be chosen by the Council of the League of Nations of "one native inhabitant of the Saar Basin."

The temporary loss of German sovereignty "will not affect the existing nationality of the inhabitants of the territory of the Saar Basin." However, "no hindrance shall be placed in the way of those who wish to acquire a diferent nationality, but in such cases the acquisition of the new nationality will involve the loss of any other."

Paragraph II of the Annex provides for "the introduction or employment in the mines and their accessories and subsidiaries of workmen from without the Basin," and paragraph I4 gives the French State "the right of establishing and maintaining, as incidental to the mines, primary or technical schools for its employees and their children, and of causing instruction therein to be given in the French language, in accordance with such curriculum and by such teachers as it may select."

In a plebiscite to be held "at the termination of a period of fifteen years ... the population of the territory of the Saar Basin will be called upon to indicate their desires in the following manner:

A vote will take place by communes or districts, on the three following, alternatives: (a) maintenance of the régime established by the present Treaty and by this Annex; (b) union with France; (c) union with Germany.

All persons without distinction of sex, more than twenty years old at the date of the voting, residing in the territory at the date of the signature of the present Treaty, will have the right to vote.

The other conditions, methods, and the date of the voting shall be fixed by the Council of the League of Nations in such a way as to fix the freedom, secrecy and trustworthiness of the voting.

The League of Nations sliall, after the voting, "decide on the sovereignty under which the territory is to be placed, taking into account the wishes of the inhabitants as expressed by the voting." 
The territory may be allotted to its final sovereign either in part or in sections, since the voting is to take place by communes.

The German comment concerning these provisions makes in effect the following points: the entire Saar Basin arrangement purports to be enforced "in compensation for the destruction of the coal mines in northern France." However, the territorial delinitations provided for go far beyond the land containing coal, "including, in addition, extensive forests, numerous lime works, glass factories, and other very profitable and partially world-renowned industries." The German Government is prepared to grant the coal demanded by France "by contracts of supply and by shares." Continuing the comment says:

According to the opinion on the economic situation expressed by the Allied and Associated Governments in their note of May 22, it would likewise be a fundamental error to believe in the necessity of exercising political sovereignty in a country in order to secure thereby an adequate portion of its production. . . .

The draft of the peace treaty formulates a demand which tears from the German Empire a purely German territory, gives France economic control over it, and attempts also to annex it politically to France. ...

Among the 650,000 inhabitants there were in 1918 not even 100 French.

The one native member on the Governing Commission is not elected by the population, but appointed by the Council of the League of Nations, subject to recall. There is no representation of the people "with any legislative competence."

The use of the German language, the schools and religious practice are placed under control, and the French State is authorized to establish public and technical schools with French as their official language, taught by teachers of its own choice. The future position of every official and employce is rendered quite uncertain... The chief right of the citizen of the Saar district is that of emigration, but there is no law to protect him from expulsion. . . .

From the days of their appearance the authorities of the French Occupation Forces have taken recourse to every possible means in order to prepare the people for annexation to France. Every attempt is made to induce a population who have been exhausted by the hunger blockade and the exertions of the war, to apply already for French citizenship. Many who not only cling in their lsearts to the old Fatherland, but make public profession of their attachment, are expelled from the country. 
The Allied reply reminds the German Delegation once more of the reparatory character of the Saar settlement. It justifies the extension of the frontiers beyond the coal lands by the desire "to secure the least possible interference with the present administrative units or with the daily vocations of this complex population." The Governing Commission is responsible to the League of Nations, not France. The territories will have their whole revenue applied to their own administrative unit and for the first time they will have "a government resident on the spot which will have no occupation and no interest except their welfare."

"The German note," the answer concludes, "constantly overlooks the fact that the whole arrangement is temporary, and that at the end of fifteen years the inhabitants will have a full and free right to choose the sovereignty under which they are to live."

In point of fact the German Government does not overlook the temporary character of the present arrangement, but its comment shows clearly the fear that the final outcome will be influenced and determined by the temporary arrangement. France has the right to employ French labor and thus is at least potentially in the position to swamp the territory. This would force the German population either to emigrate or to apply for French nationality, if in their opinion, this would seem to promise them opportunity for work. Since the Treaty provision for the plebiscite to be held at the end of the fifteen years of foreign rule gives the vote to all " "persons without distinction of sex, morc than twenty years old at the date of the voting, resident in the territory at the date of the signature of the present Treaty," those inhabitants of the Saar Basin, who, for economic reasons and against their wishes and desires might have assumed French nationality, would be entitled to vote. However, the assumption of French nationality under conditions assumed would in no way bind the voter to declare for union with France. In other words, in spite 
of the existing temporary arrangement the final decision, as far as the vote of the population is concerned, seems to depend entirely on the existing sentiment for or against Germany and on the consistency with which loyalty to Germany will be able to maintain itself. As far as the effect of emigration, voluntary or by force of expulsion, on the result of the plebiscite is concerned, it is clear that it could reduce the total number of those entitled to vote and thus the number of those actually voting, but it also is apparent that it does not effect in any way the number of those who might want to vote for Germany in proportion to the total number of those remaining and entitled to vote at all.

Article 109 of the Treaty provides that "the frontier between Germany and Denmark shall be fixed in conformity with the wishes of the population."

The Treaty of Prague of 1866 had given SchleswigHolstein to Prussia on condition that the population of the northern district of Schleswig should have the right to express its approval or disapproval of such a transfer by way of a plebiscite. This condition was, however, later eliminated from the treaty text by agreement between Austria and Prussia. ${ }^{7}$ The present Treaty provides for two zones, each to vote on different dates and the result of the vote in each to be determined on a different principle. In both zones, "every person will vote in the commune (Gemeinde) where he is domiciled or of which he [or she] is a native."

In the northern zone "the result will be determined by the majority of votes cast in the whole of this section."

The result in the second zone "will be determined by communes (Gemeinden), in accordance with the majority of the votes cast in each commune (Gemcindc)."

The right of option for Germany in the section allotted to Denmark and for Denmark in the part remaining with Germany is granted with the proviso that "persons who have exercised the above right to opt must within the ensu-

${ }^{7}$ See above, p. IIo, note 61 . 
ing twelve months transfer their place of residence to the State in favor of which they have opted."

The German reply declares the readiness of the German Government "to meet the Danish wishes for a new frontier corresponding to the principle of nationality, using the peace negotiations as a roundabout means of establishing it," but insists, "it cannot refrain from referring to the fact that the Schleswig question is not expressly mentioned in President Wilson's points." Therefore, "if Germany agrees to a plebiscite in Schleswig, she does this because she recognizes the right of self-determination of the peoples."

However, the German comment adds that Germany is "nevertheless not in a position to accept the formation of the voting districts, as well as the method and the time of voting, as proposed in the draft of the peace treaty."

Germany proposes one voting district whose boundary "toward the south shall coincide with the dividing line between the linguistic majorities, so that those communes shall vote which contain more than fifty per cent of Danes in an unbroken territorial unity."

The voting in this whole district, it is suggested, "shall be by communes."

In answer to the German proposals for the changes in the method of the voting and delimitation of the voting districts the Allied reply concedes that "in consequence of a request made by the Danish Government it has been decided to alter the limits of the territory within which the plebiscite will be held in accordance with their wishes." No further changes are affected.

The territories to be ceded by Germany to the States of Poland and Czecho-Slovakia present a problem so conlplicated in its racial aspect that no boundary arrangement seens possible which will not include in German territory Poles and Czecho-Slovaks, or Germans in the areas transferred to the new States.

The Treaty provides the transfer of German territory to Poland in part as outright cession, without consultation of 
the population, in part as cession conditioned upon the consent or refusal of the inhabitants to be transferred to Polish allegiance. There is naturally a wide divergence of opinion between the Allies and Associated Powers and Germany as to the proper lines of demarcation of the first and second zones. That the Powers who framed the terms of the Treaty were fully conscious of the fact that the sections of German territory transferred to Poland without a plebiscite contain a considerable number of Germans is shown by the inclusion in the Allied-Polish Treaty of guarantees of the rights of racial minorities.

The territories transferred without vote constitute parts of the Provinces of Posen, West Prussia, ${ }^{8}$ Pommern and, according to the original draft of the Treaty, of Schlesien.

The German reply takes exception to this transfer without regard to the racial configuration. Abiding by the consequences of its acceptance of President Wilson's Fourteen Points, Germany declares herself ready to yield to Poland those sections of Posen and West Prussia which are "inhabited by indisputably Polish populations."

Under the provisions of the first draft of the Treaty, Upper Silesia was to be ceded without a vote. The German reply contests this decision and in its argument states:

The districts of Upper Silesia demanded for Poland are not inhabited by an indisputably Polish population. The will of the population has been clearly expressed in the elections to the Reichstag in 1903 and 1907. Before 1903 not one Polish deputy had been elected. In 1907, at the general, direct and absolutely secret election for the Reichstag the Poles received 115,000 votes, the Germans 176,287 ; in 1912 the Poles obtained 93,029 and the Germans 210,100 votes; at the time of the elections for the National Assemblies (Nationalversammlungen) of the Empire in 1919, when all citizens of either sex above the age of twenty had cast their votes in a general, equal, direct and strictly sccret election, the Poles proclaimed their abstention from voting. In spite of this, almost sixty per cent

8 Only in a small section of the province of West Prussia, "comprising the Kreisc of Stuhm and Rosenberg and the portion of the Krcis of Marienburg which is situated east of the Nogat and that of Marienwerder east of the Vistula, the inhahitants will be called upon to indicate by a vote, to be taken in cach commune (Gemeinde), whether they desire the various communes situated in this territory to bclong to Poland or to East Prussia." 
of all persons entitled to vote voted and they voted for the German candidates nominated. As experience shows that at German elections about ten per cent of the electors are hindered from voting for external reasons, the Poles can claim for themselves at the highest only one-third of the vote.

As an additional argument against the cession of Upper Silesia, is cited the imperative need of Germany for the Silesian coal. To this the Allied and Associated Powers respond:

It is recognized that the problem here differs from that in Posen and West Prussia for the reason that Upper Silesia was not a part of the Polish territories when dismembered by the Partition. It may be said that Poland has no legal claim to the cession of Upper Silesia; it is emphatically not true that she has no claim which could be supported on the principles of President Wilson. In the district to be ceded, the majority of the population is indisputably Polish. Every German book of reference, every school book teaches the German child that the inhabitants are Polish in origin and in speech. The Allied and Associated Powers would have been acting in complete violation of the principles which the German Government itself professes to accept had they left unregarded the Polish claims to this district.

However, the revised draft of the treaty provides for a plebiscite in Upper Silesia and guarantees Germany a proper share in the output of the Silesian coal mines if the vote should be favorable to the inclusion of the territory in Poland.

Concerning the cession of Posen the German reply objects on the grounds that: "the province of Posen as a whole cannot be regarded as a district inhabited by an indisputably Polish population. Large parts of this province have been inhabited for many centuries by a predominantly German population; outside these districts there are enclaves of the same character." It charges that the proposed boundary lines "are not based on the principle of nationality ... but on that of the strategic preparation of an attack against German territories." In conclusion it is added that "these [strategic] considerations, however, cannot possess any importance if the relations between Germany and Poland in the future are to be subject to the regulations of the League of Nations." 
According to the German statement the sections of West Prussia to be ceded, without vote, hold about 744,000 Germans against 580,000 Poles and Cassubians.

The Treaty provides for a plebiscite in the southern section of the Province of East Prussia to decide whether this region shall go to Poland or remain with Germany. Germany protests against this proposed cession and questions the necessity of an appeal to the population. "These districts... are not inhabited by an indisputably Polish population. The circumstance that, in isolated regions, a non-German language has survived, is in itself of no moment, for, even in the oldest homogeneous States, this condition may be observed; the Bretons, Welsh, and the Basques may be mentioned in this connection. . . ."

The Allied reply justifies the cession of West Prussia and of Posen without a plebiscite on historical grounds. The Allied promise of the restoration of Poland demands the retrocession by Germany of West Prussia. The principle of nationality has been the guiding line as far as the former grounds would permit. However, slight rectifications of the frontiers on stricter racial lines were embodied in the final draft of the Treaty.

The German objections concerning the Province of Posen were overruled on the ground that the existence of German conclaves, etc., were due largely to Prussianization and that it would be impossible to draw a frontier which would not meet with some objection.

The plebiscite in the southern part of East Prussia is insisted upon.

The right of option is granted in the case of all these cessions.

By the Treaty of Peace, Germany is forced to renounce in favor of the Principal Allied and Associated Powers all rights and title over the City of Danzig and the adjoining territory which is to be constituted the Free City of Danzig under the protection of the Leaguc of Nations. 
A constitution for the Free City of Danzig is to be drawn up by the duly appointed representatives of the Free City in agreement with the High Commission to be appointed by the League of Nations.

The Free City of Danzig is to be included in the Polish Customs frontiers and Poland is to conduct the foreign relations of the Free City.

German nationality is lost ipso facto by the coming into force of the Treaty. The inhabitants become nationals of the Free City of Danzig.

Aside from the plea that Danzig is a purely German city, the following quotation gives the chief points of the German protest against the cession:

In accepting Point 13 of President Wilson's address of January 8, I9I8, Germany has agreed that the Polish State to be erected "should be assured a free and secure access to the sea." The German Government has done so in recognition of the address which President Wilson delivered to the Senate on January 22, 1917, when he said:

So far as practicable, moreover, every great people now struggling toward a full development of its resources and of its powers should be assured a direct outlet to the great highways of the sea. Where this cannot be done by the cession of territory, it can no doubt be done by the neutralization of direct rights of way under the general guarantee which will assure peace itself. With a right comity of arrangement no nation need be shut away from free access to the open paths of the world's commerce.

Germany offered the following solution:

In accordance with the above principles and in order to fulfill the obligation accepted by the German government, viz., to give Poland a free and secure access to the sea, the German Government is ready to make the ports of Memel, Königsberg, and Danzig free ports and to grant in these ports far-reaching rights to Poland.

The Allied reply grants that "the population of Danzig is, and has for long been, predominantly German" and it adds that "just for this reason, it is not proposed to incorporate it in Poland." But Danzig is to be ceded by Germany for the good of Danzig itself and for the benefit of Poland. 
The Allied reply reminds Germany that the present settlement, "will preserve the character which Danzig held during many centuries, and, indeed, until forcibly, and contrary to the will of the inhabitants, it was annexed to the Prussian State. . . But Danzig, when a Hansa city, like many other Hansa cities, lay outside the political frontiers of Germany, and in union with Poland enjoyed a large measure of local independence and great commercial prosperity. It will now be replaced in a position similar to that which it held for so many centuries." As for the second reason the reply states that "the economic interests of Danzig and Poland are identical. For Danzig, as the great port of the valley of the Vistula, the most intimate connection with Poland is essential. The annexation of West Prussia, including Danzig, to Germany deprived Poland of that direct access to the sea which was hers by right. The Allied and Associated Powers propose that this direct access shall be restored."

Danzig then is detached from Germany on the prinziple of historic and economic considerations, without the consultation of an admittedly predominant German population.

The port and city and district of Memel are to be ceded by Germany to the Principal Allied and Associated Powers, and "Germany undertakes to accept the settlement made by the ... Powers in regard to these territories, particularly insofar as concerns the nationality of the inhabitants."

The German reply states that of the total population of the district to be ceded about 68,000 are German against 54,000 Lithuanians. "Memel particularly is a purely German town." Only in the district (Kreis) Heydekrug does a slight majority of a Lithuanian speaking population exist. In the Kreis Memel only forty-four per cent, in Tilsit twenty-three per cent, and in Ragnit but twelve per cent speak Lithuanian. All speak German besides. As a further reason against cession is adduced the religious differences of the Catholic Lithuanians of the former Russian Empire and the Protestant Lithuanians of Prussia. 
The Allied answer claims the territory as predominantly Lithuanian in origin and in speech. Hence the cession does not conflict "with the principle of nationality" and "the fact that the city of Memel itself is in large part German is no justification for maintaining the district under German sovereignty, particularly in view of the fact that the port of Memel is the only sea outlet for Lithuania."

In this answer we have in the first part a rejection of the German charge that the transfer conflicts with the principle of nationality, in the second part the assertion that the principle of nationality cannot be invoked by the largely German city of Memel, because it is the only sea outlet for Lithuania.

Other transfers of German territory without a plebiscite are stipulated in Article 83. Germany renounces in favor of the Czecho-Slovak State all rights and title over a portion of Silesian territory, and in case the final demarcation of the Polish-German frontier leaves part of the Kreis Leobschütz isolated from Germany, this district is to fall, without vote, to Czecho-Slovakia.

Here, as in the case of German cessions to Poland, the Treaty recognizes the fact that the territories transferred contain a considerable German population by the guarantee given in Article 86 that "the Czecho-Slovak State accepts and agrees to embody in a Treaty with the Principal Allied and Associated Powers such provisions as may be deemed necessary by the said Powers to protect the interests of inhabitants of that State who differ from the majority of the population in race, language or religion."

The right of option is provided.

The Peace Treaty of Versailles requires of Germany the renunciation of her sovereignty over all her colonial possessions in favor of the Principal Allied and Associated Powers.

The German reply considers this regulation as "in irreconcilable contradiction to Point 5 of the Address to Con- 
gress of January 8 , I9I 8 , in which President Wilson promises a free, sincere and absolutely impartial settlement of all colonial claims."

In justification of their demand for Germany's relinquishment of her colonies, the Allies counter with the reference to President Wilson's same address to Congress, called upon by the Germans to prove the injustice of the Allies' request. Their response reads in part as follows:

In requiring Germany to renounce all her rights and claims to her overseas possessions, the Allied and Associated Powers placed before every other consideration the interests of the native populations advocated by President Wilson in the fifth point of his fourteen points mentioned in his address of the 8th of January, 1918. Reference to the evidence from German sources previous to the war, of an official as well as of a private character, and to the formal charges made in the Reichstag, especially by MM. Erzberger and Noske, will suffice to throw full light upon the German colonial administration. . . .

As an additional reason for their demand of the German colonies they answer that:

Moreover, the Allied and Associated Powers felt themselves compelled to safeguard their own security and the peace of the world against a military imperialism which sought to establish bases whence it could pursue a policy of interference and intimidation against the other Powers.

The cession by Germany to France of Alsace-Lorraine is to be unconditional, without consultation of the population as to its consent or opposition of such a transfer, in order "to redress the wrong done by Germany in 1871 both to the rights of France and to the wishes of the population of Alsace and Lorraine, which were separated from that country in spite of the solemn protest of their representatives at the Asscmbly of Bordeaux."

The right of option by the inhabitants is not specified in the Treaty. French nationality is granted by the cession ipso facto to "(I) persons who lost French nationality by the application of the Franco-German Treaty of May Io, $187 \mathrm{I}$, and who have not since that date acquired any nationality other than German; (2) the legitimate or natural descendants of the persons referred to in the immediately preceding paragraph. ..." 
French nationality may be claimed within the period of one year by Germans domiciled in Alsace-Lorraine "since a date previous to July 15,1870 , or if one of their ascendants was at that time domiciled in Alsace Lorraine," and by "all Germans born or domiciled in Alsace-Lorraine who have served in the Allied or Associated armies during the present war, and their descendants."

Subject to the above provisions, "Germans born or domiciled in Alsace-Lorraine shall not acquire French nationality by reason of the restoration of Alsace-Lorraine to France, even though they may have the status of citizens of AlsaceLorraine. They may acquire French nationality only by naturalization. ..."

Article 53 of the Treaty provides for separate agreements between France and Germany "dealing with the interests of the inhabitants, ... it being understood that Germany undertakes, . . . to recognise and accept the regulations laid down in the Annex hereto regarding the nationality of the inhabitants or natives of the said territories, not to claim at any time or in any place whatsoever as German nationals those who shall have been declared on any ground to be French, to receive all others in her territory. . . ."

The above quotation seems to indicate, or at least to permit of the assumption of the right claimed by France to force all or any Germans of Alsace-Lorraine who have not been declared French nationals to return to Germany, an inference which is apparently strengthened by the concluding remark of Article 53, which states that "those German nationals who, without acquiring French nationality shall receive permission from the French Government to reside in the said territories, shall not be subjected to the provisions of the saicl Article."

The comment of the German Peace Delegation admits that "according to the present general conceptions of right, an injustice was committed in $187 \mathrm{I}$ by the failure to hold a plebiscite." However, Germany "believed she was justified in doing so by the previous procedure of France and 
by the racial kinship of the population." In this connection the German reply states:

For the most part, Alsace-Lorraine is old German territory, having become more than a thousand years ago a part of the old German Empire. In the seventeenth and eighteenth centuries the German parts passed, mainly by conquest, under French sovereignty, without any reference to the wishes of the people, and frequently in the face of their opposition. The French régime has indeed succeeded in bringing about a political annexation to France, but the racial and political characteristics of the inhabitants have been so little influenced that even to-day four-fifths of the country's population is still German in its language and customs.

Germany has declared her willingness to right the wrong of $187 \mathrm{r}$, but the proposed outright cession of Alsace-Lorraine, without the consultation of the inhabitants, would be "a new and greater injustice." Such a settlement would not tend "to make a peace in the interest of all" and "the danger would rather arise that, in the future, this question would be the cause of new hatred among the nations."

Germany proposes a vote for the entire population of Alsace-Lorraine, to "provide for the three following possibilities: (a) Union with France, (b) Union with the German Empire as a Free State, or (c) Complete independence, especially liberty of economic relations with any of its neighbors."

In 187 I France protested the cession of Alsace-Lorraine to Germany not on the grounds of the objection of the inhabitants, but on the principle of the inviolability of French soil. However, in their reply to the present German argument the Allied rejoinder stresses the point of popular pro. test against the cession of $187 \mathrm{r}$. Hence, since "to right a wrong is to replace things, so far as possible, in the state in which they were before being disturbed by the wrong," Alsace-Lorraine must be returned on the basis of the sentiment of the people as it existed in $187 \mathrm{I}$.

The German insistence on the consultation of the inhabitants as to their sentiments at the present time is rejected on the ground that "the population of Alsace and Lorraine has never asked for it," that Alsace and Lorraine have 
thrown themselves into the arms of France "as into those of a long-lost mother" and that "a treaty founded on the right of self-determination of peoples cannot but take note of a people's will so solemnly proclaimed."

The German arguments, "based on history and language ... are formally contested by the Allied and Associated Powers and do not modify their point of view."

The request for a settlement of the question of nationality applying equally and to all the inhabitants and for the right of option for those wishing to make use of it in favor of Germany is rejected.

By the terms of the Treaty Germany is bound to acknowledge and to respect "strictly the independence of Austria, within the frontiers which may be fixed in a Treaty between tha State and the Principal Allied and Associated Powers." Germany agrees "that this independence shall be inalienable, except with the consent of the Council of the League of Nations."

Germany responds that she "has never had, and never will have, any intention of shifting the Austro-German frontier by force. But it is admitted that "should the population of Austria, whose history and culture have been most intimately connected with its mother country Germany, for more than a thousand years, desire to restore the national connection with Germany, which was but recently severed by war, Germany cannot pledge herself to oppose that desire of her German brothers in Austria, as the right of self-determination should apply universally and not only to the disadvantage of Germany."

To this the Allies reply no more and no less than the following: "The Allied and Associated Powers take note of the declaration in which Germany declares that she "has never had and never will have the intention of changing by violence the frontier between Germany and Austria."

Article 88 of the Treaty signed on September 10, 1919. between the Principal Allied and Associated Powers and 
Austria declares that "the independence of Austria is inalienable otherwise than with the consent of the Council of the League of Nations."

By Articles 49-50 of the same Treaty Austria is compelled to renounce part of her former territory to Italy, JugoSlavia, Czecho-Slovakia, and Roumania. The plebiscite seems to be prescribed only in one instance: "The inhabitants of the Klagenfurt area will be called upon . . . to indicate by a vote the State to which they wish the territory to belong." 10

Concerning the cessions required of Hungary, Bulgaria, and Turkey, no definite statement can be made, since the texts of the treaties in question are not yet accessible.

9 Text of the Treaty used is that published in the Congressional Record, Sept. 15, 1919.

${ }_{10}$ The plebiscite in the southern part of the Klagenfurt area has taken place in October, 1920. Of a total of 36,948 votes cast, 21,852 were counted for Austria (Press dispatch of Oct. 14). Since this vote was favorable to Austria, the plebiscite in the northern zone, conditionally provided for in Treaty, need not be held. Of the plebiscites called for in the Treaty of Versailles, all have taken place except the one in Upper Silesia. In West Prussia 96,899 votes were cast in favor of Germany against 7,977 for Poland; in East Prussia 353.655 votes were reported for Germany and 7,405 for Poland, with 63 small districts unaccounted (Press dispatch of July 13). The results of the plebiscites in the two Schleswig zones are given below, p. 200. Eupen and Malmédy have been definitely assigned to Belgium. 


\section{CHAPTER VII}

\section{The Practical and Theoretical Aspects of the Plebiscite}

In countries with democratic governments the popular will is ordinarily deemed equivalent to the will of a majority. Hence the plebiscite or referendum, when resorted to in matters of internal affairs, is employed as the means of establishing which side of the argument is represented by the majority and as such entitled to prevail.

When applied to the transfer of territory the plebiscite is supposed to serve a different purpose, namely, to secure recognition for a minority, that is, a minority in the whole state, but a majority in a particular territorial portion of it.

To illustrate: A state consists of two elements, a majority and a minority. The latter is dissatisfied with the form of government, the social, or religious, or any other, policy of the state, as enforced by the majority. If the minority can sufficiently increase its adherents it can change matters to suit itself. Majority and minority need, of course, not always be expressed in numbers alone; economic and other factors may furnish additional, and sometimes decisive, force to one or the other side. If the minority can not gain the required strength to alter conditions there is nothing left to do but to submit or to secede if this is possible. We have a concrete case of this kind in the separation of the Swedish-Norwegian union. Norway had tried in vain to induce Sweden to grant her separate representation in the consular service and in the cabinet and finally abrogated the union, forming an independent kingdom. Sweden accepted the new state of affairs after a plebiscite had established the fact that the separation corresponded to the nearly unanimous will of the Norwegian pcople. Equally clear-cut are 
the cases of the fusion of Valachia and Moldavia, the mersion of the Italian States, the secession of West Virginia, and the return of the Virginia section of the District of Columbia. But conditions are quite as often extremely complex, and when this is the case, the plebiscite must of necessity fall considerably short of its allotted function or even fail altogether. For what would have happened if the Norwegian vote had shown a considerable minority against the disruption of the union, or if it had turned out to be a tie vote? Judging from the statement made by $\mathrm{N}$. Edén expressing the sentiment of the Swedish Riksdag that "in itself this Norwegian unanimity is a relief to us" and that "if the Union is to be dissolved, nothing would have made a settlement more difficult than a strong Norwegian minority against such a solution "1 we may well infer that resort to arms mignt have been the result. In Great Britain, Ireland is the minority against the majority represented by the rest of Britain. If a plebiscite held in Ireland should, or rather could, establish a universal wish for separation, then it would here again be serving the purpose of gaining recognition for the minority. Unfortunately Ireland itself has its own majority and minority and as matters now stand, no plebiscite could solve the question to the satisfaction of the two conflicting factions. Another instance of this type we have in the case of Alsace-Lorraine. In I87 I the two provinces represented a solid minority against the newly created German Empire to which they were annexed against the evident will of the people. To-day a plebiscite taken on the question of retention by Germany or return to France would undoubtedly reveal in Alsace-Lorraine a majority and a minority, one way or other. Still, both Germany and France refuse to be swayed from their respective positions. Germany, up to the signing of the Peace Treaty, had consistently refused to consider the existence of whatever remained of the original sentiment in favor of France; France, on the other hand, in the Peace

1 See above, p. II 4 . 
Treaty, refused to recognize the possile existence of any sentiment in favor of Germany. The plebiscite suggested by the German reply to the first draft of the Treaty would undoubtedly establish a majority in favor of either France, Germany, or independence. But it also would establish a dissenting minority favoring one or the other of the alternatives to the decision of the majority.

In an editorial on "Self-Determination," a New York weekly ${ }^{2}$ discusses the analogous difficulties confronting the application of the principle of self-determination in the three Lithuanian provinces, Kovno, Vilna, and Suwalki. According to the Nation, the Lithuanian race constitutes 75 per cent of the first, i8 per cent of the second, and 52 per cent of the third of these provinces. "How is the plebiscite to be taken?" the Nation asks. "For the three provinces as a unit," it answers, "the Lithuanians, though in a minority, might conceivably rally a majority for independence under the pull of historic traditions. If the provinces vote separately, then Vilna, the heart of Lithuania, might decide to stay with Russia, while Kovno would be certainly independent and Suwalki probably so." Suwalki again, offers another complication. Under Russian rule it formed a part of Poland. Will then, to quote the Nation, "the new independent Poland permit Suwalki to detach itself, or will it insist on keeping the province in spite of the fact that the Poles are less than 25 per cent of the population?" In the Prussian province of Posen the Polish population numbers slightly over 60 per cent, in the province of West Prussia the Poles number about 33 per cent. Can there be the slightest hope that a decision based on a general plebiscite taken in these two provinces as units would prove satisfactory to the respective minorities? Let it be supposed plebiscites were taken locally and a racial division on local lines were clearly established, would any practical statesman propose the annexation of non-contignous districts to the

${ }^{2}$ The Nation, New York, Jan. 17, 1918. 
respective states of their race? ${ }^{3}$ The same conditions, probabiy still more complicated, confront us in the Silesian, Bohemian, Hungarian, Rumanian, Austro-Italian, and ItaloJugo-Slav situations."

The Nation concludes that "such considerations emphasize the statesmanlike programme put forth by the British Labor Party, which would leave the difficult problem of self-determination of peoples to be worked out at leisure under the super-national authority which it demands as one of the essential conditions of world-reconstruction."

There scems little likelihood that any super-national authority could, without the utmost good-will of the states concerned, unravel such entanglements to the lasting satisfaction of all concerned, while, on the other hand, a little good will on the part of the states involved would enable them to pacify their foreign enclaves through a liberal policy, guaranteeing liberty of language, cultural development and granting the greatest possible measure of local self-government. Enforced expatriation would be a measure too radical and too impracticable to be thought of.

A second phase of the difficulties involved in the successful application of the plebiscite as the means of self-determination has manifested itself in the Russo-German wrangle over the Baltic provinces. In the peace programme of December 25, I917, Germany had professed adherence to the principle of self-determination. ${ }^{\circ}$ But while Russia demanded immediate evacuation of the territories in question and a popular vote on the issue of separation after evacuation has taken place as the only way to insure real self-

3 Through the cession of Danzig and the greater part of West Prussia the Treaty of Versailles has in fact created a situation in which the province of East Prussia would be geographically severed from the rest of Germany, although retaining its political connection.

${ }^{4}$ Fairly accurate details of the racial configuration of the Central States of Europe, the Baltic provinces, and Turkey may be found in L. Dominian, The Frontiers of Language and Nationality in Europe, New York, 1017.

${ }^{3}$ For complete programme see The New Republic, Feb. 16, 1918.

- See below, p. 178 . 
determination, ${ }^{7}$ Germany held that these provinces, as far as they had, through their legislatures, declared their wish for independence and separation from Russia, already had resorted to the principle of self-determination and thus had already determined what had been open to decision. ${ }^{8}$ Aside from the additional factor of military occupation the difference between Russia and Germany then seems to have been that of a choice between self-determination by indirect vote in the legislature or by universal direct suffrage. In fact, the reply of the Central Powers to the Russian proposals for the settlement of the Baltic question stated that "... the setting up of a referendum appears to be impracticable," and that "in the opinion of the Allied Delegation, it would suffice if a vote, on a wide basis, were taken from an elected and supplemented representative body." The reply pointed out to the Russians that the separation from Russia of Finland and the Ukraine was "brought about not in the way of a referendum .... but by means of resolutions by a national assembly elected on a wider basis."”

If a direct popular vote on the issue of separation from Russia were taken, the result, in whatever form, could hardly be questioned by either party since the race issue would in such a case be practically non-existent, the Germans being, even in Courland, the most German of all these provinces, less than 10 per cent of the population. ${ }^{10}$ If, however, the issue be decided by a representative vote, an anti-Russian decision could be open to the charge of

7 Proceedings of the Brest-Litovsk Peace Conference, ... November 21, 1917-March 3,1918 (U. S. Dept. of State), Washingtion, Govt. Printing Office, 1918. See also New York Times Current History, vol. vii, part 2, pp. 280-292.

8 Proceedings of the Brest-Litovsk Peace Conference, sessions of Dec. 28, 1917, and Jan. $11,1918$.

9 Ibid., session of Jan. 14, I918. At the same occasion the Teutonic Delegations made the following statement: "The assertion that the right of self-determination is an attribute of nations and not of parts of nations is not our conception of the right of self-determination. Parts of nations can justly conclude independence and separation. ... Courland, Lithuania, and Poland also constitute national units from an historical point of view. ..."

10 See note 2 and corresponding text. 
German influence, pressure, force or bribery among the representatives voting. A drastic incident of such a character we have in the charges laid against the members of the Danish Landsthing, who, in I904, voted against the sale of the Danish West Indies to the United States. "There were in the Landsthing," so W. F. Johnson writes in The North American Revicu"," "many members who were susceptible to German influence. Some were half German, or were closely related by marriage to German families. Others owned estates in Schleswig and Holstein, the Danish provinces now held by Prussia. Others were deeply interested in trade with Prussia. So, after many weeks of intriguing, thirty-three members of the Landsthing, making exactly one-half of that body, were prevailed upon to vote against ratification." His assertion that universal regret over the result was widespread in Denmark seems to be borne out by the fact that in 1916 the Landsthing approved the purchase and a popular vote taken on the issue produced 283,694 votes in favor of and 157,596 against the sale. ${ }^{22}$ From such a result we may well infer that if a popular vote had been taken in 1904, it might have approved of the purchase of the Islands at the same time that the Landsthing voted adversely.

However, the possibility of influencing, by bribery or by other means, the members of legislative bodies exists everywhere and at all times; this is as true under normal conditions as during the stress of a national crisis. There seems to exist actually less danger of such corruption when the legislature votes on the question of a change of government, of peace and war, separation, or fusion, than when it votes on internal, social or economic measures, for the simple reason that in the former instance bribery might be treated as high treason, conviction entailing ignominy or death. While a legislature may be subject to forceful dissolution, it cannot be cajoled into doing the bidding of or

11 The North American Review, Sept., 1916, pp. 389-390.

12 Sec above, p. 126. 
be deceived into falling into the traps set by an ambitious and scheming ruler, with the same ease with which this can be achieved in the case of an unsuspecting and less informed mass of voters. When Louis Napoleon, shortly after his election to the presidency in 1848 , set out to increase his authority and to prepare for the prolongation of his rule and for what followed, he realized that he would have to meet the resistance of the Assembly and the opposition of his officers of state, of the army, and of the population. His chief concern was the Assembly. Hence, his first move was to discredit the legislature in the eyes of the country..$^{13}$ Thus, in the early part of the year I850, he promulgated a law, presented by himself to the Assembly and passed by that body, which modified the existing system of universal suffrage by means of extraordinary demands of domicile. $\mathrm{He}$ calculated, and correctly so, that a sudden and adroitly worded public request from the President, demanding the repeal of such a restriction, would surely place the executive before the land as the defender of popular rights and would prove embarrassing to the Assembly which had written it into the statute book. According to de La Gorce, ${ }^{14}$ only five persons were initiated into the schemer's ambitious plans: General Saint-Arnaud, Minister of War, who would see in the dispersing of Parliament and in the usurpation of power but an enterprise still more spectacular than his former expeditions to Africa; de Morny, hero of the salon and the bourse, future Minister of the Interior; de Maupas, prefect of police, very young, devoted to any cause in which the gain would measure up to the risk; Moquard, secretary to the chicf executive; and de Persigny, ami des maurais jours. These men being won for the Napoleonic cause, the citizens of Paris awoke on the second of December, $185 \mathrm{I}$, the anniversary of the battle of Austerlitz and the crowning of the first Napoleon, to find the walls placarded with proclamations informing them that "the

13 La Gorce, Histoire du second Empire, vol. i, pp. 3-4.

14 lbid., vol. i, pl. 4-5. 
Assembléc was dissolved, that universal suffrage was reestablished, that a state of siege was in force," that "the principles of 1789 were to remain the basis of our public law," that "the last word was to be spoken by the nation to be consulted through the voice of the plebiscite." The issue was thus sufficiently beclouded as far as the masses were concerned. To this was added the element of force. Instructions were sent out to the prefects to "replace immediately all hostile or suspected functionaries, to dissolve hostile municipal councils, not to tolerate any discussion of things that had happened, to demand the submission of the proofs of articles for the press." In Paris public and private buildings were searched for arms and dangerous literature. Even people under the least suspicion were taken into custody, filling prisons and forts. Napoleon well knew that the Assembly had no doubts about the real meaning of the proclamation. Thus, before the next dawn, sixteen of the most hostile members of the Assembly were arrested in their homes, among them Thiers. The rest were dispersed during an attempt to gather at the Palais-Bourbon. Two hundred and eighteen were taken into custody during the following night. ${ }^{15}$

The result of the plebiscite of December 20, $185 \mathrm{I}$, fully justified Napoleon's expectations. Of a total of $8,079,953$ votes cast, 7,439,216 voted in the affirmative on a ballot which stated that "the people want [vcut] the maintenance of the authority of Louis Napolcon and delegate to him the powers required to create a constitution on the basis proposed by his proclamation of December the second." 18

It may be maintained that such methods of force and compulsion can no longer be applied in a peaceful and wellgoverned commonwealth. But even to-day a territory under the military occupation of the victor, who himself demands its annexation, can hardly be styled a peaceful and wellgoverned commonwealth. It would of necessity follow that

15 Ibid., vol. i, pp. 5-6; see also La Gorce, Histoire de la seconde République française, vol. ii, books $x x-x x i$.

${ }^{16} \mathrm{La}$ Gorce, Histoire du second Empire, vol. i, p. 12. 
a plebiscite, held in whatever form, should not take place until the territory in question is once more in a state which would justify its being called peaceful and well-governed.

Eliminating from any plebiscite held on the issue of the transfer of territory the element of force and bribery, we still must admit the possibility of danger in the form of popular illiteracy and ignorance in matters of politics. ${ }^{17}$

No doubt, most peoples have, on one occasion or other, been confronted with the problem of voting on laws and ordinances, or on amendments to laws and ordinances, which not two of the best legal minds have been able to interpret to each other's satisfaction. On the other hand, to decide whether one wishes to remain with Russia, or Germany, whether one wishes to be independent or to assume a foreign allegiance, must be admitted to be an infinitely more simple process, running less danger of surpassing the average intelligence of the normal man or woman.

Assuming then, in the case of the transfer of territory, the feasibility of a popular vote on a clear and unambiguous issue, without military and police interference and without bribery, it seems that the ultimate result of the vote would be equally representative whether registered on the basis of universal suffrage, by an assembly elected on the issue to be decided, or by an assembly vote afterwards ratified by universal ballot. Questionable could be only the decision of an assembly elected on another, an unconnected, or an intentionally beclouded issue.

There remains to be considered the direct vote on a restricted franchise or the vote of a legislature elected by limited ballot. Writing of Napoleon Bonaparte's constitution of the 22 frimaire of the year VIII, submitted to the plebiscite of December, 1793, and put into effect before the end of the voting, Aulard states that "in effect universal suffrage, while being reestablished, was being annihilated at

\footnotetext{
${ }^{17} \mathrm{On}$ this subject see E. Vacherot, La République constitutionelle et parlementaire, in Revue des deux mondes, Nov. 15, 1879, vol. xxxvi, especially pp. 25z-254.
} 
the same time.18 "It was being reestablished inasmuch as henceforth all Frenchmen, twenty years of age, and domiciled for one year, except paid domestic servants, are citizens and possess the right to vote." But it was in fact annihilated by such ingenious dispositions as these:

All citizens of each communal arrondissement reduce their own number to one-tenth in designating through their vote "those among them whom they consider the best suited to conduct public affairs." This one-tenth forms the liste communale or the liste d'arrondissement from which the corresponding public functionaries must be chosen. The citizens included in these communal lists of the various departments again reduce themselves to one-tenth, thus producing the liste départementale from which must be chosen the officers for the department. All the departmental lists once more are reduced to one-tenth and thus form the liste nationale of those eligible for public national functions, e.g., the functions of deputies, tribunes, etc.

But Aulard continues:

For ten thousand, assuming that number, to be forced to designate at least one thousand, is really not designating any one . . . because the demand for such a large number does not permit of any choice at all; in order to arrive at one thousand one had to designate all and everyone who was not illiterate. At best one could exclude some individuals not fitted for position, but there was no way of excluding from the list an entire faction, or an opinion. ${ }^{18}$

However, this was more than one hundred years ago. Still, England, until well into the XIX century, and Prussia and Saxony, until the reforms of the year 1918, possessed restricted franchises scarcely superior to the one described by Aulard.

The restrictions of the French franchise of 1799 , and those of the later English, Prussian and Saxon systems, were based on the material distinctions of property or income, conditioned by internal policies, chiefly with the desire to protect prevailing social and economic principles against undesirable evolutionary or revolutionary changes. Such considerations, however, can not be adduced in the case of a vote on the transfer of territory entailing a change of allegiance. If a plebiscite in such a case is to be held, persons capable of earning their own living should be con-

${ }_{18}$ F. V. A. Aulard, Histoire politique de la Révolution française, Paris, inor, p. 706.

10 Ibid., pp. 706-707. 
sidered qualified to express themselves on such an issue, if they desire to do so.

So far the consideration of the subject has necessarily proceded on the assumption of an analogy of cause and effect between the majority vote and rule in matters of internal government and a majority decision by the plebiscite in the determination of sovereignty. Such analogy, however, does not exist. ${ }^{20}$ On the contrary, there is this fundamental difference: the decision on matters of political interest in the internal affairs of a state is, as a rule, only temporary; the elections are periodical and a different political configuration can at any time convert a majority into a minority and vice versa. Even where decisions are more or less permanent in case of a direct or indirect vote on laws, or the acceptance or amendment of a constitution, the law can, by the same legal process, be repealed or amended and the constitution changed to meet new requirements. Change of sovereignty by enforced transfer of territory from one state to another is considered and even by the treaty effecting the transfer stipulated to be permanent. By a plebiscite, deciding in favor of such a transfer by a simple majority, fifty-one out of one hundred voters can permanently force the remaining forty-nine into an objectionable allegiance. ${ }^{21}$ A tie vote would prevent a decision unless some other arbitrary way of breaking the tie were resorted to.

Be it assumed that a territory has thus, by a majority vote of $5 \mathrm{I}$ to 49 per hundred voters, severed its connection from its parent state: if the 49 per cent of dissenters live together in a district contiguous to the mother country, they should be permitted to retain their old political connection. Or they may, while living together, inhabit a stretch of country which, by the secession of the larger section, would

\footnotetext{
20 See also Stoerk, pp. 64-67.

21 "The plebiscite means subjection, subordination of a minority to a majority. A million citizens dispose of 800,000 others (without counting the women and children), thwart their interests and oppose their desires" (Bonfils, no. 570).
} 
be separated geographically from the parent state. A solution would be difficult to find. It would have to be either submission to the new state of affairs, or, assuming the consistent application of the principle of self-determination by way of the plebiscite, separation from the seceding territory. In the last case there are three possibilities of action for the dissenting minority in the seceding section: (I) demand for complete independence, (2) return to the political union with the mother state though separated geographically from the latter, and (3) affiliation with or incorporation in another neighboring state for the sake of protection or for other reasons.

There is also a possibility, or rather a probability, that the dissenters are scattered all over the seceding territory in more or less all of its localities and country districts. In this case the 49 per cent, being forced against their will into secession, will either quickly submit to the change, or they will set to work to convert their minority of 49 into a majority of $5 \mathrm{I}$ and then to reverse the decision of secession into a vote for reannexation to the parent state. This would, of course, be made more difficult if the secession from the mother country had at the same time, or afterwards, been followed by a decision for annexation to another state.

The examples here adduced, complicated as they seem to be, are, in reality, very simple. It requires no great amount of imagination to see that in the seceding territory there may be even more than two factions, all with different aims; or that after the assumed separation of the dissenting minority from the seceding majority minorities remain in both who again may claim the application of the principle of self-definition for themselves. It can readily be seen that with a consistent application of the doctrine of selfdefinition, we may in certain sections of Europe return to communal autonomy as the only solution of a complex racial tangle. Where a final disintegration into clear-cut communal divisions on racial or political lines would not be 
possible, we would have to accept perpetual strife and revolution as the alternative.

To what extent a two-thirds, three-fourths or a still larger majority would eliminate the dangers of continued demands for recognition by dissenting minorities, is a question which permits of no definite answer. The only statement that can be made with assurance is that nothing short of an effective near-unanimity can give a satisfactory solution on a basis of a decision by direct or indirect popular vote. Such an effective near-unanimity may be defined as a majority which, without any recourse to compulsory methods, proves itself able to gain the expressed or tacit consent of the minority to submit to the decision made.

In the last decades the institution of option has, in the cases of transfers of territories, frequently been applied in order to overcome, as far as possible, the opposition of the inhabitants, or of the element most hostile to the change of allegiance enforced upon them.

Bonfils and Rivier in France and Stoerk and Ullmann in Germany, while refuting the principle of the plebiscite as a practical means of overcoming the difficulties connected with the cession of territory, see the solution of this question in the practice of giving the inhabitants of the territory the option of accepting the new enforced sovereignty or of retaining their old allegiance. ${ }^{22}$ In his Option und Plebiscit, Stoerk gives an historical account of the principle of option as practiced in the past. He begins his study with a consideration of the right of emigration. In the Peace of Augsburg of 1555 and in the Treaty of Westphalia in 1648 the $j u s$ cmigrandi was granted to religious dissenters. The Peace of Augsburg had established for the German states the principle of the cuius regio, cius religio. But the same peace treaty gave the Protestant population the right of enigration in case they refused to return to the Catholic faith, to be forcel upon then by their princes. The

22 Bonfils, no. 571; Rivier, vol. i, pp. 204-208; E. von Ullnam, Vülkerrecht, Tübingen, 1908, p. 358. 
same right respectively was granted to the Catholic inhabitants of the territories where the official cult was that of the Protestant ruler. Stoerk denies to these cases the character of precedents for the modern practice of option. The motive prompting the choice of enigration, rather than of remaining under unacceptable conditions, was religious belief, not political attachment to the state in question. ${ }^{23}$ The first case of option, as defined, he sees in the Peace of Hubertsburg, between Frederic II of Prussia and Maria Theresa of the Germanic Empire in the year 1763 , at the end of the third Silesian, the so-called Seven Years IVar. ${ }^{24}$ Already Article III of the Peace of Berlin of July 28, I742, terminating the First Silcsian War, provided for the territories ceded to Prussia the choice of emigration, with the time allowance of five years. In Article $\mathrm{X}$ of the Treaty of Hubertsburg of 1763 , the right of free emigration from the city and county of Graz ceded to Prussia was granted. This emigration had to be effected within two years. No emigration tax was to be levied. ${ }^{25}$ The request for emigration within a time limit of from one to two years has become the basic principle of the options granted in most of the treaties of cession since that time. The first use of the term option is found, according to Stocrk, in the Treaty of Elisson, concerning the frontier rectifications between France and the King of Spain in the year 1785 . Articles VII of this Treaty reads: "Afin d'éviter tout préjudice aux sujets des deux souverains ... il a été convenu qu'ils auront une entière liberté de rester sous la domination dans laquelle ils se trouvent, ou de passer dans celle du souverain dans le territoire du quel se trouveront leurs possessions. Pour l'option

23 Stoerk, pp. 94-95.

24 Art. xvij of the Treaty of Ryswick of 1697 gave to the inhabitants of Strassburg the right of emigration with their belongings and without an emigration tax. This grant has been recorded by Calvo as the first instance of a clause of option (Wambaugh, p. 4 . note 4). But, as Stoerk points out, this concession can not be considered as a case of option for the reason that seventeen years had elapsed since France liad actually possessed herself of Strassburg and had, during those years, held the inluabiants in an enforced allegiance (Stoerk, pp. 97-08, note 3 ).

25 Ibid., pp. $96-97$. 
entre ces deux partis, il leur sera accordé dix-huit mois de delai. . . .."26

We have here then for the first time the expressed recognition of the principle of sovereignty and allegiance as the guiding motive for the granting of the right of emigration. With the advent of the French Revolution and the recognition by revolutionary France of the principle of national self-definition by way of a plebiscite the majority decision was made binding on the minority in the territories thus annexed to France. In the annexations of the period of I798-1805, France accepted the grant of option. In the Treaty of January, I798, by which the inhabitants of the German city of Mülhausen were declared "born Frenchmen," the right of emigration was given to those who refused to accept the rule of France. The decision for emigration had to be reached within one year, while three years were allowed to carry the decision into effect. ${ }^{27}$ The same provision was made in the Treaty of April 26, I798, by which Geneva was annexed to France. ${ }^{28}$ However, the annexations during the time of the Consulate and the Empire were effected without consideration of the wishes of the population and without option. ${ }^{20}$

The principle of option was recognized in the territorial settlement of the second Peace of Paris of November 20, I815. Article VII reads:

In all countries which shall change Sovereigns, as well in virtue of the present Treaty as of the arrangements which are to be made in consequence thereof, a period of six years from the date of the exchange of the Ratifications shall be allowed to the inhabitants, natives or foreigners, of whatever condition and nation they may be, to dispose of their property, if they should think fit so to do, and to retire to whatever country they may choose. ${ }^{30}$

The Treaty of Versailles of 1919 has embodied the principle of option in favor of Germany in transfers of terri-

26 Quoted from Stoerk, 1). 100.

27 Stoerk, p. 108.

28 Ibid.

29 lbid., p. 100 .

su Hertslet, vol. i, p. 348. 
tories from German sovereignty to Belgium, Denmark, Poland, and Czecho-Slovakia. No option is provided for in the cessions of Danzig, Memel, and Alsace-Lorraine. In the case of Alsace-Lorraine, Germany agrees to receive into her territory all Germans to whom France shall refuse French nationality and domicile.

Whatever the merits of this form of option be, the emigration stipulated is not, as Stoerk holds, voluntary, but enforced. While as a rule a more or less limited time is allowed for the disposal of inmovable property, the element of violence to the human attachment to soil and home, to friends and relatives, remains. Furthermore, it is clear that a very large percentage of those concerned are prevented from taking advantage of opting under the given conditions on account of economic and other reasons. The Treaty of Frankfort of IS7I provided for option in favor of France on condition of enforced emigration after two years. Not less than 45,000 persons availed themselves of the privilege; nevertheless, after forty-five years of German sovereignty, thirteen per cent of the population have preserved their French language and racial characteristics. ${ }^{31}$

Option with compulsory emigration may be at the present time the one measure giving the greatest amount of consideration to the natural rights of men; but in case of an enforced cession which has become inevitable, it offers no more of a solution to the ethical issues involved than does the application of the plebiscite in the same instance or in voluntary secession.

Option without the demand for emigration seems to have been applied so far only in the case of the settlement of the Spanish-American war in the cession by Spain to America

${ }^{31}$ The Encyclopxdia Britannica, IIth ed., Alsace; Meyers Grosses Konversationslexikon, 6th cd., Elssass Lothringen, gives the number of the emigrants as 50,000. Stoerk gives the following figures of the opting: total population $1,517.494$; an actual declaration of option was made: before German authorities by 159.740 , before French authorities 378.777 (Stoerk, p. 172). For the text of the treaty sce Hertslet, vol. iii, p. 1956, Art. ii. 
of the Philippine Islands. According to Article 9 of the Treaty:

Spanish subjects, natives of the Peninsula, residing in the territory over which Spain by the present Treaty relinquishes or cedes her sovereignty, may remain in such territory or may remove therefrom, retaining in either event all their rights of property. ... In case they remain in the territory, they preserve their allegiance to the Crown of Spain by making, before a court of record, within a year from the date of the exchange of ratifications of this Treaty, a declaration of their decision to preserve such allegiance. . . 32

By the "Protocole" of May 29, I900, the time limit for the declaration was extended six months. ${ }^{33}$

There is one last, and possibly the greatest stumbling block to the plebiscite as the successful expression of national self-determination. The historical survey of the plebiscites of the past has revealed the great outstanding fact that the principal of national liberation through the plebiscite has been active not only in the creation of great powers, but also in the diminution and dissolution of others. In fact any acquisition of territory, whether by force of conquest or as a peaceful accession by means of a recognized plebiscite, signifies practically always a loss of territory to some other state. It is in this circumstance that the greatest opposition to the universal sanction of the principle of self-definition as well as of the consequent and consistent employment of the plebiscite as its mode of expression must be sought.

The cases where in the past the plebiscite, referendum, or representative vote has been used in the disruption of existing political state units are the secession of the Southern States from the North American Union, the secession of West Virginia from the State of Virginia, the dissolution of the union of Sweden and Norway. In the last two cases the result of the plebiscites were recognized by Virginia and by Sweden. In the first case, the secessions, in spite of

${ }^{32}$ Compilation of Treaties in Force, Prepared under Resolution of the Senate, of February Ir, I904, IVashington, Covt. Printing Office, 1004, p). 725-726.

${ }^{33}$ Iloid., p. 728. 
popular, direct, or indirect votes, were opposed by the sword, and the seceding states forced to rescind their decisions. In both instances, however, the motive for the difference of attitude towards the seceding units was based on state policy and considerations of the legality on the principles of international law of the secession movements as such, ${ }^{34}$ rather than on favorable or unfavorable opinions regarding the plebiscites as justifying the demand for secession.

The plebiscites in the case of West Virginia and in Norway had shown a practically unanimous vote, and nothing short of war could have preserved the status quo. The possibility of defeat and, on the other hand, the chances of continued opposition of a sectional, hostile population in case of victorious war, against the certainty of a gratified and friendly neighbor, decided the issue in Norway which, being tied to Sweden in a 'real union,' was thus not an integral part of Sweden as a nation. Virginia was not an independent State but only one of a union of States. By Article IV, Sect. 3, of the United States Constitution it is stipulated that "no new States should be formed or erected within the jurisdiction of any other State... without the consent of the Legislatures of the States concerned as well as of the Congress." Since it was the section separating from Virginia which remained loyal to the Union, the latter had every reason to be favorably inclined towards the new State. The secession of the rebellious Southern States from the United States however involved the very existence of the Union as such in so far as it brought to a climax the issue of states' rights and federal rights, of state sovereignty and federal sovereignty, the question whether the states had a right to secede or not. The principle of self-preservation forced the Union to a policy of war which decided the issue against the secessionists.

No less is it a question of a wise state policy on the part of the acquiring state to sanction or even demand a plebi-

84 Sec above, pp. 119-123. 
scite in the annexed territory if by such an act it is sure to establish an outward sign of the desire or willingness of the inhabitants to be annexed.

On the other hand, the same motive would prompt a policy of opposition to any public expression where and when the result would be in doubt or be expected to be negative. Where, however, in cases of doubt or certain hostility of the population concerned, state policy has found it advisable to consent to the fictitious promise of a popular vote, reasons of state have made imperative the adoption of measures which would tend to assure a favorable result of the plebiscite. The historical review of the plebiscites of the past offers sufficient material of illustration of this.

If it is considered good policy on the part of the acquiring state to favor a plebiscite where it promises approval of its acquisition, it nust be bad policy for a state to permit a plebiscite where it would reveal a strong sentiment for cession or secession of part of its domain. The same policy would respectively dictate the inclination or disinclination of a state to subscribe to the theory of popular consent as a measure giving validity to the territorial changes contemplated or feared. It is thus easy to understand that a multinational, or multi-racial, state like the former Austro-Hungarian Empire, or Turkey, or Germany with the Polish, the Danish and the Alsace-Lorraine problen, or Great Britain with her colonies and dominions and hostile Ireland, or in fact any federated state body, should in principle or practice be opposed to the doctrine of popular consent. It is this that the French jurist alludes to when he writes that "the principle of the plebiscite, if once adopted, entails grave and dangerous consequences. Admitting the necessity of the popular suffrage in the case of voluntary or enforced cession of a province to another state, we cannot refute the pretention raised by a part of a state to separate absolutely from the other parts to join another state or to render itself independent." He asks, how is a fraction of a state, having changed its mind, to be retained with the national nuion, as 
long as [dis] this change of mind can be demonstrated by vote of the citizens? For, if the plebiscite possesses alone the efficacy of dissolving political ties, then it must alone be sufficient for this task." 35 Referring to the American secession movement he concludes that the Northern States did not hesitate to fight for the maintenance of the Union, because they possesed the consciousness that tradition and the future of the country imperiously demanded such action. ${ }^{36}$ The same view is maintained by Stoerk, who states that "here we have reached the heart of the question, which reveals the principle of the plebiscite as hostile to the state and as theoretically untenable-because its first and next consequence is the dissolution of all state existence." ${ }^{37}$

${ }^{35}$ Bonfils, no 570 .

36 Ibid.

37 Stoerk, p. 67. 


\section{CHAPTER VIII}

\section{'The Plebiscite in International and Constitutional}

LAW

The transfer of territory from one state to another is a matter of interstate, or international, relations. Such relations are subject to, and are regulated by, that body of rules by which the civilized nations have in common agreed to govern their mutual intercourse. The plebiscite in the transfer of territory must, therefore, be considered in its relations to these rules.

While the plebiscite has been considered in its international aspects by a long list of commentators, of advocates and opponents, ${ }^{1}$ the institution has, nevertheless, found little space in our standard text books on international law. The prevailing opinion expressed before the IVorld War was to the effect that the rules governing the intercourse of states do neither demand nor recognize the universal application of the plebiscite in the determination of sovereignty. W. E. Hall, for instance, speaks of the idea that the exercise of the right of alienation is "subject to the tacit or express consent of the population inhabiting the territory intended to be alienated," as a misapprehension. Thus he writes:

The doctrine appears in two forms, a moderate and an extreme one. In its more moderate shape it appears to come to little more than a denial that title by cession is complete when the ceded territory has been handed over by the original owner to the new proprietor, peaceable submission by the inhabitants being necessary to perfect the right of the latter; but it is occasionally declared that the cession of land cannot be dissociated from that of the people who live and enjoy their political rights upon it, that "a people is no longer a thing without rights and without will," that its consent, if

1 A fairly complete list of the advocates and the opponents of the plebiscite is given by Freudenthal, pp. 54-56. The list has been brought up to date by Wambaugh, pp. 21-30. 
not otherwise proclaimed, must be testified by a vote of the population or its representatives, and that international law has adopted this principle by its practical recognition in the Treaty of Turin, which regulated the cession of Savoy to France, in the Treaty of London, by which the Ionian Islands were ceded to Greece, in the Treaty of Vienna, which stipulated for the eventual cession of Venetia to Italy, and in that portion of the Treaty of Prague, which referred to Northern Slesvig. For an answer to this doctrine in its extreme form it is only necessary to traverse the allegation of fact. The principle that the wishes of a population are to be consulted when the territory which they inhabit is ceded has not been adopted into international law, and can not be adopted into it until title by conquest has disappeared. The pretension that it was sanctioned by the treaties cited has an air rather of mockery than of serious statement, when the circumstances accompanying the cession of Savoy and Nice are remembered, and when the only treaty of the number, the breach of which opportunity and desire combined to render possible, remained unobserved and has fimally been cancelled. As to the milder form of the doctrine, it is only to be said that states being the sole international units, the inhabitants of a ceded territory, whether acting as an organized body or an unorganized mass of individuals, have no more power to confirm or to reject the action of their state than is possessed by a single individual. . . .2

A. S. Hershey is equally emphatic when he states that " it is certain that the legal validity of a title based on cession does not require such action [the holding of a plebiscite or vote in Assembly] on the part of the inhabitants of the ceded territory."3 L. F. L. Oppenheim considers it "doubtful whether the Law of Nations will ever make it a condition of every cession that it must be ratified by a plebiscite." He grants that "the necessities of international policy may now and then allow or even demand such a plebiscite," but he adds that "in most cases they will not allow it."4

In the light of the expressions of eminent authority we understand why, in 1867 , Secretary of State W. H. Seward gave only his unofficial consent to the plebiscite which was to decide whether or not the inhabitants of the islands of St. Croix and St. John wished to be annexed to the United States. He apparently did not wish to recognize the principle of the plebiscite in the transfer of territory nor to create a precedent through its recognition which might prove embarassing

${ }^{2}$ Hall, pp. 46-47.

${ }^{3}$ Hershey, p. 184.

- Oppenheim, vol. i, p. 274. 
to the United States in future transactions of a similar nature. The resuit of the plebiscite, a vote of 1,244 against 22 in favor of annexation, ${ }^{5}$ seems to indicate that the favorable outcome of the plebiscite could safely be anticipated, and thus its application with unofficial consent could at least do no harm. But there can be no doubt that even this unofficial consent would not have been given if the result had been in any way in doubt. W. F. Johnson seeks to explain Seward's stand on the basis of constitutional rather than international law. He admits that "Seward was following the precedents established by Jefferson in the purchase of Louisiana and by John Quincy Adams in the annexation of Florida, under which the people of those territories were not consulted any more than cattle would be over the sale of their pasture," but he continues, "this, at least in Seward's case, was not an expression of disregard for popular rights. It was simply intended to forfend against any possible demand for Statehood by the annexed territory. If the people of the islands were consulted on the question of annexation, he cogently argued, they could logically demand to be consulted concerning the status of the islands after annexation. He preferred to follow the old precedents, and thus to be able to insist upon the constitutional rights of Congress to fix the status of the islands and to govern them as it pleased, without consulting anybody. So while he was reluctantly willing that a plebiscite should be taken, he insisted that it should not be mentioned in the treaty or be recognized in any way by the Government of the United States." In the abscnce of documentary evidence bearing out Johnson's interpretation of the motives which prompted Seward to refuse official recognition of the plebiscite, it scems just as plausible to adhere to the view that he might have been led by the same considerations which moved Secretary of State John Sherman, in his reply of August 14, I897, to the Japanese Minister, Toru Hoshi,

${ }^{5}$ W. IV. Johnson, The Story of the Danish Islands, in The North American Review, Sept., 1916, pp. 384-385; see also Wambaugh, p. 151 . 
who had suggested that a plebiscite be taken in the Hawaiian Islands on the question of annexation to the United States. This is in part the reply as quoted from Moore's Digest of International Law:

In referring to the sentiments of the population of Hawaii, you say: "It is understood that only a small fraction of their number favor annexation." You omit to state how this understanding has been ascertained, nor is it clear what is the purpose for which the statement is introduced.

It can not be that one so well informed in the history of international relations as Count Okuma could have wished to suggest thereby the propriety of appealing from the action of the Government to "the population." In international comity and practice the will of a nation is ascertained through the established and recognized government, and it is only through it that the nation can speak. This is shown in the relations of the United States with Japan. The first intercourse of this Government with the Empire was had with an authority which held a divided, if not disputed, sovereignty. Later, when all power and legislation was centered in the Emperor, this Government recognized him as the sole exponent of the public will. When parliamentary government was established the changed relation was accepted by the United States. No inquiry was thought proper to ascertain whether these various changes received the sanction of "the population." The present Government of the Hawaiian Islands, recognized by Japan and other countries, has been in existence for a series of years, during which time public peace and social order have been maintained, and the country has enjoyed an era of unprecedented prosperity. The Government of the United States sees no reason to question its complete sovereignty, or its right to express the national will. ${ }^{\circ}$

The same principle was asserted in the Memorandum of the American Peace Commission of October 27, I898, at the conclusion of the Spanish-American war, where it is stated that "much less do the American Commissioners maintain that a nation can not cede or relinquish sovereignty over a part of its territory without the consent of the inhabitants thereof. ..."'

When during the Franco-Prussian war Thiers visited the capitals of the great neutral Powers of Europe in order to solicit their support for France and particularly against the annexation of Alsace-Lorraine, Gladstone "could not understand how the French protests turned more upon the inviolability of French soil than on the attachment of the

${ }^{0}$ Quoted from Moorc's Digest, vol. i, p. 274.

? Quoted, ibid., vol. i, p. 368. 
people of Alsace and North Lorraine to their country. The abstract principle he thought peculiarly awkward in a nation that had made recent annexations of her own." In a statement to the English Cabinet he urged that "it cannot be right that the neutral Powers should remain silent, while this principle of consulting the wishes of the population is trampled down, should the actual sentiment of Alsace and Lorraine be such as to render that language applicable.".8 Morley, Gladstone's biographer, quotes part of a letter sent by Gladstone to Mr. Bright, who was prevented by illness from attending the Cabinet meeting. In this letter Gladstone writes:

I send for your private perusal the enclosed mem. which I proposed to the cabinet yesterday, but could not induce them to adopt. It presupposes the concurrence of the neutral Powers. They agreed in the opinions, but did not think the expression of them timely. My opinion certainly is that the transfer of territory and inhabitants by mere force calls for the reprobation of Europe, and that Europe is entitled to utter it, and can utter it with good effect.9

However, Europe did not utter its reprobation, nor did Mr. Bright agree with Gladstone. ${ }^{10}$ He favored the principle of territorial inviolability as did Thiers himself who, in 1867, had expressed his view's before the French Assembly to the effect that "the new principle of popular consent is an arbitrary principle, very often deceptive, and that at the bottom of it is nothing but a principle of perturbation when applied to nations." 11

In criticism of a memorandum to the neutral powers the Duke of Argyll, writing to Gladstone, expressed what Morley considers as perhaps the general view. The Duke's stand in the matter of annexation of Alsace-Lorraine by Germany is thus stated by Morley:

He had himself never argued in favour of the German annexation of Alsace and Lorraine, but only against our having any right to oppose it otherwise than by the most friendly dissuasion. The

${ }^{8}$ John M. Morley, The Life of IVilliam Ewart Gladstone, New York, 1903, vol. ii, pp. 346-347.

I Ibid.

10 lbid.

11 Quoted from Rivier, vol. i, p. 211. 
Duke held that the consent of a population to live under a particular government is a right subject to a great many qualifications, and it would not be easy to turn such a doctrine into the base of an official remonstrance. After all, he said, the instincts of nations stand for something in this world. The German did not exceed the ancient acknowledged right of nations in successful wars, when he said to Alsace and Lorraine, "Conquest in war forced upon me by the peoplc of which you form a part, gives me the right to annex, if on other grounds I deem it expedient, and for strategic reasons I do deem it."12

Equally outspoken against Gladstone's stand was Lord Granville. ${ }^{13}$

Thus, leading English statesmen approved, and neutral Europe sanctioned, the amnexation of Alsace-Lorraine to Germany without the consent of the inhabitants. They approved and sanctioned this alienation apparently on the principle of title by conquest. ${ }^{14}$ The United States, as we have seen, emphatically expressed in 1867 its adherence to the principle and practice of annexation without the consent of the peoples thus annexed, and reasserted its stand as late as 1897 and I 898 .

About two decades later, on January 22, 1917, President Wilson declared in a message to the Senate that: "No peace can last, or ought to last, which does not recognize and accept the principle that governments derive all their just powers from the consent of the governed and that no right anywhere exists, to hand peoples about from sovereignty to sovereignty as if they were property." He has repeated this dogma in a form more terse and specific on many later occasions. On April 2, 1917, he proclaimed to

\footnotetext{
12 Morley, vol. i, pp. 347-348.

13 Ibid. In 1890 at the occasion of the proposed cession of Heligoland by England to Germany, Gladstone opposed the plebiscite suggested by De la Warr, Lord Rosebery and others. See above, p. 112.

14 Speaking of the principle of title by prescription, Hall thinks that "if the severance from France of Alsace and Lorraine had been looked upon as an instance of naked conquest, it is probable that European public opinion would have been greatly shocked by the measure." He seems to make the point that in this case the principle of nationality has lessened the value of the old principle of title by prescription under which, as we must infer, France was holding the old German territories (Hall, p. 120, note I).
} 
the world that America fights "for the rights of nations great and small and the privilege of men everywhere to choose their way of life and obedience." On February II, 19I8, he said in Congress:

Peoples and provinces are not to be bartered about from sovereignty to sovereignty as if they were mere chattels and pawns in the game. ... Peoples may now be dominated and governed only by their own consent. Self-determination is not a mere phrase. It is an imperative principle of action, which statesmen will henceforth ignore at their peril. We cannot have general peace for the asking nor by the arrangements of a peace conference. It cannot be pieced together out of individual understandings between powerful states.

In his speech on the $4^{\text {th }}$ of July, 19I8, he repeats:

The settlement of every question, whether of territory, of sovereignty, of economic arrangement, or of political relationship, upon the basis of the free acceptance of that settlement by the people immediately concerned, and not upon the basis of the material interest or advantage of any other nation or people which may desire a different settlement for the sake of its own exterior influence or mastery.

Similar professions have been made by the leading statesmen of Britain, France, and Italy. Thus Winston Churchill, as First Lord of the Admiralty, declared on September II, 19I4: "Let us, whatever we do, fight for and work towards great and sound principles for the European system. And the first of those principles . . . is the principle of nationality. ..."15 Sir Edward Grey stated on March 22, 1915. while he was still Minister of Foreign Affairs, that "we wish the nations of Europe to be free to live their own independent lives, working out their own forms of government for themselves, and their own national developments, whether they be great nations or small states, in full liberty." 16 On September 26, I917, Asquith emphasized that the final settlement must not ignore "the principles of right" and set at defiance "the historic traditions, aspirations, and liberties of the peoples affected."17 Lloyd George

${ }^{15}$ Comments by the German Delegation on the Conditions of Peace, First part, II, 5 .

16 The New York Times Current History, vol. ii, p. 283 .

17 Ibid., vol. vii, part I, p. 292. 
declared on January 5, 1918, that "the days of the Treaty of Vienna are long past, . . . government with the consent of the governed must be the basis of any territorial settlement. . .".18 The same principles were voiced by the Italian Prime Minister, Vittorio Orlando, on December I2, $1917,^{19}$ and for France by Stephen Pichon, then Minister of Foreign Affairs, on December 28, 1917, and on January II, I $918 .{ }^{20}$

The statesmen of the Central Powers have been much less specific in their professions of acceptance of the new principle, and where they are explicit they follow with a qualification. In the German reply to the Pope's peace proposal, "the Imperial Government greets with special sympathy the leading idea of the peace appeal wherein his Holiness clearly expresses the conviction that in future the material power of arms nust be superseded by the moral power of right." ${ }_{21}$ The Austrian version states that "with deep-rooted conviction we agree to the leading idea... that the future arrangement of the world must be based on the elimination of armed forces and on the moral force of right and on the rule of international justice and legality." ${ }_{22}$ In their peace proposals of December, I917. they profess that "forcible annexation of territories seized during the war does not enter into the intentions of the allied [Teutonic] powers" and that "in accordance with the declaration of statesmen of the Quadruple Alliance, the protection of the rights of minorities constitutes an essential component part of the constitutional rights of peoples to self-determination, indicated by a constitution. The allied [Teutonic] Governments also grant validity to this principle everywhere, in so far as it is practicably realizable."'23 By the signing of the Armistice Germany has unconditionally accepted President Wilson's Fourteen Points and his later

\footnotetext{
18 Ibid., vol. vii, part 2, pp. 266-271.

10 Ibid., vol. vii, part 2, P. 272 .

20 Ibid., vol. vii, part 2, Pp. $210-212$; see also above, p. 177 , note 15 .

21 Ibid., vol. vii, part I, p. 285 .

22 Ibid., vol. vii, part I, p. 286.

23 Ibid., vol. vii, part 2, p. 263.
} 
four point summarization of February II, I9I8. The reply of the Republican German Government to the first Peace Treaty draft states that "in this war, a new fundamental law has arisen which the statesmen of all belligerent peoples have again and again acknowledged to be their aim: the right of self-determination. To make it possible for all nations to put this privilege into practice was intended to be one achievement of the war." 24 In the case of the proposed return of Northern Schleswig, the German reply reminds the Allies that the German Government had, independent of outside pressure, approached Denmark in the question of a rectification of their boundary. The reference reads:

Although the German Government has declared its readiness to meet the Danish wishes for a new frontier corresponding to the principle of nationality, using the peace negotiations as a roundabout means of establishing it, it cannot refrain from referring to the fact that the Schleswig question is not expressly mentioned in President Wilson's points. If Germany agrees to a plebiscite in Schleswig, she does this because she recognizes the right of self-determination of the peoples. ${ }^{25}$

What then has happened since 1867 or 1898 ? Have the Hague Conferences brought about such a fundamental change in the sentiment of the representatives of the great nations who are the makers of international law? Hardly! At the Hague the subject was not even officially discussed. Have national and international peace and pacifist societies prepared the ground? Among individuals, possibly, but not among governments!

It must be left to the future historian and student of international law to inquire into the manifold and innermost reasons for their present change of front. The present observer can only record the facts as presented.

President Wilson's attitude and proposed method of settlement of territorial changes were, of course, those of the official representative of the United States. While they had to be accepted by friend and foe, they did, after all, lack that final stamp of the comintry's approval which the

24 First part, II, 5 .

25 Second part, II, 8. 
Constitution vests in the Senate through the treaty clause. But aside from this, the President's proposed course may, from all appearances, be interpreted as the attempt to direct the American state policy with a perspective, wider and broader than that of the past.

After the ratification of the treaty of peace between Peru and Chile in March, I884, which deprived Peru of her rich nitrate and guano provinces, the Congress of Venezuela thus expressed the then prevalent sentiment of condemnation of Chile's action: "We solemnly protest against the iniquitous and scandalous usurpation of which Peru and Bolivia are the victims, in spite of their heroism, and we beseech the God of nations to look favorably on the prompt restoration of lawful sovereignty for peace and concord among the sons of America." ${ }^{26}$

At the First International American Conference held in Washington in 1890 , the following resolutions were adopted, Chile alone not voting:

First: That the principle of conquest shall not, during the continuance of the treaty of arbitration, be recognized as admissable under American public law.

Second: That all cessions of territory made during the continuance of the treaty of arbitration shall be void if made under threats of war in the presence of an armed force.

Third: Any nation from which such cession shall be exacted may demand that the validity of the cessions so made shall be submitted to arbitration.

Fourth: Any renunciation of the right to arbitration, made under the conditions named in the second section, shall be null and roid. ${ }^{27}$

Thus among the states of the American continent title by conquest was no longer to be acknowledged, and the way opened for the adoption of the principle that the wishcs of the inhabitants of the territory ceded should be consulted.

It thus seems that President Wilson, in framing his Fourteen Points on the principle of no conquests and popular consent for all territorial settlements, was in reality voicing not only his own political conviction but the summary and

${ }^{20}$ C. R. Markham, History of Peru, Chicago, 1902, p. 425.

27 Intcrnational Amcrican Conference, Washington, I880-18go, Reports of Committces and Discussions thercon, vol. ii, pp. 1147-1148. 
quintessence of the contemporary political faith of the larger America.

But as Gladstone's suggestion of a plebiscite in AlsaccLorraine could not command the assent of the neutral powers in $187 \mathrm{x}$, so has President Wilson's sponsorship of the principle of self-determination not been able to establish this dogma as a valid international rule without the universal consent of the rest of the civilized world. No more could the assent of the Pan American nations to this principle, and their adoption of it into American public law, enforce its incorporation into international law without the free consent of all or nearly all other nations. For if with Lawrence "we mean by a source of law that which gives it authority and binding force, then there is but one source of the law of nations, and that is the consent of nations," and "no rule can have authority as International Law unless it has received the express or tacit acceptance of the great majority of civilized States."28

Prior to the World War such consent had not been formally given. But, to quote Lawrence, "unless all or nearly" all civilized powers have signed a document which lays down the rule, the best evidence of their consent is practice."20 So far pre-World War history has to show hardly a single genuine case of cession by conquest where the consent of the people of the territory ceded was solicited by a referendum. Even in the case of the acquisition of Rome by the Kingdom of Italy in 1870 the plebiscite or referendum followed the acquisition by conquest and was held while the city was occupied by the conquerors, and there can be no doubt that if the result of the referendum had been unfavorable the wishes of the people would have simply been ignored. ${ }^{30}$ Technically, of course, this case constitutes a precedent for a transfer of territory by title of conquest

\footnotetext{
${ }^{28}$ Lawrence, A Handbook of Interuational Law, London, gth ed., 1915, p. 29.

20 Ibid., p. 34.

- 30 See Dupaninup's charges that the favorable result of the plebiscite was secured by fraudulent votes, above, pp. (2) -95 .
} 
where the plebiscite has been employed, and it must be cited as such. However, within the limits of this study we include territorial changes by title other than conquest on the basis of the undeniable fact that the desire of a people for the expression of its wishes in the matter of a change of sovereignty is or may be just as strong when the transfer is affected by treaty of peaceful cession as when their territory is ceded after conquest. We thus enlarge the scope of precedents by the admission of all those cases where the principle of self-determination has been applied in the cession or transfer of territory in whatever peaceful form. Still, all these precedents in their sum total do not establish the principle in question as international law unless such a practice becomes universal or so general that, by universal or at least general consent of the Powers which have established them, it is recognized as sufficiently forceful and convincing to influence new decisions plainly and explicitly on the strength of these precedents of the past.

The same forces which were instrumental in creating these earlier cases are, of course, constantly at work in the attempt to gain for these precedents international recognition and to secure final acceptance of the principle involved as universal or international law. These forces are: the impersonal opinion of the masses; the personal view of statesmen, philosophers and writers on international law, who crystallize public opinion and deduce the growing norms of international law from the accumulation of precedents; and the force of analogy of constitutional and municipal law as exponents of the public will. There can be no denial of the fact that constitutional and municipal law have come to recognize almost universally the principle of self-determination in all matters which lie within their sphere. In substantiation of this statement, one need point out only that constitutional and representative government and legislation by representative bodies elected by popular vote are almost universal. Nor can we disclaim the influence, by analogy or otherwise, of constitutional and municipal law on the 
shaping of principles and rules for decisions in matters affecting international relations, whether we hold that international law is law in the same sense that national law is $^{31}$ and that it constitutes an integral part of the municipal law of, for instance, Great Britain, the United States, and the new German Republic, ${ }^{32}$ or whether we follow those who believe that, where and when English, American, and German courts adopt and apply principles of international law, they are so applied and enforced not as international but as municipal law. ${ }^{33}$ For, where, in the application of the principles of international law by municipal courts, these principles conflict to the extent that they cannot be reconciled with the accepted norms of common or national law, the courts decide according to the law of the land. ${ }^{34}$ In such cases it is the business of the State or the Crown to allay the differences which such a decision may cause in the international relations with other states. It is in the decisions of courts in such cases of conflict between common or expressed municipal law and international practice with the possible consequence of international negotiations that we may find a field for a slow but sure encroachment of principles of constitutional and municipal law upon the realm of rules governing the conduct of nations.

However, from the point of view of constitutional law there is an obstacle to the universal acceptance of the plebiscite as a means of expression of a popular desire for selfdetermination. The constitutional legislation of revolutionary France recognized the plebiscite in the case of all revolutionary movements of whatever country or fragment of a country as a legitimate means of secession from their

31 J. B. Scott, The Legal Nature of International Law, in The American Journal of International Law, October, 1907, pp. 83i-866.

s2 Article 4 of the Constitution of the German Republic reads: "The universally recognized principles of the laws of nations are accepted as binding elements of the laws of the German Nation."

${ }^{33}$ Willoughby, The Legal Nature of International Law, in The American Journal of International Law, April, 1002\%, pp. 357-365.

at C. M. Picciotto. The Relation of International Law to the Law of England and of the United States of America, New l'ork, 1915, especially p. 26. 
old allegiance and of accession to France. But the same republican France decreed the death sentence for anyone speaking of and considering the cession of French soil to a foreign power. ${ }^{35}$ Even the French protest against the enforced cession of Alsace-Lorraine in 187 I was based, not on the rights of the population of the territories concerned, but on the violation of French territory. ${ }^{36}$ No government could expect to survive which by its fundamental law would consent in principle to a cession of territory by a vote of the secessionists and propose the way and means for such cession by its recognition of the plebiscite, as long as such consent might serve as an invitation to land-luungry neighbors to take advantage of the situation thus created in order to establish in the former state, through intrigue, plotting, and intervention, a sentiment and disaffection with a view to their own territorial aggrandizenient.

The new German Constitution of August I3, I9I9, states in Article 2: "The territory of the nation consists of the territories of the German States. Other territories may be taken into the Government by national law, when their inhabitants, by vote of self-determination, express such a desire." Territorial adjustment of state boundaries within the confines of the Republic, on the basis of popular referenda, are provided for in Article 18. But the provision for the change of frontiers of the Republic involving cession of German territory to a foreign Power does not mention the plebiscite. Article 78 reads in part: "Agreements with foreign States regarding change of national boundaries may be concluded by the nation on consent of the State involved. Alterations of the boundaries may occur only on the basis of a Government law [a federal law], except in cases where mere correction of the boundaries of uninhabited districts is in question."

In the second part of the German counter proposals to

${ }^{85}$ See above, p. 79, note 105. On Sept. 25, 1792, the Convention nationale decreed that "Ia République française est une et indivisib!e" (Arch. parl., ser. I, vol. lii, p. I43).

se See above, p. 53, note 78 . 
the Treaty, Germany asserts that: "No territory shall be separated from Germany where national adherence has been proved to be indisputable by harmonious union with the German State for centuries, or whose population has not declared its consent to such a separation." 37 This admission of the plebiscite as a means to determine popular consent to the separation of German territory rests, however, on a negative premise. It is not said that German territory may be ceded upon the recording of a popular desire to that effect, but rather, that "no territory shall be separated from Germany... whose population has not declared its consent to such a separation." Furthermore, even this concession is not made voluntarily. The separations here contemplated are those exacted by the Peace Treaty, and Germany's consent to these territorial cessions, no matter under what form, has been enforced. Lastly, the paragraph of the German reply claims to be no more than an expression of a policy which Germany desires to have applied to the territorial settlements as provided in the Treaty; as such it has no legal validity.

In the United States the constitutional right to annex foreign territory has been, at various times, and by various writers, derived from the following sources:

I. The power to admit new states into the Union.

2. The power to declare and carry on war.

3. The power to make treaties.

4. The power, as a Sovereign State, to acquire territory by discovery and occupation or by any other methods recognized as proper by international usage. ${ }^{38}$

Actual annexation of territory by the United States has taken place "in three different ways: (I) by statute, (2) by treaty, and (3) by joint resolution." 30

The consent of the inhabitants of the territories annexed need not and has not been asked. The act of annexation derives its legal force "from the body which enacts it, and

${ }^{37}$ Second part, II, I, A.

${ }^{88}$ Willoughby, The Constitutional Law of the United States, New York, 1910, vol. i, pp. 325-341.

so Ibid., vol. i, fl]. 3-14-347. 
it would be an error to hold its legal force necessarily dependent upon a consent obtained from some other source. ..." There is, according to the same authority, no reason why Congress could not make an annexation dependent upon the consent of the population of the territory to be annexed, "but this is not a matter of legal necessity." 40 "Nor is there any principle of public law, or general precedent from our own practice that requires the consent of the population of an annexed territory to be obtained. In none of the instances, except that of Texas, has the United States deemed this consent necessary." 41

Texas was annexed by Joint Resolution, annexation by treaty having been unsuccessful owing to the failure to secure a two-thirds vote in the Senate. The resolution states that "Congress doth consent that the territory properly included within and belonging to the Republic of Texas may be rected into a new State to be called the State of Texas with a republican form of government to be adopted by the people of said republic, by deputies in convention assembled, with the consent of the existing government, in order that the same may be admitted as one of the states of the Union." ${ }_{22}$ The consent here asked seems to have been more like the fulfilment of a condition requisite to admission as a state than a declaration of a willingness to be annexed, for "upon Texas taking the action called for by this clause, Congress later by Joint Resolution declared Texas one of the States of the American Union." 43

While there have been several boundary settlements in which territory formerly held by the United States has been surrendered to foreign powers, the title to these stretches of land as United States territory must be held to have been faulty and it must be assumed that the surrender was made on that ground. "There has been no instance in which territory, indisputably belonging to the United States, has

40 Ibid., vol. i, p. 347.

11 Ibicl., vol. i, p. 348.

42 Ibicl., vol. i, pp. 344-345.

43 Ibid., vol. i, p. 345. 
been alienated to another power." 44 It is generally held that the right to alienate United States territory, if the occasion should arise, is inherent in the treaty making power. This right of alienation under the treaty making power has been questioned by various obiter statements of the Supreme Court. For example, in De Geofroy v. Riggs, Justice Field asserted that the United States could not by treaty cede the territory of any State without the latter's consent. ${ }^{45}$

Reference has been made to the adjustment of the northeastern boundary dispute in 1842 with Great Britain " in which the United States, before coming into an agreement with Great Britain, obtained the cooperation and concurrence of Maine and Massachusetts." 46 However, from the correspondence of Webster, then Secretary of State, to the Governor of Maine "it does not appear . . . that he considered this a constitutional necessity, but rather that it was expedient from a political standpoint that the opinion of these two States should be considered." 47

In the case of Downes v. Bidwell, Justice White argued that the United States could not alienate under the treaty power any of its incorporated territory either by sale or trade. However, he admitted that "from the exigency of a calamitous war or the necessity of a settlement of boundaries, it may be that citizens of the United States may be expatriated by the action of the treaty-making power, impliedly or expressly ratified by Congress." 48

The American policy in the matter of alienation is well expressed in the words of Kent in his Commentaries: "The better opinion would seem to be, that such a power of cession of the territory of a State without its consent does reside exclusively in the treaty-making powers . . . yet sound

\footnotetext{
41 Ibid., vol. i, pp. 507-508.

45 Ibid., vol. i, p. 508 .

"A Ihid., vol. i, pp. 508-509.

47 Ibid., vol. $i, p .509$. In this letter Weloster wrote: "In the present position of affairs, I suppose it will not be prudent to stir in the direction of a compromise without the consent of Maine."

is A more detailed account of the United States Supreme Court statements referred to is found, ibid., vol. i, pp. $5 a^{2}-513$.
} 
discretion would forbid the exercise of it without the consent of the local governments who are interested, except in cases of great necessity, in which the consent might be presumed." 49

A recent case of the alienation of British territory is the cession of Heligoland to Germany in 1890 . On June 24, the First Lord of the Treasury, W. H. Snith, was asked in the House of Commons by Mr. Sunmers "whether he will undertake that the proposed Anglo-German Agreement shall not be signed by the British Plenipotentiary until Parliament has had an opportminty of expressing its opinion on the bill for the cession of Heligoland; and also whether the proposed ... Agreement will contain a clause providing that the portion of the Agreement which relates to the cession of Heligoland shall not take effect until it has been ratified by the passing into law by the British Parliament of a Bill authorizing the cession?" To this Mr. Smith answered that "no such clause is necessary, for the Agreement will only provide that a Bill shall be introduced to enable Her Majesty to make a cession." ${ }_{50}$

The British Government's attitude in the question of popular consent as a pre-requisite to the validity of the transfer is found in the statement made in the House of Lords by the Prime Minister and Secretary of State for Foreign Affairs, The Marquis of Salisbury, on June 19, I890: "The plébiscite is not among the traditions of the country. We have not taken a plćbiscite, and I see no necessity for doing so. . .."51

Returning to the consideration of the forces acting in favor of the international sanction of the plebiscite as the mode of expression of popular consent, it is to be observed that the negative opinions of Hall, Hershey, Oppenheim and others, are opposed by some writers. Thus Hershey cites "among the few advocates of the plebiscite in the

40 Quoted from Willougliby, vol. i, p. 511.

Bo Hansard's Parliamentary Dchates, vol. 345 , col. 1796.

81 Ibid., vol. 345 , col. 1311. 
case of cession," Funck-Brentano, Sorel, Rouard de Card, and Rotteck. ${ }^{52}$

In opposition to the opinion of Seward, Sherman, and the Duke of Argyll, we have the views of Gladstone, Wilson, Lloyd George, Pichon, Orlando, and von Hertling. While not agreeing in the details of practical application, they all seem to be in harmony as far at least as the principle itself is concerned. Lloyd George goes even so far as to demand self-determination for the German colonies. In his address of January 5, I9I8, before the Trade Union Conference, he said :

The natives live in their various tribal organizations under chiefs and councils who are competent to consult and speak for their tribes and members and thus to represent their wishes and interests in regard to their disposal. The general principle of national selfdetermination is, therefore, as applicable in their case as in those of the occupied European territories. ${ }^{53}$

In the chapter on "Treaties with uncivilized tribes," Westlake reminds us that European powers, when they set out to acquire territory of uncivilized peoples, first proceed "to conclude treaties with such chiefs or other authorities as they can discover," and he thinks that they do so "very properly, for no men are so savage as to be incapable of coming to some understanding with other men, and whenever contact has been established between men, some understanding, however incomplete it may be, is a better basis for their mutual relations than force." Granting that "natives in the rudimentary condition supposed take no rights under international law," and that "no document in which such natives are made to cede their sovereignty" can be exhibited as an international title," he adds that "an arrangement with them, giving evidence that they have been treated with humanity and consideration, may be valuable as obviating possible objections to what would otherwise be a good international title to sovereignty."54

\footnotetext{
62 Hershey, p. 183; see also ahove, 1). 171, note 1.

${ }^{63}$ New York Times Cursent History, vol. vii, pt. 2, p. 270.

54 J. Westlake, Collected Papers . . . on Public luternational Law, Cambriclge, 1914, p. 146.
} 
When uncivilized peoples are by our international jurists and by the statesmen of colonizing powers considered as deserving of humane and considerate treatment, when it is held proper to make treaties with the chiefs and leaders of uncivilized races, when an understanding completed with them seems a better basis for mutual relations than sheer force, when all this is conceded, then the question seems to be pertinent why civilized peoples, whose territories are to be transferred from one state to another, should be shown less consideration than that accorded to the Bushmen or Kaffirs? Considered from a purely humane and moral point of view the logic of the question seems to be unassailable. However, international law was not originally humane or moral. Humanitarian and moral principles were first introduced into the rules of making and conducting war and concluding peace under the influence of the mediaeval Christian writers and in a systematic attempt by Hugo Grotius to mitigate the prevailing cruelty and selfishness in both war and peace. ${ }^{55}$ But until now therc has come into existence no international agreenent on the nature and cxtent of the basic laws of humanity and ethics to apply in the relations of states.

By universal or general international agreement existing rules for the conduct of nations may be altered to suit new situations. However, where the required minimum of general consent is not ascertainable and the opposition of the dissenting states is not overcome by force of arms, a pending case must be and is decided on the basis of past practice. Under these conditions international jurists and statesmen can be of real and effective service to humanity and morals only where and when international law supplies no rule or precedent for a concrete case, and where, by deciding a new issue in accordance with recognized principles of right and wrong, they introduce into international practice a precedent established not on an unmoral, but on a moral basis.

85 Dumning, A History of Political Theories, From Luther to Montesquicu, p. $132 \mathrm{ff}$. 
But as soon as we demand a moral standard for international decisions and consequently for international law, we practically revive the difficulty which confronted the adherents of natural law as the source of the law of nations. It is the difficulty of evolving that moral standard which will find approval and acceptance by all concerned. We would have to satisfy a minimalist's and a maximalist's and even a crank's opinion. This is, no doubt, one of the reasons why up to the present day no workable code of international ethics has been evolved.

Oppenheim discusses this phase of the issue in his interpretation of the task and method of the Science of International Law. "The science of international law," he wrote in 1908 , "is . . a means to certain ends outside itself. And these ends are the same as those for which international law has grown up and is still growing-primarily, peace among the nations and the governance of their intercourse by what makes for order and is right and just. . ." According to Oppenheim one of the most important tasks of the science is criticism of the prevailing rules of international law, and, therefore, he says, "the questions which must be answered are: Is a certain rule really just and adequate, or is it antiquated, so that it ought to be restricted, abolished, or replaced"? But he gives the following warning:

If even so much importance is attributed to the criticism of the present condition of international law, it must never be forgotten that his law is like everything else conditioned by the milicu of the age. ... If anything else is dependent upon gradual historical developement, it is that delicate body of rules which is called international law. The dreamer and the schemer build their castles in the air without regard to the real facts of life. The armchair politician and the moralist lay down the law without regard to the possibilities of the age. The preacher and the philosopher defend postulates which are beyond realization in practice. But the international jurist must not walk in the clouds; he must remain on the ground of what is realizalsle and tangible. It is better for international law to remain stationary than to fall in the hands of the impetuous and hotheaded reformer. He who knows how difficult it is to unite all the members of the family of nations for the purpose 
of the shortest step forward will not lend his ear and his arm to chimerical proposals. ${ }^{58}$

What then is the "milicu of the age" to-day? Or, rather, what was the "milicu of the age" when the representatives of the Allied and Associated Powers met in conference at Paris in 1918 to frame the treaties of peace? Was it not the almost universally expressed tendency towards recognition for the principle of self-determination of nationalities and races? Had not practically all the nembers of the family of nations pledged themselves to the acceptance of the principle?

The Treaty of Versailles provides for a number of territorial cessions by Germany to her neighboring states, all entailing the loss of German nationality. Some of these cessions are demanded on the principle of national self-determination and plebiscites in some form or other are stipulated; some are outright cessions without the consultation of the populations thus transferred. In the case of the cessions of this last type we must again distinguish between a first class where the Allied and Associated Powers assume and assert the indisputable non-German character of the population transferred, and a second class where the same Powers frankly admit the German contention that the territories thus to be ceded are purely or largely German in language and racial characteristics. The first class may still be assigned to the category of territorial changes effected on the principle of national consent. This can, however, not be said of the second class. Neutral Moresnet is ceded to Belgium without special justification. Prussian Moresnet goes to Belgium "in partial compensation for the destruction of Belgian forests," that is, on economic and reparatory grounds. Western Prussia must be ceded to Poland in order that the Allies be enabled to keep their war pledge guarantecing the reestablishment of Poland. We have here the coincidence of historical reasons and of

so Oppenheim, The Science of International Law: Its Tasks and Method, in The American Journal of International Law, April, 1909, Pp. $314,318$. 
motives of an opportunistic policy. The same must be said of the enforced surrender by Germany of the City of Danzig, though here the economic needs of Poland for Danzig as an outlet to the sea are given as an added reason. The City and district of Memel are to be ceded by Germany, without consultation of the admittedly large majority of Germans in Memel, in order to secure for Lithuania an exit to the water, again on the grounds of economic arrangements. Germany is forced to renounce, in favor of CzechoSlovakia, all rights and title over part of the Kreis Leobschüz " in case after the determination of the frontier between Germany and Poland the said part of the Kreis should become isolated from Germany." The population, though German, is not to be consulted in the matter of transfer. The principle on which this transfer is based is without question that of opportunism.

The Treaty of Versailles has borne out Oppenheim's statement that "the necessities of international policy may now and then allow or even demand such a plebiscite but in most cases they will not allow it."s7

This verdict receives substantiation from the Austrian Treaty which refuses German-Austria the right to determine her political status by making her inclusion in the German Republic subject to the consent of the League of Nations which consent is, however, for the time being withheld. The same Treaty forces Austria to cede to Italy Southern Tyrol as a strategic frontier rectification promised Italy by the Allied Governments in the secret Treaty securing and conditioning Italy's entrance into the war."

Thus the principal Allied and Associated Powers in the treaties in question have on the one hand granted and demanded the application of the plebiscite in some cases of territorial settlements while in many other instances they have refused the holding of a plebiscite even where such is demanded for the territories affected by the state which is

67 See alove, p. 172, note 4.

or New York Times Current History, vol. vii, part 2, 1p. 49-4-497. 
forced to surrender them. While the term conquest has been persistently avoided in the cases of enforced cession without recourse to the principle of self-determination, those annexations by the respective Allied Powers differ neither in the method of nor in the motive for acquisition from the territorial aggrandizements of the past.

The conclusion is inevitable that the Peace Treaties ending the World War have so far not established a universal or even general practice of a settlement of territorial questions on the basis of the principle of self-determination by the plebiscite. Nor have they eliminated acquisitions of territory on the implied principle if not the expressed term of conquest.

Assuming that the ratification of the treaties by the constitutional agencies of the countries involved does establish an international law the norms on which the treaty provisions are built, we come to the inevitable conclusion that these treaties have given international legal validity to a practice which by the will of the one of two contending parties, enforced upon the other, establishes the use of the plebiscite in some territorial cessions and prohibits the expression of popular consent or disapproval in others.

But even this assumption rests on premises of a problematic nature. The present treaties, though ratified, are subject to amendment and replacement by other agreements which may offer a different solution of the territorial questions involved, changing or reversing some of their present stipulations. In fact, Article 19 of the League Covenant as part of the Treaty of Versailles provides that the Assembly of the League "may from time to time advise the reconsideration by the Members of the League of treaties which have become inapplicable and the consideration of international conditions whose continuance might endanger the peace of the world."

Another consideration against the preceding assumption is the fact that the United States Senate has twice voted 
against the ratification of the Treaty of Versailles. ${ }^{59}$ Whether a United States Senate will later ratify the Treaty or not, the two earlier refusals will play an important part in future discussions and opinions concerning the international legal validity of the principles embodied in the Treaty. What Oppenheim stated for the time prior to the World War still remains true: "It is doubtful whether the law of nations will ever make it a condition of every cession that it must be ratified by a plebiscite." 60

${ }^{59}$ Nov. 19, I9I9; Mar. 19, 1920.

60 See above, p. 172 , note 4 . 


\section{CHAPTER IX}

\section{CONCLUSION}

In the last analysis every government, from republic to absolute monarchy should depend for its existence upon the principle of popular consent. The ease or difficulty with which an existing form of government may be changed, or its acts controlled, are proportionate to the facilities or restrictions governing the manifestation of popular consent or disapproval.

Our earliest knowledge of the Germanic tribes testifies to the existence of a system which provides for the granting or withholding of popular consent in all important matters affecting the life and welfare of the tribe: regular or specially called gatherings in which all freemen, their arms in hand, partake in the decision of all those affairs which are discussed by their chiefs and "such others as are conspicuous for age, birth, military renown, or eloquence." Their leaders "gain attention rather from their ability to persuade, than their authority to command." As our authority, Tacitus, relates: "If a proposal displeases, the assembly reject it by an inarticulate murmur; if it prove agreeable, they clash their javelins." 1 These manifestations of the popular will were a matter of custom; they were not the result of rights acquired by struggle and revolution and briefed by law. With the catastrophic upheavals of the period of the migrations and the subsequent development of the feudal system, these popular gatherings of the German tribes finally ccased except with the remnants of the Burgundi and Alcmanni in their new homes in the mountains of Helvetia. The modern Western peoples sprung from the racial fragments of the old Germanic tribes have only after many centuries of po-

\footnotetext{
1 See above, p. 19.
}

$$
196
$$


litical struggle and rebellion succeeded in the reestablishment of representative government based upon the system of their forebears.

The Greeks of Homeric times, and probably all human groups living under the same social and political conditions, have had those tribal or communal gatherings for the sake of a mutual discussion and decision in matters vital to their physica! and political existence. But owing to the steady growth of the population of the tribe or of the tribes within the group, sooner or later the chiefs and leaders nearly everywhere succeeded in the more or less effectual elimination of the great mass of the people from the councils, or even in the suppression of all public consideration of the affairs of the group.

It is in the resentment of the masses thus excluded, and in the attempt to regain their old position of influence in the decisions affecting their own welfare as well as that of their kings and ruling caste, that the institution was born which has been named the plebiscite.

In the Republic of Rome the plebs began to resent the dictation of the ruling Patricians. The plebeian members of the Roman commonwealth followed the natural human instinct to gather for the discussion of their grievances and to find ways and means to redress them. Resolutions were passed accordingly, but resolutions are ineffective unless they be given legal value or are otherwise enforced. To receive legal standing these resolutions had to receive the sanction of the Patricians in the Roman Senate. To gain this sanction the plebs was compelled to pass other resolutions, deciding on the refusal to bear arms in the wars declared by the Patricians, to emigrate from the city, etc. Thus the Roman Senate was forced to yield. The resolutions and decisions passed in the plebeian assemblies received the sanction of the patres and became law not only for the plebeians alone but for all Romans. The pendulum swinging from one extreme to the other, all Rome was for a time subject to the law of the plebs. 
The conception of popular consent or of popular government of the Germanic and Greek tribal asscmblies was that of mutual participation, through discussion and decision by all classes of freemen, in all affairs vital to the group. Popular consent and government as established by the Roman plebs constituted rule over all classses by one, the plebs.

The Germanic and Greek systems provided for the rule by the majority of all freemen, while the Roman plebiscitum merely replaced the class rule of the patricians, as far as such existed through the exercise of the auctoritas patrum, by the class rule of the plebeians. The modern system of popular voting passing under the old Roman name of the plebiscite does not exhibit the feature of class limitation as an essential characteristic. There have been restrictions of the vote and of the voters in many cases where the plebiscite has been applied, but these restrictions have been as a rule not openly admitted; they have rather been surreptitiously planned and effected. From the point of view of the present the significant aspect of the rule of the Roman plebeians through their plebiscita is, then, not that of the prevailing of the plebs as a majority-though the plebs was most likely numerically stronger than the patricians-but that of the temporarily successful assertion of a class which deemed itself oppressed.

It is in this last respect that the plebiscite has functioned in international relations. For the principle and foundation of the plebiscite, as applied in territorial settlements, is to give to suppressed minorities a way of voicing their objection to the rule of the dominant political unit to which they are held against their will and to gain through the objections thus voiced their freedom in the form of independence or of another allegiance. This being the definition of the plebiscite employed in the settlements of a territorial character, its justification stands or falls with its success or failure to produce the results promised or expected. 
The plebiscite in the determination of sovereignty gives voice to a suppressed minority, and, through the voicing of the will of this minority, gains for it political separation from its superior. Whence does our modern demand for a plebiscite in a supposedly suppressed minority arise? From our conviction, first, that the minority in question is suppressed, second, that this minority wishes to be free of such suppression, and that all, or nearly all, of that minority are in agreement on this point. How does such a conviction come to us? Through the utterances and the actions of this minority! But if the utterances and the actions of this minority so clearly establish our conviction that all or nearly all its individuals are suppressed and desire delivery from this state of suppression, why demand a plebiscite to establish what is already apparent? Where this conviction is clear, the plebiscite is evidently superfluous. ${ }^{2}$ No plebiscites were needed or demanded by the Allied and Associated Powers to establish the fact that the suppressed minorities, Czecho-Slovakia, Jugo-Slavia, and Poland, desired political independence from Austria-Hungary, Russia, and Germany. The Peace of Versailles provides for two voting zones in the northern part of Schleswig. There must have been a reason for this, a conviction that this twozone arrangement would suit the requirement of the situation better than would any other arrangement. This conviction had been gained without the application of any plebiscites. In fact, the plebiscite was to be and was held under the conditions thus established upon the basis of facts already known. The subsequent plebiscites proved the ar-

2 The same conclusion is reached by Padelletti, though his argumentation proceeds from somewhat different premises. Padelletti holds that "the will of the people is manifested... always in the events themsclves: the plebiscite is always only an expression of this will." Speaking of the plebiscites in Savoy and in Nice at the occasion of the transfer of these Italian provinces to France in 1860 , he claims that "everybody knew the truth of this ohservation and best of all those who were ceded themselves," namely that the plehiscite also in this instance was "nothing but the superfluous ratification of a fait accompli" (G. Padelletti, L'Alsace et la Lorraince, et le droit des gens, in Revise de droit international et de ligislation comparée, 1871 , vol. iii, pp. 488-4sis). See also aluve, p. (x). 
rangement to have been correct. In the northern section a vote of practically 3 to $I$ in favor of Denmark was returned. $^{3}$ In the southern zone the result showed the same proportion in favor of Germany. ${ }^{4}$ Prior to the signing of the treaty, Germany had conceded to Denmark the right to the Danish sections of Schleswig. ${ }^{5}$ Denmark had objected to the original, too liberal, line of demarkation proposed by the Allies. Denmark wanted none of the German sections. Germany's reply to the first treaty draft suggested one zone to include all communes where the Danish language was spoken by at least fifty per cent of the population. ${ }^{7}$ There were in these suggestions and proposals clearly the essentials of a settlement between the parties concerned on the basis of the will of the people involved. The essential element was the willingness on the part of Germany to acknowledge the Danish sentiment of Northern Schleswig and to relinquish that territory on the grounds of this acknowledged sentiment-and Denmark's honest admission that the line as originally proposed by the Allies went beyond her legitimate claims based on popular consent. The one question which was still waiting for a decision between the three parties to the transaction was whether popular consent would be construed as meaning a simple majority, or two-thirds, or even more of the community vote. It was easily conceivable that in a few communities a vote would be required to establish the existence or nonexistence of the fixed majority, decided upon in advance as a basis for the transfer. Still in these cases the plebiscite would serve not to free a suppressed minority, but merely to establish majority rule as it does in the issues of political life in general. ${ }^{8}$ In the case of the voting in the two Schleswig zones, the decision with regard to the future

${ }^{3}$ New York Times Current History, vol. xi, part 2, pp. 424-426.

4 Ibid., vol. xii, pp. 22-24

3 See above, p. 139 .

- See notes, 2-3. See also the Allies' reply to the German counter proposals, cited above, p. 139.

7 See above, p. 139.

8 See above, p. 161; below, p. 201. 
allegiance of the voters was reached on a simple majority basis. The same has apparently been true in all instances of territorial transfers where the plebiscite has been employed.

The simple majority vote has been found practicable as an expedient method of settlement in many internal affairs of government, such as the election of representatives, executive officers, the decision on proposed ordinances and legislation. As thus employed it offers a quick decision, but it also permits a more or less speedy reversal of its verdict. In each contest the party defeated yields to the majority only temporarily, that is, until it in turn is able to cast a majority vote. This is not so in the case of territorial transfers which are considered permanent and not reversible. Here a bare majority can force a nearly equal number into a lasting undesired allegiance. By parity of reason this new subjected minority should be permitted to gather and augment its strength for a new voting contest in which it in turn may master the deciding majority, or it should, by the consistent application of the doctrine of selfdetermination, be allowed to choose its own allegiance as a separate group.

In other words, where the separatist sentiment of any minority group demanding liberation from an undesirable allegiance is not substantially unanimous, the plebiscite does not and cannot achieve its full allotted function. We have illustrations of this in the transfers enforced by the Treaty of Versailles of German territory to CzechoSlovakia and Poland, coupled with the provision that the cultural interests of the German populations under their enforced foreign allegiance shall be protected.

But even in internal affairs political practice sometimes requires a much larger, in some cases even a three-fourths majority vote in the decision of issues involving matters of great importance or of a lasting character sucl as the amendment or the change of a constitution. By force of equity one should thus demand more than a bare majority 
for the most important decision a group may be forced to make-that of choice of sovereignty. The exact proportion decided upon in each case must depend on the various motives prompting the demand for a change and whatever other factors may justly enter into the consideration of all the parties concerned.

The essential part in territorial adjustments is not the plebiscite but the agreement on that proportion of the vote which will effect a solution productive of the lasting peace of the population subject to the change proposed.

The plebiscite can render effective service only when and where such binding agreements, free from all force, have been reached in advance by the parties involved to the effect that a majority of a fixed and agreed proportion shall prevail, and where the plebiscite is employed solely to establish which side of the issue involved can muster this majority and where the resulting minority is assured a fair degrce of local autonomy and the enjoyment of its own language and religion.

But when agreements of this nature become universally possible in the case of territorial settlement and in the determination of sovereignty, the necessity of liberating suppressed minorities by way of plebiscites will no longer exist. Conquest will no longer seem profitable and will actually cease because the victor will in advance bind himeslf to relinquish his prey in case the result of a vote falls below the majority agreed upon as essential to the annexation.

However, a state ready to grant, without coercion of whatever kind, such a degree of liberty to its dissatisfied population would usually be capable of conducting its affairs in such a manner as to overcome any existing disaffection or to avoid its inception in the first place. Nor would such a state be capable of fostering secessionist movements within the confines of neighboring countries in the hope of finally adding suppressed minoritics, once they are liberated, to its own citizen body.

No state can, at the present time, from the point of view 
of constitutional law recognize the right of secession founded upon the principle of self-determination. By doing so it would invite its own destruction. For in every modern state there may be found, at one time or other, groups sufficiently dissatisfied with the conduct of the majority or of a ruling minority to demand a release from their allegiance. Such demands are especially likely to occur in a state which in the past has acquired, on the time-honored principle of conquest, groups of populations ethnically foreign to its own racial stock. 


\section{BIBLIOGRAPHY}

Annual Register, The, a Review of Public Events at Home and Abroad for the Years I890, 1905.

Appleton's American Annual Cyclopaedia and Register of Important Events for the Year 1861.

Aulard, F. V. A. Histoire politique de la Révolution française. .... Paris, A. Colin, Ig0I.

Blumer, Johann Jakob. Staats- und Rechtsgeschichte der schweizerischen Demokratien. . . . St. Gallen, Scheitlin und Zollikofer, $1850-1859$.

Bonfils, Henri. Manuel de droit international public. . . se éd. ... Paris, A. Rousseau, Igor.

Borgeaud, Charles. Histoire du plébiscite... Le plébiscite dans l'antiquité - Grèce et Rome - Genève, H. Georg, Paris, E. Thorin, I887.

Borgnet, Adolphe. Histoire des Belges à la fin du XVIIIe siècle ..., 2e éd. Bruxelles, A. Lacroix, Verboeckhoven \& cie., I8611862 .

Brown, Philip M. International Relations. . New York, C. Scribner's Sons, I9I7.

Cherbuliez, A. E. De la démocratie en Suisse. . . Paris, A. Cherbuliez et cie., I 843 .

Chuquet, A. M. Jemappes et la conquête de Belgique (1792-1793) . . Paris, L. Cerf, 1890 (Les Guerres de la Révolution, IV). Mayence. . . Paris, L. Cerf, I892 (Les Guerres de la Révolution, VII).

Compilation of Treaties in Force. Prepared under Resolution of the Senate of February II, 1904. Washington, Govt. Printing Office, I904.

David, André. Les plébiscites et les cessions de territoires. Paris, Rousseau et cie., 1918 (Thèse pour le doctorat. Université de Paris. Faculté de droit).

Deploige, Simon. The Referendum in Switzerland,... translated into English by C. P. Trevelyan. . . . Editcd with notes ... by Lillian Tomn. ... London, New York, Longmans, Green and Co.. 1898 .

Dodd, W. F. The Government of the District of Columbia.... Washington, D. C., J. Byrne \& Co., 1909.

Dunning, WV. A. A History of Political Theories, Ancient and Medireval. .. . New York, The Macmillan Company, I9ı.

-. A History of Political Theories from Luther to Montesquieu. ... New York, The Macmillan Company, 1916.

Dupanloup, F. A. P. La Souveraineté pontificale selon le droit catholique et le droit européen. . . Paris, Lecoffre, I860.

Edén. Nils. Sweden for Pcace. The Programme of Sweden in the Union Crisis. ... Upsala \& Stockholm, Almquist \& Wiksell, Itd.. I 1905.

Flach, Jacques. Les Origines de l'ancienne France, ... Xe et XIe siècles. . . Paris, L. Larose et Forcel, I886-I904. 
France. Archives parlementaires, de 1787 à 1860 . Recueil complet des débats législatifs et politiques des Chambres françaises ... fondé par MM. J. Madival et E. Laurent. . . . Paris, P. Dupont, I867-19-. Series I, 1787-1799.

Freudenthal, Felix. Die Volksabstimmung bei Gebietsabtretungen und Eroberungen. Eine Studie aus dem Völkerrecht. ... Erlangen, Th. Blaesing, I891.

Funck-Brentano, Théophile. Précis du droit des gens. Par Th. Funck-Brentano ... et A. Sorel ... ., 3e éd. Paris, PlonNourrit et cie., I900.

Gierke, O. F. Political Theories of the Middle Ages, ....translated with an Introduction by F. W. Maitland. . . Cambridge, University Press, I9I3.

Gjerset, Knut. History of the Norwegian People. . . . New York, The Macmillan Company, IgI 5.

Glasson, E. D. Histoire du droit et des institutions de la France. ... Paris, F. Pichon, I887-1903.

Great Britain. Hansard's Parliamentary Debates, vols. 345-347.

Hall, W. E. A Treatise on International Law . .., 5th ed., by J. B. Atlay. . . Oxford, Clarendon Press, 1904.

Hershey, Amos S. The Essentials of International Public Law. . . New York, The Macmillan Company, IgI6.

Hertslet, Edward. The Map of Europe by Treaty; showing the Various Political and Territorial Changes which have taken Place since the General Peace of 1814 . . . L London, Butterworths, I875-I89I.

International American Conference. Ist. Washington, D. C., I8891890. Reports of Committees and Discussions thereon... (English ed.). Washington, Govt. Printing Office, I8go.

Johnson, W. F. The Story of the Danish Islands. In The North American Review, September, Igr6.

Johnston. Alexander. Popular Sovereignty. In Lalor's Cyclopædia of Political Science, Political Economy, and of the Political History of the United States. . . . Chicago, M. B. Cary \& Company, $1883-1884$.

Jorga, Nicoláe. Geșchichte des rumänischen Volkes im Rahmen seiner Staatsbildungen. . . Gotha, A. Perthes, 1905.

King, Bolton. A History of Italian Unity, being a Political History of Italy from I8I4 to 1871 . . . New York, C. Scribner's Sons, I 899 .

La Gorce, Pierre de. Histoire de la seconde République française ... se éd. . . . Paris, Plon-Nourrit et cie., 1909.

_. Histoire du second empire. . . Paris, Plon-Nourrit et cie., 1904-1008.

Laveleye, Emile de. Le Régime parlementaire et la démocratie. In Revue des deux mondes, December 15, 1882.

Lavisse, Ernest. Histoire de France depuis les origines jusqu'à la Révolution, publiée avec la collaboration des MM. Bayet, Bloch, Carré. ... Paris, Hachette et cie., 1900-19II.

Lawrence, $\dot{T}$. $j$. A Handbook of Public International Law . ... gth ed. London, Macmillan and Co., Itd., 1915.

Le Bas, Philippe. France. Annales listoriques. . . Paris, Firmin Didot frères, I840-1843.

Lewis, V. A. Histnry of West Virginia. In Two Parts... Philadelphia, Hubbard Bros., I889. 
Lieber, Francis. De la valeur des plébiscites dans ic droit international. I $n$ Revue de droit international et de législation comparée, 1871 .

Luchaire, Achille. Manuel des institutions françaiscs. Périods des Capétiens directs. .... Paris, Hachette et cie., I892.

McPlerson, Edward. The Political History of the United States of America, during the Great Rebellion. ... New York, D. Appleton \& Co., I864.

Mano, J. G. L'Union des principautés roumaines, Etude d'histoire diplomatique \& de droit international. [Université de Paris, Faculté de droit] Thèse pour le doctorat. ... Paris, A. Rousseau, I900.

Markham, C. O. A History of Peru. ... Chicago, H. Sergel and Company, ISg2.

Martens, G. F. von. Recueil des principaux traités d'alliance, de paix, de trêve .... conclus par les puissances de l'Europe ... depuis I76I jusqu'à présent. . . Gottingue, J. C. Dieterich, I79I-1801.

Méneval, C. F. Memoirs illustrating the History of Napoleon I from I802 to I815: by Baron Claude François de Méneval. ... Edited by his Grandson, Baron Napoleon Joseph de Méneval. ... New York, D. Appleton and Company, I 894.

Meyer, Eduard. Der Ursprung des Tribunats und die Gemeinde der vier Tribus. In Hermes, vol, xxx.

Molıl, Robert von. Staatsrecht, Völkerrecht und Politik. . . . Tübingen, Laupp'sche Buchhandlung, I860-1869.

Molinier, Auguste. Etude sur la réunion de Montpellier au domaine royal (1349). In Revue historique, vol. xxiv.

Morley, John M. The Life of William Ewart Gladstone. . . New York, The Macmillan Company, I903.

Mühlbacher, Engelbert. Deutsche Geschichte unter den Karolingern. . . . Stuttgart, J. G. Cotta, 1806.

Müller, Karl O. Geschichten hellenischer Stämme und Städte .... 2., nach den Papieren des Verfassers berichtigte und vermelirte Ausgabe, von F. IV. Schneidewin. ... Breslau, J. Max und Komp., I844.

Nordlund, Karl. The Swedish-Norwegian Union Crisis. A History with Documents. ... Upsala \& Stockholm, Almquist \& Wiksell, ltd., rgo5.

Ollivier, Emile. L'empire libéral ; études, récits, souvenirs . . . [2e éd.]. Paris, Garnier frères, i895-I9I5.

Oppenheim, L. F. L. International Law ..., and ed. London, New York. Longmans, Green and Co., 1912.

Orsi, Pietro. Modern Italy, 1748-1898 .... [translated by Mary A. Vialls]. London, T. Fisher Unwin; New York, G. P. Putnam's Sons, 1900 .

Padelletti, G. L'Alsace et la Lorraine, et le droit des gens. In Revue de droit international et de législation comparée, I87I.

Philippe IV, le Bel, King of France. Lettres inédites, publiées aux frais du Ministère de l'instruction publique par l'Académie des sciences, inscriptions, et belles-lettres de Toulouse. Avec une introduction par Ad. Baudouin. Paris, II. Champion, I887.

Picciotto, Cyril M. The Relation of International Law to the Law of England and of the United States of America.... New York, McBride, Nast \& Company, I9I5. 
Plauchut, Edmond. L'Annexion de l'île Saint-Barthélemy à la France. In Revue des deux mondes, March I5, I879.

Rivier, Alphonse. Principes du droit des gens. ... Paris, A. Rousseau, 1896 .

Rotteck, K. W. R. von. Abtretung. In Das Staats-Lexikon. Encyklopädie der sämmtlichen Staatswissenschaften für alle Stände. ... Hrsg. von Carl von Rotteck und Carl Welcker. ... Altona, J. F. Hammerich, 1845-1848.

Rouard de Card, Edgard. Etudes de droit international. . . Paris, G. Pedone-Lauriel, I890.

Scott, James Brown. The Legal Nature of International Law. In American Journal of International Law, October, I907.

Solière, Eugène. Le Plébiscite dans l'annexion. Etude historique et critique de droit des gens. .... Paris, L. Boyer, Igol (Thèse pour le doctorat. Faculté de droit de Paris).

Stoerk, Felix. Option and Plebiscit bei Eroberungen und Gebietscessionen. . . Leipzig. Duncker \& Humblot, I879.

Ullmann, Emanuel von. Völkerrecht . . Neubearbeitung. . . . Tübingen, J. C. B. Mohr, 1908 (Das öffentliche Recht der Gegenwart ...., hrsg. von Dr. G. Jellinek ..., Dr. P. Laband ..., Dr. R. Piloty ...., bd. iii).

Vincent, John Martin. State and Federal Government in Switzerland. ... Baltimore, Johns Hopkins Press, I89I.

Westergaard, W. C. The Danish West Indies under Company Rule (167I-I754). With a Supplementary Chapter, I755-1917... New York, The Macmillan Company, I9I7.

Westlake, John. The Collected Papers of John Westlake on Public International Law, edited by L. Oppenheim. . . . Cambridge, University Press, 1914.

Willoughby, W. W. The Constitutional Law of the United States. ... New York, Baker, Voorhis \& Company, rgro.

- The Legal Nature of International Law. In American Journal of International Law, April, I908.

The Political Theories of the Ancient World. . . New York, London, Longmans, Green and Co., Igo3. 



\section{INDEX}

"Agreement of the people" of 1647. See England.

Alsace-Lorraine, annexations by France confirmed in Treaty of Muenster (1648), 53; indemnity to German princes for abolition of feudal rights by revolutionary France, 59 (note); annexation by Germany (I87I), I45-149, I66, I74-I76; cession by Germany to France (I9r9), see Versailles, Treaty of.

American Conference, First International. See International American Conference, First ( 1890 ).

Argyll Duke of, opposed to plebiscite in Alsace-Lorraine (I87I), I75-I76.

Asquith, Herbert $H$., on selfdetermination, 177.

Assembly vote in ancient Greece. See Greece.

Austria, Peace with Allied and Associated Powers. See St. Germain, Treaty of.

Avignon and Venaissin, vote for annexation to revolutionary France, 56,59 ; intervention by France, 58,60; Papal protests, 59,60 (note).

Baltic States, independence by assembly vote or by direct popular vote, 128-I30, 155. See also Brest-Litovsk, Treaty of.

Basel, bishopric under German sovereignty, resolution renouncing allegiance, $6 \mathrm{r}-62$; intervention by revolutionary France, 63; vote for annexation to France, 63 .

Belgium, declares itself republic, free from Austrian sover- eignty (1790), 68; reduced to former status, 69; intervention against Austria by revolutionary France, 66 ff.; French decree of Dec. I5, 1792, prepares for annexation to France, $71-72$; opposition to annexation, $71-72$; propaganda of political clubs organized by French commissioners, $72 \rightarrow 4$; votes for annexation, 74 .

Bingen. See Mainz.

Bonfils, Henri, on cession, 29 (note), 30 (note); on option, I63.

Bourgeoisie, definition of feudal, $35,4 \mathrm{I}$; relation to liege lord, $35-36,40,42$; relation to king as suzerain of liege lord, 37 . 40.

Brest-Litorsk, Treaty of, no plebiscites for Baltic States, Lithuania and the Ukraine, I28-I30.

British Labor Party, Program of peace, 154 .

Brittany, remonstrances by royal courts of, 24 (note).

Bucharest, Treaty of, no plebiscites provided, 130 .

Bulgaria, Peace with Allied and Associated Powers, I5o (note).

Cavour, becomes guiding statesman of Piedmont (1852), 86 ; resigns after king signs Preliminary Peace of Villafranca (1850), 87; becomes premier again $(1860)$, 8o. See also Italian States; Plombices.

Cession, modes of, 20. See also Bonfils; Hall: Hershey: Oppenlseim; United States Supreme Court; Willoughly:

Chile, annexation of Tacna and Arica. See Tacna and Arica. 
Consent, popular. See Popular consent.

Constitutional convention vote deemed equivalent to plebiscite in American constitutional theory, I17 (note).

Courland, German population, 155. See also Baltic States.

Danish West Indies, plebiscite for annexation to United States, 125, 172-173; assembly vote on annexation in Denmark, 125; popular vote, I26.

Danzig. See Versailles, Treaty of.

Declaration of the rights of man and citizen, 24, 54 .

England, "Agreement of the people" of $1647,20,23$ (note).

Esthonia. See Baltic States.

Etats Généraux, registration of treaties stipulating cession of French territory, 47-50.

Eupen. See Versailles, Treaty of.

Fxpatriation, enforced, 154 .

Feudalism, relation of seigneur and vassal, 32-33; consent of vassal to transfer of fief, 33 , 4(1) relation of king, seigneur and vassal, 33-34, 36; transfer of territory, 33-36; definition of people, 35, 37; consent of entire French nation required to cession of part of French territory to foreign sovereignty, 46-47; popular consent to change of allegiance, see Bourgeoisie; Etats Généraux.

Fief, alicnation of. Sec Fieudalism.

Finland, independence by assembly vote, 155 .

France, plebiscitc in internal aifairs (1848-1852), 23-27; revolutionary, renounces conquest, 54; no conquest does not mean no annexation, 76 ; revolutionary, passes decree promising aid to all peoples sceking political freedom, 6I (note); warned by England against intervention, 6I (note); asked for aid by Republic of Rauracie, 62 ; revolutionary, passes decree stipulating overthrow of old, and cstablishment of revolutionary, governments in all countries where French troops enter, 72 ; passes decree threatening with death attempt or proposal to cede French territory, 79 (note).

Fulbert de Chartres, on relation of rassal and liege lord, 34,36 .

Geneva, assembly vote against annexation to Savoy (1240), 44; annexation to France (1798), 76 (note), 165.

Germany, assembly votes of old German tribes, I9-2I ; disappearancc of assemblies, 20, I96; peace with Allied and Associated Powers, see Versailles, Treaty of.

Gex, remonstrance of, 23-24.

Gladstone, opposes plebiscite in Heligoland, II2; favors plebiscite in Alsace-Lorraine, 174176.

Greecc, ancient, assembly votes in internal affairs, 16-19, 197198; no popular consent recognized in foreign relations of, 31.

Grey, Sir Edward, on self-determination, I77.

Guéronnière, de la, on cession of French territory in feudal times, 49.

Guyenne, proposed cession by France to England (1344), 46-47.

Hall, W. E., on cession and plebiscite, $17 \mathrm{I}^{-1} \mathrm{72}$.

Hawaiian Islands, plebiscite proposed by Japan, opposed by United States, 173-174.

Heligoland, plebiscite proposed for cession to Germany, IIII12, 188

Hershey, A. S., on cession and plcbiscitc, 173.

Hertling. Georg Friedrich von, on self-determination, 178,189 . 
Hungary, Peace with Allied and Associated Powers, I50.

International American Conference, First, 1890, resolutions against conquest and for arbitration on American continent, I8o.

Inviolability of French soil, 47, 53, 79 (note), I74-I75, I84 (note).

Ionian Islands, assembly votes for union with Greece (1854I859), II 4-II5.

Ireland, 152.

Italian States, beginning of revolution against oppressive governments, $8 \mathrm{I}-82$; revolutionary movements against foreign rule and princes imposed in $1815,81-82$; revolt against Austrian rule in LombardoVenetian States, 81, 83-84; inconclusive plebiscites for union with Piedmont (I848), 84-86; inconclusive plebiscites (1859), 87-88; final plebiscites (I860), $89,91-92$; decrees of annexation, $89-90,92$; protests of the Pope and deposed princes, go9I ; final plebiscite in Venetia (I866), 92-93; plebiscite in Rome (1870), 93-94.

Klagenfurt area, plebiscites. See St. Germain, Treaty of.

Landau. See Mainz.

Laveleye, Emile de, on plebiscite and referendum, I (note), 12 (note).

Leobschiitz (Kreis). See Versailles, Treaty of.

Lex, distinguished from plebiscitum, 13.

Lieber, Francis, on plebiscite, I2 (note).

Lithuania, independence of, 129 , I53.

Livonia. See Baltic States.

Lloyd George, on self-determination, 177-178, 180 ).

I.ombardy. See Italian States.

I, 11xemburg, proposed annexation to France by plebiscite (1867), 100-110.
Lyons, citizens express desire for sovereignty of King of France (end of 13 th cent.), 38 ; citizens and nobles called upon to sanction treaty of $1307,38-40$.

Mainz, Worms, Speier and territory to left of Rhine between Landau and Bingen, intervention by revolutionary France, 74; vote for annexation to France, 74-75; opposition to annexation, $75-76$; measures to overcome opposition, 76.

Majorca, kingdom, annexed to Aragon without consultation of people, 45.

Majorities and minorities in ceded or seceding territories. See Minorities.

Malmédy. See Versailles, Treaty of.

Marseilles, citizens give city in public meeting to House of Toulouse, 40-41.

Mayence. See Mainz.

Memel. See Versailles, Treaty of.

Metz, annexation by France (I552) without consent of population, $50-53$.

Milan. See Italian States.

Minorities in ceded or seceding territories, I61-163, I98-302. See also Option

Modena. See Italian States.

Moldavia. See Valachia and Moldavia.

Montpellier, no popular consent in passing of barony to King of Aragon (1236), 44; no popular consent in assumption of suzereignty of King of France (1203), 44; King of Majorca, holding arricre fief rights, solicits support of inhabitants against suzereignty of King of France, $44^{-45}$.

More. Thomas, on popular consent, 23.

Moresnet. See Versailles, Treaty of.

Miilhansen, annexation w. France (1708), 76 (note), 165. 
Napoleon I, coup d'état by plebiscite of 1799, 25-26; consul for life by plebiscite of 1802 , 26 ; emperor by plebiscite of $1804,27$.

Napoleon III, president of France by plebiscite of 1848 , maintenance of authority by plebiscite of $185 \mathrm{I}$, hereditary emperor by plebiscite of 1852 , 27, 157; withholds and grants consent to Italian plebiscites, $89,93,97$; sponsor of plebiscite and self-determination, 93 , 96 (note), 103-104, 106-108, IIO.

Nice, intervention by revolutionary France, 66-67; vote for annexation to France, $66-67$; annexed (1793), 67; promised Napoleon III by Cavour at Plombières (1858), 86, 89, 93 , 97-98; promised by secret and public agreements (i\&60), 98 (note); cession to France (1860), 97-99. See also Savoy.

Norway, separation from Sweden by plebiscite (1904), 112II 4, I5I-I 52 .

Oppenheim, L., on cession and plebiscite, 28 (note), 30 (note), 127.

Option, history and principle of, $129,131-132,138,145,147,163-$ 167. See also Bonfils; Rivier; Ullmann; Willoughby.

Orlando, Vittorio, on self-determination, 178.

Padelletti, G., on plebiscite, 199 (note).

Padua. See Italian States.

Pamiers, people agree by acclamation to change of overlordship (1285), 42 .

Parma. See Italian States.

Peru, cession of Tacna and Arica. See Tacna and Arica.

Piacenza. See Italian Statcs.

Pichon. Stephen, on self-determination, 178

Plcbiscitc, definition and origin of, $11-12,106-108$; executive, 12 (notc); legislative, 12 (note); national (in internal affairs), 12 (note), 97, 151, 161 ; annexationist or international, I2 (note); in international relations, meaning and purpose of, $12,95-06,15 \mathrm{I}-152$, $161,195-201$; criticism of conduct of, 26, 50-51, 56-57,59$60,63-64,67,73-76,85,88-89$, $90-91,94-95,116,157-163$; as applied by revolutionary France, 78-79; not recognized in Europe outside of revolutionary France, $79-81$; in territory under military occupaton by conqueror, $154^{-1} 55,159$; on restricted franchise, I50161 ; by simple or larger majority, 161-163, 201-202; as state policy, I68; advocates and opponents of, I7I, I88-189, 199 (note).

Plebiscitum. See Rome.

Plombières, agreement of (1858), S6, 89, 93, 97-n8.

Pommern. See Versailles, Treaty of.

Popular consent, definition of, 11, 28; opposed by United States, 125, 172-174; opposed by England, III-112, 188. See also Plebiscite, in international relations; Self-determination

Popular sovereignty, proclaimed by revolutionary France, 24 , 29-30; extended to international relations, 77 ; not recognized by states outside of France, 8o; gains recognition in national life of Western Europe, $8 \mathrm{I}$; acclaimed by Italian States, 81 ff. See also Squatter sovereignty.

Posen. See Versailles, Treaty of.

Prussia, East, separated geographically from Germany. 154 (note). Sec also Versailles, Treaty of.

Prussia, West. See Versailles, Treaty of.

Rauracie, Republic of. See Basel.

Refcrcudum, definition of, II. 
Rivier, Alphonse, on plebiscite and popular sovereignty, 30 (note); on option, I63.

Romagna. See Italian States.

Rome, ancient, plebiscite in internal affairs of, I2-I6, I8-I9, I97-I98; no popular consent recognized in foreign relations of, $3 \mathrm{I}$; plebiscite in modern ( I870), 93-94.

Rotteck, $K$., on conquests of ancient Greece and Rome, 3I.

Rouard de Card, on plebiscite, 49.

Roumania. See Valachia and Moldavia.

Rovigo. See Italian States.

St. Bartholomew, plebiscite for union with France (I877), I 5 -II6.

St. Croix. See Danish West Indies.

St. Germain, Treaty of, plebiscite provided for Klagenfurt area only, I50; result of plebiscite held, I50 (note); Austria denied right to join Germany without consent of League, I50.

St. John. See Danish West Indies.

Savoy, intervention by revolutionary France, 64-65, 76 (note); vote for annexation to France, 66; return of part of, by canvass of signatures (I8I5), 80 (note); promised by Cavour to Napoleon III, 86. $89,93,97-98,98$ (note) ; cession to France by plebscite ( 1860 ), 97-10I ; cession of, as infringement upon Swiss rights, IOOIoI. See also Cavour.

Schleswig, Northern, plebiscite proposed in 186.4 , 106-107; provided in Art. V of Treaty of Prague (I866), I08-IIo, I25 (note); Art. $V$ eliminated (1878), jon-110. See also Versailles, Treaty of.

Self-determination, as applied by revolutionary France, 77; not recognized by Europe outside of France, 80; not applied by imperial France, 80-8r, I65; Allied and Associated Powers demand peace on basis of, I28, I76-I78; Central Powers consent to, I54-I55, I78-I79; by direct (popular) or indirect (assembly) vote, $155-156$; scope and aim of, I55 (note), I6II63; danger to State, I63, I67I70, 202-203; for uncivilized peoples, I89-I90; forces working for recognition of, I82I83, I88-I92; forces working against recognition of, $183^{-}$ I88; status in constitutional law, I83-I88, 202-203; status in international law, $5 \mathrm{I}, \mathrm{I} 8 \mathrm{I}$, 192-195; advocates and opponents of, I7 I, I88-I89, I99 (note); policy of state in regard to, 168. See also Popular consent.

Seward, W. H., on plebiscite. See Danish West Indies.

Sherman, John; on plebiscite. See Hawaiian Islands.

Silesia. See Versailles, Treaty of.

Spanish-American War, American Peace Commission, on popular consent, I74.

Speier. See Mainz.

Squatter sovereignty, 123-I25.

Suffrage, universal, and the plebiscite, $12,26$.

Switzerland, plebiscite in, II-I2, 20-21, 24. See also Savoy.

Tacna and Arica, annexed by Chile (I884) on condition of plebiscite to be held after ten years, 126.

Tahiti Islands, chiefs consulted regarding cession to France (i880), II6 (note).

Thiers, on plebiscite. See Alsace-Lorraine; Inviolabiiity of Ii iench soil.

Toul, annexation by France (1552) without consent of population, 50-53.

T:eviso. Sec Italian States.

Turkey, Peace with Allied and Associated Powers, 150 (note).

Tuscany. See Italian States. 
Ukraine, independence by assembly vote, 155. See also Brest-Litovsk, Treaty of.

Ullmann, Emmanuel ron, on option, 163.

United States, plebiscites, retrocession of part of District of Columbia, I17; secession movement, 117-123; secession of West Virginia from Virginia, I 19-123, I68, I 70 .

Valachia and Moldavia, union on basis of essembly votes, 101-106.

Venaissin. See Avignon and Venaissin.

Venetia. See Italian States.

Venezuelan Congress criticises conquest by Chile (I884), I 80 .

Venice. See Italian States.

Verdun, annexation by France (I552) with appeal to "free vote of the people," 50-53.

Versailles, Treaty of, cessions by Germany to be dependent on plebiscites: Eupen and Malmédy, 13I-134; Northern Schleswig, I38-I39. I99-201 ; parts of provinces of East and West Prussia and Upper Silesia, 140-142; Saar Valley, plebiscite to decide sovereignty after 15 years of foreign rule, $134-138$; results of plebiscites held in East and West Prussia and Northern Schleswig, I50 (note), 200; cessions without plebiscites: Moresnet, I3I-134; Saar Valley, 15 years of foreign rule without plebiscite. 134-138; parts of provinces of Posen, V'est Prussia, Pommern, 140-142; Danzig, I42144; Memel, 144-145; part of province of Silesia, 145; Kreis Leobschütz, conditionally, I45; German colonies, $145^{-146}$; Alsace-Lorraine, I46-149, I52153.

Vicenza. See Italian States.

Villafranca, Preliminary Peace of, 87 .

Voltaire, on plebiscite, $23-24$.

Willoughby, on cession, 29 (note); on popular consent in American constitutional law, $185-188$.

Wilson, Woodrow, on self-determination, $176-177$.

Worms. See Mainz.

Zürich, Treaty of, 92,98 . 


\section{Johns Hopkins University Studies}

\section{in Historical and Political Science}

The University Studies will continue to publish, as heretofore, the results of recent investigations in History, Political Economy, and Political Science.

The titles given below are now announced; other numbers will follow from time to time.

The United States Department of Agriculture. By Willia.y L. WANLASS.

The Amalgamated Association of Iron, Steel and Tin Workers. By Jesse S. Robinson.

The Capitalization of Industrial Good Will. By Kemper Smpson. The Virginia Frontier, I754-I763. By Louis K. Koontz.

The Employment of the Plebiscite in the Determination of Sovereignty. By J. Mattern.

The cost of subscription for the regular annual series, comprising about 600 pages, is $\$ 3.50$. Single numbers, or epecial monographe, at special prices. Complete contents of previous volumes are given on pages VIII-XII. 


\title{
Studies in History, Economics and Public Law
}

\author{
EDITED BY \\ THE FACULTY OF POLITICAL SCIENCE OF \\ COLUMBIA UNIVERSITY
}

VOLUISE LXXX. 1918. 448 pp. Price, cloth, $\$ 4.00$.

1. [185] "Valuation and Rate Making. Ry RoRERT L. IIALE, Ph.D.

2. [188] The Enclosure of Open Fields in England.

3. [187] The Land Tax in China. By MARrLe Brader, Ph.D. VOLUME IXXXI, 1918, IBY II. I. HUAN, Ph.

1. [188] Social Iifo in Rome in the Time of Plautus and Terence.

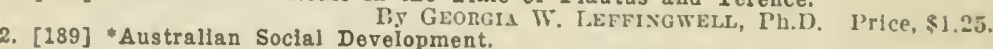

3. [190] Factory statistics and Industriacr II. NonticotT, Fh.D. Price, \$2.50. BY PHILIP S. Flotexce, Ph.n. Price, \$1.25.

VOLUME IXXXII. 1918-1919. 576 pp. Price, cloth, $\$ 4.50$.

1. [191] New England and the Bavarian Illuminati.

2. [192] Resale Price Maintenance, B Ly Venxus STAffrer, Ph.D. I'rlce, \$3.00.

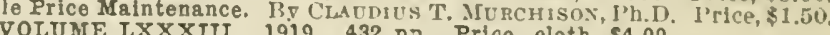
[193] The I. W. W. VOLU

1. [194] The Royal Government in Vir $534 \mathrm{pp}$. Price, cloth, $\$ 4.50$ 2. [195] Hellenic Concoptions of Peace. VOLUME LXXXV. 1919, 450 pp. Price, cloth, \$4.00. Price, \$1.25.

1. [196] The Religlous Pollcy of the Bavarian Government during the Napoleonic Period. By CHester 1" II IGBi, I'h.D. I'lice, $\$ 3.00$

2. [197] Public Debts of China.

VOLUME IXXXVI. 1919, 460 pp. Price, cloth, $\$ 4.00$.

[198] The Decline of Aristocracy in the Polltics of New York.

VOLUME LXXXVII. 1919. By DixoN RYAX Fox, Ph.D. Price, \$3.50.

[199] ] 451 pp. Price, cloth, \$4.00. RT CHoxs SU SEe, Ph.D. Price, \$3.50.

1. [200] V 2. [201] Elcctric Light Franchises in $13 y$ HARry J. CAruid, Ph.D. Price, \$2.00.

By LEONORA ARExT, Mh.D. Price, $\$ 1.50$ VOLUME LXXXIX, 1919 .

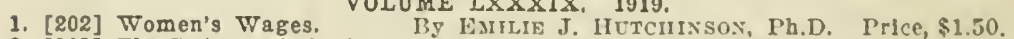

2. [203] The Return of the Democratic Party to Power in 1884.

3. [204] The Paris Bourse and French Finance.

By Williaj Pagker. J'lec, $\$ 1.00$.

VOLUME XC. 1919.

1. [205] Prison Methods in Now York State. Jy I'JlLir Kisix. (III press).

2. [206] India's Demand for Transportation. By WILLIAM E. WELD. (In priss).

VOLUME XCI. 1920

1. [207] The Infuence of Oversea Expansion on England to 1700.

2.

2. [208] The English Reform Bill of 1867. Hy Joskril I1. PARK. (In press).

3. [209] International Labor Legislation. Hy IWAO F. ArUs.1WA. (In press).

The prlce for each separate monograph is for paper-covered coples: separate monographs marked *, can be supplied bound in cloth, for $50 \mathrm{c}$ additional. All prices are net.

The set of elghty-eight volumes, covering monographs 1.201, is offered, bound, for

$\$ 300$; except that Volumes II, III, and IV can be supplied only in part, Volume

II No. 1, Volume III No. 2, and Volume IV No, 3, being out of print. Volumes

II, III, and IV, as described in the lest sentence, and Volume XXV can now

be supplied only in connection with complete sets, but the separate

monographs of each of these volumes are avallable unless marked

For further Information, apply to

$$
\text { "not sold scparatcly." }
$$

MESSRS. LONGMANS, GREEN \& CO, Nicw York.

London: P. S. FING \& SON, Itd., Orchard House, Westminster. 


\section{Recent Harvard Books}

\section{The Political Works of James I.}

Edited, with an Introduction, by Charles Howard McIlwaIN, Professor of History and Government in Harvard University. cxi +354 pages. $\$ 5.00$.

"An Englishman may be allowed the remark that the preface is the most admirable contribution to its subject that has been made by an American scholar. It is at every point learned and exact, and it is rarely indeed that it is not convincing. Its main value lies not so much in the appraisal of James's ideas, to which little attention is given, as in the attempt to set them in their historic perspective... . Nor must we miss the illuminating appendix upon the political literature of the Tudors."

$$
\text { -Mr. Harold J. Laski in Political Science Quarterly. }
$$

\section{Norman Institutions.}

By Charles Homer Haskins, Gurney Professor of History and Political Science in Harvard University. xiv +377 pages. $\$ 3.25$.

"The total harvest in what is new and in the prepared material of investigation put at the service of later workers in constructive history abundantly justifies the time and labor of the years which have gone to the making of the book."-G. B. Adams in The New Republic.

"To many readers much of the book's value will lie in the appendices, which give verbatim many of the authorities used, and supply an admirable survey of the documentary evidence; others will find pleasure in the seven excellent reproductions of Norman charters. Professor Haskins's volume, though it could not be light reading, is a great contribution to learning, and will rank as one of the chief authorities for the period."

\section{-J. D. Mackie in Scottish Historical Review.}

\section{Trade and Navigation between Spain and the Indies in the Time of the Hapsburgs.}

By Clarence Henry Haring, Assistant Professor of History in Yale University. xxviii +371 pages. $\$ 2.75$.

"Mr. Haring has produced a treatise which fully realizes the promise implied in the copious bibliography and in the citations from the various published collections of documents, as well as from manuscripts which Mr. Haring himself has examined in the Archives of the Indies at Seville and in various libraries at Madrid. The result is a minute, thorough, and comprehensive work concerning the system of commerce with the Indies under the Hapsburgs, both in its theoretic intention and in its practical working."

-F. A. Kirkpatrick in English Historical Reqimu.

Send for our new descriptive circulars of

The Harvard Historical and the Hariard Economic Studics

\section{Harvard University Press}

44 Randall Hall

Cambridge, Mass.
19) E.ist 47ril St.

NEW YORK CITY 


\title{
Early Diplomatic Relations
}

\author{
BETWEEN
}

\section{the United States and Mexico}

By WILliam R. MANNING, Pir.D.

Adjunct Professor of Latin-American History in the University of Texas

$418^{-}$pages. Cloth, $\$ 2.25$

This volume is based on a series of lectures delivered at the Johns Hopkins University in 1913 on the Albert Shaw Foundation. It deals with a period in the diplomatic relations between the United States and Mexico, which has hitherto been largely ignored by historians, whose attention has for the most part been centered on the Texas revolution, the admission of Texas into the Union, and the war between the United States and Mexico.

\section{Early Diplomatic Relations BETWEEN \\ the United States and Japan 1853-1865 \\ By PAYSON J. TREAT \\ Professor of Far Eastern History in Leland Stanford Junior University}

468 pages. $\quad 12 \mathrm{mo}$ Cloth, $\$ 2.50$

Questions of foreign policy are of course beginning to attract much more attention from Americans than they have in the past. The present volume gives the historical foundations of our commercial intercourse and diplomatic relations with Japan. It is based on an exhaustive study of the documentary sources, supplemented by a knowledge of Japanese institutions and the Japanese point of view gained by two visits to that country. Dr. Treat writes sympathetically of Japanese affairs, and his volume is the most thorough and scholarly treatment that we have had of the period covered. Sound historical work of this character will do much to promote a better understanding of the present-day relations between the two countries.

\section{THE JOHNS HOPKINS PRESS BALTIMORE, MARYLAND




\title{
Four Phases of American Development
}

\author{
FEDERALISM-DEMOCRACY-IMPERIALISM-_EXPANSION \\ By JOHN BASSETT MOORE, LL.D.
}

218 Pages. Crown 8vo. Cloth. Price, $\$ 1.50$

The lectures embraced in this volume are degigned to sketch in clear and vivid outline the great morementa by which the bistorical derelopment of the United States is distinguished and to indicate the canses to which they were due. The order in which the several topics are discussed is not intended to de. note a strict chronological succession; bence they are described as phases ratber than as stages of development. While federalism, democracy and imperialism give a dominant impress to successire periods, yet expansion has characterized the entire conrse of American bistory. The misapprehension so widely entertained, that imperialism began with the war with Spain is corrected. The imperialistio tendency, observable from the beginning, is shomn to have assumed a specially prononnced form in the Civil War and in the measures of national aelf-preservation to whiob that great conflict gave rise.

\section{The Diplomacy of the War of 1812}

\author{
By FRANK A. UPDYKE, Ph.D.
}

504 Pages. Cloth, $\$ 2.50$

The author carefully analyzes the diplomatio correspondence in regard so neutral rights and the impressment of seawen which preceded the War of 1812. The protests against interference with neusral trade made by Preslien:s Jefferson and Madison have an unexpectedly familiar sound today. Then, as now the United States was the prineipal neutral power in a war which inrolved all Enrope. The canses of the War of 1812 are clearly set fortl. The treaty of Ghent, the hundredth anniversary of which has recently been celebrated, is the central theme of the latter half of the volume. The negotiations leading to the signing of that treaty are clearly degcribed. The terms of the treaty are examined as well as the questions in dispute whioh were omitted, and which continned to distarb the relations of the two countries for wany jears. In the conoluding chapter each of these disputed questions is traced to its final solution.

\section{THE JOHNS HOPKINS PRESS}

\author{
BALTIMORE, MARYLAND
}




\section{A REPRINT OF ECONOMIC TRACTS}

The Johns Hopkins Press invites subscriptions to a reprint of four important economic essays of the seventeenth century, to be issued consecutively under the editorial direction of Professor Hollander:-

A Treatise of the Canker of Englands Common Wealth. By Gerrard DR Malynes. London, I60I.

A Discourse of Trade, from England unto the East Indies: Answering to diverse Objections which are usually made against the same. By Тномds MUN. London, I621.

The Treasure of Traffike. Or a Discourse of Forraigne Trade. By Lewes ROBERTS. London, I6 4 I.

Brief Observations concerning Trade, and Interest of Money. By Josian CHILD. London, 1668.

Of the tracts heretofore reprinted, a limited number can yet be obtained as follows. As the editions approach exhaustion, the prices indicated are likely to be increased without notice:-

Asgill, "Several Assertions Proved" (London, 1696), Price, 50 cents.

Barbon, "A Discourse of Trade" (London, I690), Price, 50 cents.

Berkeley, "The Querist": Parts I, II, III (Dublin, 1735-37), Price, \$1.oo.

Fauquier, "An Essay on Ways and Means" (London, 1756), Price, 50 cents.

Fortrey, "Englands Interest Considered" (Cambridge, I663), Price, 50 cent3.

Longe, "A Refutation of the IVage-Fund Theory" (London, 1866), Price, \$1.00.

Malthus, "An Inquiry into the Nature and Progress of Rent" (London, 1815) (Out of print).

Massie, "The Natural Rate of Interest" (London, 1750), Price, 50 cents.

North, "Discourses upon Trade" (London, 1691), Price, 50 cents.

Ricardo, "Three Letters on 'The Price of Gold" " (London, 1809) (Out of print), Vanderlint, "Money Answers All Things" (London, 1734), Price, \$1.00.

West, "Essay on the Application of Capital to Land" (London, 1815), Price, $\$ 1.00$.

\section{THE JOHNS HOPKINS PRESS}

BALTIMORE, MD. 


\title{
The West Florida Controversy of 1798-1813
}

\section{A Study in American Diplomacy}

\author{
By ISAAC JOSLIN COX \\ Associate Professor of History, Unirersity of Cincinnati
}

710 Pages. $12 \mathrm{mo}$. $\$ 3.00$.

This volume has recently been published in the series of the Albert Shaw Lectures on Diplomatic History. It is based on lectures delivered in the Johns Hopkins University in 1912, and later revised for publication. The subject involves one of the most intricate problems in American history, and Professor Cox has spared no pains in searching for new sources of information. He has not only availed himself of the collections in Washington and of the material in the Department of Archives and History at Jackson, Mississippi, but he has personally searched the Archives at Seville and Madrid.

The volume deals with the secret intrigues of statesmen and diplomats in the capitals of America and Europe on the one hand, and with the aggressive, irresponsible movements of impatient frontiersmen on the other. Professor Cox thinks that the sturdy pioneers of the Southwest outstripped the diplomats, and that their deeds were the decisive factors in the settlement of the long and bitter controversy that was waged over West Florida.

\section{THE JOHNS HOPKINS PRESS}

\author{
BALTIMORE, MARYLAND
}




\section{JOHNS HOPKINS UNIVERSITY STUDIES}

\section{IN \\ Historical and Political SCIENCE}

Edited by. HERBERT B. ADAMS, 1882-1901

- Not sold separately.

FIRST SERIES.-I883.- $\$ 4.00$.

(Volume sold only with complete set.)

I. An Introduction to $\Delta$ morican Institutional Filstory. By F. A. Frenmav. 25 cents.

II. The Germanlo Origln of Now England Towns. By H. B. ADAMS. 50 cents.

III. Looal Government in IIllnois. BJ ALDERT SHAT.-Local Government in Ponoujl. vanla. By E. R. L. Gould. 30 cents.

IV. Baron Tithlngmen in America. BY II. B. ADA3rs, 50 cents.

V. Local Government in Kiohlgan and tho Northwest. By F. W. BEars. 25 cents,

Vi. Parish Inetitutions of Karyland. By EDward INGLe. 40 cents.

- ViI. Old Maryland Manors. BJ JonN Heisier Jorsisos.

VIII. Norman Constables in America. By $\Pi$. B. $\Delta$ Dass, 60 cents.

IX-X. Village Communitles of Cago $\Delta$ na and Salom. By H. B. AdaMa. 50 cents.

XI. The Genesle of New England Strte. I3y A. JoInstos. 30 cents.

- XII. Looal Government and Schools In South Carollar. By B. J. Ranage.

\section{SECOND SERIES.- 1884 .}

(Folume sold only with complete sets.)

-I-II. Yrothod of Historfoal Study. By II. R. ADAMB.

III. The Past and Present of Polltical Economy. By R. T. ELr. 35 cents.

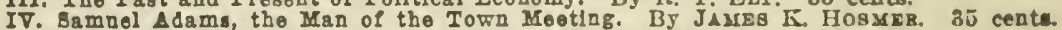

$\checkmark-\nabla I$. Taxation in the United States. By HEXrY CARTER ADAMB. 50 cents.

VII. Institutional Beginaings in \& Westorn Stato. BY JESBE MACY. 25 cents.

VIII-IX. Indlan Money in Now England, etc. By WILLIAM B. WEEdes. 50 cents.

- $\mathbf{z}$. Town and County Government In the Colonles. By D. CuAxisig.

- Xi. Rudimentary Socloty among Boys. BJ J. Hearsler Jollssos.

XII. Land Lawa of Mining Dlstricts. By C. H. SniNi. 50 cents.

\section{THIRD SERIES. - I885. $\rightarrow 4.00$.}

I. Maryland' Infuence upcn Land Cesstons to the U. S. By H. B. ADAus. 75 cents. II-III. VIrglala Local Institutions. By E. INoLs. 75 cents. IV. Recent Amerlcan Sociallsm. BY RicHard T. ELT. 50 cents.

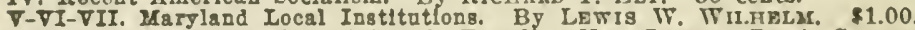
VIII. Iniuence of the Proprleters in Founding Now Jersey. By A. BcoTr. 25 centa. IX-X. American Constitutions. By HORACE DATIs, 50 cents.

XI-XII. The Clty of Washington. By J. A. I'ORTER. 50 cents.

FOURTH SERIES.-1886.-\$4.00.

-1. Dntch Village Communitles on the Fudson RIver. By I. EutiNe.

II-III. Town Government in Rhodo Island. By W. E. Fostr. - Tho Narragansett Plent ars. By Entrarn Cuannivo. 50 cents.

TV. Pentsjlvanla Boroughs. By William P. Bolcomb. 50 cents.

V. Introduction to Constitutional History of tho States. BJ J. F. JAMrsox, Go centa. Vi. Tho Puritan Colony at Annapolis, Maryland. I3y D. R. RANDaL. 50 cents.

VII-VIII-IX. The Land Question in the Unlted 8tates, BV S. SATO. \$1.00.

X. Town and Oity Government of New Haven. BF C. II. Lerenuore. 50 cents.

XI-XII. Land Syatem of the Now England Colonles. By 3I. EGLEsTon. 50 cents.

FIFTH SERIES.-1887. $\$ 4.00$.

I-II. City Government of Phlladolphla. By D. P. Alllinson and B. Pendose. 50 cents III. City Government of Boston. I3j JAMres M. BUGREE. 25 cents.

IV. City Government of St. Louls. My Marsinall S. Sxow.

$\nabla$-VI. Local Government In Canada. By JoIr GEORe BOURINot. 50 cents.

VII. Effect of the War of 1812 upon tho Amerlorn Union. BY N. M. BuTLER. 25 ceate. VIII. Notes on the Ilteratore of Charities. 13v IIERBEIT B. ADAMB. 25 cents.

IX. Predletlons of Hamilton and Do Tooquevilio. I3y JAsrs Bricr. 25 cent.

X. Tho study of History in England and Scotland. By P. Frenonesco. 25 centi XI. Seminary Llbrarios and Unlversity Extension. Ry II. 13. ADAMs. 25 centa.

- XI. Europor School of History and Polltics. RF A. D. W'irite.

$$
\text { SIXTH SERIES. }-1888 .-\$ 4.00 \text {. }
$$

The Histor of Co-operstion In the United States. 


\section{SEVENTH SERIES.-1889.}

(Volume sold only with complete set.)

I. Arnold Toynbeo. By F. C. Montaguv, 50 cents.

II-III. Hunicipal Government in San Francisco. Bj BEnNARD Hoses. 50 cents.

IV. Municipal Historg of Now Orleans. By WM. W. Howr. 25 cents.

- V-VI. English Culture in Virginla. By Williais P. Trent.

VI-VIII-IX, The Rlver Towns of Conneoticut. By CHARIES M. ANDRWWs, \$1.00.

- X-XI-XII. Federal Government in Canads, By JoHN G. Вобвгот.

\section{EIGHTH SERIES.-1890.}

(Volume sold only with complete set.)

I-II. The Beginnings of American Nationallty, By A. W. Sscall, $\$ 1.00$

III. Local Government In Wiscousin. By D. E. SPENCER. 25 cents.

IV. Spanish Colonization In the Southwest. By F. W. BrackMar.

V-VI. The Study of History in Germany and France, By P. FrEDrice. 1.00

VII-IX. Progress of the Oolored People of Maryland. By J. R. BRACEET. \$1.00.

- $\mathrm{X}$. The Study of History in Belgium and Holland. By P. FreDERICQ.

XI-XII. Seminary Notes on Historical Iiterature. By H. B. ADdus and others. 60 cents.

NINTH SERIES.- $-189 \mathrm{r}$.

(Volume sold only with complete set.)

-I-II. Government of the United States. By W. W. WrLlodGHBY and W. F. WLLLOUGHBY III-IV. University Education in Maryland. By B. C. STEINER. Tho Johns Hoplos University (1876-1891). By D. C. GILMAN. 50 cents.

- V-VI. Munlcipal Unity in the Lombard Communes. By IV. K. TVilurass.

VII-VIII. Publie Lands of the Roman Republic. BY A. STEPHExsos. 75 centa.

IX. Constitutional Development of Japan. BY T. IYENAGA. 50 cents.

- $\mathrm{X}$. A History of Liberia. By J. H. T. MCPHEnSON.

XI-ZII. The Indian Trade in Wisconsin. BJ F. J. TuRner. 50 cente.

\section{TENTH SERIES.-1892.-\$4.00.}

I. The Bishop Hill Colonj. By MICHAEL A. MIKKELSEN. 50 cents.

II-III. Church and State in New England. By PAUL E. LAUEr. 50 cents.

IV. Church and State in Maryland. By Georom Perrie. 50 cents.

V-VI. Religious Development of North Carolina. BY S. B. WEEKS. 50 cents. VIr. Maryland's Attitude in the Struggle for Canada. By J. W. BLAcK. 50 cents. VIII-IZ. The Quakers in Pennsylvania. By A. C. APPLEGARTi." 55 cento.

$\mathbf{Z}$-XY. Columbus and his Discovery of America. BY H. B. ADAMrs and H. Woob. 50 cents. XII. Causes of the American Revolution. By J. A. WOODBDRN, 50 cents.

\section{ELEVENTH SERIES.-1893.-\$4.00.}

I. The Bocial Condition of Labor. By E. R. I. Gould, 50 cents.

II. The Worla's Representative Assemblies of To-Day. By E. K. ALDEN, 50 cents.

III-IV. The NegTo in the District of Columbia. Ry EDWARD INOLE. \$1.00.

$\checkmark-\nabla I$. Church and stato in North Carolina, By STEPuEN B. Werks. 50 cents.

VII-VIII. The Condition of the Western Farmer, otc. BY A. F. BENTLEY. \$1.00.

IX-X. History of Slavery in Connecticut. By BerNard C. STEINer. 75 cents.

XI-XII. Local Government in the Sonth. By E. W. BkMis and others. $\$ 1.00$.

\section{TWELFTH SERIES. $-1894 .-\$ 4.00$.}

I-II. The Cinolnnatl Southern Rallway. By J. H. HoI.ANDEr. $\$ 1.00$

III. Constltutlonal Beginnlngs of North Carolina, By J. S. BA8sxTr. 50 cents. IV. Struggle of Dissenters for Toleration in Virginla. By H. R. Mcliwaris. VIT X. English Institutions and the American Indian. By J. A. JAMES. 25 cents. X. English lastltutions and the Amorican Indian. By J. A. Jasies. THIRTEENTH SERIES.-1895.-\$4.00.

I-II. Government of the Colony of South Carolina. By D. I. WuITNEr. 75 cents. III-IV. Early Relations of Maryland and Virglala. BJ J. II. I I TANA. 50 cents. $\checkmark$. The Rise of the Bicameral System in America. By T. W. Moran, bo cents. Vi-VII. White Servitude in the Colony of Virginia. Ry J. C. BardaAr. b0 cente. VIII. The Genesis of Callfornig's First Constitution. IJY IR. D. IIONT. 50 cents, IX. Bonjamin Franklin as an Economist. Bj W. A. WETzEI. 60 cents. X. The Proplsional Government of Maryland. By J. A. Silver. ho cente.

Xi-ZII. Government and Religion of the Virglnia Indlans. Hy S. It. HeNives. 60 cents

$$
\text { FOURTEENTH SERIES.-1896. } \$ 4.00 \text {. }
$$

1. Constitutional Hiatory of Hawall. By HaNhY F. Cinamern. 25 cents.

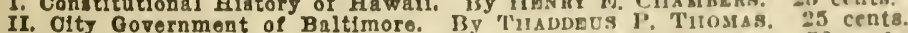
IIx, Oolonial Origing of New England Senates. By F. L. Ilsi.eY. 50 cents. IV-V. Servitude in the Colony of North Carolina. $13 y$ J. \&. BAssarT. 50 cents. VI-Vir. Representation in Virginla. IIy J. A. t: CIIANDi.e K. BO cesits. VIII. History of Taxation in Oonnectlout (1036-1776). lig ir. 12. Joses. 50 cents. IX-X. A Study of glavery In New Jersey. Iy IIPNR 8. Coni.er. 50 cents. XI-XII. Oauses of the Maryland Revolution of 1689 . 1ig ir. 1s. Spakks. 50 cents. 
FIFTEENTH SERIES.-1 $\varepsilon_{97}-\$_{4.00}$

I-II. TE. Iotacco Iadastry in Vizglala stace 1960. By B. T. ARvoLD. 50 cents.

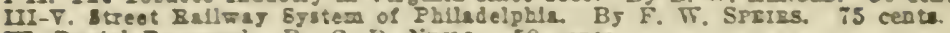

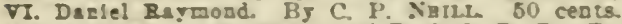

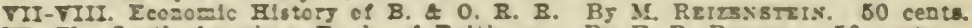

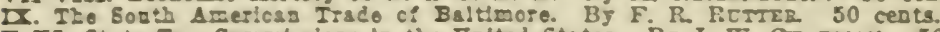

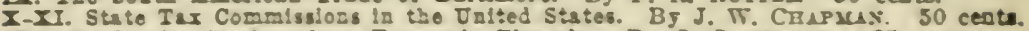

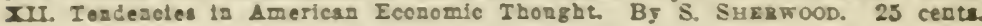

SLXTEENTH SERIES.- $-1898 .-\$_{4}, 0$.

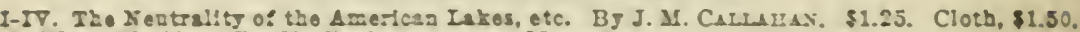
Y. Wus Florida. BY H. E. CHAMBERS. $2 J$ cenLs.

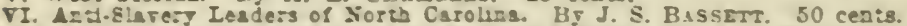

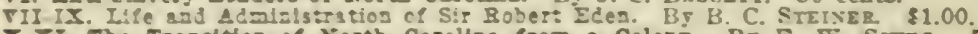

X-3I. The Irasstion o? Siorth Cerclins sro a Colonj. BJ E. W. Sikrs. 50 centa XII. Jared Spark ad Alexis Do Iocgreflle. By B. B. ADAYs. 25 cents.

SEVENTEENTH SERIES.-1\$99.-\$4.00.

I-II-III. Elstory of State Barking in Marglaze By A. C. Baras. \$1.00.

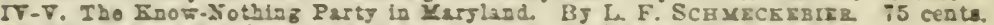
VI. Tro Labedist Colong io Karjlard. By B. B. Jaxes. 50 cents.

VI-VIII. Ristos of Slaterg 10 Sortb Carollas. BJ J.S. BAsseTT. 75 cents. II-X-XI. Defolopmezt of tho Chesspesto \& OL!o Cansi. By G. Tr. TAR. is ceora

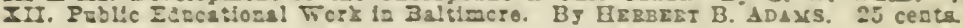

\section{EIGHTEENTH SERIES.- $1900 . \$_{4} .00$.}

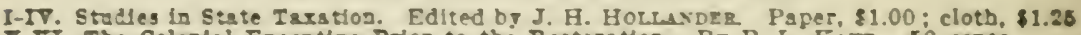
T-TI. Tte Colozlal Exocrtire PTo: to tho Bestorstoz. BJ P. L. Kirg. 50 cents.

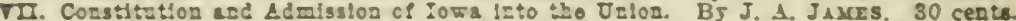
VIII-IX. Tto Cburch and Popalar Edacation. BJ H. B. dDANS. S0 cents.

X-XII, Beliglons Freedor in Firginla: Ibo Bapdets. By W. T. TBOM. is centa.

\section{NINETEENTH SERIES.-I901.-\$4.00.}

i-III. Amerles in the Paclsc acd the Iar East. BJ J. M. Cazlarzas. i5 cegts

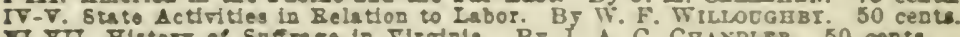

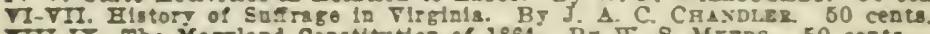

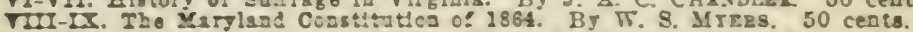
x. Ilfo of Cozmissary Jazes Blatr. BJ D. E. Ṕortur. 25 cents.

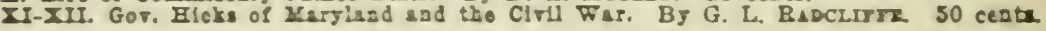

\section{TWENTIETH SERIES.-I902.-\$4.00.}

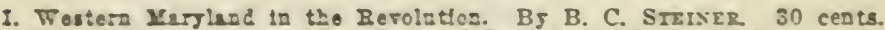

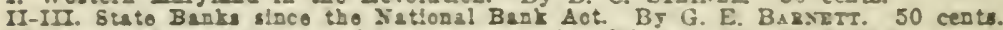

IV. Eurly History of Iternal Impzoremests in Alabams. By W. E. MABIs. 80 centa. - $\nabla$-VI. Irust Compazies in the Ualied Siates. By Grozgz Catoz.

TI-VII. The Xarjlead Corstitutloz of 1551. B5 J. W. 11 Ar8T. 50 cents.

IX-Z. Polltical Actritles of Phllip Freness. By S. E. Forsax. 50 ceats.

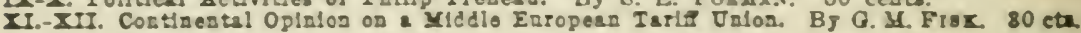

\section{TWENTY-FIRST SERIES.-1903.-\$4.00.}

-I-II. Tho Fabash Trade Boute. Bj E. J. Brxtos.

III-IV. Interoal Improvements is dorth Carolina. BJ C. C. Wratas 50 centa. T. IIstory of Japareso Papez Carrezcy. BJ M1. TAEAKI. 30 cents.

VI-FII. Econcrics and Polltics is Merthed, 1720-1750, and tho Publso sorven of Derlol Driery tho Elder. By St. G. L. Siotsant. 50 cents. -

II-XIL Ib. Eagliab Statutes to Yargiand. BY ST. G. L SiocsBat. 50 cents.

TWENTY-SECOND SERIES.-1904.-\$4.00.

I-II. $\triangle$ Tral Bibllorrapby of American Trade-Unlon Pablicstioss. 50 certs.

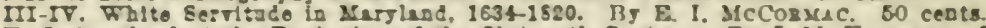

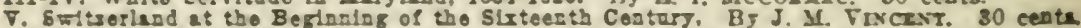

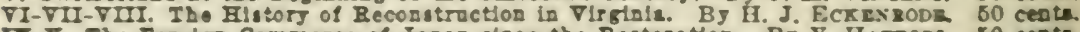

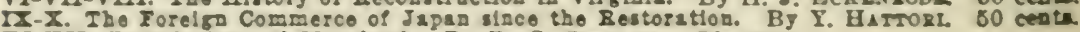
II-XII. Doscriptions of Karthend. By B. C. STrisez 50 cent.

\section{TWENTY-THIRD SERIES.-1905. $-\$ 4.00$.}

I-II. Eecossirection is Serta Carolina. BF J. P. Horj.s. 50 ceacs. III-IV. Sts to Goverameat in Merslead, 177-i78i. By B. W. Bord JR 50 cents.

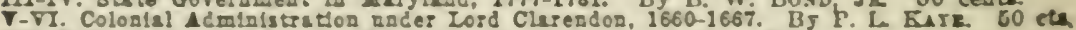
TI-TII Jastice ta Coloalal Virmala. BY O. P. CHITwOOD. Co ceale.

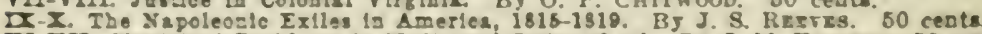

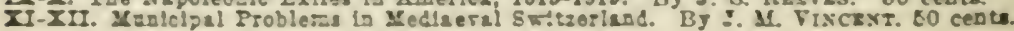


I-II. Spanish-Amerlcan Diplomatlc Zelatiors beiore 1898. Bj E. E. Fucz. 50 cezts III-IV. The Flnazces of Bmerican Trado Tn!ons. BJ A. M. SAROLBZI. 75 ceDts.

V-VI. Dlplomatio Negotiations of the United Stetes with Russis. BY J. C. HnD. s0 eth VI-VII. 8tate RIghts and Partles in Forth Carolina, 1776-1831. BJ H. iL WLGSIN. SOC

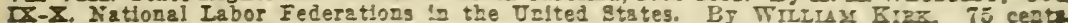
XI-XII. Yarglard During the English Clfil Wars. Part I. By B. C. Srzarsz 50 cents.

\section{TWENTY-EIFTH SERIES.-I907.-\$4.00.}

T. Internal Taxatice in the Philipplices. Dy JOES S. HOZD. 30 cezts.

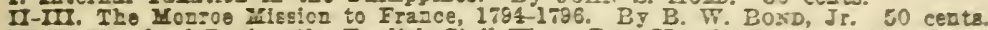

T- - Y. Yargland During tice English Civil Wars, Part II. By BERYADD C. STz:rzn. EDe VI-VII. Tho State in Constitutional and International Iaw. B. B. T. Cisiz. 50 cects. VUI-IX-Z. Financlel Listory of Mazjland, 1783-1848. By HigI S. HAxiL T5 cezte

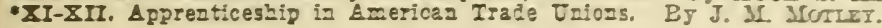

\section{TWEITTY-SIZIH SERIES.-I908.-\$4.00.}

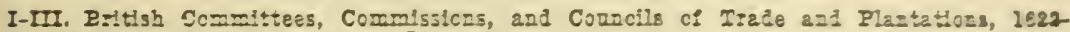
1675. BY C. MS. AVD2ams. 75 cents.

IV-VI. Jieutral Bights and Obligations in the Arglo-Boer War. By B. G. CArpezi= 75 cents.

VII-VIII. The Elizabethan Parish in its Eccleslagtcal asd Finazclal Lspecte. Ey S. L TARE. 50 ceJts.

IX-Z. $\Delta$ Study o! the Topograpty and Municipal Blstory of Praereste. By R. F. D. MAGOFFIX. 50 cents.

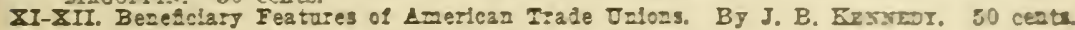

\section{TWENTY-SEVENTH SERIES.-I909,-\$4.00.}

I-II. The Belf-Ieconstrection o: Yasyland, 1581-1867. By W. S. Mrrzs. 50 ceatu. III-IV-V. The Detolopment of the Englibh Law of Corsplracy. By J. W. Bizax. 75 cents.

VI-VI. Lejlistive and Jud!cial Eistory o: the Fifteezth Ameacoezt. By J. $\boldsymbol{U}$ MATEEW \&. 75 ceDts: cloth $\$ 1$.

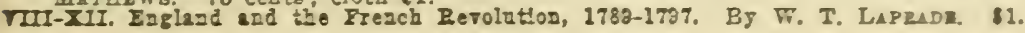

\section{TWENTY-EIGHTH SERIES.-I9I0.-\$4.00.}

(Complete in four numbers.)

I gletory of Reconstretion in Loplsieas (Through 1838). By J. R. Ficsur. 11.00; clotb $\$ 1.25$.

II. Tho Trad Ǘlar Iabel. By E. R. Sprodzar. 50 cents: eloth 75 cents.

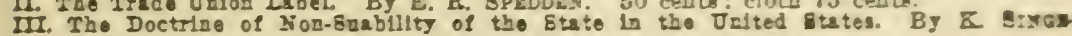
ward. 50 cents: rloth 75 cents.

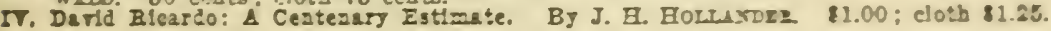

\section{TWENTY-NINTH SERIES.-I9II.-\$4⿻. \\ (Complete io three aumers.)}

L. Yariand Onder the Commonwealth: A Chronlele of the years 1642-1ess. By B. C STINER 81 : clotb $\$ 1.25$.

I. Tho Doteh B cloth $\$ 1.75$.

- III. Tho Cloed shop lo Ameriean Trado Ualoss. BY F. T. SFocrior.

\section{THIRTIETH SERIES.-:912.-\$400.}

(Complete in three numbers.)

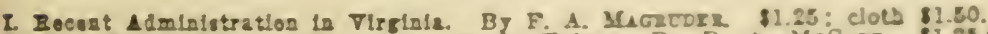

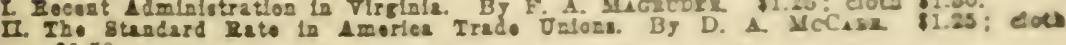

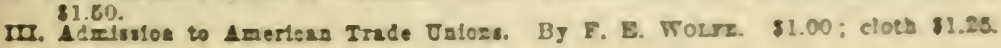


THIRTY-FIRST SERIES.-1913. $-\$ 4.00$.

(Complete is sour aumbers.)

2. The Iand systom In Maryland, 1720-1765. By Ciansicx P. GooLd. 75 cents; clots 81.00 .

II. The Government of Amerlean Trado Unlons. By T. W. GLocker \$1.00; cloth \$1.2\$. III. The Tree Nesto In VIr Jinia, 1619-1865. Bj J. H. ROBsel. \$1.00; eloth \$1.25. IV, The Quinquennales: An Historical 8 tudy. BJ R. V. D. Mucorrix. 60 centa ; elet 75 cents.

\section{THIRTY-SECOND SERIES.-I9I4.-\$4.00. \\ (Complete in three numbers.)}

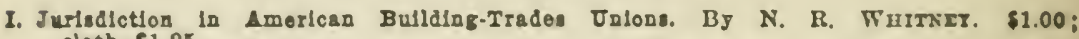
cloth $\$ 1.25$.

II. Blevery in Mlesourl, 1804-1865. By H. A. TREXLER, $\$ 1.25$ : cloth $\$ 1.50$.

UI. Colonial Trado of Maryland. By M. S. Moraiss. $\$ 1.00$; cloth $\$ 1.25$.

\section{THIRTY-THIRD SERIES.-1915.-\$4.00.}

(Complete in lour numbers.)

1. Yoney and Traneportation in Maryland, 1720-1765. By Cuarsicz P. Goold. To cents; cloth $\$ 1.00$

1. The Finanolal Adminlatration of the Colony of Virginla. By Perci Scotr Furpix. 50 cents: cloth 75 cents.

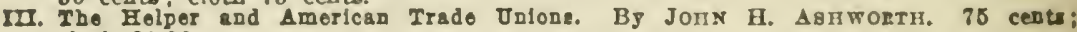
cloth $\$ 1.00$.

IV. The Constitutional Dootrines of Justlce Errian. By Flord BarziLIA CueK, \$1.00; cloth $\$ 1.25$.

\section{THIRTY-FOURTH SERIES.-1916. $\$ 4.00$.}

(Complete in four numbers.)

I. The Boycott In American Trade Unlons. By IEO WOL3Ax, \$1.00; cloth, \$1.25.

II. The Postal Power of Congress. BJ LixDSAI ROGERS. \$1.00; cloth, 1.25 .

III. The Control of Strikes in American Trado Unlons. By G. M. Jaíes. 75 cents: cloth, \$1.00.

IV. Stato Administration in Maryland. BJ JoHs L. Dosardosox. \$1.00; cloth \$1.26.

\section{THIRTY-FIFTH SERIES.-1917.-\$4.00}

(Complete in three numbers.)

I. The Virginla Committe system and the American Revolution. Bg J. M. Lnix. $\$ 1.00$; cloth $\$ 1.25$.

II. The Orgenlzability of Labor. By W. O. WEYFORTH. \$1.50: cloth $\$ 1.75$.

II. Party Organization and Machinery in Mloblgan since 1890. By A. C. MILfspador. $\$ 1.00$; cloth $\$ 1.25$.

\section{THIRTY-SIXTH SERIES.-1918.-\$4.00.}

(Complete In lour numbers.)

I. The Standard of Ilvlag in Japan. B5 K. Morrзото. \$1.25; cloth $\$ 1.50$. II. Sumptusry Law in NHrnberg. By K. R. GREvNFieI.n. \$1.25; cloth \$1.50.

III. The Privileges and Immunitles of State Citizenship. BS R. HoweLs \$1.00;

IV. French Protestantism, 1559-1562. BF C. G. KeLLY. \$1.25; cloth $\$ 1.50$.

\section{THIRTY-SEVENTH SERIES.-1919.-\$4.00.}

I. Tnemplojment and Amerlcan Trade Unions. BI D. P. SMELSER, JR \$1.25; cloth $\$ 1.50$.

II. The Labor Law of Maryland. By M. II. IACCIIFIMER \$1.25: cloth \$1.50.

III. The American Colonization Soclety i817-1840. $\quad \therefore$ L. Fox. \$2.0n: cloth \$2.25.

IV. The Obligation of Contracts Clause of the Unlted States Constitution. 1iy W. B. 11ustro. \$1.00; cloth \$1.2t.

The set of thlrty-seven serles of stulies is offerel, unlformls bound in clotb, for library use for \$148.06 net. The separate volumes nas also he had bound in cloth at the prlces stated. 


\section{.}





S Wanlass, William Lawrence
21 The United States Department
C9W3 of agriculture

\title{
Biological
}

\& Medical

PLEASE DO NOT REMOVE

CARDS OR SLIPS FROM THIS POCKET

\author{
UNIVERSITY OF TORONTO LIBRARY
}


